\title{
Verloren zonsondergangen : Hans-Jurgen Syberberg en het linkse denken over rechts in Duitsland.
}

Citation for published version (APA):

Goossens, G. H. (2004). Verloren zonsondergangen : Hans-Jurgen Syberberg en het linkse denken over rechts in Duitsland. [Doctoral Thesis, Maastricht University]. Universiteit Maastricht. https://doi.org/10.26481/dis.20040101gg

Document status and date:

Published: 01/01/2004

DOI:

10.26481/dis.20040101gg

Document Version:

Publisher's PDF, also known as Version of record

\section{Please check the document version of this publication:}

- A submitted manuscript is the version of the article upon submission and before peer-review. There can be important differences between the submitted version and the official published version of record.

People interested in the research are advised to contact the author for the final version of the publication, or visit the DOI to the publisher's website.

- The final author version and the galley proof are versions of the publication after peer review.

- The final published version features the final layout of the paper including the volume, issue and page numbers.

Link to publication

\footnotetext{
General rights rights.

- You may freely distribute the URL identifying the publication in the public portal. please follow below link for the End User Agreement:

www.umlib.nl/taverne-license

Take down policy

If you believe that this document breaches copyright please contact us at:

repository@maastrichtuniversity.nl

providing details and we will investigate your claim.
}

Copyright and moral rights for the publications made accessible in the public portal are retained by the authors and/or other copyright owners and it is a condition of accessing publications that users recognise and abide by the legal requirements associated with these

- Users may download and print one copy of any publication from the public portal for the purpose of private study or research.

- You may not further distribute the material or use it for any profit-making activity or commercial gain

If the publication is distributed under the terms of Article $25 \mathrm{fa}$ of the Dutch Copyright Act, indicated by the "Taverne" license above, 


\section{Inhoud}

\section{Hoofdstuk 1 De non-kunstenaar}

1.1 Het verschijnsel

1.2 Het probleem

1.3 De bedoeling

\section{Hoofdstuk 2 Leerjaren}

2.1 Inleiding

2.2 Het verloren huis

2.3 De artistieke pleegvader: Bertolt Brecht 23

2.4 De Brecht-Lukács-controverse: het expressionisme-debat 26

2.5 Het absurde bewustzijn

2.6 De intellectuele pleegvader: Hans Sedlmayr

2.7 De Sedlmayr-Adorno-controverse: het modernisme-debat 34

2.8 De post-brechtiaanse avant-garde

2.9 De vroege films

Hoofdstuk 3 Wagners tweede verschijning

3.1 Inleiding

3.2 Wagner-travestie

3.3 Een esthetisch schandaal?

3.4 Het éne Duitsland van Thomas Mann

3.5 Kunst als redding uit de Duitse misère

3.6 De muziek van de nazi's volgens Ernst Bloch

3.7 Strategieën van herijking

\section{Hoofdstuk 4 De oude dame}

4.1 Inleiding

4.2 Het verhaal van een vriendschap

4.3 Emotionele zelfverminking

4.5 De rouwverwerking waar Alexander en Margarete Mitscherlich om vroegen

4.6 Traumatische bewustwording

4.7 Een flirtende gymnasiast 
(4) $\quad 4+\cdots$

औ.

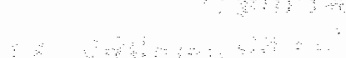


Hoofdstuk 5 Een psychologisch Versailles

5.1 Inleiding

5.2 Bekennen

5.3 Het pedagogische schema van beschuldiging en verontschuldiging $\quad 134$

$\begin{array}{ll}5.4 \mathrm{De} \text { ingeslagen en geleerde weg van het argumenteren } & 141\end{array}$

$\begin{array}{ll}5.5 \text { Fascistische hunkeringen volgens Susan Sontag } & 143\end{array}$

5.6 De gistende werking en lenigheid van het dialectische intellect $\quad 150$

$\begin{array}{ll}5.7 \text { Een duistere eed van trouw } & 154\end{array}$

$\begin{array}{ll}5.8 \text { Slot } & 157\end{array}$

Hoofdstuk 6 De geschiedenisfabriek

6.1 Inleiding $\quad 161$

$\begin{array}{lr}6.2 \text { Voor eeuwig onze broeder } & 166\end{array}$

$\begin{array}{ll}\text { 6.3 De summa van onze ervaringen } & 178\end{array}$

6.4 Het heden: de Duitse herfst van $1977 \quad 186$

$\begin{array}{lr}\text { 6.5 Partizanenexistentie } & 190\end{array}$

6.6 Het motief van de post-histoire $\quad 193$

$\begin{array}{lr}6.7 \text { Counterhistory } & 197\end{array}$

$\begin{array}{ll}6.8 \text { Slot } & 201\end{array}$

Hoofdstuk 7 Tweeërlei zonsondergangen

$\begin{array}{ll}7.1 \text { Inleiding } & 205\end{array}$

7.2 Hitler, een film van een jood uit Duitsland $\quad 109$

$\begin{array}{ll}7.3 \text { Een Kehre? } & 215\end{array}$

7.4 Post-Hitler: het Pruisen-Requiem $\quad 220$

$\begin{array}{ll}7.5 \text { Grosse gedankliche Klärung } & 226\end{array}$

7.6 Transgressie: het teruggevonden Huis $\quad 230$

7.7 De flater van de neo-filosofie $\quad 235$

7.8 Slot $\quad 239$

Hoofdstuk 8 Finale

8.1 Inleiding $\quad .243$

8.2 De Wende van 1989-1990 $\quad 244$

8.3 De filmer en het nieuwe Duitsland $\quad, 249$

8.4 Een kunstenaarsloopbaan $\quad 254$

$\begin{array}{ll}8.5 \text { Differentie verdragen } & 264\end{array}$

Bronnen $\quad 269$

$\begin{array}{lr}\text { Bronnen } & 289\end{array}$

$\begin{array}{ll}\text { Summary } & 293\end{array}$

$\begin{array}{ll}\text { Dankwoord } & 295\end{array}$

Over de auteur 


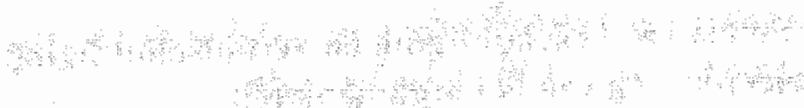
and

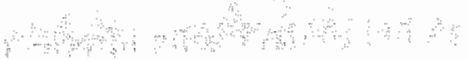

s.

?

3

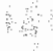

क

तs

B.

$1 / 1$

te

$+3$ 
$\mathrm{Na}$ talrijke successen te hebben geboekt aan het Spaanse hof, schilderde Goya in zijn latere leven de zwarte muren van zijn kleine huis vol met taferelen, waryan de betekenis tot op heden duister is. Vele bewonderaars van de vroegere, oplichtende en strijdbare beelden begrepen er niets meer van en wilden die oude, beroemde werken niet eenvoudigweg door hun eigen meester ter discussie gesteld zien.

Hans Jürgen Syberberg 


\subsection{Het verschijnsel}

Een 'non-kunstenaar', maak ik op uit een in 1983 verschenen tentoonstellingscatalogus, is iemand die aanspraak maakt op het kunstenaarschap. ' Niet zelden gaat het ook om personen, waarvan het kunstenaarschap in het verleden ten volle is onderkend. Maar in onze ogen hebben hun werken opgehouden kunst te zijn. De samenstellers van de bewuste catalogus denken in dit verband met name aan de Duitse beeldhouwer Arno Breker. Ooit ontdekt door de joodse galeriehouder Alfred Flechtheim, aan het begin van de vorige eeuw een invloedrijk apologeet van de avant-garde; in het interbellum op handen gedragen door Jean Cocteau en Aristide Maillol; groot geworden onder het mecenaat van de nazi's. Sindsdien rust op het werk van Breker het stigma van het 'non-kunstenaarschap'. Wanneer de Duitse verzamelaar Peter Ludwig halverwege de jaren ' 80 het voorstel lanceert enkele sculpturen van Brekers hand opnieuw toe te laten tot het museum van moderne kunst, als exemplarisch voor een monumentalisme dat in de jaren ' 30 wereldwijd in zwang was, oogst hij een storm van protest vanuit de kunstwereld: "Keine Nazi-Kunst ins Museum!" Het werk van Breker, zo de communis opinio, is geen kunst maar kitsch - een propagandistische uitbeelding van een mensonterende dwaalleer, hooguit interessant vanuit een geschiedwetenschappelijk oogpunt. ${ }^{2}$

Ook rond de persoon, waarmee we ons in dit boek zullen bezighouden, hangt de geur van een 'non-kunstenaar'. Nee, het gaat niet om iemand die in het Derde Rijk furore heeft gemaakt. De persoon in kwestie was aan het eind van de oorlog nog een kind. Zijn debuut heeft hij gemaakt in 1965 en zijn meest bekende werken dateren uit de jaren "70 en vroege jaren ' 80 . En toch is de vergelijking met Arno Breker beslist niet vergezocht. "Waar over cultuur wordt gesproken, heeft Hans Jürgen Syberberg niets meer te zoeken," aldus een criticus van de Frankfurter. Allgemeine Zeitung in $1990 .^{3}$ En op dit soort plekken wordt van de filmmaker dan ook nog slechts zéér sporadisch iets vernomen. Het is de laatste jaren opmerkelijk stil geworden rond Syberberg - zo stil zelfs, dat het soms lijkt alsof hij zijn artistieke loopbaan heeft beëindigd. In eigen land geniet hij vrijwel uitsluitend nog een beperkte naamsbekendheid als auteur van pamfletten, die titels dragen als Eigenes und Fremdes (1993) of Das Rechte - tun (1995). Zijn bezorgde poging de Duitse identiteit te redden uit de gretige klauwen van veramerikaniseerde materialisten en ontwortelde joden krijgt de goedkeuring van de ranzige pagina's van de uiterst rechtse National-Zeitung, constateert de Nederlands/Britse publicist Ian Buruma in The Wages of Guilt (1994). "Zijn essaybundels worden daar samen met fotoboeken van stuka's en tanks aangeprezen - een vreemde plaats voor deze romantische estheet. Maar hij wordt gemeden door de progressieve intelligentsia." 4

Bijna zou je vergeten, dat ook Hans Jürgen Syberberg ooit, nog niet eens zo heel lang geleden, betere tijden heeft gekend. In filmhandboeken uit de jaren ' 70 en de vroege jaren ' 80 kan men zijn naam terugvinden onder het kopje 'Nieuwe Duitse Cinema'. Samen met Rainer

\footnotetext{
'Szymanski, R., Vorwort. in: Skulptur und Macht. Figurative Plastik im Deutschland der 30er und 40er Jahre. Hrsg. Akademie der Künste. Berlin, 1983. p. 5f.

${ }^{2}$ Nazi-Kunst ins Museum? Hrsg. K. Staeck. Göttingen, 1988.

${ }^{3}$ Citaat van Werner Fuld, ontleend aan: Baier, L., Eine ungeheuerliche Neuigkeit? Nachfragen zur Debatte um den Pamphlettisten Syberberg. in: Neue Rundschau. 1 (1990). pp. 117-138, zie: 121.

${ }^{4}$ Buruma, I., Het loon van de schuld. Herinneringen aan de oorlog in Duitsland en Japan. Vert. T. Davids. Amsterdam, 1994. p. 81.
} 
Werner Fassbinder, Werner Herzog, Alexander Kluge, Volker Schlöndorf, Margarete von Trotta, Wim Wenders en het filmende echtpaar Jean-Marie Straub en Danièle Huillet werd hij gerekend tot de boegbeelden van deze Westduitse nouvelle vague, dankzij welke de Duitse cinema kortstondig weer een internationale uitstraling kreeg, vergelijkbaar met de hoogtijdagen van de UFA "toen een verslagen Duitsland het respect van de gehele cultuurwereld won door de films die het maakte" (aldus de verteller van Malcolm Lowry's, uit 1947 daterende roman Under the Volcano). ${ }^{5}$ Goed, het thuispubliek heeft de Nieuwe Duitse Filmmaker Syberberg op zijn zachtst gezegd nooit weten te bekoren. In de inleiding van een in 1980 verschenen bundel met Amerikaanse, Franse en Italiaanse besprekingen van zijn werk, bespeurt de Westduitse filmcriticus Klaus Eder "een opmerkelijke polarisatie van meningen - hier, in de Bondsrepubliek Duitsland, contra ginds, het buitenland". Terwijl zijn films, theatervoorstelling en installaties wereldwijd "een intellectuele repons [vonden], zoals gedurende de afgelopen jaren vrijwel geen Westduitse kunstuiting", werd in eigen land "uitermate onbehouwen". met deze cineast omgesprongen: "Spot en cynisme en hoon en scherpe polemiek waren de ingenomen houdingen; geargumenteerd (ook in de afwijzing) werd nauwelijks". En, kunnen we hier aan toevoegen, al relatief vroeg, bij het verschijnen van het pamflet Die freudlose Gesellschaft in 1981, viel in een gezaghebbend links-liberaal periodiek, het weekblad Die Zeit, het voor elk kunstenaarschap dodelijke verwijt dat Syberberg doelen zou nastreven "die vrijwel identiek zijn aan die van Hitler"?

Daar staat echter tegenover, dat Syberberg indertijd ook weer niet meer of minder controversieel was dan, pakweg, Rainer Werner Fassbinder, van wie sommige werken (waaronder het beruchte, uit 1975 daterende Der Müll. Die Stadt und der Tod) eveneens aanleiding waren voor tumult in de Westduitse media, waarbij beladen termen als 'antisemitisch' en 'fascistoïde' niet werden geschuwd. Ook voor Fassbinder, ja eigenlijk voor elk van Syberbergs collega's uit de Nieuwe Duitse Cinema, gold dat ze hun roem eerst en vooral te danken hadden aan de receptie van hun werk in Frankrijk, Italië, Groot-Brittannië, de Benelux en - bovenal - de Verenigde Staten. Wat dat betreft valt wel wat te zeggen voor de stelling van de Britse filmtheoreticus John Sandford (1980), dat Syberberg het "extreme voorbeeld [was] van de algemene regel, dat de Nieuwe Duitse Cinema in het buitenland meer werd geapprecieerd dan in de Bondsrepubliek". 8 We zouden ons zelfs kunnen afvragen, of hij niet het extreme voorbeeld was van de algemene regel, dat veel eigentijdse Westduitse kunst uit deze periode überhaupt elders meer, of in elk geval vroeger werd gewaardeerd dan in het land van herkomst. Zo zijn er tevens onmiskenbaar parallellen met de receptie van het werk van beeldende kunstenaars als Anselm Kiefer, Markus Lüpertz, Gerhard Merz of Günther Förg, met wie Syberberg - terecht - dikwijls in één adem werd genoemd. Wat hem met deze beeldende kunstenaars verbond was het zogenaamde 'Duitse motief - een begrip dat in het Westduitse kunstdebat door Lüpertz werd geinntroduceerd als overkoepelende titel voor een reeks werken uit de vroege jaren '70: in een onverbloemd laat-romantische of neoexpressionistische stijl geschilderde stillevens van Stahlhelmen, officiersmutsen, wapenrokken, affuiten en andere parafernalia uit de Hitler-tijd, die in Syberbergs decorbeelden hun filmische pendant vonden. In eigen land lag deze, zoals het laatdunkend werd getypeerd, Deutschtümelei tot ver in de jaren ' 80 zéér gevoelig. Net als Syberberg werden ook Kiefer, Lüpertz, Merz en Förg ervan verdacht apologeten van een verrechtsing te

\footnotetext{
${ }^{5}$ Lowry, M., Onder de vulkaan. Vert. J. Vandenbergh. Amsterdam, 1966, 1995. p. 45.

${ }^{6}$ Eder, K., Vorwort. in: Syberbergs Hitler-film. Texte von Susan Sontag, Jean-Pierre Faye, Jean-Pierre Oudart. Christian Zimmer, Michel Foucault, Bernard Sobel, Alberto Moravia, Vito Zaggarrio, Heiner Müller. Hrsg. K.

Eder. München, Wien, 1980. pp. $5 f$.

${ }^{7}$ Hamm, P., Syberbergs Kampf. Der Regisseur des Hitler-Films als Autor. in: Die Zeit. 32 (31-07-1981).

${ }^{8}$ Sandford, J., The New German Cinema. London, 1980. p. 116.
} 
zijn. Meer nog: door een macaber spel te spelen met nationaal-socialistische, of op zijn minst Duitsnationalistische fantasmagorieën, zouden deze kunstenaars de antinazistische consensus van de naoorlogse Duitse politieke cultuur ondermijnen. ${ }^{9}$

Hoe anders daarentegen was de receptie van deze Nieuwe Duitse Schilderkunst buiten de Bondsrepubliek. In een schril contrast tot de "ronduit afwijzende, ja misprijzende" bejegening door Westduitse critici, stond " $(. .$.$) het jubelgezang rond Anselm Kiefer, dat (...)$ in onophoudelijk crescendo door de internationale kunstpers galmde", aldus de Duitse kunsthistorica Sabine Schütz in haar in 1999 verschenen proefschrift Anselm Kiefer. Geschichte als Material: "Zu einem Engel wollten einige ihn verklären, der mit segnender Geste den Pinsel schwingt". ${ }^{10}$ En zo is het ook Syberberg jarenlang vergaan. Internationaal doorgebroken is hij begin jaren ' 70 met de art-house-film Ludwig - Requiem für einen jungfräulichen König (1972), het eerste deel van een reeks van zes films over de geschiedenis van Duitsland tussen de Reichsgründung van 1871 en de 'zwarte herfst' van 1977: de mammoetcyclus De Graal (1972-1982). Met name in Frankrijk, waar hij op het toppunt van zijn roem illustere intellectuelen als Michel Foucault en Gilles Deleuze tot zijn bewonderaars mocht rekenen, was deze biopic van de maanzieke Wagner-mecenas Ludwig II van Beieren een ongekend succes. Alleen al in Parijs trok de film in korte tijd zoveel bezoekers, dat de recette het filmtheater Cinéma Marais in staat stelde uit te breiden met twee extra zalen, die met de prémiere van een ander deel uit de Graal-cyclus, de gedramatiseerde documentaire Theodor Hierneis oder: wie man ehem. Hofkoch wird (1973), feestelijk in gebruik werden genomen. ${ }^{11}$ Het was hier ook, in het Parijse filmhuiscircuit, dat Syberbergs meest bekende en invloedrijke exegete, de Amerikaanse schrijfster-essayiste Susan Sontag, voor het eerst kennis maakte met het werk dat doorgaans werd gezien als zijn magnum opus: het zeven uur durende vijfde deel van De Graal, Hitler, ein Film aus Deutschland (1977). In een uit 1978 daterende brief aan de regisseur kenschetste Sontag dit werk als "één van de grote kunstwerken van de twintigste eeuw" ${ }^{12}$ Niet veel later publiceerde The New York Review of Books een beroemd geworden essay van Sontags hand, waarin de tegenwoordige 'nonkunstenaar' op een lijn werd geplaatst met zulke grootheden uit de kunstgeschiedenis als Richard Wagner, Thomas Mann, Sergej Eisenstein, James Joyce, Louis-Ferdinand Céline en Antonin Artaud. Want als het ging om Syberberg schoten superlatieven te kort en werden zelfs vergelijkingen met Johann Wolfgang Goethe niet geschuwd. "In Hitler, ein Film aus Deutschland is Syberbergs weergaloze ambitie van een formaat, dat alles overtreft wat ooit op het witte doek te zien is geweest," meende Sontag. "Voor Syberberg geldt wat iemand eens spijtig opmerkte over Wagner: hij bederft onze ontvankelijkheid voor de anderen."14 En dat is nog maar een deel van het verhaal.

Hoe vreemd dit terugblikkend ook mag lijken: in de ogen van zijn bewonderaars gold Hans Jürgen Syberberg als meer dan louter een briljant filmkunstenaar (filmauteur zou een te zwak woord zijn). Vooral in kringen van Franse filosofen en literatuur- of

\footnotetext{
${ }^{9}$ Zie bijvoorbeeld: Krüger, $\mathrm{P}$. "Uberdosis an Teutschem.' Pressestimmen zur Neuen Malerei. in: Arbeit in Geschichte / Geschichte in Arbeit. Hrsg. G. Bussmann. Hamburg, 1988. pp. 65-70.

${ }^{10}$ Schütz, S., Anselm Kiefer. Geschichte als Material. Arbeiten 1969-1983. Köln, 1999. pp. 62ff. Zie eveneens: Schütz, S., Das 'Kiefer-Phänomen'. Zu Werk und Wirkung Anselm Kiefers. in: Deutschlandbilder. Kunst aus einem geteilten Land. Hrsg. E. Gillen. Berlin, 1997. pp. 584-591.

"Overbey, Di, Ludwig's Cook. in: Sight and Sound. International Film Quarterly. 43 (1974). pp. $213 \mathrm{f}$.

${ }^{12}$ Sontag, S., Dear Mr. Syberberg in: Cahiers du Cinéma. Numéro hors-Serié: Syberberg. ed. S. Daney. (februari 1980). p. 94: "I do not think simply that you have made a great film. It is, in some respects, the most extraordinary film I have ever seen, and one of the great works of art of the twentieth century".

${ }^{13}$ Faye, J-P, Faust, Teil III. in: Syberberg Hitler-Film, a.w., pp. 33-35.

${ }^{14}$ Sontag, S., Syberbergs Hitler. in: In het teken van Saturnus. Essays. Vert. D. Brisk. Weesp, 1984. pp. 181 -

222, zie: 222 .
} 
cultuurwetenschappers uit het. Angelsaksische taalgebied, die in het kielzog van Sontag zijn werk ontdekten, genoot hij de reputatie "één van de meest overtuigende en vruchtbare denkers over moderne Duitse identiteit" te zijn, zoals hij nog in '96 in een Amerikaans essay wordt geportretteerd. ${ }^{15}$ Waarbij ongetwijfeld zal hebben meegespeeld, dat de filmmaker ook toen al, begin jaren ' 80 , een indrukwekkend aantal geschriften op zijn naam had staan, die vrijwel onmiddellijk in het Frans en het Engels werden vertaald en net als zijn artistieke werk buiten de Bondsrepubliek enthousiast werden ontvangen. Zo werd het in eigen land reeds bij verschijnen als crypto-fascistisch verguisde pamflet Die freudlose Gesellschaft omstreeks dezelfde tijd aan gene zijde van de Rijn door Philippe Lacoue-Labarthe, een filosoof uit de indertijd buitengewoon productieve en invloedrijke groep rond Jacques Derrida, ${ }^{16}$ gerecenseerd als " $(.$.$) een van de beste boeken, die ooit over het naoorlogse Duitsland zijn$ geschreven". Syberberg, aldus Lacoue-Labarthe in deze recensie uit 1981, heeft "het denken iets te denken [gegeven], wat alle analyses van het nazisme tot dusver nog niet eens bij wijze van een eerste aanzet ter sprake hebben gebracht". Zijn werk zou fundamentele inzichten bieden in tenminste vier issues, die sinds het midden van de jaren '60 hoog op de academische agenda stonden. Wat is nationaal-socialisme? Hoe kan de aantrekkingskracht worden verklaard, die het nationaal-socialisme op de massa heeft uitgeoefend? Hoe verhoudt het nationaal-socialisme zich tot de Duitse cultuurgeschiedenis in het algemeen en de lijn Nietzsche-Heidegger in het bijzonder? En hoe kan het nationaal-socialisme adequaat worden verwerkt, zowel maatschappelijk als artistiek en filosofisch? In de woorden van LacoueLabarthe:

\begin{abstract}
"Syberbergs cinema kent slechts één thema: Duitsland. En wordt door slechts één vraag voortbewogen: hoe was dat mogelijk, het nazisme? In een schril contrast tot hen, die zich beperken tot beschrijven, reconstrueren, onophoudelijk herhalen, of louter aanklagen en een soort sado-maso- of travestieten-versie bieden; die vergeten of domweg niets meer ermee te maken willen hebben, stelt Syberberg vragen. Hardnekkige vragen. En probeert hij te antwoorden, dat wil zeggen: het vragen tot het uiterste toe te spitsen. Daarin schuilt vermoedelijk zijn specifieke originaliteit en kennelijk heeft men moeite om hem dit te vergeven." 17
\end{abstract}

Luttele jaren later behoort Philippe Lacoue-Labarthe zelf tot de weinig vergevingsgezinden.

\title{
1.2 Het probleem
}

Het moment waarop Hans Jürgen Syberberg van een kunstenaar van toch niet gering formaat tot een ook door veel progressieve intellectuelen buiten de Bondsrepubliek gemeden "nonkunstenaar' is geworden, laat zich tot op de maand nauwkeurig bepalen. In de zomer van 1990, niet lang na de val van de Berlijnse muur, is de filmer weer eens het middelpunt van een oproer in de Duitse media. Steen des aanstoots is dit maal het door de chique, in Franse filosofen gespecialiseerde Münchense Matthes \& Seitz-Verlag ${ }^{18}$ uitgegeven pamflet Vom Unglück und Glück der Kunst in Deutschland nach dem letzten Kriege (1990) - het laatste

\footnotetext{
${ }^{15}$ Brockmann, S., Syberberg's Germany. in: The German Quarterly. 69.1 (winter, 1996). pp. 40-62, zie: p. 40.

${ }^{16}$ Zie: Berns, E., Usseling, S, Moyaert, P., Denken in Parijs. Taal en Lacan, Foucault, Althusser, Derrida. Alphen aan den Rijn, 1979. p. 239.

${ }^{17}$ Lacoue-Labarthe, Ph., Syberberg: Über Deutschland nach Hitler. in: Politics / Poetics. Hrsg. Documenta X. Kassel, 1997. pp. 480-484.

${ }^{18}$ Zie: hoofdstuk 7 , paragraaf 8.
} 
deel van een trilogie Notizen, waartoe ook het indertijd zo door Lacoue-Labarthe bewierookte Die freudlose Gesellschaft behoort. Auf deutschem Roß, kopt Die Zeit. ${ }^{19}$ Frühling fü Hitler?, doet Der Spiegel er nog een schepje bovenop: "Syberberg, een "geëngageerde antifascist"? In het meest gunstige geval een eeuwige Hitler-Junge, die zich idealistisch een net, zuiver fascisme wenst - milieuvriendelijk, geworteld in de Heimat en met een fatsoenlijk, want principieel antisemitisme." ${ }^{20}$ Ook de reactie van de achterban in Parijs of New York lijkt zich aanvankelijk te voltrekken volgens het vertrouwde, reeds tien jaar eerder door Klaus Eder geschetste stramien. In Der Spiegel verschijnt een ingezonden brief van de Franse filosoof Jean-Pierre Faye, evenals Sontag en Lacoue-Labarthe een bewonderaar van het eerste uur, waarin protest wordt aangetekend tegen de behandeling van de filmer door de Duitse media. ${ }^{2 !}$ En Sontag laat zich begin oktober zelfs overvliegen naar Oost-Berlijn, om het tijdens een bijeenkomst in de kunstacademie aldaar voor de regisseur op te nemen. "Een Duitse kunstenaar wordt door Duitse intellectuelen als antisemiet verguisd," vat het linkse Franse blad Libération de stand van zaken samen. "Dezelfde kunstenaar wordt door Franse en Amerikaanse intellectuelen met een joodse achtergrond verdedigd."22 Maar de schijn bedriegt:

Zo werpt de afwezigheid van een prominent Syberberg-exegeet als Lacoue-Labarthe, die naar eigen zeggen nadrukkelijk heeft geweigerd zitting te nemen in het inderhaast door Sontag en de Franse filmcriticus Bernard Sobel bijeengeroepen steuncomité, reeds bij voorbaat een zwarte schaduw over dit debat in de Oostberlijnse Akademie. Met de "Pruisenliefde", het "banale neo-romanticisme" en het "domweg onvergeeflijke antisemitisme" van deze late Syberberg, wenst de filosoof niet te worden geassocieerd. ${ }^{23}$ En ook Sontag zelf heeft het er in Oost-Berlijn duidelijk moeilijk mee. Van een onvoorwaardelijke verdediging kan dit maal geen sprake zijn. In plaats daarvan kiest de publiciste voor een beproefde strategie: ze maakt een scherp onderscheid tussen Syberbergs denkbeelden en zijn kunst. Voor de denkbeelden van de auteur van Vom Ungluck und Glitck der Kunst in Deutschland nach dem letzten Kriege heeft ook zij geen goed woord over. Sterker: door sommige uitlatingen in dit nieuwe pamflet voelt ze zich als jodin zelfs 'persoonlijk gekwetst'. Maar, aldus Sontag, dat laat onverlet dat de man die hier in de beklaagdenbank staat "een groot Europees kunstenaar" is, misschien zelfs eén van de grootste überhaupt, die met Hitler, ein Film aus Deutschland een werk heeft afgeleverd, dat zijn evenknie in de geschiedenis van de cinema niet kent. Of, zoals de Oostduitse theatermaker en (latere) intendant van het Brecht-theater aan de Schiffbauerdamm Heiner Müller, een oude vriend van de regisseur, het tijdens deze bijeenkomst formuleert: "Wenn er im Politischen ein Idiot ist, so spricht das nicht gegen seine Kunst". ${ }^{24}$

Het debat krijgt een enigszins tumultueus verloop, wanneer gaandeweg duidelijk wordt dat het Syberberg zelf grote moeite kost deze opsplitsing van zijn persoon in het kunstscheppende genie enerzijds en de 'politieke idioot' anderzijds te onderschrijven. Er

\footnotetext{
${ }^{19}$ Nenning, G., Auf deutschem Roß. Die neue Kunst ist groß, und Syberberg ist ilar Prophet. in: Die Zeit. 31 (27 juli 1990).

${ }^{20}$ Karasek, H., Frühling für Hitler? Zu einem Buch des unverbesserlichen Hans: Jürgen Syberberg. in: Der Spiegel. 36 (1990). pp. $240-245$, zie 240 r, 245.

${ }^{21}$ Zie: Baier, a.w., p. 123.

${ }^{22}$ Citaat ontleend aan: ibidem.

${ }^{23}$ Lacoue-Labarthe, a.w., p. 484.

${ }^{24}$ Baier, a.w, p. 124. Zimmer, D.E., Die Farbe Braun. Ignorant oder Wahnsinniger? - zur Debatte um Hans Jürgen Syberberg in der Ost-Berliner Akademie. in: Die Zeit. 43 (19 oktober 1990) p. 91. Buruma, I., There's no place like Heimat. in: The New York Review of Books. 20 (20-12-1990). pp. 34-43. Boogaard, R., van den, Syberberg pleit voor Duitse cultuur zonder "joods-linkse" invloed. in: NRC Handelsblad. 19-10-1990.
} 
vallen harde woorden over en weer. ${ }^{25}$ En sindsdien is het tussen deze filmmaker en zijn vroegere achterban nooit meer goed gekomen. In de loop van de jaren ' 90 zullen de bewonderaars van het eerste uur zich een voor een distantiëren van de auteur van Vom Unglück und Glück der Kunst in Deutschland nach dem letzten Kriege, wiens denkbeelden nu ook door hen vrijwel unaniem worden gekwalificeerd als "buitengewoon weerzinwekkend" (de Amsterdamse filmtheoreticus Thomas Elsaesser) ${ }^{26}$ Hooguit bestaat onenigheid over de vraag, of deze late Syberberg nog mag doorgaan voor een kunstenaar. Terwijl sommigen, zoals Lacoue-Labarthe, het late werk integraal als platvloerse "non-kunst" verwerpen, ${ }^{27}$ pleiten anderen in navolging van Sontag en Müller voor de noodzaak het kunstwerk tegen de politiek-ideologische hersenspinsels van de maker in bescherming te nemen ${ }^{28}{ }^{28}$ Het is, zoals gezegd, een beproefde strategie, die wel vaker wordt aangewend om kunstscheppende 'politieke idioten' voor het stigma van de 'non-kunstenaar' te behoeden. We hoeven in dit verband slechts te denken aan de discussie rond Arno Breker, waaraan ik hierboven reeds refereerde. Of aan die rond de voormalige ster-cineaste van het Derde Rijk Leni Riefenstahl, waarop ook zij, die minder vertrouwen stellen in Syberbergs kunstenaarschap, zich beroepen. "Zijn [Syberbergs, G.G.] betoog moet met esthetische én politieke argumenten worden tegengesproken;" meent bijvoorbeeld de Belgische kunstfilosoof Klaas Tindemans (1991). "We mogen ons niet meer bezondigen aan de fout die vele progressieve critici in de jaren "70 maakten, die esthetische vorm en maatschappelijke boodschap in een kunstwerk van elkaar loskoppelden, en daarbij Leni Riefenstahl tot een artistiek voorbeeld verhieven - daarbij voorbijgaand aan het feit dat haar enige esthetische en politieke standpunt de verheerlijking van het nazisme was." ${ }^{29}$ Maar zo eenvoudig ligt het misschien toch niet helemaal. Al was het maar, omdat Tindemans zich hier uitgerekend richt tegen degene, die indertijd op deze fout opmerkzaam heeft gemaakt.

Wat de discussie rond deze vermeende 'non-kunstenaar' intrigerend maakt, is zeker óók de samenstelling van zijn voormalige achterban. Stel dat de bewondering beperkt zou zijn gebleven tot een handvol warhoofdige Ewiggestrige; in dat hypothetische geval zou de bijeenkomst in de Oostberlijnse Akademie vast niet zoveel internationale media-aandacht hebben getrokken. Maar zo kunnen Sontag of Lacoue-Labarthe, die beiden met respectievelijk het Riefenstahl-essay Fascinating Fascism (1974) en de Heidegger-studie La fiction du politique (1986) klassiekers op het terrein van het fascisme-onderzoek op hun naam hebben staan, toch bezwaarlijk worden genoemd. ${ }^{30}$ Het was Susan Sontag, die in haar indertijd baanbrekende Riefenstahl-essay als één van de eersten waarschuwde, dat een kieskeurig formalistische omgang met dit soort 'non-kunst' makkelijk zou kunnen leiden tot "een merkwaardig onoplettende aanvaarding van propaganda voor allerlei destructieve gevoelens" - "Het is onoprecht en tautologisch te beweren, dat je alleen maar door Triumph des Willens en Olympia gegrepen wordt omdat ze gemaakt zouden zijn door een geniale

\footnotetext{
${ }^{25}$ ibidem.

${ }^{26}$ Elsaesser, Th., Fassbinder's Germany. History, Identity, Subject. Amsterdam, 1996. pp. 209f.

${ }^{27}$ Lacoue-Labarthe, a.w., p. 484.

${ }^{28}$ Bijvoorbeeld Elsaesser in: Elsaesser, a.w., p. $144 f$.

${ }^{29}$ Tindemans, K., 'Was ist des Teutschen Vaterland'. De besmette woorden van Syberberg. in: Etcetera. Tijdschrift over theater. 35 (15 september - 15 december 1991). pp. 46-52, zie: 46.

${ }^{30}$ De Heidegger-studie van Lacoue-Labarthe werd door Jean-Francois Lyotard ooit getypeerd als "de eerste filosofische bepaling van het nazisme". Citaat ontleend aan: Manschot, H., Woord vooraf bij de Nederlandse uitgave. in: Lyotard, J.-F., Heidegger en 'de joden'. Vert. C. Janssen. Kampen, 1990. pp. 7-20, zie: 15.Voor het Riefenstahl-essay van Sontag en de invloed die het heeft uitgeoefend op het (kunst-)historische debat over de esthetische dimensie van het nazisme, zie: hoofdstuk 5, paragraaf 5 . Alsmede, voor de betekenis van dit essay binnen het Riefenstahl-debat: Leeflang, Th., Leni Riefenstahl. Baarn, 1991. pp. $51 \mathrm{ff}$.
} 
cineaste". ${ }^{31}$ En deze vroegere inzichten hoeven niet noodzakelijk strijdig te zijn met haar latere stellingname in de Oostberlijnse Akademie. Reeds in de jaren '70 heeft Sontag zich er fel tegen verzet, dat Syberberg met 'een allerakeligste propagandiste' als Riefenstahl in éen hoek wordt geplaatst. In haar optiek hoort deze Nieuwe Duitse Filmmaker "tot het ras scheppende kunstenaars als Wagner, Artaud, Céline, Joyce in zijn late periode". ${ }^{32}$ En of het in het geval van déze kunstenaars eveneens "wat al te makkelijk en tot op zekere hoogte ook onoprecht zou zijn kunst te scheiden van ideologie," zoals bijvoorbeeld de Amerikaanse literatuurwetenschapper Stephen Brockmann (1996) betoogt ${ }^{33}$ - daarover kan men van mening verschillen. "Het is niet zo, dat zij [Sontag, G.G.] voorbij gaat aan bepaalde aspecten van Syberberg, waardoor menig Duitse criticus zo overstuur is (...)," verwoordt Tan Buruma in een in 1990 verschenen essay het standpunt van de publiciste. "Maar ze begrijpt dit soort aspecten als slechts één onderdeel van een vruchtbare combinatie van ideeën, beelden en reflecties. Weliswaar moeten we ons rekenschap geven van dit onderdeel - echter zonder ons het zicht te laten benemen op het geniale van dit oeuvre, dat zich niet laat reduceren tot enkele vulgaire opinies en eigenaardigheden, die welhaast onlosmakelijk verbonden zijn aan een groot en excentriek kunstenaarschap." ${ }^{34}$

En toch: als een 'politieke idioot' of, zo men wil, een non-intellectueel werd deze filmmaker, zoals ik hierboven reeds liet doorschemeren, tot aan het verschijnen van dit nieuwe pamflet door zijn bewonderaars beslist niet gezien. Het tegendeel is waar. Niet slechts werden vroegere pamfletten van zijn hand gerecenseerd als meesterlijke traktaten, waardoor men zich in de eigen filosofische of cultuurtheoretische praktijk onbekommerd liet inspireren. ${ }^{35}$ Er bestond bovendien brede consensus, dat Syberbergs denkbeelden dienden te worden beschouwd als het kloppende hart van zijn artistieke werk, dat dan ook alom werd bejubeld als briljante ideeënkunst. "Met deze film is het witte doek gedachte geworden," schreef Jean-Pierre Faye in 1978 over Hitler, ein Film aus Deutschland. "Hij biedt tegenwicht aan de risico's, die de Duitse filosofie tussen Nietzsche en Heidegger op zich heeft genomen. Het volk van de filosofie heeft nu de film, die het verdient en die het vermoedelijk zal moeten miskennen." 36 Zover ging Sontag nog net niet. Maar ook haar houding was aanmerkelijk dubbelzinniger dan je op grond van haar optreden in de Oostberlijnse Akademie zou vermoeden. Nog eind jaren '80, tijdens een symposium aan een Amerikaanse universiteit, noemde ze als het belangrijkste verschil tussen Syberbergs Hitlerfilm en Riefenstahls Triumph des Willens: "Syberbergs film is geen representatie [van de esthetische dimensie van het nazisme, G.G.]. Het is een kritisch werk (...), om een woord te

\footnotetext{
${ }^{31}$ Sontag, S., Fascinerend Fascisme. in: In het teken van Saturnus, a.w, pp. 100 145, zie: 133f. Zie eveneens: hoofdstuk 5 , paragraaf 5 .

${ }^{32}$ Sontag, Syberbergs Hitler, a.w., p. 221.

${ }^{33}$ Brockmann, a.w., p. 59: "(...) Bewonderaars van Syberbergs films bevinden zich in een positie, die vergelijkbaar is met die van de voorvechters van Richard Wagners muziekdrama's. Ze zien zich geconfronteerd met een ontzagwekkend talent, dat helaas wordt ontsierd door een opgeblazen egoïsme en een reactionair, bij tijd en wijlen racistisch denken. In dit soort situaties is het wat al te makkelijk en ook in hoge mate onoprecht, om kunst te scheiden van ideologie en te beweren dat tussen de twee geen connectie bestaat."

${ }^{34}$ Buruma, a.w., p. 34.

${ }^{35}$ Zoals Lacoue-Labarthe in onder meer de genoemde Heidegger-studie. Lacoue-Labarthe, Ph., Heidegger, Art and Politics. The Fiction of the Political. Translation by Ch. Tumer. Oxford, Cambridge, Mass., 1990. pp. $61 \mathrm{ff}$. Zowel de Hitler-film als het pamflet Die freudlose Gesellschaft worden in deze studie door Lacoue-Labarthe gepresenteerd als een filosofische eye-opener. Zie eveneens: Lacoue-Labarthe, Syberberg: Über Deutschland nach Hitler, a.w., p. 484, waarin hij de schatplichtigheid betuigt van zijn, mij onbekende studie Le mythe Nazi (1991) aan Syberbergs werk: "Zonder Hitler, ein Film aus Deutschland zou deze analyse niet mogelijk zijn geweest".

${ }_{36}^{36}$ Faye, a.w., p. 33.
} 
gebruiken, dat ik nooit eerder heb gebruikt: a work of deconstruction". ${ }^{37}$ En dit strookt met het beeld, dat rond Syberbergs oeuvre was ontstaan. In een 1992 verschenen teragblik vat de, aan de afdeling Duitsland-studies van de Universiteit van Chicago verbonden literatuurwetenschapper Eric L. Santner de Syberberg-receptie als volgt samen:

"Wat Syberberg uniek maakte onder de Duitse filmmakers van de jaren 70 , wat hem zo problematisch maakte voor het Duitse publiek en zo intrigerend, ambivalent en ambigu voor het buitenlandse publiek, was - en op dit punt zijn de parallellen met Kiefer frapperend - dat hij zich meer dan welke andere Duitse kunstenaar ook rekenschap gaf van bepaalde esthetische en politieke taboes, voortvloeiend uit het onvermogen om in het reine te komen met de symbolische schuldlast van het nationaal-socialisme, die het onmogelijk maakten ideologische fantasiebeelden adequaat te verwerken en te begraven (...). Syberbergs "dialoog' met de spookverschijningen van het nazisme spitste zich toe op de cruciale rol, die film, schouwspel en culturele productie in het algemeen hebben gespeeld in het tot stand komen en overbrengen van libidineuze fixaties op de fantasie van de organische, nationale gemeenschap, de Volksgemeinschaft. Zijn werk, en dan bovenal de Hitlerfilm, leek niet slechts de Trauerarbeit, waar de Mitscherlichs om vroegen in een esthetische praktijk te vertalen, maar bood bovendien een radicale demonstratie en kritiek van die specifieke 'esthetisering van de politiek', die door Walter Benjamin werd geduid als de sleutel tot een juist begrip van het vermogen van het nationalsocialisme om de massa te mobiliseren." 38.

In hetzelfde stuk laat ook Eric Santner er geen misverstand over bestaan de denkbeelden van de auteur van Vom Unglück und Glück der Kunst in Deutschland nach dem letzten Kriege "obsceen" te vinden. ${ }^{39}$ Maar eigenaardig genoeg ziet hij hierin geen aanleiding zijn beeld van vroegere werken als Hitler, ein Film aus Deutschland, waarvoor het aangehaalde citaat tekenend mag worden genoemd, nog eens kritisch tegen het licht te houden. Net als bijvoorbeeld Lacoue-Labarthe of de Amsterdamse filmtheoreticus Thomas Elsaesser houdt ook Santner vast aan zijn eerdere analyse. Hun kritiek op de late Syberberg ten spijt, verschijnen van de hand van deze auteurs ók in de jaren ' 90 nog veelvuldig essays, waarin het door Santner geschetste beeld wordt verdedigd. ${ }^{40}$ Het enige verschil met vroeger is, dat aan de oude interpretatie nu af en toe een voetnoot wordt toegevoegd, in de trant van: "Ik bevestig alle predikaten van mijn werkanalyse en veroordeel zonder voorbehoud alle 'bijkomstige' uitlatingen van Syberberg [in Vom Unglück und Glück der Kunst in Deutschland nach dem letzten Kriege, G.G.] - in het bijzonder de mijns inziens domweg onvergeeflijke antisemitische uitlatingen" (Lacoue-Labarthe). ${ }^{41}$ Met als gevolg dat tot op de dag van vandaag twee Syberberg-beelden de ronde doen, die zó fundamenteel van elkaar

\footnotetext{
${ }^{37}$ Salmagundi. A quarterly of the humanities and social sciences. 85-86 (winter-spring 1990). pp. 197-313, zie: 217.

${ }^{38}$ Santner, E. L., The Trouble with Hitler: Postwar German Aesthetics and the Legacy of Fascism. in: New German Critique. 57 (zomer 1992). pp. 5-24, zie: pp. 11 f.

39 idem, p. 21.

${ }^{40}$ Bijvoorbeeld: Elsaesser, Fassbinder's Germany, a.w., de passages over Syberberg. Elsaesser, Th., Subject Positions, Speaking Positions: From Holocaust, Our Hitler and Heimat to Shoah and Schindler's List. in: The Persistence of History. ed. V. Sobchack. New York, 1995. pp. 235-287, de passages over Syberberg. Elsaesser. Th., Hitler, ein Film aus Deutschland. in: Sight and Sound. International Film Quarterly. 5 (1992). pp. 49-50. Elsaesser, Th., Filming Fascism: Is History Just an Old Movie? in: Sight and Sound. International Film Quarterly. 5 (1992). pp. 18-21.

${ }^{41}$ Lacove-Labarthe, Syberberg: Uber Deutschland nach Hitler, a.w., p. 484.
} 
verschillen, dat het soms wel eens lijkt dat er tevens twee filmmakers met deze naam moeten bestaan. Volgens het ene beeld, dat van de 'eeuwige Hitler-Junge', hebben we hier van doen met een buitengewoon abjecte 'non-kunstenaar' in de geest van Riefenstahl en Breker die, zoals het in een artikel in de Volkskrant van 7 september 1990 wordt geformuleerd, reeds lang voordat hij op het idee kwam 'zijn gebral aaneen te smeden tot een cultuurfilosofie van Mein Kampf-achtige dimensies, niet vies was van politiek extremisme'. Zoals onder meer uit de Hitler-film zou blijken. ${ }^{42}$ Het andere beeld is dat van Syberberg als een groot dichterdenker in de geest van Walter Benjamin, de Frankfurter Schule en het links-geêngageerde psychiaterechtpaar Alexander en Margarete Mitscherlich, die echter met name in eigen land zou zijn gestoten op een muur van onbegrip. Hetgeen, meent Lacoue-Labarthe in zijn recensie van Die freudlose Gesellschaft, allerminst hoeft te verbazen: "Want (...) in Duitsland (...) behoort onbegrip bij wijze van spreken tot de normaliteit. Hier heeft de eerste de beste, ook dubieuze, maar zich ijverig opdringende illusionist van oudsher meer erkenning gevonden dan de authentieke kunstenaar. En bedroevend lang is, op zijn laatst sinds Hölderlin, de lijst van hen, de allergrootsten meegerekend, die door Duitsland werden veroordeeld tot zwijgen, ballingschap, isolement, waanzin, of zelfmoord."

Het is een van de 'predikaten' van zijn 'werkanalyse', die door Lacoue-Labarthe in een voetnoot bij een in '97 verschenen herdruk van deze recensie worden 'bevestigd'. Maar laat een dergelijk predikaat zich nog wel overeind houden, sinds de ontboezemingen van deze 'authentieke kunstenaar' in Vom Unglück und Glück der Kunst in Deutschland nach dem letzten Kriege? Moet in het licht van zijn latere ontwikkeling niet worden geconcludeerd, dat Duitse kritieken op Syberberg in de jaren 770 op zijn minst voor een deel gerechtvaardigd waren? Of heeft sinds het nog alom geprezen magnum opus Hitler en het pamflet Die freudlose Gesellschaft in zijn denken wellicht een radicale omslag plaats gevonden $?^{44}$ En zo $\mathrm{ja}$, wat kan dan in deze filmmaker gevaren zijn? Hoe is het mogelijk dat iemand die uitgerekend door de wijze waarop hij zich rekenschap gaf van het nazi-verleden in brede kring respect afdwong, zich in minder dan een decennium ontpopt tot een antisemiet of neonazi? Zou Duitsland er dan toch uiteindelijk in geslaagd zijn óók deze "James Joyce van de Nieuwe Duitse Cinema" (de Amerikaanse filmtheoreticus James Franklin) ${ }^{45}$ tot waanzin te drijven, ja tot een onvervalste artistieke én intellectuele zelfmoord? Behoort hij tot het slag

\footnotetext{
${ }^{42}$ Weerdenburg, O., van, Op zoek naar nieuwe mythes om de Duitse dorst te lessen. Neo-fascistisch schotschrift van regisseur Syberberg. in: de Volkskrant. 07-09-1990: "De Duitse regisseur Hans Jürgen Syberberg is niet vies van politiek extremisme. Hij bewondert gewelddadige heersers uit de Duitse geschiedenis, beschreef het Derde Rijk als een groot kunstwerk en zorgde met films als Ludwig II, Karl May en Hitler voor een heftige controverse over de esthetische charme van het demonische. Zelfs de meest integere democraat heeft volgens de cineast een zwak voor de droomkoning uit Beieren, de western-schrijver uit Saksen of de korporaal uit Bohemen. De taboes over die aantrekkingskracht van Ludwig, May en Hitler - als tijdelijke representanten van een eeuwig irrationeel Duits wezen - wil hij met zijn films en radicale theorieen breken. Ware kunst leeft volgens hem van de 'duistere verlangens van het volk', maar zorgt er tegelijkertijd ook voor dat die verlangens niet opnieuw door een mislukte schilder worden bevredigd. Een goede regisseur creëert nieuwe mythes, die de 'Duitse' dorst naar macht, wraak en oorlog op een vreedzame wijze lessen. (..) Hoongelach is natuurlijk Syberbergs deel, maar juist dat lijkt hem ertoe te hebben verleid om een stapje verder te gaan en zijn paranoïde gebral aaneen te smeden tot een 'cultuurfilosofie' van Mein Kampf-achtige dimensies. Vom Ungluck und Glück der Kunst in Deutschland nach dem letzten Kriege heet dit neo-fascistische schotschrift dat onlangs bij de Zuidduitse witgeverij Matthes und Seitz verscheen. (..) Met zijn vaderlandslievende werk zoekt hij aansluiting bij een 'kunst die geweten, eer en moed hoog in haar vaandel heeft': We kunnen dus een paar stevige oorlogsfilms van deze regisseur tegemoet zien."

${ }^{43}$ Lacoue-Labarthe, a.w., p. 482.

${ }^{44}$ Zoals respectievelijk Brockmann, a.w., p. 59 en Baier, a.w., p. 125 zich afvragen. In beide gevallen is de vraag retorisch bedoeld. Duitse kritieken op Syberberg in de jaren '70, denken Brockmann en Baier, waren gerechtvaardigd; Syberbergs denken heeft nadien geen noemenswaardige veranderingen ondergaan.

${ }^{45}$ Franklin, J., New German Cinema: From Oberhausen to Hamburg. London, 1983. p. 164.
} 
mensen, dat in het Duits wel wordt aangeduid met de mooie, maar vrijwel onvertaalbare term Wendehals? Of is hij misschien domweg tot andere conclusies gekomen en heeft hij zich op nieuwe denkwegen begeven, waarop zijn vroegere achterban hem niet langer kan volgen? En zijn de denkbeelden van deze late Syberberg wel zo weerzinwekkend, als vriend en vijand veronderstellen?

Dit soort vragen lijkt me niet louter interessant, voor wie geïnteresseerd is in deze specifieke filmmaker. Terecht legt ook Santner de link met Anselm Kiefer. Jarenlang waren kritieken op de Nieuwe Duitse Filmmaker Syberberg en deze exponent van een Nieuwe Duitse Schilderkunst inwisselbaar - zowel qua inhoud, als teneur. Het ging, met andere woorden, in het Syberberg-debat niet alleen om Syberberg, maar indirect ook om een bepaald soort Westduitse kunst, die begin jaren ' 70 opkwam en, zoals hierboven reeds opgemerkt, werd gekenmerkt door een teruggrijpen op door het nazi-regime gebruikte of misbruikte 'Duitse motieven'. Inmiddels is Kiefer ook in eigen land gerehabiliteerd en kun je geen Duits museum voor moderne kunst binnenlopen, zonder reeds in de hal met een van diens loden vliegtuigen te worden geconfronteerd. Dat het in het geval van Syberberg anders is gelopen, kan diverse redenen hebben. Maar ook in de jaren '90 staat de 'zaak Hans Jürgen Syberberg' niet op zichzelf. Amper drie jaar na het uitwoeden van de controverse rond Vom Unglück und Glück der Kunst in Deutschland nach dem letzten Kriege ontstaat in de Bondsrepubliek grote opschudding over een pamflet van de toneelschrijver en essayist Botho Strauss. ${ }^{46}$

$\mathrm{Nu}$ behoort Botho Strauss tot de weinigen op wier werk de hierboven geformuleerde 'algemene regel', dat Westduitse kunst uit de jaren ' 70 in het buitenland meer werd gewaardeerd dan in het land van herkomst, niet van toepassing is. Strauss was de cultfiguur van tenminste twee generaties Westduitse academici, ${ }^{47}$ die in hem de rechtmatige erfgenaam meenden te ontwaren van de pessimistische cultuurfilosofie van de late Adomo. ${ }^{48}$ Maar net als Syberberg heeft ook hij in de jaren ' 90 zijn vroegere achterban van zich vervreemd - eerst met het 'reactionaire opstel' Anschwellender Bocksgesang (1993), waarin hij zich onverbloemd 'rechts' noemt, en vervolgens door toestemming te verlenen voor een herdruk van dit opstel in het beruchte Nieuw Rechtse groepspamflet Die selbstbewusste Nation (1994), waaraan ook Syberberg een bijdrage heeft geleverd. ${ }^{49}$ Is de voormalige Adornobewonderaar Botho Strauss een fascist geworden?, luidt een in deze controverse veelgestelde vraag. ${ }^{50}$ Zelf geeft de schrijver (1994) hierop het volgende antwoord: "Dat 'rechts', waarom het in deze controverse nog steeds gaat (en dat voor mij wordt belichaamd door het contrarevolutionaire type van Novalis tot Rudolf Borchardt) is inmiddels tot een intellectueel verslavingsprobleem geworden. Het zal ermee te maken hebben, dat dit 'rechts' in een zeer gespannen relatie staat tot het revolutionaire en totalitaire rechts, dat staat en volk in de morele afgrond heeft gestort. Hier is het categorische onderscheid nog bij lange na niet zo

\footnotetext{
${ }^{46}$ Terecht wijst Brockmann, a.w., passim op parallellen tussen de controverses rond Syberbergs Vom Unglück und' Glück der Kunst in Deutschland nach dem letzten Kriege en Strauss' Anschwellender Bocksgesang. Op een in '95, door de Süddeutsche Zeitung in samenwerking met Bayerisches Staatsschauspiel / Marstall georganiseerd symposium over das Rechte, wordt Syberbergs pamflet gepresenteerd als het beginpunt van het zogenaamde What's right, what's left?-debat. Zie de 'editorische Notiz' van Anton Wallner in: Syberberg, H.J., Das Rechte- Iun. München, 1995.

${ }^{47}$ Zoals hij wordt getypeerd in: Radisch, I., Der alte Mann. in: Die Zeit. 33 (12-08-1994).

${ }^{48}$ Zie bijwoorbeeld: Herzinger, R., Die Heimkehr der romantischen Moderne. Über Ithaka und die kulturphilosophischen Transformationen von Botho Strauss. in: Theater Heute. 8 (1996). pp. 7-12.

${ }^{49}$ Die selbstbewusste Nation. 'Anschwellender Bocksgesang' und weitere Beiträge zu einer deutschen Debatte. Hrsg. H. Schwilk, U. Schacht. Frankfurt am Main, Berlin, 1994. Voor de controverse rond Botho Strauss, zie: hoofdstuk 8, passim. De typering van Anschwellender Bocksgesang als een 'reactionair opstel' is ontleend aan een brief van de schrijver aan Theater Heute. Strauß, B., Wille, F., Bekenntnisse eines Unpolitischen? Ein 
vanzelfsprekend als aan de kant van links. Niemand zou het in zijn hoofd halen een schrijver, die opkomt voor een democratisch socialisme, in verband te brengen met de bloedbaden van het stalinisme. Maar zoals bekend geldt alleen al deze symmetriegedachte voor velen als een bron van ergernis." 51

Het is, daarover bestaat brede consensus, een nieuw fenomeen in de Duitse kunsten van de jaren '90: kunstenaars, die het recht opeisen rechts te mogen zijn zönder met de barbarij van het nazi-regime in verband te worden gebracht of als 'non-kunstenaar' uit de kunstgeschiedenis te worden weggeschreven. Jarenlang behoorden begrippen als rechts, conservatief, reactionair, decadent en fascistoide tot hetzelfde semantische veld ${ }^{52}$ Kunstenaars, merkt Botho Strauss op in een essay uit 1987, werden doorgaans verdeeld in drie typen: de sociaal-geëngageerde romanschrijver, de betroffen anarcho-radicaal en de hermetisch-fragmentarische poëet. ${ }^{53}$ Laten we zeggen: de typen Heinrich Böll, Peter Weiss en Paul Celan. En, aldus Strauss in dit essay, alles wat niet aan deze typen beantwoordde, viel domweg buiten het bevattingsvermogen. Nog eind jaren ' 80 zocht je in Duitse handboeken tevergeefs naar het kopje 'naoorlogse conservatieve Duitse literatuur'. Voor zover er überhaupt wel eens gewag van werd gemaakt, constateert de Amerikaanse literatuurwetenschapper Jay J. Rosellini (1997) na raadpleging van enkele standaardwerken uit die periode, werd het begrip 'conservatieve literatuur' steeds gereserveerd voor "een fenomeen dat bestond tot de opkomst van de studentenbeweging en werd vertegenwoordigd door bepaalde auteurs met een duidelijke religieuze signatuur of door bepaalde oude reactionairen (Ewiggestrige)" ${ }^{54}$ Volgens de communis opinio was dit rechtse of conservatieve kunstenaarschap een relict uit het 'bruine' Duitse verleden, dat op zijn laatst sinds de meidagen van '68 door de dialectische vooruitgang als een contradictio in terminis of 'non-kunstenaarschap' zou zijn ontmaskerd.

Daarin is in de jaren ' 90 verandering gekomen. Stond Syberberg bij het verschijnen van Vom Unglück und Glück der Kunst in Deutschland nach dem letzten Kriege nog te boek als een geval apart, achteraf kan worden vastgesteld dat het rumoer rond dit pamflet slechts de opmaat was tot een lange reeks vergelijkbare controverses, waarvan die rond Botho Strauss, de filosoof Peter Sloterdijk en de schrijver Martin Walser de grootste bekendheid genieten. ${ }^{55}$ Zelfs de brechtiaan Heiner Müller, in 1990 nog een politiek onverdacht en gezaghebbend lid van het steuncomité voor zijn oude vriend Syberberg, zal luttele jaren later als vermeende Rechtsintellektueller in opspraak raken. ${ }^{56}$ In de Duitse media wordt midden jaren ' 90 druk gespeculeerd over een renaissance van de na ' 45 afgebroken denktraditie van de Gegenaufklärung. Sommigen spreken zelfs over een nieuwe Conservatieve Revolutie, die in links-liberale en gematigd conservatieve kringen in snel tempo aan aanhang zou winnen. ${ }^{57}$

\footnotetext{
${ }^{51}$ Strauss, B., Der eigentliche Skandal. in: Der Spiegel: 16 (1994). pp. $168 f$.

52 Aldus: Schumann, H.-G., Einleitung, in: Konservatismus. Hrsg. H.-G. Schumann. Königstein, 1984. pp. 11 22, zie: 13 .

${ }^{53}$ Strauss, B., Distanz ertragen. in: Borchardt, R, Das Gespräch über Formen und Platons Lysis Deutsch.

Stuttgart, 1987. pp 101-118 zie: $116 \mathrm{f}$.

${ }^{54}$ Rosellini, J.J., A Revival of Conservative Literature? The 'Spiegel-Symposium 1993' and Beyond. in: Beyond 1989. Re-reading German Literature since 1945. ed. K. Bullivant. Povidence, Oxford, 1997. pp. 109-128, zie: $109 \mathrm{f}$.

${ }^{55} \mathrm{Zie}$ : Gegijzeld door het verleden. Controverses in Duitsland van de Historikerstreit tot het Sloterdijk-debat. red. P. Dassen, T. Nijhuis. Amsterdam, 2001.

${ }^{56}$ Zie bijwoorbeeld: Herzinger, R., Die obskuren Inseln der kultivierten Gemeinschaft. Heiner Müller, Christa Wolf, Volker Braun - deutsche Zivilisationskritiek und das neue Antiwestlertum. in: Die Zeit. 23 (04-06-1993). Eörsi, I., 'Massaker als Sinnsuche'. Über die seltsame Allianz von Heiner Müller und Botho Strauss. in: Der Spiegel. 37 (1994). pp. 215-220.

${ }^{57}$ "Eine neue Konservative Revolution," schrijft bijvoorbeeld de CDU-ideoloog Friedbert Pflüger in een in 1994 verschenen boekje met de veelzeggende titel Deutschland driftet, "wendet sich mit beachtlicher intellektueller
} 
Deze studie wil voorzien in een lacune. De "sleutelfiguur van een vervloekte Duitse intelligentsia" (Le Monde), ${ }^{58}$ die menig bewonderaar in hem meende te ontwaren, is Hans Jürgen Syberberg nooit geweest. We hebben hier echter wel van doen met een markante persoonlijkheid, die zich al vroeg een eigen plek in het (West-)Duitse culturele leven heeft weten te veroveren - ook al was het in de marge en fungeerde hij hoofdzakelijk als een mikpunt van 'spot, cynisme, hoon en scherpe polemiek' (Eder). Met iemand bovendien, die door velen buiten de Bondsrepubliek werd gerekend tot de boegbeelden van de Nieuwe Duitse Cinema, zo niet van de naoorlogse Europese cinema überhaupt en in wiens werk zich belangrijke tendensen weerspiegelen uit de (West-)Duitse kunsten van de afgelopen decennia - van het opduiken van het 'Duitse motief' in de vroege jaren ' 70 tot de renaissance van het gedachtegoed van de Gegenaufklärung in de jaren '90. En, niet te vergeten, met iemand, die internationale weerklank heeft gevonden tot ver buiten de kaders van het vakgebied van de filmkritiek. Van meet af aan hebben zich, naast filmcritici, ook literatuurwetenschappers, filosofen, historici, kunsttheoretici en psychoanalytici gemengd in de discussie rond zijn werk, ${ }^{59}$ dat met name vanuit de Verenigde Staten is ingebracht in de meest uiteenlopende disputen: het postmodernisme-debat, ${ }^{60}$ het wijsgerige Heidegger-debat, ${ }^{61}$ het Vergangenheitsbewälitigungs-debat, ${ }^{62}$ het What's right, what's left?-debat, ${ }^{63}$ het geschiedfflosofische debat over de grenzen aan de mogelijkheden van een wetenschappelijke interpretatie van het verleden, ${ }^{64}$ het (kunst-)historische debat over de esthetische dimensie van het nazisme. ${ }^{65}$

und publizistischer Macht gegen die freiheitliche Demokratie und beeinflußt das Denken der Gesellschaft bis tief hinein in bürgerliche Kreise. Schon haben sich auch führende deutsche Intellektuelle infiziert. Sie folgen dem neuen rechten Zeitgeist, der mit wirklich konservativen Denken fast nichts zu tun hat, wohl aber den Versucht unternimmt, die pluralistische Demokratie revolutionär zu überwinden." Pflüger, F., Deutschland driftet. Die Konservative Revolution entdeckt ihre Kinder. Düsseldorf, Wien, New York, Moskau, 1994. p. 15. Zie eveneens: hoofdstuk 8 , de paragrafen 2 en 3.

${ }^{58}$ Citaat ontleend aan: Mohal, A., Paris applaudiert dem deutschen Ruinentheater. in: Süddeutsche Zeitung. 0210-1984.p. 33.

${ }^{59}$ Ook op dit punt bestaan onmiskenbaar parallellen met de Kiefer-receptie. "Vielfach griff die Diskussion über den immanent künstlerischen oder kunstgeschichtlichen Rahmen hinaus," aldus Schütz, Anselm Kiefer, a. w., p. 62. "So meldeten sich zu Kiefer neben Kunstkritikern und Kunstwissenschaftlern wiederholt fachfremde Autoren zu Wort, etwa aus den Bereichen Geschichts- und Literaturwissenschaf, Philosophie und Psychoanalyse."

${ }^{60}$ Bijyoorbeeld: Kaes, A., From Hitler to Heimat. The Return of History as Film. Cambridge, Mass., London, 1989. Kaes, A., Holocaust and the End of History: Postmodern Historiography in Cinema. in: Probing the Limits of Representation. Nazism and the 'Final Solution'. ed. S. Friedländer. Cambridge, Mass., London, 1992. pp. 206-222.

${ }^{61}$ Bijvoorbeeld: Lacoue-Labarthe, Heidegger, Art and Politics, a.w., pp. 61ff. Loytard, a.w., p. 105.

${ }^{62}$ Bijvoorbeeld: Santner, E.L., Stranded Objects. Mourning, Memory, and Film in Postwar Germany. Ithaca, London, 1990. pp. ix-xiv, 103-149. Rahe, B., Notwendige Trauerarbeit. in: Sammlung: Jahrbuch für antifaschistische Literatur und Kunst. Frankfurt am Main, 1991. pp. 119-123.

${ }^{63}$ Bijwoorbeeld: Brockmann, a.w., passim.

${ }^{64}$ Bijvoorbeeld: Kaes, Holocaust and the End of History, a.w., passim. Koshar, R., Hitler, A Film from Germany. in: American Historical Review. 4 (oktober 1994). pp. 1122-1124. Koshar, R., Hitler, A Film from Germany: Cinema, History, and the Structures of Feeling. in: Revisioning History: Film and the Construction of a New Past. ed. R.A. Rosenstone. Princeton, 1994. pp. 155-173.

${ }^{65}$ Bijvoorbeeld: Friedländer, S., Kitsch und Tod. Der Widerschein des Nazismus. Übersetzt von M. Grendacher. München, Wien, 1994. Bussmann, G., 'Ich kann beim besten Willen kein Hakenkreuz entdecken.' in: Faszination und Gewalt. Zur politischen Asthetik des Nationalsozialismus. Hrsg. B. Organ, W.W. Weiß. 
Toch ontbreekt tot op heden een gedegen monografie, waarin de zaken op een rij worden gezet. Grosso modo kan de secundaire literatuur worden onderverdeeld in drie categorieën. Het leeuwendeel (tenminste negentig procent) bestaat uit recensies, die zijn verschenen in kranten, tijdschriften en vakbladen als Sight and Sound, Cahiers du Cinéma, New German Critique, American Historical Review, of Zeitgeschichte. In de regel gaat het om besprekingen van één werk, die een sterk wisselend niveau vertonen. Zo behoren tot deze categorie, naast tal van weinig diepgravende journalistieke stukken, ook scherpzinnige analyses als Lacoue-Labarthe's recensie van Die freudlose Gesellschaft en Sontags zéer invloedrijke commentaar op de Hitler-film. De tweede categorie betreft studies, waarin het werk van Syberberg wordt geinstrumentaliseerd voor eigen onderzoeksdoeleinden. Ik denk in dit verband bijvoorbeeld aan Lacoue-Labarthe's Heidegger-studie, of aan het zwaar op Sontags Riefenstahl-essay leunende Kitsch und Tod Der Widerschein des Nazismus (1982) van de Israëlische historicus Saul Friedländer. Beide studies gaan niet specifiek over Syberberg, maar gebruiken diens Hitler-film (en, in het geval van Lacoue-Labarthe, Die freudlose Gesellschaft) als een eye-opener voor een analyse van de nationaal-socialistische 'esthetisering van de politiek'. De derde categorie, tenslotte, komt het meest dicht in de buurt bij wat mijzelf voor ogen staat: beschouwingen, die wél specifiek over Syberberg gaan, maar in plaats van zich te beperken tot één werk een beknopte intellectuele en artistieke biografie bieden. De meest belangrijke voorbeelden van deze categorie zijn: Thomas Elsaessers Myth as the Phantasmagoria of History: H.J. Syberberg, Cinema and Representation (1981), Russell R. Bermans Hans Jürgen Syberberg: Of Fantastic and Magical World $(1984)^{67}$ en de hoofdstukken over Syberberg in John Sandfords The New German Cinema (1980), James Franklins New German Cinema: From Oberhausen to Hamburg (1983) en Eric Santners Duitsland-studie Stranded Objects. Mourning, Memory, and Film in Postwar Germany (1990).

Het nadeel van deze, wat ik maar gemakshalve zal aanduiden als overzichtsartikelen, is dat ze alle dateren uit de tijd van vór Vom Unglück und Glück der Kunst in Deutschland nach dem letzten Kriege (1990). En sindsdien hebben in de Syberberg-receptie een tweetal fundamentele veranderingen plaats gevonden. De meest opmerkelijke verandering is het vrijwel gehele stilvallen van het 'secundaire vertoog'. In de jaren ' 90 verschijnen wereldwijd nog slechts mondjesmaat artikelen over Syberberg, waarvan het overgrote deel afkomstig is uit de pen van bewonderaars van het eerste uur als Thomas Elsaesser die, zoals gezegd, onvoorwaardelijk vasthouden aan hun vroegere 'werkanalyse'. Maar in wat nog rest van het Syberberg-debat is deze eerdere lichting exegeten in het defensief gedrongen. Dit is de tweede verandering: ook in de waardering voor Syberbergs werk kan wereldwijd een duidelijke omslag worden waargenomen. Misschien laat de tegenwoordige stand van zaken zich nog het makkelijkste verduidelijken aan de hand van een uitvoerige beschouwing in de German Quarterly van winter 1996 - een van de weinige grote essays over Syberberg, die sinds het nieuwe pamflet nog zijn verschenen en niet uit de pen van een bewonderaar van het eerste uur stammen. In het bewuste stuk grijpt de Amerikaanse literatuurwetenschapper Stephen Brockmann de betrokkenheid van de filmmaker bij het Nieuw Rechtse groepspamflet rond Botho Strauss Die selbstbewusste Nation aan voor een balansopname. De conclusies van Brockmann liegen er niet om. Het Syberberg-beeld van Susan Sontag, Thomas Elsaesser, Eric Santner en Russell Berman, tegen wie hij zich met name richt, zou berusten op een pijnlijke inschattingsfout. Sinds de Hitler-film, betoogt Brockmann, hebben Syberbergs denkbeelden geen noemenswaardige veranderingen ondergaan. En Duitse critici

\footnotetext{
${ }^{66}$ in: New German Critique. 24-25 (fall/winter 1981-1982). pp. 108-154.

${ }^{67}$ in: New German Filmmakers. From Oberhausen Through the 1970s. ed. K. Phillips. New York, 1984. pp. 359-378.
} 
hadden dan ook recht van spreken, toen ze de maker van dit werk reeds eind jaren ' 70 als een gevaarlijke Ewiggestriger verguisden. ${ }^{68}$

In deze studie zal dit, tegenwoordig ook buiten de Bondsrepubliek meest gangbare Syberberg-beeld worden bijgesteld. Met Brockmann ben ik van mening dat op de interpretaties van Elsaesser, Santner, Berman en, tot op zekere hoogte ook Sontag inderdaad het nodige valt af te dingen. Of in elk geval is de Kehre, die Syberberg in de jaren ná zijn Hitler-film zou hebben doorgemaakt, aanmerkelijk minder ingrijpend dan deze auteurs veronderstellen. Maar dit betekent nog niet noodzakelijk, dat de ongemeen felle kritiek, die hij met name in eigen land van meet af aan over zich heen heeft gekregen, gerechtvaardigd zou zijn. Om de geldigheid van deze kritiek te kunnen bepalen, zullen we eerst antwoord moeten geven op een aantal voor de hand liggende vragen, die ik in de vorige paragraaf terloops heb aangestipt. Ik formuleer dezelfde vragen nogmaals in iets andere bewoordingen. Wat kan deze filmer/pamflettist, die jarenlang door velen buiten de Bondsrepubliek werd gezien als "het geweten van een natie wier wonden nog altijd niet geheeld zijn" (Libération), ${ }^{69}$ ertoe hebben gebracht zich in (extreem-)rechts vaarwater te begeven? Is de tegenwoordige Syberberg daadwerkelijk de crypto-fascist, waarvoor hij nu zelfs in kringen van zijn meest fervente bewonderaars van weleer doorgaat? En zo ja, hoe verhoudt zich dit dan tot vroegere werken als Hitler, ein Film aus Deutschland? En hoe tot de diverse duidingen, die voor- en tegenstanders van deze vroegere werken hebben gegeven?

We zullen enkele van Syberbergs speelfilms, documentaires, theatervoorstellingen en installaties nog eens onder de loep nemen. Waarbij onze aandacht niet zozeer zal uitgaan naar artistieke aspecten, als wel naar kunstpolitieke ideeën, zoals die door vormgeving én inhoud worden gearticuleerd. Want een scheiding met terugwerkende kracht tussen esthetische vorm en maatschappelijke boodschap in een kunstwerk, waarvoor sommigen in de discussie rond Vom Unglück und Glück der Kunst in Deutschland nach dem letzten Kriege hebben gepleit, lijkt me met het oog op de probleemstelling weinig vruchtbaar. Geheel in lijn met de receptie tot aan het verschijnen van dit pamflet, zal Syberbergs artistieke werk worden geïnterpreteerd als ideeën-kunst. En, wederom geheel in lijn met de receptie tot dan, zal ik in mijn interpretatie van deze ideeën-kunstwerken veelvuldig gebruik maken van interviews met en boeken, pamfletten, essays en voordrachten van de maker. Zelf heeft Syberberg er tijdens het debat in de Oostberlijnse Akademie op gewezen, dat hij in Vom Unglück und Glück der Kunst in Deutschland nach dem letzten Kriege niet aan het woord is als politicoloog, filosoof of activist, maar als kunstenaar die zijn toevlucht heeft gezocht tot het papier om in de kunstwerken gearticuleerde ideeën nader toe te lichten en verder uit te werken. ${ }^{70}$ En zo zal het niet-artistieke werk, ongeacht of het gaat om een tekst van eigen hand of een door derden opgetekend interview, in deze studie ook worden benaderd.

Maar het zijn niet louter de kunstpolitieke ideeën van de kunstenaar Syberberg, waarmee we ons in deze studie zullen bezig houden. Ook het 'secundaire vertoog' verdient,

\footnotetext{
${ }^{68}$ Brockmann, a.w., passim. Zie eveneens: Baier, a.w., passim. Ook Ian Buruma, a.w., passim, beschouwt de Syberberg van de Hitler-film als een 'reactionaire estheet'. En volgen we Rosellini, a.w., p. 128, dan wordt Syberberg door Brockmann nog te mild behandeld: "Stephen Brockmann (...) speaks of an ideological affinity between 'the two conservative aesthetes' Hans Jürgen Syberberg and Botho Strauss. Although there are indeed similarities between the two figures, one cannot ignore significant differences. Strauss is not an anti-Semite, and he is not obsessed with the notion of a purely German culture. (...) Unlike Syberberg, who spent the first decade of his life in the Third Reich, he is also not fascinated by Hitler." Het Syberberg-beeld, dat in dit citaat wordt geschetst, mag in hoge mate typerend worden genoemd voor de reputatie, die de filmer sinds de publicatie van Vom Unglück und Glück der Kunst in Deutschland nach dem letzten Kriege ook buiten de Bondsrepubliek heeft gekregen.

${ }^{69}$ Citaat ontleend aan: Mohal, a.w., p. 33.

${ }^{70}$ Baier, p. 124
} 
naar ik meen, onze aandacht. Aan de duidingen door voor- en tegenstanders hoop ik niet slechts waardevolle inzichten te ontlenen in dit oeuvre, maar ook in de ideeënhistorische context waarin de maker zich beweegt en waarin de discussie rond zijn werk zich heeft afgespeeld. Ik wees er reeds op, dat de 'zaak Hans Jurgen Syberberg' nooit op zichzelf heeft gestaan. Ook Anselm Kiefer, Markus Lüpertz of een collega uit de Nieuwe Duitse Cinema als Rainer Werner Fassbinder werden er jarenlang in eigen land van verdacht apologeten van een verrechtsing te zijn. De lijst met namen van illustere Duitse kunstenaars en intellectuelen, die op een gegeven moment van hun carrière met (extreem-)rechts in verband zijn gebracht, laat zich zelfs moeiteloos aanvullen. Want de zichzelf rechts noemende kunstenaar mag dan pas relatief laat zijn intrede in de naoorlogse Duitse kunstgeschiedenis hebben gedaan; de vrees voor een nieuwe Conservatieve Revolutie, oók en misschien zelfs bovenal in gematigd conservatieve en linkse kringen, is bij wijze van spreken van alle tijden. "Het ideologische klimaat van de jaren ' 70 (..) wordt beheerst door een brouwsel van nieuwe en oude conservatieve stromingen," meende bijvoorbeeld de Frankfurter filosoof Jürgen Habermas in $19777^{71}$ Achteraf kost het niet veel moeite om vast te stellen, dat deze indertijd breed gedeelde vrees ongegrond is gebleken. Veeleer werd het ideologische klimaat in én buiten de Bondsrepubliek vanaf pakweg het midden van de jaren ' 60 tot ver in de jaren '80 juist beheerst door een conglomeraat van nieuwe en oude línkse stromingen. Ook de discussie rond het werk van Syberberg was een vrijwel exclusief linkse aangelegenheid, in de zin dat vrijwel alle deelnemers aan deze discussie argumenteerden langs lijnen die reeds in het interbellum waren uitgezet door neo-marxistische theoretici als Walter Benjamin en Theodor Adorno. En om tot een afgewogen oordeel te kunnen komen over deze filmmaker en de bewondering en weerzin die hij heeft opgeroepen, is deze ideeënhistorische context mijns inziens van cruciaal belang:

Zo zullen we zorgvuldig moeten nagaan wat binnen het toenmalige, door links gedomineerde publieke debat, de exacte connotatie was van begrippen als rechts, conservatief, reactionair, decadent en fascistoïde. In dit verband uitermate invloedrijk, zowel in de discussie rond Syberberg als meer in het algemeen, waren een reeks 'dialectisch materialistische" studies van de Hongaarse filosoof Georg Lukács, waarin het rechtse denken (in de ruime zin van het woord) wordt gedefinieerd als een 'reactie' op de 'redelijke vooruitgang' van de geschiedenis in de richting van een socialistische samenlevingsvorm. Van Lukács stamt de klassiek geworden tweedeling van de Duitse cultuurgeschiedenis in 'rationele' en 'irrationele' traditiesporen, die zich tot elkaar zouden verhouden als these en anti-these (reactie). Tegenover de 'rationele' Verlichtingstraditie Lessing-Schiller-MarxThomas Mann-Ulbricht stond de 'irrationele' anti-Verlichtingstraditie Schelling-WagnerNietzsche-Heidegger-Hitler ${ }^{72}$ In deze zin blijkt ook Habermas het begrip conservatisme te gebruiken. De 'nieuwe en oude conservatieve stromingen', waarop de filosoof in het hierboven aangehaalde citaat doelt, hebben met elkaar gemeenschappelijk hun oriëntatie op de 'irrationele' (lees: rechtse, conservatieve, reactionaire, decadente en fascistoïde) tradítie van het (post-)nietzschiaanse denken, die "dioor de nazi's zo grondig in diskrediet" zou zijn gebracht dat "in de Bondsrepubliek een (...) "authentiek conservatisme' niet langer kon bestaan" ${ }^{73}$ En ook de toenmalige kritiek op kunstenaars als Syberberg en Kiefer dient in dit licht te worden begrepen: met hun recycling van 'Duitse motieven' uit de koker van het 'irrationalisme' zouden ze het ware linkse project van de Aufarbeitung van de Verlichtingstraditie in gevaar brengen.

\footnotetext{
${ }^{71}$ Habermas, J., Kleine Politische Schriften. (I-IV). Frankfurt am Main, 1981. p. 285

${ }_{72}$ Zie: hoofdstuk 2, paragraaf 4.

${ }^{73}$ Habermas, a.w., pp. $386,444-464$.
} 

werk ons waardevolle inzichten in dit debat. Behalve een intellectuele kunstenaarsbiografie biedt deze studie dan ook, via de omweg van Syberberg, tevens een kleine geschiedenis van het linkse denken over rechts in Duitsland.

Vooruitlopend op de hierna volgende hoofdstukken, kunnen in dit oeuvre een drietal, elkaar deels overlappende fasen worden onderscheiden: een post-brechtiaanse, een neowagneriaanse en een Conservatief Revolutionaire. De eerste fase, die het onderwerp vormt van hoofdstuk 2 Leerjaren, begint in het Oost-Berlijn van de vroege jaren ' 50 , meer specifiek in het Deutsches Theater, alwaar het Brecht-gezelschap Berliner Ensemble een tijdelijk onderkomen heeft gevonden. Op verzoek van Brecht verfilmt een amper achttien jaar oude Hans Jürgen Syberberg diens, door het SED-regime fel bekritiseerde enscenering van de Urfaust (1953). Het zijn, in het Oosten van Duitsland, de hoogtijdagen van de formalisme/realisme-strijd, die in grote lijnen een voortzetting is van het expressionismedebat van de jaren '30, ook wel de Brecht-Lukács-controverse genoemd. Omstreeks dezelfde tijd woedt in het Westen van Duitsland een verhitte controverse tussen traditionalisten als de kunsthistoricus Hans Sedlmayr en modernisten als Theodor Adorno: het modernisme-debat. $\mathrm{Na}$ zijn vlucht uit de DDR midden jaren '50 studeert Syberberg kunstgeschiedenis en germanistiek aan de Universiteit van München, waar Hans Sedlmayr een van zijn docenten is. Later, in de jaren ' 90 , zal hij Sedlmayr aanwijzen als zijn grote voorbeeld. Maar van het rechtsintellectualisme van zijn Münchense hoogleraar, wiens naam tot op de dag van vandaag welhaast een synoniem is voor het ultra-conservatieve verzet tegen de moderne tijd, is de jonge Syberberg nog ver verwijderd. In zijn vroege films, die ontstaan tussen 1965 en 1970, zoekt hij aansluiting bij een artistieke stroming, die door cultuurconservatieven als Sedlmayr en 'orthodox marxisten' als Lukács eensgezind als decadente non-kunst wordt verguisd: het post-brechtiaanse absurdisme van Friedrich Dürrenmatt en Samuel Beckett.

Wie Syberberg zegt, denkt echter vooral aan zijn werk uit de tweede, neowagneriaanse fase: de mammoet-cyclus De Graal (1972-1982). Zoals reeds opgemerkt gaat het om zes films. De spil wordt gevormd door drie speelfilms, de zogenaamde Duitse trilogie: Ludwig - Requiem für einen jungfräulichen König (1972), Karl May - Auf der Suche nach dem verlorenen Paradies (1974) en Hitler, ein Film aus Deutschland (1977). Daarnaast bevat de Graal-cyclus een tweetal bijfilms. De gedramatiseerde documentaire Theodor Hierneis oder: Wie man ehem. Hofkoch wird (1972), waarin de Beierse volksacteur Walter Sedlmayr op historische locatie vrijwel integraal de memoires naspeelt van de voormalige keukenchef aan het hof van 'sprookjeskoning' Ludwig II, het 'maagdelijke' hoofdpersonage van het eerste deel van de Duitse Trilogie. En de beruchte Bayreuth-documentaire Winifred Wagner und die Geschichte des Hauses Wahnfried von 1914-1975 (1975), een vijf uur durend marathon-interview met Winifred Wagner-Williams, de schoondochter van Richard Wagner, intendant in ruste van het Wagner-festival in Bayreuth én hartsvriendin van het heel wat minder 'maagdelijke' hoofdpersonage van het laatste deel van de Duitse trilogie: Adolf Hitler. De cyclus wordt afgesloten met de filmopera Parsifal (1982) - een "vertaling in cinema' van Wagners gelijknamige Bühnenweihfestspiel. Alles bij elkaar goed voor een kleine 23 uur. Het moge duidelijk zijn, dat dit werk ons voor een keuze stelt: ofwel het geheel in vogelvlucht analyseren, ofwel enkele films eruit lichten en wat meer de diepte ingaan. Ik heb gekozen voor de laatste optie.

Het overgrote deel van het boek, de hoofdstukken 4 tot en met 7 , gaat op aan een minutieuze bespreking van twee delen. Dat hiertoe Hitler, ein Film aus Deutschland behoort, zal na het voorafgaande niet als een verrassing komen. Om een drietal redenen is mijn keuze voor het andere werk gevallen op de Winifred-Wagner-documentaire. Om te beginnen hebben we hier van doen met het, op de Hitler-film na, meest bekende deel van De Graal. De esthetische vormgeving is bovendien minder complex dan die van de overige delen, hetgeen 
niet slechts een detailanalyse, maar ook een vergelijk van interpretaties aanzienlijk vergemakkelijkt. Maar de belangrijkste reden is het onderwerp: de geschiedenis van het Wagner-festival in Bayreuth. Terecht noemt Thomas Elsaesser (1981) Wagner "the key complex"76 in deze cyclus: Wagner is de verbindende schakel, die als een thematische én esthetische rode draad door alle delen loopt. Het specifieke karakter van Syberbergs verhouding tot Wagner en de plaats van zijn neo-Wagner-films binnen het Wagner-debat; vanaf de controverse Ernst Bloch-Lukács/Thomas Mann in het interbellum tot het rumoer rond het linkse wagnerianisme van Neu Bayreuth in de jaren '70 en ' 80 , zal worden onderzocht in hoofdstuk 3 Wagners tweede verschijning.

De receptiegeschiedenis komt uitvoerig aan bod in hoofdstuk 4 De oude dame, waarin ik een reeks Duitse en Angelsaksische commentaren op de Winifred-Wagner-documentaire de revue zal laten passeren. De besproken commentaren, onder meer van de hand van Elsaesser en Santner, hebben met elkaar gemeenschappelijk, dat ze Syberbergs werk situeren binnen het door Alexander en Margarete Mitscherlich halverwege de jaren "60 aangezwengelde debat over het Duitse 'onvermogen om te rouwen'. Syberbergs positie binnen dit maatschappijpsychologische debat en het nauw eraan gelieerde (kunst-)historische debat over de esthetische dimensie van het nazisme, zal verder worden uitgediept in hoofdstuk 5 Een psychologisch Versailles, waarin eveneens de Winifred-Wagnerdocumentaire centraal staat. Uitgangspunt van deze Westduitse controverses uit de jaren ' 70 is de aanname, dat de Duitsers na ' 45 'irrationele' denkpatronen, gevoelens en fantasmagorieèn niet adequaat zouden hebben verwerkt, maar verdrongen. Nu, drie decennia later, zou het indertijd verdrongene weer aan de oppervlakte komen en het 'ideologische klimaat' opnieuw worden 'beheerst door een brouwsel van oude en nieuwe conservatieve stromingen' (Habermas). Het debat over deze vermeend conservatief/reactionaire Tendenzwende, dat met het postmodemisme-debat tussen Habermas en Franse postnietzschianen als Michel Foucault en Jacques Derrida een grensoverschrijdend karakter heeft gekregen, vormt de achtergrond van mijn analyse van Hitler, ein Film aus Deutschland in hoofdstuk 6 De geschiedenisfabriek.

Zeker is, dat Syberberg zelf zich gedurende deze periode nog niet ziet als rechts. Deze Syberberg van de Winifred-Wagner-documentaire en de Hitler-film staat in zijn eigen beleving nog met beide benen in een weliswaar dissidente, maar toch uitgesproken linkse denktraditie, die teruggaat op Brecht, Bloch en Mayer. Pas halverwege de jaren ' 80 , in de tijd van de theaterperformance Die Nacht (1984), rijpt bij de kunstenaar gaandeweg het inzicht, dat hij langs de door deze neo-marxistische theoretici gebaande denkwegen niet meer verder komt en neemt de derde, Conservatief Revolutionaire fase een aanvang. Deze conservatieve Kehre, die zich afspeelt tegen het decor van het debat over de betekenis van de $8^{\text {ste }}$ mei 1945 - bevrijding of nederlaag? -, zal worden geanalyseerd in hoofdstuk 7 Tweeërlei zonsondergangen. In dat hoofdstuk zal tevens antwoord worden gegeven op de probleemstelling: hoe verhoudt het rechts-intellectualisme van de late Syberberg zich tot reeds in de Hitler-film gearticuleerde denkbeelden? In het afsluitende hoofdstuk 8 tenslotte, Finale, keren we terug naar het schandaal rond Vom Unglück und Glück der Kunst in Deutschland nach dem letzten Kriege, dat dan binnen het kader zal worden geplaatst van het mede door Botho Strauss met zijn Bocksgesang-essay aangezwengelde What's right, what's left?-debat van midden jaren ' 90 .

\footnotetext{
${ }^{76}$ Elsaesser, Myth as the Phantasmagoria of History, a.w., p. 150.
} 


\subsection{Inleiding}

De titel van het hoofdstuk spreekt voor zich. 'Leerjaren' noemen we de fase in ons leven, waarin we onze intellectuele vorming hebben genoten. Maar leren doen we altijd met het oog op een latere doel. In het geval van Syberberg zal de vorming $\mathrm{pr}$ ' goed vruchten gaan afwerpen in de jaren '70 en de vroege jaren '80, als hij zijn meest beroemde en geprezen werken maakt: de films van De Graal. Met deze latere films in het achterhoofd zullen we hier op zijn vroegere fase terugblikken. Want als hij in ' 72 internationaal doorbreekt met Ludwig Requiem für einen jungfräulichen König, het eerste deel van De Graal, is Syberberg reeds 37 jaar oud. Hij heeft dan al een bescheiden oeuvre opgebouwd van acht films, is gepromoveerd in de kunstgeschiedenis en korte tijd gelieerd geweest aan het Brecht-theater in Oost-Berlijn. Het hoofdstuk schetst deze voorgeschiedenis - de periode die aan De Graal voorafgaat en waarin hij de intellectuele en artistieke bagage vergaart, die hem in staat zal stellen deze werken te maken. We zullen de filmer op zijn levenspad volgen, vanaf de geboorte tot aan de vroege films uit de tweede helft van de jaren ' 60 en onderwijl een tweetal lijnen uitzetten, die als rode draden door de hierna volgende hoofdstukken lopen. Elk van deze lijnen is verbonden met een persoon, die door Syberberg in een bepaalde fase van zijn carrière wordt aangewezen als zijn grote voorbeeld. In de jaren ' 80 en ' 90 , de periode waarin hij zich steeds nadrukkelijker zal gaan manifesteren als een cultuurconservatief, beroept hij zich steevast op de Oostenrijke kunsthistoricus Hans Sedlmayr, één van zijn docenten aan de Münchense Ludwig-Maximillians-Universität. Tot dan ontvangt zijn werk de belangrijkste stimulans van het tweede grote voorbeeld: Bertolt Brecht, bij wiens Berliner Ensemble zijn loopbaan in de vroege jaren ' 50 een aanvang neemt.

\subsection{Het verloren huis}

Hans Jürgen Syberberg wordt in 1935 als zoon van een hereboer geboren in Nossendorf, een klein dorp in het landelijke, in het Noorden van Duitsland gelegen Voor-Pommeren. Naar het zich laat aanzien heeft het weinig gescheeld of hij zou in de voetsporen van zijn vader zijn getreden. Dat het anders is gelopen, komt door een samenloop van omstandigheden. Om te beginnen dient hier te worden gewezen op de cinefiele passie van de beide ouders. Over de moeder doet in de familie het verhaal de ronde, dat ze een half uur voor de bevalling nog in de bioscoop zou hebben gezeten. En de vader staat in het dorp te boek als een bevlogen amateurfotograaf. Van zijn hand zijn de eerste films, die Syberberg als kind ziet: $8-\mathrm{mm}$ opnamen van het leven op het Pommerse platteland aan de vooravond van de Tweede Wereldoorlog ${ }^{1}$ - het Arcadië, waarvan hij later in zijn eigen Requiem voor het einde van Pruisen (1984-'91) het verlies zal beklagen.

De foto's uit het familiealbum, die Syberberg in 1980 publiceert in het Franse filmblad Cahiers du Cinéma, verschaffen een indruk van deze "vroegste films voor het oog van het geheugen". 2 Ze tonen Syberbergs geboortehuis, de kolossale hereboerderij van Nossendorf, temidden van uitgestrekte velden, akkers en bossen; de arbeiders, werkend op het land tijdens het binnenhalen van de oogst; de vader, in luitenantsuniform, compleet met monocle en

\footnotetext{
Syberberg, H.J. Syberbergs Filmbuch. München, 1976. p. 110.

${ }^{2}$ Syberberg, H.J., Au dossier d'une généalogie. in: Cahiers du Cinéma. Numéro hors-serie: Syberberg. ed. S.

Daney. (februari 1980). p. 88.
} 

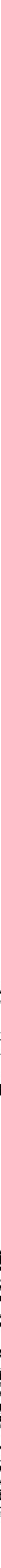
rijzweepje, als cavalerist tijdens de Eerste Wereldoorlog; de moeder, zichtbaar onwennig poserend samen met enkele arbeidersvrouwen voor de auto van de vader - naar verluidt de eerste auto van het dorp. Ook krijgen we een eerste glimp (afbeelding 1) van Syberberg zelf te zien. In de zomer van ' 38 wandelt hij als peuter van amper drie hand in hand met zijn vader langs de stranden van de Oostzee. Foto's die, aldus Syberberg in een toelichting, "de vroegste kindertijd, voor de tijd van het bewustzijn tot een mythe maken": "Zo bestaat mijn moeder, die zich een jaar na de geboorte heeft laten scheiden, louter in deze beelden. Zoals zoveel andere dingen overleeft ze als fotoherinnering."

$\mathrm{Na}$ de scheiding verhuist de moeder naar Berlijn. Syberberg blijft achter op het landgoed. Hij wordt, tot de vader hertrouwt, groot gebracht door gouvernantes en geniet naar eigen zeggen een strenge, Pruisisch-conservatieve opvoeding. ${ }^{4}$ Toch zal hij zichzelf later typeren als: "een gelukkig kind, ver weg en in vrede op het platteland levend." Voedselschaarse en bommennachten, de voor veel Duitsers zo traumatische ervaringen van de laatste oorlogsjaren, heeft hij dankzij de 'genade van de plattelandsgeboorte' nooit aan den lijve ondervonden. Terwijl leeftijdsgenootjes in de vuurzeeën van de Duitse' steden proberen te overleven, speelt Syberberg in de beschermende omgeving van het huis van de vader met kleine modelletjes van U-boten en torpedo's. "Mijn herinneringen [aan de oorlog, G.G.] zijn verder voornamelijk akoestisch," bekent hij in een in 1977 afgenomen interview. "Geluiden op de radio, stemmen, muziek. Optisch beperken ze zich tot informatie over overkomende vliegtuigen." Pas in mei 1945, met de komst van de soldaten van het Rode Leger in het dorp; "het schrikbeeld van de late kindertijd", ${ }^{7}$ breekt de oorlog ook in Syberbergs Arcadië binnen. Het versje, dat zijn vader hem heeft geleerd en dat hij tijdens de oorlogsjaren samen met de kinderen uit het dorp zingt, blijkt dan een profetische betekenis te hebben: "Geniet van de oorlog, want de vrede zal verschrikkelijk zijn. ${ }^{8}$

Nossendorf, dat een kleine honderdvijftig kilometer ten westen van de Oder ligt, ${ }^{9}$ wordt een onderdeel van de Russische bezettingszone, de latere Duitse Democratische Republiek. Anders dan de Duitsers in Oost-Pommeren, blijft Syberberg het lot van verdrijving bespaard. Wel voeren de Sovjets in hun zone een strenge denazificatiepolitiek, die zich onder meer richt tegen het grootgrondbezit - het, zoals het in een DDR-geschiedschrijving uit de vroege jaren ' 50 wordt genoemd, "historisch allang overleefde bolwerk van de reactie en het militarisme," 10 waartoe ook Syberbergs vader behoort. De agrarische standenmaatschappij van het oude Pommeren wordt opengebroken. De vader, die tot dan als grondbezitter in het dorp een positie heeft ingenomen vergelijkbaar met die van een heer, wordt in staat van beschuldiging gesteld en van zijn rechten beroofd. Het familiebezit, waaronder Syberbergs geboortehuis, wordt door de bezetter geconfisqueerd; de landerijen worden onteigend, gecollectiviseerd en versnipperd.

\footnotetext{
${ }^{3}$ ibidem.

${ }^{4}$ Müller, A., Im Gespräch mit ... Hamburg, 1989. pp. $183 \mathrm{ff}$.

${ }_{6}^{5}$ Syberberg, HJ., Die freudlose Gesellschaft. Notizen aus dem letzten Jahr. München, Wien, 1981. pp. 145ff.

${ }^{6}$ Winter, de, L., Het Duizendjarig Rijk als filmlokatie. in: Hollands Diep. 6 (26-03-1977). pp. 40-43, zie: 43.

${ }^{7}$ Syberberg, a.w., p. 146.

${ }^{8}$ Syberberg, H.J., Vom Unglück und Glück der Kunst in Deutschland nach dem letzten Kriege. München, 1990. p. 98.

En dus niet in Oost-Pommeren, zoals bijvoorbeeld Ian Buruma en James Franklin denken. In tegenstelling tot wat Buruma beweert, behoort Syberberg niet tot zogenaamde Heimatvertriebenen. Buruma, $L$., There's no place like Heimat: in: The New York Review of Books. 20 (december 1990). pp. 34-43. Franklin, J., New German Cinema. London, 1983. p. 165.

${ }^{10}$ Bartel, W., Einfuhrung. in: Die Deutsche Demokratische Republik auf dem Wege nach dem Sozialismus. Teil I. (1945-1949) Hrsg. P. Stulz, S. Thomas. Berlin, 1959.
} 
Op een van de foto's in het familiealbum (afbeeiding 2) zien we het geboortehuis, kort na de plunderingen door het Rode Leger. De voorheen zo statige hereboerderij is een ruine geworden; het eff ligt bezaaid met door onkruid overwoekerd puin. "Je kunt je niet voorstellen, wat voor een symbool dat was," vertelt Syberberg in een interview uit 1983. "Het huis overgenomen door hen, alles vernield dat heilig was voor mijn ouders: de schilderijen, het Meißen-Porselein, en mijn vader gereduceerd tot iemand die elke dag doodgeschoten kon worden, want dat is wat normaliter gebeurde. (...) Hij had geen enkele rechten meer, niet alleen omdat hij Duitser was, maar daarbij ook nog grondbezitter. (...) Van het ene uur op het andere was ik teruggebracht van de prins van het dorp tot niets". "De vernietiging van het geboortehuis is niet slechts een symbool voor het collectieve identiteitsverlies, dat zijns inziens na " 45 in Duitsland heeft plaats gevonden - voor "de deling van het land" en "het einde van Duitsland onder de oude omstandigheden". ${ }^{12}$ Het is ook, en misschien zelfs bovenal, het persoonlijke symbool van een kunstenaarschap, dat bij wijze van spreken temidden van de ruïnes wordt geboren. "Uit de foto's van de herinneringen aan de kindertijd en de in het leven van mijn vader productief geworden catastrofe 1945 , de ineenstorting van Duitsland, ontstond langs eigenaardige omwegen mijn huidige existentie," schrijft hij in de Cahiers du Cinéma. "Ik vraag me vaak af, of ik dit ooit geworden zou zijn, gedaan zou hebben, zonder het afgedwongen offer van mijn vader en het verlies van zijn toenmalige existentie en het totale opnieuw beginnen in de ook voor hem dierbaar geworden wereld van de fotografie, de eerste stap tot mijn latere films."13

Omdat de vader (een "Duitsnationalistische Hitler-opponent" ${ }^{\text {"14 }}$ ) geen lid van de NSDAP is geweest, wordt zijn leven door de commandant van het Rode Leger gespaard. Op het verlies van huis en haard zou hij aanvankelijk nogal laconiek hebben gereageerd. In de veronderstelling verkerend, dat de bezetting van tijdelijke duur zal zijn, neemt hij plaats in het Bureau voor de Vrede, dat de grond onder de kleinere boeren moet verdelen en werkt hij schouder aan schouder met zijn voormalige loonarbeiders op de gecollectiviseerde landerijen. "Nooit heb ik [hem] boos zien worden op de Russen, die de oorzaak waren van zijn onteigening en de verwoesting van zijn leven. Liever lachen om zoveel komische situaties vol levensangst en oneconomische domheid."15

Het zal twee jaar duren voordat het ook Alois Syberberg, zoals de naam van de vader luidt, duidelijk wordt dat de tijden van weeleer niet spoedig terugkeren. In 1947 - het jaar waarin de staat Pruisen door de geallieerde controleraad definitief wordt opgeven - verlaat hij het dorp en vestigt hij zich samen met zijn zoon in Rostock aan de Oostzee, de meest dichtbij gelegen grote stad. Om in zijn levensonderhoud te voorzien laat hij zich omscholen tot fotograaf en opent een klein winkeltje in fotografische artikelen. Syberberg bezoekt de inmiddels gestaliniseerde middelbare school. Hij leert Russisch, verdiept zich in 'diamat', de leer van het 'dialectische materialisme' en maakt, dankzij de cultuurpolitiek in de DDR (zie hier beneden), kennis met de Duitse klassieken - "een kunstopvoeding in [Pruisisch-Duitse] cultuurerfenis en socialistisch realisme van Russische herkomst, in de Oostduitse cultuurkolonie (...)". ${ }^{16}$ Een meer ambachtelijke kunstopvoeding krijgt hij in het ouderlijk huis. In de doka van de vader, de eerste artistieke leermeester, maakt ook Syberberg zich het vak van filmer en fotograaf eigen. In 1951, hij is dan zestien jaar oud, plaatst het stalinistische blad Berliner Mlustrierte een foto van zijn hand: een opname van een oorlogsinvalide met het

\footnotetext{
${ }^{11}$ Bilder, E., Hans Jürgen Syberberg. Amsterdam, 1983. pp. 35f.

${ }^{12}$ ibidem.

${ }^{13}$ Syberberg, Au dossier d'une généalogie, a.w., p. 88.

${ }_{14}^{14}$ Syberberg, Die freudlose Gesellschaft, a.w., p. 82.

${ }^{15}$ ibidem. Zie eveneens: Bilder, a.w., pp. $37 \mathrm{f}$.

${ }^{16}$ Syberberg, Filmbuch, a.w., p. 307 . Zie eveneens: Bilder, a.w., p. 36.
} 
onderschrift: "Nooit meer oorlog". De foto mag typerend worden genoemd voor de invloeden die hij gedurende deze periode ondergaat. Anders dan tijdens zijn kinderjaren in Nossendorf, ziet hij in de bioscoop van Rostock geen idyllische beelden van het Pommerse platteland, maar moraliserende vertellingen over de verschrikkingen van de oorlog, waaraan door de autoriteiten in de DDR een opvoedkundige waarde wordt toegekend. ${ }^{18}$ Omstreeks dezelfde tijd ontstaan de eerste, nooit uitgebrachte films. Met een van de vader geleende 8$\mathrm{mm}$ Agfa-Movex-camera verfilmt Syberberg in de plaatselijke schouwburg voorstellingen van rondtrekkende gezelschappen. Langs deze weg leert hij in 1952 Benno Besson kennen, een jonge, uit Zwitserland afkomstige regisseur, die zich op uitnodiging van Bertolt Brecht in de DDR heeft gevestigd en als assistent is verbonden aan diens roemruchte gezelschap het Berliner Ensemble. ${ }^{19}$ Kort daarop reist ook Syberberg, met een aanbevelingsbrief van de assistent op zak, naar Berlijn, om zijn probeersels aan Brecht te tonen.

\subsection{De artistieke pleegvader: Bertolt Brecht}

Wie Brecht zegt, denkt automatisch aan kunst in de DDR. En vice versa: wie het heeft over kunst in de DDR, denkt automatisch aan Bertolt Brecht. Maar liefst 121 verwijzingen levert het trefwoord 'Brecht' op in het register van het officiële, door het 'Institut für Gesellschaftswissenschaften beim ZK der SED' uitgegeven handboek Zur Theorie des sozialistischen Realismus (1974). Ter vergelijking: het trefwoord 'Marx' telt 139 verwijzingen, terwijl dichtervorst Goethe het moet doen met een schamele $39 .^{20}$ Het mag tekenend worden genoemd voor het aanzien, dat de in '56 overleden grondlegger van het 'epische theater' postuum in de DDR heeft genoten. Postuum, want als de jonge Syberberg in het voorjaar van '53 met zijn van de vader geleende $8-\mathrm{mm}$ Agfa-Movex-camera bij Brecht aanklopt, is deze hard op weg een dissident te worden. ${ }^{21}$

Dat de communist Brecht na de oorlog door de stalinistische cultuurminister Johannes $\mathrm{R}$. Becher met open armen in zijn nieuwe vaderland wordt verwelkomd, heeft in dit verband weinig te betekenen. Naar verluidt heeft Becher zelfs de oud-Bayreuther dirigent Wilhelm Furtwängler, die omstreeks dezelfde tijd wordt gedagvaard door de denazificatie-rechtbank van de westerse geallieerden, voor de socialistische zaak proberen te winnen. ${ }^{22}$ Het zijn de nadagen van het zogenaamde 'volksfront' tegen het fascisme - de, vanuit Moskou verordonneerde alliantie van alle antifascistische krachten, ongeacht hun politieke oriëntatie. En Brecht is beslist niet de enige Duitse intellectueel van naam en faam, die aan de lokroep vanuit het Oosten gehoor heeft gegeven. Een niet onaanzienlijk deel van Duitslands kritische intelligentsia keert na de oorlog niet terug in het Westen van het land, maar in de door de Sovjets bezette Oost-Zone. Zo ook latere dissidenten als de filosoof Ernst Bloch en de literatuurwetenschapper Hans Mayer, die beiden een leerstoel krijgen in Leipzig en van

\footnotetext{
${ }^{17}$ Syberberg, H.J., Der Wald steht schwarz und schweiget. Neue Notizen aus Deutschland. Zürich, 1984. p. 41.

${ }^{18}$ Erkkila, B., Hans Jurgen Syberberg. An Interview. in: Syberberg. A Filmmaker from Germany. Edinburgh, 1992. ed. H. Stewart. pp. 27-34, zie: 27.

${ }^{19}$ Benno Besson. Schweizer Theaterregisseur und -intentant. in: Munziger-Archiv/Int. Biograph. Archiv. 26/87.

${ }^{20}$ Zur Theorie des sozialistische Realimus. Hrsg. Institut für Gesellschaftswissenschaften beim ZK der SED. Lehrstuhl für marxistisch-leninistische Kultur- und Kunstwissenschaften. Berlin, 1974.

${ }^{21}$ Voor Brechts positie in de DDR, zie bijvoorbeeld: Mittenzwei, W., Das Leben des Bertolt Brecht oder Der Umgang mit den Welträtseln. Zweiter Band. Berlin, Weimar, 1986, 1997. passim en met name p. 741 ff, waar deze positie wordt samengevat als: enerzijds "Verteidigung der DDR", anderzijds "rigorose Ablehnung ihrer Kulturpolitik". "Wer sich [in de jaren '50, G.G.] zu Brecht bekannte, war ständig damit beschäftigt, ihn zu verteidigen. Er mußte vor den Auffassungen der offiziellen Kulturpolitik der DDR ebenso in Schutz genommen werden wie vor der Polemik aus dem Westen."

22 idem, p. 282.
} 
hieruit nauwe banden met het Brecht-theater in Oost-Berlijn onderhouden. Zelfs de 'burgerlijke' Thomas Mann, die aanvankelijk twijfelt of hij überhaupt nog wel naar Duitsland wil terugkeren, steekt zijn sympathie voor het Sovjet-model niet onder stoelen of banken. ${ }^{23} \mathrm{En}$ gedurende de eerste naoorlogse jaren moet het hier, in wat weldra de DDR zal gaan heten, voor een kunstenaar ook goed toeven zijn geweest.

Het lijkt vanuit onze huidige kennis bekeken misschien eigenaardig. Maar in de SBZ (Sowjetische Besatzungszone) is het politieke klimaat aanvankelijk aanmerkelijk liberaler en kunstvriendelijker dan in het 'vrije' Westen. ${ }^{24}$ Cultuurofficieren, als de door de Sovjets in Oost-Berlijn aangestelde Majakowski-exegeet en Brecht-bewonderaar Alexander Dymschiz, ${ }^{25}$ zien erop toe dat intellectuelen tal van privileges genieten, van extra levensmiddelen en papier, tot boekpublicaties, eigen tijdschriften en, in het geval van Brecht, een eigen theater. En langzaam maar zeker begint in steden als Dresden en Berlijn - "die berg puin nabij Potsdam: een ets van Churchill naar een idee van Hitler" (Brecht) ${ }^{26}$ - het culturele leven uit de Weimar-tijd, waarvan Brecht één van de belangrijkste vertegenwoordigers was, weer op te bloeien. Tot omstreeks 1948 een drastische omslag plaats vindt. In dat jaar verschijnt in de Sovjet-Unie een beruchte polemiek van de stalinist Andrej Sjadanov tegen componisten als Dmitri Sjostakovitsj en Sergej Prokofjev. ${ }^{27}$ Het is het begin van een, vanuit Moskou georkestreerde kruistocht tegen het 'formalisme', waarin ook het op dialectischmaterialistische leest geschoeide Brecht-theater niet worden gespaard.

In de tijd waarin Syberberg in Berlijn opduikt, is Brecht reeds het middelpunt van een onverkwikkelijke affaire, die de annalen is ingegaan als: de 'controverse over de juiste interpretatie vän het classicisme'. Of, ook wel, kortweg: de 'Unfaust-controverse', naar het gelijknamige drama van Goethe, dat in het najaar van $\$ 52$ door het Berliner Ensemble op de planken wordt gebracht. Geheel in overeenstemming met 'de leer van het epische theater', hebben Brecht en zijn regieassistent Egon Monk zich enkele vrijheden veroorloofd. Zo wordt de titelfiguur, bij Goethe zelf nog de onbetwiste held van deze oerversie van de Faust, ten tonele gevoerd als een gluiperige, raaskallende intellectueel (als we Hans Mayer mogen geloven, was "wantrouwen jegens intellectuelen" sowieso Brechts "lievelingsthema"); blijkt het lieftallige Gretchen plotseling een knorrig, geëmancipeerd dametje te zijn, en krijgt de duivel opmerkelijk sympathieke, ja welhaast menselijke trekken ${ }^{28}$ Maar al snel wordt Brecht duidelijk gemaakt, dat men een dergelijke profanatie in de Boeren -en Arbeidersstaat niet langer kan appreciëren. "De 'controverse over de juiste interpretatie van het Duitse classicisme", schrijft regieassistent Monk in een in 1993 gepubliceerde terugblik, "(..$)$ was een voortzetting van het realisme-debat, dat Brecht in de jaren '30 met [de Hongaarse filosoof, G.G. ] Georg Lukács had gevoerd. Nu evenwel, in de late jaren ' 40 en de vroege jaren '50, onder voor Brecht verslechterde omstandigheden. Inmiddels had Andrej Alexandrovitsj Sjadanov de opvattingen over wat socialistisch-realisme zou zijn veranderd in officiële richtlijnen, waaraan in de communistische landen de status van wetten werd toegeschreven. Het debat, dat nu de naam 'formalisme/realisme-strijd' kreeg, werd in de DDR gezien de ongelijkheid van krachten met onderdrukte gevoelens van verbittering door een kleine minderheid uitgevochten. Aan de ene kant stond Brecht, ondersteund door Hans

\footnotetext{
${ }^{23}$ Grunenberg, A., Antifaschismus - ein deutscher Mythos. Ein Essay. Hamburg, 1993. p. 127. Zie eveneens: hoofdstuk 3, paragraaf 4 .

${ }^{24}$ idem, pp. 127f. Zie eveneens: Thomas, K., Zweimal deutsche Kunst nach 1945. 40 Jahre Nähe und Ferne.

Köln, 1985. pp. 9-40.

${ }^{25}$ Mittenzwei, a.w., pp. $283 \mathrm{f}$.

${ }^{26}$ Citaat ontleend aan: idem, p. 283.

${ }^{27}$ idem, pp. 333, 416 f.

${ }^{28}$ Mayer, H., Brecht. Frankfurt am Main, 1996. p. 217.
} 
Mayer; aan de andere kant het front van de cultuurbonzen, waartoe ook de van de staatsbureaucratie afhankelijke publicisten en journalisten behoorden."29

Nadat de enscenering in verscheidene periodieken, waaronder het officiële partijorgaan Neues Deutschland, als "formalistisch" knoeiwerk is neergesabeld, hetgeen gelijk staat aan een informeel verbod, worden de uitvoeringen gestaakt. Om echter te voorkomen dat zijn dissidente visie op Goethe's drama in het bijzonder en de omgang met het Duitse classicisme in het algemeen in vergetelheid zal raken, vraagt Brecht de dan achttien jaar oude Syberberg het stuk tijdens een besloten voorstelling op film vast te leggen. Het materiaal, dat door Syberberg een jaar later op zijn vlucht uit de DDR wordt meegesmokkeld naar het Westen, verschijnt in 1970 in een bewerkte vorm en voorzien van een commentaar van hemzelf en de (inmiddels eveneens naar het Westen uitgeweken) literatuurwetenschapper Hans Mayer in de Bondsrepubliek onder de titel Nach meinem letzten Umzug... Het is een film, die in zijn onbeholpen amateurisme vooral aandoenlijk aandoet. Onbedoeld wekken de houterige en dikwijls onscherpe beelden de associatie met slapstick. Authentiek geluid ontbreekt - zover reikt het technische vernuft van de scholier kennelijk nog niet. En toch heeft de jonge Syberberg met deze Brecht-documentaire wel degelijk een werk van importantie afgeleverd. $\mathrm{Al}$ was het maar omdat het hier gaat om de enige filmbeelden van het Berliner Ensemble uit de Brecht-periode. Dat Syberberg niet zomaar een stuk heeft verfilmd, maar uitgerekend de 'verboden' Urfaust, maakt Nach meinem letzten Umzug... bovendien tot een document van onschatbare waarde over het Oostduitse cultuurdebat in een tijd waarin, aldus Mayer in zijn filmcommentaar, diverse opties nog open staan en Brechts enscenering een redelijk alternatief ten opzichte van de officiële, stalinistische partijlijn representeert - "de mogelijkheid van een nieuwe, andere cultuurpolitiek en interpretatie van de klassieke Duitse literatuur", die weldra voorgoed $\mathrm{zal}$ worden afgesloten. ${ }^{30}$

We ontkomen er niet aan hier aandacht aan dit debat te besteden. In interviews en geschriften mag Syberberg zich er graag op beroepen bij Brecht "in de leer" te zijn geweest." Meer nog: hij noemt Brecht zijn artistieke "pleegvader". 32 Op het eerste oog lijkt dit lichtelijk overtrokken. Zijn verblijf aan het Berliner Ensemble duurt hooguit enkele weken en tot assistent heeft hij het dan ook, anders dan Mayer denkt in een in 1996 verschenen Brechtmonografie, ${ }^{33}$ nooit gebracht. Maar inderdaad kan de invloed van deze, door de jonge Syberberg zo 'vereerde Meister, 34 moeilijk worden overschat. Niet slechts zouden veel van zijn latere films zonder Brechts vernieuwing van de 'aristotelische' dramaturgie ondenkbaar zijn; de cultuurstrijd tussen Brecht en de bonzen van het stalinisme, die hij als achttienjarige scholier in Nach meinem letzten Umzug... heeft gedocumenteerd, zal in de jaren ' 70 - althans in Syberbergs beleving - zijn eigen cultuurstrijd worden, ditmaal met de bonzen van Nieuw Links als belangrijkste opponent. "De Rode Cellen in München en aanverwante groeperingen wijzen film überhaupt van de hand met het argument, dat Lenin zich niet bezig hield met het maken van films, maar met het ontketenen van revolutie," laat de volwassen Syberberg ons in

\footnotetext{
${ }^{29}$ Monk, E., Auskünfte. in: Drucksache 4. Berliner Ensemble 1953 - Syberberg filmt bei Brecht. Hrsg. Berliner Ensemble Berlin, 1993. pp. 135-140, zie: 138. Zie eveneens: Mittenzwei, a.w., pp. 460-481. Alsmede: Ehrlich, L., 'Gemeingut der ganzen Gesellschaft'. Weimarer Klassilk in der DDR. in: Wege nach Weimar. Auf der Suche nach der Einheit van Kunst und Politik. Hrsg. M. Dorrmann, H. Wilderotter. Weimar, 1999. pp. 277-290, zie: 286.

${ }^{30}$ Mayer, H., Syberberg, H.J., 1971 - Nach meinem letzten Umzug... in; Drucksache 4, a.w., pp. 141-149, zie: 147.

${ }^{31}$ Syberberg, Kunst in Deutschland, a.w., p. 17.

${ }^{32}$ Syberberg, H.J., Die Kunst als Rettung aus der deutschen Misere. Ein Essay. in: Hitler, ein Film aus Deutschland. Hamburg, 1978. p. 33.

${ }^{33}$ Mayer, a.w., p. 479. Dat Syberberg nooit Brechts assistent is geweest, ontleen ik aan: Syberberg, Aus der Zeit der letzten Unschuld, in: Drucksage 4, a.w., p. 103.

${ }^{34}$ Syberberg, a.w., p. 103.
} 
de documentaire weten. "Zullen we de crisis doorstaan met alle experimenten en verschillende aanzetten, die onze enige hoop zijin, esprit en moed ontwikkelen, steeds weer? Dat is toegepaste Brecht vandaag de dag. Daarom interesseert mij, als filmmaker, deze vastberaden cultuurstrijder Brecht." 35

\subsection{De Brecht-Lukács-controverse: het expressionisme-debat}

Inderdaad was de formalisme/realisme-strijd in de vroege DDR, zoals Brechts assistent Egon Monk opmerkt in het hierboven aangehaalde citaat, de voortzetting van een oudere controverse, die midden jaren ' 30 de emigrantencultuur in den vreemde verscheurde: het zogenaamde realisme- of expressionisme-debat. ${ }^{36}$ In de kern van de zaak ging het om een tweetal kwesties. Ten eerste: welke Duits-Europese tradities behoorden tot het progressieve erfgoed, waarop in de postfascistische samenleving kon worden voortgebouwd. En ten tweede: welke eigentijdse kunst mocht zich de rechtmatige erfgenaam noemen van deze progressieve traditiesporen. Of, in de woorden van de indertijd naar Moskou gevluchte Georg Lukács, met wiens beruchte, in 1934 gepubliceerde essay Größe und Verfall des Expressionismus het gewoel een aanvang nam: "Welke auteurs, welke literaire stromingen vertegenwoordigen de vooruitgang in de huidige literatuur?"37

Misschien laten deze vragen zich nog het makkelijkste beantwoorden door eerst aan te geven welke eigentijdse literaire stromingen in de optiek van Lukács in elk geval niet in dienst van de vooruitgang stonden - namelijk: "de literatur van de zogenaamde avant-garde van het naturalisme tot aan het surrealisme". ${ }^{38}$ In een reeks studies, waarvan het grotendeels in ballingschap geschreven Die Zerstörung der Vermunft (1954) de meeste bekendheid geniet, meende Lukács de avant-garde te hebben ontmaskerd als het geesteskind van een reactionaire stroming in de Duitse cultuurgeschiedenis, waarvan het hitlerisme "het diabolischwereldbeschouwelijke culminatiepunt" ${ }^{\$ 39}$ zou zijn: de lijn Schelling-Fichte-SchopenhauerWagner-Nietzsche-Jünger-Heidegger. Typerend voor deze denkrichting was een gemis aan 'kritisch realisme'. Dat wil zeggen: ze droeg er niet toe bij het klassenbewustzijn van de arbeidersmassa te vergroten, door de "objectieve ontwikkelingstendensen" in de richting van een socialistische samenleving "inzichtelijk te maken en vorm te geven". ${ }^{40}$ Ongeacht of het ging om symbolisme, naturalisme, dadaïsme, futurisme, expressionisme of surrealisme steevast waren de esthetische vormen "formalistisch, inhoudsloos, van de grote stroom van de maatschappelijke totaal-ontwikkeling losgescheurd"; "een subjectivistische, vervormde, en mismaakte stemmingsecho van de werkelijkheid, die de gewone man in de straat onmogelijk naar zijn eigen levenservaringen kan terugvertalen". 41 Niet zelden, zoals in het geval van Nietzsche en diens navolgers, stonden de vertegenwoordigers van deze stroming zelfs ronduit vijandig ten opzichte van de vooruitgang in de geschiedenis en wierpen ze zich op als

\footnotetext{
${ }^{35}$ Mayer, Syberberg, a.w., p. 149.

${ }^{36}$ Zie bijvoorbeeld: Die Expressionismusdebatte. Materialien zu einer marxistischen Realismuskonzeption. Hrsg. H.J. Schmitt. Frankfurt am Main, 1973, 1978. Dürr, J., Die Expressionismus-Debatte. Untersuchungen zum Werk von Georg Lukács. München, 1982. Mittenzwei, W., Das Leben des Bertolt Brecht oder der Umgang mit den Welträtseln. Erster Band. Berlin, Weimar, 1986, 1997. pp. 604-616. Mittenzwei, W., Erprobung einer neuen Methode. Zur ästhetischen Postion Bertolt Brechts, in: Positionen. Beiträge zur marxistischen Literaturtheorie in der DDR. Hrsg. W. Mittenzwei. Leipzig, 1969. pp. 77-83. Kunst und Literatur im antifaschistischen Exil. 19331945. Band I/1. Hrsg. S. Barck, K. Jarmatz. Leipzig, 1989. pp. 40-50, 91-97, 121-141, 188-275.

${ }^{37}$ Lukăcs, G., Es geht um den Realismus. in: Die Expressionismusdebatte, a.w., pp. 192-230, zie: 193f.

${ }^{38}$ ibidem.

${ }^{39}$ Lukács, G., Die Zerstörung der Vernunft. Neuwied am Rhein, Berlin, 1962. p. 567.

${ }^{40}$ Lukács, Es geht um den Realismus, a.w., pp. $216 \mathrm{f}$.

${ }^{41}$ idem, pp. 193, $202 \mathrm{ff}, 228$.
} 
woordvoerders van de "reactie". En omdat de "logos" van het maatschappelijke vooruitgangsproces voor de hegeliaanse marxist Lukács de diallectiek was, noemde hij deze tegenbeweging: de geschiedenis van het anti-dialectische denken, de onzuivere rede, of ook wel, kortweg, het 'irrationalisme". 42

Naast deze 'irrationele' richting dacht Lukács in de Duitse culturgeschiedenis nog een andere, progressieve lijn te kunnen onderscheiden, die echter sinds de mislukte revolutie van 1848 door reactionaire krachten zou zijn overvleugeld of geïncorporeerd: de traditie van Lessing, Goethe, Schiller, Hölderlin, Büchner, Heine, Marx en (de late) Thomas Mann, wiens Zauberberg en - bovenal - Doktor Faustus ${ }^{43}$ aan de 'zogenaamde avant-gardisten' als toonbeelden van 'kritisch-realisme' ten voorbeeld werden gesteld. Dat Thomas Mann zelf zich, zoals het in Zur Theorie des sozialistischen Realismus wordt geformuleerd, nimmer "in Lenins zin met het proletariaat" heeft geidentificeerd, ${ }^{44}$ deed aan deze voorbeeldfunctie weinig af. De dialectisch-materialistisch ingestelde kunstcriticus diende een onderscheid te maken tussen 'subjectieve intenties' en 'objectief effect'. En objectief gezien betekenden Manns late romans, met hun scherpe analyse van politieke, culturele en artistieke vervalsverschijnselen, de doorbraak van een anti-burgerlijke en anti-feodale maatschappijkritiek. ${ }^{45}$ Sterker nog: het was Thomas Mann die reeds in het interbellum de weg naar de toekomst had gewezen, toen hij schreef dat men de Duitsers voor een keuze moest stellen "Goethe of Wagner. Beiden samen gaat niet." ${ }^{46}$ - en dat dit land pas met zichzelf in het reine zou komen, wanneer 'Marx het werk van Hölderlin zou lezen'" 47 Dit, Marx het werk van Hölderlin laten lezen, dat wil zeggen: de marxistische revisie van de progressieve traditie in de Duitse cultuurgeschiedenis, was ook de panacee die Lukács voor de Duitsers in gedachten had. Hij begreep zijn studies als "een oproep" aan "het volk van Marx en Goethe" tot "het verrichten van arbeid". De Duitsers moesten zich ervan bewust worden, dat het werk van Karl Marx en Friedrich Engels "de levend werkende kracht van een eigen Duitse cultuur" was en "middels een kritische bewerking van de rijke, nog steeds niet volledig erkende vooruitstrevende erfenis, een werkelijke, echte Duitse toekomst opbouwen". "A "Afbreken, verbreken en opbreken is geen makkelijk werk. Zelfs met de beste wil kunnen reactionairirrationele tradities van meer dan een eeuw niet in enkele dagen of maanden worden overwonnen. Maar anders is een wending naar genezing niet mogelijk."49

Vanaf eind jaren " 40 is de twee-Duitslanden-theorie van Lukács het theoretische fundament gaan vormen van de cultururpolitiek van de DDR, die tot ver in de jaren ' 60 in het teken stond van 'een renaissance van het classicisme door het socialisme'. Zoals het naziregime het 'diabolisch-wereldbeschouwelijke culminatiepunt' was geweest van alle reactionaire krachten in de Duitse cultuurgeschiedenis, zo begreep het SED-regime zich als het dialectisch-wereldhistorische culminatiepunt van alle progressieve krachten. De oriëntatie op het 'vooruitstrevende' classicisme van Lessing, Schiller en Goethe werd tot officiële

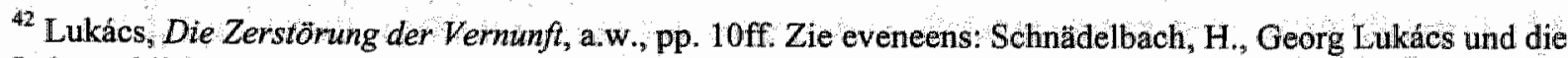
Lebensphilosophie. in; Gearg Lukács: Kultur-Politik-Ontologie. Hrsg. U. Bermbach. Opladen, 1987. pp. 200207, zie: 200 f.

${ }^{43}$ Met enige goede wil zou je Die Zerstörung der Vernunft kunnen zien als een marxistische variant van Mann's eigen 'burgerlijke' afrekening in Dr. Faustus met het demonische 'irrationalisme" van Nietzsche-Hugo WolfHitler. Zie in dit verband bijvoorbeeld: Bohrer, K.H., Die Asthetik des Schreckens. Die pessimistische Romantik und Ernst Jüngers Frühwerk. Frankfurt am Main, Berlin, Wien, 1983. pp. 528ff. Alsmede: hoofdstuk 3, paragraaf 4.

${ }_{44}$ Zur Theorie des sozialistischen Realismus, a.w., p. 181.

${ }^{45}$ Mayer, a.w., pp. 216, 253. Zie eveneens; hoofdstuk 3, paragraaf 4.

${ }^{46}$ Mann, Th., Wagner und unsere Zeit. Aufsätze, Betrachtungen, Briefe. Hrsg. E. Mann. Frankfurt am Main, 1963, 1983. p. 30 .

${ }_{48}^{47}$ Lukács, a.w., p. 661. Lukács citeert: Mann, Th., Die Forderung des Tages. Berlin, 1930. p. 196.

${ }^{48}$ idem, pp. $35,660 \mathrm{ff}$.

${ }^{49}$ idem, p. 662 .
} 
partijlijn verheven. Onder het mom van een terugkeer naar de humanistische en democratische geest van het klassieke Weimar diende opnieuw aansluiting te worden gezocht bij de (naar men in navolging van Lukács meende) na 1848 verraden traditie van het redelijke vooruitgangsdenken. 'Irrationalisten', als Wagner, Nietzsche en de 'zogenaamde avantgardisten', waarvan (opnieuw in navolging van Lukács) werd verondersteld dat ze niet in de traditie van de socialistische literatuur thuishoorden aangezien ze met de progressieve erfenis van de Verlichting zouden hebben gebroken, werden uit de Duitse canon verwijderd. ${ }^{50}$ En tot op zekere hoogte kon ook Brecht zich wel in deze officiële partijlijn vinden. Ook hij had zich wel eens verbaasd over de "fouten" en "vergissingen" van sommige futuristen - "Ze plaatsen op een reusachtige kubus een reusachtige augurk, verven het hele gevaarte rood en noemen het: portret van Lenin". Maar om daarom alles wat ook maar enigszins vernieuwend was "met een enkel handgebaar als onmenselijk van tafel te vegen', ging Brecht wat al te ver. Noch mocht dit een argument zijn ten gunste van burgerlijke auteurs als Thomas Mann, die weliswaar in staat bleken een portret te schilderen dat een treffende gelijkenis vertoonde met een levensechte Lenin, maar "wier manier van schilderen op geen enkele wijze aan Lenins manier van strijden herinnert". 51

Volgen we Hans Mayer, dan was Brecht de "grote theoretische tegenhanger" van Lukács. Reeds in het expressionisme-debat; dat lange tijd ook wel bekend stond als de 'Brecht-Lukács-controverse', hoorde hij samen met Ernst Bloch tot de felste opponenten van "de man, die zijn betekenis uitsluitend ontleent aan het feit dat hij in Moskou zit en schrijft", zoals hij Lukács ooit typeerde. ${ }^{52}$ Het citaat geeft treffend weer hoe Brecht over deze "kunstrechter" dacht. Smalend had hij het in zijn pamfletten over het "geheven vingertje" van een "bloedeloze estheet", die vanachter een lessenaar in het verre Moskou kunstmakers als zijn goede vriend Hanns Eisler het leven zuur maakte. ${ }^{54}$ Let wel: dat iemand zich geroepen voelde het doen en laten van kunstenaars nauwlettend in de gaten te houden, was zijn goed recht. Ook zelf schroomde Brecht niet indien nodig ferm de antifascistische lakmoesproef te hanteren. "Ik geef grif toe, dat ik welhaast geldoffers zou brengen, om het verschijnen van bepaalde boeken te verhinderen," polemiseerde hij. Maar als er al kunst verboden diende te worden, dan toch zeker het Verzamelde Werk van Thomas Mann! Was deze door Lukács zo bewonderde auteur immers niet bij uitstek het prototype van "de bourgeois producent van artistiekerige, ijdele en onbruikbare boeken"? "Daar verzint iemand in het zweet van ons aangezicht louter dingen, waarover hij ironisch kan lachen," hoonde Brecht over de Zauberberg. "Nog voordat ook maar iets op papier staat, is dit heerschap voor alle zekerheid alvast ironisch." 56

\footnotetext{
${ }^{50} \mathbb{I k}$ volg hier in grote lijnen: Ehrlich, a.w., passim. Overigens zal Wagner in de jaren ' 70 en ' 80 door de DDR als antifascistische revolutionair op de barricaden in Dresden worden herontdekt en in ere hersteld. Het voorheen als 'irrationeel' verguisde kunstwerk de Ring blijkt dan plotseling een fundamentele kritiek op het kapitalisme te zijn. Een fraai voorbeeld van deze zogenaamde 'linkse Wagner-Welle' is het essay De ontzetting der Berg-

Kobolden. Zondevallen en verlossingsbegrippen in Wagners Ring-Festspiel van de voormalige DDR-auteur Friedrich Dieckmann, die zich erop laat voorstaan reeds in DDR-tijden onomstotelijk te hebben aangetoond dat Wagner het werk van Marx heeft gelezen. in: Nexus 19 (1997). pp. 86-112, zie: 95.

${ }^{51}$ Brecht, B., Gesammelte Werke 19. Schriften zur Literatur und Kunst 2. Frankfurt am Main, 1967, 1990. pp. $219 f, 297$.

${ }^{52}$ Mayer, a.w., pp. 27, 179, 425. Zie eveneens: Schmitt, H.J., Einleitung. in: Die Expressionismusdebatte, a.w., pp. 8ff: "Der Höhepunkt der Debatte muß in den Auseinandersetzungen zwischen Bloch und Lukács einerseits und Lukács und Brecht anderseits gesehen werden". Voor de bijdrage van Bloch aan dit debat, zie: hoofdstuk 3, paragraaf 6.

33 "Ich selbst war nie ein Expressionist, aber solche Kunstrichter ärgern mich." Brecht, a.w., p. 291.

54 idem, pp. $311,337$.

${ }^{55}$.Brecht, B., Gesammelte Werke 18. Schriften zur Literatur und Kunst 1. Frankfurt am Main, 1967, 1999 p. 49.

${ }^{56}$ idem, 28.
} 
In feite, betoogde Brecht, kwam het realisme-concept van Lukács neer op een terugkeer naar de vroeg-burgerlijke roman. Zijn esthetica was doortrokken van een droefenis over het openbreken van de grote harmonische klassiek-burgerlijke vertelling. Nieuwe technieken, die hiertoe hadden bijgedragen, zoals montage en stream of consciousness, werden door Lukács stuk voor stuk afgedaan als tekenen van verval. Zelfs de door Brecht zelf ontwikkelde anti-aristotelische dramaturgie kon in de ogen van de Hongaarse filosoof weinig genade vinden. ${ }^{57}$ Van kunstenaars werd geëist, dat ze degelijke, ouderwets-aristotelisch gecomponeerde werken schiepen. En in het reanimeren van overleefde esthetische vormen was Thomas Mann inderdaad een meester. Al moest je volgens Brecht wel "een beetje wereldvreemd" zijn om een roman als de Zauberberg als een navolgenswaardig model van 'kritisch-realisme" te kunnen bewonderen. ${ }^{58}$ Wat Lukács maar niet kon of wilde inzien, was dat eigentijdse kunstenaars zich geen raad wisten met esthetische vormen die dateerden uit een tijd waarin de bourgeoisie nog de progressieve klasse was. Terwijl hij als marxist toch zou moeten weten, dat de wereld sinds de hoogtijdagen van burgerlijke cultuur, die door Mann nog "monter"59 werd vertegenwoordigd, ingrijpend was veranderd. En: "De beschrijving van een zich voortdurend veranderende wereld vereist steeds nieuwe middelen van verbeelding". ${ }^{60}$ In deze zin, redeneerde Brecht, diende het werk van de door Lukács van 'formalisme' en 'irrationalisme' betichte avant-gardisten te worden begrepen: deze kunstenaars probeerden nieuwe esthetische vormen te ontwikkelen, die recht deden aan een nieuwe realiteit. Lukács daarentegen bewandelde exact de tegenovergestelde weg. In plaats van de realiteit als ijkpunt te nemen voor zijn esthetica, drong hij bepaalde "vertel- en beschrijvingsvormen in zijn hoofd" aan de realiteit op. ${ }^{61}$ "Hij [Lukács, G.G.] keert terug naar de vaderen en bezweert de ontaarde telgen hem hierin te volgen," sneerde Brecht. "Treffen schrijvers een ontmenselijkte mens aan? Is zijn binnenleven verwoest? Wordt hij in een jachtig tempo door zijn leven gejaagd? Is zijn logische denkvermogen verzwakt en lijken de dingen niet meer met elkaar samen te hangen, zoals ze ooit met elkaar samenhingen? Dan moeten schrijvers zich gewoon eventjes aan de oude meesters houden, een rijk binnenleven produceren, het tempo van de gebeurtenissen omarmen door langzaam te vertellen, met hun kunst de individuele mens weer in het middelpunt van de gebeurtenissen duwen, enzovoorts enzovoorts." $" 62$

Het behoefde wat Brecht betrof geen betoog, dat een dergelijke zienswijze aanmerkelijk irrationeler was dan de vermeend 'irrationele' kunst van de avant-garde. Een kunstenaar, die aanspraak maakte op het predikaat 'kritisch-realisme', kon niet volstaan met een onvoorwaardelijke "adhesiebetuiging aan Lessing en de onveranderlijke geldigheid van de Duitse klassieken" (Mayer) ${ }^{63}$, zoals Lukács in zijn studies bepleitte. "Het Duitse classicisme diende te worden omgeturnd," vat Mayer de positie van Brecht samen. "De aristotelische dramaturgie moest plaats maken voor een niet-aristotelische." ${ }^{, 64}$ En volgen we Brecht, dan was een dergelijke strijdbare, dialectische benadering - "Aus einer Kritik des Theaters wird neues Theater" - ook meer in overeenstemming met de "strijdbare geest" van Weimar dan de door Lukács voorgeschreven "piëteitvolle ontroering in de omgang met de klassieken". ${ }^{66}$ "Wanneer we ons laten intimideren door een valse, oppervlakkige, decadente,

\footnotetext{
57 idem, pp. 317,320 .

s8 idem, pp. 296,416 .

59 Brecht, Gesammelte Werke 19, a.w, p. 480

60 idem, p. 416

61 idem, pp. 317,416 .

62 idem, pp. $297 f$.

63 Mayer, a.w., p. 217.

64 ibidem.

${ }^{65}$ Brecht, B., Gesammelte Werke 16. Schriften zum Theater 2. Frankfurt am Main, 1967, 1990. p. 943.

${ }^{66}$ Brecht, Gesammelte Werke 19, a.w., p. 337
} 
bekrompen opvatting van het classicisme, zullen we nooit tot levendige, menselijke ensceneringen van de grote werken komen. Het oprechte respect, dat deze werken mogen verlangen, vereist dat we het schijnheilige, kruiperige, valse respect aan de kaak stellen." Aldus Brecht in de beroemde, uit 1954 daterende tekst Einschüchterung durch die Klassizität, waarin hij zijn Urfaust-enscenering tevergeefs tegen de officiële cultururpolitiek van de DDR probeerde te verdedigen. ${ }^{67}$

\subsection{Het absurde bewustzijn}

Einübung ins Irrationale, luidt de titel van een vernietigende, in 1980 verschenen kritiek van de Westduitse, neo-marxistische historicus Reihnhard Kühnl op Syberbergs magnum opus Hitler, ein Film aus Deutschland (1977). Het is een titel, die de inhoud treffend weergeeft. Zich beroepend op Die Zerstörung der Vernunft en Manns Doktor Faustus, probeert Kühnl aan te tonen, dat de Hitler-film dient te worden beschouwd als een schoolvoorbeeld van wat Lukács verstond onder 'irrationalisme':

"De film articuleert (...) een ongetwijfeld wijdverbreid, diffuus onbehagen over de tegenwoordige wereld. De handarbeidende massa edoch, zal hij niet bereiken. (...) De adressant is, naar het zich laat aanzien, de intelligentsia - en wel de door de omvattende sociale en geestelijke crisisverschijnselen teleurgestelde, bang gemaakte, gedesoriënteerde, naar een uitweg zoekende intelligentsia. De boodschap, die deze 'veeleisende', met insider-toespelingen overladen film verkondigt, bevestigt hun vertwijfeling en hulpeloosheid: het is een wereld, waarin het zich niet loont te leven ze is duister, onbegrijpelijk en wordt door irrationele krachten beheerst. (...) Zo voegt deze film zich - op subtiele wijze - in een nieuwe golf van de Nietzsche-cultus, $(. .$.$) in$ dat bele ideologische brouwsel uit vertwijfeling, irrationalisme en elitaire fantasieën, dat altijd al een voortreffelijke voedingsbodem was voor reactionaire offensieven. ${ }^{, 68}$

Veel moeite om de Hitler-film als een 'irrationeel' kunstwerk in de zin van Lukács te ontmaskeren, zal het de historicus niet hebben gekost. In het als inleiding op het Hitler-script gepubliceerde pamflet Die Kunst als Rettung aus der deutschen Misere (1978), waaraan ook Kühnl meermaals refereert, maakt Syberberg zich sterk voor een eerherstel van de traditie van het 'irrationalisme', die ten onrechte met fascisme over één kam zou worden geschoren. ${ }^{69}$ Sterker: hoewel de Hongaarse filosoof zelden met name wordt genoemd, loopt de polemiek tegen de kunsttheorie van Lukács als een rode draad door alles wat Syberberg sinds zijn verfilming van Brechts dissidente Urfaust heeft geschreven en gemaakt. Of in elk geval zal hij zich steeds keurig blijven houden aan de door Lukács gemaakte tweedeling, door consequent werk af te leveren dat vanuit diens kunsttheorie geredeneerd inderdaad met recht 'formalistisch', 'irrationeel', 'decadent', of 'reactionair' mag worden genoemd. Wat dat

\footnotetext{
${ }^{67}$ Brecht, B., Gesammelte Werke 17, Schriften zum Theater 3. Frankfurt am Main, 1967, 1990. p. 1277.

${ }^{68}$ Kühnl, R., Einübung ins Irrationale. in: Sammiung: Jahrbuch für antifaschistische Literatur und Kunst. Band 4. Frankfurt am Main, 1984. pp. 123-127, zie: 125f.

${ }^{69}$ Syberberg, Die Kunst als Rettung..., a.w., pp. 12,15. “(...) Syberberg's defense of the tradition of German irrationalism is directed against the orthodox Marxist view of the identity of Fascism with the irrational trends in bourgeois culture. In as far as the orthodox point of view in the Expressionism debate of the Thirties equated irrationalism with bourgeois decadence and modernism, a point of view which still influences present debates, Syberberg's insistence on the irrational heritage of German culture had both political and aesthetic implications." Aldus Roswitha Müller in het bij mijn weten enige commentaar, waarin een link met het expressionisme-debat wordt gelegd. Müller, R., Hans-Jürgen Syberberg's Hitler. An Interview - Montage. in: Discourse: Berkeley Journal for Theoretical Studies in Media and Culture. 2 (1980). pp. 60-82, zie: 61.
} 
betreft wordt de toon reeds gezet in Zum Drama Friedrich Dürrenmatts, waarop hij in 1963, inmiddels 28 jaar oud, aan de Universiteit van München promoveert.

Samen met Samuel Beckett, Eugène Ionesco en Albert Camus, behoort de Zwitser Friedrich Dürrenmatt tot de meest bekende vertegenwoordigers van een loot aan de stam van de avant-garde die, als we Lukács mogen geloven, qua decadentie voorafgaande stromingen zo mogelijk nog overtrof: het absurdisme. Deze kunstenaars verzuimden niet enkel de arbeidersmassa 'klassenbewust' te maken door de 'objectieve ontwikkelingstendensen' in de geschiedenis bloot te leggen; de voorstelling van een an sich redelijke werkelijkheid werd door hen expliciet verworpen. ${ }^{70}$ In het theater van de absurdisten was de wereld inderdaad, om Kühnl's kritiek op de Hitler-film te parafraseren duister, onbegrijpelijk, irrationeel. ${ }^{7 !}$ Maar geheel in de geest van zijn 'artistieke pleegvader' Brecht neemt de promovendus Syberberg in Zum Drama Friedrich Dürrenmatts de toenmalige theatrale avant-garde in bescherming: "Als een poging tot dramatische vormgeving van het levensbewustzijn rond het midden van de twintigste eeuw, is het theater van Dürrenmatt een artistiek product dat essentiële geestelijke en gevoelsmatige existentieervaringen van deze tijd (...) en eigentijdse middelen van verbeelding (...) in zich verenigt. Eventuele levensbeschouwelijke of gevoelsmatige bezwaren ten spijt, zal men het moeten erkennen als een cultuirhistorisch getuigenis van symptomatische stromingen en kunstintenties van de tegenwoordige tijd. (..) Het tegenwoordige levensgevoel wordt treffend door de drie grondervaringen van het absurde bewustzijn geaccentueerd: uitzichtloos, ongerijmd, zinloos". ${ }^{2}$

Getuigt het van al te veel psychologie van de koude grond om te veronderstellen dat de promovendus hier ook spreekt over zijn eigen 'levensgevoel' in die dagen? Een kleine tien jaar zijn verstreken, sinds hij in 1954 de Oost-Zone heeft verlaten. In de tussenliggende periode leidt Syberberg het typische bestaan van een vluchteling: een leven in opvangkampen kriskras verspreid door de Bondsrepubliek in afwachting van het felbegeerde paspoort. De tocht voert langs kampen in Berlijn (de woonplaats van zijn voorkeur, waar hij echter gezien de overbevolking niet mag blijven), via kampen in Noordrijn-Westfalen, in de omgeving van Keulen en omstreken, en Düsseldorf, naar Petershagen nabij Minden, waar hij drie jaar lang bijzonder middelbaar onderwijs volgt voor vluchtelingen uit het Oosten. Na zijn eindexamen in '56, krijgt hij door de autoriteiten München als nieuwe woonplaats aanwezen en laat hij zich aan de universiteit inschrijven als student kunstgeschiedenis en germanistiek. "Het was een mogelijkheid de tijd door te komen en geld te ontvangen, want als je je examens haalde kreeg je geld $(. .$.$) , een budget om van te leven," aldus Syberberg. { }^{73}$ Het zal ook een mogelijkheid zijn geweest om nieuwe indrukken op te doen, waarop in de DDR een taboe rustte. Zoals het door de stalinisten als 'reactionair' verguisde theater van de absurdisten. Of de kunsttheorie van de indertijd in München docerende Hans Sedlmayr - de reactie in persoon.

Dat deze, ook in het Westen omstreden Oostenrijkse kunsthistoricus in het voor- en nawoord van het proefschrift voor geboden 'ondersteuning' en 'adviezen' wordt bedankt, ${ }^{74}$

\footnotetext{
${ }^{70}$ Voor de kritiek van Lukáes op Dürrenmatt en Beckett, zie: Mayer, a.w, pp. 423-429.

${ }^{71}$ Sommigen, zoals de Britse filmcriticus John Sandford, zinspelen in dit verband op mogelijke invloeden van Dürrenmatt op de Hitler-film. Evenals Dürrenmatt zou Syberberg worden gefascineerd door "de paradoxaliteit van de wereld en de uitvergroting van de paradox als een beredeneerd provocatief theatraal middel". En evenals deze Zwitserse auteur zou hem een vorm van filmtheater voor ogen staan, dat "de dualiteiten van de wereld" bestrijkt en mogelijkheden biedt om "de complexiteiten en polariteiten van de menselijke conditie" te overwinnen. Sandford, J, Hans Jürgen Syberberg: Films from Germany. in: Syberberg. A Filmmaker from Germany. a.w., pp. 5f. Zie eveneens: Franklin, a.w., pp. 165, 171f.

${ }^{72}$ Syberberg, H.J., Zum Drama Friedrich Dürenmatts. Zwei modellinterpretationen zur Wesensdeutung des modernen Dramas. München, 1963. p. 141.

${ }^{73}$ Bilder, a.w., pp. 40-43.

${ }^{74}$ Syberberg, a.w., p. III.
} 
geeft te denken. Want Syberberg mag zich dan in Zum Drama Friedrich Dürrenmatts opwerpen als een apologeet van de avant-garde; volgen we de Bochumse kunsthistoricus Beat Wyss (1985), dan kwam de aanval op de avant-garde in het naoorlogse Duitsland vanuit twee hoeken: "Links leidde Lukács; het rechtse spectrum van het gezonde mensenverstand werd bepaald door figuren als Hans Sedlmayr". ${ }^{75}$ Toch zal Syberberg, met name in geschriften en interviews uit de jaren " 80 en ' 90 , zijn Münchense hoogleraar kunstgeschiedenis steeds naar voren schuiven als zijn tweede grote voorbeeld naast Bert Brecht. Ik zou in dit verband nog een stap verder willen gaan: is Brecht de 'artistieke pleegvader', dan mag Sedlmayr, tenminste als we de late Syberberg mogen geloven, genust de 'intellectuele' worden genoemd - "Al mijn rationele oordelen komen van hem"."

\subsection{De intellectuele pleegvader: Hans Sedlmayr}

Hans Sedlmayr is de nestor van de naoorlogse Duitse conservatieve cultuurkritiek. Bekendheid geniet hij vooral als auteur van een in ' 48 verschenen bestseller, waarvan de titel in het Duits welhaast spreekwoordelijk is geworden: Verlust der Mitte. Aan de hand van een 'diepte-duiding' van de kunsten in de afgelopen twee eeuwen wordt de stelling verdedigd, dat de cultuur van het Avondland sinds de Franse Revolutie met het christelijke geloof tevens haar geestelijk centrum ('Mitte') zou hebben verloren. Ongetwijfeld laat Verlust der Mitte zich nog het beste typeren als een cultuurkritisch pamflet in de traditie van de Conservatieve Revolutionairen uit de Weimar-tijd. Zelf presenteert Sedlmayr, een autoriteit op het terrein van de middeleeuwse kunstgeschiedenis, zich bij voorkeur als een katholiek denker. De christelijke openbaring fungeert, samen met middeleeuwse teksten als de Theologica Mystica ('God is Licht'), als leidraad in zijn analyse van de kunstgeschiedenis. Het kunstwerk, merkt hij op in de inleiding van Verlust der Mitte, is behalve een "feit", ook een "symptoom" dat, mits met de "juiste" - lees: katholieke - instelling benaderd, een "diagnose van het lijden van de tijd" mogelijk maakt. ${ }^{77}$ En vanuit deze katholieke instelling kan er weinig twijfel over bestaan, dat de bloeiperiode van de cultuur van het Avondland ergens in de middeleeuwen dient te worden gesitueerd.

Vier cultuurepochen, waarin God zich in steeds wisselende gedaanten openbaart, worden door Sedlmayr onderscheiden. In de epoche van de romaanse kunst (550-1150) zit Hij als strenge Vader en Rechter hoog boven de portalen van duistere kathedralen, omringd door apocalyptische wezens, die de mens aan de jongste dag herinneren. De hemel klaart op in de epoche van de gotiek (1140-1470), wanneer in het gezelschap van de Maagd Maria en de Heiligen de 'God-Mens' verschijnt. Het licht breekt in de kathedraal binnen - en hiermee in de middeleeuwse samenleving, die met het Goddelijke Licht wordt doorstroomd. Op een aantal wijzen symboliseert de gotische kathedraal voor Sedlmayr de 'Mitte', dat later verloren zal gaan. Als Gesamtkunstwerk is de kathedraal het spirituele en ruimtelijke centrum, waarin alle andere kunsten (architectuur, schilderkunst, beeldhouwkunst, muziek, theater enzovoorts) onder de noemer van één epoche bepalende stijl, de gotiek, tot een harmonische en organische eenheid worden verenigd. Zowel geestelijk als ook maatschappelijk fungeert de kathedraal als het centrum van de middeleeuwse werkelijkheid, die naar haar voorbeeld is gemodelleerd als een hiërarchisch gestructureerd Gesamtkunstwerk van hemel en aarde, kerk en staat, cultuur

\footnotetext{
${ }^{75}$ Wyss, B., Trauer der Vollendung. Zur Geburt der Kulturkritik. Köln, 1985, 1997 p. 299.

${ }^{76}$ Bilder, a.w., pp. 44f.

${ }^{77}$ Sedlmayr, H., Verlust der Mitte. Die bildende Kunst des 19. und 20. Jahrhunderts als Symptom und Symbol der Zeit. Frankfurt am Main, Berlin, 1948, 1983. Pp. 7-12. Zie eveneens: Hoffmann, W., Zu einer Theorie der Kunstgeschichte. In: Zeitschrift für Kunstgeschichte. 41 (1951). pp. 118-123. In de hierna volgende weergave van de theorie van Sedlmayr volg ik in grote lijnen: Wyss, a.w., pp. 282-295.
} 
en natuur (de door God gegeven organische standenmaatschappij). En de kathedraal staat voor de centrale betekenis van het Goddelijke in het menselijke bestaan, voor de harmonische eenheid tussen God, de mens en de schepping of de natuur, die in de gotiek voor het eerst als spiegelbeeld van de almacht, wijsheid en goedheid van de Schepper de moeite van het verbeelden waard wordt geacht. ${ }^{78}$

In de kunst van de gotiek krijgt God een tastbare gedaante. Van Giotto tot Van Eyck verscherpt zich de blik van de kunstenaars voor de waarneembare natuur. Deze aandacht voor het zintuiglijke opent de weg naar de derde Goddelijke verschijningsvorm: de "Goddelijke Mens', de Christus van de renaissance en de barok (1470-1760), die als een olympische Apollo triomferend naar de hemel opstijgt. De lichamelijke schoonheid van de klassieken heeft zich met de geest van het christendom verenigd. Tegelijk is het culturele centrum verschoven van de kathedraal naar het paleis. De kunstenaar zelf treedt in zijn werk op de voorgrond. De vierde cultuurepoche, tenslotte, begint met de tijd van de Verlichting (1760-). De band tussen God, mens en schepping is verbroken. De mens plaatst zichzelf op Gods troon; God wordt dood verklaard, de koning onthoofd en de natuur gedesacraliseerd. De kerk en het paleis - de Gesamtkunstwerken van de voorafgaande cultuurepochen - verliezen hun centrale positie binnen de cultuur. Het Gesamtkunstwerk valt uit elkaar. De diverse kunsten gaan hun eigen weg. De architectuur, tot dan de alle andere kunsten samenbindende kunstvorm, krijgt een veelvoud aan nieuwe taken toebedeeld: het monument, het woonhuis, het theater, de fabriek en het museum - het nieuwe, artificiële Gesamtkunstwerk van de moderne tijd, dat zal gaan fungeren als een asiel voor de ontheemde, aan de kunstmarkt overgeleverde overige kunsten. Van eeén epoche bepalende stijl, zoals in de gotiek, is niet langer sprake. Wat resteert een wirwar van -ismen die, meent Sedlmayr, symptomatisch is voor de chaos waarin de moderne, van God losgeraakte mens leeft, in een soort postcultuir zonder moreel centrum of samenbindende moraal, zoals die in de grote cultuurepochen voorafgaande aan de Franse Revolutie door het christelijke geloof werd verschaft. ${ }^{79}$

In het in hetzelfde jaar als Syberbergs proefschrift verschenen Tod des Lichtes (1963) vergelijkt Sedlmayr de moderne crisis in de kunsten met de 'zonsverduistering uit de eindtijd' - een verduistering van het 'centrale', oorspronkelijke, ongeschapen en scheppende Licht, dat de cultuur in de bloeiperiode van de gotiek doorstroomde en tot een organisch geheel verenigde. Het meest totaal is de verduistering in de schilderkunst. Van Goya tot de abstracte kunst in de Twintigste Eeuw hebben kunstenaars het Licht buitengesloten en Gods schepping, de natuur, in hun schilderijen vervormd, verminkt, in stukken gehakt en vernietigd. De beelden van Goya zijn niet langer geïnspireerd door het Licht, maar weerspiegelen de visioenen van een zieke tijdgeest. De 'hel' is in deze beelden, die een toestand van uitzichtloze verdoemenis schilderen, absoluut geworden; de Apocalyps lijkt begonnen. Want hoe kan deze vrijwel algehele verduistering van het Licht in de moderne kunst anders worden uitgelegd, dan als een omen van de 'komst van de antichrist'? De geest van de antichrist is niet slechts navoelbaar in de atheïstische moderne kunst, maar ook en bovenal in de sinds de Franse Revolutie op hol geslagen technische vooruitgang, die een spoor van vernietiging door de schepping trekt. We bevinden ons op een keerpunt in de wereldgeschiedenis. De dag der dagen komt naderbij; Mefistofeles, die de gedaante heeft aangenomen van de machine, daagt God uit tot de definitieve strijd tussen Goed en Kwaad. ${ }^{80}$

\footnotetext{
${ }^{78}$ Wyss, a.w.y.pp. 287, 288. Zie eveneens: Sedlmayr, a.w., pp. 217-222. Sedlmayr, H., Die Geburt der Kathedrale. In: Epoche und Werke. Gesammelte Schriften zur Kunstgeschichte 1. Wien, 1959. pp. 155-181.

Sedlmayr, H., Die gotische Kathedrale Frankreichs als europaïsche Königskirche. in: idem. pp. 182-198.

${ }^{79}$ Wyss, a.w., pp. $288 \mathrm{ff}$. Sedlmayr, Verlust der Mitte, a.w., pp. $143 \mathrm{ff} ., 223 \mathrm{ff}$.

${ }^{80}$ Wyss, a.w.,.pp. $288 \mathrm{ff}$. Sedlmayr, a.w., pp. $229 \mathrm{ff}$. Sedlmayr, H., Tod des Lichtes. Übergegangene Perspektiven zur modernen Kunst. Salzburg, 1963. passim.
} 
Het is zijn katholieke geloofsovertuiging, die Sedlmayr ervan weerhoudt geheel in pessimisme weg te zinken. Het laatste hoofdstuk van Verlust der Mitte heeft veel weg van een preek. De zondige, modeme mens wordt opgeroepen tot boetedoening. De tijd is gekomen om partij te kiezen tussen Goed en Kwaad, Licht en Duisternis - de twee elkaar tegenstrevende krachten, die in de cultuurgeschiedenis werkzaam zijn. De desacralisering van het sacrale moet een halt worden toegeroepen door een sacralisering van het profane. De techniek hoeft niet te worden afgeschaft, het is voldoende haar tot het Ware Geloof te bekeren. Door de machines te zegenen, arbeiders te dopen en de architectuur van huurkazernes en fabrieken te kerstenen, dient de profane industriêle samenleving in een religieuze traditie te worden geplaatst. ${ }^{81}$ Dit alles is echter onmogelijk, zonder een religieus reveil bij het individu. De lezer wordt dan ook gemaand het Licht opnieuw in zijn bestaan toe te laten. Hij moet zichzelf opnieuw leren zien als "het - potentiële - evenbeeld van God" en een schakel in "een - zij het - uit balans gebrachte wereldorde" 82

Aan het eind van Verlust der Mitte lijkt ook Sedlmayr zich ervan bewust, dat deze 'Hetoimasia' (bereidwilligheid), misschien wat al te veel gevraagd is van de heidense lezer. Maar uitgerekend in de verguisde kunsten van de afgelopen twee eeuwen ontwaart hij een tot hoop stemmende onderstroom. Wat alle grote kunstenaars van de negentiende en twintigste eeuw met elkaar gemeenschappelijk hebben is, merkt hij op, "een enorme solidariteit in het lijden onder de tijdgeest". Ongeacht of het gaat om Hölderlin, Goya, Runge of Casper David Friedrich, om Kleist, Nietzsche, Dostojewski, Strindberg, Trakl of Van Gogh - "allen lijden ze eraan, dat God ver weg of dood is en de mens vernederd". Dit collectieve lijden van de kunstenaars van het stervende Avondland, schept niet slechts een onderlinge verbondenheid, maar biedt ook nieuwe, positieve mogelijkheden. Een genezing van de zieke cultuur is alleen dan mogelijk, wanneer de ziekte gevoeld wordt, men eraan lijdt, zich ervoor schaamt en vertwijfelt. Er bestaan mensen, die eerst een catastrofe moeten doormaken, alvorens hun metafysische zwaartepunt te vinden. En wellicht geldt dit ook voor volken en culturen. "Wat echter de kunsten betreft," rondt Sedlmayr af, "zal het misschien binnen afzienbare tijd, en wellicht binnen langere tijd ook, niet mogelijk zijn, iets in het lege centrum ["Mitte'] te plaatsen. In dat geval moet echter op zijn minst het bewustzijn levend blijven, dat in het verloren centrum ['Mitte'] de troon staat, die is leeg gelaten voor [de terugkeer van] de volkomen mens, de God-Mens. Zij, die dit bewustzijn gegeven is en die het koesteren, zullen de 'Nieuwe Tijd' zien, ook wanneer ze die nog niet betreden mogen.,"83

\subsection{De Sedlmayr-Adorno-controverse: het modernisme-debat}

Van het Brecht-theater in Oost-Berlijn naar de collegebanken van Licht-filosoof Sedlmayr het moet voor de jonge Syberberg, ook mentaal, een grote overgang zijn geweest. De marxistische avant-gardist Brecht en Sedlmayr, de ultra-conservatieve bestrijder van de avantgarde, zijn niet alleen wat hun wereldbeeld betreft tegenpolen. Ook hun levenslopen lijken zich in diametraal tegengestelde richtingen te hebben afgespeeld. De een is in alle opzichten representatief voor de emigranten-generatie, die begin jaren ' 30 uit nazi-Duitsland wordt verdreven en de Hitler-tijd en oorlogsjaren als balling in den vreemde doorbrengt; de ander aanvaardt in ' 34 aan de universiteit van Wenen een leeropdracht in de kunstgeschiedenis van de middeleeuwen en de nieuwe tijd. In de eerste helft van de jaren ' 40 , wanneer Brecht in het gezelschap van Theodor Adorno, Max Horkheimer, Ernst Bloch en Thomas Mann in Californië het einde van de oorlog afwacht, verzorgt Sedlmayr in Wenen colleges over het

\footnotetext{
${ }^{81}$ Wyss, a.w., pp. 294, 295.

${ }^{82}$ Sedlmayr, Verlust der Mitte, a.w., p. 246.

${ }^{83}$ idem, pp. 246-248.
} 
'Verlust der Mitte', waarin de oorlog (evenmin als later in het boek) niet een keer ter sprake komt. Door de emigranten in Califomie wordt het einde van de oorlog beleefd als een (ook persoonlijke) bevrijding en overwinning; Sedlmayr wordt in 45 aan de Weense universiteit weggedenazificeerd. De emigranten, die in de veronderstelling verkeren dat alleen nazi's, hardleerse Ewiggestrige en meelopers in Hitler-Duitsland zijn achtergebleven, keren na de oorlog als morele triomfators terug, om de wederopbouw en heropvoeding ter hand te nemen; Sedlmayr, wiens Verlust der Mitte, in de Bondsrepubliek van Adenauer herdruk op herdruk zal beleven, groeit samen met geestverwanten als Martin Heidegger, Carl Schmitt en de gebroeders Ernst en Friedrich Georg Jünger uit tot de personificatie van het innerlijke verzet tegen de belerende emigranten, van wie wordt verondersteld dat ze gedurende de voor thuisblijvers zware laatste oorlogsjaren aan de Californische stranden een gerieflijk leventje hebben geleid. ${ }^{84}$

Het conflict tussen de emigranten en de thuisblijvers, stelt de Akense politicologe Antonia Grunenberg in een in '93 gepubliceerd essay, zal tot ver in de jaren '60 een schisma veroorzaken in het intellectuele leven van de Bondsrepubliek. (In de DDR, waar vrijwel de gehele politieke en culturele elite uit emigranten is gerekruteerd, wordt de thuisblijvers of, zoals ze zichzelf zien, 'innerlijke emigranten', minder recht van spreken gegund.) Twee volstrekt heterogene belevingswerelden botsen op elkaar. Het vertoog wordt beheerst door tegenstellingen en tegenspraak; het beweegt zich rond de polen schuld - niet-schuld, aanpassing - verzet, meedoen - afstand bewaren, innerlijke emigratie - 'slagveld van de rede', het lijden in Duitsland - vlucht en ballingschap. ${ }^{85}$ Dit geldt zeker ook voor de Kulturstreit, die Sedlmayr begin jaren '50 in de Bondsrepubliek met Verlust der Mitte ontketent: het zogenaamde modernisme-debat, waarin Theodor Adorno en de abstracte schilder Willi Baumeister, wiens werk sinds ' 41 in nazi-Duitsland was verboden, als belangrijkste opponenten optreden. Het argument, dat het meest veelvuldig tegen Sedlmayr wordt ingebracht, is zijn Weense leerstoel gedurende de Hitler-jaren. Sedlmayrs aanklacht tegen een gedegenereerde, anorganische en amorele moderne kunst, roept bij menig criticus associaties op met de Entartungs-fraseologie van de nazi's. En bij een nadere beschouwing zou zijn katholieke cultuurfilosofie zelfs niet veel meer behelzen dan, zoals Baumeister opmerkt, de cultuurkritiek van Alfred Rosenberg in een christelijke vermomming. ${ }^{86}$

Adorno lijkt meer genuanceerd in zijn oordeel. Toch klinkt ook in zijn kritiek de nog vers in het geheugen liggende ervaring van vlucht en ballingschap door. "De gedachte, dat na deze oorlog het leven 'normaal' verder kan gaan, of zelfs de cultuur 'heropgebouwd' zou kunnen worden - alsof niet de wederopbouw van cultuur alleen al een contradictio in terminis is -, is bespottelijk," schrijft hij in zijn vier jaar na Sedlmayrs pamflet verschenen Minima Moralia (1951). "Miljoenen joden zijn omgebracht, en dat zou slechts een intermezzo zijn en niet de catastrofe zelf? Waarop wacht deze cultuur eigenlijk nog?"87 Auschwitz, in Verlust der Mitte niet eens een voetnoot, dient te worden beschouwd als een cultuurhistorische en morele caesuur ${ }^{88}$ - een noodzakelijke breuk met de oude Kultur, die Sedlmayr nog door

\footnotetext{
${ }^{84}$ Vergl. Grunenberg, a.w., pp. 105-113.

${ }^{85}$ ibidem.

${ }^{86}$ Wyss, a.w., p. 286. Hoffmann, a.w., p. 122. Wyss, B., Willi Baumeister und die Kunsttheorie der Nachkriegszeit. In: Deutschlandbilder. Kunst aus einem geteilten Land. Hrsg. E. Gillen. Berlin, 1997. pp. 532538, zie: 535, 536. Schütz, S., Anselm Kiefer. Geschichte als Material. Arbeiten 1969-1983. Köln, 1999. pp. 92-97. Voor een verzameling van verschillende bijdragen aan het modernisme-debat, zie: Die Herausforderung. Darmstädter Gespräche. Hrsg. H. W. Sabais. München, 1963. passim.

${ }^{87}$ Adorno, Th. W., Minima Moralia. Reflexionen aus dem beschädigten Leben. Frankfurt am Main, 1951, 1989. p. 65 .

${ }^{88}$ Centraal in Adorno's late filosofie staat; aldus de kunsthistoricus Eckhart Gillen, " (...) das Bewustsein der unüberbrückbaren Kluft, die sich durch die Zivilisationsbruch von Auschwitz aufgetan und jede Fortsetzung kultureller Traditionen in Deutschland unmöglich gemacht habe". Gillen, E., Tabula rasa und Innerlichkeit.
} 
middel van een ethisch-religieus reveil hoopt te reanimeren. Tijdens een in ' 53 gehouden voordracht plaatst Adorno de theorie van het verloren 'centrum' op haar kop. Waar Sedlmayr en diens geestverwanten een beroep doen op de kunstenaar om, in de woorden van de Zwitser Max Picard, de innerlijk verscheurde wereld "haar ongeschondenheid terug te schenken", of op zijn minst "het verlies aan geschondenheid te betreuren", 89 betoogt Adorno dat de "harmonie van het [moderne] kunstwerk daaruit bestaat, dat het het verscheurde, zelf onverzoend, onbeantwoord tot uitdrukking brengt en tegen [de verscheuring] standhoudt", en dat "in dit standhouden het enige verzoenende ligt (...)". Het is juíst het ontbreken van een 'centrum' in de zin van Sedimayr, dat de kwaliteit van moderne kunst uitmaakt: "Elke poging om, bijvoorbeeld onder verwijzing naar het kosmische, deze harmonie in de moderne kunst te realiseren, loopt daarop uit; dat we ons voor onze eigen kwetsbaarheid schamen en precies die brug naar het verleden willen slaan, die moet worden afgebroken". 90

Of Syberberg tijdens het schrijven van Zum Drama Friedrich Dürrenmatts op de hoogte is van deze nieuwe 'esthetische theorie', die vanaf eind jaren ' 60 richting bepalend voor de Westduitse kunsten zal gaan worden, ${ }^{91}$ is een vraag die zich moeilijk laat beantwoorden. In het proefschrift zelf ontbreekt elke verwijzing naar Adorno of het modernisme-debat. Later zal hij zich, zinspelend op het schisma in het Westduitse intellectuele leven van de jaren ' 50 , gelukkig prijzen, dat hij zijn intellectuele vorming niet heeft genoten in het Frankfurt van Adorno, en Sedlmayr aanwijzen als "degene die me het meeste heeft beïnvloed". ${ }^{22}$ Een van de weinige critici, die deze schatplichtigheid heeft onderkend, is Susan Sontag. In haar beroemde essay over de Hitler-film merkt Sontag tussen de regels door op, dat "de houding van volkomen superioriteit die Syberberg ten aanzien van het moderne aanneemt - in werkelijkheid gelooft hij alleen in Goethe en een degelijke gymnasiumopleiding -, doet denken aan de auteur van Verlust der Mitte, Hans Sedlmayr, bij wie hij in de jaren vijftig aan de universiteit van München kunstgeschiedenis heeft gestudeerd"..$^{93}$ Merkwaardig genoeg heeft dit terzijde van Sontag binnen de discussie over Syberbergs werk nooit veel aandacht gekregen. ${ }^{94}$ Het is niet een van zijn exegeten, maar Syberberg zelf, die in interviews steeds weer het belang van de door Sontag geboden "coup d'oeil in mijn biografie" heeft onderstreept. "Het feit dat men naar aanleiding van mijn film opnieuw spreekt over dit boek [Verlust der Mitte, G.G.], en dat nog wel dankzij een Amerikaanse, is een buitengewoon gelukkig toeval," meent hij bijvoorbeeld in '81 tijdens het in Brussel georganiseerde symposium 'Cinéma/Hitler/Nous'.

Deutschlandbilder vor und nach 1945. in: Deutschlandbilder, a.w., pp. 48-54, zie: $52 \mathrm{ff}$. Zie eveneens: Wyss, Willi Batumeister, a.w., pp. $536 \mathrm{ff}$. Steunebrink, G., 'Ik zal niet beschaamd staan in eeuwigheid'. Adorno en de betekenis van de Tweede Wereldoorlog voor de kunst. in: Een halve eeuw geleden. De verwerking van de Tweede Wereldoorlog in de literatuur. red. H. Ester, W. de Moor. Kampen, 1994. pp. 68-79. Saltzman, L., Anselm Kiefer and Art after Auschwitz. Cambridge, 1999. pp. 17-47.

${ }_{89}$ Picard, M., Die Atomisienung in der modernen Kunst. Hamburg, 1954. p. 10.

${ }^{90}$ Citaat ontleend aan: Wyss, a.w., p. 536.

91 idem, p. 536f. In het modernisme-debat, schrijft Wyss, "skizziert Adorno das Programm seiner 'Ästhetischen Theorie', die als luzideste philosophische Position zur Nachkriegskunst gelten kann - zur westeuropaïschen Nachkriegskunst, um genau zu sein". Zie in dit verband eveneens: Saltzman, a.w., p. 17: "Adorno"s statement (...). After Auschwitz to write a poem is barbaric' (...) has (...) come to function as a moral and aesthetic dictate to the postwar era". Syberberg, Kunst in Deutschland, a.w., p. 36, spreekt in dit verband over een "oberstes Gesetz der Nachkriegsästhetik". Zie eveneens: hoofdstuk 7, paragraaf 6.

${ }_{92}$ Syberberg, Der Wald, a.w., pp. 181 f. Bilder, a.w., pp. 44,45 .

${ }^{93}$ Sontag, S., Syberbergs Hitler. in: In het teken van Saturnus. Essays. Vert. D. Brisk. Weesp, 1984. p. 217.

Voor de invloed van Sedlmayrs kunsttheorie op deze film zie: hoofdstuk 6, paragraaf 6.

${ }^{94}$ Weliswaar merkt Eric Santner op, dat 'SSedlmayrs voorstelling van een 'verloren centrum' gedurende zijn gehele carrière een belangrijke invloed heeft uitgeoefend op Syberbergs denkbeelden over kunst en samenleving", maar ook hij laat in het midden wat deze kunstheorie precies inhoudt. Santner, E., Stranded Objects. Mourning, Memory and Film in Postwar Germany. Ithaca, London, 1990. p. 106. 
"Het stelt ons in staat de dingen eens een keer vanuit een volstrekt ander gezichtspunt [dan dat van Adorno, G.G.] te bediscussiëren. Sedlmayr heeft na de oorlog de gemoederen hoog doen oplopen met zijn stelling, dat we sinds het einde van de $18^{\mathrm{e}}$ eeuw, de tijd van de filosofie van de Verlichting en de Franse Revolutie, in de architectuur, de schilderkunst of de literatuur, de grote oude systemen hebben verloren, dat wil zeggen het grote iconografische systeem van de antieke tijd, van het christendom, enzovoorts. Alle grote systemen zijn in elkaar gestort en dit heeft geleid tot, wat Sedlmayr noemt, een 'verloren midden' in het binnenste van de kunsten. $\mathrm{Na}$ de oorlog heeft over dit onderwerp een grote discussie plaats gevonden en vervolgens heeft men het domweg vergeten. Het zou buitengewoon interessant zijn, dit alles nog eens te overdenken (...) vanuit een totaal andere instelling. Susan Sontags herontdekking van dit boek, biedt hiertoe de mogelijkheid. (...) Ook een gesprek met Sedlmayr zelf, die inmiddels 84 jaar oud is, gaat opnieuw tot de mogelijkheden behoren. Een dergelijk gesprek is uitermate belangrijk voor Duitsland, waar men in de regel meer kennis heeft van buitenlandse denk-tradities, dan van de eigen traditie die Sedlmayr vertegenwoordigt."

Sontags terzijde wordt door Syberberg dankbaar aangegrepen als argument voor een heropening van het modernisme-debat. $\mathrm{Nu}$ het stof van de toenmalige Kulturstreit is opgetrokken, wordt het mogelijk de verguisde kunsttheorie van Sedlmayr nog eens onder de loep te nemen - met een onbevangen en onbevoordeelde blik, zoals Syberberg die bij de Amerikaanse publiciste meent aan te treffen; niet vertroebeld door de schuldvraag of de traumatische ervaringen van vervolging en ballingschap. Voor het gesprek met Sedlmayr heeft Syberberg aanvankelijk een soortgelijke vorm in gedachten als de documentaire die hij in ' 75 heeft gemaakt over Wagners schoondochter Winifred Wagner-Williams: een lange monoloog over "het leven, de betekenis van kunst en de ondergang van onze Europese cultuur" door "de laatste grote humanist en leraar van de systematische kunstgesichiedenis", gefilmd tegen de achtergrond van een gotische kathedraal, een romaans klooster, een kasteel van Fischer von Erlach of desnoods, bij gebrek aan een geschikte locatie in de openlucht waar ongestoord kan worden gesproken ("Van het hooggebergte tot Athene en Rome en Parijs, overal onderbroekentoerisme"), een projectie van een door hemzelf uitgekozen schilderij." De film is nooit tot stand gekomen (Sedlmayr overlijdt in ' 84 op 88 jarige leeftijd in Salzburg), maar begin jaren ' 90 lukt het Syberberg alsnog met het door hemzelf als een vervolg op Verlust der Mitte gepresenteerde pamflet Vom Unglück und Glück der Kunst in Deutschland nach dem letzten Kriege (1990) de jaren' 50 kortstondig te doen herleven. Alsof de tijd veertig jaar stil heeft gestaan, voltrekt de (in de inleiding van dit boek beschreven) discussie zich volgens de destijds geijkte patronen. De echo van het modernisme-debat klinkt niet slechts door in commentaren, waarin Syberbergs kunsttheorie, niet gehinderd door een al te groot historisch besef, wordt vergeleken met de cultuurkritiek van Alfred Rosenberg; ${ }^{97}$ ook zijn eigen schelden op de 'joods-linkse' emigranten, wekt pijnlijke herinnering aan het toenmalige verbale geweld. ${ }^{98}$

\footnotetext{
${ }^{95}$ Revue Belge du Cinéma. Hans Jürgen Syberberg. (3) 1983. p. 33.

${ }^{96}$ Syberberg, a.w., p. 466 . Voor de documentaire over Winifred Wagner, zie: hoofdstuk 4.

${ }^{97}$ Zie bijvoorbeeld: Buruma, a.w., p. 35 .

${ }^{98}$ Syberberg, Kunst in Deutschland, a.w, p. 14: "Wie met de joden en de linksen in zee ging, maakte carrière. (...) Hoe konden de joden dat verdragen? Of waren ze alleen maar uit op macht?" Carl Schmitt in 1949: "Een volledig Europa-vreemd type, (...) dankzij de Russen omhooggeklommen beroepsrevolutionairen en joodse emigranten, (...) werd ons als maatstaf van normaal Duits gedrag opgedrongen. (...) [Gustav] Radbruch en [Karl] Jaspers waren na ' 45 de cultuurwetenschappelijke pin-ups van het bevrijde Duitsland; ze waren trots op hun successen. Tegenwoordig ervaren ze het verontwaardigd als een hernieuwde denazificatie van Duitsland, dat ze vervelend zijn geworden en terzijde worden geschoven. Maar alvorens als pin-up te worden neergehaald
} 
Maar hoezeer deze filmmaker ook ambieert de Hans Sedlmayr van de babyboomgeneratie te worden; tussen hem en zijn leermeester staat tenminste één obstakel. "Ik vermoed dat Sedlmayr mijn Hitler-film niet erg zou hebben gewaardeerd," moet Syberberg in een in 1991 afgenomen interview toegeven. ${ }^{99}$ Dit mag gerust een understatement worden genoemd. Terecht brengt Sontag de esthetiek van Hitler, ein Film aus Deutschland in verband met Wagner en de uit het wagnerianisme voortgevloeide kunst van het symbolisme en het surrealisme ${ }^{100}$ - dat wil zeggen: met precies die 'moderne' stromingen, die binnen de kunsttheorie van Sedlmayr (wat dat betreft zat hij met de stalinist Lukács geheel op één lijn) doorgaan voor de meest goddeloze: "das Chaos des totalen Abfalls". "En dan laten we gemakshalve nog maar buiten beschouwing, dat de cinema een bij uitstek modernistische vorm is; dermate gedegenereerd, dat Sedlmayr er in zijn pamfletten maar liever geen woorden aan vuil maakt. We mogen ons door alle verwijzingen naar het gedachtegoed van deze Oostenrijkse conservatief, waarmee vooral de late Syberberg zijn films en pamfletten doorspekt, dan ook niet op het verkeerde been laten zetten. Zijn houding ten opzichte van het moderne is aanmerkelijk dubbelzinniger dan die van de 'intellectuele pleegvader'. Zoals onder meer blijkt uit een passage in Der Wald steht schwarz und schweiget (1984), waarin hij de theorie van het 'verloren centrum' van enkele kritische kanttekeningen voorziet.

In Verlust der Mitte ontwaart Sedlmayr in de kunstgeschiedenis een aantal "tegenbewegingen", die de moderne atomisering van het Gesamtkunstwerk trachten op te heffen. De belangrijkste is de rond het midden van de negentiende eeuw door Richard Wagner en de architect Gottfried Semper (die onder meer het Festspielhaus in Bayreuth heeft ontworpen) ondernomen poging om aan het theater, dat in deze periode "sacrale ambities" koestert, de leidinggevende rol toe te bedelen, die in de grote drie cultuurepochen werd vervuld door de bouwkunst. Maar wat aanvankelijk begint als "een dionysische oppositie tegen de apollinische kunsttempel van het museum" zou nog voor Wagners dood ontaarden in een pijnlijke "theatralisering" van de overige kunsten: onder invloed van het theater verwordt de architectuur tot "theatraal schouwspel" (Neu-Schwanstein), de schilderkunst tot "toneeldecor" en het monument tot "een massieve en driedimensionale decoratie van een Wagner-opera". 102 Syberberg, edoch, blijkt op dit punt een fundamenteel andere mening toegedaan. "Lees bij Sedlmayr in Verlust der Mitte zijn verwijzing naar Richard Wagner en het Gesamtkunstwerk in het hoofdstuk 'theater", waar de theatralisering van alle kunsten (...) door hem wordt beschreven als een kritische factor in de ondergang van de oude kunsten," merkt hij op in Der Wald steht schwarz und schweiget. "Dit alles is voor hem uiteraard een symptoom van het allergrootste verval van de oude kunsten. Deze grote analyticus van het verval van het Avondland en de internationalisering van de onze cultuur begrijpt niet, hoe kunst hier nog eenmaal aanspraak maakt op haar ethische opgave en rechtvaardiging, en hoe door een nieuw programma, een nieuwe iconografie en een nieuwe esthetiek, die gebruik maakt van het oude, zoekend naar een nieuw aura, kunst ontstaat en oude dimensies opnieuw tot stand komen."103

Scherper had Syberberg het verschil met zijn spiritus rector niet kunnen formuleren.

\footnotetext{
[abgehängt], kunnen beter nog wat Duitsers worden opgehangen. Tot elk verraad vastbesloten verklaren ze, tot het uiterste te zullen strijden. Dat zullen ze ook doen. Hun pensioenen zullen ze tegenwoordig net zo min verliezen als in 1933. Dus op in de strijd voor vrijheid van meningsuiting en mensenrechten." Citaat ontleend aan: Grunenberg, a.w., pp. 109f. Grunenberg heeft dit citaat ontleend aan: Schmitt, C., Glossarium.

Aufeichnungen der Jahre 1947-1951. Berlin, 1991, p. 256.

${ }_{99}$ Interview met de auteur en Eling Delleman, zomer 1991.

${ }^{100}$ Sontag, a.w., pp. $193 \mathrm{ff}, 210 \mathrm{ff}$. Zie eveneens: hoofdstuk 3, passim.

${ }^{10 l}$ Sedlmayr, a.w. pp. 133-136.

102 idem, pp. $40 \mathrm{ff}, 58,88$.

${ }^{103}$ Syberberg, Der Wald, a.w., p. $286 \mathrm{f}$.
} 
Enerzijds zou je zijn cinematografische poëtica ongegeneerd rückwärtsgewandt kunnen noemen, in de zin dat het er telkens weer om zal gaan 'oude dimensies' te herstellen, zo men wil: 'precies die brug naar het verleden te slaan', die volgens Adorno zou moeten worden 'afgebroken'. Zo verdedigt hij tegenover Adorno's fameuze Hegel-omkering in de Minima Moralia, "Das Ganze ist das Unwahre", ${ }^{104}$ met verve de oude klassiek-idealistische geloofsovertuiging: "Men kan het totale alleen in delen weergeven. Das Ganze aber ist das Wahre." ${ }^{105}$ Anderzijds zal Syberbergs werk, vanaf de vroege filmexperimenten in Rostock en Oost-Berlijn tot aan de multimedia-installaties uit de jaren 90 , steeds in het teken staan van 'een zoeken naar een nieuw programma, een nieuwe esthetiek, een nieuwe iconografie', en hekelt hij de starre fixatie van zijn Münchense leermeester op de kunsten van vóór 1800. In dat opzicht zal hij altijd, zelfs in zijn meest conservatieve perioden, het 'pleegkind' blijven van de avant-gardist Bert Brecht; in een onophoudelijk gevecht verwikkeld met het 'geheven vingertje' van een bepaald slag 'kunstrechters' (Brecht over Lukàcs), dat maar niet wil inzien dat uitsluitend een esthetica "overeenkomstig een nieuwe kunst-wil op basis van ons tegenwoordige bewustzijn" (Syberberg) ${ }^{106}$ levensvatbaar is. Waarbij het op de keper beschouwd weinig uitmaakt, of de aanval op de avant-garde komt uit de hoek van de stalinist Lukács, of (zie hierboven) 'de Rode Cellen in München en aanverwante groeperingen', danwel vanuit die van een conservatief als Sedlmayr."Het zou de opgave moeten zijn van een analyticus deze nieuwe kunstrealiteit te onderzoeken; zo niet, dat schiet hij als historicus schromelijk tekort," vervolgt Syberberg in Der Wald steht schwarz und Schweiget. "Dat deze grote oude man van de kunstgeschiedenis een dergelijke sprong niet langer aandurfde, (...) behoort tot zijn tragiek." 107

\subsection{De post-brechtiaanse avant-garde}

Hiermee zij uiteraard niet gezegd, dat de 'artistieke pleegvader' Bertolt Brecht wél veel plezier aan Syberbergs Hitler-film zou hebben beleefd. Tegenover wagnerianisme, symbolisme en surrealisme stond Brecht - "Alles wat pogingen tot hypnotisering moet verbeelden, waardeloze roes moet voorbrengen, benevelt, dient te worden opgegeven" $108-\mathrm{zo}$ mogelijk nog afwijzender dan Sedlmayr. Toch is het esthetische programma, dat aan deze en andere films ten gronde ligt, in zijn kern onvervalst brechtiaans. Nog in de jaren '90 klinkt de echo van de 'leer van het epische theater' door in Syberbergs roep om de vercommercialiseerde cinema van zijn dagen om te vormen tot een 'moreel instituut' in de zin van Friedrich Schiller - of, om de titel van een bekend essay van Brecht te parafraseren: van een 'pleziertheater' tot een 'leertheater' ${ }^{109}$ Cinema, aldus Syberberg, kan meer zijn dan louter "stompzinnige amusementsindustrie", namelijk een instrument tot "artistiek-maatschappelijke vormgeving", 110 zoals Brecht zijn epische of anti-aristotelische theater begreep. Hiertoe is het echter noodzakelijk, dat de cinema opnieuw aansluiting vindt bij de theatrale avant-garde. Of,

\footnotetext{
${ }^{104}$ Adorno, a.w, p. 57.

${ }^{105}$ Syberberg, H.J., Gesamtkunstwerk. in: Gesamtkunstwerk: Europaïsche Utopien seit 1800. Aurau, 1983. pp. 433-436, zie: 436. Zie eveneens: Syberberg, Der Wald, a.w., pp. $157 \mathrm{ff}$.

${ }^{106}$ Syberberg, Der Wald, a.w, p. 258.

${ }^{107}$ Syberberg, a.w, p. 287.

${ }_{108}^{10}$ Brecht, B., Gesammelte Werke 17. Schriften zum Theater 3. Frankfurt am Main, 1967, 1990. p. 1011.

${ }^{109}$ Syberberg, Aus der Zeit der letzten Unschuld, a.w., p. 101. Brecht, B., Gesammelte Werke 15. Schriften zum Theater I. Frankfurt am Main, 1967, 1990. pp. 262-272. Zie eveneens: hoofdstuk 3, paragraaf 3.

${ }^{110}$ Mayer, Syberberg, a.w., p. 149.
} 
om nog eenmaal Brecht aan te halen, de naar haar vorm nog steeds aristotelische cinema dient op "het technische niveau van het moderne theater" te worden gebracht. ${ }^{11 .}$

Misschien gaat het wat al te ver Syberbergs esthetiek te kenschetsen als "theater vertaald in film" (de literatuurwetenschapper Anton Kaes). ${ }^{112}$ Wel verraadt vrijwel het gehele latere werk een voor een cineast ongebruikelijk sterke oriëntatie op wat in het moderne theater gaande is. En het is verleidelijk ook zijn proefschrift in dit licht te lezen. Natuurlijk; tot op zekere hoogte zou je Zum Drama Friedrich Durrenmatts een typisch produet uit de Sedlmayrschool kunnen noemen. De invloed van de kunsthistoricus is het meest evident in de slotbeschouwing, waarin het ontstaan van het 'absurde bewustzijn' wordt toegeschreven aan "een honderdjarig proces van een desacralisering van het sacrale" dat "het proces van een sacralisering van het profane" zou "tegenwerken". "113 Het leeuwendeel van het proefschrift gaat echter op aan een nauwgezette, misschien een tikkeltje schoolse analyse van nieuwe theatrale technieken, zoals die door Dürrenmatt zijn ontwikkeld. En met het oog op het latere werk zouden dergelijke, meer ambachtelijke observaties wel eens interessanter kunnen zijn dan de bij tijd en wijle nogal geforceerd aandoende poging om de avant-garde in te passen binnen de kaders van Sedlmayrs ultra-conservatieve 'structuur-analyse'. Want het kan haast niet anders, of ook het "moderne theater van de post-Brecht-tijd", zoals het absurdisme in het voorwoord wordt getypeerd, ${ }^{11.4}$ moet voor de film/theater-maker in spe een dankbare bron van inspiratie zijn geweest.

Wat te denken bijvoorbeeld van de paragraaf, die Syberberg wijdt aan de functie van het citaat in de eerste akte van Dürrenmatts 'tragische komedie' Der Besuch der alten Dame (1956)? Het is onder exegeten min of meer gebruikelijk om Syberbergs films, waarin het citaat welhaast tot stijlprincipe lijkt te zijn verheven, te interpreteren als "postmodern'. ${ }^{115}$ Lees je echter zijn proefschrift, dan valt moeilijk de indruk te vermijden, dat het hier gaat om een techniek, die van het Dürrenmatt-theater is afgekeken, om vervolgens door Syberberg in zijn films steeds verder te worden geperfectioneerd. In elk geval verschilt zijn analyse van het citeer-karakter van Der Besuch der alten Dame, niet wezenlijk van wat hij een decennium later in de bundel Filmbuch zal schrijven over een film als Karl May-Auf der Suche nach dem verlorenen Paradies (1974). Het citeren van namen en/of attributen met een cultuurhistorische of morele betekenis, legt de promovendus uit, dient eerst en vooral een praktisch nut: personages of situaties worden binnen een bepaalde context geplaatst. Maar het hergebruik van "vroeger en, eventueel, ook heden ten dage nog met gevoelswaarde beladen begrippen uit culturele werelden" als "etiketten voor een gebruikswaarde", of het samenvoegen van heterogene culturele tekens ("namen met een sterke nationaalpatriottistische gevoelswaarde staan naast namen met een mercantiele connotatie"), kan ook een "verrassend" en "provocerend" effect hebben. Het kan, naast "een glimlach", een "innerlijk gevoel" oproepen van "een verlies van onze culturele of taalkundige traditie".

\footnotetext{
111 "Die Oper war auf den technischen Standard des modemen Theaters zu bringen." Brecht, Gesammelte Werke 17, a.w., p. 1008. Volgen we Syberberg, dan is de cinema genealogisch aan de opera verwant. Zie bijvoorbeeld: Syberberg, H.J., Parsifal. Ein Filmessay. München, 1982. pp. $18 \mathrm{ff}$. Zie eveneens: hoofdstuk 3, paragraaf 3.

${ }^{112}$ Kaes, A., From Hitler to Heimat. The Return of History as Film. Cambridge, Mass., London, 1989. pp. $42 \mathrm{f}$.

${ }^{113}$ Syberberg, Zum Drama Friedrich Dürrenmatts, a.w., p. 141: "De religieuze verhouding van het kunstwerk tot zijn goddelijke voorbeeld werd zwakker en het kreeg een zellfstandig-onafhankelijke Licht-intensiteit. In ogenblikken van compensatie, ontstond er een balans tussen deze twee, aan elkaar tegengesteld verlopende ontwikkelingen. Het immanente en het transcendente doordrongen elkaar, zonder zichzelf door de predominantie van het ene over het andere uit te doven. En zoals de kunst in vroeger tijden het gevaar liep door de hegemonie van het transcendente van haar wereldse component te worden beroofd en daarmee vergaand in haar bestaan te worden bedreigd (het middeleeuwse mysteriespel), zo lijkt de tegenwoordige hegemonie van het immanente het kunstwerk niet slechts te bepalen, maar vooral tot zelfvernietiging toe in gevaar te brengen."

114 idem, p. 1.

115 Zie bijvoorbeeld: Kaes, a.w., passim. Santner, a.w., passim. Reijnders, R., Verdwijnpunt Object. in: Van het postmodernisme. red. J. Boomgaard. S. Lopez. Amsterdam, 1985. pp. 113-137.
} 
Waarbij hij in parenthesi opmerkt, dat dit verlies in Der Besuch der alten Dame slechts wordt aangeduid als symptoom van de tijdgeest. Het stuk "provoceert lachen en ontzetting", maar "beoogt (...) niet oude cultuur te redden". "Dit alles zal zich wellicht onbewust bij de lezer of de toeschouwer voltrekken. Het citaat slaat een toon aan en brengt een associatieve reeks van gedachten op gang. Misschien heeft het citaat een heterogeen karakter en vermengen de associaties zich met een niet controleerbare gevoels- en gedachteverwarring."

En er laten zich vanuit dit proefschrift nog wel meer lijnen naar het latere werk trekken. Ik wees reeds op het wereldbeeld van de Hitler-film, dat door de neo-marxist Kühnl met een beroep op Lukács wordt bekritiseerd als 'irrationeel'. Je zou dit tevens een van de meest in het oog springende verschillen kunnen noemen tussen Syberberg en het Brechttheater, waarin de dialectische redelijkheid van het zijnde nog wel als (marxistisch) axioma wordt voorondersteld. Kühnl gaat in dit verband nog een stap verder: de verwerping van dit axioma zou de Hitler-film in een totale oppositie tot het Brecht-theater plaatsen. ${ }^{17}$ Maar Syberberg blijkt, het zal niet verbazen, een andere visie toegedaan. Dat Brecht de "rationalistische noodzaak" van het moderne theater beklemtoonde, is misschien begrijpelijk vanuit de antifascistische "cultuurstrijd tegen zijn tijd", meent hij in Die Kunst als Rettung aus der deutschen Misere (1978). "Logisch en alleen mogelijk en noodzakelijk was het niet". 18 Zoals Syberberg ongetwijfeld zal hebben opgestoken uit zijn studies van het Dürrenmatttheater, waarin " $(. .$.$) het zelfbewustzijn, of op zijn minst de zelfgenoegzaamheid van de ratio$ aan het wankelen [wordt] gebracht", 119 zonder dat dit resulteert in een breuk met de door Brecht ontwikkelde anti-aristotelische dramaturgie. Zijn immers niet ook de stukken van absurdisten als Dürrenmatt of Beckett naar hun vorm anti-aristotelisch? Ook in Becketts Wachten op Godot ontbreekt de voor de aristotelische dramaturgie typerende ontwikkeling naar een climax of plot. Het toont slechts een toestand die alsmaar voorduurt en als voornaamste kenmerk heeft, dat men steeds weer uitkomt op het punt waar men begon. Het enige verschil met het Brecht-theater lijkt te zijn, dat het levensgevoel, dat spreekt uit dit stuk, moderner aandoet. Want het klinische rationalisme van Brechts op dialeetisch-materialistische leest geschoeide 'leerstukken', zo zouden we Syberbergs argumentatie in het proefschrift kunnen samenvatten, strookt niet langer met het 'levensbewustzijn van rond het midden van de twintigste eeuw', waarin de desillusie hoogtij viert. En door dit 'tegenwoordige levensgevoel' tot uitgangspunt van hun stukken te maken en te zoeken naar 'nieuwe vormen van verbeelding', hebben 'absurdisten' als Dürrenmatt of Beckett, zonder de door Brecht geïnitieerde vernieuwingen van de aristotelische dramaturgie terug te draaien, een nieuwe, meer eigentijdse vorm van anti-aristotelisch theater gecreëerd, waarin ruimte is voor een absurde beleving van de werkelijkheid.

Volgen we de promovendus, dan zouden we deze post-brechtianen bovendien schromelijk tekort doen, wanneer we ervan uitgingen dat hun theater weinig meer is dan een

\footnotetext{
${ }^{116}$ Syberberg, Zum Drama Friedrich Dürenmatts, a.w., pp. 38-47. Voor Syberbergs latere analyse van het gebruik van het symbool in Karl May, zie: Syberberg, Filmbuch, a.w, 36-46. Voor een voorbeeld van de manier waarop Syberberg het symbool gebruikt, zie: hoofdstuk 6, de paragrafen 1 en 2.

117 "Bei alledem erhebt Syberberg allen Emstes den Anspruch, in der Brecht-Tradition zu stehen," schrijft Kühnl. "Es mag sein, daß er sich in technischer Hinsicht von Brecht einiges abgeschaut hat. Der Aussage nach aber steht er eindeutig auf der Gegenseite. Brecht gehörte genau zu jenen von Syberberg geschmähten 'Materialisten', die den Faschismus und seine Politik im Zusammenhang mit kapitalistischen Interessen gesehen haben. Die Berufung auf Brecht muß deshalb als Versuch der Irreführung gekennzichnet werden." a.w., p. 124. En dit is uiteraard goed mogelijk. Zoals we in het hiema volgende hoofdstuk zullen zien, vermoedt ook Susan Sontag in haar Hitler-essay dat het zich beroepen op Brecht wel eens een poging van de Hitler-regisseur zou kunnen zijn, om zich onpartijdiger voor te doen dan hij in wezen is - "(..) het kan niet anders, of hij heeft meer van Wagner dan van Brecht in zich (...)". Sontag, a.w., p. 209. Maar ironisch is het wel; om te moeten meemaken hoe Syberberg uitgerekend met een beroep op Lukács uit de Brecht-traditie wordt weggeschreven.

${ }_{118}$ Syberberg, Die Kunst als Rettung..., a.w., p. 29.

${ }^{119}$ Syberberg, Die freudlose Gesellschaft, a.w., p. 366.
} 
affirmatie van de absurditeit van het bestaan - of, om Kühnl te parafraseren: een affirmatie van de 'hulpeloosheid' en 'ontreddering' van de moderne mens. Van het 'socialistische realisme', dat de arbeidersmassa klassenbewust probeert te maken, zijn we hier inderdaad ver verwijderd. Maar 'decadent', zoals de absurdisten door Lukács en diens navolgers wordt verweten, is dit theater allerminst. Opmerkelijk is, meent Syberberg in zijn proefschrift, dat moderne auteurs als Dürrenmatt teruggrijpen op "formele en ethische oerelementen van het theaterspel en het handelen"; ze zijn op zoek naar "het oerdramatische en het oerethische of religieuze". Deze oervorm van drama en ethiek of religie is, verduidelijkt Syberberg, "het spel". Waarbij 'spel', voegt hij hieraan toe, geheel mag worden begrepen in de geest van Johan Huizinga's definitie in de Homo Ludens (1938). Dat wil zeggen als een op zichzelf staande realiteit, die weliswaar een "vormgevende vrijheid" en "vormgevend vermogen" veronderstelt, maar tegelijk bepaalde (spel-)regels als "absoluut bindend" poneert; die anders is dan de gewone wereld en haar anders-zijn ook voortdurend accentueert; waaraan geen materieel belang is verbonden en die geen nut kent, maar "een doel zoekt in een in-zich-zelfzijn, zonder goed of kwaad te impliceren". Het spel, schrijft Syberberg, ontstaat uit "(...) een hunkering of hartstochtelijk verlangen [Sehnsucht] naar een gevoel van spanning en vreugde en een bewustzijn van een anders-zijn dan het gewone leven". Dit geldt ook voor wat Huizinga het "heilige spel" of de cultus noemt: de hunkering naar transgressie, naar een overschrijding van de orde van het profane, is de "oerkracht van het ethisch-religieuze bewustzijn". ${ }^{20}$ En waar het in de tegenwoordige kunsten op aankomt is, betoogt Syberberg, of modeme theatermakers als Dürrenmatt zich verliezen in vrijblijvende "vorm- en denkspelen", of in staat blijken deze "oerkracht", die ergens diep in het binnenste van de profane moderne mens nog moet sluimeren, "te reactiveren". "Het theater van Dürrenmatt geeft zich rekenschap van die hoogst absurde vrijheid, die aanvankelijk bij de auteur geen verblijdend gevoel maar een uiterst problematische beklemming teweegbrengt, hem uiteindelijk echter toch een hoge mate aan menselijke vreugde schenkt, als hij zich geroepen voelt vanuit zichzelf de wereld te begrijpen en te doorstaan, alsook in een kunstwerk autogeen te vormen. De verwijzing naar de pijn en de angst voor de vertwijfeling, of de ogenschijnlijk nogal oppervlakkig en schalks lijkende uitweg in humoristische lichtzinnigheid, verraden bij een nadere beschouwing serieuze en radicale pogingen tot geestelijke reiniging.".121

De post-brechtiaan biedt niet langer leerstukken over een maakbare samenleving, maar nodigt het publiek uit tot het spelen van een moreel spel op basis van het 'tegenwoordige levensgevoel'. De inzet van het spel is, door het reactiveren van ethisch-religieuze 'oerkrachten', als het ware door de moderne crisis heen, een nieuw metafysisch evenwicht proberen te vinden, dat " $(. .$.$) tegen de als absurd beleefde wereld als ethisches Trozdem kan$ worden ingebracht". ${ }^{122}$ Dürrenmatt maakt de mens en de wereld niet mooier dan ze zijn. Hij toont ons de mens zoals die in zijn onmetelijke vrijheid geworden is: een "tragisch" en tegelijk "komisch" schepsel, dat "op zichzelf is aangewezen" in een uitzichtloze, absurde en zinloze wereld en dat "zonder hulp uit een transcendent domein beslissingen moet nemen over goed en kwaad, die eigenlijk zonder een het menselijk domein overstijgende maatstaf niet genomen kunnen worden". Maar wellicht, speculeert Syberberg, kan dit tragi-komische spel een pijnlijk proces van 'geestelijke reiniging' in gang zetten en leiden tot een herwonnen ethisch-religieus bewustzijn van een anders-zijn dan de profane wereld, dat de mens de innerlijke kracht geeft zich tegen de uitzichtloosheid, absurditeit en zinloosheid teweer te stellen. "Het gaat om de vraag, in hoeverre het dramatische kunstwerk van de tegenwoordige tijd in staat is mensen ten tonele te voeren, die in hun spel uit hun innerlijk een

\footnotetext{
${ }^{120}$ Syberberg, Zum Drama Friedrich Dürrenmatts, a.w., pp. 143, 144. Zie eveneens: Huizinga, J., Verzamelde werken 5. Haarlem, 1950. pp. 26-246, met name: pp. 26-55, 74-104.

${ }^{121}$ Syberberg, a,w., pp. 14l ff.

122 ibidem.
} 
geloofwaardige ethiek [reactiveren] en met een religieuze zuiverheid voorbeeldig ten tonele voeren. (...) Dan zal blijken, of de mens in zijn onmetelijke vrijheid in staat is [de als absurd beleefde wereld] te verdragen; of hij vertwijfelt en aan haar te gronde gaat, of uit zijn innerlijk een ethisch desondanks reactiveert, dat hem een levensvreugde waarborgt, die weliswaar zwaar bevochten is en steeds weer wordt bedreigd, maar uiteindelijk alle twijfel overwint., ${ }^{, 23}$

\subsection{De vroege films}

De jonge Syberberg spreekt hier de taal van zijn tijd. In de ogenschijnlijk zo optimistische wederopbouwjaren - het zijn de hoogtijdagen van het existentialisme - is het besef van een zingevingscrisis wijdverbreid. En de promovendus heeft gelijk: typerend voor de westerse kunsten van de jaren '50 en de vroege jaren '60 is de hang naar het archaïsche, naar de mythische oerbronnen van esthetiek en moraal. ${ }^{124}$ We hoeven in dit verband slechts te denken aan de 'archetypische', door het symbolisme van Carl Gustav Jung geïnspireerde Wagnerensceneringen van Wieland Wagner, de artistieke leider van de Bayreuther Festspiele tussen 1949 en 1966; ${ }^{125}$ aan de 'organisch-mythische' sculpturen van Ewald Mataré, de leermeester van Joseph Beuys; ${ }^{126}$ of aan de esoterische abstracte kunst van Willi Baumeister, die we hierboven hebben leren kennen als één van de belangrijkste opponenten van Sedlmayr in het modernisme-debat. ${ }^{127}$ Terecht merkt Beat Wyss op dat Sedlmayr en Baumeister, naast alle evidente verschillen in hun politieke oriëntatie, ook veel met elkaar gemeenschappelijk hebben. De kritiek op het 'technische tijdperk', dat de moderne mens van zijn spirituele houvast zou hebben beroofd (Entzauberung), wordt door het merendeel van Sedlmayrs opponenten in dit debat volmondig onderschreven. En net als deze Oostenrijkse conservatief staan ook moderne kunstenaars als Baumeister nog met beide benen op de 'kosmische brug naar het verleden', waarvan Adorno eist dat die wordt 'afgebroken'. "In de boekenkast van de kunstenaar [Baumeister, G.G.] wordt de belangrijkste plaats nog steeds ingenomen door Meister Eckhart (...)," aldus Wyss. ${ }^{128}$

Ook Syberbergs vroege films uit de tweede helft van de jaren "60 ademen nog geheel de sfeer van de Westduitse kunsten vóór Adorno. De eerste schreden op het pad van filmmaker moeten een ontnuchterende ervaring zijn geweest. Alle grote idealen in het proefschrift ten spijt, begint Syberbergs loopbaan niet, zoals die van zijn collega-NieuweDuitse-Filmmakers Alexander Kluge en Rainer Werner Fassbinder, met een assistentschap bij respectievelijk Fritz Lang, of een sleutelpositie bij het Münchense Anti-Teater, maar met hand- en spandiensten in het centrum van de later zo fel bekritiseerde mediacratie: de televisie. Van 1963 tot ' 66 maakt hij als freelancer voor de Bayerische Rundfunk naar eigen zeggen 185 documentaires, in speelduur variërend van 3 tot 30 minuten: "Nieuws, gebruiksfilms naar aanleiding van de culturele actualiteit, kalender-verhalen over

\footnotetext{
${ }^{123}$ ibidem.

124 "Seit der Romantik hat der Mythos kaum so sehr die Geister beschäftigt wie heute," schrijft de publicist Kurt Hoffman, in de inleiding van een uit 1965 daterende bundel met essays van onder meer Karl Jaspers. "Auf Kritik und Ablehnung folgt eine neue Ehrfurcht vor dem Mythos - trotz der Wissenschaftsgläubigkeit und der Technisierung, die unser Zeitalter prägen. Im Mythos wird in unserer Zeit eine unvergängliche Wahrheit wiederentdeckt, eine Wahrheit die nötig ist und fruchtbar sein kann und die dem Wissenschaftlichen Fortschritt nicht nur nicht widerspricht, sondern als notwendiges Gegengewicht von ihm gefordert wird." Hoffman, K., Einführung. in: Die Wirklichkeit des Mythos. Hrsg. K. Hoffman. München, Zürich, 1965. pp. 5-10, zie: Sf.

${ }^{125}$ Zie bijvoorbeeld: Panofsky, W., Wieland Wagner. Bremen, 1964.

${ }^{126}$ Bijvoorbeeld: Thomas, a.w., pp. $40 \mathrm{ff}$.

${ }^{127}$ Bijvoorbeeld: Ernste Spiele. Der Geist der Romantik in der deutschen Kunst 1790-1990. Hrsg. Ch. Vitali. München, 1995. pp. 18f.

${ }^{128}$ Wyss, a.w., p. 536.
} 
onderwerpen die geen hond interesseerden". ${ }^{129}$ Wellicht mogen we deze aanloopfase, zoals de Amerikaanse literatuurwetenschapper Russell R. Berman (1984) heeft geopperd, ${ }^{130}$ beschouwen als een soort leertijd, waarin Syberberg het oorspronkelijk van zijn vader geleerde métier beter onder de knie krijgt. Dat hij inderdaad in techniseh opzicht sinds het nogal amateuristisch aandoende jeugdwerk de nodige vooruitgang heeft geboekt, blijkt uit de film waarmee hij in 1965, hij is dan dertig jaar oud, debuteert: de nog door de Bayerische Rundfunk geproduceerde theaterdocumentaire Fünfter Akt, siebente Szene. Fritz Kortner probt Kabale und Liebe.

Alsof hij de pijnlijke ervaring van de voorafgaande "hel van artistieke inactiviteit"131 alsnog met terugwerkende kracht wil uitwissen, neemt Syberberg de draad van zijn artistieke loopbaan weer op, waar die meer dan tien jaar eerder met de vlucht uit de DDR werd afgebroken. Qua opzet lijkt Fünfter $A k t$, siebente Szene een duplicaat van de theaterfilmpjes, die hij in de vroege jaren ' 50 als scholier in Rostock en Berlijn heeft gemaakt. Drie dagen lang heeft Syberberg met een kleine crew in de schouwburg van München de repetities verfilmd van Schillers 'burgerlijke tragedie' Kabale und Liebe, onder regie van de in eigen land legendarische acteur/regisseur Fritz Kortner, de grootmeester van het expressionistische theater uit de Weimar-tijd. Het resultaat is een documentaire, waarin stap voor stap is vastgelegd hoe eén specifieke scène - de zevende scène uit de vijfde akte, waarin het liefdespaar Ferdinand en Louise een zelfverkozen dood door gif sterft - onder Kortners hand van een tekst op papier langzaam maar zeker uitkristalliseert tot theater. Volgens Syberberg een film over "de moeite die het de mens kost, om kunst tot stand te brengen".

In de daaropvolgende jaren zal Syberberg zich vooral als documentairemaker profileren. Uit hetzelfde jaar als Fünfter Akt, siebente Szene dateert het portret van Romy Schneider, Romy. Anatomie eines Gesichts (1965), dat overigens, na onenigheid met Schneiders manager en de Nederlandse producer Rob Houwer, zonder de naam van Syberberg op de titeirol in roulatie wordt gebracht. Een tweede Kortner-film uit 1966, Kortner spricht Monologe für eine Schallplatte, toont de grote acteur in enkele van zijn vroegere glansrollen, waaronder Richard III en Shylock. De meest bekende vroege documentaire is Sex-Business made in Pasing (1969) of, zoals de titel oorspronkelijk had moeten luiden: Bis daß es aus der Hose raucht. Aan de hand van een ontluisterend, maar bij vlagen ook hilarisch portret van softpornoproducent Alois Brummer (Graf Porno), neemt Syberberg ons mee op een, in cinéma-vérité-stijl gefilmde hellevaart door de duistere krochten van de Beierse seksindustrie en formuleert hij een verbitterde, met tabellen en statistieken onderbouwde aanklacht tegen een filmwereld, waarin het 'pleziertheater' geheel de overhand heeft gekregen: "De bioscoop als bordeel, met veel reden tot lachen, als het niet zo ernstig was". ${ }^{133}$

Meer ambitieus zijn de eerste speelfilms. Bij een oppervlakkige beschouwing heeft Scarabea - Wieviel Erde braucht der Mensch?, zoals de titel van het speelfilmdebuut uit ' 68 luidt, nog wel iets weg van een brechtiaans fabelstuk. De film is losjes gebaseerd op Tolstoj's novelle Hoeveel aarde heeft de mens nodig?, waarin een boer door de duivel wordt verleid te streven naar steeds meer land. Tijdens een bezoek aan de steppen in Zuid-Rusland, sluit hij met de aldaar levende nomaden een op het oog profijtelijke overeenkomst: in ruil voor al zijn meegebrachte geld krijgt hij zoveel land als hij op een dag kan belopen. Maar hebzuchtig als hij is, weet de boer geen maat te houden. Het land dat hij beloopt heeft een dermate grote omvang, dat hij aan het eind van de dag, tot grote vreugde van de nomaden, van uitputting

\footnotetext{
${ }^{129}$ Syberberg, Filmbuch, a.w., p. 47.

${ }^{130}$ Berman, R. A., Hans Jürgen Syberberg. Of Fantastic and Magical Worlds. in: New German Filmmakers.

From Oberhausen Through the 1970. ed. K. Philips. New York, 1984. pp. 359-378, zie: 360.

${ }^{131}$ Syberberg, a.w., p. 111.

132 idem, p. 71.

${ }^{133}$ idem, p. 80.
} 
dood neervalt - zoveel aarde heeft de mens nodig: een eenvoudig graf, van twee meter in de lengte en twee meter in de diepte. In Scarabea heeft Syberberg deze vertelling overgeplaatst van de Zuidrussische steppen naar Sardinië. De boer uit Tolstoj's novellie is een egomane Duitse toerist, die zijn oog heeft laten vallen op een stukje strand, een soortgelijke overeenkomst met de plaatselijke bevolking aangaat, maar - anders dan Tolstoj's boer-nog voor het vallen van de avond tot het inzicht komt, dat hij diep in zijn hart eigenlijk nooit veel meer heeft verlangd dan een rustige oude dag in het zonnige Zuiden en uiteindelijk gelouterd sterft. De katharsis gaat gepaard met het nodige dionysische feestgedruis. Op het marktplein in het Sardijnse dorpje worden, ten behoeve van een feestmaal, koeien geslacht en hersenpannen en oogbollen doormidden gekliefd. Honden doen zich tegoed aan een kadaver, uit darmen kruipen maden - de gelouterde Duitser wordt overgoten met moedermelk. Een en ander wordt door Syberberg dermate plastisch in beeld gebracht, dat naar verluidt door de distributeur is bedongen al te teergevoellige toeschouwers, middels een in de bioscoop tot klinken gebrachte gong, bijtijds voor de meest gruwelijke scènes te waarschuwen. ${ }^{134}$

Scarabea vertelt geen lineair verhaal met een coherente plot. De film, door een Duitse criticus getypeerd als "een ratjetoe van Tolstoj's legende, Johan Sebastian Bachs Italiaanse Concert en motieven uit de Grieks-Romeinse mythologie met schetsen van Leonardo da Vinci en Goethe's Faust in woord en beeld", ${ }^{135}$ is opgebouwd uit een aaneenrijging van beelden met een mythische connotatie. "Op een formeel niveau," schrijft Russell Berman, "houdt dit nietbeklemtonen van een spannende plot de weerlegging in van de Hollywood-cinema (...)". ${ }^{136}$ En dit is inderdaad hoe Syberberg zijn film begrepen wil zien: als een vroege, nog aarzelende poging tot een niet-aristotelische cinema in de traditie van Schillers theater als "moreel instituut' als antwoord op het 'pleziertheater' uit Hollywood. In een interview uit '73 noemt Syberberg Scarabea een "archaiische film". ${ }^{137}$ Evenals het theater van Dürrenmatt grijpt de film terug op het 'oerdramatische en het oerethische of religieuze': het dionysische spel, waaraan een louterende werking wordt toegeschreven. Want Scarabea mag dan geen spannende plot kennen; katharsis - ook bij het publiek - is wel degelijk het thema én de programmatische inzet van deze epische film: de scarabee is in de Egyptische mythologie het symbool van de wedergeboorte. Of verlossing ook daadwerkelijk mogelijk is, blijft echter vooralsnog een open vraag. Voor Syberberg is de titel meerduidig: de scarabee torst de zon met zich mee, gelijk Sisyphus zijn rotsblok tegen de bergwand probeerde op te wentelen. ${ }^{138}$

Toch mist deze film het onderkoeld tragikomische, dat zo typerend is voor Dürrenmatts absurdisme. Met zijn wilde surrealistische esthetiek - Syberberg spreekt over een "surreëel sprookje"139 - roept Scarabea nog het meeste associaties op met latere werken van eigen hand als Ludwig - Requiem für einen jungfräulichen Konig. (1972). Al denk je, gezien de archaïsche vorm, onwillekeurig ook aan de tragediefilms van Pier Paolo Pasolini, die omstreeks dezelfde tijd ontstaan (Edipo Re, Medea). De associatie met Pasolini (maar dan eerder de Pasolini van Accatone) is nog sterker bij de met het Italiaanse neo-realisme flirtende speelfilm San Domingo (1970). Opnieuw gaat het om een literatuurverfilming, dit maal van een novelle van Heinrich von Kleist met wiens werk Syberberg zich vanaf het midden van de jaren '80 (Requiem voor het einde van Pruisen) intensief zal gaan bezighouden. In Die Verlobung in St. Domingo valt een blanke officier ten prooi aan de intriges van een groep zwarte rebellen. Een mulattin krijgt de opdracht, door hem te verleiden, de officier bezig te

\footnotetext{
${ }^{134}$ Sandford, a.w, p. 6.

${ }^{135}$ Citaat ontleend aan: Hans-Jürgen Syberberg. Deutscher Filmregisseur und -produzent; Dr. phil, in: MunzigerArchiv/Int.Biograph.Archiv. $41 / 84$.

${ }^{136}$ Berman, a.w.; p. 364.

${ }^{137}$ Zaagsma, F., Ludwig-Requiem für einen jungfräulichen König/Theodor Hierneis-oder wie man ehemaligen Hofkoch wird. in: Skoop. 5 (oktober 1973). pp. 34-37, zie: 34. Zie eveneens: Syberberg, a.w., pp. $47 \mathrm{ff}$.

${ }^{138}$ Vergl. Syberberg, a.w., p. 50.

${ }^{139}$ ibidem.
} 
houden, tot de rebellenleider arriveert om hem te vermoorden. De toestand wordt enigszins gecompliceerd, wanneer de vrouw echt verliefd blijkt te zijn. De verliefdheid zet een proces van geestelijke loutering in gang, waarin ze de ware aard van haar rebellenvrienden leert doorzien. Aan het eind van de novelle vindt ze samen met haar blanke minnaar de dood. Als locatie voor de film heeft Syberberg aanvankelijk een van de voormalige Duitse koloniën in gedachten. Financiële problemen (onder meer veroorzaakt door de commerciële flop van Searabea) dwingen hem echter ertoe de set dichter bij huis te plaatsen: ${ }^{140}$ San Domingo is gesitueerd in het München van 1969. De officier uit Kleists novelle is een langharig burgermanszoontje, dat ervan droomt aan de benauwende wereld van zijn ouders te ontsnappen richting het Zuiden, liefst Afrika. Dit burgermanszoontje komt in contact met een groep criminele rockers die, met zijn toestemming, de ouders proberen te chanteren met een in scène gezette ontvoering van zoonlief. Een mulattin, de dochter van een Duitse vrouw en een Amerikaanse GI, moet hem van zijn reisplannen afhouden tot de ouders hebben betaald. Maar meer nog dan in Scarabea doet het verhaal eigenlijk nauwelijks terzake.

De film, schrijft Syberberg in een toelichting, ontstaat op een moment, dat een nieuwe generatie in haar stijl van leven en samenwonen "radicaal breekt met alles wat tot dan gebruikelijk is op het gebied van cultuur, zeden, moraal, politiek besef enzovoorts". ${ }^{141}$ Deze totale 'Umwertung aller Werte', die het feitelijke thema vormt, liet zich met methoden van de speelfilm niet in kaart brengen. San Domingo is gedraaid in de cinéma-verité-stijl van de een jaar eerder verschenen documentaire over softpornokoning Alois Brummer. Met de novelle van Kleist als losse rode draad biedt de film, die de vorm heeft van een gedramatiseerde documentaire, een intrigerend portret van de opkomende tegencultuur in de Bondsrepubliek aan het eind van de jaren ' 60 . Het burgermanszoontje wordt gevolgd op zijn tocht door communes; drugsfeesten, popconcerten en rokerige achterafzaaltjes waarin de revolutie wordt voorbereid. Afgezien van de hoofdrol worden alle rollen, analoog aan de conventies van het Italiaanse neorealisme; vertolkt door lekenacteurs met een zwaar Beiers accent. (De film heeft een Duitse ondertiteling.) Dit geldt ook voor de rollen van de APO-studenten, die zich in een sleutelscène als vertegenwoordigers van de communistische 'Rode Cellen' tussen de criminele rockers mengen, om met hen op de klanken van Amon-Düül-muziek temidden van hasjwalmen te discussiëren over geweld en revolutie. Maar hoe groot de stijlbreuk met het speelfilmdebuut ook mag zijn; tussen San Domingo en Scarabea laten zich ook thematische overeenkomsten aanwijzen. De potlatch uit Scarabea heeft in deze film de gedaante aangenomen van het dionysische feest van een tegenculturur. San Domingo eindigt met een citaat van de zwarte activist Eldridge Cleaver, waarin wordt gewaarschuwd "waakzaam te zijn en deze jeugd niet te vergeten of te onderschatten en te verachten, omdat in dat geval catastrofen van grote omvang zullen ontstaan, revoluties of anarchie, waarin alles aan diggelen zal worden geslagen" - een profetische tekst in het licht van de crisis die de tegencultuur in de jaren '70 zal doormaken (als we Syberberg mogen geloven, hoort hij de namen van de linkse terroristen Baader en Meinhof voor het eerst in de discussies rond deze film). ${ }^{142}$

In de meest opmerkelijke vroege film, Die Grafen Pocci (1967), wordt het procédé van de gedramatiseerde documentaire omgedraaid. Strikt genomen is de film, die nog voor het speelfilmdebuut tot stand komt, een documentaire over de geschiedenis van een Beierse adellijke familie. Franz Graf von Pocci (1807-1876) was ceremoniemeester aan het hof van koning Ludwig I van Beieren en een niet onverdienstelijke toneelauteur, karikaturist en componist van muziekstukken in de stijl van Mendelssohn. Bekendheid verwierf hij vooral als

\footnotetext{
140 idem, p. 52.

141 ibidem.

142 idem, p. 54.
} 
de uitvinder van de Kasperl (Jan Klaassen) voor het Münchense marionettentheater. ${ }^{143}$ De film toont de laatste nog levende nazaten van de beroemde graaf: twee vrijgezelle broers (het geslacht zal weldra uitsterven), die een teruggetrokken bestaan leiden op het inmiddels tot ruine vervallen kasteel van hun grootvader en de dagen vullen met het land bewerken, voetballen en het bespelen van de drums - "Hippies in der Lederhose", noemt Syberberg hen, die er niet voor terugschrikken zich per tractor te begeven naar een galadiner in het Münchense Hilton. ${ }^{144}$ Anders dan in de (overigens latere) documentaire Sex-Business made in Pasing worden deze levensgenieters niet in beeld gebracht met de stijlmiddelen van de cinéma vérité. Misschien wel als een eerbetoon aan de oude graaf Pocci, heeft de film veel weg van een marionettentheater. De esthetiek wijst opnieuw vooruit naar Ludwig - de surrealistische popart/operettefilm, waarmee Syberberg begin jaren ' 70 bij een breed filmhuispubliek zal doorbreken. De film, die volgens Syberberg is geïnspireerd op surrealistische en magisch-realistische schilderijen ("een hoofd dat plotseling in het landschap staat, een fiets met bloemen") ${ }^{145}$, bestaat uit een bonte collage van associatief naast elkaar geplaatste anekdotes. Historische documenten, waaronder tekeningen, muziekjes en marionettenstukjes van de oude graaf, zijn verweven met actuele opnamen van de beide broers, die op opa"s vervallen landgoed "een vrolijk ondergangsethos [fröhliches Untergangsethos] demonstreren". 146 Het gebruik van vervreemdingstechnieken (tussenteksten) roept herinnering op aan Brecht, maar het rationalisme van diens leerstukken is opgeheven in een hogere vorm van anti-aristotelisch filmtheater dat, meent Syberberg, gezien het associatieve karakter zich nog het beste laat vergelijken met een muziekstuk: "Geen dramatiek die stijgt en daalt, zoals bij Aristoteles, maar een ritme". ${ }^{147}$

Binnen Syberbergs vroege oeuvre zijn de gebroeders Pocci de tegenspelers van de faustiaanse Duitse toerist uit Scarabea. In de slotscène zien we een van de broers, een vrolijke Beier van middelbare leeftijd, in zijn jachthut mijmeren over de geneugten van het landleven. Hoe vaak hoort hij niet mensen jammeren, dat ze moeten werken? Maar wie de armen uit de mouwen steekt, smaakt het brood in de mond toch een stuk beter? Zelf heeft hij zijn beroep onvoorwaardelijk lief. Soms kan hij zich wel de kleren van het lijf scheuren van vreugde, zo mooi is het hier in het moerasland. De aandrang om, zoals de Duitse toerist uit Scarabea of Tolstoj's boer, te streven naar als maar meer bezittingen, is deze graaf ten enen male vreemd. Niets wordt hier verkocht! Wat is tweehonderdduizend mark vergeleken met een landgoed? Gesteld dat vandaag nog iemand zou langskomen en hem zou smeken een paar vierkante meter grond van de hand te doen, dan zou hij, al was het zijn beste vriend, beleefd antwoorden: luister eens vader, jij wilt kopen, ik echter niet verkopen! Natuurlijk weet hij ook wel, dat hij zich door deze instelling allang niet meer de luxe kan permitteren die eigenlijk bij een graaf past. Maar het zal hem allemaal worst wezen: "Ob da an der Toilette a Pappadeckel ist für"n Winter oder ne Scheibe, das spielt gar ka Rolln". ${ }^{148}$

\footnotetext{
${ }^{143}$ Zie: Franz Graf von Pocci. Die Gesamte Druckgraphik. Hrsg. M Berhhard. München, z.j.. "Eine wichtige Informationsquelle ist schließlich Hans-Jürgen Syberbergs Film über die Grafen von Pocci," schrijft Marianne Bernhard in een 'Editionsnotiz' (a.w., pp. 10f). "Er führt eindringlich die Atmosphäre der heute im Inneren verfallenen Pocci-Schlosses am Starnberger See vor. Kasperl Larifari als bewegliche Marionette kommentiert dessen Vergangenheit und Gegenwart und vermittelt einen Eindruck der alten Puppenspielerkunst und -tradition. Vor allem aber zeigt dieser Film heute unzugängliche Arbeiten Poccis: seine Gäste- und Jagdbücher, ungedruckte Vorzeichnungen zu einem Totentanz, familiäre Briefe, Rätzel- und Vexierspiele."

144 Syberberg, a.w., p. 75.

${ }^{145}$ Zaagsma, a.w., p. 36.

${ }^{146}$ Syberberg, a.w., p. 75 .

147 Zaagsma, a.w., p. 36.

${ }^{148}$ Citaten ontleend aan: Syberberg, a.w., p. 310.
} 
In deze reverieên van Konrad Pocci, zoals de naam van de graaf luidt, meent Syberberg de echo te beluisteren van Adalbert Stifters 'sanftes Gesetz' [zachte wet]. ${ }^{149} \mathrm{De}$ grote gebeurtenissen in de natuur, stelt deze negentiende-eeuwse dichter in Was ist menschliche Größe?, de beroemde inleiding van de bundel Bunte Steine (1853), zijn niet onweer, storm, vulkaanuitbarstingen, of aardbevingen. Weliswaar trekken dergelijke gebeurtenissen de aandacht van onwetende en onoplettende lieden. Maar de wijze mens, die oog heeft voor het totale en het algemene, beschouwt als de waarlijk grote natuurgebeurtenissen veeleer het waaien van de wind, kabbelen van het water, groeien van het graan, uitbotten van de aarde, of glanzen van de sterrenhemel. Een berg die lava spuwt komt slechts sporadisch op enkele plekken voor, als een effect van een veel hogere wetmatigheid die in het ogenschijnlijk kleine overal op aarde werkzaam is - ook in de wereld van de mens. Anders dan de nietsnut zwerft de mens niet als een nomade door het landschap, maar is hij in het landschap dat hij bewerkt thuis. De natuur vormt de omlijsting en de achtergrond van het menselijke bestaan. Beide werelden, de natuurlijke en de menselijke, worden geregeerd door dezelfde 'zachte wet'.

Stifters levensideaal is de gerijpte en gelouterde Bildungsbürger, die zijn eigenzinnige hartstochten en gevoelsuitbarstingen heeft overwonnen en zich berustend invoegt in de grote verbanden van het menselijke bestaan: familie, beroep, staat enzovoorts. Eerbied voor de medemens, zachtmoedigheid en bedrijvigheid zijn hoofddeugden. ${ }^{150}$ En het is dit humanistische levensideaal, dat Syberberg zijn publiek met Die Grafen Pocci wil meegeven als een 'ethisch desondanks', dat tegen de uitzichtloosheid, absurditeit en zinloosheid van het moderne bestaan kan worden ingebracht. De moraal wordt niet, zoals in Brechts leerstukken, vanaf de kansel gepredikt. Syberberg biedt slechts een collage van anekdotische beelden, die elkaar associatief, op het ritme van de montage opvolgen. Maar wellicht zet het bekijken van dit filmische muziekstuk bij het publiek een proces van geestelijke loutering in gang, vergelijkbaar met het bewustwordingsproces van de faustiaanse Duitse toerist in Scarabea. "De uitspraken van [Konrad] Pocci serieus nemen, zou een revolutie betekenen," schrijft Syberberg in een toelichting op de film.

"Een revolutie van ons handelen en denken: niet langer alles kopen en verkopen, niet langer aandringen, eens een keer niet 'moderniseren', tot de laatste mogelijkheid alles doen, alle bomen omkappen, wegen verbreden, plankgas geven, asfalteren, huizen afbreken, eten uit blik pakken, niet-zorgend denken, maar ons tijd en moeite gunnen, zich afvragen of 'het dat wel waard is' en 'met een karton voor het wc-raampje leven'; eens een keer ook lichtzinnige Aufklärungsneugier achterwege laten, stoere gewoontes en begeerten van de rationalisten voorbij laten trekken en geheimen en raadsels verdragen, niet achter elke deur willen kijken, oude mythen, wijsheid en rampspoed indachtig. Een redding van het materialistische, door de ratio gedomineerde, prestatiegerichte, brutaal op winst georiënteerde Avondland in de richting van goede tradities uit eigen bronnen, met mooie zijdelingse blikken op Chinese gebruiken en Indische voorbeelden."

\footnotetext{
${ }^{149}$ idem, pp. 75-76.

${ }^{150}$ Harberts, D.W., Meyer, H., Deutsche Dichtung. Anthologie und Literaturgeschichte. Amsterdam, 1959. pp. 176-178.

is1 Syberberg, a.w., pp. 310, 311 .
} 


\subsection{Slot}

"De grote oer-belevenissen van de kindertijd," schrijft Hans Sedlmayr in zijn autobiografische schets Das goldene Zeitalter (1986), "doorlichten het hele latere leven, vormen het voor en geven het houvast". ${ }^{152}$ En volgen we de late Syberberg, die van het zwaar op Sedlmayrs kunsttheorie leunende pamflet Vom Unglück und Glück der Kunst in Deutschland nach dem letzten Kriege (1990), dan geldt dit zeker ook voor 'de grote oer-belevenissen' van een kindertijd op het Pommerse platteland: het waaien van de wind, kabbelen van het water, groeien van het graan, uitbotten van de aarde, of glanzen van de sterrenhemel. "Een kindertijd in een hiërarchisch gestructureerde landelijke cultuur, zoals die in het Oosten van Duitsland tot 1945 heeft bestaan (...), vormt een gevoel van verantwoordelijkheid voor de wereld, dat totaal vreemd is aan stedelingen (...)," stelt hij in een in 1987 afgenomen interview. ${ }^{153}$

Het is, zoals we zagen, Syberbergs "houding van volkomen superioriteit ten aanzien van het moderne', die bij Susan Sontag associaties oproept met de auteur van Verlust der Mitte. Deze 'coup d'oeil in zijn biografie' heeft ook de filmer zelf aan het denken gezet. $\mathrm{Na}$ zijn vertrek van de Münchense universiteit zou hij aanvankelijk hebben geprobeerd zich uit het academische keurslijf te bevrijden door rigoureus tabula rasa te maken. Academisme werkt intellectualisme en rationalisme in de hand, terwijl het kunst-spel de impulsiviteit en spontaniteit van de creatieve Homo Ludens vereist. ${ }^{154}$ Maar als hij begin jaren '80, hiertoe geïnspireerd door Sontags terzijde, zijn films op sporen van Sedlmayrs kunsttheorie begint te onderzoeken, doet hij naar eigen zeggen een verrassende ontdekking. Namelijk: dat het gehele oeuvre door 'de grote oer-belevenissen'. uit de kindertijd wordt 'doorlicht'. Zoals onder meer zou blijken uit zijn affiniteit met het organische denken van figuren als Konrad Pocci, Adalbert Stifter, Tolstoj of Sedlmayr. ${ }^{155}$ Ook Hans Sedlmayr is, in 1896, op het platteland geboren. Als zoon van een rentmeester heeft hij de kinderjaren doorgebracht op een landgoed in Slovenië, in de omgeving van Fünfkirchen, het tegenwoordige Pées. Deze biografische achtergrond 'doorlicht' inderdaad zijn kunstfilosofie. Het Avondland, waarvan Sedlmayr het verlies betreurt, is een geỉdealiseerde agrarische standenmaatschappij ${ }^{156}$ - een plattelandsidylle, zoals Syberberg die nog meent waar te nemen in de foto's en 8-mm filmpjes van zijn vader, 'die de vroegste kindertijd, vóór de tijd van het bewustzijn, tot een mythe maken'. De kindertijd, denkt ook Sedlmayr in Das goldene Zeitalter, is een mythische tijd, waarin we het blijvende hebben ontmoet, dat de wereld voor ons heeft ontsloten. "Dit blijvende kent geen consecutio temporum, het is eenvoudig, hetzij vroeger of later, het is. (..) Want de tempus van de kindertijd is de wederkeer, een jaar zoals het andere, wederkeer van de feesten, de tijd vergaat niet, alles loopt in een kring - dat is het paradijselijke van de kindertijd". 157

Toch ontvangt dit oeuvre, zoals we in de hierna volgende hoofdstukken nog meer in detaill zullen zien, tot ver in de jaren ' 80 niet zijn belangrijkste stimulans van Sedlmayr. "Mijn allergie voor de Duitse filmkritiek heeft te maken met DDR-ervaringen en een meer diepgewortelde pijn," onthult Syberberg in Die freudlose Gesellschaft (1981). ${ }^{158}$ En inderdaad: het is, naar ik meen, eerst en vooral hier, in het stalinistische Oosten, dat de sleutel tot een juist begrip van Syberbergs werk dient te worden gezocht. Nogal wat zaken, waaronder ook de verheerlijking van het leven op het platteland, blijven raadselachtig, zolang

\footnotetext{
${ }^{152}$ Sedlmayr, H., Das goldene Zeitalter. Eine Kindheit. München, 1986. p. 177.

${ }^{153}$ Citaat ontleend aan: Santner, a.w., p. 186.

${ }_{155}^{154}$ Interview met de auteur en Eling Delleman, zomer 1991.

155 ibidem.

${ }^{156}$ Vergl. Wyss, a.w.y p. 536. Wyss, Trauer der Vollendung, a.w., p. 293.

${ }^{157}$ Sedlmayr, a.w., pp. $175,178$.

${ }^{158}$ Syberberg, Die freudlose Gesellschafi. a.w, p. 94.
} 
je ze niet bekijkt in het licht van, wat de filmer zelf noemt, "het schrikbeeld van de late kindertijd': de vernietiging van 'alles wat heilig was voor mijn ouders', als onderdeel van een vanuit Moskou verordonneerde antifascistische heropvoedings-politiek, waarin ook aan de kunsten een belangrijke taak wordt toebedeeld. Samenvattend kunnen we stellen, dat het hier een tweeledige taak betreft. Enerzijds wordt van kunstenaars geëist, dat ze de (vermeend) progressieve traditiesporen, middels een ingrijpende dialectisch-materialistische Aufarbeitung, opnieuw tot een aanknopingspunt van het politieke identiteitsgevoel maken. Anderzijds zijn ze verplicht te streven naar een radicale overwinning van al datgene, wat op gespannen voet staat met de 'redelijke' ontwikkeling van de geschiedenis in de richting van een socialistische samenlevingsvorm. Welke stromingen "de vooruitgang vertegenwoordigen" (Lukács), dan wel tot de 'irrationele' reactie behoren, is de inzet van het expressionisme-debat van de jaren ' 30 , waarin twee partijen diametraal tegenover elkaar staan. In het ene, aan Moskou gelieerde kamp, wordt de toon gezet door Georg Lukács; het andere staat onder aanvoering van Brecht en Bloch, die weldra bijval zullen krijgen van Hans Mayer.

Eind jaren ' 40 wordt deze linkse controverse, na een machtswoord vanuit Moskou, in de door de Sovjets bezette gebieden beslecht in het voordeel van de eerste partij. 'Irrationeel' is voortaan een denktraditie, die zou lopen via Schelling, Schopenhauer, Wagner en Nietzsche naar de 'zogenaamde avant-garde' (Lukács), waartoe alle moderne stromingen in de kunsten vanaf het midden van de negentiende eeuw worden gerekend en de hiermee corresponderende filosofische richtingen, dat wil zeggen: het post-nietzschiaanse denken in al zijn varianten (Houston Stewart Chamberlain, Heidegger, Jünger, Sedlmayr, maar ook de existentialisten) ${ }^{159}$. Wat volgt is de formalisme/realisme-strijd van de vroege jaren ' 50 , waarin zowaar ook enkele leerstukken van Brecht op de index worden geplaatst. En temidden van het strijdgewoel maakt een jonge Hans Jürgen Syberberg zijn eerste serieuze werk: een verfilming van Brechts 'verboden' enscenering van de Urfaust. Het zal de opmaat blijken te zijn tot een oeuvre dat, vanuit de kunsttheorie van Lukács en diens Nieuw Linkse navolgers in de Bondsrepubliek van de jaren ' 70 bezien, uitsluitend 'irrationele' kunstwerken omvat. Goed, van het Brecht-theater in Oostberlijn naar de Deutsche National-Zeitung is een lange weg. Maar welk werk van Syberbergs hand men ook neemt, steeds geldt: het gaat om een poging het 'irrationele' kunstwerk van zijn stigma te zuiveren, door de sinds Lukács in marxistische of ideologiekritische kringen gemeengoed geworden connotatie van 'irrationalisme' met 'decadentie' en 'fascisme" 160 te problematiseren. Hooguit zal hij zich, gedurende verschillende fasen die hij na zijn verblijf aan het Berliner Ensemble doorloopt, telkens op een andere tak van 'het irrationalisme' gaan oriënteren.

In de tweede helft van de jaren ' 60 , de periode die in dit hoofdstuk centraal stond, streeft Syberberg met zijn filmkunst nog vooral een hervorming na van de bioscoopfilm, die naar brechtiaans model moet worden omgeturnd van een 'pleziertheater' tot een vormingstheater dat zich op het technische en geestelijke niveau bevindt van de avant-garde. De voorhoede in het theater wordt in die dagen gevormd door het absurdisme van Dürrenmatt, Beckett, Camus en Ionesco. Aan deze post-brechtianen ontleent Syberberg niet enkel tal van innovaties, maar ook hun wereldbeeld: de moderne mens is op zichzelf aangewezen in een als absurd beleefde wereld. De uitweg uit deze zingevingscrisis zoekt Syberberg in een teruggrijpen op, wat hij in navolging van Johan Huizinga begrijpt als de 'oervorm' van drama,

\footnotetext{
159 Voor de visie van Lukács op het existentialisme, zie het hoofdstuk Uber den Irrationalismus der Nachkriegszeit in: Die Zerstörung der Vermunft. Lukács. a.w., pp. 663-738.

${ }^{160}$ Bohrer, a.w., pp. 525ff: "Politisch folgenreich war Georg Lukács' 'Die Zerstörung der Vernunft", in dem Begriffe, wie 'Präfaschismus', 'Faschismus', und 'Irrationalimus' als Termini für einander übergleitende Phänomene des 'bürgerlichen Imperialismus' verwendet werden. (...) Marxistisch oder ideologiekritisch orientierte Literaturwissenschaftler haben in der Nachfolge von Lukács den Begriff 'Dekadenz' - analog zu den Begriffen 'Präfaschismus' und 'Irrationalismus' - polemisch benutzt, um so die bürgerliche Literatur zu charakterisieren".
} 
ethiek en religie: het spel. Het spelen van een spel 'op basis van het tegenwoordige levensgevoel' moet de moderne mens in staat stellen uit zijn innerlijk een 'ethisch desondanks' te reactiveren, dat opnieuw houvast biedt. En dit 'ethisch desondanks' denkt Syberberg te hebben gevonden in een humanistisch levensideaal, zoals dat onder meer wordt uitgedragen door Pocci. De 'redding van het materialistische, door de ratio gedomineerde, prestatiegerichte, brutaal op winst georiënteerde Avondland' bestaat uit een ethos van zorgzaamheid, matigheid en berusting, in harmonie met de 'zachte wet' (Stifter) van de natuur. Gemeten aan de maatstaven van Lukács, mogen ook deze vroege films reeds worden gerekend tot de 'irrationele' reactie, in de zin dat ze de binnen de stalinistische kunsttheorie tot dogma verheven Verlichte voorstelling van een an sich redelijke, zich heilzaam ontwikkelende en maakbare werkelijkheid verwerpen. Maar, aldus Mayer in zijn hierboven reeds aangehaalde Brecht-monografie: begrippen als 'reactie' of 'conservatief', die binnen deze kunsttheorie een negatieve connotatie hebben, kunnen ook een "positief element" bevatten - "ein Element des Erhaltens" als antwoord op "een vooruitgang, die alles vernietigt en ten gunste van een kwantitatief principe de mens alsmaar meer geestelijk afstompt, alsmaar meer egaliseert". ${ }^{161}$

In de bundel Filmbuch (1976) vertelt Syberberg, hoe hij begin jaren ' 70 dankzij Hans Mayer het werk heeft "leren kennen en appreciëren" van die andere grote 'Meester' uit het Duitse theater vóór Brecht: Richard Wagner. ${ }^{162}$ Een nieuwe fase breekt aan, waarin de aandacht verschuift van de post-brechtiaanse avant-garde naar de late romantiek. Of, in de terminologie van Lukács: van het postfascistische 'irrationalisme' naar het prefascistische.

161 Mayer; a.w., p. 428.

${ }^{162}$ Syberberg, Filmbuch, a.w., p. 250. 
$\begin{array}{llll}4 & - & \vdots\end{array}$

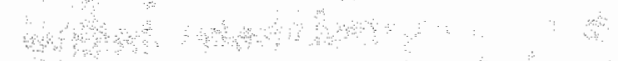

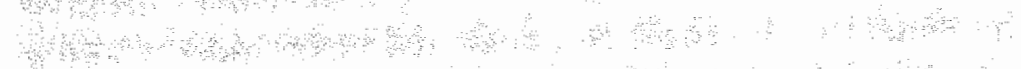

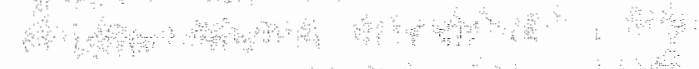

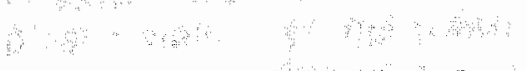
a) अ

s. 


\section{Hoofdstuk 3 Wagners tweede verschijning}

\subsection{Inleiding}

"Er zou een wetenschappelijke verhandeling te houden zijn over, zoals men dat deftig noemt, de invloeden van Wagner op Syberberg," verzucht de Amsterdamse sociologe Agnes Schreiner, onder meer bekend van de samen met Kees Vollemans geschreven kleine Wagnerstudie Een golf van bloed (1981), tijdens in een ' 83 gehouden voordracht. "(...) Een weinig opbeurende bezigheid, want zo'n verhandeling zou niet alleen een langdurig en zwaarlijvig verhaal opleveren, het zou ook op niets meer neerkomen dan een invuloefening: zeg Syberberg in plaats van Wagner en herkauw alle commentaren en kritieken over de laatstgenoemde (...). Niet Wagner als leermeester van Syberberg, maar de terugkeer van Wagner of beter de tweede verschijning, het voor de tweede keer opduiken van Wagner (na eerst te zijn geweest $1813-1883$ ) is het fascinerende".

Volgen we Syberberg, dan heeft hij Wagner pas laat leren kennen en waarderen. Hij zou zelfs in het geheel niets van deze negentiende-eeuwse totaalkunstenaar hebben afgeweten, tot hij zich begin jaren 70 verdiept in de cultus rond diens mecenas Ludwig II van Beieren. 2 Vanaf dat moment zal het onderwerp hem echter gedurende vele jaren niet meer loslaten. Op een foto uit 1982 (afbeelding 1) zien we Syberberg aan het werk op de set van de filmopera Parsifal, een adaptatie van Wagners gelijknamige Bühnenweihfestspiel. Achter zijn rug doemen de contouren op van een reusachtige replica - 15 meter in de lengte, 9 meter in de breedte en 4,50 meter in de hoogte - van Wagners dodenmasker, die in deze film dienst doet als speelvlak. Het behoont tot Syberbergs meest originele invallen: het idee om Wagners laatste werk, volgens menigeen zijn testament, geheel op en rond het gelaat van de dode componist te situeren. Het dodenmasker, één van de belangrijkste relieken uit de Wagner-cultus, krijgt in deze film het karakter van een dodenlandschap, Van dichtbij gefilmd heeft het bedrieglijk veel weg van een rotsgebergte, met de fameuze neus van de componist als top. Zo wordt Wagners oogholte tot een bergmeertje gevuld met tranen, waarin Kundry in de eerste akte ontwaakt en uiteindelijk zal worden gedoopt. Het gevaarte blijkt ook demontabel te zijn. Wanneer je de delen uit elkaar schuift ontstaat een duister labyrint van spelonken en kronkelige paden, waarlangs we aan de hand van de acteurs afdalen. Als 'maden die zich te goed doen aan een kadaver' dolen we rond in het innerlijk van de kunstenaar, aldus de Franse filmeriticus Guy-Patrick Sainderichin. ${ }^{3}$ Een mooiere metafoor voor zijn werk uit de jaren ' 70 en de vroege jaren ' 80 , had Syberberg niet kunnen bedenken.

Parsifal is het laatste deel van een cyclus, die tien jaar eerder, in Ludwig - Requiem für einen jungfräulichen König (1972), begint met de openingsklanken van Wagners Rheingold - de oertoon van het 'Es-dur', die de geboorte van de tragedie uit het Ewigweibliche van de muziek moet verbeelden. Op het eerste gezicht bestaat De Graal, zoals de overkoepelende titel luidt, uit een reeks biopics van illustere Duitse persoonlijkheden. Maar zoals over de Ring des Nibelungen well wordt gezegd dat de verschillende personages,

\footnotetext{
${ }^{1} \mathrm{De}$ (ongepubliceerde) tekst van deze, tijdens een Syberberg-seminar gehouden voordracht, kan worden ingezien in het Filmmuseum te Amsterdam. Zie eveneens: Vollemans, K., Schreiner, A., Een golf van bloed. Over Wagner en wagnerisme. in: Kunsthistorische Schriften 7. Amsterdam, 1981.

${ }^{2}$ Syberberg, HJ., Syberbergs Filmbuch. München, 1976. p. 250. Rayns, T., Forms of address. Tony Rayns interviews three German Film-Makers. in: Sight and Sound. International Film Quarterly. 44 (1975). pp. 2-7, zie: 7.

${ }^{3}$ Sainderichin, G.-P., Voyage à Munich. Hans Jürgen Syberberg tourne 'Parsifal'. in: Cahiers du Cinéma. (Januari 1982). pp. 23-29, zie: 26.
} 


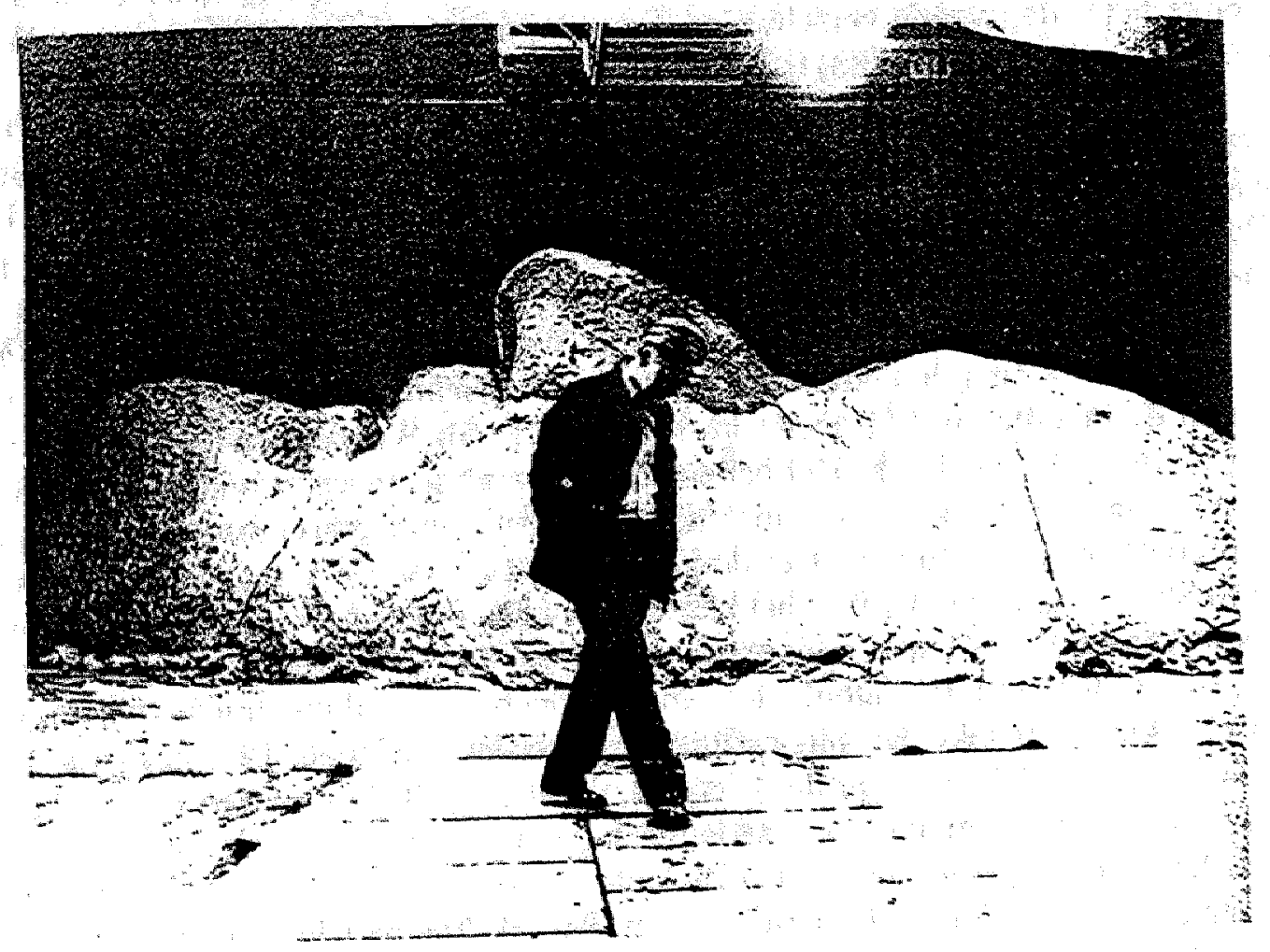


van Woglinde tot Hagen, afsplitsingen zijn van één karakter, ${ }^{4}$ zo zou je staande kunnen houden dat de diverse figuren van deze mammoet-cyclus het mozailek vormen van eén monumentaal portret. Als een rode draad waart de geest van Wagner door Syberbergs portrettengalerij: wagneriaan en Wagner-mecenas Ludwig II; volksschrijver, mysticus en Ludwig-biograaf Karl May, in wiens 'surrealistische colportage-esthetiek' Ernst Bloch ooit mogelijkheden zag voor "Wagners redding'; Wagners schoondochter Winifred WagnerWilliams, de leidster van het Bayreuther Festival tussen 1930 en 1949 ; en, last but not least, Wagner-aanbidder Adolf Hitler.

De spil wordt gevormd door de zogenaamde Duitse Trilogie, Ludwig, Karl May Hitler, die door Syberberg met Parsifal naar analogie van de antieke tragedie én Wagners Ring is uitgebreid tot een Duitse Tetralogie: drie treurspelen (de Duitse Trilogie, waarvan het laatste deel, Hitler, ook zelf weer vier delen kent) en een komedie of satyrdrama, zoals hij zijn Parsifal-film nadrukkelijk presenteert. ${ }^{6}$ Want Wagner is, naar het zich laat aanzien, niet enkel het onderwerp van deze cyclus. Terecht merkt Susan Sontag (1980) op, dat Hitler, ein Film aus Deutschland in een 'deels parasitaire navolgingsrelatie' tot Wagners muziekdrama's staat. De publiciste wijst in dit verband, behalve op de tetralogie-vorm, ook op het gebruik van symbolen als leidmotief, de "verleidelijk, uitdagend lange speelduur" ( 7 uur!) en het stilistische eclecticisme. Net als de naar een alomvattende synthese strevende muziekdrama's van Wagner, put de film uit "heterogene stilistische bronnen" en beweegt hij zich op het kruispunt van theater, beeldende kunst, muziek en literatuur. ${ }^{7}$ En dit soort opzichtige Wagner-citaten in de films zelf zijn nog maar het topje van de ijsberg. Zoals de hierboven aangehaalde verzuchting van Agnes Schreiner reeds doet vermoeden, beperkt de Wagnernavolging zich namelijk niet tot het witte doek. Ook Syberbergs denkbeelden en manier van doen zullen met het klimmen der jaren alsmaar meer wagneriaanse trekjes gaan vertonen. Soms heb je zelfs wel eens het ongemakkelijke gevoel, dat hij gaandeweg zijn eigen identiteit verliest, om geheel en al met zijn grote voorbeeld samen te vallen - inderdaad: "Wagners tweede verschijning' (Schreiner) te worden. '(...) Hij [Wagner, G.G.] werd als figuur zo dominant, dat hij me bijna heeft verpletterd," bekent Syberberg in een interview uit $1988^{8}$

Dat een dergelijke, onverbloemd wagneriaanse enscenering van het kunstenaarschap door menigeen in én buiten de Bondsrepubliek met argusogen wordt gevolgd, behoeft amper betoog. De populariteit van zijn muziek in onze concertzalen ten spijt ligt Wagner nog steeds uitermate gevoelig. Misschien gaat het wat al te ver te spreken over een Duitse bron van ergernis, zoals de titel luidt van een in 1982, door Der Spiegel uitgegeven boekje met essays over deze componist. ${ }^{9}$ Maar niet te loochenen valt, dat Wagner tot op de dag van vandaag aanleiding geeft tot heftige controverses. De feiten mogen bekend worden verondersteld. Onder leiding van zijn erfgenamen Cosima, Siegfried en Winifred Wagner heeft het festival in Bayreuth zich na Wagners dood ontwikkeld tot het onbetwiste artistieke én politieke centrum van een extreem Duitsnationalistisch anti-Verlichtingsdenken, van waaruit reeds in de vroege jaren '20 nauwe banden worden onderhouden met Adolf Hitler. Feit is ook, dat Hitler graag mocht poseren als een kunstenaar/politicus, die handelde in hogere opdracht van de 'Meester' en dat het werk van Wagner, met instemming van de toenmalige festivalleiding, door de nazi's voor propagandistische doeleinden is gebruikt. Na de Tweede Wereldoorlog hebben Wieland en Wolfgang Wagner het festival proberen te denazificeren door resoluut te

\footnotetext{
${ }^{4}$ Magee, B., Aspects of Wagner. London, 1968, 1972. pp. $27 \mathrm{f}$.

${ }^{5}$ Bloch, E., Erbschaft dieser Zeit. Erweiterte Ausgabe. Frankfurt am Main, 1963, 1985. pp. $372-380$.

"Syberberg, H.J., Parsifal Munchen, 1982. pp. $12 \mathrm{ff}$.

${ }^{7}$ Sontag, S., Syberbergs Hitler. in. In het teken van Saturnus. Essays. Vert. D. Brisk. Weesp, 1984. pp. 181-222, zie: $183,186,193,206 \mathrm{ff}, 220 \mathrm{ff}$.

${ }^{8}$ Muller, A., Im Gespräch mit... Hamburg, 1989. p. 191.

${ }^{9}$ Richard Wagner. Ein deutsches Ärgernis. Hrsg. K. Umbach. Hamburg, 1982.
} 
breken met, wat nu wordt genoemd, de 'oud-Bayreuther traditie' en door een strikte scheiding te propaganderen tussen kunst en politiek. Niettemin is de vraag blijven bestaan, hoe de Duitsnationalistische en nationaal-socialistische politisering van het festival ten tijde van het 'oude Bayreuth' zich verhoudt tot Wagner zelf. Of meer specifiek: bestaat er een eventuele relatie tussen Hitlers bewondering én de politieke koers van het festival onder Cosima, Siegfried en Winifred Wagner enerzijds en de artistieke concepten en esthetischpolitieke theorieën van Richard Wagner anderzijds? ${ }^{10}$ Grosso modo zijn in het naoorlogse Wagner-debat op deze vraag vier verschillende antwoorden gegeven. Alvorens terug te komen op Syberberg, vat ik de diverse posities beknopt samen.

De eerste positie is het officiële standpunt van de naoorlogse festivalleiding in deze kwestie. Tussen Wagner en het soort wagnerianisme, zoals dat tot het einde van de oorlog op de Groene Heuvel gangbaar was, bestaat geen enkel verband. De oud-Bayreuther traditie berust op een ideologisehe vervalsing, die haaks staat op de, naar men meent, in wezen humanistische bedoelingen van de kunstenaar. "Meer gangbaar in kringen van Wagnerliefhebbers is echter de tweede positie. Zij ontkent niet, dat Wagner er tal van bedenkelijke ideeên op na hield die, al dan niet in een aangescherpte vorm, door de oud-Bayreuther wagnerianen zijn overgenomen en ook in de ideologie van het nationaal-socialisme kunnen worden teruggevonden. Waarbij, uiteraard, behalve aan zijn deutschbewusste, tegen de Verlichting gerichte messianisme (Duitse Kultur versus Franse Zivilisation), vooral wordt gedacht aan zijn Judenfeindlichkeit. Maar betwijfeld wordt, of dit soort ideeen repercussies hebben voor zijn artistieke werk. Dat Wagner wellicht een geestverwant is geweest van de oud-Bayreuther wagnerianen en de nationaal-socialisten hoeft een waardering voor zijn muziekdrama's niet in de weg te staan. Muziek is politiek neutraal en heeft niets te maken met nationalisme en nationaliteit. Er bestaan geen antisemitische opera's, noch morele of amorele, fascistische of antifascistische, joodse of anti-joodse, Duitse of anti-Duitse manieren van componeren, cellospelen of Wagner zingen. ${ }^{2}$

De meest bekende en, binnen het Wagner-debat invloedrijke vertegenwoordiger van de derde positie is Thomas Mann. "Er is veel "Hitler" in Wagner," luiden de beroemd geworden woorden van Mann in een uit 1949 daterende brief aan zijn goede vriend Emil Preetorius, die in vrijwel geen enkele kritische Wagner-studie ontbreken. ${ }^{13}$ En in tegenstelling tot de vertegenwoordigers van de tweede positie meende Mann deze geestverwantschap niet enkel te bespeuren in het karakter van de kunstenaar, of zijn denkbeelden, maar ook in zijn muziek die wel degelijk typisch Duits en zeer politiek geladen zou zijn. ${ }^{14}$ Zijn faam als een van de meest scherpzinnige critici van Wagner dankt Mann met name aan een reeks geschriften uit de jaren ' 40 , waarin hij radicaal afrekent met het oudBayreuther wagnerianisme waarvan hij in zijn jeugdjaren nog een vurig aanhanger was en de componist ontmaskert als een "spirituele voorloper" van de nazi-barbarij. "Toch is Mann zich altijd blijven beschouwen als een wagneriaan, zij het een kritische met een scherp oog voor de artistieke kwaliteiten van Wagners oeuvre. "Nietzsche sprak over de dubbele optiek, die Wagners enorme talent domineerde - zijn ambitie om zowel de meest fijnbesnaarden, als

\footnotetext{
${ }^{10}$ Karbaum, M., Studien zur Geschichte der Bayrewther Festspiele. (1876-1976). Regensburg, 1976. passim.

"Zie bijwoorbeeld: Wagner, W[olfgang], Lebems-Akte. Autobiographie. München, 1994, 1997. pp. 11-14, 4549.

12 Aldus de Nederlandse Wagner-kenner Martin van Amerongen en de dirigent Daniel Barenboim, wier argumenten ik hier samenvat. Amerongen, M., van, De buikspreker van God. Amsterdam, 1983. pp. 189-198. Voor Barenboim, zie het interview: Waard, M., de, Muziek is lucht. in: NRC Handelsblad. 06-07-2001. p. 22.

${ }^{13}$ Mann, Th., Wagner und unsere Zeit. Aufsaitze, Betrachtungen, Briefe. Hrsg. E. Mann. Frankfurt am Main, $1983,1986$. p. 168.

i4. idem, p. 158 .

15 idem, p. 159 .
} 
ook de meest redelozen voor zich te winnen," verduidelijkt Mann in een tekst uit 1940 zijn eigen positie. "Een $(.$.$) consequentie van deze ambitieuze ambiguitteit inherent aan dit$ kunstenaarschap, is een corresponderende ambiguïteit inherent aan elke hogere vorm van kritiek. (...) Dergelijke kritiek zal altijd een element van onenigheid en hartstochtelijke ironie in zich dragen. Het zal altijd een curieus mengsel zijn van overgave en wantrouwen (...)."16

In de Wagner-kritiek van de vertegenwoordigers van de vierde positie, tenslotte, ontbreekt deze 'corresponderende ambiguïteit'. Binnen deze, wat Mann zou noemen, lagere vorm van Wagner-kritiek wordt het meerduidige kunstwerk geheel ondergeschikt gemaakt aan het eenduidig politieke. Wagner wordt niet zozeer gezien als een kunstenaar, als wel veeleer als een politieke ideoloog, de spiritus rector achter het Derde Rijk, die kunst enkel zou hebben gebruikt als een vehikel om zijn politieke boodschap over te brengen. Vanuit deze propagandistische kunstwerken loopt een rechte lijn naar de misdaden van de nazi's. Op zijn laatst sinds Parsifal (1882) lag de blauwdruk al klaar; alles wat nog hoefde te gebeuren was Wagners waandenkbeelden in een politieke realiteit vertalen. ${ }^{17}$ En zoals Thomas Mann geldt als de meest bekende vertegenwoordiger van het kritische wagnerianisme, zo wordt Bertolt Brecht vaak naar voren geschoven als de personificatie van dit anti-wagnerianisme. ${ }^{18}$ Brecht heeft er nooit een misverstand over laten bestaan het werk van deze "mythesmid" buitengewoon gevaarlijk te vinden. ${ }^{19}$ Typerend voor het wagneriaanse Gesamtkunstwerk is, in zijn optiek, de hang naar "versmelting". Het "smeltproces" betreft niet slechts de diverse kunsten, die in het Kunstwerk van de Totaliteit hun individualiteit en autonomie verliezen; ook de toeschouwer "wordt ingesmolten" en tot "een passief (lijdend) deel" van het Gesamtkunstwerk gemaakt. ${ }^{20}$ In combinatie met een ideologische boodschap ontstaat aldus een effectief "Opiat der Verneblung der Geister". ${ }^{21}$

Opmerkelijk is dat vrijwel alle deelnemers an de discussie rond Syberbergs Graalcyclus mogen worden gerekend tot de derde en de vierde groep. Dat er een direct verband bestaat tussen het pamflettistische én artistieke werk van Richard Wagner en de politieke praktijk van het nationaal-socialisme wordt ook door bewonderaars van deze films volmondig onderschreven. Twistpunt is slechts of hun maker zich in zijn Wagner-navolging van deze verstrengeling tussen het wagnerianisme en het hitlerisme wel voldoende rekenschap geeft. Susan Sontag beantwoordt deze vraag met een volmondig ja. Geheel in de geest van de late Thomas Mann zou Syberberg in de films van De Graal 'een hogere vorm' van Wagner-kritiek beoefenen:

"Syberberg is een groot wagneriaan, de grootste sinds Thomas Mann. (...) Om de grootsheid en tekortkomingen van het wagnerianisme op te roepen, worden in Hitler,

\footnotetext{
${ }^{16}$ idem, pp. $154 f$.

${ }^{17}$ Zie bijvoorbeeld: Zelinsky, H, Die 'feuerkur' des Richard Wagners oder die 'neue religion' der 'Erlösung' durch 'Vernichtung' in: Musik-konzepte 5. Richard Wagner. Wie antisemitisch darf ein Künstler sein? (juni $1981)$ pp. 79-112. Köhler, J., Wagners Hitler. Der Prophet und sein Vollstrecker. München, 1997.

${ }^{18}$ Bijvoorbeeld door de Britse Wagner-kenner Michael Tanner. Zie: Tanner, M., Wagner. London, 1996, 1997.

p. 8. Zie eveneens: Söring, J., Wagner und Brecht. Zur Bestimmung des Musik-Theaters. in: Richard Wagner 1883-1983. Die Rezeption im 19. und 20. Jahrhundert. Hrsg. U. Müller ea. Stuttgart, 1984. pp. $451-514$.

${ }_{19}$ Brecht, B., Gesammelte Werke 15. Schriften zum Theater 1. Frankfurt am Main, 1967, 1990. p. 485. Voor Brechts visie op de invloed van Wagner op het Derde Rijk, door hem getypeerd als de "Bayreuther Republik", zie bijwoorbeeld Brecht, B., Gesammelte Werke 18. Schriften zur Literatur und Kunst 1. Frankfurt am Main, 1967, 1990. pp. 254 ff.

${ }^{20}$ Brecht, B., Gesammelte Werke 17. Schriften zum Theater 3. Frankfurt am Main, 1990. pp. 1008-1011.

${ }^{21}$ Mittenzwei, W., Das Leben des Bertolt Brecht oder der Umgang mit den Welträtseln. Erster Band. Berlin, Weimar, 1986, 1997. p. 458: "Wagner, den er [Brecht, G.G.] als genialsten Verführer Deutschlands bezeichnete, hielt er für gefährlich; werde dessen Musik 'gehörig mit Weltanschauung verbrämt', dann sei sie ein 'Opiat der Verneblung der Geister"'.
} 
ein Fulm aus Deutschland wagneriaanse elementen gebruikt die telkens terugkeren en worden geparodieerd. Syberberg wil zijn fillm een anti-Parsifal laten zijn en vijandigheid jegens Wagner is dan ook een van de hoofdmotieven: de geestverwantschap tussen Wagner en Hitler. De hele film zou beschouwd kunnen worden als een profanatie van Wagner, ondernomen in het volle besef van de tweeslachtigheid van deze aanpak, want Syberberg probeert tegelijk binnen en buiten zijn artistieke oerbron te staan. (...) Aan Mann herinneren niet slechts Syberbergs opvattingen dat het nazisme een uitbarsting van demonie van Duitse aard zou zijn, alsmede de nadruk die hij legt op collectieve schuld. Ook de door de vertellers herhaaldelijk gestelde vraag 'Wie zou Hitler zijn geweest zonder ons?' bevat een nagalm van Mann, die in 1939 een essay heeft geschreven onder de titel Achtung Europa!, waarin hij betoogt dat de hele kwestie [het Derde Rijk, G.G.] 'een verwrongen fase van het wagnerianisme is' .",22

Met deze prikkelende stelling, dat Syberberg in de Wagner-kritische traditie van de late Thomas Mann zou staan heeft Sontag de lijnen uitgezet waarlangs de positieve receptie van de Graal-cyclus zich in de daaropvolgende jaren is gaan bewegen. Voor zover haar interpretatie in kringen van bewonderaars kritiek heeft opgeroepen spitst deze zich veelal toe op de vraag of de publiciste 'de vijandigheid jegens Wagner' niet nog wat zwaarder had moeten aanzetten. In een vaak aangehaalde passage van het als inleiding op het Hitler-script gepubliceerde 'essay" Die Kunst als Rettung aus der deutschen Misere (1978) presenteert Syberberg de esthetiek van zijn Duitse Trilogie als een 'scandaleuze combinatie' van Wagners muziekesthetiek met Brechts leer van het epische theater. ${ }^{23}$ Sontag wijst deze esthetische formule als ongeloofwaardig van de hand: "Het kan niet anders, of hij heeft meer van Wagner in zich dan van Brecht (....)."24 Anderen, zoals Thomas Elsaesser (1981), Eric Santner (1990), Anton Kaes (1989) en de Wagner-kenner Hans Vaget (1982) zijn op dit punt minder wantrouwig. Zij vermoeden achter de Wagner \& Brecht-formule een Wagnerkritische "strategie" (Vaget): de brechtiaanse - lees: anti-wagneriaanse - pool van Syberbergs "contradictoire esthetische systeem" (Santner) zou het mogelijk maken de wagneriaanse aan een ideollogiekritische deconstructie te onderwerpen. ${ }^{25}$

\footnotetext{
${ }^{22}$ Sontag, a.w., pp. 199f, 207.

${ }^{23}$ Syberberg, H.J, Die Kunst als Rettung aus der deutschen Misere. Ein Essay. in: Hitler, ein Film aus Deutschland. Hamburg, 1978. p. 28. Zie eveneens: paragraaf 3 van dit hoofdstuk.

${ }^{24}$ Sontag, a.w, p. 209.

${ }^{25}$ Vaget, H.R., Syberberg's Our Hitler. Wagnerianism and Alienation. in: The Massachusetts Review. 23 (winter $1982)$ pp. 593-612, zie: 596, 610ff. Santner, E. L., Stranded Objects. Mourning, Memory, and Film in Postwar Germany. Ithaca, London, 1990. p. 207. Kaes, A., From Hitler to Heimat. The Return of History as Film. Cambridge/Mass., London, 1989. pp. 44f. Elsaesser, Th., Myth as the Phantasmagoria of History: H.J. Syberberg, Cinema and Representation. in: New German Critique. 24/25 (Fall/Winter 1981). pp 108-154, zie: 146,150 . "Wagners mythologische ensembles zijn opengebroken, ze worden aangehaald als brokstukken en gefragmentariseerde passages, maar hun grand design, hun functie als structurerende metaforen van een wereldbeschouwing zijn ontmaskerd als pathetisch-bombastische gebaren van de wil van een epoche tot geïdealiseerde zelf-representatie". Aldus Elsaesser over de Hitler-film, die door hem wordt getypeerd als: "(...) een anti-Ring, met dezelfde monstrueuze proporties, die om volledig tot zijn recht te komen een anti-Bayreuth Bayreuth nodig heeft". Zie in dit verband eveneens: Corrigan, Th., New German Cinema: The Displaced Image. Bloomington, Indianapolis, 1983,1994 . pp. 164f., die zijn toevlucht zoekt tot de structuralistische psychoanalyse van Jacques Lacan: "In deze dubbele beweging [Wagner \& Brecht, G.G.] wordt operatesk discours de belangrijkste ondersteuning, aangezien het een model aanreikt, dat zowel irrationele fascinatie uitjokt als conventionele structuren waarop het is gebaseerd uitdaagt. (...) Als een 'nabootsing van Wagner' (...) onthult (...) Hitler die onderdrukte en onverwoordbare figuur van de geschiedenis (met name gerelateerd aan de blootgestelde en gecastreerde vrouw); zodoende creëert [de film] gigantische ontwrichtingen in ruimte,
} 
Maar bij lange na niet iedereen is overtuigd van de Wagner-kritische bedoelingen van deze filmmaker. Volgen we Schreiner en Vollemans (1981), Reinhard Kühnl (1980), Hartmut Zelinsky (1982), Gabriele Förg (1984), Leon Wesseltier (1980), of de in New York woonachtige Duitse kunstenaar en academiedocent Hans Haacke (1982), dan is het zelfs nog maar zeer de vraag of Syberbergs Wagner-navolging zich überhaupt laat indelen bij een van de vier hierboven geschetste gangbare posities in het naoorlogse Wagner-debat. Wat deze vier posities met elkaar gemeenschappelijk hebben is de verwerping van het oud-Bayreuther wagnerianisme. En daarvan zou bij Syberberg geen sprake zijn. Wanneer we deze critici mogen geloven hebben we hier van doen met een rasechte wagneriaan van de oude stempel, wiens films en pamfletten weinig meer behelzen dan een recycling van de oud-Bayreuther ideologie. Verwijzingen naar Thomas Mann of Bertolt Brecht worden door hen afgedaan als "een bewuste poging tot misleiding" (Kühnl). ${ }^{26}$ Inderdaad. 'Syberberg is een groot wagneriaan' (Sontag) - maar dan wel in de traditie van de oud-Bayreuther festivalleidster Winifred Wagner-Williams, zo niet van Adolf Hitler. "Syberbergs epische film [Hitler, G.G.] heropent een specifieke traditie van metafysica en cultuur, waarvan werd verondersteld dat die was geëindigd met Thomas Manns Doktor Faustus," vat Leon Wesseltier, redacteur van The New Republic, de visie van de critici samen in een in 1980 verschenen essay met de veelzeggende titel German Romanticism Lives. $^{27}$

Of één van deze interpretaties recht doet aan het specifieke karakter van Syberbergs wagnerianisme, valt nog te bezien. Er is, naar ik meen, een vierde interpretatie mogelijk. Het heeft te maken met, wat ik zelf beschouw als de rode draad in dit oeuvre: de polemiek tegen de cultuurpolitiek van de DDR in haar begindagen. In zijn intrigerende, nog in DDR-tijden verschenen Brecht-biografie Der Umgang mit den Welträtseln (1986) vertelt de Oostduitse literatuurwetenschapper Werner Mittenzwei hoe hij in de jaren '50 dankzij een van zijn promotoren met de toenmalige opvattingen van het 'cullturapparaat' werd geconfronteerd. Brecht, zo werd de promovendus duidelijk gemaakt, diende op dezelfde manier te worden bejegend als de partij omging met Richard Wagner: "Al met al waren beiden geen echte, volkstümliche kunstenaars, maar vertegenwoordigers van de decadentie". ${ }^{28}$ Bekijk je het door deze bril van de indertijd in de DDR heersende kunstpolitieke opvattingen, dan is het slechts een kleine stap van Brechts dissidente Urfaust waarmee Syberbergs loopbaan in de vroege jaren ' 50 een aanvang nam, of het theater van de absurdisten waaraan zijn vroege films uit de tweede helft van de jaren '60 verwant waren, naar Richard Wagner en de late romantiek. En het is, aldus Syberberg in de bundel Filmbuch (1976), Hans Mayer die hem deze stap heeft

schaal en euclidische representatie van zichzelf, als een fantastische en biologerende droom bedoeld on bij de toeschouwer binnen te treden."

${ }^{26}$ Kühnl, R, Einübung ins Irrationale. in: Sammlung: Jahrbuch für antifaschistische Literatur und Kunst. Band 4. Frankfurt am Main, 1980. pp. 123-127, zie: $125 \mathrm{f}$.

${ }^{27}$ Wesseltier, L., Syberberg's Hitler. German Romanticism Lives. in. The New Republic. 08-03-1980. pp. 27-30, zie: 28. Zelinsky, a.w., p. 80. Umbach, K., 'Zu schönen Klängen eine brutale Ideologie.' Spiegel-Gespräch mit Wagner-Forscher Hartmut Zelinsky über 'Parsifal" und dessen Auswirkungen auf Hitler und Holocaust. in: Richard Wagner. Ein deutsches Argernis, a.w., pp. 38-52, zie: 46. Zelinsky, H., Richard Wagners letzte Karte. Anmerkungen zum Gehalt des Bühnenweihfestspiels 'Parsifal'. in: Richard Wagner Parsifal. Texte,

Materialien, Kommentare. Hrsg. A. Scampai, D. Holland. Hamburg, 1984 pp. 252-256, zie: 252. Förg, G., Der Schlaf der Vernunft gebiert Monstern. Eine Collage zu Hans Jürgen Syberberg. in: Unsere Wagner: Joseph Beuys, Heiner Mïller, Karlheinz Stackhausen, Hans Jürgen Syberberg. Essays. Hrsg. Gabriele Förg. Frankfurt am Main, 1984. pp. 124-163. Haacke, H., To the Editor. in: Art Forum. (December 1982). pp. 3f. Schreiner, A., Vollemans, K., Een neutrum in de hoogste zin van het woord, in -en uitademen: Film der toekomst. in: Ontwerp en theorie. Een seminar. Delft, 1981. pp. 193-242. Schreiner, A., Vollemans, K., Hans Jürgen Syberberg.

Parsifal. in: Skrien. 131 (1983). pp. 4-8.

${ }^{28}$ Mittenzwei, W., Das Leben des Bertolt Brecht oder Der Umgang mit den Welträtseln. Zweiter Band. Berlin, Weimar, 1986, 1997. pp. 240f, $740 f$. 
helpen zetten" "Met hulp van Hans Mayer uit Tübingen" zou hij het werk van Wagner hebben "leren kennen en appreciëren". 29

Ter herinnering. Hans Mayer, voormalig hoogleraar literatuurwetenschappen aan de universiteit van Leipzig, is de co-conmentator van Syberbergs Brecht-documentaire Nach meinem letzten Umzug (1970) - de laatste vroege film voor het Ludwig-Requiem (1972), het eerste deel van De Graal. Tot zijn vlucht uit de DDR in '63 behoort hij, net als zijn collega in Leipzig, de twee jaar eerder gevluchte hoogleraar Wijsbegeerte Ernst Bloch, tot de groep dissidente intellectuelen rond Brechts Berliner Ensemble die, aldus Mayer in een in ' 81 afgenomen interview, ten overstaan van de "regressief op alle taboes en classicismen van het tsarisme en de burgerlijke samenleving tenuggrijpende cultuurpolitiek van de stalinisten het alternatief van een socialistische avant-garde [proberen] te ontwikkelen". "Ten opzichte van het werk van Wagner staat Mayer echter ook dan al aanzienlijk minder afwijzend dan Brecht zelf. En dit geldt in nog veel sterkere mate voor Ernst Bloch, die zich reeds in zijn jeugdwerk Geist der Utopie (1918) manifesteert als een bevlogen wagneriaan. ${ }^{31}$ Zijn Thomas Mann en Brecht de meest bekende en invloedrijke vertegenwoordigers van respectievelijk de derde en de vierde positie in het Wagner-debat; Mayer en Bloch gelden als de belangrijkste theoretici van de eerste positie, dat wil zeggen: die van de naoorlogse festivalleiding. Beiden zijn in de jaren ' 60 en de vroege jaren ' 70 als officieuze huisfilosofen nauw bij het "Nieuwe Bayreuth' van Wieland en Wolfgang Wagner betrokken en hebben in deze rol een onuitwisbare stempel gedrukt op het naoorlogse Wagner-beeld. Met name de invloed van Bloch, die persoonlijk met Wieland Wagner bevriend was en ook de grafrede voor deze in 1966 overleden festivalleider heeft gehouden, kan nauwelijks worden overschat. ${ }^{32}$ En ik ben ervan overtuigd, dat ook de wortels van Syberbergs wagnerianisme eerder in deze hoek dienen te worden gezocht. Maar laten we, de woorden van Agnes Schreiner indachtig, beginnen met een kleine invuloefening.

\subsection{Wagner-travestie}

In eerste instantie wekt Sontags associatie van Syberberg met de late Thomas Mann enige bevreemding. In zijn hierboven reeds aangehaalde brief aan Preetorius somt Mann een aantal karaktertrekken van Wagner op, waaruit diens geestverwantschap met Hitler zou moeten blijken: Wagners "onnoemlijke onbescheidenheid", zijn "snoeven, het eeuwige peroreren, alleen-willen-spreken, over alles mee-willen-spreken", uiteraard ook zijn "zelfverheerlijking

\footnotetext{
${ }^{29}$ Syberberg, Filmbuch, a.w., p. 250.

${ }^{30}$ Mayer, H., Metzger, H.-K., Riehn, R., Diskussion über Recht, Unrecht und Alternativen. in: Musik-Konzepte, a.w., pp. 54-76, zie: 60 . Zie eveneens: hoofdstuk 2, de paragrafen 3, 4 en 10.

${ }^{31}$ "Kleinsüchtige, blicklose Schuften," noemt Bloch in dit werk de criticaster van Wagner - 'kleinzerige schoften zonder visie': "Wat werd er niet allemaal tegen ingebracht en aan gemeenheid opgegraven! En tegenwoordig is men al weer zover, dat de meest onwaarachtige kletskousen zich als moraalesthetische rechters verheffen, waar zelfs Beethoven uitsluitend met de hoed in de hand enkele berispingen zou hebben uitgesproken". Bloch, E., Geist der Utopie. Erste Fassung. Frankfurt am Main, 1971, 1985. p. 131. 32 "Ich kann es nicht besser sagen als Ernst Bloch, mit dem mein Bruder [Wieland Wagner, G.G.] und ich freundschaftlich verbunden waren," vat de festivalleider Wolfgang Wagner in zijn autobiografie zijn visie op het thema Wagner en het nationaal-socialisme samen. Wagner, W[olfgang], a.w., p. 48. Zie eveneens: Amerongen, van, a.w., pp. 164ff. Skelton, G., Wieland Wagner. The positive sceptic. London, 1971. pp. 193ff. Alsmede: Wagner, W[ieland], Wieland Wagner. Sein Denken. Aufsätze, Reden, Interviews. Hrsg. Bayreuther Festspiele. Bayreuth, 1991.pp. 89-95, 108: "Ich bin ein ausgesprochener Bloch-Verehrer. Er ist einer der originellsten Köpfe unserer Zeit. (...) Nietzsche war der letzte große Kopf vor Bloch. (...) Adorno, Bloch und Mayer geben heute den AnstoB zur Beschäftigung mit Richard Wagners Werk."
} 
en mystagogische zelf-enscenering". ${ }^{33}$ Het zijn stuk voor stuk karaktertrekken, die ook bij Syberberg kunnen worden aangetroffen. Zoals Sontag niet blijkt te zijn ontgaan. De voor Wagners karakter typerende " $(. .$.$) gevoelstegenstellingen (...), komen bij Syberberg weer$ boven water," constateert de publiciste: "radicale democraat en rechtse elitarist, estheet en moralist, schetteraar en droefgeestige figuur". Eveneens wagneriaans zijn te noemen, voegt ze hieraan toe: zijn "bevlogen spraakzaamheid" - "ook al probeert hij te zwijgen (...), hij kan het spreken niet laten" -; zijn "weergaloze," "alles wat ooit op het witte doek te zien is geweest overtreffende" "ambitie"; zijn "streven naar volledigheid en diepgang", zijn "voorliefde voor het grootse", zijn "geloof in kunst als een radicale handeling", zijn "zendingsbesef" en "de graagte waarmee hij aanstoot geeft" - "hij kan geen essay schrijwen of het wordt een manifest". ${ }^{34}$

Wat dit laatste betreft, kan worden volstaan met een vluchtige blik in Syberbergs Filmbuch, zijn tweede boekpublicatie sinds het in het vorige hoofdstuk besproken proefschrift. De flaptekst van deze, uit ' 76 daterende bundel belooft een zelfportret van de filmmaker, alsmede een uiteenzetting met 'filmalledaagsheid, filmindustrie en filmkritiek'. Maar dit is een vlag, die de lading slechts zijdelings dekt. Filmbuch heeft, zoals de Nijmeegse filmtheoreticus Eric de Kuyper (1977) terecht opmerkt in een recensie, sterk het karakter van een "pleidooi pro domo en een scherp polemiseren tegen de Duitse kunstkritiek, die zijn [Syberbergs, G.G.] waarde niet heeft willen erkennen". ${ }^{35}$ Zoals wel meer kunstenaars, voelt Syberberg zich miskend in eigen land. Dezelfde films, die door Duitse critici genadeloos zouden zijn neergesabeld, zouden aan gene zijde van de Rijn alom worden beschouwd als meesterwerken. En met een overvloed aan bewijsmateriaal, heeft hij dit 'onrecht' proberen te documenteren. Een niet onaanzienlijk deel van Filmbuch (26 van de in totaal 315 pagina's) gaat op aan een bloemlezing bewierokende Franse kritieken op deze en andere films, in een vertaling van Syberbergs vrouw Elisabeth. Om de Duitse lezer nog eens extra met de neus op de feiten te drukken, zijn de meest lovende passages gecursiveerd: "Ik dank Visconti's Ludwig II, dat in zijn kielzog de beste Duitse film tot ons komt, die we sinds jaren hebben gezien" (Nouvelles Littéraires, 4 juni 1973); "Beslist de meest originele en rijke film, die de Duitse cinema ons sinds 30 jaar geschonken heeft" (Valeurs actuelles, 21 mei 1973). ${ }^{36}$

Van de hand van Elisabeth Syberberg, maar dit maal in samenwerking met Syberbergs toenmalige secretaresse Dr. Marion Kroner, is ook het Wörterbuch des deutschen Filmkritikers (38 pagina's), dat aan deze bloemlezing vooraf gaat. Keurig alfabetisch gerangschikt, compleet met bronvermelding en voorbeeldzin, zijn in dit lexicon de belangrijkste scheldwoorden opgenomen, die Duitse critici tegen Syberberg hebben gericht. Het 'Woordenboek' begint onder A met "Abgefeimtesten Psychotester", Ponkie, AZ, München 1970: "Syberberg is een doortrapte doorgronder van maatschappelijk bepaalde mentaliteit", en eindigt onder Z met "Zynische Ablehung", Frank Hauck, Vorwärtz, Bonn 1974: "Syberbergs cinema is total anti-filmisch, een cynische afwijzing van het medium, waarvan hij zich bedient". 37 Merkwaardig genoeg ontbreekt onder M: mythograaf. Toch is ook dit een woord, dat niet zelden in Duitse commentaren opduikt. Fischer, Hembus, Der neue deutsche Film, München 1980: "(..) Hans Jürgen Syberberg is zijn eigen mythograaf, een kleinburgerlijke dwerg, die met een mapje goede getuigschriften (...) rondloopt, voortgedreven door de panische angst dat iemand ooit zou kunnen vergeten, dat de Duitse

\footnotetext{
${ }^{33}$ Mann, a.w., p. 168.

${ }^{34}$ Sontag, a.w., pp. 186, 206ff, $220 \mathrm{ff}$.

${ }^{35}$ Kuyper, de, E., Boekbespreking. in: Streven. (Oktober 1977). pp. 96, 96.

${ }^{36}$ Syberberg, a.w., pp. 181-220, zie: 206, 212.

${ }^{37}$ idem, pp. 143-180.
} 
cultuur sinds Goethe, Kleist en Wagner (...) geen zo goddelijke verschijning meer heeft gehad $(. .)^{\prime \prime 38}$

Van meet af aan wekt Syberberg in eigen land, naast irritatie en zelfs woede, ${ }^{39}$ ook de nodige spotlust op. "Hij is de grote egomaan," vat Klaus Jeziorkowsky, hoogleraar filologie in Frankfurt, het gangbare oordeel in eigen land samen. "De anderen zijn de hel, hijzelf ziet zich als de hemel, de heil- en vreugdebrengende, de door de boosaardige massa miskende en gekruisigde." ${ }^{40}$ En in een Duits satirisch tijdschrift verschijnt begin jaren "80 zowaar een 'Oproep tot de oprichting van een Hans-Jürgen-Syberberg-genootschap': "Het levenswerk van Hans Jürgen Syberberg, wordt in de Bondsrepubliek nog altijd niet op waarde geschat. (..) Wij eisen daarom dat (...) in de inleiding van alle films van Leni Riefenstahl en alle boeken van de Duitse auteur Friedrich Nietzsche er voortaan op wordt gewezen, dat het hier gaat om artistieke voorlopers van het werk van Hans Jürgen Syberberg. (... " ${ }^{41}$ Of dit soort hoon Syberberg ook maar een moment heeft doen overwegen zich meer bescheiden op te stellen, mag gerust worden betwijfeld. Anders dan door alle critici klakkeloos wordt aangenomen, is het Wörterbuch des deutschen Filmkritikers in de Duitse kunstgeschiedenis namelijk geen noviteit. Geheel volgens Agnes Schreiners procédé: 'Zeg Syberberg in plaats van Wagner en herkauw alle commentaren en kritieken op de laatstgenoemde', hebben we hier van doen met een actualisering van het op de kop af honderd jaar eerder (1876) verschenen Wörterbuch der Unhöflichkeit, enthaltend grobe, höhnende, gehässige und verleumderische Ausdrücke, die gegen den Meister Richard Wagner, seine Werke und seine Anhänger von den Feinden und Spöttern gebraucht wurden.

De samensteller van dit negentiende-eeuwse scheldwoordenlexicon was de Duitse muziektheoreticus en schrijver Wilhelm Tappert. Door de meest voorkomende antiwagneriaanse 'onhoffelijkheden' overzichtelijk te inventariseren (alfabetisch gerangschikt, met bronvermelding en voorbeeldzin), probeerde deze bevlogen wagneriaan een tweetal zaken te bewerkstelligen. Enerzijds hoopte hij dat de criticasters, door hen een spiegel voor te houden, tot inkeer konden worden gebracht en beschaamd om de eigen onnozelheid voorgoed hun geraas zouden staken. Anderzijds wilde hij aantonen, dat kunst die tegen een dergelijke vloedgolf van aantijgingen en bespottingen standhoudt, welhaast noodzakelijk over bijzondere kwaliteiten moet beschikken. "De meest achterlijke vormen van onbeschoftheid, de meest impertinente domheden en onwetendheden, worden behaaglijk gekoesterd en gebruikt," schrijft Tappert in een voorwoord bij de eerste uitgave. ${ }^{42}$ En iets soortgelijks moet ook Syberberg hebben gedacht, toen hij opdracht gaf een eigentijdse versie van dit scheldwoordenlexicon te vervaardigen. Natuurlijk kunnen we naar de motieven van de filmmaker slechts gissen. Maar het heeft er verdacht veel van weg, dat hier de spot wordt gedreven met de spottende Duitse critici, die weliswaar de mond vol hebben over wagnerianisme, maar niet eens in staat blijken een zo overduidelijk Wagner-citaat te herkennen. ${ }^{43}$

Kan het Wörterbuch des deutschen Filmkritikers nog met enige goede wil worden opgevat als een pastiche, aanzienlijk moeilijker ligt het met andere stukken in Filmbuch.

\footnotetext{
${ }^{38}$ Fischer, R., Hembus, J., Der neue deutsche Film 1960-1980. München, 1980. pp. 70-72, 135-137, zie: 72.

${ }^{39}$ Günther, W., Winifred Wagner und die Geschichte des Hauses Wahnfried von 1914-1975. in: Medium. (mei 1976). pp. 32-33, zie: 32: "Over Hans Jürgen Syberberg wilde ik al langer eens een keer iets schrijven, om eindelijk de woede en ergernis over zijn films te kunnen afreageren".

40 Jeziorkowsky, K., Das Glück der Wurzelbürste. in: Der Spiegel. 26 (1981). pp. 167-170, zie: 167.

${ }^{41}$ Citaat ontleend aan: Förg, a.w., pp. 124, 126.

${ }^{42}$ Hurenaquarium und andere Unhöflichkeiten. Richard Wagner im Spiegel der zeitgenössischen Kritik. Hrsg. W. Tappert. München, 1968, 1983. p. 9.

${ }^{43}$ Terzijde zij hier opgemerkt, dat bij mijn weten ook geen van Syberbergs buitenlandse bewonderaars, ooit de link met Tapperts lexicon heeft gelegd.
} 
Neem de openingstekst van de bundel het op verzoek van de Parijse Cinématèque geschreven manifest Film als Musik der Zukunft. Eine Ästhetik, dat oorspronkelijk (1975) in een Franse vertaling is gepubliceerd ${ }^{44}$ Met de films Ludwig - Requiem fuir einen jungfräulichen König, Theodor Hiernies oder wie man ehem. Hofkoch wird, Karl May - Auf der Suche nach dem verlorenen Paradies en Winifred Wagner und die Geschichte des Hauses Wahnfried als uitgangspunt, heeft Syberberg zich gewaagd aan een formulering van zijn cinematografische poëtica. Veel verder dan een 'invuloefening' is hij echter niet gekomen. Weliswaar heeft de filmmaker zich enkele aanpassingen van Wagners kunsttheorie veroorloofd. Vanzelfsprekend is het hem niet te doen om een revolutie in de opera, maar in de cinema. En dat, anders dan bij Wagner, de inzet van deze revolutie niet is de bevrijding van het Duitse volk van de mode van de Franse smaak, maar het tot stoppen brengen van de naoorlogse veramerikanisering van de Duitse cultuur (Hollywood!), behoeft gezien de receptiegeschiedenis van zijn werk evenmin een betoog. Maar afgezien van dit soort voor de hand liggende aanpassingen, houdt Syberberg zich in Film als Musik der Zukunft hoofdzakelijk bezig met afstoffen en recyclen. Alsof sinds de negentiende eeuw niets is voorgevallen, passeren de belangrijkste concepten van Wagners kunstheorie opnieuw de revue: Gesamtkunst, tragedie, verlossing, leidmotief, mythe, innerlijkheid enzovoorts. "Die Geburt der Tragödie aus dem Geiste der Musik was het geschenk van Nietzsche aan Richard Wagner, de fel strijdende kunstrevolutionair," aldus Syberberg in dit pamflet. "Hij heeft het met een groot en dankbaar gebaar zelf bij Richard Wagner aan huis gebracht, en deze accepteerde het met benijdenswaardige graagte. Daarom is het geoorloofd om Richard Wagner en de wil tot mythe van Nietzsche en Wagner aan te boren, en - zij het wat aangepast voor onze tijd - in te zetten, doordat ik voor mij probeer de film als muziek van de toekomst te beschrijven." 45

Het parasitaire karakter is zo sterk, dat je bijna zou gaan vermoeden dat een dergelijk manifest anders dient te worden gelezen en geduid. Dat wil zeggen niet inhoudelijk, als een exposé van Syberbergs poëtica, maar figuurlijk, als een decorstuk in een wagneriaanse enscenering van het kunstenaarschap. Opnieuw gaat het om een nabootsing van een historische tekst, dit maal van de hand van de Meester zelf. Niet, zoals men zou kunnen denken, het programmatische hoofdwerk Kunstwerk der Zukunft heeft model gestaan, maar het minder bekende manifest Zukunftmusik - Wagners toelichting op de 'quatre poèmes d'opera' (Tannhäuser, Holländer, Lohengrin, Tristan), dat in 1860 naar aanleiding van de Parijse uitvoering van de Tannhäuser in een Franse vertaling werd gepubliceerd. (Evenals bij Film als Musik der Zukunft verscheen het Duitse origineel een jaar later.) En voor het begrijpen van Syberbergs, ten behoeve van het Parijse publiek geschreven toelichting op zijn 'quatre poème de cinéma' (Ludwig, Hiernies, May, Winifred), zou het verhaal achter deze historische Wagner-tekst wel eens interessanter kunnen zijn dan de inhoud "Of de gebeurtenis consequenties heeft of niet, laat me vooralsnog koud," schreef Wagner op 6 april 1861 aan Mathilde Wesendonk over "zijn bedenkelijke Parijse avontuur". "Alles, wat ik in dit yerband voel, is - matheid, walging." ${ }^{46}$ De Parijse uitvoering van de Tannhäuser, die kort daarvoor had plaats gevonden, was uitgemond in een schandaal dat zijn weerga in de muziekgeschiedenis niet kent. Door middel van luid gesis, gesnerp en gelach, had een groep operavrienden gemeend zijn ongenoegen over Wagners Toekomstmuziek te moeten kenbaar maken. En na drie voorstellingen had de componist het verder voor gezien gehouden. Maar: "De lieden die denken dat zij Wagner hebben vernietigd, verheugen zich te vroeg," voorspelde Charles Baudelaire enkele weken later in het schotschrift Richard Wagner et le

\footnotetext{
${ }^{44}$ Syberberg, a.w., pp. 9-94. Voor de ontstaansgeschiedenis van dit manifest, zie: pp. 97, 307.

${ }^{45}$ idem, p. 14.

${ }^{46}$ Richard Wagner an Mathilde Wesendonk. Tagebuchblätter und Briefe 1853-1871. Berlin, 1906. p. 270.
} 
Tannhäuser à Paris. ${ }^{47}$ De vervulling van Baudelaire's profetie zou echter nog honderd jaar op zich laten wachten. Pas in de jaren ' 70 van onze eeuw wordt de Parijzenaren een tweede kans gegund, die ze deze keer met beide handen aangrijpen: en masse gaat ze op de knieën voor de filmische Toekomstmuziek van Wagners tweede verschijning.

Onwillekeurig dringt de associatie zich op met Besetzungen, de beroemde fotoperformance uit eind jaren '60, waarin Anselm Kiefer op enkele monumentale plekken in Europa poseert als triomferende nazi. ${ }^{48}$ Ook Syberberg, die hier als een soort triomferende 'tweede verschijning' van Richard Wagner opduikt op de plek van diens grootste nederlaag, is wellicht een poseur. Al begin je tijdens het lezen van Filmbuch soms te twijfelen. Wörterbuch des deutschen Filmkritikers en Film als Musik der Zukunft zijn niet de enige voorbeelden van Wagner-travestie (een ander woord laat zich vooralsnog moeilijk bedenken), die in deze bundel kunnen worden aangetroffen. Uit vrijwel elke pagina stijgt een parasitaire, bijna necrofiele geur op, die direct of indirect herinnert aan de negentiende-eeuwse Wagnercultus. Zelfs een op het oog onschuldig kiekje, waarop te zien is hoe het echtpaar Syberberg met gasten in de tuin achter hun Münchense woning enkele genoeglijke uurtjes doorbrengt ${ }^{49}$, blijkt bij een nadere beschouwing van deze geur doordrongen. Een intrigerend fenomeen in de Duitse kunstgeschiedenis is de kunstenaarsvilla. Alleen al München telde rond de eeuwwisseling een groot antal van dit soort villa's - statige woonhuizen annex ateliers, waarin toenmalige sterren als de beeldhouwer Adolf von Hildebrand hun soirées organiseerden en het classicistische ideaal van de harmonie tussen leven, artistieke arbeid en vormgegeven natuur in de praktijk brachten. ${ }^{50}$ Met de teloorgang van het Duitse idealisme na de Tweede Wereldoorlog, zijn ook deze kunstenaarsvilla's goeddeels verdwenen. Voorzover ze nog bestaan, zoals het Hildebrand-Huis in München of - uiteraard - de Wagner-villa Wahnfried in Bayreuth, hebben ze een nieuwe bestemming gekregen als musea. Maar sinds midden jaren '60, als Syberberg zijn huis aan de Münchense Genterstraße betrekt (waar hij zijn gehele verdere leven zal blijven wonen), kent Duitsland weer een levende kunstenaarsvilla, in de oude zin van het woord.

Evenals in vervlogen tijden het Hildebrand-Huis of de Villa Wahnfried, is ook de Syberberg-villa een woon/werkhuis met een representatieve nevenfunctie. Het belangrijkste deel van de villa is de tuin. Hier ontvangt de filmmaker bij voorkeur zijn gasten, laat hij zich interviewen en fotograferen, of verliest hij zich tijdens "het bijeenharken van verdorde bladeren in de herfst ${ }^{51}$ (Il faut cultiver son jardin) in duistere bespiegelingen. In de tuin (ongetwijfeld met uitzicht op deze bladeren, die vanaf Hitler een sleutelrol in zijn werk zullen gaan vervullen) bevindt zich ook de als studeercel ingerichte hut, waar Syberberg zijn scripts en pamfletten schrijft, of schetsen maakt voor een nieuwe film-collage. Het huis zelf biedt ruimte aan het omvangrijke archief, het secretariaat van Syberberg-Film-Produktion (het eigen productiebedrijfje, dat hij eind jaren ' 60 heeft opgericht) en de woonvertrekken van de gezinsleden die, naar goed negentiende-eeuws gebruik, nauw bij de artistieke arbeid betrokken zijn - dochter Amelie bijvoorbeeld als één van de hoofdrolspelers in Hitler, vrouw Elisabeth als vertaalster, redactrice, secretaresse, gastvrouw, muze en troosteres. ${ }^{52} \mathrm{De}$ bezoekers op de foto in Filmbuch zijn twee leden van die andere beroemde Duitse

\footnotetext{
${ }^{47}$ Ik ontleen dit citaat aan Amerongen, van, a.w., pp. 42f., waarin ook een plastische beschrijving van het Parijse Tannhäuser-schandaal kan worden aangetroffen.

${ }^{48}$ Zie bijvoorbeeld: Rosenthal, M., Anselm Kiefer. Chicago, Philadelphia, 1987. p. 15

${ }^{49}$ Syberberg, a.w., p. 283.

${ }^{50}$ Zie bijvoorbeeld: Kehr, W., Rebel, E., Zwischen Welten. Adolf von Hildebrandt (1847 bis 1921). Person,

Haus tund Wirkung. München, 1998.

${ }^{51}$ Syberberg, Die freudlose Gesellschaft. Notizen aus dem letzten Jahr. München, Wien, 1981 . p. 78.

${ }^{52}$ Voor de betrokkenheid van Elisabeth Syberberg, zie, naast de gegeven voorbeelden, ook: Syberberg, a.w., p.

6. Alsmede: Syberberg, Parsifal. a.W., p. 279.
} 
kunstenaarsfamilie: Gottfried Wagner (in die dagen nog de gedoodverfde kandidaat voor de erfopvolging in Bayreuth) en zijn vrouw Beatrice.

De eerste verschijning had in koning Ludwig II van Beieren een machtige mecenas gevonden, die hem de financiële middelen bood om op loopafstand van zijn kunstenaarsvilla een eigen theater te bouwen. Maar een dergelijk geluk lijkt de tweede verschijning, in een tijd waarin het koningschap definitief is afgeschaft, niet langer vergund. Alhoewel? "Het is altijd zo geweest, dat de kunst het betere Duitsland vertegenwoordigde (...). We wachten op de democratische politicus, die als de grote mecenassen [van weleer] dit onderkent en als eerste begint met wat gedaan moet worden. Hij zal de geschiedenis van de nieuwe tijd ingaan, zoals Ludwig de geschiedenis van de muziek van Richard Wagner." 53

\subsection{Wagner \& Brecht - een esthetisch schandaal?}

Syberbergs claim, dat de esthetiek van de Duitse Trilogie voortspruit uit een dualiteit Wagner-Brecht (zie hierboven), hoeft niet noodzakelijk strijdig te zijn met deze wagneriaanse enscenering van het kunstenaarschap. Begreep immers niet ook Wagner de esthetiek van zijn muziekdrama's als een 'aanstootgevende' - in de zin van: indruisend tegen de destijds gangbare opera-esthetiek - symbiose van twee esthetische systemen? "De kunstenaar van de toekomst (...)," vat de Britse filosoof Bryan Magee de programmatische inzet van Wagners werk samen in zijn nog altijd zeer lezenswaardige kleine studie Aspects of Wagner (1968), "zou de prestaties van Shakespeare en Beethoven combineren in éen kunstvorm die, naar analogie van het poëtische drama, muziekdrama kan worden genoemd." ${ }^{154}$ Zoals, ben ik geneigd hieraan toe te voegen, de filmmaker van de toekomst de prestaties van Wagner en Brecht zal combineren in één kunstvorm die, naar analogie van Wagners Toekomstmuziekdrama's, 'Film als Muziek van de Toekomst' kan worden genoemd: Maar alvorens over te gaan tot voorbarige conclusies, kan het geen kwaad eerst de filmer zelf eens aan het woord te laten over dit 'esthetische schandaal' dat hij beweert te hebben gezocht. In de bewuste passage van Die Kunst als Rettung aus der deutschen Misere, waarin de Wagner \& Brecht-formule wordt geïntroduceerd, schrijft Syberberg het volgende:

"Ik heb me aan het esthetische schandaal gewaagd Brechts leer van het epische theater te combineren met de muziek-esthetiek van Richard Wagner - in de film het epische systeem als anti-aristotelische cinema te verbinden met de wetmatigheden van een nieuwe mythe. De tegenwoordige bioscoopfilm is voor mij de tot boulevardnietszeggendheid verloederde vorm van de aristotelische dramaturgie, sinds vele eeuwen zonder poëtische, esthetische en geestelijke innovaties. Een reactionaire vorm van cultuur in de handen van handelaren en bureaucraten. De grote uitvindingen van het moderne theater, met zijn belangstelling voor de tradities van de epische dramaturgie, hebben de cinema nooit bereikt. De film van de laatste vijftig jaar wist niet de geestelijke erfenissen te benutten, die de tradities ons aanreiken - van Aeschylus en Sophocles, het mysteriespel en Shakespeare, het Duitse romantische theater, de 'Sturm und Drang' en de revoluties van het Duitse classicisme, tot Brecht, Homerus of Dante en Bach, zoals Wagner het Gesamtkunstwerk begreep. (...) Deze lijn van het anti-aristotelische theater, dat door Brecht het epische werd genoemd, is gebaseerd op de voor de cinema zo vruchtbare mogelijkheid van elementen als staties, dat wil zeggen hoofdstukindeling, vervreemding, tekensystemen, distantie,

\footnotetext{
${ }^{53}$ Syberberg, Die Kunst als Rettung..., a.w., p. 57.

${ }^{54}$ Magee, a.w., p. 15.
} 
onregelmatige flashback, doorbreken van de illusie, achterwege laten van kleur, handeling met kans op een open einde, een verteller in plaats van een held, monoloogkarakter enzovoorts. Maar dit systeem bood ook de mogelijkheid in de structuur van de muziek de oorsprong van de tragedie serieus te nemen. Wij, die films maken, zijn de erfgenamen van het Avondland. Niet zonder reden zegt men, dat Wagner en Schiller heden ten dage films zouden hebben gemaakt. Zo kan men ook en vooral in deze traditie van de epische, niet-aristotelische dramaturgie, een sterk ceremonieel karakter waarnemen. En nu komt de sprong, die belangrijk voor me is. In het kader van de cultuurstrijd van zijn tijd had Brecht het volste recht om de rationalistische noodzaak en het anti-metafysische effect te beklemtonen van deze oude en nieuwe esthetiek, waarvan hij de belangrijkste agitator was. Logisch en alleen mogelijk en noodzakelijk was het niet. Het irrationalisme, met al zijn zusterbegrippen als surrealisme enzovoorts, is juist ook hier mogelijk en verenigbaar (...), zoals de traditie van deze esthetiek bewijst, van de Griekse tragedie via het mysteriespel en Bachs oratoriums tot Wagners Ring." 55

Zoals ik reeds schreef in de inleiding van dit hoofdstuk heeft een niet onaanzienlijk deel van Syberbergs bewonderaars de Wagner \& Brecht-formule geïnterpreteerd als een Wagnerkritische strategie. Maar voor een dergelijke interpretatie zie ik op grond van deze tekst weinig aanleiding. Wat opvalt is met name het curieuze gebruik van het brechtiaanse concept anti-aristotelisch of episch theater. Volgen we Brecht zelf in Der Messingkauf (1940) dan "verwerpt" de door hem ontwikkelde epische dramaturgie "een praktijk van theater, zoals die millennia lang werd beoefend" ${ }^{56}$ Dit traditionele, aristotelische theater was, in de visie van Brecht, in essentie een verleidingskunst. Met behulp van een breed scala aan theatrale 'foefjes', 'magie' in allerlei soorten en maten, werd het publiek verleid tot empathische identificatie met de gebeurtenissen op het toneel. Ruimte om zelf kritisch over zaken na te denken bestond nauwelijks. De rol van het publiek was louter passief. Het hoefde zich slechts voor de suggestie open te stellen en te laten meevoeren, zo men wil: betoveren. Overbodig hieraan toe te voegen, dat het wagneriaanse Gesamtkunstwerk - het theater van de 'versmelting' - door Brecht werd beschouwd als aristotelisch in de overtreffende trap. ${ }^{57}$

Ook de gedachtegang in dit citaat mag, vanuit een klassiek-brechtiaans standpunt geredeneerd, gerust een schoolvoorbeeld van een wagneriaanse 'versmeltingsstrategie' worden genoemd. Niet slechts wil Syberberg de brechtiaanse esthetiek van 'de radicale scheiding van de elementen' ${ }^{58}$ laten samensmelten met haar antipode, de wagneriaanse esthetiek van de alomvattendheid, tot een meta-cinema waarin ideologische opposities verdwijnen als sneeuw voor de zon. Zijn ambitie reikt veel verder dan dit: het ideaal is een meta-cinema, die vrijwel de gehele theatergeschiedenis van het Avondland absorbeert, 'zoals Wagner het Gesamtkunstwerk begreep'. En uitgerekend dit wagneriaanse ideaal wordt door hem voorzien van het brechtiaanse etiket episch theater, waarvan hij de betekenis zozeer oprekt, dat je je afvraagt of in de ogen van deze filmmaker niet willekeurig welke theatrale vorm anti-aristotelisch is - afgezien dan van de bioscoopfilm uit Hollywood, die hij laatdunkend typeert als 'de tot boulevard-nietszeggendheid verloederde vorm van de aristotelische dramaturgie'. Om de antieke tragedie of wagners muziekdrama's te laten doorgaan voor anti-aristotelisch ontkomt hij er echter niet aan afstand te nemen van precies

\footnotetext{
${ }^{55}$ Syberberg, a.w., pp. $28 \mathrm{f}$.

${ }^{56}$ Brecht, B., Gesammelte Werke 16. Schriften zum Theater 2. Frankfurt am Main, 1967, 1990. p. 568.

${ }^{57}$ Brecht, Gesammelte Werke 15, a.w., pp. 240ff. Brecht, Gesammelte Werke 17, a.w., pp. 1004-1011.

${ }^{58}$ Brecht, Gesammelte Werke I7, a.w., pp. 1010: "Der Einbruch der Methoden des epischen Theaters in die Oper führt hauptsächlich zu einer radikalen Trennung der Elemente".
} 
datgene, wat Brecht zelf zag als het werkelijk revolutionaire van zijn hervorming van het moderne theater: door af te zien van "alles wat pogingen tot hypnotisering moet verbeelden, waardeloze roes moet voortbrengen, beneveld", werd de toeschouwer in staat gesteld zijn kritische distantie tot het toneelgebeuren te herwinnen. ${ }^{59}$ Inderdaad kan, zoals Syberberg opmerkt in het citaat, het grote belang dat Brecht hechtte aan rationalistische transparantie niet los worden gezien van 'de cultuurstrijd van zijn tijd". "Het fascisme met zijn groteske beklemtoning van het gevoel (...) dwong me tot een sterkere beklemtoning van de ratio," aldus Brecht. ${ }^{60}$ Maar kennelijk kost het Syberberg moeite zijn 'artistieke pleegvader' op dit punt te volgen. Door het 'irrationele', het metafysische en het surreële uit het moderne theater te verbannen en grote delen van de traditie te verwerpen, zou Brecht in zijn vernieuwingsdrift te ver zijn doorgeschoten. En de esthetische formule Wagner \& Brecht lijkt hoofdzakelijk bedoeld om het naar Syberbergs smaak wat al te intellectualistische Brecht-theater van nieuwe impulsen te voorzien. Wellicht met Brechts fameuze leuze "Aus einer Kritik des Theaters wird neues Theater" ${ }^{\text {"61 }}$ in het achterhoofd, heeft hij zich naar eigen zeggen aan een dialectische 'sprong' uit de klassiek-brechtiaanse esthetica gewaagd.

Hoe het ook zij: weliswaar ontleent Syberberg aan het Brecht-theater tal van technische innovaties; Brechts bedoelingen met dit theater onderschrijft hij overduidelijk niet. Tot deze conclusie komt ook de Wagner-kenner Hans Vaget in zijn in 1982 verschenen essay Syberberg's Our Hitler. Wagnerianism and Alienation. Terecht plaatst Vaget een kanttekening bij een hardnekkig misverstand, dat vrijwel alle deelnemers aan de discussie over Syberbergs Graal-cyclus parten speelt. Alom wordt aangenomen dat Wagner en Brecht een "onmogelijke alliantie" (Kaes) vormen. ${ }^{62}$ De wagneriaanse en de brechtiaanse esthetiek zouden in een complete en radicale oppositie tot elkaar staan. Sommigen, zoals Susan Sontag, gaan zelfs zover de formule als ongeloofwaardig van de hand te wijzen. Dat deze filmmaker wel eens evenveel van Brecht in zich zou kunnen hebben als van Wagner is voor de publiciste kennelijk wat al te veel van het goede. ${ }^{63}$ En zoals we zagen strookt dit inderdaad met hoe Brecht zelf tegen deze kwestie aankeek: voor hem belichaamde de 'mythesmid' uit Bayreuth het exacte tegendeel van alles waar zijn eigen kunstenaarschap voor stond. Sontags bedenkingen zouden dan ook gerechtvaardigd zijn, redeneert Vaget, wanneer het de filmmaker te doen was om een synthese tussen de ideeën van Wagner en Brecht over kunst, politiek, cultuur, nationale identiteit, enzovoorts. Maar: "Het behoeft geen betoog, dat Syberberg niets te maken wil hebben met de politieke opvattingen van Brecht noch Wagner." Integendeel: hij probeert juist, vermoedt Vaget, "het medium van de boodschap te scheiden". Niet gehinderd door de ideologische preoccupaties van zijn beide invloedsbronnen, combineert hij wagneriaanse en brechtiaanse elementen tot een geheel eigen esthetisch systeem. Brechtiaanse vervreemdingstechnieken worden door hem gebruikt als een "tegengif" voor de verleidingen van het wagnerianisme; wagneriaanse verleidingstechnieken als een instrument om het klinische rationalisme van Brechts 'wetenschappelijke theater' te

\footnotetext{
${ }^{59}$ idem, a.w., pp. 1010 f.

${ }^{60}$ Brecht, Gesammelte Werke 15, a.w., p. 242.

${ }^{61}$ Brecht, Gesammelte Werke 16, a.w., p. 943.

${ }^{62}$ Kaes spreekt over een "onmogelijke alliantie", waarvan de "hybride oorsprong" zou leiden tot "plotselinge breuken, ongemotiveerde verschuivingen in stemmingen en perspectief en (...) ambivalenties die elke poging tot interpretatie tarten". Kaes, a.w., pp. $44 \mathrm{f}$.

${ }^{63}$ Sontag, a.w., p. 209: "Volgens Syberberg spruit zijn werk voort uit de 'dualiteit Brecht-Wagner'; dat is het esthetische schandaal dat hij beweert te hebben gezocht. In interviews noemt hij altijd beiden als zijn artistieke voorvaderen, naar we mogen aannemen gedeeltelijk om de politieke gezindheid van de één door die van de ander te laten neutraliseren en zichzelf te verheffen boven de strijdvragen van links en rechts, gedeeltelijk om onpartijdiger te lijken dan hij is. Maar het kan niet anders, of hij heeft meer van Wagner in zich dan van Brecht; gezien het feit dat de veelomvattende wagneriaanse esthetiek ook gevoelstegenstellingen bestrijkt (eveneens op ethisch en politiek terrein)".
} 
omzeilen. "Dat hij [Syberberg, G.G.] het heeft aangedurfd Wagner en Brecht te combineren hun artistieke innovaties accepterend en hun ideologische bagage verwerpend - zou wel eens het werkelijke schandaal van zijn werk kunnen zijn," denkt Vaget. "Hij heeft aldus iets bewerkstelligd, dat indruist tegen de gangbare esthetische overtuiging, dat ideologie en artistieke methode onscheidbaar zijn. In mijn visie is het precies deze scheiding, die ervoor zorgt dat deze film [Hitler, G.G.] doorbreekt naar een nieuw domein in de kunst van de cinema. Dit nieuwe domein omvat zowel het Gesamtkunstwerk van Wagner als het epische theater van Brecht,

Vaget had mijns inziens zijn punt nog sterker kunnen maken door erop te wijzen, dat een combinatie van een wagneriaanse en een brechtiaanse esthetiek ook allerminst een noviteit is. Een dergelijke combinatie mag dan een ongehoorde nieuwigheid zijn in de cinema; in het theater vormen Wagner en Brecht reeds sinds lang een hecht duo. Zelfs in het theater op de Groene Heuvell te Bayreuth - ondanks verwoede pogingen tot demystificatie nog steeds het centrum van de Wagner-cultus. Zo gebruikt Hans Mayer in zijn studie Richard Wagner in Bayreuth (1976) vrijwel dezelfde formule om de esthetiek van Götz Friedrichs Bayreuth-Tannhäuser van 1972 te typeren: "De op identificatie met het toneelgebeuren berustende esthetiek van Bayreuth werd verbonden met een [brechtiaanse, G.G.] esthetiek van de vervreemding." ${ }^{65}$ En we zouden nog verder terug kunnen gaan in de tijd. Reeds een kleine tien jaar eerder, in 1963, heeft Wieland Wagner in een enscenering van de Meistersinger brechtiaanse vervreendingstechnieken toegepast. ${ }^{66}$ Het behoorde zelfs tot de favoriete stokpaardjes van deze legendarische festivalleider, die geldt als één van de meest toonaangevende Wagner-interpreten van na de oorlog: de kloof tussen Wagner en Brecht, zo werd hij niet moe te benadrikken, is aanzienlijk minder diep dan de communis opinio doorgaans graag wil geloven. "Kijkt u alleen al eens naar de Walkïre - dat is toch episch theater par excellence," aldus Wieland Wagner in een interview uit 1963. "Een zwaard wordt uit een stam getrokken. Een God doodt zijn zoon. Een slag met een speer tegen een rots laat vlammen opflakkeren. En waar vind je elders in de Ring niet-vervreemdende theatrale handelingen? Ook de andere werken zijn zeer aan het epische theater verwant:"67

Inderdaad zouden nogal wat zaken die we hierboven hebben aangeduid als typisch wagneriaans evengoed typisch brechtiaans kunnen zijn. Neem de 'drang tot polemiseren en de graagte om aanstoot te geven' - als we Sontag mogen geloven één van Syberbergs meest in het oog springende wagneriaanse karaktertrekken. Ook Brecht kon, om de publiciste te parafraseren, 'geen essay schrijven, of het werd een manifest'. Dezelfde messianistische

\footnotetext{
${ }^{64}$ Vaget, a.w., pp. 610f. Zie in dit verband eveneens: Brunette, P. Ludwig: Requiem für einen jungfräulichen König. in: Film Quarterly, XXXIV (Spring 1981). pp. 58-61 "Het overwicht van brechtiaanse vervreemding ten spijt," merkt ook deze filmcriticus scherp op, "is de film [Ludwig, G.G.] uiteindelijk dramatisch, zelfs in de conventionele betekenis van het woord (...). We blijven achter, met een sterk gevoel van genegenheid voor Ludwig. Mogelijk duidt dit op Syberbergs erkenning van het failliet van het brechtiaanse model als het gaat om overdraagbare menselijke emoties of identificatie. Of misschien gebeurt het ook tegen zijn wil. lk ben geneigd te denken, dat Syberberg zeer goed weet waar hij mee bezig is en in feite een veelbelovende, nieuwe variatie heeft gecreëerd op de traditionele brechtiaanse esthetica, die zowel zou kunnen fungeren als een revitalisering, alsook als een actualisering."

${ }_{65}$ Mayer, H., Richard Wagner in Bayreuth 1876-1976. Stuttgart, Zürich, 1976, 1978. pp. 191ff. Zie eveneens: Ely, N., Götz Friedrich - Tannhäuser oder der Künstler in der Gesellschaft. in: Regie heute. Musiktheater in unserer Zeit. Hrsg. N. Ely, S. Jaeger. Berlin, 1984. pp. 135-160.

${ }^{66}$ Wagner, W[ieland], a.w., p. 43.

${ }^{67}$ idem, pp. 103f. Overigens bespeurt Mayer op dit punt de invloed van Thomas Mann. In een in '42 gehouden voordracht typeert ook Mann de muziekdrama's van Wagner als 'episch theater'. "Auch ohne Brecht wäre es zu einer Theaterkunst der distanzierende Verfremdung gekommen," aldus Mayer, a.w., pp. 178f. Zie in dit verband eveneens: Mann, a.w., pp. 13f: "Ich habe oft mühe ihn [Wagner, G.G.] als Dramatiker zu empfinden. Ist er nicht eher ein theatralischer Epiker? (...) Es [de Ring, G.G.] ist im innersten episch, es ist homerischen Ursprungs."
} 
mentaliteit, waarvan de pamfletten van Wagner zijn doortrokken, waart door het Verzamelde Werk van zijn vermeende tegenpool. Sterker: dezelfde overwegingen, die Wagner ertoe brachten - figuurlijk - de brand te steken in de opera van zijn dagen (zie hier beneden), vormden de grondslag van Brechts revolutionering van de aristotelische dramaturgie. Doorn in het oog van zowel de 'mythesmid' als de 'wetenschappelijke theatermaker' was een theater, dat zich met huid en haar had uitgeleverd aan de commercie en uitsluitend nog fungeerde als producent van in slaap sussend amusement. Hier tegenover verdedigden zowel Brecht met zijn anti-aristotelische dramaturgie als Wagner met zijn anti-opera Toekomstmuziekdrama's het ideaal van een theater met een morele, maatschappelijke, politieke, ja zelfs universeel-historische missie. Het is dit gemeenschappelijke ideaal, dat deze ogenschijnlijke tegenpolen niet enkel met elkaar verbindt, maar bovendien in een gemeenschappelijke traditie plaatst, die via het theater van de Verlichting (Gottsched, Lessing, Schiller) en het poëtische drama van Shakespeare terugreikt tot Homerus en de door Brecht niet minder dan door Wagner bewonderde tragedieschrijvers Aeschylus, Sophocles en Euripides. ${ }^{68}$ Of, in de woorden van Wieland Wagner: "Voor mij is het [de Ring, G.G.] ten eerste een herstel van de antieke tragedie; ten tweede een terugkeer naar mythische bronnen; en ten derde moreel drama in de trant van zowel Schiller als Brecht." ${ }^{" 69}$ En dit blijkt ook de visie van Syberberg te zijn.

In zijn kern behelst het hierboven aangehaalde citaat uit Die Kunst als Rettung aus der deutschen Misere weinig meer dan een bekentenis tot een bepaalde theatrale traditie, waarbij Syberberg met zijn vroege films uit de tweede helft van de jaren ' 60 reeds heeft proberen aan te knopen - al werd de dialectische 'sprong' uit de klassiek-brechtiaanse esthetica indertijd nog niet werd geïnspireerd door Wagner, maar door het absurdistische theater van Friedrich Dürrenmatt. ${ }^{70}$ Syberberg had nogal wat verwarring onder zijn exegeten kunnen vermijden, wanneer hij deze traditie niet zou hebben aangeduid als episch of anti-aristotelisch, maar zijn toevlucht had gezocht tot een ander brechtiaans begrippenpaar: 'pleziertheater' en vormingstheater. ${ }^{71}$ Binnen de lange traditie van het morelle drama, het vormingstheater, of het theater als een moreel instituut in de zin van Friedrich Schiller, zijn Wagner en Brecht niet zozeer tegenpolen als veeleer kunstenaars die elk in hun eigen tijd deze vorm van theater ingrijpend hebben vernieuwd - naar goed artistiek gebruik hun voorgangers verguizend. Zoals na hen bijvoorbeeld de post-brechtiaan Dürrenmatt - ook al een künstenaar, die 'geen essay kon schrijven, of het werd een manifest". Zo kan het gebeuren, dat "de polemische rusteloosheid van Syberbergs theoretische geschriften" bij de Britse filmtheoreticus John Sandford geen herinneringen blijkt op te roepen aan Wagner, maar aan "Duirrenmatts essays en monstertoespraken". ${ }^{2}$

\footnotetext{
${ }^{68}$ Zie bijvoorbeeld: Söring, a.w., passim. Alsmede: Bermbach, U., Der Wahn des Gesamtkunstwerks. Richard Wagners politisch-ästhetische Utopie. Frankfurt am Main, 1994. pp. 186f. Het werk van Wagner, meent ook deze Hamburgse hoogleraar politicologie, "steht (...) in der Tradition der Aufklärung, zumindest in dieser Hinsicht, da Wagner den Verlust der Vorbildfunktion des Theaters beklagt, den alten aufklärerischen Vorwurf einer bloß unterhaltenden Darbietung aufnimmt, ihn argumentiv ausweitet, indem er ihn gesellschaftstheoretisch fundiert, und ihn zugleich rhetorisch verschärft."

${ }^{69}$ Citaat ontleend aan: Skelton, a.w., p. 178. Zie in dit verband eveneens: Wagner, W[ieland], a.w., pp. 44-49.

${ }^{70}$ Zie: hoofdstuk 2 , de paragrafen 8 en 9 .

${ }^{71}$ Brecht, Gesammelte Werke 15, a.w., pp. 262ff,

${ }^{72}$ Sandford, J., Hans Jürgen Syberberg: Films from Germany. in: Syberberg. A Filmmaker from Germany. ed. H. Steward. Edinburgh, 1992. pp. 5-12, zie: p. 5.
} 


\subsection{Het éne Duitsland van Thomas Mann}

Minder overtuigend is Vagets suggestie, dat deze filmmaker vanzelfsprekend met de politieke opvattingen van Wagner noch Brecht iets te maken zou willen hebben. Terecht merkt Vaget op, dat Syberbergs Hitler-film "niet is gesitueerd in een ideologisch niemandsland": "Het ideologische profiel van deze film draagt overduidelijk het stempel van een esthetisch georiënteerd conservatisme, dat hem in het kamp plaatst van Thomas Mann en niet in dat van Brecht. 73 Waarbij Vaget geheel in de lijn van de positieve receptie sinds Susan Sontag denkt aan de Thomas Mann van na diens democratische Kehre. Van deze late Thomas Mann zou Syberberg de zogenaamde 'Eén Duitsland'-theorie overnemen. Het betreft hier een theorie, verduidelijkt Vaget, die de, ook door Brecht onderschreven marxistische interpretatie verwerpt van "het nazisme als een instrument, dat door het kwaadaardige, kapitalistische Duitsland werd gebruikt om het andere, goede Duitsland aan zich te onderwerpen". In plaats daarvan begrijpt de "Een-Duitsland'-theorie het nazisme als "het karakteristieke resultaat van de Duitse sociale en intellectuele geschiedenis". "Maar deze uitleg is niet geheel adequaat, want er laten zich wel degelijk ook theorieën bedenken die beide elementen in zich verenigen. Bijvoorbeeld de in het vorige hoofdstuk besproken stalinistische "TweeDuitslanden'-theorie van Georg Lukács, die niet zonder reden vaak in een adem met de auteur van Doktor Faustus (1947) wordt genoemd. ${ }^{75}$

Zoals we zagen in hoofdstuk 2 beschouwde ook Lukács zelf Manns afrekening in deze roman met het diabolische 'irrationalisme' van Wagner-Nietzsche-Hugo Wolf-Hitler als de 'burgerlijk-realistische" pendant van zijn eigen dialectisch-materialistische 'irrationalisme'-kritiek in onder meer het cultuurfilosofische hoofdwerk Die Zerstörung der Vermunft (1954). ${ }^{76}$ Volgen we het officiële, door het 'Institut für Gesellschaftswissenschaften beim ZK der SED' uitgegeven handboek Zur Theorie des sozialistischen Realismus (1974), dan school hierin zelfs de belangrijkste verdienste van de Hongaarse filosoof voor de opbouw van de socialistische samenleving: met zijn Aufarbeitung van Manns werk had hij ervoor gezorgd dat deze "grote burgerlijk conservatieve antifascist" kon worden opgenomen in de canon van de realistische literatuur - als "een jjkpunt dat tot op de dag van vandaag zijn uitstraling op de kunst van de DDR en de wereldkunst niet heeft verloren". ${ }^{77}$ En Mann op zijn beurt mocht zich dit eerbetoon graag laten aanleunen. Meer nog: hij rekende "deze communist" (dat will zeggen: Lukács) tot de zeer weinige critici, die er werkelijk in geslaagd waren door te dringen tot de diepere lagen en continuiteiten van zijn oeuvre. ${ }^{78}$

Verguld was Mann met name door een essay van Lukács uit de eerste helft van de jaren ' 40 waarin de vroege novelle Tod in Venedig (1912) samen met Heinrich Manns roman Der Untertan (1918) werd geduid als "de grote voorloper van de richting, die het gevaar heeft gesignaleerd van een barbaarse onderwereld als een noodzakelijk complementair product binnen de moderne Duitse civilisatie". Het was, aldus Mann over dit essay in Die Entstehung

\footnotetext{
${ }^{73}$ Vaget, a.w., p. 611.

${ }^{74}$ ibidem.

${ }^{75}$ Bijvoorbeeld door Kühnl, a.w., pp. 124-127. Voor Kühnls door Lukács én Thomas Mann geïnspireerde kritiek op de Hitler-film, zie eveneens: hoofdstuk 2, paragraaf 5.

${ }^{76}$ Hoofdstuk 2, paragraaf 4.

${ }^{n}$ Zur Theorie des sozialistischen Realismus. Hrsg. Institut für Gesellschaftswissenschaften beim ZK der SED. Lehrstuhl für marxistisch-leninistische Kultur- und Kunstwissenschaften. Berlin, 1974. pp. 173, 181. De formulering "der große bürgerlich konservative Antifaschist Thomas Mann" is ontleend aan: Barack, S., Jarmatz, K., e.a. Kunst und Literatur im Antifaschistischen Exil 1933-1945. Band I/l Exil in der UDSSR. Leipzig, 1989. p. 188.

${ }^{78}$ Mann, Th., Die Entstehung des Doktor Faustus. Roman eines Romans. Frankfurt am Main, 1984, 1989. pp. $96 f$.
} 
des Doktor Faustus (1949), “(...) een sociaal-psychologische presentatie van mijn existentie en werk zoals ik die van dit niveau nog niet had beleefd en die me dan ook met grote dankbaarheid vervulde - niet in de laatste plaats, omdat de recensent mijn [toenmalige, G.G.] positie niet louter 'historisch' zag, maar met de Duitse toekomst in verbinding bracht" "79 Voor het eerst was iemand erin geslaagd duidelijk te maken, hoezeer het vroegere werk van vóór zijn democratische Kehre reeds, zij het nog onbewust en van een foutieve politiekideologische inschatting uitgaand, naar het latere, 'irrationalisme'-kritische vooruitwees. En dit was in grote lijnen ook hoe Mann door de stalinisten werd bejegend: als de grote burgerlijke "erflater" van het socialistische realisme, die in zijn vroege werk instinctief bepaalde tendensen in de Duitse cultuurgeschiedenis had doorschouwd, om vervolgens een politiek-ideologisch bewustwordingsproces door te maken, dat uiteindelijk zou uitmonden in nieuwe wereldbeschouwelijke inzichten. Natuurlijk, ook in zijn latere fase zou Mann zich nimmer "in Lenins zin met het proletariaat identificeren". Evenals zijn broer Heinrich, of Arnold Zweig en Lion Feuchtwanger, bleef ook hij volharden in zijn oude klassenpositie en de hiermee corresponderende burgerlijke idealen en illusies. ${ }^{80}$ Maar daar staat tegenover dat deze 'burgerlijke realisten' na ' 45 wel openlijk hun sympathie voor het Sovjet-model betuigden $^{81}$ en ook actief in de cultururpolitiek van de vroege DDR participeerden. ${ }^{82}$

Dit betekent niet, dat Vagets contrapositionering van Manns 'Eén-Duitsland'-theorie ten opzichte van de marxistische theorie van de 'Twee Duitslanden' geheel uit de lucht zou zijn gegrepen. Waar is, dat de stalinistische 'Duitsland-formule' uitging van twee traditiesporen binnen één Duitse cultuurgeschiedenis, waarvan werd aangenomen dat ze in een polaire oppositie tot elkaar stonden. Laten we zeggen: de lijn van het classicisme (Goethe) en die van de late romantiek (Wagner). ${ }^{83}$ Terwijl Mann op dit punt op zijn zachtst gezegd nogal wispelturig was. Nu eens meende hij, geheel in de geest van Lukács, dat men "de Duitsers voor de keuze [moest] stellen": "Goethe of Wagner. Beiden samen gaat niet". Dan weer verklaarde hij: "(...) Deze beiden samen zijn (...) wij - Goethe en Wagner, beiden samen vormen Duitsland. Het zijn de meest verheven namen voor twee zielen in onze borst, die zich van elkaar willen scheiden en wier conflict wij toch als eeuwig vruchtbaar, als de levensbron van innerlijke rijkdom steeds opnieuw moeten leren ervaren; voor de Duitse tweevoudigheid, de Duitse tweespalt, die altijd in het innerlijk van de hogere Duitser aanwezig is (...)" ${ }^{85}$ En het is vooral in dit licht, dat Manns verwerping van "de legende van het 'goede' en het "kwaadaardige' Duitsland" ${ }^{86}$ - "Er bestaat slechts één Duitsland, niet twee, niet één goed en één kwaadaardig" ${ }^{\text {"87 }}$ - dient te worden begrepen.

Het wordt vaak gezegd, dat Doktor Faustus slechts een spiegelbeeldige herhaling van het vroege geschrift Betrachtungen eines Unpolitischen voorstelt - de gedachten over

\footnotetext{
${ }^{79}$ Ibidem. Mann refereert hier aan het mij onbekende essay van Lukács: Auf der Such nach dem Bürger.

${ }^{80}$ Zur Theorie des sozialistischen Realismus, a.w., pp. 83ff, $173 \mathrm{ff}$.

${ }^{81}$ Mann, a.w, p. 47. "Voor een fatsoenlijke liberaal-democratische republiek is dit land verloren" Zie eveneens: Grunenberg, A. Antifaschismus - ein deutscher Mythos, Ein Essay. Hamburg, 1993. p. 127f. "Selbst Thomas Mann, der weder in den Westen noch in den Osten Deutschlands zurückkehren wollte, bekannte seine Sympathie für das DDR-modell".

${ }^{82}$ Zie bijvoorbeeld: Ehrlich, L., 'Gemeingut der ganzen Gesellschaft'. Weimarer Klassik in der DDR. in: Wege nach Weimar. Auf der Suche nach der Einheit von Kunst und Politik. Hrsg. H. Wilderotter, M. Dorrmann.

Weimar, 1989. pp. 277-290. Voor de cultuurpolitiek in de vroege DDR, zie: hoofdstuk 2, paragraaf 4.

${ }^{83}$ Zie hoofdstuk 2, paragraaf 4.

${ }^{84}$ Mann, Th., Wagner und unsere Zeit, a.w., p. 30.

${ }^{85}$ idem, p. 131.

${ }^{86}$ Mann, Die Entstehung des Doktor Faustus, a.w., p. 83.

${ }^{87}$ Mann, Wagner und unsere Zeit, a.w., p. 159.
} 
Duitsland als mythologische grootheid niet opgevend. ${ }^{88}$ En inderdaad antwoordde Mann nog in 1940 op de vraag "Wat is Duits?' met een verwijzing naar het traditionele onderscheid tussen Franse civilisatie en Duitse "innerlijkheid". Het spiegelbeeldige van Doktor Faustus schuilt hierin, dat de auteur van deze roman nu de Duitse mythopoëtische ziel als hoofdschuldige voor de nazi-barbarij aanwijst. "Nationaal-socialisme, in al zijn onuitsprekelijke empirische verachtelijkheid, is de tragische consequentie van de mythische politieke onschuld van de Duitse geest". De Duitse Kultur, dacht Mann, heeft een gevaarlijke januskop, die in het werk van Wagner het meest duidelijk te voorschijn is gekomen. Enerzijds ging het hier om kunst van een grootsheid, zoals een Fransman met zijn 'sociale instinct' die nooit en te nimmer had kunnen scheppen. Anderzijds mochten we niet vergeten, wat Nietzsche ooit had opgemerkt over de Meistersinger: het is "een lans tegen de civilisatie (...), tegen de gehele, sinds de renaissance dominante cultuur en samenleving". 90 Maar naties, aldus Mann, tonen niet altijd hetzelfde gezicht. Het is afhankelijk van tijd en omstandigheden, hoe hun contante kwaliteiten verschijnen. ${ }^{91}$ En zo had ook Duitsland ooit een ander, meer humaan gezicht getoond, dan in de epoche van de ondergang van de burgerlijke cultuur - namelijk; dat van het Europese Duitsland van Goethe. ${ }^{92}$ Want in Manns visie was 'het kwaad' eerst en vooral een vervalsverschijnsel. Het was 'het goede' in een gedegenereerde en geperverteerde vorm - "das Gute auf Irrwegen und im Untergang".93 Lukács had het niet beter kunnen verwoorden.

Zeker, Manns essentialistische denkbeelden over de mythopoëtische Duitse ziel zullen in de DDR ongetwijfeld zijn weggewuifd als aan zijn burgerlijke klassenpositie inherente illusies. Zijn degeneratie-theorie, evenwel, sloot naadloos aan bij de stalinistische voorstelling van een in de tijd van het classicisme nog progressieve burgerlijke cultuur, die in haar nadagen was verworden tot een broeinest van reactionaire en 'irrationele' krachten. ${ }^{94}$ Wat Mann bovenal met de stalinisten verbond was zijn cultuurconservatisme, hetgeen enerzijds tot uiting kwam in een verwerping als 'decadent' van vrijwel alle modeme kunststromingen sinds het midden van de negentiende eeuw (waaronder vanzelfsprekend ook het atonale expressionisme van duivelskunstenaar Adrian Leverkühn), anderzijds in de oriëntatie op het vooruitstrevende, 'humane' classicisme van de Goethe-tijd. ${ }^{95}$ Uitgangspunt

\footnotetext{
Bohrer, K.H., Die Ästhetik des Schreckens. Die pessimistische Romantik and Ernst Jüngers Frühwerk. Frankfurt am Main, Berlin, Wien, 1978, 1983. p. 528. Zie eveneens: Mosse, G.L., The Culture of Western Europe. The Nineteenth and Twentieth Centuries. London, 1988. p. 400.

89 Mann, a.w., p. 158.

90 idem, pp. 154ff. Zie eveneens: pp. $60 \mathrm{f}$

"1 idem, p. 159.

${ }^{92}$ idem, p. 131.

${ }^{93}$ Mann, Die Entstehung des Doktor Faustus, a.w., p. 83. Zie eveneens: Schütz, S., Anselm Kiefer - Geschichte als Material. Arbeiten 1969-1983. Köln, 1999. pp. 89, 109: "Hauptthema [van Doktor Faustus, G.G.] ist der kollektive sowie individuelle katastrophale Rückfall des Hoch- und überentwickelten Geistes in archaische Primitivität".

${ }^{94}$ Binnen de (post-)stalinistische kunstkritiek van na Lukảcs was het in dit verband zelfs goed gebruik te wijzen op Wagners "overgang" na '48 van "een baanbrekende radicaal-democratische Vormärz-positie" naar "een irrationalistische, pessimistische wereldbeschouwing". Zie: Zur Theorie des sozialistischen Realismus, a.w., pp. 71,80 .

${ }_{95}$ Zoals we zagen in hoofdstuk 2, paragraaf 4 berustte de cultuurpolitiek van Lukács en de stalinisten in de DDR op een "antimodernes", tegen de "Avantgardekunst seit den achtziger Jahren des 19. Jahrhunderts" gericht "Kulturmodell". Grunenberg, a.w., p. 128. Niet zonder reden spreekt Theodor Adorno over de "cultuurconservatief Lukács". Adorno, Th., Ästhetische Theorie. Frankfurt am Main, 1970, 1972. p. 213. Het was bovenal dit, wat Lukács verbond met Thomas Mann. "Mann sieht als Möglichkeit, der Kunstkrise zur begegnen, nichts anderes als den Rückgriff auf die Mittel der traditionellen Ästhetik." Busch, A., Faust und Faschismus. Th. Manns Doktor Fausius und A. Döblins November 1918 als exilliterarische Auseinandersetzungen mit Deutschland. Frankfurt am Main, Bern, New York, Nancy, 1984. pp. $137 \mathrm{ff}$.
} 
van de cultuurpolitiek in de DDR was de aanname, dat zich onder de ruïnes van de ondergaande burgerlijke cultuur nog levend gebleven elementen van het klassieke burgerlijk humanisme bevonden, die konden worden aufgearbeitet en met een marxistisch humanisme verbonden. ${ }^{96}$ Of, zoals Mann het formuleerde in een tekst uit 1940: "Het nationaal-socialisme moet worden verslagen. In de praktijk betekent dit, helaas, Duitsland moet worden verslagen. En wel in een heel specifieke zin - ook een spirituele. (..) Het wil zeggen, dat men het [Duitsland, G.G.] moet dwingen constructieve sociale elementen te reactiveren uit het kapitaal van zijn tradities uit vroeger eeuwen." Alleen zo kon wellicht een situatie ontstaan, waarin het buitenland niet langer over Duitse kunst hoefde te verzuchten: "Het is groots, het is prachtig, maar het is gericht tegen de civilisatie". 97

En dit nu is precies het probleem met Wagners tweede verschijning. Dat zijn films groots en prachtig zijn, wordt ook door critici als Agnes Schreiner, Gabrielle Förg, of Leon Wesseltier niet ontkend. Wel hebben ze het bange vermoeden dat deze films wel eens, net als de totaalkunstwerken van de eerste versehijning, gericht zouden kumnen zijn tegen de civilisatie. En Syberberg doet weinig moeite deze vrees weg te nemen. Laten we het hierboven aangehaalde lange citaat uit Die Kunst als Rettung aus der deutschen Misere, waarin hij zijn Wagner \& Brecht-formule introduceert, nog eens nader bekijken. De film van de afgelopen vijftig jaar, schrijft hij, 'wist niet de geestelijke erfenissen te benutten, die de tradities ons aanreiken - van Aeschylus en Sophocles, het mysteriespel en Shakespeare, het Duitse romantische theater, de Sturm und Drang en de revoluties van het Duitse classicisme, tot Brecht, Homerus of Dante en Bach, zoals Wagner het Gesamtkunstwerk begreep'. Deze cursief gedrukte toevoeging is zeker niet irrelevant. Wellicht in navolging van Theodor Adorno huldigt Syberberg de opvatting dat de cinema uit de geest van het wagneriaanse Gesamtkunstwerk is geboren. ${ }^{98}$ Ook de cinema is een vorm van Gesamtkunst - een synthese tussen theater, beeldende kunst, literatuur en muziek, met montage en projectie als het samenbindende element. ${ }^{99}$ Het is deze genealogische verwantschap, waarop de tot 'boulevard-nietszeggendheid verloederde' bioscoopfilm zich zou moeten herbezinnen. Als het Gesamtkunstwerk van de twintigste eeuw draagt de cinema, aldus Syberberg in het citaat, de mogelijkheid in zich 'de oorsprong van de tragedie' serieus te nemen. Al moet hiertoe wel het 'anti-metafysisische effect', dat Brecht aan deze vorm van theater toekende worden overwonnen. Nogal wat hoogtepunten uit de geschiedenis van het epische theater, van de antieke tragedie tot Wagners muziekdrama's, hebben zowel een anti-aristotelisch als ook "een

\footnotetext{
${ }^{96}$ Het was dit ook, waar burgerlijke realisten als Mann zich volgens Zur Kritik des sozialistischen Realismus mee bezig hielden: "Ohne in der Regel ihre bürgerliche Klassenposition prinzipiell aufzugeben, übernehmen die großen bürgerlichen Realisten, so etwa (...) Thomas und Heinrich Mann, in verschiedenem Umfang bestimmte Seiten und Formen des marxistischen (realen) Humanismus und versuchen, ihn mit den am lebendigsten gebliebenen Elementen des klassischen bürgerlichen (idealen) Humanismus zu verbinden. Auf diese Weise erreichen sie, daßB ihre humanistischen Intentionen und Lösungen neben dem unvermeidlichen Utopischen, Illusionären und Idealistischen auch mehr oder minder viele reale, vom Geschichtsprozeß in der Haubtsache bestätigte Elemente und Züge enthalten." Zur Theorie des sozialistischen Realismus, a.w., p. 87. En zoals hierboven reeds opgemerkt, liet Mann, die actief in de cultuurpolitiek van de DDR participeerde, zich dit eerbetoon graag aanleunen.

${ }_{97}^{97}$ Mann, Wagner und unsere Zeit, a.w., pp. $159 \mathrm{f}$.

${ }^{98}$ Adomo, Th. W., Versüch über Wagner. Frankfurt am Main, 1952, 1974. p. 100. "In ihm [het wagneriaanse Kunstwerk van de Toekomst, G.G.] ereichnet sich die Geburt des Films aus dem Geiste er Musik". Voor Syberbergs opvattingen over de genealogische verwantschap tussen de cinema en het wagneriaanse Gesamtkunstwerk, zie: Syberberg, Parsifal, a.w., pp. $16 \mathrm{ff}$.

${ }_{99}$ De voorstelling van de cinema als het Gesamtkunstwerk van de twintigste eeuw staat centraal in alle pamfletten vanaf Filmbuch (1976) tot Der Wald steht schwarz und schweiget (1984). "Veel sterker dan Eisenstein ooit heeft gedaan, beschouwt Syberberg letterlijk de belofte wan film als synthese van de beeldende kunsten, muziek, literatuur en tonee] - en de moderne vervulling van wat Wagner als totaal kunstwerk voor ogen stond," merkt Susan Sontag terecht op. Sontag, a.w., p. 208.
} 
sterk ceremonieel karakter'. En door de 'nieuwe', maar in feite 'oude' esthetiek van het Brecht-theater met 'de wetmatigheden van een nieuwe mythe' te verbinden, probeert Syberberg het ceremoniële karakter van het epische kunstwerk in ere te herstellen. Wat Gesamtkunst, tragedie, metafysica, ceremonie en mythe met elkaar te maken hebben en waarom de filmmaker zoveel waarde hecht aan deze zaken, is echter een vraag die zich inderdaad - moeilijk laat beantwoorden zonder kort in te gaan op 'hoe Wagner het Gesamtkunstwerk begreep'.

\subsection{Kunst als redding uit de Duitse misère}

Het tot boulevard-nietszeggendheid verloederde ideaal van de antieke tragedie, sinds vele eeuwen zonder poëtische, esthetische en geestelijke innovaties; een reactionaire vorm van cultuur in de handen van handelaren en bureaueraten - zo zouden we, Syberberg parafraserend, de visie van Wagner op de opera van zijn dagen kunnen samenvatten. De opera was het "monstrueuze" 100 product van een proces van artistieke én maatschappelijke degeneratie, waarvan de eerste tekenen zichtbaar werden in de vierde eeuw voor Christus de periode waarin, naar Wagner meende, met het uiteenvallen van de polisdemocratie tevens een einde was gekomen aan de eenheidservaring van kunst. De antieke tragedie werd door Wagner om een viertal redenen beschouwd als de belichaming van deze eenheidservaring. Om te beginnen betrof het hier Gesamtkunst in zijn meest perfecte vorm: tot een harmonische eenheid samengesmolten dienden de kunsten één gemeenschappelijk doel. Maar minstens even belangrijk was de tweede reden: de tragedieschrijvers ontleenden hun stof aan mythen. En zoals het Gesamtkunstwerk de synthese was van alle kunsten (beeldend, mimisch uitbeeldend, verklankend en redevoerend), zo waren de mythen de synthese van alle menselijke ervaringen - archetypische, de tijd overstijgende en universele vertellingen, waarin het menselijke bestaan in al zijn facetten werd belicht. ${ }^{101}$

Deze archetypische vertellingen werden door de tragedieschrijvers niet verzonnen. Volgen we Wagner, dan diende het volk te worden gezien als de 'collectieve dichter' van de mythische overlevering. Niet enkel waren de mythen aan de collectieve ervaring van het volk ontsproten en hoefden ze door de tragedieschrijvers slechts te worden bewerkt en geduid; het interpreteren van de mythen was ook een collectieve aangelegenheid, waarbij heel het volk was betrokken. Ook in deze zin kon de tragedie worden begrepen als de belichaming van de eenheidservaring van kunst; het ceremoniële festival, tijdens welke de tragedies werden opgevoerd, fungeerde als een centraal ontmoetingspunt, dat de polis haar sociale cohesie verschafte. Hier, rondom het Gesamtkunstwerk, versmolt het volk tot een eenheid, of beter: werd het een met zichzelf. Want het opvoeren van deze archetypische vertellingen, die een expressie waren van collectief-menselijke ervaringen, was in de ogen van Wagner voor een niet gering deel een collectieve handeling van zelf-interpretatie. In de dialoog met de mythische overlevering, (her-)formuleerde het volk zijn collectieve identiteit en bepaalde het (opnieuw) zijn plaats binnen de grotere kosmische orde van voorvaderen, omringende natuur en godenwereld. De vierde reden hing hier nauw mee samen. Kunst was in die dagen nog synoniem met cultus en nam de plaats in van religie. Aan het kunstwerk ontleende de mens een metafysica, die als een samenbindende moraal fungeerde. "Voor de Grieken was de opvoering van een tragedie een religieuze festiviteit," schreef Wagner. "Op het toneel bewogen zich goden, die de mens hun wijsheid spendeerden."102

\footnotetext{
${ }^{100}$ Wagner, R[ichard]., Oper und Drama. Stuttgart, 1984, 1994. p. 21.

101 idem, pp. $161 \mathrm{ff}$. Zie eveneens: Bermbach, a.w., pp. 189, 208ff.

${ }^{102}$ Citaat ontleend aan Bermbach, a.w., p. 162 . Zie eveneens: pp. 154ff, 162ff, $208 \mathrm{ff}, 213$.
} 
Lang voordat hij naar eigen zeggen met het werk van Wagner vertrouwd is geraakt heeft ook Syberberg, geheel in lijn met de traditie van het vormingstheater, aan het kunstwerk een ethische opdracht toegekend. "Het gaat om de vraag," kunnen we in de slotconclusie van Zum Drama Friedrich Dürrenmatts lezen, "in hoeverre het dramatische kunstwerk van de tegenwoordige tijd in staat is mensen ten tonele te voeren, die in hun spel uit hun innerlijk een geloofwaardige ethiek [reactiveren] en met een religieuze zuiverheid voorbeeldig voorspelen". ${ }^{103} \mathrm{Nu}$, in de jaren ' $70 \mathrm{komt}$ hier onder invloed van Wagner nog een ander aspect bij, dat in het vroege werk nagenoeg afwezig was: de ethische opdracht van het kunstwerk krijgt nadrukkelijk een plaats binnen een nationaal kader. Uitgangspunt van het manifest Die Kunst als Rettung aus der deutschen Misere is het klassiek- maar ook romantischidealistische idee dat kunst een centrale spil binnen 'de polis' dient te zijn, zoals ooit de antieke tragedie - een sacraal oord, waar het volk bijeenkomt om hulde te brengen aan de voorvaderen, zich te herbezinnen en zich door middel van het verrichten van riten geestelijk te reinigen. ${ }^{104}$ Maar het nastreven van wagneriaanse maatstaven, merkt Susan Sontag fijntjes op, "is in de consumptiemaatschappij van de Bondsrepubliek (..) geen makkelijke levenstaak". ${ }^{105}$ De tijden dat goden het toneel bevolkten om het volk met hun wijsheid te overstelpen zijn sinds lang vervlogen. Zoals Wagner in zijn eeuw reeds moest ondervinden.

Tot op zekere hoogte was Wagners beeld van het negentiende-eeuwse operabedrijf weinig meer dan een omkering van het door hem gekoesterde ideaal van de antieke tragedie. Vrijwel alles wat hij aan de tragedie hoog achtte was in de opera tot nietszeggendheid verloederd. Van een Gesamtkunstwerk kon niet langer sprake zijn; opera liet zich nog het beste typeren als muziek met een bedenkelijk toneelstukje. In plaats van hun stof te ontlenen aan de mythische overlevering verzonnen librettoschrijvers inhoudsloze en op de koop toe slaapverwekkende verhaaltjes, waarvan de plots in de regel ronduit ridicuul waren en die uitsluitend dienden ter verstrooiing en vermaak van het publiek. Bestond dit publiek in de tijd van de antieke tragedie nog uit heel het volk; opera was een elitaire bedoening van de gegoede bourgeoisie en een handvol decadente dandy's. En van de ethische opdracht van het kunstwerk was al helemaal weinig overgebleven; van een kunsttempel was het theater gedegenereerd tot een "industriële onderneming" in de handen van handelaren en bobo"s " $(\ldots)$ dezelfde lieden, die gisteren nog speculeerden met graan en morgen met hun aangeleerde kennis een onderneming in suiker onder hun hoede nemen...," aldus Wagner: ${ }^{106}$

Het kost Syberberg weinig moeite dit beeld naar de cinema te transponeren. Meer dan een eeuw nadat Wagner zijn opvattingen aan het papier toevertrouwde, ziet een Duitse kunstenaar zich opnieuw geconfronteerd met een kunstvorm, die in potentie tragedie-kunst is, maar aan commerciële en geestelijke verloedering te gronde dreigt te gaan en zijn basis in het volk nagenoeg heeft verloren. En meer dan een eeuw na Wagner beklimt een Duitse kunstenaar opnieuw de barricade om - zoals Nietzsche naar aanleiding van Wagners kunst jubelde - "de wederopstanding van de Duitse mythe" te vieren. ${ }^{107}$ "De mythe (...) is de

${ }^{103}$ Syberberg, H.J., Zum Drama Friedrich Dürrenmatts. Zwei Modellinterpretationen zur Wesensdeutung des mondernen Dramas. München, 1963.p. 142. Zie eveneens: hoofdstuk 2, paragraaf 8 .

${ }^{104}$ Syberberg, Die Kunst als Rettung..., a.w., p. 9f: "Kann und darf, gerade und ausgerechtnet; ein Film über Hitler und sein Deutschland hier erklären, Identitäten wiederfinden, heilen und erlösen? (...) Ja, nur hier, in einem Film der Kunst unserer Zeit, über gerade diesen Hitler in uns, aus Deutschland, wird Hoffinung kommen dürfen. Für unsere Zukunft müssen wir ihn und damit uns überwinden, besiegen, und nur hier kann eine neue Identität durch Anerkennung und Trennung, Sublimierung und Arbeit an unserer tragischen Vergangenheit gefunden werden."

105 Sontag, a.w, p. 206.

${ }^{106}$ Citaat ontleend aan Bermbach, a.w., p. 185. Zie eveneens: pp. 167-188. Alsmede: Wagner, R[ichard], a.w., pp. $13 \mathrm{ff}$.

${ }^{107}$ Citaat ontleend aan: Jamme, Ch., Einfuihrung in die Philosophie des Mythos. Band 2: Neuzeit und Gegenwart. Darmstadt, 1991. p. 87. 
moeder van ironie en pathos, die in een incestueuze liefde het irrationele verwekken, onophoudelijk met het genot van een nieuwe mythologisering van de ziel, die wij [de Duitsers, G.G.] dringend nodig hebben om te overleven," schrijft Syberberg in Die Kunst als Rettung aus der deutschen Misere. "Omdat we de mythen serieus namen, letterlijk, vonden we Troje, heel reëel onder de puinhopen van de geschiedenis. We hebben de puinhopen van de geschiedenis (..) en moeten nu de mythen daaronder zoeken. (...) De wil tot mythe is de culturele prestatie van een volk (...)". 108

Het concept 'Duitse misère" uit de titel van dit manifest is afkomstig uit de klassiekmarxistische maatschappijtheorie. Bij Marx stond de 'Duitse misère' voor het onvermogen van de Duitse bourgeoisie om de historisch noodzakelijke revolutionaire omwenteling van een feodale naar een burgerlijke samenlevingsorde tot stand te brengen. Hoewel reeds volkomen parasitair geworden, slaagde de bourgeoisie er maar niet in de feodale klasse uit de politieke leiding te verdringen. ${ }^{109}$ Wellicht heeft ook Syberberg met deze marxistische connotatie gespeeld en moet de titel van zijn manifest worden gelezen als: de kunst als redding uit het Duitse onvermogen revolutionaire omwentelingen te doen slagen. Overigens was ook Wagner zich zeer wel van dit onvermogen bewust. In 1849 had hij nog met zijn goede vriend Michael Bakoenin actief deelgenomen aan de aprilrevolutie in Dresden en, zo wil een hardnekkig gerucht, eigenhandig de opera in brand gestoken - "De fakkel, ha! Zij brandde! En alles ligt in as - overal, allerhande - dat ooit des Mammons was!"110 Maar geheel in overeenstemming met de diagnose van Marx mislukte ook deze Duitse revolutie, hetgeen Wagner kwam te staan op een ballingschap van ruim tien jaar.

Of het afbranden van het operagebouw van Dresden daadwerkelijk kan worden toegeschreven aan een kordate soloactie van de totaalkunstenaar, mag gerust worden betwijfeld. Dat hij zich echter genoodzaakt zag de barricade te bestijgen, hing wel degelijk nauw samen met zijn beschrijving van de misère die in dit soort gebouwen heerste. Voor een deel kon de ellende, meende hij, worden geweten aan een 'aangeboren gebrek': de opera was ontstaan aan de "weelderige Italiaanse hoven", als amusement en verstrooing voor een verwende adel. "Voor een deel ging het ook om een directe neerslag van de corruptie van de maatschappij: in een samenleving waarin Mammon of het kapitaal regeert wordt kunst, zoals vrijwel alles wat van waarde is, gereduceerd tot een middel voor het vergaren van geldelijk gewin. Zonder een revolutie van de maatschappij had een wedergeboorte van de tragedie dan ook weinig kans van slagen. Maar omgekeerd gold ook: zonder kunst was een revolutie van de maatschappij weinig meer dan een zinloos tijdverdrijf. Diende het uiteindelijke doel van de revolutie, ook in de ogen van strijdmakkers als Marx en Bakoenin, immers niet te zijn: de bevrijding van de mens en het opheffen van de vervreemding? Welnu, redeneerde Wagner, de waarlijk vrije mens is de kunstzinnige mens en de waarlijk vrije samenleving het Gesamtkunstwerk van volk plus staat plus kunst, zoals de oude Grieken dat nog hadden gekend voordat het in de $4 \mathrm{de}$ eeuw voor Christus in "duizend egoïstische richtingen

\footnotetext{
${ }^{108}$ Syberberg, a.w., p. 17.

${ }^{109}$ In deze zin begrepen werd het concept ook veelvuldig gebezigd door de marxist Bert Brecht, bijvoorbeeld in een in 1939 verschenen opstel over het werk van Heinrich Mann. Volgen we Brecht in dit opstel, dan was Mann er in zijn roman Der Untertan voortreffelijk in geslaagd de 'Duitse misere" te verbeelden. De bourgeois gedroeg zich in de staat op exact dezelfde wijze als 'de onderdaan' in zijn bedrijf: enerzijds, keurig volgens de spelregels van Marx, naar beneden trappend en de arbeidersklasse ijverig onderdrukkend; anderzijds naar boven likkend, in de hoop een wit voetje te halen bij de Duitse keizer - het "anachronisme op de troon", dat hij geheel in strijd met zijn klassennatuur als een voorbeeld aanbad. Zie: Brecht, B., Gesammelte Werke 19. Schriften zur Literatur und Kunst 2. Frankfurt am Main, 1967, 1990. p. 470.

${ }^{110}$ Citaat ontleend aan: Amerongen, van, a.w., p. 53 .

"Wagner, R[ichard], a.w., pp. 19, 20. Zie eveneens: Bermbach, a.w., p. 170.
} 
versplinterde". Daarom moest de revolutie de kunst dienen, zoals omgekeerde de kunst uit welbegrepen eigenbelang zich in dienst van de revolutie moest stellen. ${ }^{112}$

Dat het hoogste goed van de mens schuilt in een actualisering van zijn kunstzinnige potentie, een opvatting die door Syberberg wordt ondersehreven, gaat terug op Friedrich Schiller. Door Schiller werd schoonheid beschouwd als het verbroederende element in de geschiedenis van de mensheid. Alleen het schone kon tegenstellingen overbruggen en harmonie stichten. Immers: was het hartstochtelijke verlangen naar sublieme schoonheid niet eigen aan elk mens - ja zelfs bij uitstek datgene, wat een mens tot mens maakt? De hoogste vrijheid van de mens, daarvan was Schiller niet minder overtuigd dan Wagner, bestond uit het ontplooien van zijn artistieke aanleg. 'Schoonheid als doel en expressie van humanitaire vrijheid' (Syberberg). ${ }^{113}$ Wie wil weten hoezeer de 'Homo Ludens' in de afgelopen twee eeuwen dit levensdoel heeft veronachtzaamd, kan wat Syberberg betreft volstaan met een bezoek aan een willekeurig museum voor moderne kunst. De oude esthetiek van het Ware, het Schone en het Goede heeft in dit soort kunstbunkers vrijwel geheel plaats gemaakt voor de moderne esthetiek van "het Kleine, het Smerige en het Zieke". ${ }^{114}$ En wie zich dan nog afvraagt wat de neerslag van dit soort vunzigheid op de samenleving zou kunnen zijn, hoeft slechts zijn ogen goed te kost geven wanneer hij zich, in de hoop het museum voor moderne kunst heelhuids te bereiken, een weg baant door de asfaltjungle van de moderne stad.

$\mathrm{Nu}$ is lelijkheid natuurlijk niet het monopolie van de Duitsers. "Houden we wacht. Voor hen. In de Nacht," verzucht de filmmaker, wanneer hij na een dagje Amsterdam troost zoekt bij Rembrandts Nachtwacht. ${ }^{115}$ Maar in Duitsland, denkt Syberberg, ondergraaft de amuzische tijdgeest de fundamenten van de collectieve identiteit. Om iets van de sfeer van zijn werk te kunnen proeven loont het zich de filmer nog eenmaal in een langer citaat aan het woord te laten. "Vooral in de vrijwillige opgave van zijn scheppende irrationalisme, en wellicht zelfs uitsluitend hier, heeft Duitsland werkelijk de oorlog verloren," luidt de openingszin van Die Kunst als Rettung aus der deutschen Misere.

"We hebben het vlijtig geleerd, ingehaald en schooljongensachtig gedemonstreerd: democratische praktijk, een nieuw sociaal bestel, economische knowhow en een bepaalde solidariteit ten opzichte van de zwakken en andere staten in de wereld. (..) $\mathrm{Ja}$, dit land is grof en materialistisch geworden. (...) Een generatie lang hebben de kinderen in Duitsland statistieken van Auschwitz van buiten geleerd; de deugden van de revolutie, hoe verkeerd begrepen ook, vanuit een smalle Duitse traditie en zonder burgermoed, die ze meteen als heldenverering 'demystificeerden'. Sociologie en psychologie werden per kort geding ingevoerd. Vlijtig bestudeerden ze de vrijemarkteconomie, als methode van democratische vrijheid - haar radicale minachting meteen ingesloten. Het ethos van een consumptie- en kassademocratie ontstond. Wie koopt is ervoor, het volk beslist aan de kassa. Ze leerden reclametrucs, opinieonderzoek en ontwikkelden een fijne neus voor de macht van het geld en ook voor de vloek, altijd tot de zwijgende meerderheid te willen behoren, waaraan niemand voorbij kon. En ze leerden hoe door mensen samen te brengen en alles te

\footnotetext{
112 Citaat ontleend aan: Safranski, R, Fundering van mythen door kunst. Een toelichting aan de hand van Richard Wagner. Vert. M. Wildschut. in: Nexus. 19 (1997). pp. 23-36, zie: 26, 27, wiens interpretatie ik hier overneem. Zie ook: Bermbach, aw., p. 189.

${ }_{113}$ Syberberg, Der Wald, a.w., pp. 112, 114, 465, 470, 519, 574. Syberberg, Vom Unglück und Glück der Kunst in Deutschland Kunst in Deutschland nach dem letzten Kriege. München, 1990. pp. 29, 34f, 57, 60, 62. Zie eveneens: Mosse, G.L., Die Nationalisierung der Massen. Von den Befreiungskriegen bis zum Dritten Reich. Übersetzt von O. Weith. Frankfurt am Main, Berlin, Wien, 1976. pp. 33-61.

${ }^{114}$ Syberberg, Kunst in Deutschland, a.w., pp. $38 \mathrm{ff}$.

${ }^{115}$ Syberberg, Der Wald, a.w., p. 489.
} 
moderniseren, opnieuw op te bouwen uit het niets, een koopkracht kon worden ontwikkeld, waarop iedereen jaloers was. Het modern zijn werd een teken van vooruitgang en al het nieuwe was goed. Een geheel eigen moraal ontstond, of wat zij daarvoor hielden, de verdedigingswal van een nieuwe rationaliteit, want gevoelens en idealen leiden naar de afgrond, dat heeft men hen verteld. (..) Nee, men heeft ze bedrogen en ze hebben zichzelf belogen. Tijdens ijverige lessen op het gebied van rationalisme en materialisme hebben ze een van hun belangrijkste tradities, de vervloekte navelstreng van hun wezen verdrongen, de nazi's zonder strijd toegeschoven, haar als fascistisch verdoemd. Het is de lange geschiedenis van het irrationalisme en alles wat daartoe behoort. En daarmee alles wat mystiek is, Sturm und Drang, grote delen van het classicisme, de romantiek, Nietzsche, Wagner en de expressionisten en tenslotte hun muziek en delen van het beste, wat ze hadden. Afgestaan, onderhands verkocht, verdrongen. (...) Duitsland werd geestelijk onterfd en onteigend (...)."116

\subsection{De muziek van de nazi's volgens Ernst Bloch}

"De Tweede Wereldoorlog," schrijft Leon Wesseltier in zijn in de inleiding van dit hoofdstuk reeds aangehaalde essay uit 1980, "leerde Duitsland tenslotte wat het nooit werkelijk kon: tegen zichzelf indenken. Het maakt niet uit, dat zijn leraren Eisenhower en Zhukov waren: er was een nieuwe kritische redelijkheid. Eindelijk leek Duitsland afstand te nemen van zijn duizendjarige fantasieën en werd het zich bewust van de gevaren van zijn mythen. Het begon zich te oriënteren op zijn problemen in plaats van op zijn noodlot; te vertrouwen op zijn intelligentie in plaats van op van zijn ziel. Syberberg heeft gelijk - de Bondsrepubliek heeft Duitsland doen verdwijnen. Ze heeft de oude Duitse verbeelding begraven en daarin schuilt haar kracht. Zou Syberberg dit alles willen terugdraaien?"117 Daar heeft het inderdaad veel van weg.

Wanneer de tekenen niet bedriegen is het deze filmer daadwerkelijk te doen om, in de woorden van Wesseltier, "een heropening van de specifieke traditie van metafysica en cultuur, waarvan werd verondersteld dat die was afgesloten met Thomas Manns Doktor Faustus. . Goed, dat hij bepaalde inzichten aan Mann heeft ontleend mag niet op voorhand worden uitgesloten. In Die Kunst als Rettung aus der deutschen Misere lijkt soms een echo van de 'Eén-Duitsland'-theorie door te klinken: het 'irrationalisme', dat Syberberg geheel in overeenstemming met Lukács en Mann definieert als het "tegenprincipe" van het Verlichtingsdenken. ${ }^{118}$ Maar het is niet de late Thomas Mann, aan wie Syberbergs cultuurkritiek herinneringen oproept. Veeleer waart door dit manifest de geest van de vroege Thomas Mann, van de auteur van Betrachtungen eines Unpolitischen. Of anders geformuleerd: Syberberg staat niet zozeer vijandig ten opzichte van Wagner, als wel veeleer ten opzichte van de pluralistische, op het Westen georiënteerde democratische samenlevingsvorm, zoals die na de Tweede Wereldoorlog in Duitsland geleidelijk aan gestalte heeft gekregen. Eeuwenlang, zo zouden we zijn boodschap in deze Hitler-scriptinleiding kunnen samenvatten, is het Volk van de Dichters en de Denkers erin geslaagd onder de bezielende leiding van zijn kunstenaars een vuist te maken tegen het Duitse "wezen" vreemde invloeden uit Frankrijk of Hollywood. Sinds de laatste oorlog is hierin echter drastisch verandering gekomen. Handig inspelend op het Duitse schuldcomplex hebben de

\footnotetext{
116 Syberberg, a.w., pp. 9, 14 f.

117 Wesseltier, a.w., p. 30.

${ }^{118}$ Syberberg, a.w. p. 12 .
} 
geallieerde overwinnaars de Duitsers alsnog op de knieën gekregen en hen ertoe gebracht het hen eigene, dat wil zeggen: hun 'irrationele', anti-moderne geaardheid te offeren op het altaar van Mammon. En dit strookt inderdaad in grote lijnen met de Zivilisationskritik van de oudBayreuther wagnerianen, die reeds lang voordat ook maar één GI voet op Duitse bodem had gezet tot de conclusie waren gekomen, dat het onduitse verlichtingsdenken in het land van de Gegenaufklärung als een besmettelijke ziekte om zich heen sloeg. ${ }^{19}$

Rest de vraag, of dergelijke overeenkomsten volstaan om Syberberg te ontmaskeren als de Ewiggestriger, die critici als Wesseltier in hem menen te zien? Om dit te kunnen bepalen zullen we eerst antwoord moeten geven op enkele andere vragen, die hij in Die Kunst als Rettung aus der deutschen Misere aan ons voorlegt:

"Hoe (...) willen ze Hölderlin begrijpen, wanneer ze hem als revolutionair ergens tussen Lessing en Marx situeren? En hoe zou Novalis kunnen bestaan, als voorbeeld van de Amerikaanse roadmovies? En zonder irrationalisme geen Räuber van Schiller en geen sprookjes en geen volksliederen en geen Runge. Alles Hitler en Goebbels cadeau doen? En is C.D. Friedrich meteen rechts en fascistisch? Is Irrationalisme meteen links of rechts? Hebben ze vergeten, dat het de door hen zo bewonderde Ernst Bloch was, die (..) over Heimat sprak, dat uit Duitsland verdreven woord? En dat hij het was, die reeds ten overstaan van de nazi's waarschuwde voor een ondervoeding van de volksfantasie? ${ }^{120}$

Dat Syberberg zich hier beroept op Ernst Bloch, zal niet louter te maken hebben met diens reputatie in de jaren ' 70 als een van de beschermheiligen van het westerse marxisme. ${ }^{121}$ Bloch was, naast Brecht, de grote opponent van Lukács in vrijwel alle linkse controverses van rond het midden van de twintigste eeuw, van het expressionisme-debat in de jaren ' 30 tot de formalisme/realisme-strijd in de vroege jaren ' 50 . En, wat in dit verband zo mogelijk nog interessanter is: Bloch was ook degene, die eind jaren ' 30 een felle polemiek uitvocht met fellow-traveller Thomas Mann, nadat deze in een emigrantenblad de stelling had geponeerd, dat het door de nazi's "heillos geschändete" revolutionaire vocabulaire niet langer voor socialistische doeleinden kon worden gebruikt. ${ }^{122}$ In dit citaat refereert Syberberg aan twee werken van de neo-marxistische cultuurfilosoof en kunsttheoreticus: het uit eind jaren " 40 daterende Das Prinzip Hoffnung - "(...) so entsteht in die Welt etwas, das allen in die Kindheit scheint und worin noch niemand war: Heimat." ${ }^{123}$ - en het indertijd in emigrantenkringen beruchte Erbschaft dieser Zeit (1935), waarin Bloch niet enkel zijn antifascistische kameraden waarschuwde 'voor een ondervoeding van de volksfantasie' (Syberberg), maar bovendien van Manns stelling geen spaander heel liet. De titel van deze

\footnotetext{
${ }^{119}$ Zie bijwoorbeeld: Ulbricht, J.H., Die Geburt der Deutschen aus dem Geist der Tragödie. in: Wege nach Weimar, a.w., pp. 127-142. In hun in 1981 verschenen essay Film der Toekomst leggen Agnes Schreiner en Kees Vollemans feilloos de vinger op de zere plek: "Syberbergs verontwaardiging zou zo vlammend niet zijn als het moderne rationalisme en progresissme geen moord zou betekenen, moord op het meest eigene van het Duitse volk en de Duitse cultuur: de erfenis van het irrationalisme, het Es van Duitsland", Vollemans, Schreiner, Film der Toekomst, a.w., p. 223.

${ }_{120}^{12}$ Syberberg, a.w., p. 15.

${ }^{121}$ Zoals Bloch wordt getypeerd in: Laqueur, W., Weimar. Die Kultur der Republik. Ubersetzt von O. Weith. Frankfurt am Main, Wien, Berlin, 1976, 1977. p. 85.

${ }_{122}$ Zudeieck, P., Der Hintern des Teufels. Ernst Bloch - Leben und Werk. Bühl-Moos, 1985. pp. 176f. Voor Blochs positie in het expressionisme-debat, zie: idem, pp. 133-152. Markun, S., Ernst Bloch. Hamburg, 1977. pp. 43-58. Schmitt, H.J., Einleitung. in: Die Expressionismusdebatte. Materialien zu einer marxistischen Realismuskonzeption. Hrsg. H.J. Schmitt. Frankfurt am Main, 1973, 1978. pp. 7-28.

${ }^{123}$ Bloch, E., Das Prinzip Hoffnung. Dritter Band. Frankfurt am Main, 1959, 1976. p. 1628.
} 
tweede studie leent zich goed om Blochs fundamentele verschil van mening met de 'irrationalisme'-kritische richting van Lukács en Mann duidelijk te maken.

Voor zowel Lukáes als Mann was het immers nog maar zeer de vraag, of van deze moderne tijd uberhaupt iets te erven viel Vanuit verschillende politiek-ideologische vertrekpunten waren de stalinist en de conservatief tot soortgelijke inzichten gekomen: in haar laat-kapitalistische fase bracht de ondergaande burgerlijke cultuur louter nog afval voort. En tot dit afval rekende Lukács niet enkel Brechts anti-aristotelische dramaturgie, het kubisme van Picasso, de atonaliteit van Schönberg, de stream of consciousness van Joyce, of de montage-technieken van Dos Passos, maar ook het metafysische denken van Ernst Bloch, die zich reeds met zijn jeugdwerk Geist der Utopie (1918) had opgeworpen als vertegenwoordiger van een expressionistische, uitgesproken anti-classicistische, ja welhaast neo-nietzschiaanse linkse filosofie. Net als Brecht verdedigde Bloch in het expressionismedebat dan ook vooral zijn eigen filosofische positie. Op de argumenten van Brecht zijn we in hoofdstuk 2 reeds uitvoerig ingegaan. Zoals we zagen, verweet hij "kunstrechter" Lukács en diens navolgers een zekere "wereldvreemdheid". De wereld was, sinds de door Lukács en Mann zo bewonderde burgerlijke cultuur van de Goethe-tijd ingrijpend veranderd.

En: "De beschrijving van een zich voortdurend veranderende wereld vereist steeds nieuwe middelen van verbeelding". ${ }^{24}$. Dit was in grote lijnen ook, wat Bloch tegen Lukács inbracht. De grote harmonische, klassiek-burgelijke vertelling, waarvan Manns historische romans exponenten waren, deed geen recht aan de complexe realiteit van de vroege twintigste eeuw. Deze werd namelijk, dacht Bloch, gekenmerkt door "ongelijktijdigheid" [Ungleichzeitigkeit]. ${ }^{125}$

Tot op zekere hoogte stemde de betekenis, die Bloch aan dit concept toekende, overeen met wat Lukács verstond onder 'irrationalisme'. Als marxist ging ook Bloch uit van de voorstelling van een an sich redelijke werkelijkheid, die zich langzaam maar zeker dialectisch ontwikkelde in de richting van een socialistische samenlevingsvorm, ook al stond deze toekomst nog open. 'Gelijktijdig" noemde hij een bewustzijn, dat met deze dialectische ontwikkeling gelijke tred hield. Maar alle propaganda van de communisten ten spijt beschikten in de vroege twintigste eeuw slechts zeer weinigen over een dergelijk 'klassenbewust' bewustzijn. Typerend voor het bewustzijn van het overgrote deel van de geproletariseerde massa. was veeleer het vasthouden aan verouderde leef- en denkpatronen, "Überbauten die längst umgewälzt schienen". ${ }^{126}$ Niet zelden ging het hier om "brokstukken van een nog levend gisteren", die stamden uit een tijd van ver vóór de kapitalistische fase. Zoals in het geval van de keuterboeren: "Op het platteland kom je gezichten tegen, die in al hun jeugdigheid zo oud zijn, dat zelfs de oudste mensen in de stad zich niet meer aan hen herinneren. (...) [Men] leeft [daar] nog precies als de voorouders, doet hetzelfde als zij."127.

Meer nog dan dat van de kleine boeren, werd ook het bewustzijn van de inmiddels geproletariseerde stedelijke klasse van de beambten, die in het interbellum welhaast tot een kweekvijver van de nazi-beweging was geworden, door deze 'ongelijktijdigheid' getekend: "De boeren geloven bij tijd en wijle nog aan heksen en exorcisten, maar bij lange na niet zo vaak als het gros van de stedelingen gelooft aan spookachtige joden en de nieuwe Baldur. De boeren lezen bij tijd en wijle nog het zogenaamde zesde en zevende boek van Mozes, een colportage tegen ziekten in de stal en over de krachten en geheimen van de natuur; maar de

\footnotetext{
${ }^{124}$ Brecht, B., Gesammelte Werke 19. Schriften zur Literatur und Kunst 2. Frankfurt am Main, 1967, 1990. pp. 291f, 297. Zie eveneens: hoofdstuk 2, paragraaf 4.

${ }^{125}$ Busch, a.w., pp. $278 \mathrm{ff}$. Voor Blochs 'theorie van de ongelijktijdigheid', zie behalve Zudeick, a.w., pp. $133 \mathrm{ff}$ en Markun, a.w., pp. $45 \mathrm{ff}$, ook: Nolte, E., Vierzig Jahre Theorien über den Faschismus. in: Theorien über den Faschismus. Hrsg. E. Nolte. Köln, Berlin, 1970. pp. $28 \mathrm{f}$.

${ }^{126}$ Bloch, Erbschaft dieser Zeit, a.w., p. 109.

${ }^{127}$ idem, p. 106.
} 
halve middenstand gelooft aan de Wijzen van Zion, aan jodenstrikken en vrijmetselaarssymbolen overal, aan de galvanische krachten van het Duitse bloed en meridianen. Wild en oorlogszuchtig slaat de beambte om zich heen; hij wil nog wel gehoorzamen, maar uitsluitend als soldaat, strijdend, gelovend." 28 Dat zo iemand, in weerwil van zijn klassenbelangen, vroeg of laat uitkwam bij het nationaal-socialisme, verbaasde Bloch allerminst. Immers, zoals hij in zijn vrijwel onvertaalbare Duits opmerkte: "Nicht zu leugnen, neben der Rohheit laufen [bij de nazi's, G.G.] auch sehr alte Träume mit unter". ${ }^{39}$ "Herinneringen komen boven aan de vitusdansers en latente kindermoordenaars, die "houdt de dief!' roepen, als ze joden van rituele moordpraktijken beschuldigen. Denk aan de melodie: 'Wenn Judenblut vom Messer spritzt, ' die als een muzikale swastika boven de SAtroepen hangt. Men bespeurt in dit soort nationaal-socialisme de droom van een behouden waanzin, vastgehouden overcompensaties uit de puberteit. Men bespeurt de colportage van Indische moordsekten en Chinese geheime genootschappen; dat hele sluipwoud, fluisterwoud van vroegere colportage (van de Wijzen van Zion of de grotten van de vrijmetselaars in het binnenste van de berg). Men stuit op oeroud sadisme, zelfs bij de dodenherdenkingen; wraakeden, of woedende ceremonies bij het 'gedenkteken'.",130

$\mathrm{Nu}$ was het vanzelfsprekend ook Lukács niet ontgaan, dat de geproletariseerde massa zich anders verhield dan je op grond van haar klassenbelangen mocht verwachten. Maar hij meende dit probleem vrij eenvoudig te kunnen oplossen: wanneer je de door het 'irrationele' denken in de war gebrachte proletariër maar voldoende in 'burgerlijk realistische' of dialectisch-materialistische 'irrationalisme'-kritiek onderwees, zou hij op den duur vanzelf wel weer 'klassenbewust" worden en zijn weg naar het communisme terugvinden. Doch door zo te redeneren, repliceerde Bloch, maakte deze stalinist tenminste drie cruciale denkfouten. Om te beginnen overschatte hij schromelijk de louterende werking, die uitging van redelijke verklaringen en diagnosen. De mens is nu eenmaal niet het calculerende, rationele wezen waar Lukács hem voor hield. Hij leeft, behalve in het heden, ook in het verleden en de toekomst; heeft, naast een verstand, ook een fantasie, waarmee hij zich bepaalde wensvoorstellingen maakt die, hoe irrationeel ook, de wereld zin geven en het leven draaglijk maken. Zoals de nationaal-socialisten, aldus Bloch, maar al te goed begrepen. Dit in tegenstelling tot "vulgaire marxisten" als Lukács, wier propaganda over het algemeen "koud, schoolmeesterachtig, louter economisch" was. ${ }^{131}$

Blochs tweede kritiekpunt hing hier nauw mee samen. Voor Lukács was "irrationeel" een ander woord voor 'reactionair'. Maar, zo hield Bloch de Hongaarse filosoof voor, kon in het 'ongelijktijdige' niet ook "een stuk verouderd en romantische verzet tegen het kapitalisme" worden waargenomen? Ja, wat was dit zogenaamde "irrationele" anders dan een expressie van een diepgewortelde onvrede, van een opgekropte woede jegens de heersende kapitalistische verhoudingen en hiermee, indirect ook, van een utopische hoop op een terugkeer naar' betere, in het verleden gesitueerde tijden - 'Heimat, waarin niemand ooit was...'? ${ }^{132}$ De krampachtigheid waarmee de keuterboer zich vastklampte aan Bodenständigkeit en Naturgebundenheit, was zijn machteloze antwoord op een als rampzalig ervaren technische vooruitgang. In het nostalgische verlangen naar het leven van gisteren, vond de geproletariseerde middenstander troost voor zijn val van de maatschappelijke ladder. De romantische cultus van het gevoel bood jongeren de mogelijkheid te ontsnappen aan de tot in het extreme doorgevoerde zakelijkheid van een geheel en al entzauberte tegenwoordige

\footnotetext{
128 idem, p. 109.

129 idem, p. 63.

${ }^{130}$ idem, p. 115

13.1 idem, p. 128

132 idem, p. $15 f$
} 
tijd. ${ }^{133}$ En vroeg of laat liepen ze een voor een in de fuik van het nationaal-socialisme, dat als geen ander wist hoe dit soort 'ongelijktijdige' bewustzijnsvormen konden worden gemanipuleerd. Dit, opnieuw, in tegenstelling tot 'vulgaire marxisten' als Lukács, die "alles noch Irrationale" meenden te kunnen afdoen als "einfach auffösbare Dummheit". 134

Inderdaad kon het 'ongelijktijdige' klip en klaar vooruitgangsvijandig zijn, zoals Lukács betoogde en de politieke realiteit van het interbellum nog eens pijnlijk onderstreepte. Maar dit nam niet weg, dat marxisten dit romantische anti-kapitalisme, de primitieve angst voor de emotionele kilte van het machinetijdperk, serieus dienden te nemen, vooropgesteld dat ze ooit het proletariaat voor zich wensten te winnen: "Grote delen van de Duitse massa (...) konden alleen al daarom nationaal-socialistisch worden, omdat het marxisme, dat hen duidt, niets voor hen beduidt". ${ }^{35}$ Terwijl marxisten het proletariaat toch zoveel te bieden hadden, namelijk de eeuwenoude wensdroom van de Commune. Alles wat ze hoefden te doen, om de 'opgekropte woede' van de geproletariseerde massa in goede banen te leiden, was deze gevoelswaarde van het communisme in hun propaganda benadrukken. "In plaats daarvan ondersteunt menige vulgaire marxist welhaast de karikatuur, die de irrationalisten van de 'mechanische' rede hebben gemaakt. (...) In het succes van het nationaal-socialisme wordt ook een stuk schuld zichtbaar, namelijk die van het wat al te gangbare vulgaire marxisme. (...) De vulgaire marxisten zijn in de utopie niet thuis. Daaraan danken de nationaal-socialisten hun aantrekkingskracht en ze zullen de laatsten niet zijn. Men heeft zowel de hel als de hemel, zowel de berserkerwoede als de theologie zonder strijd aan de reactie afgestaan." 136

Maar niet slechts overschatte Lukács de mogelijkheden van klinisch rationalistische propaganda en ging hij voorbij aan de "antikapitalistische Trieb", ${ }^{137}$ die aan het vermeend reactionaire irrationele inherent was; deze 'vulgaire marxist' had bovendien een volstrekt vertekend beeld van het nationaal-socialisme. Dit was Blochs derde kritiekpunt. Een "schadelijke mode" noemde hij het in een in 1942 gepubliceerd essay met de tot de verbeelding sprekende titel Der Nazi kocht im eigenen Saft: de gewoonte van 'irrationalisme'-critici als Lukács of Thomas Mann om in de Duitse cultuurgeschiedenis op zoek te gaan naar "spirituele voorloper(s) van de metapolitieke beweging, die heden ten dage de wereld terroriseert" (Mann over Wagner). ${ }^{138}$ Weliswaar slaagden deze 'irrationalisme'critici erin figuren als Wagner en Nietzsche, die in hun genealogieën nimmer ontbraken, omlaag te halen door hen in verband te brengen met zaken, waaraan ze strikt genomen part noch deel hadden; de keerzijde van de medaille was, dat het nationaal-socialisme erdoor onbedoeld werd opgewaardeerd - tot een serieuze aangelegenheid gemaakt, zeer de moeite van het overdenken waard. Je kon je zelfs afvragen, peinsde Bloch, of het uiteindelijke resultaat niet zou zijn dat de nazi's, die maar wat graag met dergelijke illustere voorzaten mooie sier maakten, vanuit onverwachte hoek nieuwe propagandistische bijval kregen. Want was het niet precies dit, wat de nazi-propaganda altijd graag wilde doen geloven: dat het Derde Rijk diende te worden beschouwd als de min of meer noodzakelijke actualisering van wat bij Wagner en Nietzsche reeds in potentie aanwezig was - zoals in Die Zerstörung der Vernunft en Doktor Faustus werd beweerd? ${ }^{139}$ "Ook Wagner heeft weliswaar iets nazistisch

\footnotetext{
133 idem, pp. $104 \mathrm{ff}$.

134 idem; p. 19.

135 idem, p. 66.

136 idem, pp. $66 \mathrm{f}, 153 \mathrm{f}$.

137 idem, p. 15

${ }^{138}$ Mann, a.w., p. 159.
}

${ }^{139}$ Blochs essay Der Nazi kocht im eigenen Saft verscheen in het emigrantenblad Freies Deutschland. 6 (april 1942). Ik baseer mijn samenvatting op: Sziklai, L., Georg Lukács - Kritiker der unreinen Vernunft. in: Georg Lukács. Kultur-Politik-Ontologie. Hrsg. U. Bermbach, G. Trautman. Opladen, 1987. pp. 187-199, zie: 196. 
over zich, tamtam, komediantendom, decadente barbarij: Tristan heeft de (..) sympathie [van Hitler, G.G.] desondanks niet verdiend, Hans Sachs nog minder". ${ }^{140}$ Immers: "De muziek van de nazi's is niet het voorspel tot de Meistersinger, maar het Horst Wessellied. Een andere verdienste hebben ze niet, een ander eerbewijs kan hen niet worden gegund." 141

Volgen we Bloch, dan was het toch echt wat al veel eer voor deze Hitler en zijn trawanten om hen af te schilderen als het "diabolisch-wereldbeschouwelijke culminatiepunt" (Lukács) $)^{142}$ van de lijn Schelling-Schopenhauer-Wagner-Nietzsche. In werkelijkheid ging het hier namelijk om weinig meer dan een ordinaire roversbende. Origineel was hooguit hun eclecticisme; het materiaal hadden ze echter uit de meest uiteenlopende bronnen bijeengejat. En tot hun buit behoorde niet slechts de fine fleur van Deutschlands Geisteshelden. "Zelfs niet het lied, waarmee de nazi verleidt, heeft hij zelf verzonnen. Zelfs niet het buskruit, waarmee hij voor vuurwerk zorgt, noch de fabriek die hem in staat stelt te bedriegen." 143 Wat te denken bijvoorbeeld van sleutelbegrippen uit de nazi-propaganda als 'Volk', 'Nation', 'Vaterland', 'Heimat', 'Boden', 'Führer', 'der Gral', 'das Dritte Reich'?'144 "Het begrip Derde Rijk," schreef Bloch in Erbschaft dieser Zeit, "heeft vrijwel alle opstanden van de middeleeuwen begeleid. Het was een hartstochtelijk toekomstbeeld, dat evenveel jodendom als gnosis, evenveel revolte van de boerenoorlogen als wilde speculaties met zich droeg."145 Zou het niet een enorm verlies betekenen voor het Duits/Europese, socialistische, ja zelfs joodse culturele erfgoed, wanneer je zo'n begrip bij wijze van spreken 'aan de nazi's cadeau' deed, door je bij de pervertering ervan neer te leggen? Het zou in elk geval, dacht Bloch, een kritische filosoof onwaardig zijn.

De ware kritische filosoof gooide niet achteloos de handdoek in de ring, maar bond juist de strijd aan met dit soort bandieten door zich ook zelf te ontpoppen als een rover en op plundertocht te gaan in de Duitse cultuurgeschiedenis. ${ }^{146}$ Dat wil zeggen: zo iemand deed niet de nazi-propaganda nog eens dunnetjes over door Wagner, Nietzsche of (om een andere bezoedelde Duitse Geistesheld te noemen die Bloch hoog had zitten) Karl May met terugwerkende kracht als 'spirituele voorlopers' van de nazi-barbarij te ontmaskeren. Integendeel: het zou juist de taak moeten zijn van een echte kritische filosofie, dit soort propagandaleugens door te prikken, de aanspraken die de nazi's maakten op de Duitse cultuurgeschiedenis te bestrijden en het erfgoed, dat ze zich hadden toegeëigend, weer aan hen te ontfutselen. Pas wanneer je als socialist weer wel met goed fatsoen naar de Meistersinger kon luisteren, Ardistan und Dschinnistan kon lezen of begrippen als volk, natie, vaderland, Heimat, bodem, Führer, de Graal, het Derde Rijk in de mond kon nemen pas dan, en niet eerder, zou het nationaal-socialisme werkelijk verwerkt en overwonnen zijn. $^{147}$

Lukács en Thomas Mann daarentegen bewandelden precies de tegenovergestelde weg. Niet slechts vergrootten ze met hun 'irrationalisme'-kritische genealogieën het aanzien van de nazi en dreven ze Hitler grote delen van de Duitse cultuurgeschiedenis in handen ${ }^{148}-$ nee, alsof dat alles nog niet genoeg was, lieten ze zich ook nog eens zelf uitplunderen. Zonder

\footnotetext{
${ }^{140}$ Bloch, a.w, pp. $85 f$.

${ }^{141}$ Bloch, E., Die Musik der Nazis. in: Über Wagner. Von Musikern, Dichtern, Liebhabern. Eine Anthologie.

Hrsg. N. Wagner. Stuttgart, 1995. p. 272.

${ }_{142}$ Lukács, G,, Die Zerstörung der Vernunft. Neuwied, Berlin, 1962. p. 567.

${ }^{143}$ Bloch, Erbschaft dieser Zeit, a.w., pp. $126 \mathrm{ff}$.

${ }^{144}$ idem, pp. $18,63 \mathrm{ff}$; $126 \mathrm{ff}$.

${ }^{145}$ idem, p. 63ff, 163ff. Zie eveneens: Bloch, Das Prinzip Hoffnung. Zweiter Band. Frankfurt am Main, 1959,

1976. pp. $590 \mathrm{ff}$.

${ }_{146}$ Bloch, Erbschaft dieser Zeit, a.w., p. 19.

${ }^{147}$ Vergl. Zudeick, a.w., pp. $136 \mathrm{ff}$. Markun, a.w., pp. $45 \mathrm{ff}$.

${ }^{148}$ Aldus Bloch in Der Nazi kocht im eigenen Saft, zie: Sziklai, a.w., p. 196.
} 
enige gêne verdedigde Mann de stelling, dat het geperverteerde revolutionaire vocabulaire niet langer voor socialistische doeleinden bruikbaar was - nota bene de kroonjuwelen van de beweging van de Commune de nazi's welhaast op een presenteerblaadje aanbiedend... ${ }^{149}$

\subsection{Strategieën van herijking}

In de inleiding van dit hoofdstuk heb ik reeds geopperd, dat Bloch wel eens een interessanter aanknopingspunt zou kunnen zijn om over de aard van Syberbergs wagnerianisme na te denken dan de esthetische formule Wagner \& Brecht of de vergelijking met de late Thomas Mann. "Anders dan Thomas Mann in Doktor Faustus - de degeneratie en pervertering van het classicistische ideaal van zelftranscendentie -, richt Syberberg zich in eerste instantie op de heel wat meer triviale en pathetische Ludwig II, de Krankzinnige Koning van Beieren, en Karl May, die hij daadwerkelijk 'einen Trival-Faust' noemt," merkt de Amsterdamse filmtheoreticus Thomas Elsaesser scherp op in zijn in 1981 verschenen essay Myth as the Phantasmagoria of History: H.J. Syberberg, Cinema and Representation. ${ }^{150}$ Dat wil zeggen: hij richt zich op precies die zijde van de Duitse cultuurgesehiedenis, waar ook de aandacht van Bloch in Erbschaft dieser Zeit of Das Prinzip Hoffnung naar uitgaat. Namelijk die van het sprookje, de legende, de mythe, de sage en de colportage, kortom: de 'ongelijktijdige' wensdroom waarvan Wagners muziek, de kitschpaleizen van sprookjeskoning Ludwig II, de esoterische avonturenromans van Karl May, of de mythologische vertellingen over de queeste naar de Graal (de titel van Syberbergs cyclus!) binnen Blochs filosofie expressies zijn. ${ }^{15}$ "Het Requiem," schrijft Syberberg in de bundel Filmbuch over Ludwig-Requiem für einen jungfräulichen König, "omcirkelt de geheime landschappen van het hoogste goed, ook dat zegt Bloch: 'Heimat, waarin niemand ooit was', doelgebieden van menselijke zwerftochten, waar paradijzen en utopieën, het gouden tijdperk, het beroemde Eldorado van de wenslandschappen van onze legenden en sprookjes zich als wensen van de volkeren gevestigd hebben in de kunst van de dromen en de fantasie, alsmaar weer gerealiseerd in onze kunstwerken." 152

Maar ook de manier waarop Syberberg met deze 'ongelijktijdige' of 'irrationele' dimensie van de Duitse cultuurgeschiedenis omgaat, verraadt een sterke invloed van Ernst Bloch. Welk werk van zijn hand men ook neemt, schreef ik in het slot van het vorige hoofdstuk, steeds geidt: het gaat om een poging het 'irrationele' kunstwerk van zijn stigma te zuiveren door de sinds Lukács in marxistische of ideologiekritische kringen gemeengoed geworden connotatie van 'irrationalisme' met decadentie en fascisme te problematiseren. Ook deze films uit de jaren '70 en de vroege jaren ' 80 , waarin Syberberg zijn aandacht verlegt van het theater van de absurdisten naar de late romantiek - of, zo men wil: van het postfascistische 'irrationalisme' naar het prefascistische - dienen mijn inziens in dit licht te worden begrepen. Ongetwijfeld komt de Franse filosoof Philippe Lacoue-Labarthe nog het meest dicht in de buurt bij de bedoelingen van de filmmaker. Terecht interpreteert LacoueLabarthe in zijn in 1987 verschenen Heidegger-studie La fiction du politique (1987)

\footnotetext{
${ }^{149}$ Zudeick, a.w., pp. $176 \mathrm{f}$.

${ }^{150}$ Elsaesser, a.w., p. 116.

${ }^{151}$ idem, pp. 127ff. Zie eveneens: Kaes, a.w., pp. 60ff., 67: Syberberg "deals with the soil in which the Third Reich grew and took shape, a soil saturated with trivial literary myths. Ernst Bloch was one of the first to recognice Karl May's importance for the emotional and spiritual life of the Germans in the early twentieth century. (...) Already in the late 1920s, Ernst Bloch, a Marxist, correctly pointed out the mass appeal of irrational elements in National Socialism and wamed about the consequences of ignoring these potentially explosive forces.".

${ }^{152}$ Syberberg, Filmbuch, a.w., pp. $92 \mathrm{f}$.
} 
Syberbergs filmopera Parsifal, het laatste deel van De Graal, als: "een vertwijfelde poging Wagner weer aan het nationaal-estheticisme [nationaal-socialisme, G.G.] te ontfutselen, middels een subtiele en tegelijk gewelddadige strategie van herijking". ${ }^{153}$

Vandaar ook, zou ik hieraan willen toevoegen, dat Syberberg in deze portrettengalerij een prominente plaats heeft toebedeeld aan Hitler en Winifred Wagner-Williams, de leidster van het Bayreuther festival ten tijde van het Derde Rijk. Wie Wagner weer aan de nationaalsocialisten will ontfutselen ontkomt er immers niet aan zich rekenschap te geven van deze duistere episode in de geschiedenis van het wagnerianisme. In een sleutelscène van Hitler, ein Film aus Deutschland, waarover ik in hoofdstuk 6 nog uitvoerig kom te spreken, ${ }^{154}$ gaat hij zelfs zover het titelpersonage als een soort reïncarnatie van de Bayreuther totaalkunstenaar te laten opstaan uit diens graf achter de villa Wahnfried. Vanuit dit tableau lijkt het slechts een kleine stap naar de fameuze woorden van Mann an Preetorius over de geestverwantschap tussen Wagner en Hitler (zie hierboven). ${ }^{155}$ Maar de schijn bedriegt. De kritiek van Bloch, dat Mann en Lukács, door zich zonder slag of stoot neer te leggen bij de pervertering het nationaal-socialisme grote delen van de Duitse cultuurgeschiedenis in handen zouden hebben gespeeld, wordt door deze filmmaker volmondig onderschreven. De ware kritische filosoof of kunstenaar geeft de bruinhemden niets cadeau, maar ontwikkelt strategieën die het mogelijk maken het geroofde culturele erfgoed weer op hen terug te veroveren. Zoals Syberberg naar eigen zeggen in deze filmcyclus heeft geprobeerd:

"We weten dat Thomas Mann in zijn Doktor Faustus de terugneming van Beethovens $9^{e}$ symfonie quasi als een soort zoenoffer van de Duitsers aan de geschiedenis voorstelde. Hoe frivool en ongehoord, hoe aanmatigend en pretentieus is het dan, een film, Hitler genaamd [Hitler, ein Film aus Deutschland, G.G.] te laten eindigen met deze $9^{e}$ symfonie van Beethoven, alsof zij wordt teruggeschonken aan dit land. (...) Maar (...) ze [de Duitse critici, G.G.] beseften niet eens, wat zich hier afspeelde - de terugneming door Thomas Mann en dit geschenk nu, aangeboden na zoveel inspanningen en risico's. (...) Een samenleving, een land en zijn intellectuelen, die dat niet merken, eenvoudig niet merken, al hun beweerde Bloch-verering ten spijt moeten zij niet vreugdeloos worden genoemd of, erger nog: vrijheid en hoop beschamend?"156

$\mathrm{Nu}$ ben ik me terdege ervan bewust, dat ook dit soort verwijzingen naar Bloch, waarvan het werkelijk wemelt. in Syberbergs pamfletten uit de jaren '70 en de vroege jaren ' 80 , makkelijk zouden kunnen worden uitgelegd als 'een bewuste poging tot misleiding' (Kühnl). Goed, er valt wel wat te zeggen voor de stelling van de Amerikaanse historicus Walter Laqueur (1974), dat Bloch onder de westerse marxisten de meest trouwe erfgenaam is van de Duitse idealistische filosofen. Laqueur gaat zelfs nog een stap verder: zijn lippendienst aan het

\footnotetext{
${ }^{153}$ Lacoue-Labarthe, Ph., Heidegger, Art and Politics. The Fiction of the Political. Translation by C. Turner. Oxford, Cambridge, Mass., 1990 p. 63. De historicus Saul Friedländer, die minder positief ten opzichte van Syberberg staat, spreekt in dit verband over een poging tot exorcisme. Friedländer, S., Kitsch und Tod. Der Widerschein des Nazismus. Übersetzt von M. Grendacher. München, Wien, 1984. pp. 8ff. Voor Friedländers kritiek op Syberbergs Hitler-film, zie: hoofdstuk 5, paragraaf 5.

${ }^{154}$ Zie: hoofdstuk 6, de paragrafen 1 en 2.

${ }^{155}$ Een kleine stap, die bijvoorbeeld wordt gezet door Sontag, a.w., pp. $207 \mathrm{f}$ en Vaget, a.w., passim.

${ }^{156}$ Syberberg, Der Wald, a.w., pp. 22, 556. Syberberg refereert hier aan: Mann, Th., Doktor Faustus. Das Leben des deutschen Tonsetzers Adrian Leverkühn erzählt von einem Freunde. Frankfurt am Main, 1971, 1988. pp. 489f: " $(\ldots)$ Es ist gleichsam der umgekehrte Weg des 'Liedes an die Freude', das kongeniale Negativ jenes Überganges der Symfonie in den Vokal-Jubel, es ist die Zurücknahme. (...) es solle nicht sein, das Gute, die Freude, die Hoffnung, das solle nicht sein, es werde zurückgenommen, man müsse es zurücknehmen!"
} 
historische materialisme ten spijt zou Bloch een in wezen onmarxistische filosofie bieden een eigenaardig brouwsel van expressionistisch maniërisme en oud-testamentair pathos, overgoten met een flinterdun sausje neo-marxistische retoriek. ${ }^{157}$ En dit zal ook de belangrijkste reden zijn geweest, waarom de stalinisten in de DDR deze voormalige hoogleraar Wijsbegeerte aan de universiteit van Leipzig eind jaren ' 50 tot persona non grata hebben verklaard. Daar staat echter tegenover, dat het Bloch in Erbschaft dieser Zeit wel degeijik te doen is om een herijking vanuit marxistisch perspectief. Of, in zijn eigen woorden: om de transformatie van werkelijk dionysische dromen met wortels in het mythische tot revolutionaire. ${ }^{158}$ Terwijl Syberberg op zijn zachtst gezegd van dit soort marxistische revisies van de Duitse cultuurgeschiedenis geen warm voorstander is.

Wanneer Syberberg in Die Kunst als Rettung aus der deutschen Misere de retorisch bedoelde vraag stelt, 'hoe Hölderlin zou kunnen worden begrepen door hem als revolutionair ergens tussen Lessing en Marx te situeren' (zie hierboven), heeft hij naar we mogen aannemen de cultuurpolitiek van de stalinisten in gedachten. Maar er is geen twijfel over mogelijk, dat zijn kritiek zich ook richt tegen het Nieuwe Bayreuth van Wieland en Wolfgang Wagner die, aldus Syberberg in een ander pamflet, na '45 Wagner opnieuw dachten te kunnen legitimeren door hem af te schilderen als een held van de revolutionaire Vormärz. ${ }^{159}$ Ik wees er reeds op in de inleiding van dit hoofdstuk dat Bloch en de zwaar aan diens filosofie schatplichtige literatuurwetenschapper Hans Mayer, de co-commentator van Syberbergs Brecht-documentaire Nach meinem letzten Umzug (1970), na hun vlucht uit de DDR als adviseurs van Wieland Wagner een onuitwisbaar stempel hebben gedrukt op het officiële naoorlogse Wagner-beeld. Weliswaar was Wieland Wagner reeds eind jaren ' 40 zónder de hulp van Bloch en Mayer tot het inzicht gekomen, dat de oud-Bayreuther traditie met haar agressieve, antisemitische Deutschtümelei berustte op een ideologische vervalsing, die haaks stond op de ware geest van het wagnerianisme. Het is echter hoofdzakelijk aan deze neo-marxistische huisfilosofen te danken, dat hij zich in de loop van de jaren '60 steeds nadrukkelijker begon te manifesteren als een 'linkse wagneriaan'. Of meer specifiek: onder de invloed van Bloch en Mayer begon hij Wagner steeds nadrukkelijker te beschouwen als een, laten we zeggen, utopische socialist - een geestverwant van Bakoenin en Proudhon, die als kunstenaar diende te worden gesitueerd in de Verlichte traditie van het vormingstheater van Schiller tot Brecht. ${ }^{160}$

Bij een oppervlakkige beschouwing lijkt dit weinig te verschillen van Syberbergs visie op Wagner. Zoals we zagen in paragraaf 3 gaat ook hij ervan uit dat Wagner en Brecht

\footnotetext{
${ }^{157}$ Laqueur, a.w., pp. 85f: "Warum duldeten die Kommunisten so lange einer der ihren fremde Philosophie, wăhrend in anderen Fällen Missetäter wegen der leichtesten Abweichung ausgeschlossen wurden?" Hetzelfde punt wordt bijvoorbeeld gemaakt door Nolte, a.w., p. 38: "So erschüttert Bloch nicht nur Marx" Lehre vom Überbau (...)". Overbodig hieraan toe te voegen, dat ook Lukács de filosofie van Bloch begreep als in wezen onmarxistisch. Voor de visie van Lukäcs op Bloch, zie bijvoorbeeld: Lukács, G., Voorwoord. in: Theorie van de roman. Een poging tot een geschiedfilosofische beschouwing van de grote epische vormen. Vert. W.D. Tieges. Amsterdam, 1973, 1980. pp. 15ff. Alsmede: Markun, a.w., pp. 49ff.

${ }_{158}$ Bloch, a.w., p. 66. Zie eveneens: Zudeick, a.w., pp. 136 f.

${ }^{159}$ Syberberg, a.w., p. 321 .

160 "Ik ben een felle tegenstander van de orthodoxe wagnerianen," aldus Wieland Wagner in een interview uit 1963, waarin hij zichzelf typeert als "een wagneriaan uit de linkse hoek". "Zij verwarren namelijk de letter met de geest en gebruiken het werk van Richard Wagner als een soort roesmiddel. Bijna zou ik met Brecht zeggen: kijk niet zo romantisch uit jullie ogen." Wagner, W[ieland], a.w., p. 81. Zie eveneens: Wagner, G[ottfried], Wer nicht mit dem Wolf heult. Autobiographische Aufzeichnungen eines Wagner-Urenkels. Köln, 1997. p. 59: “(...) Wieland hatte sich durch seine Kontakte mit Bloch immer mehr nach links entwickelt (...)". Alsmede: Mayer, Metzger, Riehn, a:w., passim. Mayer, a.w., pp. 168ff: "Der Nibelungenring ist in seiner Grundkonzeption ein Erzeugnis des Revolutionärs Richard Wagner, der mit den Anarchisten Bakunin befreundet war, aus dem Jahre $1848^{\prime \prime}$.
} 
geen tegenpolen zijn, maar als kunstenaars binnen dezelfde epische traditie staan. Ik houd zelfs gedegen rekening met de mogelijkheid, dat hij zijn Wagner \& Brecht-formule aan Wieland Wagner of, wat nog meer voor de hand ligt, Hans Mayer heeft ontleend. Niettemin bestaat tussen zijn Wagner-beeld en dat van deze linkse wagnerianen één fundamenteel verschil: Syberberg rekent laat-romantici als Wagner nog tot een andere traditie, namelijk die van de deutsche Gegenaufklärung of het Duitse 'irrationalisme' in de zin van Mann en Lukács. ${ }^{161}$ En het is precies deze traditie, waarmee Bayreuth onder leiding van Wieland en Wolfgang Wagner heeft gebroken. Of beter: die men in linkse zin heeft proberen te herijken. Door het 'irrationele' te herdefiniëren als 'ongelijktijdigheid', waarin een sterk element van het "principe hoop' in de zin van Bloch kon worden aangewezen, ${ }^{162}$ probeerde men aan te tonen dat deze denktraditie zich ook in een heel andere richting had kunnen ontwikkelen. Meer nog: men probeerde aan te tonen, dat het linkse wagnerianisme van Bloch, Mayer en Wieland Wagner de rechtmatige erfgenaam was van de 'irrationele traditiesporen in de Duitse cultuurgeschiedenis. In een essay uit 1995 gebruikt Wieland Wagners dochter, de theaterwetenschapster Nike Wagner, twee elkaar deels overlappende begrippen, om het Wagner-beeld van het Nieuwe Bayreuth te kenschetsen: entdeutscht en entideologisiert. ${ }^{163}$ Wieland Wagners herijking kwam er op neer, dat Wagners kunstwerken werden ontdaan van connotaties met een ideologie, die enerzijds deze kunstwerken begreep als in wezen Duits, anderzijds dit Duitse wezen zocht in een gerichtheid tegen de Westerse civilisatie.

Syberberg, daarentegen, blijkt met zijn herijking iets volstrekt anders na te streven. Hij heeft zich naar eigen zeggen tot doel gesteld "de Duitse geest te begrijpen, te eren en te redden". ${ }^{164}$ En, daarvan is deze filmer stellig overtuigd: de Duitse geest begrijpen, eren en redden doe je niet, door Duitse kunstenaars als Hölderlin of Wagner, wier werk uit deze geest is voortgesproten, als 'revolutionairen ergens tussen Lessing en Marx te situeren'. Volgen we Syberberg, dan berust ook het linkse Wagner-beeld van het Nieuwe Bayreuth op een ideologische vervalsing. ${ }^{165}$ Het is een vervalsing van de "Kräften des uns eigentümlichen Wesens": het na "45 "verdrongen" en "verraden" Duitse anti-Verlichtingsdenken, "166 dat in de films yan De Graal wordt gereanimeerd. Want deze films "komen uit andere bronnen, unzeitgemäß in een barre tijd zonder Duitse identiteit". 167

\subsection{Slot.}

Mogen we hieruit concluderen, dat de tegenstanders het met hun kritiek bij het rechte eind hebben? Inderdaad heeft het er veel van weg, dat we ons in dit hoofdstuk in een cirkel hebben

\footnotetext{
${ }^{161}$ Syberberg, Die Kunst als Rettung.., a.w., p. 14.

${ }^{162}$ Mayer: "Elk kunstwerk is (...) een expressie van een bepaalde maatschappelijke constellatie. Het kan de situatie affirmatief behandelen, opportunistisch bevestigend. (...) [Maar] het kan ook een scherpe (...) tegenpositie demonstreren, hetzij in de vorm van de destructie, de negatie van de samenleving en haar kunstvoorstellingen, hetzij in de vorm van een alternatief ontwerp van een utopisch bewustzijn. Bij Wagner is een element ongetwijfeld affirmatief. En ik ben geneigd te stellen: het is het geringere, onbelangrijkere element van de late Richard Wagner (...). Het andere in Wagner is het element van de negatie, van de destructie, van de brand van het Walhalla als een, op Proudhon teruggrijpende poging on het imperialisme in een instemming met haar vernietiging te overwinnen. Aan het slot van de Ring-tetralogie, die geen gesloten cirkel is, (..) ja zelfs van de Parsifal, kan een opening, een utopisch tegen-element worden aangewezen. Es gibt bei Wagner ein Element des "Prinzips Hoffnung"." Mayer, Metzger, Riehn, a.w., p. 75.

${ }^{163}$ Wagner, N[ike], Bayreuth - ? in: Uber Wagner, a.w., pp. 323-339, zie: 333.

${ }^{164}$ Syberberg, HJ., Winifred Wagner-Symbol unsere Vergangenheit. in: Die Zeit. 12 (1980). p. 41.

165 ibidem.

${ }^{166}$ Syberberg, Die Kunst als Rettung..., a.w., p. 9.

${ }^{167}$ idem, p. 48.
} 
bewogen. Via een lange omweg langs Brecht (paragraaf 3), de late Thomas Mann (paragraaf 4), Wagner zelf (paragraaf 5) en Ernst Bloch (paragraaf 6) lijken we weer te zijn uitgekomen bij ons vertrekpunt: de constatering, dat de Syberberg van de jaren ' 70 en de vroege jaren ' 80 zich hult in de travestie van een tweede verschijning van Richard Wagner. En deze tweede verschijning is, naar het zich laat aanzien, eerder een geestverwant van Winifred WagnerWilliams dan van de linkse wagnerianen Bloch, Mayer en Wieland Wagner. Maar laten we, alvorens het kind met het badwater weg te gooien, eerst de zaken nog eens op een rij zetten.

Wat we in elk geval zeker weten is, dat deze filmmaker niet thuishoort in het kamp van de anti-wagnerianen. Van een 'vijandigheid jegens Wagner' (Sontag) is weinig te merken - ook niet in de fameuze passage van Die Kunst als Rettung aus der deutschen Misere, waarin hij zijn Duitse Trilogie presenteert als een scandaleuze samenvoeging van een wagneriaanse en een brechtiaanse esthetiek. Veeleer lijkt Syberberg in deze passage afstand te nemen van de anti-wagneriaan Brecht, die ten onrechte het 'irrationele', het surreèle en het metafysische uit het moderne theater zou hebben verbannen. Ook kunnen we met aan zekerheid grenzende waarschijnlijkheid stellen, dat hij niet op een lijn zit met de late Thomas Mann. Het is goed mogelijk, dat hij zijn 'irrationalisme'-concept aan diens theorie van het 'Éne Duitsland' heeft ontleend. Maar zijn Zivilisationskritik roept eerder herinneringen op aan de vroege Thomas Mann van Betrachtungen eines Unpolitischen. Daarbij komt, dat Syberberg zich een fel criticaster toont van een richting in de Duitse cultururtheorie, waarvan de late Mann en Lukács de belangrijkste vertegenwoordigers zijn. En we weten, dat hij zich in zijn kritiek op Mann en Lukács laat souffleren door hun grote opponent in het linkse cultuurdebat, de neo-marxistische avant-gardist en (latere) huisfilosoof van het Nieuwe Bayreuth Ernst Bloch. Waaraan we nog kunnen toevoegen, dat de onderwerpskeuze van de filmcyclus De Graal en de talrijke verwijzingen in de pamfletten sterk doen vermoeden, dat hij Bloch grondig moet hebben bestudeerd:

En tot op zekere hoogte hoeft dit ook niet te verbazen. Syberbergs geestelijke Heimat is de linkse dissidentencultur in de vroege $\mathrm{DDR}$, ${ }^{168}$ waarvan ook de Brecht-ideoloog én (latere) huisfilosoof van het Nieuwe Bayreuth Hans Mayer deel uitmaakt. Dankzij Mayer zou deze post-brechtiaan, zoals ik Syberberg in het vorige hoofdstuk heb getypeerd, de weg hebben gevonden van zijn 'artistieke pleegvader' Brecht naar diens vermeende tegenpool Richard Wagner. Zoals omgekeerd de post-wagneriaan Wieland Wagner mede onder de invloed van Mayer en Bloch de weg heeft gevonden van zijn grootvader Richard naar diens vermeende tegenpool Bert Brecht. Want, ook dat zijn we inmiddels te weten gekomen: van Brecht naar Wagner is een aanzienlijk kleinere stap dan doorgaans wordt aangenomen. Zeker wanneer je het bekijkt door de bril van de stalinisten, die zowel Wagner als Brecht er lange tijd van hebben verdacht vertegenwoordigers van de decadentie te zijn. De polemiek tegen de cultuurpolitiek van de stalinisten is de verbindende schakel tussen alle werken, die Syberberg sinds zijn verfilming van Brechts 'verboden' Urfaust (1953) heeft gemaakt. Ook de vroege, aan het theater van de absurdisten verwante films uit de tweede helft jaren '60 waren reeds een poging het 'irrationele' kunstwerk te herijken. $\mathrm{Nu}$, in de jaren ' 70 , is hij zich op een andere tak van het 'irrationalisme' gaan oriënteren: de late romantiek. En hij verwoordt nadrukkelijker dan voorheen de programmatische inzet van zijn 'irrationele' kunstwerken in een jargon, dat soms letterlijk van Bloch lijkt te zijn overgeschreven: de ware kritische

\footnotetext{
${ }^{168}$ Daarnaast is Syberberg natuurlijk ook een leerling van de conservatief Hans Sedlmayr. Maar deze stond, zoals we in paragraaf 7 van het vorige hoofdstuk hebben gezien, ten opzichte van het werk van Wagner niet minder afwijzend dan de anti-wagneriaan Brecht. Zoals ik reeds schreef in dat hoofdstuk, ontvangt Syberbergs oeuvre tot ver in de jaren ' 80 niet zijn belangrijkste stimulans van Sedlmayr, de ultra-conservatieve bestrijder van de avant-garde, maar van de neo-marxistische avant-gardisten Brecht, Bloch en Mayer. Hooguit lijkt de eerstgenoemde in de jaren " 70 als spiritus rector iets meer op de achtergrond te treden.
} 
filosoof of kunstenaar legt zich niet neer bij de pervertering, maar ontwikkelt strategieën om het geroofde culturele erfgoed weer aan de nazi's te ontfutselen. Maar we weten ook, dat het einddoel dat Syberberg in de jaren ' 70 met zijn herijking van de 'irrationele' traditiesporen nastreeft - 'het begrijpen, eren en redden van de Duitse geest' - haaks staat op Blochs pleidooi voor een revisie van de Duitse cultuurgeschiedenis vanuit een marxistisch perspectief.

Dit stelt ons, op de keper beschouwd, voor drie mogelijkheden, die elkaar overigens niet hoeven uit te sluiten. Ofwel de verwijzingen naar Bloch zijn een moedwillige poging ons zand in de ogen te strooien. Ofwel Syberberg heeft deze idiosyncratische filosofie van de utopische hoop niet op alle punten even goed begrepen. Ofwel hij drijft Bloch op de spits, door de premissen van diens dialectiek tot het uiterste door te denken. Immers: gesteld dat het zinvol is te streven naar een denazificatie van zwaar geperverteerde begrippen als volk, natie, vaderland, Heimat, bodem, Führer, de Graal, of het Derde Rijk, zoals Bloch in Erbschaft dieser Zeit betoogt; waarom dan wel de bezoedelde 'Duitse geest' zonder strijd aan de nazi's cadeau doen? Zijn niet ook in de naoorlogse Entdeutschung en Entideologisierung zaken verloren gegaan, die voor het tegenwoordige Duitsland van waarde hadden kunnen zijn? Bijvoorbeeld dit na '45 'verdrongen' en 'verraden' mythopoëtische Duitse wezen, waarvan de oud-Bayreuther wagnerianen of de vroege Thomas Mann nog hoopten, dat een door de Verlichting uit haar voegen geraakte wereld eraan zou kunnen genezen?

Door Bloch, de neo-marxist, zou een dergelijke 'sprong' ongetwijfeld zijn afgedaan als ridicuul, zo niet reactionair. Maar een neo-marxist is Syberberg nimmer geweest. We hebben hem in het vorige hoofdstuk leren kennen als een absurdist, die in zijn films op zoek was naar een 'ethisch desondanks', dat opnieuw houvast moest bieden ten opzichte van "een vooruitgang, die alles vernietigt en ten gunste van een kwantitatief principe de mens alsmaar meer geestelijk afstompt, alsmaar meer egaliseert" (Hans Mayer). ${ }^{169}$ Dit 'ethisch desondanks' of, zo men wil 'principe hoop', meende hij indertijd te hebben gevonden in een humanistische levensfilosofie, zoals die onder meer wordt uitgedragen door Konrad Graf von Pocei: een ethos van zorgzaamheid, matigheid en berusting in harmonie met de 'zachte wet' (Adalbert Stifter) van de natuur. ${ }^{170} \mathrm{Nu}$, in de jaren ' 70 , krijgt het 'ethisch-desondanks' een exclusief Duits karakter. "Zonder rood te worden van schaamte heeft Syberberg in zijn monumentale Hitler-fantasie duidelijk gemaakt, dat de Duitsers na de crimineel verloren oorlog niet enkel Hitler gevaarlijk hebben verdrongen, maar ook zichzelf, dat wil zeggen: datgene wat hun 'geestelijke mogelijkheid' uitmaakt," aldus de Duitse literatuurwetenschapper Karl Heinz Bohrer in een indertijd geruchtmakend essay uit 1979: Deutschland - noch eine geistige Möglichkeit? Bemerkungen zu einem nationalen Tabu. "Als eerste sprak de regisseur voor een buitenlands publiek iets uit, waarop de met hun slechte geweten worstelende Westduitse conservatieven dertig jaar lang niet zijn gekomen, nadat de liberale en linkse intelligentsia het hen op straffe van het verlies van eer en invloed had verboden. Wanneer we niet terugkeren naar de ons aangeboren grote stijl van de verbeelding, van de metafysica, ja de stijl van het domweg verbodene - zo zal hij het hebben bedoeld zullen we voortaan geestelijk en seelisch gekoloniseerd blijven."171

Karl Heinz Bohrer, hoogleraar aan de universiteit van Bielefeld en hoofdredacteur van Merkur. Deutsche Zeitschrift für europäisisches Denken, hoort niet tot de oud-Bayreuther wagnerianen. Hij geldt als een van de meest toonaangevende intellectuelen van de

\footnotetext{
${ }^{169}$ Mayer, H, Brecht. Frankfurt am Main, 1996. p. 428. Zie eveneens: hoofdstuk 2, paragraaf 10.

${ }^{170} \mathrm{Zie}$ : hoofdstuk 2, paragraaf 9.

${ }^{171}$ Bohrer, K.H., Deutschland - noch eine geistige Möglichkeit? Bemerkungen zu einem nationalen Tabu. in: Frankfurter Allgemeine Zeitung. 28-04-1979.
} 
Bondsrepubliek van de late jaren ' $70 .{ }^{172}$ Mede daarom wil ik dit hoofdstuk afsluiten met een langer citaat van zijn hand:

"Hij [Syberberg, G.G.] is als experiment een alarmerend signaal: de taboeïsering van het zogenaamde 'irrationele' in naam van de rede, de moraal, de positivistische logica, de nieuwe sociologie is zover gegaan, dat zelfs verschijnselen als het Franse surrealisme door kopstukken van de Westduitse intelligentsia ideologiekritisch en cultuurpolitiek in verzekerde bewaring werden genomen, tot een enkeling eind jaren 60 dit taboe doorbrak - en nog wel onder het mom van een linkse cultuurrevolutie, die meteen weer als een romantische terugval werd bekritiseerd. (...) De puriteinse verdoeming van 'het irrationele' trof ook kunstrichtingen en cultuurconcepten, waaronder buitenlandse, die zich zelfs met de meest kwade wil niet als reactionair, regressief of fascistisch laten omschrijven. Het tegendeel is waar: dit verdoemingsoordeel trof het centrum van de Europese en Duitse avant-garde. (...) Onze metafysica is opgegaan in de methodologische zelfreflectie van de individuele wetenschappen en het syncretisme heeft zich opgelost in het sop van de ideologiekritische ratio. In zoverre is de Duitse mythologie definitief als geperverteerd ad acta gelegd. Maar betekent dit, dat we die ingenieuze ontdekking van het Ik niet langer zouden moeten voortzetten; van eenvoudig dat Ik, dat Fichte, een leerling van Kant, dramatiseerde en waarin hij een hele geciviliseerde wereld opnam? (...) De angst voor het 'irrationele' is de angst voor het intellectueel nog onbekende. Het is de angst voor het woord 'revolutie', dat als historische mogelijkheid en als geschiedfilosofische categorie wordt vernietigd. Maar hoezo zou de romantiek 'irrationeel' zijn en de Verlichting louter 'redelijk'? Wie kon meer een casuïst zijn dan Friedrich Schlegel en wie meer vurig-hartstochtelijk dan Gotthold Ephraim Lessing? Wie was spitsvondiger dan Novalis en wie onberekenbaarder dan Lichtenberg? En wie heeft überhaupt het sublieme als esthetische categorie suggestiever beschreven dan Kant? Men zal eindelijk eens moeten ophouden onze grootse traditie op te delen in rede en onrede. Waaraan we zouden kunnen aanknopen is: de geest van het ontdekkende, de stijl van de rebellie tegen het normatieve. We hebben vergeten, dat precies dit, van de Verlichting tot de avant-garde, de Duitsers als "geestelijke mogelijkheid" eervol onderscheidde."173

\footnotetext{
${ }^{172}$ De invloed van Bohrer op de intellectuele ontwikkeling in de Bondsrepubliek was een van de criteria op grond waarvan hij door de Frankfurter filosoof Jürgen Habermas werd uitgenodigd een bijdrage te leveren aan de prestigieuze bundel Stichworte zur geistigen Situation der Zeit (1981). Zie: Habermas, J., Kleine Politische Schriften. (I-IV) Frankfurt am Main, 1981. pp. 411 f. Overigens staat Habermas, die zich de kritiek van Bohrer op de linkse taboeìsering van het 'irrationele' in Deutschland - noch eine geistige Möglichkeit? persoonlijk aantrekt, zeker niet onverdeeld positief tegenover deze literatuurwetenschapper. Zie in dit verband, naast paragraaf 1 van het volgende hoofdstuk, ook Habermas, a.w., p. 440: "Der einzige, der sich heute, politisch unbefangen und souverän, etwas von der radialität und die neuromantischen Intelligenz eines Jungkonservativen bewahrt hat, ist Karl Heinz Bohrer." Hoewel de zichzelf eerder als links dan als conservatief beschouwende Bohrer beslist niet tot de Neue Rechte mag worden gerekend, strookt dit door Habermas geschetste beeld in grote lijnen met de reputatie, die hij geniet. Zo wordt hij door de historicus Frits Boterman in Terug naar Berlijn. Dutsland no de val van de muur. Amsterdam, 1999. p. 164 getypeerd als: "de auctor intellectualis van het neoromantische en "unpolitische' denken". Maar zo zou je natuurlijk ook de linkse neo-nietzschiaan Ernst Bloch kunnen typeren.

${ }^{173}$ Bohrer, a.w.
} 


\section{Hoofdstuk 4 De oude dame ${ }^{1}$}

\subsection{Inleiding}

Een 'jong-conservatief noemt de Frankfurter filosoof Jürgen Habermas (1981) de Duitse literatuurwetenschapper Karl Heinz Bohrer, met wiens uit '79 daterende essay Deutschland noch eine geistige Möglichkeit? Bemerkungen zu einem nationalen Tabu ik het vorige hoofdstuk heb afgesloten. Hetgeen zoveel wil zeggen als: iemand die in traditie staat van de Conservatieve Revolutionairen uit de Weimar-tijd: Carl Schmitt, Gottfried Benn, Martin Heidegger en de gebroeders Ernst en Friedrich Georg Jünger. Volgen we Habermas, dan "legt Bohrer Syberberg zijn eigen geloofsbelijdenis in de mond", wanneer hij schrijft: "Wanneer we niet terugkeren naar de ons aangeboren grote stijl van de verbeelding, van de metafysica, ja de stijl van het domweg verbodene, zullen we voortaan geestelijk en seelisch gekoloniseerd blijven". 2 Doch dit berust op een misverstand. Zoals we zagen in hoofdstuk 3 gaat het hier om een alleszins adequate samenvatting van Syberbergs boodschap in de Hitlerscript-inleiding Die Kunst als Rettung aus der deutschen Misere (1978). Betekent dit, dat ook deze filmer gemeten aan de maatstaven van Habermas in de hoek van de 'jongconservatieven' dient te worden gesitueerd? In dat geval bevindt hij zich in goed gezelschap. Want 'jong-conservatief' zijn in de optiek van Habermas ook de Italiaanse cineast, dichter en semioticus Pier Paolo Pasolini, of de Franse filosofen Michel Foucault, Jacques Derrida en Jean-Francois Lyotard..$^{3}$ En het kan geen kwaad dit bij het lezen van Duitse kritieken op Syberberg voortdurend goed in het achterhoofd te houden. Je hoeft het zo bont nog niet te maken om in de Bondsrepubliek van de late jaren ' 70 als een Conservatieve Revolutionair of erger aan de schandpaal te worden genageld. Het volstaat om met instemming Nietzsche te lezen - de voormalige huisfilosoof van het oude Bayreuth, die door Georg Lukács reeds in het interbellum als de hoofdschuldig van alle kwaad in de twintigste eeuw is ontmaskerd. ${ }^{4}$ Immers, aldus Habermas: "Über allen schwebt natürlich der Geist des in dēn 70er Jahren wiedererweckten Nietzsche".

Het is intrigerend om te zien, hoe het indertijd door de stalinist Lukács gemaakte onderscheid tussen 'rationele' en 'irrationele' traditiesporen in de Duitse cultuurgeschiedenis inderdaad, zoals Bohrer in zijn essay betoogt, ook in het Westen sterk het karakter heeft gekregen van een heus links dogma, waaraan onder geen enkele voorwaarde mag worden getornd. ${ }^{6}$ Wie hiertoe een poging waagt laadt onherroepelijk de verdenking op zich een, zoals het in het jargon van die dagen heet, apologeet van de conservatieve Tendenzwende te zijn. En als we Habermas mogen geloven, komen de aanvallen op het zuivere Verlichtingsdenken vanuit alle richtingen. Waren de eerste, naoorlogse decennia een periode, waarin Duitsland er

\footnotetext{
${ }^{1}$ Alle citaten in dit hoofdstuk zijn, tenzij anders aangegeven, ontleend aan de documentaire Winifred Wagner und die Geschichte des Hauses Wahnfried von 1914-1975. Het gros van de citaten staat eveneens afgedrukt in: Syberberg, H.J., Syberbergs Filmbuch. München, 1976. pp. 245-296. Alsmede in: Syberberg, H.J., Winifred, Wahnfried und wir. in: ZeitMagazin. 18 (1976). pp. $18 \mathrm{ff}$.

${ }^{2}$ Habermas, J., Kleine Politische Schriften I-IV. Frankfurt am Main, 1981. pp. $429 f$.

${ }^{3}$ idem, pp. 440, 463. Zie eveneens: Reese-Schäfer, W., Lyotard zür Einführung: Hamburg, 1988, 1989. pp. 92ff.

4 "In der tragisch endenden Untergangsgeschichte der Degradierung der Vernunft wurde Nietzsche von Lukács eine mephistophelische rolle zugedacht." Sziklai, L., Georg Lukács - Kritiker der unreinen Vernunft. Brüche in der frühen Politiktheorie von Georg Lukács. in: Georg Lukács. Kultur-Politik-Ontologie. Hrsg. U. Bermbach e.a.. Opladen, 1987. pp. 188-199, zie: 188. Voor de Duitsland-theorie van Lukács, zie: de paragrafen 2.4 en 3.4. ${ }^{5}$ Habermas, a.w., p. 463.

${ }^{6}$ Bohrer, K.H., Deutschland - noch eine geistige Möglichkeit? Bemerkungen zu einem nationalen Tabu. in: Frankfurter Allgemeine Zeitung. 28-04-1979. Zie eveneens: hoofdstuk 3, paragraaf 8.
} 
dankzij linkse intellectuelen als hijzelf " $(. .$.$) voor het eerst in slaagde de toch al verminkte en$ alsmaar weer verdrongen Verlichtingstraditie van Lessing tot Marx in haar volle omvang te doen gelden, dat wil zeggen tot een medium van intellectuele productiviteit en een aanknopingspunt van het politieke identiteitsgevoel te maken"; nu, in de jaren '70, zou het "ideologische klimaat" opnieuw worden "beheerst door een brouwsel van oude en nieuwe conservatieve stromingen". ${ }^{7}$ Schrijvers grijpen terug op traditionele vormen van een subjectivistische beleving van de werkelijkheid; architectuur en stedenbouw lijken geheel en al in het teken te staan van een neo-historisme; in de kerken predikt men een nieuw piëtisme; onder historici is het narrativisme in de mode; filosofen nemen en masse afstand van het "universalisme van de Verlichting" en plaatsen "(...) tegenover de instrumentele rede manicheïstisch een louter nog voor evocatie toegankelijk principe, hetzij de Wil tot Macht of de soevereiniteit, hetzij het Zijnde of het dionysische"; zelfs in de wetenschapstheorie viert het relativisme hoogtij.

En dan is er natuurlijk nog de, wat Habermas noemt, "Wendung (...) zum Spätexpressionismus" in de cinema en de schilderkunst. ${ }^{9}$ Dat wil zeggen: de heropleving van precies die 'zogenaamde avant-garde' (Lukács), waarvan het vermeend fascistische gehalte reeds in de jaren "30 aanleiding was voor een verbitterde controverse binnen de antifascistische emigrantencultuur: het expressionisme-debat, waarin Lukács en de late Thomas Mann diametraal stonden tegenover de neo-marxistische avant-gardisten Bertolt Brecht, Ernst Bloch en Hans Mayer: ${ }^{10}$ "Zo Duits!" "Teutoonse krachtpatserij." "Bedenkelijk gekoketteer met geschiedenis." "Een spel met het irrationalisme en de brutaliteit, dat door geen vorm, door geen moraal wordt bewaakt." "Met geheven vlag marcheert hij terug in het glorieuze verleden van de Nibelungen; de ontmoeting met Adolf Hitler is bij een dergelijke Blut-und-Boden-trip onvermijdelijk." "Wie erin geslaagd is het hoofd koel te houden, staat het zwoele fascistoïde duidelijk voor ogen." Nee, het is niet 'Wagners tweede verschijning", die hier de gemoederen zo hoog doet oplopen. Ik ontleen deze citaten aan een door de kunsthistoricus Peter Krüger samengestelde bloemlezing van tussen 1980 en 1988 verschenen Duitse kritieken op de 'nieuwe expressionistische schilderkunst' van Anselm Kiefer, Georg Baselitz, Markus Lüpertz, A.R. Penck en de zogenaamde Nieuwe Wilden. ${ }^{11}$ Maar het hadden heel goed commentaren op Syberberg kunnen zijn. Sterker: met name met Anselm Kiefer wordt hij in die dagen nog steevast door vriend en vijand in één adem genoemd. ${ }^{12}$

\footnotetext{
${ }^{7}$ Habermas, a.w., pp. 386, 412: "Wenn an der Parole, der Geist stehe links, je etwas daran gewesen ist, ich meine in Deutschland, dann während der Jahre, als trotz der massiven gesellschaftlichen Restauration die Erinnerung an den Nazismus und an die Traditionen, mit denen dieser gebrochen hatte, wachgehalten wurde von einer intellektuellen Linken, die das kulturelle Milieu mit einer gewissen Selbstverständlichkeit prägen konnte. Damit ist nun vorbei"

${ }^{8}$ idem, pp. $436,463$.

idem, p. 436.

${ }^{10}$ Zie: hoofdstuk 2, paragraaf 4; hoofdstuk 3, de paragrafen 4 en 6.

"Kriger, P., 'Überdosis an Teutschem.' Pressestimmen zur Neuen Malerei. in: Arbeit in Geschichte/ Geschichte in Arbeit. Hrsg. G. Bussmann. Hamburg, 1988. pp. 65-70.

${ }^{12}$ Zoals ook de Duitse kunsthistorica Sabine Schütz opmerkt. Schütz, S., Anselm Kiefer. Geschichte als Material. Arbeiten 1969-1983. Köln, 1999. p. 314. Zie eveneens: hoofdstuk 1, de paragrafen 1 en 2. Alsmede: Thomas, K., Zweimal deutsche Kunst nach 1945. 40 Jahre Nähe und Ferne. Köln, 1985. pp. 121f: "Nähen Kiefers zu filmischen Arbeiten von Hans-Jürgen Syberberg wie 'Parsifal' sind unverkennbar, vor allem auch in einer collagenhaften Inszenierungsmethodik, die Bilder und Worte, Mythos, Dichtung und Reflexion, politisches Zeitgeschehen und atmosphärischen Zeitgeist, Vergangenheit und Gegenwart miteinander verschränkt. (...) Kiefers Gemälde und Syberbergs Filme (...) beschäftigen sich (...) mit dem mentalen Umfelt dessen, was sich begrifflich nur vage als 'deutsche Seele' fassen läßt." Dat wil zeggen met datgene, wat Bohrer, a.w., probeert te omschrijven als: 'de ons Duitsers aangeboren grote stijl van de verbeelding, van de metafysica, van de rebellie tegen het normatieve', kortom: 'de stijl' van het door 'de linkse en liberale intelligentsia" 'op
} 
Toch zou het wat al te kortzichtig zijn de bij vlagen ongemeen felle kritiek die Syberberg in eigen land over zich heen heeft gekregen uitsluitend toe te schrijven aan eigenaardigheden van het linkse cultuurdebat, zoals bijvoorbeeld de Wuppertaalse hoogleraar esthetica Bazon Brock in de hitte van de strijd heeft gedaan. ${ }^{13}$ Op zijn laatst sinds de Wende van 1989-1990, is dit cultuurdebat ook in de Bondsrepubliek een zachte dood gestorven. ${ }^{14}$ Het 'irrationalisme' heeft allang opgehouden een 'nationaal taboe' (Bohrer) te zijn. Nietzsche, Bohrer, Pasolini en de Franse post-nietzschianen zijn gerehabiliteerd En hetzelfde geldt voor Anselm Kiefer en de zijnen. Ook voor Syberberg zijn de tekenen aanvankelijk beslist niet ongunstig. Zoals we nog zullen zien in hoofdstuk 7 ontstaat halverwege de jaren 80 in de marge van het kunsthistorische Kiefer-debat ook rond zijn werk een meer genuanceerde en positieve Duitse beeldvorming. ${ }^{15}$ Maar niet te loochenen valt, dat deze filmmaker zich uiteindelijk wel degelijk aan Nieuw Rechts heeft gelieerd - en dan niet aan de spookverschijning die Habermas oproept, maar aan de échte Neue Rechte, dat wil zeggen: de zichzelf Conservatieve Revolutionair noemende activisten uit de rechts-extremistische subcultuur van underground-bladen als Deutsche National-Zeitung, Nation Europa, Mut, Junge Freiheit en Criticón. Hetgeen de Amerikaanse literatuurwetenschapper Stephen Brockmann (1996) terecht de vraag heeft doen stellen, of "Duitse kritieken op Syberberg in de jaren '70 (..) niet op zijn minst voor een deel gerechtvaardigd" waren. ${ }^{16}$ of anders geformuleerd: moet, nu het stof van de toenmalige Kulturkampf (Brock) is opgetrokken niet worden geconcludeerd, dat de exegeten van het eerste uur een pijnlijke inschattingsfout hebben gemaakt, toen ze deze filmmaker tegen de kritiek van het Westduitse cultuurestablishment in bescherming meenden te moeten nemen?

Deze vraag laat zich makkelijker stellen dan beantwoorden. Daarvoor vormen Syberbergs bewonderaars eenvoudig te zeer een heterogeen gezelschap. Met name tussen een Franse filosoof als Philippe Lacoue-Labarthe, een leerling van Derrida, en een Amerikaanse 'postmodernist' als de literatuurwetenschapper en Duitsland-deskundige Eric Santner, die overduidelijk meer op de lijn zit van Habermas, ${ }^{17}$ bestaat een wereld van verschil. Beperken we ons echter tot de, laten we zeggen, Angelsaksische tak van de Syberberg-exegese, dan denk ik dat het antwoord bevestigend moet zijn. In dit hoofdstuk zal ik een reeks invloedrijke Angelsaksische commentaren bespreken op de film waarmee Syberberg midden jaren ' 70 ook in eigen land is doorgebroken: de vijf uur durende Bayreuth-documentaire Winifred Wagner und die Geschichte des Hauses Wahnfried von 1914-1975 (1975), het vierde deel van De Graal. Na een korte introductie (paragraaf 2), zal ik achtereenvolgens de Amsterdamse filmtheoreticus Thomas Elsaesser, de Amerikaanse literatuurwetenschapper Russell R. Berman, de Britse filmtheoreticus John Sandford, de reeds genoemde Eric L. Santner en de Amerikaanse publiciste Susan Sontag hun licht over dit werk laten schijnen. En om een goed zicht te krijgen op de verschillen en overeenkomsten tussen de binnen- en buitenlandse receptie, zal ik mijn bespreking van deze buitenlandse kritieken beginnen en afsluiten met

\footnotetext{
straffe van eer en invloed' 'domweg verbodene'. Voor een voorbeeld van Syberbergs 'collagenhaften Inszenierungsmethodik', zie: hoofdstuk 6, de paragrafen 1 tot en met 3.

"Alsmede: hoofdstuk 1, de paragrafen 1 en 2.

${ }^{13}$ Brock, B., The End of Avant-Garde? And so the End of Tradition? Notes on the Present 'Kulturkampf' in

West Germany. in: Art Forum. (Summer 1981) pp. 62-67. Ook Brock noemt Kiefer en Syberberg in één adem.

${ }^{14}$ Zie hoofdstuk 8 , passim.

${ }^{15}$ Zie: hoofdstuk 7, paragraaf 7. Alsmede: hoofdstuk 6, paragraaf 8 .

${ }^{16}$ Brockmann, S., Syberberg's Germany. in: The German Quarterly (Winter 1996). pp. 48-62, zie: 59. Zie eveneens: hoofdstuk 1, paragraaf 3 .

${ }^{17}$ Zoals de historicus Saul Friedländer terecht heeft opgemerkt. Friedländer, S., Introduction. in: Probing the Limits of Representation. Nazism and the 'Final Solution'. ed. S. Friedländer. Cambridge, Mass., London, 1992. pp. 1-21, zie: 13 . Zie eveneens: hoofdstuk 7, paragraaf 3 .
} 
een Duits commentaar van de hand van respectievelijk de cultuursocioloog Nicolaus Sombart en Wagners achterkleinzoon, de theaterwetenschapper Gottfried Wagner, die bij de opnamen als regieassistent betrokken was.

Winifred Wagner und die Geschichte des Hauses Wahnfried leent zich goed voor een dergelijk vergelijkend warenonderzoek. Het is een, voor Syberbergs doen, opmerkelijk sober werk. Vijf uur lang krijgen we weinig meer te zien dan een vrouw op leeftijd die, zittend achter een schrijftafel in haar werkkamer, terugblikt op haar leven. Als Syberberg midden jaren " 70 dit geruchtmakende documentaire portret maakt, is deze vrouw ook in eigen land een grotendeels vergeten historische figuur, wier naam hooguit bij een enkeling nog herinneringen zal hebben opgeroepen aan lang vervlogen tijden waarin het zwart-wit-rood samen met de swastika op de nok van het Bayreuther festivalhuis wapperde. Amper 33 jaar oud was de van geboorte Engelse, toen ze in 1930 de leiding over het Wagner-festival van haar overleden echtgenoot Siegfried Wagner overnam. Zeven jaar eerder had een jeugdige Adolf Hitler voor het eerst zijn opwachting op de Groene Heuvel gemaakt. Het zou het begin worden van een vriendschap voor het leven, die bij vlagen zo intens was dat na de oorlog bij de geallieerden het misverstand bleek te hebben postgevat, dat het woonhuis van de Wagners tot de persoonlijke eigendommen van de Duitse dictator behoorde. ${ }^{18}$ Over deze vriendschap doen tal van anekdotes de ronde. Berucht is de publieke stellingname van Wagners schoondochter naar aanleiding van de mislukte putsch van "23: "Sinds jaren volgen we met de grootste innerlijke deelname en instemming de opbouwende werkzaamheden van Adolf Hitler". ${ }^{19}$ En het was Winifred Wagner-Williams die, zo wil de overlevering, Hitler het papier stuurde waarop hij in de gevangenis van Landsberg Mein Kampf schreef. ${ }^{20}$

Een van de laatste publieke optredens van de toenmalige festivalleidster vond plaats in 1947 - het jaar waarin ze zich moest verantwoorden voor de denazificatierechtbank. Afgaande op de processtukken kon haar bij die gelegenheid weinig ten laste worden gelegd. De geallieerde rechters hanteerden een onderscheid tussen vijf categorieën: hoofdschuldige, bezwaarde of activist, minder bezwaarde, meeloper, niet betrokkene. Winifred Wagner werd aanvankelijk, tot onvrede van de openbare aanklager die in haar een hoofdschuldige meende te ontwaren, ingedeeld bij de tweede groep en ervan beschuldigd een profiteur van het Derde Rijk te zijn geweest. Maar dit vonnis hield in hoger beroep niet stand. Na het aanhoren van een groot aantal ontlastende getuigenverklaringen van joodse musici, die ze door hen in dienst te nemen de gang naar de nationaal-socialistische dodenkampen zou hebben bespaard, kwamen de rechters tot het oordeel dat de grande dame van het oude Bayreuth diende te worden beschouwd als een minder bezwaarde. Haar straf bleef beperkt tot een geldboete van 60.000 DM ten gunste van een Wiedergutmachungsfonds en een verbod om gedurende een periode van tweeëneenhalf jaar als "zelfstandig onderneemster, lerares, predikster, redactrice, schrijfster of radio-omroepster" (sic!) actief te zijn. ${ }^{21}$ Twee jaar later hield de "Koningin van Bayreuth", zoals ze door Hitler bewonderend werd genoemd, de eer aan zichzelf en droeg ze het beheer van Wagners materiële en artistieke erfenis over aan haar zonen Wieland en Wolfgang. Sindsdien werd van Winifred Wagner-Williams weinig meer vernomen. Drie decennia lang hulde ze zich in stilzwijgen en leidde ze een anoniem bestaan achter de schermen, door de naoorlogse festivalleiding zorgvuldig afgeschermd van de openbaarheid. Met Syberbergs film doorbreekt ze de stilte rond haar persoon en treedt ze, mede op verzoek

\footnotetext{
${ }_{18}^{18}$ Mayer, H., Richard Wagner in Bayreuth 1876-1976. Stuttgart, Zürich, 1976, 1978. pp. $125 \mathrm{f}$.

${ }^{19}$ Citaat ontleend aan: Karbaum, M., Studien zur Geschichte der Bayreuther Festspiele 1876-1976. Regensburg, 1976. p. 68.

${ }^{20} \mathrm{Veld}$, in 't, R., Uit liefde voor de Führer. Vrowwen van het Derde Rijk. Zutphen, 1995. p. 108.

${ }^{21}$ Berufungssenat Bayreuth. Ber-.-Reg. Nr. 3/B/47. Aktenzeichen I. Instanz II/347/47. in: Bayreuth im Dritten Reich. Richard Wagners politische Erbe. Eine Dokumentation. Hrsg. B.W. Wessling. Mannheim, Basel, 1983. pp. $284 \mathrm{ff}$. Zie eveneens: Mayer, a.w., pp. $140 \mathrm{ff}$. Alsmede: Karbaum, pp. $96 \mathrm{ff}$.
} 
van haar kleinzoon Gottfried, voor het eerst sinds het denazificatieproces met het verhaal van haar leven naar buiten.

De documentaire bestaat uit een integrale registratie van een interview dat Syberberg en Gottfried Wagner in het voorjaar van 1975 met de dan 78 jaar oude vrouw hebben gevoerd. Al is interview misschien niet het juiste woord om deze omvangrijke filmmonoloog te typeren. Winifred Wagner und die Geschichte des Hauses Wahnfried heeft meer weg van filmmemoires - een orale en visuele autobiografie, of zelfportret in woord en beeld, waarbij Syberberg en zijn regieassistent primair als ghostwriters hebben gefungeerd. Binnen Syberbergs oeuvre is de film nog het meest verwant met de gedramatiseerde documentaire Theodor Hierneis oder: wie man ehem. Hofkoch wird (1972). Uitgangspunt van die spin-off van Ludwig - Requiem für einen jungfräulichen König (1972) was het amusante memoiresboekje Der König speist (1953) ${ }^{22}$ van de hand van ene Theodor Hierneis, voormalig keukenhulpje aan het Beierse hof ten tijde van Ludwig II, dat door Syberberg werd bewerkt tot een twee uur durende filmmonoloog. Als een volleerd touringguide leidt de gepensioneerde hofkok ons in de film rond door zijn voormalige werkplek, de kitschpaleizen van de Beierse sprookjeskoning, en haalt hij veelal culinaire herinneringen op aan het hofleven van weleer. Zoals Winifred Wagner ons in deze film, al pratende vanachter haar werktafel, rondleidt door de geschiedenis van het huis dat ze (met een korte onderbreking in de periode direct na de oorlog) sinds haar huwelijk met Wagners zoon Siegfried in 1915 heeft bewoond: de Wagner-villa Wahnfried in Bayreuth, die op dat moment wordt gerenoveerd en omgebouwd tot Richard-Wagner-Museum.

Het zelfportret begint met een korte inleiding, waarin een melancholiek klinkende voice-over aan de hand van enkele historische foto's mijmert over het roerige verleden van dit huis. De transformatie van woonhuis tot museum is een indicatie dat in Bayreuth een epoche ten einde loopt. Aan deze epoche zijn verschillende namen verbonden. Friedrich Nietzsche en Franz Liszt waren in dit huis te gast, evenals Joseph Goebbels en Adolf Hitler. De Britse cultuurfilosoof Houston Stewart Chamberlain, die volgens Hitler het 'geestelijke zwaard' zou hebben 'gesmeed' waarmee de nazi's 'vochten', schreef hier zijn belangrijkste werken. In het laatste oorlogsjaar werd Wahnfried gedeeltelijk door bommen verwoest. In de tuin achter de villa dansten zwarte GI's in het schijnsel van het maanlicht op Wagners graf de jitterbug. Begin jaren vijftig begon de moeizame periode van wederopbouw onder leiding van Winifreds zonen Wieland en Wolfgang Wagner. Nieuwe namen kondigden de dageraad van een nieuwe tijd aan: de emigranten Theodor Adorno, Hans Mayer en Ernst Bloch, joden en neo-marxisten, behoorden tot de belangrijkste adviseurs van de naoorlogse festivalleiding. Winifred Wagner wordt geïntroduceerd als een ooggetuige van deze epoche. Daarna is het woord aan de geportretteerde zelf.

De oude dame betreedt het vertrek. Ze werpt een vluchtige blik op de cameraploeg, neemt plaats achter de tafel, schikt enkele papieren en begint te vertellen.

\subsection{Het verhaal van een vriendschap}

We vernemen dat Winifred Wagner-Williams in 1897 als dochter van een theaterrecensent en een actrice in het Engelse Hastings is geboren. Haar ouders, die beiden kort na de geboorte overleden, heeft ze nooit gekend. De kinderjaren bracht ze door in weeshuizen en pleeggezinnen. Rond haar tiende verhuisde ze naar Pruisen, waar ze werd opgenomen in het gezin van de pianopedagoog Karl Klindworth, een oude boezemvriend van Richard Wagner. "Het spreekt natuurlijk vanzelf, dat ik in het huis van Klindworth streng in de zin van Wagner

${ }^{22}$ Hierneis, Th., Ein Mundkoch erinnert sich an Ludwig II. Hrsg. H.J. Syberberg. z.p., 1972. 
en Bayreuth werd opgevoed," meent ze. In 1914 vergezelde ze haar pleegvader op een van diens bezoeken aan Wahnfried en bij deze gelegenheid leerde ze Siegfried Wagner kennen. "Ik ben dus halsoverkop op Siegfried verliefd geworden en merkwaardig genoeg was het vooral zijn stem, die me onvoorwaardelijk voor hem innam." Aan de eerste jaren na het huwelijk bewaart $z$ e uitsluitend goede herinneringen. Samen met de kinderen en schoonmoeder Cosima woonde het paar in de monumentale villa Wahnfried. Op loopafstand van de villa bevond zich het huis van haar zwager Houston Stewart Chamberlain, met wie ze overigens uitsluitend Duits sprak, want haar moedertaal was in kringen rond Cosima Wagner taboe. De dagen werden gevuld met wandelen, lezen, pianospelen en het bijwonen van de vele theekransjes van schoonmoeder Cosima, waar tal van beroemdheden hun opwachting maakten. Omdat Cosima Wagner vond dat de jonge vrouw iets omhanden moest hebben, nam ze Franse les en hielp ze de bedienden bij het afstoffen van de 'grote zaal'. Voor het slapengaan las ze haar schoonmoeder voor uit de wereldliteratuur en tijdens deze genoeglijke uurtjes samen ontdekte ze dat de hoogbejaarde dame, die wijd en zijd bekend stond om haar deftigheid, zowaar over een fikse dosis humor beschikte. Maar er werd sowieso veel gelachen in huize Wahnfried en het is met name deze sfeer van onbezorgde vrolijkheid, die haar uit die tijd het beste is bijgebleven.

Zo praat de vrouw door, tot na ongeveer tien minuten de eerste filmrol vol is (het aflopen van de rol wordt duidelijk zichtbaar in beeld gebracht) en haar enkele minuten pauze wordt gegund. Een bandrecorder die tijdens de rolwisseling blijft aanstaan, moet de kijker een indruk verschaffen van hetgeen tussentijds is besproken. Als een nieuwe filmrol is ingelegd, neemt ze de draad van haar verhaal opnieuw op en volgt, volgens een vast stramien dat tot het einde toe zal worden volgehouden, een nieuwe scène: eerst een totalshot van de vrouw achter de tafel, waarna de camera langzaam inzoomt tot een close-up van het vertellende gezicht. Gedurende vrijwel de gehele film spreekt ze met het gezicht gewend naar de camera - en hiermee naar de toeschouwer, die door Syberberg wordt gedwongen dit gezicht in het donker van de bioscoopzaal vijf uur lang gade te slaan. Het is een merkwaardige gewaarwording: vijf uur kijken naar een gezicht, dat toebehoort aan een wildvreemde, maar op den duur toch erg vertrouwd wordt. Natuurlijk gaat het om een optische illusie. Winifred Wagner kijkt niet ons aan; naar we mogen aannemen zoekt ze oogcontact met haar kleinzoon Gottfried, die haar tot dit avontuur heeft verleid en tijdens de opnamen ergens naast de camera heeft plaats genomen. Want Winifred Wagner wordt in deze film niet zozeer geportretteerd als de voormalige intendant van het Wagner-theater; veeleer zien we een grootmoeder, die zich met haar levensverhaal tot haar kleinzoon richt. Niet Winifred Wagner en de geschiedenis van het Wagner-festival is het onderwerp, maar Winifred Wagner en de geschiedenis van haar woonhuis - het domein van haar privé-leven. Het gevolg van deze invalshoek is, dat de film van meet af aan een sterk anekdotisch karakter heeft. Voor het overgrote deel gaat het om een aaneenrijging van particuliere herinneringen aan ogenschijnlijk onbeduidende voorvallen. Voor het inslapen dronk Cosima Wagner elke avond in bed nog een fles bier, weet de schoondochter zich te herinneren. En een papagaai, die ze in een belendend vertrek herbergde, schiep er zichtbaar genoegen in het klokken van het bier na te bootsen. Als de fles leeg was krijste het beest: goede nacht, goede nacht. Waarop Cosima Wagner, elke avond opnieuw, antwoordde: goede nacht, goede nacht.

Ook de stijl van interviewen werkt het anekdotische karakter in de hand. Af en toe wordt Winifred Wagner onderbroken door een vraag van de regisseur, maar kritisch wordt een dergelijke vraag zelden. Naar het zich laat aanzien, is Syberberg niet geïnteresseerd in de mogelijkheden van een kruisverhoor. Hij lijkt ervoor te hebben gekozen zijn gesprekspartner zoveel mogelijk de vrije hand te laten. Het meest in het oog springend is dan ook het ontbreken van een strakke regie. Veel meer dan de grootmoeder voor een draaiende camera te 

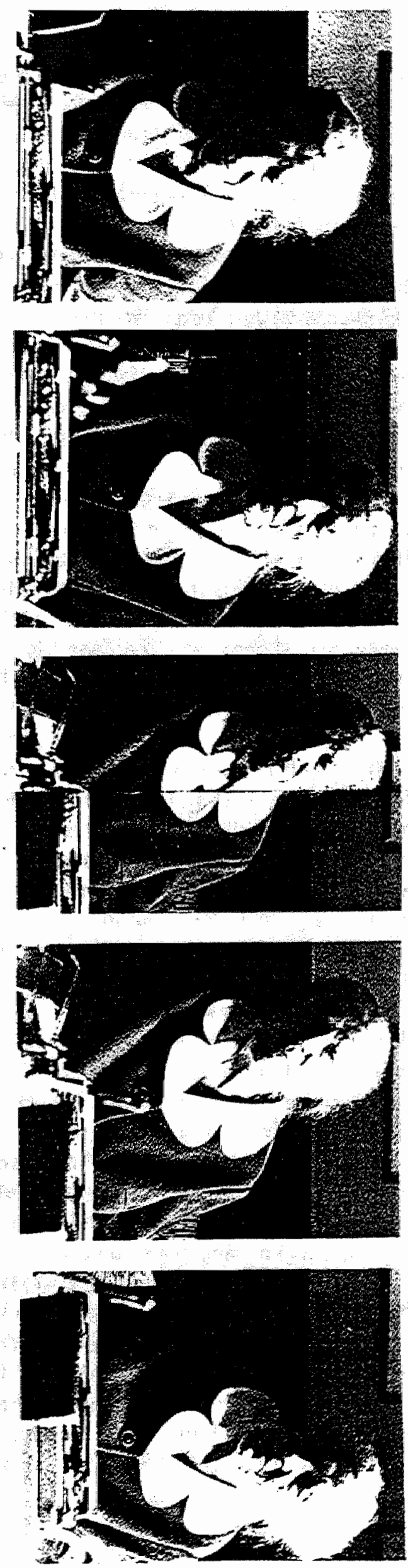
plaatsen, lijkt Syberberg niet te hebber gedaan. Met de chronologie van haar levensverhaal als rode draad mag Winifred Wagner vertellen wat in haar opkomt. En zoals een ghostwriter betaamt, houdt Syberberg zich vooral bezig met het optekenen van herinneringen. Zijn eigen inbreng blijft, zeker gedurende de eerste uren, beperkt tot enkele geschreven tussenkopjes, die het gesprokene op milde toon becommentariëren. Afgezien van deze tussenteksten wekt de film de indruk alsof er nauwelijks montage aan te pas is gekomen. Filmrollen zijn integraal achter elkaar geplakt in de volgorde waarin ze zijn opgenomen. Moeite om het materiaal thematisch te ordenen of bepaalde passages te schrappen heeft Syberberg niet genomen. Winifred Wagner und die Geschichte des Hauses Wahnfried is duidelijk het werk van een regisseur, wiens belangrijkste kwaliteiten niet schuilen in een vermogen zich tot het wezenlijke te beperken. Elk woord, hoe trivaal ook, elke zucht en elk gebaar van Winifred Wagner is op band vastgelegd en ook daadwerkelijk in de film opgenomen. En toch is het juist deze schroom om de coupeerschaar te hanteren, waaraan de documentaire zijn kracht ontleent. Vijf uur lang zitten we - letterlijk - oog in oog met een vrouw die worstelt met haar geschiedenis. En de uitputtende integrale registratie maakt het mogelijk deze worsteling van minuut tot minuut te volgen. We zien hoe de vrouw zich vergist, hoe ze twijfelt en een veelzeggende stilte laat vallen, zichzelf corrigeert, aarzelend zoekt naar het juiste woord, of teruggrijpt op iets dat eerder verteld is. "De spanning blijft er in omdat je wéét dat ze het zal moeten gaan hebben over haar verhouding met Hitler," merkt de Nederlandse cineast en filmcriticus Wim Verstappen scherp op. "Ze kan lang om de hete brij heendraaien, alle mogelijke achtergrondinformatie geven die het allemaal begrijpelijk maakt - het onderwerp komt tenslotte ter sprake, en als het een keer ter sprake is geweest, komt het telkens weer terug.",23

De naam van Hitler valt bijna terloops, nadat ruim negentig minuten zijn verstreken. En als de vrouw merkt dat de nieuwsgierigheid van de regisseur door deze naam wordt geprikkeld, reageert ze aanvankelijk terughoudend. "De grote belangstelling van de openbaarheid lijkt zich altijd maar weer te richten op onze relatie met Hitler," stelt ze misprijzend vast. Maar al snel weet ze haar minachting voor het onderwerp te overwinnen. Ze vertelt hoe ze Hitler in 1923 heeft leren kennen, toen hij als jonge politicus zijn eerste redevoering hield in Bayreuth. Bij het optreden zelf kon ze spijtig genoeg niet aanwezig zijn, maar na afloop vond een ontmoeting plaats ergens in de stad. "Ik moet eerlijk bekennen, dat ik direct een zeer grote en diepe indruk had van die man," vertrouwt ze haar interviewer toe. "Als persoonlijkheid, vooral zijn ogen waren enorm aantrekkelijk; volkomen blauw, grote expressieve ogen. En ik nodigde hem uit eens een keer naar Wahnfried te komen, omdat hij zich daar natuurlijk erg voor interesseerde, voor Wagners woning, voor Wagners graf, dat wilde hij graag zien." In de daaropvolgende jaren blijkt Hitler kind aan huis in de Wagnervilla te zijn geweest. Soms kwam hij alleen om het jaariijkse festival bij te wonen, maar wanneer zijn drukke rooster het ook maar enigszins toeliet bezocht hij de Groene Heuvel meerdere keren per jaar. Hier, in het voormalige woonhuis van de aanbeden Richard Wagner, kon hij zich na een periode van hard werken temidden van vrienden en geestverwanten ontspannen. En door de Wagners werd hij verwelkomd als een huisvriend, op wiens komst ze zich telkens weer verheugden. Winifred Wagner heeft hem in die jaren leren kennen als een innemende man, met gevoel voor humor. Een overtuigd vegetariër, die niettemin altijd bereid bleek voor een goed klaargemaakte Leberknödelsuppe naar oud Beiers recept een kleine zonde te begaan. Een gentleman, die vrouwen met veel egards tegemoet trad en, hoewel zijn omgeving dit afkeurde, hen gaarne de hand kuste. Een bevlogen wagneriaan ook, die zelf niet onverdienstelijk piano speelde, met regisseurs en decorontwerpers spontaan meedacht over

\footnotetext{
${ }^{23}$ Verstappen, W., De strijd om de leiding van de Wagner-dynastie. in: Skoop. 12 (december 1976) pp. 11-14, zie: p. 14.
} 
ensceneringsproblemen en zich aan de telefoon, bij wijze van grap, voorstelde als 'Kapellmeister Wolf'. "Want we hebben elkaar getutoyeerd," glimlacht ze. "Ik bedoel, ik heb hem Wolf genoemd en hij heeft me Wini genoemd. We hebben elkaar getutoyeerd en de kinderen hebben dit ook allemaal gedaan. Wolf hebben de kinderen hem genoemd. Ik denk, dat ik dat gerust mag toegeven. Ik bedoel, dat de kinderen hem Wolf hebben genoemd."

Over politiek blijkt Winifred Wagner het in al die jaren met haar vriend de politicus zelden of nooit te hebben gehad. "Daarover werd bij ons überhaupt niet gesproken," merkt ze streng op. "Ten hoogste verbaasd" was ze dan ook geweest, toen men haar tijdens het denazificatieproces voortdurend de politiek voor de voeten wierp. Ik heb toch geen politiek bedreven, had ze haar rechters voorgehouden. Maar die hadden allemaal gelachen: Natuurlijk heeft u politiek bedreven! Lieve hemel, mevrouw Wagner, men overstelpt u welhaast met emmers vol modder, zou de dirigent Wilhelm Furtwängler, die ook zelf gedenazificeerd moest worden, haar na afloop hebben toegefluisterd. Toch had het haar "allemaal koud gelaten". "En ik geloof dat het komt, door dat ik me in geen enkel opzicht aan een of ander vergrijp of misdaad schuldig voelde." Want ze had nu eenmaal geen politiek bedreven: "Ik ben een door en door a-politieke vrouw". Waarmee ze niet wil zeggen, dat ze een opponent van Hitlers politiek zou zijn geweest. Dat hij de jeugd opnieuw een doel in het leven gaf en aanspoorde op een gezonde manier met sport bezig te zijn, kan ze ook nu nog alleen maar toejuichen. En was het destijds niet gelukt de werkloosheid meester te worden? ${ }^{*} \mathrm{lk}$ denk dat, wanneer het nationaal-socialisme in zijn verfijnde vorm [Edelnationalsozialismus] zich zou hebben doorgezet, dit zeer zeker op brede instemming had kunnen rekenen. Waarom men niet ergens enthousiast voor zou mogen worden, begrijp ik niet." Maar haar vriendschap met Hitler had vooral een persoonlijk karakter en ze stelt er prijs op dat de regisseur dit goed in het oog houdt: er was sprake van een "zuiver menselijke, persoonlijke en vertrouwelijke band". Dit was overigens ook Hitlers standpunt. Hij kwam niet naar Wahnfried om over politiek te spreken, maar om de kinderen te zien en van het gezinsleven te genieten. "Hij was heel aandoenlijk met de kinderen, ging op alles in wat ze wilden. En de kinderen hebben hem eigenlijk beschouwd als een goede oom." Wieland Wagner, de naoorlogse leider van het Wagner-festival, was Hitlers oogappel: "Mijn zoon Wieland heeft hij boven alles gewaardeerd. (...) Dat leidde er bijvoorbeeld toe, dat hij bij het aanbreken van de oorlog Wieland van dienstplicht vrijstelde. (...) Hij wilde dat Wieland zich hier snel bij het festival zou inwerken."

Gedurende de laatste twee uur, begint de regisseur meer gericht vragen te stellen. Graag zou hij bijvoorbeeld nog eens van haar willen horen, waarom Winifred Wagner destijds zo door Hitler werd gefascineerd. Voor de jonge generatie is het moeilijk te begrijpen waarom de mensen destijds zo enthousiast waren, verduidelijkt hij. Nogal wat jongeren lachen tegenwoordig, wanneer ze archiefbeelden van Hitler bekijken. Maar men moet proberen deze beelden serieus te nemen. Men moet zich afvragen: waarom hebben de mensen destijds niet gelachen, maar deze man als hun leider geaccepteerd? ${ }^{24}$ De oude vrouw gaat er eens goed voor zitten. "Mijn God, u zou het precies zo zijn vergaan," vermoedt ze. Men hoeft alleen maar te denken aan de erbarmelijke toestand, waarin het land in de jaren direct na de Eerste Wereldoorlog verkeerde. De inflatie, de werkloosheid, het politieke geweld op straat, het gevaar van links, de vernederende vrede van Versailles... "En we mogen ook niet vergeten, dat binnen onze familie een zeer sterk Deutschbewußtsein voorhanden was. Mijn

\footnotetext{
24 "Ein heutiges Publikum," merkt Erwin Leiser op in de inleiding van zijn oorspronkelijk in 1968 verschenen studie Deutschland erwachel, "lacht an Stellen, wo man im Dritten Reich dem Bann der Propaganda erlag, und wird immer wieder die Frage stellen, wie es denn möglich war, daß man die Lügen nicht durchschaute. Aber nur zu oft bleibt einem das Lachen im Halse stecken". Leiser, E., Deutschland erwache! Propaganda im Film des Dritten Reiches. Hamburg, 1968, 1989. p. 14.
} 
man [Siegfried Wagner, G.G.] was totaal deutschbewußt, heeft mateloos onder de nederlaag van 1918 geleden en zocht overal contacten met mensen die bereid waren Duitsland weer op te bouwen." Maar het belangrijkste was Hitlers charisma. "Aan iemand die Hitler niet gekend heeft, kan men deze persoonlijkheid niet beschrijven," zegt ze nadenkend. "Dat kan men eenvoudig niet. Ik bedoel, woorden... net zo goed als ik bijvoorbeeld de prestatie van een zanger niet in woorden kan weergeven..., dat moet men domweg gehoord hebben. De uitstraling van een mens..., die is toch zo belangrijk. (...) Ik weet dat ik u teleurstel, maar... (...) Het was gewoon een absolute fascinatie..., een persoonlijkheid, zoals die heden ten dagen jammer genoeg nog maar zeer zelden voorkomt .... (...) Ik ben ook niet de enige, die erdoor in de ban is geraakt... U weet zelf, hoe het volk op hem heeft gereageerd!' Dat dit volk sinds de nederlaag niets meer met haar overleden vriend te maken wil hebben, behoort tot de grote raadsels van haar leven. Zelfs haar eigen familieleden, haar zonen Wieland en Wolfgang voorop, hebben van het ene op het andere moment met de 'goede oom' gebroken. Die man heeft voor mij afgedaan, had Wieland Wagner haar in 1945 plotsklaps laten weten. Alleen zij, een van geboorte Engelse, is de Duitse leider haar leven lang trouw gebleven. "Wij, oude nationaal-socialisten, hebben na de oorlog een nieuwe schuilnaam voor hem bedacht, omdat we in het openbaar niet langer over hem konden spreken. Wanneer we het over hem hadden, noemden we hem USA. Dat betekent in het Duits: Unser Seliger Adolf."

De beroemde woorden - misschien wel de meest beroemde uit Syberbergs gehele oeuvre - vallen als de film bijna is afgelopen. "Verloochenen zal ik mijn vriendschap met hem [Hitler, G.G.] nooit, dat kan ik niet," merkt Winifred Wagner op. "Weet u, ik ben in staat (...) de Hitler die ik heb gekend volkomen te scheiden van al datgene wat men hem tegenwoordig allemaal ten laste legt." Syberberg: "Kan men dat?" Winifred Wagner: "Ik kan het nu eenmaal. Ik kan het! Ik bedoel, al het andere betreur ik ten zeerste. Dat betreur ik. Maar voor mijn persoonlijke band maakt dat geen verschil. Dat deel van hem, dat ik ken, waardeer ik ook tegenwoordig nog, net als vroeger. En die totaal af te wijzen Hitler bestaat voor mij innerlijk niet, omdat ik hem zo nooit heb gekend. Begrijpt u...? Ik bedoel, mijn relatie met hem was strikt persoonlijk. Dat wil zeggen... aangenomen dat Gottfried hier nu vandaan zou gaan en, weet ik wat, een of ander meisje zou afslachten en begraven, enzovoorts, enzovoorts... dat zou mijn relatie met hem in het geheel niet verstoren." Syberberg: "Grootmoeder-kleinzoon-relatie." Winifred Wagner: "Ik bedoel, ik zou me kunnen voorstellen, dat er familieleden zijn, die zeggen: die wijzen we af, met die willen we niets meer te maken hebben, enzovoorts. Maar dat is iets, dat er bij mij domweg niet in wil. Ik weet niet hoe ik dat moet uitleggen, het is misschien onbegrijpelijk, maar het is nu eenmaal zo. Wanneer bijvoorbeeld Hitler hier vandaag door de deur naar binnen zou komen, dan zou ik net zo vrolijk en net zo gelukkig zijn als altijd om hem hier te zien en weer bij ons te hebben. De duistere kant van zijn persoonlijkheid... ik weet dat die bestaat, maar voor mij bestaat die niet, omdat ik die kant niet ken. Weet $u$, voor mij telt in een relatie met een mens enkel de persoonlijke ervaring... de strikt persoonlijke ervaring. Maar dat zal misschien voor altijd onbegrijpelijk blijven." Syberberg: "Nu neemt dat bij Hitler echter reusachtige dimensies aan... het gaat hier immers beslist niet om een individu... om een machtige die zich vergist heeft... zoals in het aristocratisch-monarchistische tijdperk een oorlog tevergeefs..." Winifred Wagner: "Dat zie ik ook wel in... De wereld is veranderd... de hele wereld... Zeker." Syberberg: "Duitsland is gedeeld... Duitsland is geruïneerd... Maar u permitteert zich daardoor uiteraard een ongelooflijke luxe... de persoonlijke luxe van het hart." Winifred Wagner: "Wel, dat moet u aan een dieptepsycholoog overlaten... ik bedoel, zelfs wanneer het raadselachtig voor de eventuele toeschouwer blijft... laat het dat dan blijven, in Godsnaam. Ik bedoel, ik kan het zelf niet verklaren... Ik weet niet, of $\mathrm{u}$ dat begrijpt... maar ik ben op de keper beschouwd een waanzinnig trouw persoon. Dat zal 
iedereen, die me kent, beamen. Wanneer ik eenmaal voor een mens genegenheid koester, dan blijft dat zo in voor- en tegenspoed. Ik bedoel, dan blijf ik hem steunen. Ik keur zijn wandaden niet goed, maar zeg: die verstoren mijn verhouding met hem niet. Dat kan ik volkomen van elkaar scheiden." Syberberg: "Heeft u destijds ook met hem gediscussieerd over dat jodenvraagstuk?" Winifred Wagner: "Met hem nooit. We hebben het nooit over dit soort dingen gehad... daarvoor heb ik me, eerlijk gezegd, niet competent genoeg gevoeld..."

\subsection{Emotionele zelfuerminking}

Eén persoon zou hij graag eens ontmoeten, schreef de Britse overste Spottíswood, de commandant van het militaire district Münster, in december 1945. Namelijk een nazi, die uitkomt voor zijn overtuigingen. Weliswaar hadden hij en zijn officieren inmiddels een groot aantal voormalige partijleden ontmoet. Maar al deze brave mannen en vrouwen waren uitsluitend lid geworden, omdat ze voor hun gezimnen moesten zorgen en ook na de nationaal-socialistische machtsovername hun banen niet wilden verliezen. Naar verluidt had geen van hen ooit in Hitlers politiek geloofd of deze zelfs maar goedgekeurd. ${ }^{25}$ Dertig jaar later gaat de wens van de Britse overste alsnog in vervulling. "We kunnen gerust stellen, dat we iets dergelijks tot dusver niet te zien hebben gekregen," meent de Duitse cultuursocioloog Nicolaus Sombart (1975) in een van de eerste besprekingen van Syberbergs film. "Hier wordt een ongeretoucheerde close-up geboden van een echte nazi (...). Zoals we [echter] sinds 30 jaar weten, bestaan de nazi's überhaupt niet. En mochten ze bestaan, dan hebben ze zich verstopt." 26

De film gaat begin juli 1975 in prémiere, tijdens een speciaal rond Syberbergs werk georganiseerd festival in de Parijse Cinémathèque. Enkele dagen later publiceert het weekblad Die Zeit onder de kop De goede oom van Bayreuth een bloemlezing van Winifred Wagners uitspraken, ${ }^{27}$ die voor grote opschudding zorgt in de Westduitse media. ${ }^{28}$ In Bayreuth ziet haar opvolger Wolfgang Wagner zich genoodzaakt alsnog afstand van de film te nemen. Hij heeft een eerste, nog ongemonteerde versie nauwlettend bestudeerd en "niet oninteressant" bevonden, laat de zoon tijdens een inderhaast bijeengeroepen persconferentie weten. Wel vond hij het jammer, dat de regisseur niet dieper is ingegaan op de geschiedenis van het festival, die zijn moeder sinds 1914 van nabij heeft meegemaakt. In plaats daarvan zou een film zijn ontstaan, die "voor 75 procent geklets over Adolf Hitler bevat". Goed, ook hij is zich terdege ervan bewust, dat zijn moeder met haar ondoordachte vitlatingen hiertoe zelf alle aanleiding heeft gegeven. Graag zou hij echter nog eens willen benadrukken, dat Winifred Wagner zich in 1949 volledig uit het festivalbedrijf heeft teruggetrokken. En om eventuele misverstanden te vermijden, heeft hij de vrouw inmiddels de toegang tot het Festspielhaus ontzegd. Begrijp hem niet verkeerd; hij wil zijn moeder beslist niet "muilkorven". Maar het politieke rumoer dat ze met haar uitlatingen heeft opgeroepen, laat

\footnotetext{
${ }^{25}$ Benz, W., Stumme Verweigerung. Deutschland unter allierter Besatzung 1945 bis 1949. in: Spiegel Special. Die Deutschen nach der Stunde Null 1945-1949. 4 (1995). pp. 121-124, zie: 122.

${ }^{26}$ Sombart, N., Besuch bei der alten Dame. Zum Dokumentarfilm über Winifred Wagner. in: Merkur. 12 (1975). pp. $1166-1173$, zie: 1166.

${ }^{27}$ Donner, W., Der gute Onkel von Bayreuth. in: Die Zeit. 18-07-1975.

${ }^{28}$ Wirbel um offene Worte Winifreds. Film-Bekenntnisse gerieten in politisches Zwielicht. in: Richard Wagner. Ein deutsches Thema. Eine Dokumentation zur Wirkungsgeschichte Richard Wagners (1876-1976). Hrsg. H. Zelinsky. Berlin, 1976, 1983. p. 273.
} 
hem geen andere keus. "Sinds 1951 [het jaar van de heropening van het festival, G.G.] is de politiek hier in het Festspielhaus weggevaagd." 29

Voor Syberberg komt met het schandaal eindelijk de langverwachte doorbraak in eigen land. Voor het eerst weet een film van zijn hand de weg naar een breed publiek te vinden. En de (West-)Duitse kritiek is opvallend mild gestemd. Vrijwell unaniem zijn critici van mening, dat de importantie van Syberbergs documentaire het actuele schandaal verre overstijgt. Natuurlijk: "Weerzinwekkend is (..) opnieuw alles, wat van Syberberg zelf afkomstig is," meent de filmcriticus Winfried Günther (1976). "Dat wil zeggen het geleuter in het begin (...), dat als het Orakel van Delphi over de toeschouwer komt en grotendeels bestaat uit een onzinnige verzameling als diepzinnig gepresenteerde platitudes (...). Syberbergs vragen zijn veelal buitengewoon pijnlijk (...). Hetzelfde geldt voor het merendeel van de tussenteksten, die door Syberberg als commentaar door de film heen zijn gemonteerd." Maar ook hij kan niet ontkennen, dat dit warhoofd er nu eens voor de verandering in is geslaagd een werk af te leveren, dat op zijn minst de moeite van het bekijken waard is - alle "typisch syberbergiaanse gebabbel" ten spijt: "De kwaliteit van de documentaire schuilt hierin (...), dat uit de massa van op zichzelf genomen onbeduidende details (...) familiegeschiedenis als sociale geschiedenis ontstaat. Ontwikkelingen en gebeurtenissen van deze eeuw worden hier nu eens werkelijk navoelbaar en begrijpbaar." En Nicolaus Sombart, die onder meer bekendheid geniet als auteur van enkele psychoanalytische studies over het gedachtegoed van conservatieve intellectuelen als Carl Schmitt, Ernst Jünger en (zijn vader) Werner Sombart, spreekt zelfs over "een toetssteen voor het historisch-culturele zelfbegrip van de Duitsers" - "Wat een thema! Voor een ieder, die zich ook maar enigszins voor actuele Duitse geschiedenis interesseert (...) is de rijkdom aan associaties ronduit overweldigend,"31

Het essay van Sombart is in hoge mate typerend voor de richting die de kritiek in de daarop volgende jaren zal nemen. Winifred Wagners verzoek in de film om de analyse van haar karakter 'over te laten aan een dieptepsycholoog' (zie hierboven), moet op critici de uitwerking te hebben gehad van een rode lap op een stier. Want van meet af aan hebben de commentaren veel weg van dieptepsychologische duidingen. "De verbitterde onthouding van - men zou kunnen zeggen: elk overtollig menselijk gevoel - tekent het gezicht van de oude vrouw, die men vijf uur voor zich ziet," observeert Sombart, die op dit terrein een reputatie heeft hoog te houden. ${ }^{32}$ En de sleutel tot deze, zoals hij het noemt, "verkommering" en "verharding", van haar karakter, denkt de culturursocioloog te hebben gevonden in het sociale assimilatieproces, dat Winifred Wagner sinds haar kinderjaren heeft doorgemaakt: van een naïef, vrijwel ongeletterd weesmeisje van Engelse komaf tot een vastberaden en tiranniek familiehoofd, een bazige moeder en grootmoeder en een bekwame zakenvrouw.

Een makkelijk leven zal ze niet hebben gehad, vermoedt Sombart. Als een volstrekt onbekende jonge vrouw van amper achttien kwam ze terecht in een bij uitstek patriarchale familie, die tot in het arrogante van haar eigen traditie en betekenis was doordrongen. $\mathrm{Ze}$ moest worden ingewijd in de riten van de cultus en de duistere geheimen van dynastie. Want kent niet elke dynastie haar duistere geheimen? Het geheim van de Wagner-dynastie betrof de seksuele geaardheid van festivalleider Siegfried Wagner. Om de erfopvolging veilig te stellen had Wagners zoon zich bereid getoond met de bijna dertig jaar jongere Winifred in het

\footnotetext{
${ }^{29}$ Pressekonferenz mit Wolfgang Wagner. in: idem, p. 272. Voor Wolfgang Wagners visie op de documentaire, zie eveneens: Wagner, W., Lebens-Akte. München, 1994, 1997.p. 424ff.

${ }^{30}$ Günther, W., Winifred Wagner und die Geschichte des Hauses Wahnfried von 1914-75. in: Medium. 6 (mei 1976) pp. 32-33.

${ }^{31}$ Sombart, a.w, p. 1166.

32 idem, a.w., p. 1171.

${ }^{33}$ ibidem.
} 
huwelijk te treden. Alom was echter bekend dat de seksuele voorkeur van de festivalleider veeleer uitging naar het eigen geslacht. En van zijn jonge echtgenote werd verwacht, dat ze dit publieke geheim weliswaar kende, maar er in het belang van het festival "aan voorbij keek". Om een dergelijk assimilatieproces succesvoll te doorlopen, zoals Winifred WilliamsKlindworth heeft gedaan, is meer vereist dan enkel een "Pruisisch-puriteins-Kantiaans plichtsbewustzijn", diagnosticeert Sombart: "Daartoe behoort ook karaktersterkte en een hardheid, die slechts daardoor verkregen kan worden dat men brede registers van zijn gevoel en elke twijfel in zichzelf rigoureus uitroeit. De zich aldus in een proces van zelfverminking vormende persoonlijkheidsstructuur, die het mogelijk maakt het bedenkelijke of het schandaal in eigen huis niet te zien - of in de taal van de sociale laag en de tijd, de schande soeverein te ignoreren - kwalificeert in hoge mate voor de uitoefening van macht" ${ }^{34}$

Het is deze emotionele 'zelfverminking', waarvan Sombart de sporen in het gezicht van de bejaarde dame meent te bespeuren. Wanneer men een adolescent traint cruciale karakterfouten bij een naaste over het hoofd te zien, wordt dit 'weg-kunnen-kijken' op den duur tot een gewoonte, die het mogelijk maakt ook in de omgang met anderen de ogen te sluiten voor 'de donkere zijde' van iemands karakter. Of anders geformuleerd: dezelfde persoonlijkheidsstructuur, die het haar indertijd mogelijk maakte succesvol te integreren in een masculiene gemeenschap, maakte haar tevens blind voor Hitlers keerzijde en staat na de ineenstorting van het oude Bayreuth een herbezinning in de weg. Koppig houdt ze vast aan haar eigen Hitler-beeld en weet ze het allemaal beter dan alle denazificatierechtbanken en historische onderzoeken bij elkaar. In deze halsstarrigheid, peinst Sombart, heeft ze wel iets weg van een doorleefde boerin, die verbeten om haar kroost en erf vecht; een bikkelharde vrouw "(...) voor wie een ieder, die niet tot de clan behoort, een potentiële vijand is en die om de dooie dood niet het geheim zal prijsgeven, dat zij alleen nog kent. Dan lacht ze alleen maar honend, als ze merkt, dat iemand zo dom kan zijn te menen, dat hij het haar zou kunnen ontfutselen". 35

Toch moeten we ons ervoor hoeden niet dezelfde fout te maken als Winifred Wagner, door ervan uit te gaan dat haar beeld van Hitler louter op zelfbedrog zou berusten. In de naoorlogse collectieve herinnering mag dan de 'duistere kant' van zijn persoonlijkheid meer gewicht in de schaal leggen; dit neemt niet weg, betoogt Sombart, dat Hitler wel degelijk ook de 'goede oom' was, die Winifred Wagner denkt te hebben gekend - een innemende man, die naar de Groene Heuvel kwam om van het gezinsleven te genieten en de kinderen te zien. Uitvoerig staat Sombart stil bij Hitlers relatie met de beide zonen. Voor de gevoelsarme moeder waren de zonen hooguit een managementprobleem: de jongens moesten worden klaargestoomd om in de toekomst de fakkel in Bayreuth over te nemen. Hitler, daarentegen, moet met name de oudste zoon, Wieland Wagner, boven alles lief hebben gehad. Op gezette tijden schonk hij zijn Wini een grote bos rode rozen - echter steeds op dagen die voor de oudste zoon belangrijk waren: eindexamen, communie, huwelijk. Hoogstpersoonlijk droeg de opperbevelhebber van de Duitse strijdkrachten er zorg voor, dat zijn oogappel van dienstplicht werd vrijgesteld. En als de vrouw des huizes zich na middernacht in haar slaapvertrek terugtrok, zat de Kapellmeister nog, niet zelden tot in het ochtendgloren, met Wieland rond de piano, om met hem te fantaseren over de toekomst van het festival nà de oorlog - zoals hij met de jonge Albert Speer urenlang, over pompeuze gipsmodellen gebogen, kon fantaseren over de toekomstige stedenbouwkundige vormgeving van Berlijn, München of Parijs. Het is, kortom, de Hitler uit Speers memoires, die we in deze filmmemoires van de voormalige festivalleidster opnieuw tegenkomen: "De gemankeerde kunstenaar [verhinderter Künstler], de hartstochtelijke architect en megalomaan die, verdwaald in de politiek en totaal

\footnotetext{
${ }^{34}$ idem, pp. $1168 \mathrm{f}$.

${ }^{35}$ idem, pp. $1169 f, 1172$.
} 
vereenzaamd aan de top van de macht, dweept met jonge mensen, die hij tot zijn volgelingen, leerlingen, aangenomen zonen maakt, omdat hij hoopt dat ze onder zijn invloed het artistieke werk tot stand zullen brengen, waarvan hemzelf het te scheppen nooit was vergund. Het gaat hier om misschien wel de meest extreme vorm van een schizofreme splitsing van een persoonlijkheid in enerzijds een kunstenaar en anderzijds een politicus, die berust op de scheiding tussen kunst en politiek - een wereld van de innerlijkheid en een wereld van de uiterlijke beslommeringen (... $)^{36}$

Er is weinig twijfel over mogelijk, vervolgt Sombart, dat van deze twee innerlijk verscheurde boezemvrienden, niet zij - de intendant van het Wagner-theater -, maar hij - de politicus tegen wil en dank - de feitelijke kunstenaar was. Wat de Kapellmeister adoreerde in de oudste zoon, moet de emotioneel rigide moeder op haar beurt hebben aanbeden in haar vriend Wolf: de muzische mens. Sombart gaat in dit verband nog een stap verder. Deze bazige vrouw, die zich zo voortreffelijk in een masculiene wereld had weten staande te houden, ja zelfs erin geslaagd was alle mannen in haar omgeving te overvleugelen, gedroeg zich in haar omgang met Hitler geheel als man. Haar verhouding met Wolf vertoont alle kenmerken van een mannenvriendschap: kameraadschap, trouw, loyaliteit tot in de dood. In haar bijzijn was Hitler de vrouw - muzisch, humeurig, emotioneel, zweverig. Of beter: in haar bijzijn kon de gemankeerde kunstenaar de vrouwelijke kant van zijn schizofrene persoonlijkheid volledig tot uiting laten komen, omdat hij wist dat zijn niet minder schizofrene vriendin de andere kant niet wilde leren kennen. "Het vermoeden is dan ook gerechtvaardigd, dat deze, in een mannelijke heersersrol gedrongen, volstrekt masculiene persoonlijkheid in de 'polymorf perverse' Hitler een complementaire figuur heeft gevonden, die een heuse libidineuze fixatie teweeg bracht.,"37

Maar hoe je 't ook wendt of keert, rondt Sombart af: zeker is dat Syberbergs bedoelingen met deze film geen hout snijden. De documentairemaker probeert ons ervan te overtuigen, dat het werk van Wagner ideologisch met het nationaal-socialisme verwant was Bayreuth als de culturhistorische schakel tussen het Tweede en het Derde Duitse Rijk. In plaats daarvan verlaat je echter de bioscoop in de overtuiging, dat "de buitengewone vriendschap tussen deze twee lieden met de muziek van Wagner evenmin iets te maken had als met het nationaal-socialisme". Wagners muziek en de nazi-beweging vormden hooguit het historische decor, tegen de achtergrond waarvan de vriendschap zich afspeelde. Natuurlijk: in hun eigen ogen waren Wini en Wolf nationaal-socialisten én wagnerianen in hart en nieren. Maar door zijn nationaal-socialistische kameraden werd het gedweep van de Führer met Wagners complexe muziek amper begrepen. Zoals een rechtgeaarde wagneriaan als Thomas Mann amper begrip kon opbrengen voor het gedweep van de festivalleidster met het nationaal-socialisme. Het Wagner-beeld van dit illustere vriendenpaar was de "geannexeerde, mishandelde en vervalste" Wagner, die de goegemeente van het oude Bayreuth tegen "het geniale Wagner-beeld" van Thomas Mann in bescherming had menen te moeten nemen. En het meest shockerende van deze film is dan ook niet, concludeert Sombart, het onvermogen van een koppige bejaarde om afstand te nemen van haar nazi-verleden. Het meest shockerende is " $(. .$.$) de totale Wagner-vreemdheid van de vrouw, die decennia lang Wagners$ erfenis heeft beheerd. 'Absoluut' is het woord, dat het meest vaak in de film voorkomt."

\footnotetext{
${ }^{36}$ idem, pp. 1169-1171

${ }^{37}$ idem, p. 1171.

${ }^{38}$ idem, p. $1172 \mathrm{f}$.
} 


\subsection{Uitgeroeide gevoelens en groteske trouw}

Alvorens over te gaan naar de Angelsaksische receptie, lijkt het me van belang eerst een korte opmerking te maken over de vorm van de commentaren van Thomas Elsaesser, Russell Berman, John Sandford en Eric Santner. Deze hebben stuk voor stuk het karakter van overzichtsartikelen, waarin een beeld wordt geschetst van Syberbergs ontwikkeling vanaf de eerste filmexperimenten in de jaren ' 50 (Brecht) tot het werk dat doorgaans wordt gezien als zijn magnum opus: Hitler, ein Film aus Deutschland (1977). Het mag tekenend worden genoemd voor de mate, waarin buitenlandse auteurs jarenlang de serieuze Syberberg-receptie hebben gedomineerd, dat dit soort overzichtsartikelen in het Duits ontbreken. In de regel overstijgt de Duitse receptie nauwelijks het niveau van krantenartikelen. Beschouwingen met een diepgang als het essay van Sombart, die vanuit zijn eigen persoonlijke onderzoeksbelangstelling over de film schrijft (dat wil zeggen: de plaats van het Conservatief Revolutionaire gedachtegoed binnen de cultuur- en mentaliteitshistorische context van een opkomend matriarchaat in een masculiene samenlevingorde ${ }^{39}$ ), zijn in het Duitse debat een zeldzame uitzondering. Terwijl omgekeerd in het buitenlandse debat natuurlijk wel tal van stukken bestaan, die zich beperken tot een analyse van deze ene film. Maar deze behoren weer niet tot de teksten, die de aan de afdeling Duitslandstudies van de Universiteit van Chicago verbonden literatuurwetenschapper Eric Santner (1990) terecht "de meest belangrijke essays over Syberberg in het Engels" noemt. ${ }^{40}$

Het op een na oudste van deze essays is Thomas Elsaessers invloedrijke Myth as the Phantasmagoria of History: H.J. Syberberg, Cinema and Representation (1982). Beperken we ons tot wat deze hoogleraar film- en televisiestudies aan de Universiteit van Amsterdam te berde brengt over de Winifred-Wagner-documentaire, dan is het opmerkelijk hoe weinig zijn analyse inhoudelijk van die van Sombart verschilt. "De film", merkt Elsaesser op, "is veelvuldig geïnterpreteerd als een poging te laten zien, dat Wagners werk is gecompromitteerd door zijn associatie met het nationaal-socialisme - een bezoedeling die haar symbolische expressie heeft gevonden in de vriendschap tussen Winifred Wagner en Hitler. (...) Binnen de context van Syberbergs Duitse Trilogie [Ludwig, May, Hitler, G.G.] als een geheel, echter, is de documentaire veeleer een essay, waarin wordt geprobeerd inzichtelijk te maken dat deze vriendschap (...) op haar beurt was gebaseerd op een veelzeggende splitsing - een systeem van repressies, compensaties, libidineuze fixaties en ontkenning." De maanzieke Wagner-mecenas uit Ludwig, de faustiaanse colportageschrijver uit Karl May en de Kapellmeister uit deze filmmemoires hebben, redeneert Elsaesser, vooral één ding met elkaar gemeenschappelijk: alledrie deze historische figuren belichamen in hoge mate het type van de artiste manque of verhinderter Künstler. Als gemankeerde kunstenaar werd Hitler geboeid door de muziek van Wagner, zoals hij eveneens gefascineerd was door ensceneringsproblemen, projectie, decor, architectuur, stedenbouw, transporttechnologieën en de massamedia. Toch blijkt ook Elsaesser tijdens het bekijken van de film ervan overtuigd te zijn geraakt, dat Wagner binnen de vriendschap met de festivalleidster hooguit een "secundaire rol" heeft gespeeld. Weliswaar fungeerden Bayreuth en de Wagner-cultus als een "extern raamwerk" en als "rationalisatie". Maar de vriendschap zelf was, zoals de documentaire volgens Elsaesser overtuigend laat zien, op iets volstrekt anders gebaseerd:

\footnotetext{
${ }^{39}$ Zie bijwoorbeeld: Sombart, N., Die deutschen Männer und ihre Feinde. Carl Schmitt - ein deutsches Schicksal zwischen Männerbund und Matriachatsmythos. München, Wien, 1991.

${ }^{40}$ Santner, E. L., Stranded Objects. Mourning, Memory, and Film in Postwar Germany. Ithaca, London, 1990.

p. 185. Tot deze essays rekent Santner: Susan Sontag (1980), Thomas Elsaesser (1981), Frederic Jameson

(1981), Timoty Corrigan (1983), Russell R. Berman (1984) en Anton Kaes (1989). Ik denk, dat we de twee essays over Syberberg, die Santner zelf op zijn naam heeft staan $(1990,1992)$ aan deze lijst mogen toevoegen.
} 
"Beiden herkenden bij de ander een eigenaardige en radicale splitsing tussen privé en politiek, en een discontinuïteit tussen 'persoonlijkheid' als een bewust aanvaarde rol en het handelingsterrein waarbinnen deze persoonlijkheid zichzelf manifesteerde".

Deze schizofrene "splitsing" is het meest evident bij Winifred Wagner. Niet enkel negeerde de vrouw willens en wetens wat haar vriend Wolf tijdens publieke optredens deed en zei; het lukte haar, vermoedt Elsaesser, vrijwel niet deze publieke Hitler überhaupt waar te nemen. En evenals Sombart zoekt de filmtheoreticus de sleutel tot Winifred Wagners emotionele rigiditeit in het assimilatieproces, dat ze sinds haar inhuwen moest doorlopen:

"(...) Haar leven lang was [ze] getraind om de zwakke plekken van mensen die dicht bij haar stonden niet te zien. Winifred had haar persoonlijke gevoelens verdrongen, uitgeroeid, met het doel de publieke representant te worden van het private, de familie Wagner. In haar nabijheid kon Hitler op zijn beurt geheel privé zijn, omdat hij wist dat zij alles wat politiek was negeerde. Zijn private zelf, de verdrongen kunstenaar, de dilettant, de performer, de impotente stichter van een dynastie van kunstenaars (Speer, Goebbels en anderen) vond in de familie Wagner, en dan vooral in Winifreds zonen, een traditie van artistieke en huiselijke cultuur (...). Zoals Hitler in Wagner de retoricus, de performer-kunstenaar, de magiër van de wil bewonderde, zo aanbad hij Winifred en makte hij haar het hof als de moeder van kunstenaars, die hem een familie verschafte (...) en de ruimte bood de zwakke, impulsieve, kinderlijke rol in deze relatie op zich te nemen." 41

Origineler dan Elsaesser is de Amerikaanse literatuurwetenschapper Russell R. Berman, die in zijn in 1984 gepubliceerde essay Hans-Jürgen Syberberg. Of Fantastic and Magical Worlds twee-en-een-halve pagina's aan de documentaire wijdt. Ook Berman vestigt de aandacht op de rigiditeit van Winifred Wagners karakter. Typerend voor het relaas van de oude vrouw is "de afwezigheid van elke vorm van zelfkritiek of onwil om het verleden te onderzoeken", hetgeen "een rigide vijandigheid jegens verandering en intolerantie ten opzichte van contradicties" zou verraden. De verklaring die Berman voor dit soort karaktertrekken aanreikt, verschilt echter opmerkelijk van die van Sombart en Elsaesser. De film wordt door hem geïnterpreteerd als een 'voortzetting' van het "onderzoek naar de onderlinge afhankelijkheid tussen de traditie van het wagnerianisme en het tot wasdom komen van het nationaal-socialisme", waarmee Syberberg in Ludwig-Requiem zou zijn begonnen. En anders dan Sombart en Elsaesser, ziet Berman dan ook wel degelijk een hoofdrol voor Wagner in deze documentaire weggelegd. Zonder de ideologische invloed van haar schoonvader, kan Winifred Wagners rigiditeit onmogelijk worden begrepen. "De motieven van loyaliteit, stabiliteit en trouw, waarop ze zich bewust beroept," stelt Berman, zonder verdere uitleg refererend aan Wagners essay Was ist Deutsch?, "maken deel uit van

\footnotetext{
${ }^{41}$ Elsaesser, Th., Myth as the Phantasmagoria of History: H.J. Syberberg, Cinema and Representation. in: New German Critique. 24-25 (Fall/Winter 1981-'82) pp. 108-154, zie: 130f. In het buitenlandse Syberberg-debat wordt de interpretatie van Elsaesser overgenomen door onder meer Anton Kaes. Het onderwerp van de documentaire, meent ook deze aan de universiteit van Berkeley docerende literatuurwetenschapper, is "de persoonlijke vriendschap tussen Wagners schoondochter en Hitler". En het interview zou getuigen van "Syberbergs belangstelling voor Hitler als mislukte kunstenaar, die in Winifred Wagners familie een soort substituut-thuis vond". Kaes, A., From Hitler to Heimat. The Return of History as Film. Cambridge, Mass., London, 1989. p. 228. Overigens komt Elsaesser zelf in zijn latere standaardwerk over de Nieuwe Duitse Cinema tot een iets andere interpretatie. De film, meent hij in deze studie, " $(. .$.$) is primarly the documentary of$ a person's ability' to create and live, all external evidence to the contrary, her life as a private, self-created fiction". Elsaesser, Th., New German Cinema. A History. London, 1989. p. 168. Helaas verzuimt Elsaesser deze interpretatie uit te werken.
} 
de wagneriaanse ideologische erfenis waarin het gezonde, het homogene en het zuivere de oppositie vormen van het vermengde, het gedifferentieerde en het veranderende,"

Maar Berman blijkt nog een andere verklaring voor de rigiditeit van de voormalige festivalleidster achter de hand te hebben. "Binnen de Westduitse context is haar uiting van ongeschokte loyaliteit ten opzichte van Hitler een zeldzame uitzondering," merkt de literatuurwetenschapper op. En het is vooral in deze "groteske" trouw, dat hij de ideologische invloed van Wagner vermoedt. "Echter," voegt hij hier aan toe, "haar onwil om, zoals ze het eufemistisch noemt, [Hitlers] 'donkere zijde' nauwkeurig te onderzoeken, is paradigmatisch." En Syberberg heeft met deze film dan ook meer afgeleverd dan enkel een studie over de onderlinge verhouding tussen het wagnerianisme en het nationaal-socialisme:

"Winifred representeert de oppositie tegen elke principiële verandering, en de film onderzoekt de relatie tussen een versteende visie op het verleden en de morbide stabiliteit van het heden. Door deze samenhang bloot te leggen, probeert Syberberg een rouwverwerking [ $a$ work of mourning] te initiëren - de confrontatie met het verleden, die noodzakelijk is voor een vrij leven in het heden. Hij [Syberberg, G.G.] beschrijft de film als 'een kwestie van het verbreken van een betovering met filmische middelen'. Het gaat om een psychobiografie van een conservatieve samenleving waarin voormalige tegenstanders van Hitler nog steeds met wantrouwen worden bejegend en Winifred beslist niet alleen staat met haar opvatting, dat het in dienst treden van Willy Brandt in het Noorse leger met het doel de nazi-agressie te weerstaan, een onvergeeflijke daad van verraad was. ${ }^{~}, 42$

\subsection{De rouwverwerking waar Alexander en Margarete Mitscherlich om vroegen}

Rouwverwerking. A work of mourning. Trauerarbeit. Met dit uit de klassiek freudiaanse psychoanalyse afkomstige begrip, dat ook door de filmer zelf wordt gebruikt om de inzet van zijn documentaire te typeren, zijn we reeds aangekomen bij de kern van de Angelsaksische Syberberg-receptie. Opmerkelijk is dat het in de originele Duitse versie van de documentaire, waarop Sombart zijn lezing baseert, nog ontbreekt. We komen het voor het eerst tegen in een sterk apologetisch getint essay in de bundel Syberbergs Filmbuch (1976). Zoals we zagen in paragraaf 3 heeft festivalleider Wolfgang Wagner niet lang na de Parijse prémiere afstand genomen van de film, die 'voor 75 procent geklets over Adolf Hitler' zou bevatten. En door te benadrukken, dat hij de festivalleiding slechts behulpzaam wilde zijn bij het verwerken van het verdrongen nazi-verleden, probeert Syberberg zijn film tegen de kritiek uit Bayreuth in bescherming te nemen: "Bayreuth heeft een schuldige gevonden. Analoog aan de aloude verdringingspatronen wordt de seismograaf schuldig bevonden aan de aardbeving. (...) Niet ik heb de geschiedenis van ons volk gemaakt. En het gras groeit daarover slechts zolang, tot het verwelkt. (...) Ik moet voor Bayreuth verwerken, wat Bayreuth alleen niet verwerken kan of wil (...). Het is zwaar werk. Trauerarbeit." 43

Vervolgens duikt het begrip eveneens op in de Amerikaanse versie, die op een aantal punten van de Duitse afwijkt. Zo blijkt de oorspronkelijke speelduur van 5 uur met eenderde te zijn ingekort. En de oorspronkelijke titel Winifred Wagner und die Geschichte des Hauses Wahnfried heeft plaats gemaakt voor The Confessions of Winifred Wagner. Nieuw zijn ook

\footnotetext{
${ }^{42}$ Berman, R.A., Hans-Jürgen Syberberg. Of Fantastic and Magical Worlds. in: New German Filmmakers. From Oberhausen through the 1970s. ed. K. Phillips. New York, 1984. pp. 359-378, zie: 369-371. Berman ontleent het citaat van Syberberg aan Filmbuch, a.w., p. 293.

${ }^{43}$ Syberberg, a.w., pp. 243-296, zie: $247,258,292$.
} 
enkele tussenteksten, waaronder een nogal plichtmatig aandoende verwijzing naar Hannah Arendt - Berman: "(...) Syberberg onderbouwt Hannah Arendts these van de banaliteit van het kwaad $(. .)^{\prime}$ " 44 En een tekst waarin het Amerikaanse publiek erop wordt geattendeerd, dat 'deze film deel uitmaakt van Hans Jürgen Syberbergs Trauerarbeit'. De tekst leest als een soort gebruiksaanwijzing en blijkt door het merendeel van de exegeten ook als zodanig te zijn begrepen. Sinds de apologie in Filmbuch en deze tussentekst is het in buitenlandse commentaren goed gebruik tenminste een keer het begrip 'rouwverwerking' te laten vallen, als "de sleutel tot Syberbergs concept van cinematografische vorm" (Thomas Elsaesser)." Of, in de woorden van Eric Santner: "Geen hedendaagse Duitse kunstenaar wordt meer consistent geassocieerd met de taak van het treuren dan de filmmaker Hans Jürgen Syberberg. Er bestaat geen belangrijk essay over Syberberg, waarin niet vroeg of laat het begrip Trauerarbeit wordt aangehaald, als de sleutel tot de metapsychologische onderbouwing van Syberbergs film-esthetiek en als een metafoor voor de esthetische en intellectuele arbeid, waartoe Syberberg zijn publiek met elke film opnieuw uitnodigt."46

Alom wordt aangenomen, dat Syberberg het begrip heeft ontleend aan een uit 1968 daterende bestseller van het links-geëngageerde psychiaterechtpaar Alexander en Margarete Mitscherlich, waaraan het inderdaad zijn halo aan bijbetekenissen op het terrein van Vergangenheitsbewältigung dankt: Die Unfähigkeit zu trauern. Terecht typeert Berman dit boek als een cultuurkritiek. Doorn in het oog van de Mitscherlichs, legt de literatuurwetenschapper uit, is het Duitse Wirtschaftswunder met zijn ongebreidelde consumentisme. ${ }^{47}$ En hun these is even innovatief als invloedrijk. ${ }^{48}$ Aan ogenschijnlijk rationele handelingen liggen voor de psychoanalyticus niet zelden minder rationele drijfveren ten gronde. Zo is het mogelijk dat de Duitsers na ' 45 zoveel tijd en energie investeerden in het bouwen huizen, omdat ze graag comfortabel wilden wonen en het land weer diende te worden opgebouwd. Maar evengoed kan de naoorlogse bouwlust zijn voortgevloeid uit een collectieve behoefte bepaalde zaken uit het verleden te vergeten. In dat geval zou het gedrag van de Duitsers wel eens vergelijkbaar kunnen zijn met dat van een minnaar, die na het overlijden van zijn geliefde vergetelheid zoekt in zijn werk: door zich met hart en ziel over te geven aan een of andere tijd- en energierovende bezigheid, bijvoorbeeld het bouwen van een nieuw huis, slaagt de minnaar erin het traumatische verlies tijdelijk uit zijn gedachten te verdringen. ${ }^{49}$

De geliefde waar het hier om gaat is niemand minder dan Adolf Hitler. Volgen we Alexander en Margarete Mitscherlich, dan had de relatie die de Duitse Leider onderhield met zijn miljoenen volgelingen veel weg een liefdesrelatie. Als charismatisch massa-idool was Hitler het object van de libidineuze fixaties van zijn volk. Uiteraard speelde dit nationale minnespel zich niet af tussen gelijkwaardige partners. De liefde van het Duitse volk had een

\footnotetext{
${ }^{44}$ Berman, a.w., p. 370.

${ }^{45}$ Elsaesser, Myth as the Phantasmagoria of history, a.w., p. 146.

${ }^{46}$ Santner, a.w., p. 103.

${ }^{47}$ Berman, a.w., pp. 377,378 .

48 Voor de invloed van de theorie van de Mitscherlichs op het debat over de Duitse omgang met het naziverleden, zie bijvoorbeeld: Wielenga, F., Schaduwen wan de Duitse geschiedenis. De omgang met het nazi-en DDR-verleden in de Bondsrepubliek Duitsland. Amsterdam, 1993. pp. 26ff. Alsmede: hoofdstuk 5, paragraaf 3. Tekenend voor de ongekende populariteit van deze psychoanalyse van het Duitse 'onvermogen om te rouwen' is ook de volgende anekdote van Ian Buruma. In The Wages of Guilt vertelt Buruma hoe hij in de zomer van ' 91 , een jaar na de eenwording, in Berlijn een lezing bijwoont van Margarete Mitscherlich: "Ik had een halflege zaal verwacht. Er stond echter een enorme rij van voornamelijk jonge mensen, tot aan het eind van de straat. Ze hadden wat weg van het publiek bij een rockconcert." Buruma, I., Het loon van de schuld. Herinneringen aan de

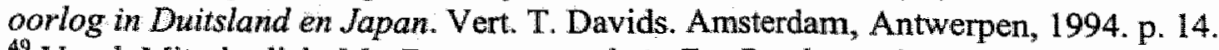

${ }^{49}$ Vergl. Mitscherlich, M., Erinnerungsarbeit. Zur Psychoanalyse der Unfähigkeit zu trauern. Frankfurt am Main, 1987. p. 25f.
} 
onvolwassen en narcistisch karakter. Evenals zijn ideologische rivaal Vadertje Stalin, werd Hitler aanbeden als een vaderfiguur. Voor zijn volgelingen gold hij als het grote voorbeeld een $\ddot{U b e r}$-Vater, die ze in hun dagelijkse leven imiteerden, zoals een zoon zijn vader imiteert. Eigen aan elke liefdesrelatie is de idealisering van het beminde object. De minnaar verheerlijkt zijn Laura, de zoon plaatst de vader op een voetstuk, het volk projecteert zijn dromen en idealen op de Über-Vater. In een onvolwassen en narcistische relatie zijn de scheidslijnen tussen het beeld van de beminde 'ander' en dat van het eigen 'ik' echter diffuus. Het object van de Duitse liefde was een geïdealiseerd zelfbeeld of 'ik-ideaal', dat op de $\ddot{C b e r-}$ Vater werd geprojecteerd - en via hem werd teruggeprojecteerd op het volk, dat als het ware aan een weerkaatsing van de eigen projectie zijn identiteit ontleende. In de persoon van Hitler werd het volk een met zichzelf. Hij was de ideale mens, hij was het volk en hij was Duitsland. $^{50}$ Maar aan deze Duitse eigenliefde kwam in 45 een abrupt einde. De C̈ber-Vater beroofde zich temidden van de rü̈nes van een verwoeste hoofdstad van het leven. Zijn imago werd door de geallieerde bezetter met terugwerkende kracht gecriminaliseerd. En je zou denken, redeneren de auteurs van Die Unfähigkeit zu trauern, dat een dergelijk traumatisch verlies ingrijpende consequenties moet hebben gehad voor de psychische gesteldheid van zijn (voormalige) bewonderaars.

In Trauer und Melancholie, een essay uit 1915 waarop de Mitscherlichs zich veelvuldig beroepen, maakte Freud een onderscheid tussen twee verschillende vormen van rouwverwerking. ${ }^{51}$ Rouw (Trauer) vindt plaats binnen een volwassen en gelijkwaardige relatie, bijvoorbeeld wanneer een minnaar zijn geliefde verliest. Een dergelijk verlies kan pijnlijk zijn, maar hoeft niet noodzakelijk gepaard te gaan met een traumatisch verlies van eigenwaarde. Onder normale omstandigheden identificeert een minnaar zich slechts gedeeltelijk met zijn geliefde, in de zin dat hun samenzijn het ego verrijkt. Of meer specifiek: een vreemd object neemt niet de plaats in van het eigen 'ik', dat in een volwassen en gelijkwaardige relatie zijn kritische functies behoudt. Geheel anders daarentegen liggen de zaken bij een onvolwassen en narcistische relatie, zoals die tussen de Duitsers en hun CberVater. Konden de "triomferende opponenten" van het Hitler-regime na het einde van de oorlog "de realiteit aanvaarden" en "de slachtoffers van deze oorlog betreuren" zonder zich "minder waardig [te hoeven] voelen" [ohne Entwertungsgefuhle]; de Duitsers werden, aldus de Mitscherlichs, door de ineenstorting van het Derde Rijk in "het centrum van hun eigenwaarde" getroffen. ${ }^{52}$ Zo ook, zouden we hier met de Mitscherlichs meedenkend aan kunnen toevoegen, de voormalige festivalleidster.

Het is zeker niet gering, wat deze vrouw in luttele jaren tijd te verwerken heeft gekregen. Als vriendin van Hitler en nationaal-socialiste van het eerste uur, als grande dame van het oude Bayreuth en als Duitse met een zeer sterk nationaal gevoel, ontleent ze haar gevoel van eigenwaarde en haar beeld van het zelf aan een reeks identificatie-objecten, die in 1945 zijn ten onder gegaan. Haar idool Hitler is gecriminaliseerd als misdadiger tegen de mensheid en haar nationaal-socialistische geloofsovertuiging bleek een mensonterende

\footnotetext{
${ }^{50}$ Mitscherlich, A., Mitscherlich, M., Die Unfähigkeit zu trauern. Grundlagen kollektiven Verhaltungs. München, 1967, 1990. pp. 71-77.

${ }^{51}$ Eigenlijk maakte Freud een onderscheid tussen drie vormen van rouw: normale rouw (rouwwerwerking), pathologische rouw (depressie) en melancholie. De melancholicus onderscheidt zich van de 'treurzieke' door een identificatie met het verloren object. Freud, S., Rouw en melancholie. in: Sigmund Freud - Nederlandse editie. Psychoanalytische theorie. (P.T.) 1. Amsterdam, 1985. 67-91. Zie eveneens: Laplanche, J., Pontalis J.B., Das Vokabular der Psychoanalyse. Übersetzt von E. Moersch. Frankfurt am Main, 1972, 1986. p. $512 \mathrm{f}$. Dit onderscheid is in de geschriften van de Mitscherlichs echter niet scherp. Melancholie en depressie worden gebruikt als synoniemen; Trauerarbeit oder Trauerkrankheit luidt de ondertitel van een essay van Margarete Mitscherlich in de bundel Erinnerungsarbeit, a.w., pp. $67 \mathrm{ff}$.

${ }^{52}$ Mitscherlich, Mitscherlich, a.w., p. 35. Zie eveneens: Mitscherlich, a.w., p. 121.
} 
dwaalleer te zijn. De oud-Bayreuther traditie, waarin ze is opgevoed en waaraan ze de beste jaren van haar leven heeft gewijd, lijkt door de verstrengeling met het Derde Rijk voorgoed te zijn geruineerd. En hetzelfde geldt, als we de Mitscherlichs mogen geloven; voor de Duitse traditie in het algemeen. ${ }^{53}$ Het Duitse nationale gevoel wordt overschaduwd door "de herinnering aan Auschwitz en Lidice". Weimar, kan een Duitser, die tot nuchter denken in staat is, nog slechts met gekromde tenen aan dit soort gevoelens terugdenken, wetend, waartoe ze hebben geleid en voor wie ze de weg hebben gebaand." 55

Hoe is het mogelijk, dat een vrouw als Winifred Wagner geen last heeft van gekromde tenen? Hoe kan zo iemand nog in de spiegel kijken, zonder vervuld te zijn van schaamte of in gewetensnood te geraken, ja zelfs "zonder teken van gekrenkte trots" - "als het ware niet pijnlijk in [haar] eer getroffen"? $?^{56}$ Dit is de vraag, die de auteurs van Die Unfähigkeit zu trauern met betrekking tot de Duitsers in het algemeen bovenal bezig houdt. Let wel: het gaat er niet enkel om, dat de vrouw zich voor haar verleden moet gêneren, of de haren uit het hoofd trekken van wroeging - al zou ze hiertoe natuurlijk wel alle redenen hebben. De psychische gevolgen van de ineenstorting van het Derde Rijk hadden vele malen ingrijpender moeten zijn. Wat een vrouw als Winifred Wagner is overkomen laat zich, althans binnen de theorie van de Mitscherlichs, misschien mog het beste omschrijven als een totale pervertering van de bronnen van haar identiteit. Van het ene moment op het andere heeft ze de grond onder haar voeten verloren - "de fundamenten van [haar] oriëntatie". ${ }^{57} \mathrm{Al}$ datgene wat haar een houvast bood, of waaruit ze levensvreugde en zelfrespect kon putten, is in één klap weggevaagd. Zo iemand zou eigenlijk een diepe identiteitscrisis moeten doormaken. Of, in het psychoanalytische jargon van Die Unfähigkeit zu trauern: er zou "een melancholische verarming van het zelf' moeten plaats vinden. ${ }^{58}$

Binnen de klassiek freudiaanse psychoanalyse is melancholie een pathologische variant van rouw - een "treurziekte" $[$ Trauerkrankheit $] .{ }^{59}$ De melancholicus heeft een verlies geleden, dat hem diep in zijn eigenwaarde krenkt en zijn zelfbeeld ondermijnt. Het verlies brengt 'een buitengewone kleinering van het ik-gevoel', een 'ik-verarming', of zelfs een totale 'ik-lediging' teweeg, hetgeen tot uiting komt in een ziekelijk, dwangmatige fixatie op het verlorene en extreme, 'manische' gevoelens van neerslachtigheid, treurnis, angst, schaamte, zelfhaat, wanhoop, woede. Maar een dergelijke melancholische reactie zou in het naoorlogse Duitsland zijn uitgebleven. "De Bondsrepubliek." luidt de werkhypothese van de Mitscherlichs, "is niet aan melancholie ten prooi gevallen (... $)$ "60 - hoewel dit wel degelijk “(...) voor een groot aantal mensen, de onontkoombare consequentie [had moeten zijn] van hun narcistische verliefdheid op de Führer en de met hun hulp gewetenloos gepleegd misdaden". ${ }^{61}$ Het Duitse antwoord op de onthullingen van de nazi-misdaden was daarentegen "een opvallende emotionele rigiditeit" [eine auffallende Gefühlsstarre] - een "quasistoïcijnse mentaliteit", die onmiskenbaar zou duiden op "emotionele afwending". 62

\footnotetext{
${ }^{53}$ Mitscherlich, Mitscherlich, a.w., pp. $20,21$.

s4 idem, p. 26.

55 Mitscherlich, a.w., p. 9.

${ }^{56}$ Mitscherlich, Mitscherlich, a.w., pp. $20 f, 26$.

57 idem, p. 21.

si idem, p. 35 .

${ }^{59}$ Mitscherlich, a.w., p. 67ff. Zie eveneens: Mitscherlich, Mitscherlich, a.w., p. 48, waar melancholie wordt omschreven als: "[eine] Pathologie der Trauer".

${ }^{60}$ Mitscherlich, Mitscherlich, a.w., pp. $37 \mathrm{f}$.

61 idem, p. 79

62 idem, p. 40 .
} 
Het achterwege blijven van een melancholische reactie wordt door de Mitscherlichs toegeschreven aan een onvermogen van de patiënt om de situatie waarin hij of zij zich bevindt te accepteren. In plaats van de realiteit "in een berouwvolle omarming" te aanvaarden, ${ }^{63}$ heeft de patiënt een subjectieve werkelijkheid gecreëerd, waarin schuld en verlies niet existeren. Of, opnieuw in het psychoanalytische jargon van Die Unfähigkeit zu trauern: met behulp van 'derealisatie-technieken' is ze het hem of haar gelukt gevoelens als schuld, schaamte, angst, of verdriet 'af te weren'. ${ }^{64}$ De belangrijkste van deze derealisatietechnieken is, zoals we zagen, de wederopbouwbedrijvigheid. Voor het ophalen van herinneringen aan het verleden bleef in de Adenauer-tijd amper tijd en energie over, druk doende als men was met het restaureren van het verwoeste nationale huis. Een ander, niet minder effectieve techniek, is de snelle en gemakzuchtige verwisseling van identiteiten (Identitätswechsel), dat wil zeggen de plotselinge identificatie met de slachtoffers van het nazi-regime en de geallieerde overwinnaars. ${ }^{65}$ Alsof hun trouw aan Hitler nooit veel om het lijf had gehad, wisselde het gros van de Duitsers van identiteit, zoals men een oude jas inruilt tegen een nieuwe. Door het historisch besef van de slachtoffers en de triomferende opponenten over te nemen, verschaften ze zichzelf een alibi. In plaats van, zoals een schuldige verliezer betaamt, "[de] dood en het lijden schuldig [Schuldhaft] te beleven en te betreuren", ${ }^{66}$ begonnen ze zichzelf met terugwerkende kracht te beschouwen als slachtoffers onder andere slachtoffers - ja zelfs niet zelden als de eigenlijke slachtoffers van deze oorlog. ("Projectie: 'Niet de anderen, maar wij waren de onschuldige slachtoffers'.") ${ }^{67}$ En als zodanig hoefden ze zich vanzelfsprekend niet schuldig te voelen. De Duitsers gingen zich na ' 45 hoofdzakelijk te buiten aan zelfbeklag. Van oprechte empathie met de slachtoffers van hun ideologische verblinding uit het verleden kon geen sprake zijn. Vele malen sterker dan de positieve identificatie met de slachtoffers, de bevrijders of de normen en waarden van de naoorlogse liberale democratie, was de afkeer van de oude Über-Vater. De idealisering van het idool van weleer sloeg om in een demonisering. En het kwaad werd geëxternaliseerd buiten het zelf gelokaliseerd. ${ }^{68}$

Nu behoeft het geen betoog, dat dit alles op een 'oude nationaal-socialiste' (haar eigen woorden) als Winifred Wagner slechts zeer ten dele van toepassing is. Als nazi behoort Winifred Wagner in het naoorlogse Duitsland tot een kleine minderheid, die zich van de meerderheid onderscheidt doordat ze hun "identiteit" hebben "behouden" en door de jaren heen trouw zijn gebleven aan een "nog altijd geîdealiseerde ideologie". Maar opdat hen dit lukt, zijn ze wel ertoe veroordeeld "de realiteit aanhoudend onder de paranoïde bevelen van de nationaal-socialistische ideologie te beschouwen". ${ }^{69}$ Voor deze voormalige festivalleidster lijkt de tijd stil te staan. Dertig jaar na het einde van de oorlog en tuim een decennium na het Eichmann-proces in Jeruzalem en de Duitse Auschwitz-processen, is Hitler in haar subjectieve beleving van de werkelijkheid nog steeds de 'goede oom'. (Verloochening) De 'duistere', onaangename zijde van Hitlers persoonlijkheid - ze 'weet dat het bestaat, maar voor haar bestaat het niet, omdat ze hem zo nooit heeft gekend'. Of in elk geval kan ze zich niet herinneren, hem zo ooit te hebben gekend. (Verdringing) En voor de gruweldaden van deze andere, haar onbekende Hitler, voelt ze zich dan ook in geen enkel opzicht verantwoordelijk'. Ze is 'in staat de Hitler, die ze heeft gekend, volkomen te scheiden van al datgene wat men hem tegenwoordig allemaal ten laste legt'. (Isolering) "Een dergelijke

\footnotetext{
63 idem, pp. 55

${ }^{64}$ idem, pp. $36 \mathrm{ff}, 58,44 \mathrm{ff}, 65,97$.

${ }^{65}$ idem, pp. $40 \mathrm{f}$. Zie eveneens." Mitscherlich, a.w., pp. 13ff, $37 \mathrm{ff}$.

${ }^{66}$ Mitscherlich, Mitscherlich, a.w., p. 59.

${ }^{67}$ Mitscherlich, a.w., p. 120.

${ }^{68}$ Mischerlich, Mitscherlich, a.w., p. 60.

${ }^{69}$ idem, $59,44 \mathrm{f}$.
} 
mentaliteit komt hierop neer," stellen de Mitscherlichs in hun studie met betrekking tot het naoorlogse Duitsland, "dat alleen passende fragmenten van het verleden tot de herinnering worden toegelaten. Alle gebeurtenissen waarmee we door eigen schuld verbonden zijn worden verloochend, of in hun betekenis omgeduid. De verantwoordelijkheid wordt afgeschoven, of in elk geval niet tijdens het opnieuw beleven in de herinnering aan de eigen identiteit vastgeknoopt. De zegerijke veldtochten worden verheerlijkt; aan de onverantwoordelijkheid, waarmee ook miljoenen Duitsers in een vlaag van grootheidswaan werden opgeofferd, wordt zelden nog gedacht. Deze splitsing tussen een aangename en een onaangename herinnering, vergt heel wat psychische energie. $" 70$

Goed, we mogen van de auteurs van Die Unfähigkeit zu trauern verzachtende omstandigheden laten gelden. Afweermechanismen, verduidelijken de Mitscherlichs, zijn heel normale psychische processen. Het gaat om onbewuste, in ons psychische apparaat geïntegreerde "beschermingsmechanismen" tegen driften, herinneringen, fantasieën, of bepaalde gebeurtenissen, die als onbehaaglijk worden ervaren en het innerlijke evenwicht dreigen te verstoren. Zonder zo'n psychisch kordon, dat in noodsituaties automatisch in werking treedt, zou ons ik niet kunnen overleven. ${ }^{71}$ Dat Winifred Wagner er weinig voor voelt de 'duistere', onaangename zijde van Hitlers persoonlijkheid te leren kennen, kan haar dan ook niet kwalijk worden genomen. Voor deze vrouw geldt iets soortgelijks als de Mitscherlichs opmerken over één van hun patiënten. Ze is geen "leugenaarster" of een "bedriegster", die "zich eruit probeert te praten". "Afweermechanismen laten zich nauwelijks bewust dirigeren." ${ }^{72}$ En de last van de schuld, waarmee schuldige verliezers als Winifred Wagner worden geconfronteerd, is zozeer onverenigbaar met een om te kunnen voortleven ontbeerlijk gevoel van eigenwaarde dat, zeker gedurende de eerste naoorlogse jaren, het afweren van de ervaringen van een melancholische verarming van het zelf "de meest dringende opgave van het psychische apparaat" moest zijn. ${ }^{73}$

Echter: "Rouw is met afweerprocessen (...) niet te verenigen, omdat deze juist erop gericht zijn inzicht in de realiteit en daarmee verbonden pijn te vermijden". ${ }^{74}$ En zonder rouw zal een vrouw als Winifred Wagner er nimmer in slagen van haar verleden los te komen. Ruimte voor nieuwe identificaties kan slechts ontstaan door middel van een moeizame en pijnvolle rouwverwerking - "een innerlijk proces waarin het individu een verlies verwerkt". 75 Trauerarbeit, schrijft Margarete Mitscherlich in de bundel Erinnerungsarbeit (1997), is "een leerproces van het afscheid nemen". Een dergelijke proces is een voorwaarde om het nieuwe te kunnen denken en waarnemen, gedragspatronen te veranderen, onbewuste motieven in handelingen en reacties te onderkennen en nieuwe identificaties op te bouwen. ${ }^{76}$ En met zijn films uit de jaren '70 en de vroege jaren ' 80 zou Syberberg, aldus Eric Santner (1992), deze "Trauerarbeit, waar de Mitscherlichs om vroegen, in een esthetische praktijk vertalen"."

\footnotetext{
70 idem, p. 26.

71 idem, bijvoorbeeld: pp. $30,35,38,55,58$.

72 idem, p. 55.

73 idem, pp. $30,35,58$.

74 idem, p. 78.

75 idem, p. 9.

${ }^{76}$ Mitscherlich, a.w., p. 16.

${ }^{77}$ Santner, E. L., The Trouble with Hitler. Postwar German Aesthetics and the Legacy of Fascism. in. New German Critique. 57 (Summer 1992). pp. 5-24, zie: 12.
} 


\subsection{Traumatische bewustwording}

Dit roept de voor de hand liggende vraag op, voor wie deze filmische therapie bedoeld zou kunnen zijn? De Britse filmtheoreticus John Sandford, die ten onrechte in Santners opsomming van belangrijke Syberberg-exegeten ontbreekt, gokt op Winifred Wagner zelf. In het hoofdstuk over Syberberg van zijn handboek The New German Cinema (1980), ontwaart Sandford een verrassende parallel tussen de documentaire en de een jaar eerder ( 74 ) tot stand gekomen speelfilm over Karl May, waarin acteurs die in de Hitler-tijd furore hebben gemaakt de hoofdrollen vertolken - een casting die, weet de filmtheoreticus zich te herinneren, menigeen de wenkbrauwen heeft doen fronsen, maar door Syberberg zou zijn verdedigd als "een poging in het reine te komen met de verdrongen geschiedenis van de Duitse cinema". Hoe het ook zij; een zeker gevoel voor ironie, kan de filmer niet worden ontzegd, meent Sandford: zonder zichzelf hiervan bewust te zijn, worden de bejaarde sterren van weleer geconfronteerd met de geperverteerde dromen uit hun jonge jaren. En iets soortgelijks zou Syberberg in deze documentaire proberen te bewerkstelligen. Opnieuw gaat het om "de confrontatie van een oudere Duitser met haar medeplichtigheid aan het nazi-verleden (...)". "De openhartigheid en spraakzaamheid van de oude dame volstaan om een onbedoeld, maar haarscherp beeld te creëren van het angstjagende vermogen tot zelfbedrog, dat de Duitse bourgeoisie ten toon spreidde in haar omgang met de nazi-misdaden," schrijft Sandford.

"Zoals zoveel moderne Duitsers van haar generatie (en, alarmerender nog, ook jongere Duitsers), bewondert ze met dankbaarheid de 'goede' dingen die Hitler heeft gedaan - het herstel van orde, fatsoen en een doel in het nationale leven. (...) Het onvermogen om de politieke implicaties van zelfs de meest intieme vriendschap aan te voelen, is alledaags genoeg; Winifred Wagners verhaal illustreert op een zeer intense wijze, hoe deze verblinding het voor grote delen van het culturele establishment in het vooroorlogse Duitsland mogelijk maakte, instemmend te flirten met de vernietiging van precies die waarden, waar ze ogenschijnlijk voor stonden."

Maar mocht het Syberberg inderdaad te doen zijn om een confrontatie van de voormalige festivalleidster met haar schuldige verleden, dan is de therapie mislukt. De Engelse titel, The Confessions of Winifred Wagner, is gezien de connotatie met a confession of guilt misplaatst; moet Sandford toegeven (overigens zonder dat hij hieraan consequenties verbindt voor zijn uitleg). Winifred Wagner toont zich in de film immers "duchtig onboetvaardig". ${ }^{78}$ En ook nadien heeft de vrouw nimmer blijk gegeven van een mogelijke genezing: tot in het graf is ze in haar opvattingen blijven volharden.

Een andere optie is, dat Syberberg niet de oude dame heeft willen genezen, maar het Duitse publiek. Zoals we zagen, denkt Russell Berman in deze richting. Winifred Wagners onwil om de 'duistere zijde' van de Über-Vater - en hiermee van de eigen verloren identiteit - nauwkeurig te onderzoeken, is 'paradigmatisch' voor het naoorlogse Duitse onvermogen om te rouwen. En, zo zouden we Bermans uitleg kunnen samenvatten, door vijf uur lang in te zoomen op haar emotioneel rigide gezicht, houdt Syberberg het Duitse publiek een soort lachspiegel voor, waarin de eigen psychische anesthesie op 'groteske' wijze wordt uitvergroot. De blik in de spiegel zou een therapeutisch effect moeten hebben. In deze zin heeft ook Eric Santer de film geïnterpreteerd. "Syberberg," vermoedt Santner in zijn in 1990 verschenen studie Stranded Objects. Mourning, Memory, and Film in Postwar Germany, "zal

\footnotetext{
${ }^{78}$ Sandford, J., The New German Cinema. London, 1980. pp. 125, 126. Zie eveneens: Sandford, J., Hans Jürgen Syberberg: Films from Germany. in: Syberberg. A Filmmaker from Germany. ed. H. Stewart. Edinburgh, 1992. pp. 5-12, zie: 9 .
} 
waarschijnlijk instemmen met de these van de Mitscherlichs, dat de rigiditeit die niet enkel tekenend is voor een figuur als Winifred Wagner, maar voor de collectieve gevoelshuishouding van het naoorlogse Duitsland in het algemeen voortvloeit uit een onvermogen van het land om te rouwen en de wonden te genezen die gedurende de naziperiode zijn geopend."79

Om de therapeutische inzet van de film te verduidelijken, refereert de literatuurwetenschapper aan een casus uit een interviewboek van de Oostenrijkse joumalist Peter Sichrovsky: Born Guilty: The Children of the Nazis (1988). Het betreft het geval van ene Susanne - een in 1944 geboren Duitse vrouw, die aan ons wordt voorgesteld als de dochter van een man die werkzaam is geweest in Auschwitz. Susanne blijkt tot op late leeftijd last te hebben gehad van "substantiële, psychische gevoelloosheid" ten opzichte van de Holocaust, hetgeen met name tot uiting kwam in een onvermogen om onafhankelijk van haar vader een "nieuwsgierigheid" naar deze duistere episode in de Duitse geschiedenis te ontwikkelen. De "sleutel" tot deze psychische anesthesie zoekt Santner in de wijze waarop ze als jong meisje door haar vader van het verleden in kennis werd gesteld. Makkelijk blijkt de man het zich niet te hebben gemaakt. Toen Susanne 16 jaar oud was, nam hij haar zelfs mee op een studiereis naar Auschwitz. Maar nooit liet hij zijn dochter blijken, dat hij persoonlijk werd geraakt door de verschrikkingen die hier hadden plaats gevonden. Elk teken van "emotionele betrokkenheid", van "schaamte", "wroeging" of "verdriet", kortom alles wat zou kunnen wijzen op een affectieve herinnering die de herinnering aan feiten en gebeurtenissen aanvulde," was bij Susanne's vader zo goed als afwezig. "Nooit zag ik tranen," citeert Santner de dochter. ${ }^{80}$ En tranen heeft de literatuurwetenschapper ook bij Wagners schoondochter niet kunnen ontdekken. Evenals Susanne en haar vader, gaat Winifred Wagner gebukt onder een versteend, of beter: bevroren gevoelsleven. Het meest in het oog springend, merkt Santner op over de documentaire, is de "(...) rigiditeit van haar karakter en een welhaast grotesk onvermogen om berouw te voelen voor haar betrokkenheid bij Hitler en het nationaal-socialisme, empathie met hen die leden, of begrip voor hen die verzet leverden tegen het nazi-regime". 81

Naast deze emotioneel rigide personen, figureert in Santners casus echter ook nog ene Dieter - de in 1966 geboren zoon van Susanne. Deze blijkt zich in het kader van een middelbaar schoolproject te hebben verdiept in het nazi-verleden van zijn geboortestad. Samen met klasgenoten raadpleegde hij archieven, schreef hij brieven aan joodse instellingen en nam hij contact op met overlevenden van de Holocaust. In de loop van dit onderzoek deed Dieter een gruwelijke ontdekking: het huis, waarin hij was opgegroeid, bleek tot 1941 te hebben toebehoord aan een joodse familie, die in Auschwitz werd omgebracht. Geëmotioneerd confronteerde Dieter zijn moeder met zijn bevindingen. Het optreden van de zoon - 'Jouw dierbare moeder trok samen met jouw dierbare vader in dit huis de dag nadat ze werden weggevoerd' - leidde aanvankelijk tot spanningen binnen het gezin, maar zou uiteindelijk ook Susanne in staat stellen haar psychische anesthesie te overwinnen. Deze mentale omslag werd nog niet eens zozeer veroorzaakt door het plotselinge besef, dat haar persoonlijke levensgeschiedenis al die jaren verweven was geweest met de collectieve geschiedenis van de holocaust: ze bleek te zijn opgegroeid in een huis dat toebehoorde aan vermoorde joden - iets wat haar vader haar nimmer had verteld. Belangrijker was, stelt Santner, dat Susanne voor het eerst in haar leven werd geconfronteerd met gevoelens die ze tot dan niet had gekend: woede, verdriet, schaamte, berouw. Het was vooral deze, vanuit de psychoanalyse van de Mitscherlichs geredeneerd, meer gepaste emotionele reactie van de

\footnotetext{
${ }^{79}$ Santner, Stranded Objects, a.w., p. 130.

80 idem, pp. 43-45:

81 idem, pp. 129, 130 .
} 
zoon op de verschrikkingen van de jodenmoord, die ook bij Susanne een "verlaat verwerkingsproces" op gang bracht. "Het trauma van de bewustwording van deze jongen van de gewelddadige geschiedenis van zijn huis," schrijft Santner, "is niet onvergelijkbaar met het trauma, dat Syberberg zijn publiek wil laten doormaken tijdens deze eigenaardige rondtocht door de geschiedenis van de villa Wahnfried aan de hand van Wagners schoondochter." ${ }^{83}$

De metafoor is minder gezocht, dan het op het eerste oog misschien wil voorkomen. Ook in Syberbergs documentaire staat, zoals Santner terecht opmerkt, een familiehuis centraal: de Wagner-villa Wahnfried. En hoewel het nooit joods bezit is geweest, heeft ook dit huis een 'gewelddadige geschiedenis'. Letterlijk vertaald in het Engels, doceert de literatuurwetenschapper, betekent Wahn-fried: respite of delirium - rust van waanzin of razernij. Maar in Syberbergs film, voegt hij hieraan toe, figureert de Wagner-villa niet zozeer als een plek van vrede en gemoedsrust. Veeleer is Wahnfried voor Syberberg "(...) de ruimte waarin de relaties leesbaar worden tussen de metafysische sabbat, waar Wagner naar verlangde en de politieke formuleringen van dergelijke verlangens in het nazisme" ${ }^{84} \mathrm{En}$ Santner had op nog meer overeenkomsten met het onderzoek van Dieter kunnen wijzen. Zoals eerder vermeld in paragraaf 3 heeft ook deze documentaire geleid tot spanningen binnen de familie. Festivalleider Wolfgang Wagner heeft zijn moeder naar aanleiding van haar optreden in de film zelfs verboden nog langer het Wagner-theater te betreden.

Toch is Santners uitleg niet geheel overtuigend. Hij typeert de film als 'een eigenaardige rondtocht door de geschiedenis van de villa Wahnfried aan de hand van Wagmers schoondochter'. Maar wanneer dit inderdaad een correcte typering is, ligt het dan niet veel meer voor de hand om de film te vergelijken met de studiereis van Susanne en haar vader? Zoals Susanne door haar vader werd rondgeleid door de geschiedenis van Auschwitz, zo wordt het publiek in deze film door Winifred Wagner rondgeleid door de geschiedenis van de villa Wahnfried. De inspanningen van de vader hadden volgens Santner een averechts effect; nog jaren nadien zou Susanne worstelen met 'substantiële psychische gevoelloosheid'. Welnu, op grond waarvan weet Santner, dat niet ook deze film een averechts effect zal hebben? "(...) Op mensen die het Derde Rijk niet [wensen] te verdringen, [heeft] de film het effect van nazi-propaganda," meent regieassistent Gottfried Wagner (1997). ${ }^{85}$

\subsection{Een flirtende gymnasiast.}

Voor wie deze filmmaker en zijn werk uitsluitend mocht kennen uit de hierboven besproken Angelsaksische commentaren, moet het verslag dat Gottfried Wagner in zijn in 1997 verschenen autobiografie van de opnamen biedt een ontnuchterende ervaring zijn. Volgen we deze zoon van festivalleider Wolfgang Wagner, een leeftijdgenoot van Santners Susanne, dan zou ook hij aanvankelijk in de documentaire een mogelijkheid hebben gezien om een 'verlaat verwerkingsproces' (Santner) op gang te brengen: "Doorslaggevend voor mijn toezegging, aan de voorbereidingen, opnamen en montage van de film mee te werken, was mijn hartstochtelijke belangstelling voor het bloot leggen van de meest duistere periode uit de familiegeschiedenis. (...) Ik wilde dat alles boven water zou komen." Immers: "Alleen

\footnotetext{
82 idem, pp. $43-45$.

83 idem, p. 128 .

${ }^{84}$ ibidem.

${ }^{85}$ Wagner, G., Wer nicht mit dem Wolf heult. Autobiographische Aufzeichnungen eines Wagner-Urenkels. Köln, 1997. p. 133. Het koosnaampje 'Wolf' uit de titel verwijst zowel naar vader Wolf(-gang) Wagner, als naar Adolf - "ome Wolf' - Hitler.
} 
wanneer de betrokkenheid van mijn familie bij het nationaal-socialisme volledig onthuld zou worden, kon ze de schuld verwerken". ${ }^{86}$ En hij drong er naar eigen zeggen dan ook bij Syberberg op aan, de vrouw niet met zachte handschoenen aan te pakken. Evenals de Dieter uit Santners casus, blijkt Gottfried Wagner een voorstander te zijn geweest van een confronterende benadering: door haar met de neus op de feiten te drukken, diende de grootmoeder uit haar psychische anesthesie te worden wakker geschud. Maar Syberberg bleek andere plannen te hebben.

Nog voordat de eerste filmrol goed en wel was volgeschoten, weet Gottfried Wagner zich te herinneren, begon hij de regisseur "(...) te wantrouwen wegens zijn distantie- en kritiekloze manier van ondervragen en zijn devote omgang met mijn grootmoeder". ${ }^{87}$ Met verbijstering moest de regieassistent toezien, hoe zijn grootmoeder vijf uur lang baarlijke nonsens mocht opdissen zonder dat haar door de regisseur ook maar één strobreed in de weg werd gelegd. In plaats van de vrouw duchtig het vuur aan de schenen te leggen, liet Syberberg haar domweg praten en gaf hij reeds in de eerste minuten de regie uit handen:

"Zij [Winifred Wagner, G.G.] nam direct het commando over. Om het duidelijk te zeggen: bij de opnamen in het Siegfried-Wagner-Huis [een zijvleugel van de villa Wahnfried, G.G.] ontstond een film van en met Winifred Wagner, onder assistentie van Syberberg. Hij werd door mijn grootmoeder tijdens de opnamen direct overklast. Grootmoeder zag het uur van haar waarheid gekomen en greep deze kans met beide handen aan. Syberberg op zijn beurt gedroeg zijn als een flirtende gymnasiast [flirtender Oberprimaner], die Winifred smachtend aankeek. (...) En arme ik, wanneer ik uit mijn vel sprong van woede, omdat $\mathrm{ik}$ grootmoeders toneelspel niet langer verdroeg, dan beweerde Syberberg meteen in de uitoefening van zijn kunst belemmerd te worden:" 88

Of de regieassistent zich daadwerkelijk dusdanig kwaad heeft gemaakt, valt zoveel jaar na dato moeilijk na te gaan. Gottfried Wagner lijkt niet helemaal oprecht. Weliswaar heeft hij zich nog vóor zijn vader van de film gedistantieerd en geëist dat zijn naam van de titelrol zou worden geschrapt. Maar zijn toenmalige kritiek luidde, dat Syberberg de naoorlogse wederopbouw en denazificatie in "een volledig verkeerd licht" zou hebben geplaatst door in enkele tussenteksten te zinspelen op historische continuïteiten tussen het oude en het nieuwe Bayreuth. ${ }^{89}$ In die dagen werd de in 1947 geboren achterkleinzoon van Richard Wagner nog alom beschouwd als de meest plausibele kandidaat voor de erfopvolging. ${ }^{90}$ Sindsdien heeft zijn leven echter een opmerkelijke wending genomen. Midden jaren 80 raakt Gottfried Wagner bevriend met de publicist Ralph Giordano, de auteur van de door Mitscherlichs geïnspireerde bestseller Die zweite Schuld oder Von der Last Deutscher zu sein. (De 'tweede schuld' staat hier voor de naoorlogse verdringing en ontkenning van de eerste, dat wil zeggen

\footnotetext{
${ }^{86}$ idem, pp. $126 \mathrm{f}$

${ }^{87}$ idem, p. 129.

88 idem, p. 128.

${ }^{89}$ Pressekonferenz mit Wolfgang Wagner, a.w., F. 272. Syberberg zelf merkt in dit verband op: "Gottfried bat mich zwischendurch und später, doch auf die Tatsache der frühen Verwaisung des zweijährigen Wini-Kindes in den Kommentaren und Zwischentiteln hinzuweisen. Das müsse doch gerade heute verstanden werden und viel von ihrer späteren Haltung auch in der Anlehnung an den starken Hitler erklären. Sicher hat er recht. Ich hoffe, daß es im Film rauskommt, ohne von meiner Seite zu sentimental vorgehalten worden zu sein." Syberberg, a.w., p. 257.

${ }^{90}$ Zie bijvoorbeeld: Amerongen, M., van, De buikspreker van God. Amsterdam, 1983. pp. 179f.
} 
de schuld aan de nazi-misdaden. ${ }^{91}$ ) Hij reist naar Israël om lezingen te verzorgen over het onverwerkte nazi-verleden van zijn familie en richt samen met geestverwanten uit de Verenigde Staten de eerste internationale Post-Holocaust-Dialog-Gruppe (PHDG) op - een gespreksgroep voor kinderen van nazi-slachtoffers en nazi-daders. In 1990 wordt hij door zijn vader van de Groene Heuvel verbannen, nadat hij de joodse dirigent Daniel Barenboim heeft bestempeld als 'excuus-jood'. "Ik verwacht dat de gevestigde orde van Bayreuth na de shoah net als Willy Brandt in Auschwitz [sic!, G.G.] op de knieën valt;" stelt hij in een in '93 afgenomen interview. "Op de Groene Heuvel is het vermogen om te rouwen zelfs nooit opgekomen." ${ }^{92}$

In interviews die Gottfried Wagner twee decennia eerder in zijn hoedanigheid als gedoodverfde festivalleider heeft gegeven, zal men dit soort strijdbare taal vergeefs zoeken. En het mag dan ook zeker niet worden uitgesloten, dat de anti-wagneriaanse Wagnerachterkleinzoon', zoals hij zichzelf in zijn autobiografie typeert, ${ }^{93}$ hier met terugwerkende kracht zijn latere engagement projecteert op zijn regieassistentschap bij de inmiddels door zijn Nieuw Rechtse activisme in opspraak geraakte Syberberg. Maar zelfs wanneer zijn verslag van de opnamen van a tot $\mathrm{z}$ verzonnen mocht zijn, betekent dit nog niet noodzakelijk dat de kritiek van Gottfried Wagner geheel ongegrond is. "Het merkwaardige is," merkt de Nederlandse historica René in 't Veld scherp op in haar kleine studie Uit liefde voor de Führer. Vrouwen van het Derde Rijk (1995), "dat Syberberg haar [Winifred Wagner, G.G.] blijkbaar bewondert." aanleiding van de documentaire heeft gegeven (juli 1975), plaatst Syberberg de oude dame op een voetstuk als een "monument van burgermoed" [Denkmal an Zivilcourage]: "Zonder kwaad te worden of koppig te zijn, komt ze uit voor haar verleden en in deze houding is ze volstrekt uniek. Wie heeft tegenwoordig al de moed om te zeggen: ik heb meegedaan en ben daarom niet kwaad op de geschiedenis van mijn leven? Er lopen nog zoveel verbitterde figuren rond. Dan is het toch iets bijzonders, wanneer een vrouw zo frank en vrij van haar leven getuigenis aflegt." 95

Dat het hier allerminst gaat om een verspreking, blijkt twee jaar later uit de hierboven reeds aangehaalde apologie in de bundel Filmbuch (1976), waarop overigens ook Berman, Sandford en Santner voor een niet onbelangrijk deel hun uitleg baseren. Met de vermeende rigiditeit van Winifred Wagners karakter blijkt het in dit essay wel mee te vallen. Laat staan dat de oude dame 'paradigmatisch' (Berman) zou zijn voor de 'collectieve psychologische gevoelshuishouding (Santner) van het naoorlogse Duitsland. Wel heeft Syberberg naar eigen zeggen in het voorjaar van ' 75 op de Groene Heuvel iemand gefilmd die, "oud geworden en belast, welhaast vrolijk opgelucht en door jongeren bewonderd, de verantwoording op zich neemt $(. .$.$) , zonder koppig te zijn of kwaad te worden (. .$.$) - een verbazingwekkende vrouw$ (...) uit de keuken van een van onze trotse Europese geestelijke centra [aus der Küche eines

\footnotetext{
${ }^{91}$ Giordano, R., Die zweite Schuld oder Von der Last Deutscher zu sein. Hamburg, 1987. p. 11. Zie eveneens: Giordano, R., Verschlußsache 'USA' in: Wagner, G., a.w., pp. 11-26.

${ }_{92}$ Goldschneider, G., De achterkleinzoon van Richard Wagner heeft iets recht te zetten. in: Vrij Nederland. 1804-1993. p. 76. Zie eveneens: Wagner, G., a.w., passim. Voermans, E., Wagner tegen wil en dank. in: Het Parool. 27-02-1996. p. 45. Milnes, R., Standing up to the past. Gottfried Wagner talks to Rodney Milnes. in: Opera. 8 (1995). pp. 91 1-914. Beer, M., 'Eine böse, ganz giftige Brühe'. Gottfried Wagner über Richard Wagner, antisemitismus und Bayreuth. in: Opernwelt. 9 (1995). pp. 30-33. Kesting, J., 'Es ist viel Hitler in Wagner' Neue Variationen zu alter Leid-Motive, in: Opernwelt. 5 (1997). pp. 60-61.

${ }^{93}$ Wagner, G., a.w., pp. 360,361 .

${ }^{94}$ Veld, in 't, a.w., p. 111 .

${ }^{95}$ Wirbel um offene Worte Winifreds. a.w., p. 273.
} 
unserer stolzen geistigen Zentren von ganz Europa]". ${ }^{96}$ En dit strookt met wat Syberberg ook elders over deze documentaire heeft geschreven of opgemerkt. Zeker, wie lang zoekt kan in teksten van zijn hand ook enkele minder flatteuze uitspraken aanwijzen over deze "met bloed bevlekte".97 vrouw. Met Winifred Wagners nazi-sympathieën, die hij "een levensdwaling" noemt, lijkt de filmer niet veel op de hebben. En haar antisemitisme noemt hij "een onuitwisbaar kwellend gif in mijn herinnering". Dankzij een "duistere opmerking over het jodendom", die door de vrouw tijdens de opnamen "schallend als lach [werd] geoffreerd", zou hem zelfs nog lang nadien de schrik in de benen hebben gezeten - "Hoe a-muzisch moet deze nazi-tijd geweest zijn, dat deze Winifred Wagner op een zo prominente plaats deze Hitler kon vereren (...) ${ }^{\text {"98 }}$ Maar dit soort terzijdes zijn geenszins representatief voor de teneur van Syberbergs eigen commentaren, die inderdaad overwegend bewonderend is. "Ik meen te mogen zeggen, dat Winifred Wagner, als personage in deze film, Duitsland een grote dienst heeft bewezen;" kunnen we bijvoorbeeld lezen in de (eveneens in het Engels vertaalde) Hitler-script-inleiding Die Kunst als Rettung aus der deutschen Misere (1978). "Ze heeft de schuld op zich genomen [Schuld auf sich genommen], volstrekt openhartig en voor het eerst volstrekt eerlijk. De film laat het zien (...). Ze heeft daarmee vele anderen van hun leugens verlost". 99 Helemaal bont maakt de regisseur het in een reeks necrologieën, die in maart 1980 naar aanleiding van Winifred Wagners overlijden in diverse Duitse dag- en weekbladen zijn verschenen. In één van deze necrologieën, in Der Spiegel van 10 maart 1980, laat Syberberg weten zich vaak als haar "aangenomen zoon" te hebben gevoeld. Hij heeft, aldus de filmer, deze voormalige festivalleidster "lief gehad", haar gekend als een "hartelijk persoon", "goedmoedig bijna". Ja, ze was een "edelmoedige vrouw", wier "schandaal" hieruit bestond, "dat ze de schuld op zich nam, op een perverse wijze, inderdaad fier, in een wereld vol conformisten". En zo zou hij ook graag willen, dat ze in de collectieve herinnering voortleefde: als een "Wundertier", dat "de Duitsers die zich vergisten, verloren, schuldig werden, hun eer heeft teruggeschonken - niet door de feiten, die we kennen, maar door haar persoonlijkheid: een raadsel, onoplosbaar". "De onsterfelijke is gestorven en daarmee tot een monument geworden, dat iedereen mag heroïseren." ${ }^{100}$

Geen mens belichaamt het absolute kwaad. Maar, meent Gerard R. Koch in de Frankfurter Allgemeine van 20 maart van dat jaar: "Ook voor hen, die het niet per se noodzakelijk vinden loodzware rotsblokken van het morele fatsoen op de lijkkist van een overledene te werpen, moeten Syberbergs lofspraken op de Hitler-vriendin een bron van ergernis zijn". ${ }^{101}$ En voor het eerst wordt nu ook buiten de kringen van Nieuw Links openlijk de vraag gesteld, "wiens geesteskind" (Koch) deze filmmaker zou kunnen zijn. Bijvoorbeeld door één van de belangrijkste opponenten van Habermas in de zogenaamde Historikerstreit, de publicist Joachim Fest, die in zijn reisboek Im Gegenlicht (1987) ten overstaan van een Italiaanse kennis zijn onbehagen als volgt onder woorden brengt: "Ik vertelde hem hoe Winifred Wagner de familieraad bijeen had geroepen nadat Syberberg haar had bezocht om te vragen om een interview; en hoe zij na veel heen en weer gepraat de kwestie had afgedaan met de woorden: "Ik zal het doen, want diep in mijn hart voel ik dat hij een van ons is'."102

\footnotetext{
${ }^{96}$ Syberberg, a.w., pp. 246f. Terzijde zij hier opgemerkt, dat de filmer doelt op Wahnfried: "de ruimte waarin de relaties leesbaar worden tussen de metafysische sabbat, waar Wagner naar verlangde en de politieke formuleringen van dergelijke verlangens in het nazisme' (Santner).

${ }_{98}^{97}$ Syberberg, H.J., Eine Zeugin und eine Schuldige. in: Der Spiegel. 11 (1980). pp. 234f, zie: 235.

${ }^{98}$ Syberberg, Filmbuch, a.w., pp. 252f, 285.

${ }^{99}$ Syberberg, Die Kunst als Rettung..., a.w., p. 34.

100 Syberberg, Eine Zeugin und eine Schuldige. a.w., pp. 234f. Zie eveneens: Syberberg, H.J., Winifred Wagner - Symbol unserer Vergangenheit. in: Die Zeit. 12 (1980). p. 41.

${ }_{101}^{10}$ Koch, G.R., Syberbergs Bekenntnisse. in: Frankfurter Allgemeine Zeitung. 20-03-1980. p. 25.

${ }^{102}$ Fest, J., Tegenlicht. Een Italiaanse reis. Vert. T. Davids. Amsterdam, 1990. pp. 267.
} 
De anekdote is ongetwijfeld apocrief, maar wel veelzeggend voor de manier waarop inmiddels in eigen land tegen de filmmaker wordt aangekeken. "Jarenlang [heeft] die man zijn verwardheid laten doorgaan voor morele wroeging of diepgang van gedachten, en iedereen, tot en met Susan Sontag, [heeft] hem geloofd," maakt Fest zich vrolijk. ${ }^{103}$

\subsection{Tendresse}

'Een raadsel, onoplosbaar', noemt Syberberg in de Spiegel-necrologie het karakter van de oude dame. En 'een raadsel, onoplosbaar', zouden we hier aan kunnen toevoegen, zijn ook de hierboven besproken Angelsaksische commentaren. Hoe het mogelijk is, zal wel altijd een mysterie blijven; maar nog in 1990 (het jaar van Santners Stranded Objects) blijken de Duitse zorgen nauwelijks tot de serieuze, buitenlandse Syberberg-receptie te zijn doorgedrongen. ${ }^{104}$ Meer nog: dat de filmer deze vrouw wel eens zou kunnen bewonderen, komt bij Elsaesser, Berman, Sandford en Santner niets eens op. En dit, terwijl de Amerikaanse literatuurwetenschapster Marcia Landy er reeds in een in 1979 (!) gepubliceerd essay op heeft gewezen, dat Syberberg zich "lijkt te associëren met de attituden, die hij in zijn film onderzoekt" - "Hij deelt de zonden van zijn onderwerpen Winifred Wagner en Hitler"." ${ }^{105}$ Hoewel Elsaesser er in een voetnoot wel degelijk aan refereert, ${ }^{106}$ heeft dit essay van Landy in de serieuze, buitenlandse receptie geen enkele rol gespeeld. En hetzelfde geldt voor een ingezonden brief in het Amerikaanse blad Art Forum van december 1984, waarin de in New York woonachtige Duitse kunstenaar en academiedocent Hans Haacke een tevergeefse poging heeft ondernomen het buitenlandse Syberberg-beeld te corrigeren door de exegeten te confronteren met een reeks citaten uit onder meer deze Spiegel-necrologie. ${ }^{107}$

Het zal tot in de jaren ' 90 duren, tot het ook tot Elsaesser, Berman, Sandford en Santner begint door te dringen, dat met deze filmmaker iets niet helemaal in de haak is. Maar, hetgeen zo mogelijk nog eigenaardiger is, hun kritiek op de late, Nieuw Rechtse Syberberg ten spijt, heeft geen van deze auteurs ooit aanleiding gezien de eigen vroegere interpretaties nog eens kritisch tegen het licht te houden. In plaats daarvan pleit Thomas Elsaesser er in een essay uit 1995 voor "de films (...) tegen de persoonlijke statements van hun maker in bescherming te nemen". Syberbergs films worden nu door Elsaesser beschouwd alls "populaire teksten, met een eigen politiek onbewuste" dat "zich per definitie aan de controle van de maker onttrekt en precies om deze reden een cultureel en historisch feit op zichzelf wordt". ${ }^{108}$ En toch is dit beslist niet, hoe Elsaesser zelf indertijd over het werk van Syberberg heeft geschreven. Integendeel: typerend voor de door mij besproken buitenlandse commentaren is juist hun intentionalistische karakter. Deze auteurs geven niet zozeer hun

\footnotetext{
${ }^{103}$ idem, p. 266.

${ }^{104}$ Van de 46 pagina's, die het hoofdstuk over Syberberg in Stranded Objects telt (eenvierde van het hele boek), is welgeteld één regel gewijd aan de schandalen in eigen land: "Indeed, at least one of the sources of Syberberg's isolation from his colleagues in the New German Cinema, as well as from the cultural scene generally, has been his insistence that he alone among German artists has been willing to take on the postwar burdens of mouming and reparing the damage of their nation's bereft cultural identity." Santner, a.w., p. 103. Maar of dit op zichzelf voldoende is, om in de Bondsrepubliek dermate omstreden te raken, waag ik te betwijfelen. Helaas laat Santner in het midden, was de andere 'sources' zouden kunnen zijn.

${ }^{105}$ Landy, M., Politics, Aesthetics, and Patriarchy in The Confessions of Winifred Wagner. in: New German Critique. An interdisciplinary joumal of German Studies. 18 (1979). pp. 151-166, zie: $162 \mathrm{f}$.

${ }^{106}$ Elsaesser, a.w., p. 131.

${ }^{107}$ Haacke, H., To the editor. in: Art Forum. (December 1982) pp. 3 f.

${ }^{108}$ Elsaesser, Th., Subject Positions, Speaking Positions: From 'Holocaust', 'Our Hitler' and 'Heimat' to

'Shoah" and Schindler's List. in: The Persistence of History. ed. V. Sobchack. New York, 1995. pp. 235-287.

Zie eveneens: Elsaesser, Th., Fassbinder's Germany: History, Identity, Subject. Amsterdam, 1996. pp. $144 f$.
} 
eigen indrukken weer. Veeleer pretenderen ze aan hun lezers uit te leggen, waar deze filmmaker voor staat, wat hij denkt ("Syberberg would apparently agree with the Mitscherlichs' thesis"), verafschuwt ("Syberberg despises: vulgar entertainment and shallow didacticism"), wil ("Syberberg wants to lead his audience"), probeert ("Syberberg attempts to initiate a "work of mourning"), dan wel nastreeft ("What Syberberg aims at, is again quite clear"). ${ }^{109}$

Maar zelfs al hadden deze auteurs wel hun eigen indrukken weergegeven, dan nog zouden we ons kunnen afvragen of op hun duidingen niet het nodige valt af te dingen. Ik beperk me hier tot twee voorbeelden. "Wanneer Wilhelm Furtwängler haar [Winifred Wagner, G.G.] vraagt naar haar gevoelens over de behandeling door de rechters en het publiek na de oorlog," schrijft Santner in Stranded Objects, "typeert haar antwoord de bevroren zijde van een persoon die het ten enen male ontbreekt aan een vermogen om te rouwen". En om de lezer in staat te stellen tot een eigen oordeel te komen, voegt hij het volgende citaat uit de film aan deze diagnose toe: "Ik heb hem [Furtwängler, G.G.] geantwoord, dat het me allemaal weinig kon schelen. En toen heb ik me afgevraagd, waarom... En ik geloof, dat het komt doordat ik me in geen enkel opzicht aan een of ander vergrijp of misdaad schuldig voelde. Wanneer ik me wel schuldig zou hebben gevoeld, zouden [deze aanvallen] me hoe dan ook hebben geraakt. Nu heeft het me allemaal koud gelaten." documentaire over 'emmers vol modder'.)

Inderdaad lijken deze woorden over de geldigheid van Santners diagnose geen twijfel te laten bestaan. Problematisch wordt de geboden diagnose pas, wanneer we het citaat terugplaatsen in de context van de film. Wie op grond van zijn lectuur van Stranded Objects verwacht, dat Syberberg deze uitspraak van Winifred Wagner aangrijpt om de vrouw op de 'bevroren zijde' van haar karakter te attenderen, zal teleurgesteld zijn. Wel wil hij in de film graag weten, of de in Hastings geboren Winifred Wagner-Williams zich misschien toch nog, gezien haar reactie op de manier waarop ze na de oorlog werd behandeld, een beetje Engelse voelt: "Gelooft u, dat u soms toch een Engelse bent, wanneer u op deze wijze reageert?" "Ach, dat kan ik niet zeggen," mijmert de vrouw. "Maar... een zekere Kaltschnäuzigkeit, of hoe men dat noemen moet... Dat wil zeggen een zeker vermogen om afstand te nemen tot de dingen... minder persoonlijk op dingen te reageren... dat is misschien toch een Engelse eigenschap..."

Samen met de vrouw speelt Syberberg met de mogelijkheid dat haar, zoals ze het zelf noemt, Kaltschnäuzigkeit, iets te maken zou kunnen hebben met haar Engelse afkomst. Mocht dit zo zijn, dan is deze Kaltschnäuzigkeit eerder een typisch Engelse, dan een typisch Duitse karaktertrek. Haar ogenschijnlijke gevoelloosheid - maar beter: onverstoorbaarheid, gelijkmoedigheid -, dient dan niet zozeer te worden toegeschreven aan een eventueel Duits onvermogen om te rouwen, als wel veeleer aan de gewoonte van veel Engelsen om zelfs onder de meest moeilijke omstandigheden a stiff upper lip te bewaren. Wat aanvankelijk een negatieve karaktertrek leek (het ontbreken van een gepaste emotionele reactie op de holocaust), blijkt bij nader inzien een positieve karaktertrek te zijn. "Soms komt het me voor, dat ik relatief nuchter denk over dingen, waarover andere mensen zich mateloos opwinden," vertrouwt ze de regisseur toe. "Ook ik geloof, terugblikkend op die emmers vol modder, dat uw reactie anders is dan die van andere mensen," valt deze haar bij. "Ach, dat kan ik eenvoudig niet beoordelen," glimlacht de vrouw. "Ik ken niemand in een vergelijkbare positie, die heeft moeten doormaken, wat ik heb doorgemaakt. Maar ik ben nu eenmaal met

\footnotetext{
${ }^{109}$ Citaten ontleend aan respectievelijk: Santner, a.w., p. 130. Sandford, a.w., p. 117. Santner, a.w., p. 128. Berman, a.w., p. 370. Elsaesser, Myth as the Phantasmagoria of History, a.w., p. 128.

${ }^{110}$ Santner, a.w., pp. 129,130 .
} 
een gezegende gelijkmoedigheid op de wereld gekomen. Een moment lang raken de dingen me wel. Maar ik kan me er snel overheen zetten."

Mijn tweede voorbeeld is ontleend aan Russell Berman. Aan het slot van de documentaire leest Winifred Wagner een nawoord voor, waarin ze verklaart dat haar opmerkingen over Hitler uitsluitend op "strikt persoonlijke ervaringen" zijn gebaseerd. Een kritische stellingname wijst ze van de hand - "huidige en toekomstige historici" zullen een oordeel moeten vellen. Het nawoord eindigt met de laatste woorden van de film - tevens de laatste woorden die de in 1980 overleden grande dame van het oude Bayreuth in het openbaar heeft uitgesproken: "Het schijnt dat de openbaarheid zich erover verbaast, dat ik zogezegd dertig jaar lang heb gezwegen en zich afvraagt, waarom ik nu plotseling heb besloten te spreken. Daarentegen vraag ik: Warum denn eigentlich nicht?"

Dit nawoord, dat op verzoek van festivalleider Wolfgang Wagner in de film is opgenomen, wordt door Berman geïnterpreteerd als een "dementi". Zelfs de laatste mogelijkheid om nog een teken van berouw te tonen, heeft Winifred Wagner voorbij laten gaan. In plaats van zich alsnog "kritisch te distantiëren van de inhoud van haar presentatie," volhardt ze in haar "ontkenning" en blijft ze weigeren Hitlers 'duistere zijde' te onderzoeken. Om te benadrukken hoe erg het met de vrouw gesteld is, refereert Berman aan een passage in Filmbuch, waarin Syberberg vertelt hoe Winifred Wagner zich tijdens de opnamen vrolijk maakte over de slotwoorden: 'Waarom eigenlijk niet?'. Wat was aan deze woorden zo amusant? "Syberberg bericht, dat Winifred geamuseerd was door dit ultieme gebaar en het beschreef als een 'joods einde'," schrijft Berman. "Ze bedoelde dat de openheid en wuftheid ervan contrasteerden met de door haarzelf verdedigde onbarmhartige loyaliteit." "11 Maar Berman vertelt slechts het halve verhaal. Wat Winifred Wagner amuseerde was niet enkel de, naar ze meende, joodse "ironie" van dit open einde; ze was tevens blij verrast, dat iemand haar kennelijk zo goed aanvoelde, dat hij voor haar woorden wist te bedenken, die haar eigen woorden hadden kunnen zijn ${ }^{112}$ - hádden kunnen zijn, want de geciteerde regels zijn niet van Winifred Wagner zelf. "Syberberg schreef dit dementi (...)," merkt Berman tussen neus en lippen op. ${ }^{113}$

In de film zelf komt deze uitspraak van Winifred Wagner over het 'joodse einde" niet voor. Zelfs het voorlezen van het nawoord wordt niet in beeld gebracht. Terwijl Winifred Wagner spreekt zien we "een serie still shots," aldus Berman. ${ }^{114}$ Eén van deze 'still shots' (zie afbeelding 2) staat eveneens afgedrukt in Syberbergs Filmbuch. ${ }^{115}$ De foto is ontstaan kort voor de bandopname van het nawoord. Winifred Wagner bereidt zich voor op haar laatste optreden in de film. Aandachtig leest ze de tekst door, die ze weldra op band zal gaan inspreken. De microfoon staat al klaar. Naast haar aan tafel zit de regisseur. Het lijkt alsof hij haar iets probeert duidelijk te maken. Vermoedelijk moet Winifred Wagner worden overgehaald om de woorden, die hij voor haar heeft bedacht, als haar eigen woorden te aanvaarden. Veel overredingskracht is hier, naar het zich laat aanzien, niet voor nodig. Winifred Wagner beleeft zichtbaar plezier aan hetgeen de regisseur haar te vertellen heeft. Rond haar mondhoeken speelt onmiskenbaar een glimlach. Maar interessanter is de houding van de regisseur. Woede? Verdriet? Schaamte? Berouw? Zoals je op grond van de besproken buitenlandse commentaren zou verwachten? ${ }^{116}$ De sfeer lijkt eerder geanimeerd te zijn.

\footnotetext{
11 Berman, a.w., pp. $369 \mathrm{f}$.

112 Syberberg, Filmbuch, a.w., pp. $284 \mathrm{f}$.

${ }^{113}$ Berman, a.w., p. 370.

114 ibidem:

115 Syberberg, a.w., p. 285.

${ }^{116}$ Santner, a.w., p. 45: "Alleen dankzij de woede en het verdriet wan de derde generatie (...) werd het voor de tweede generatie mogelijk een verlaat verwerkingsproces te initiëren".
} 


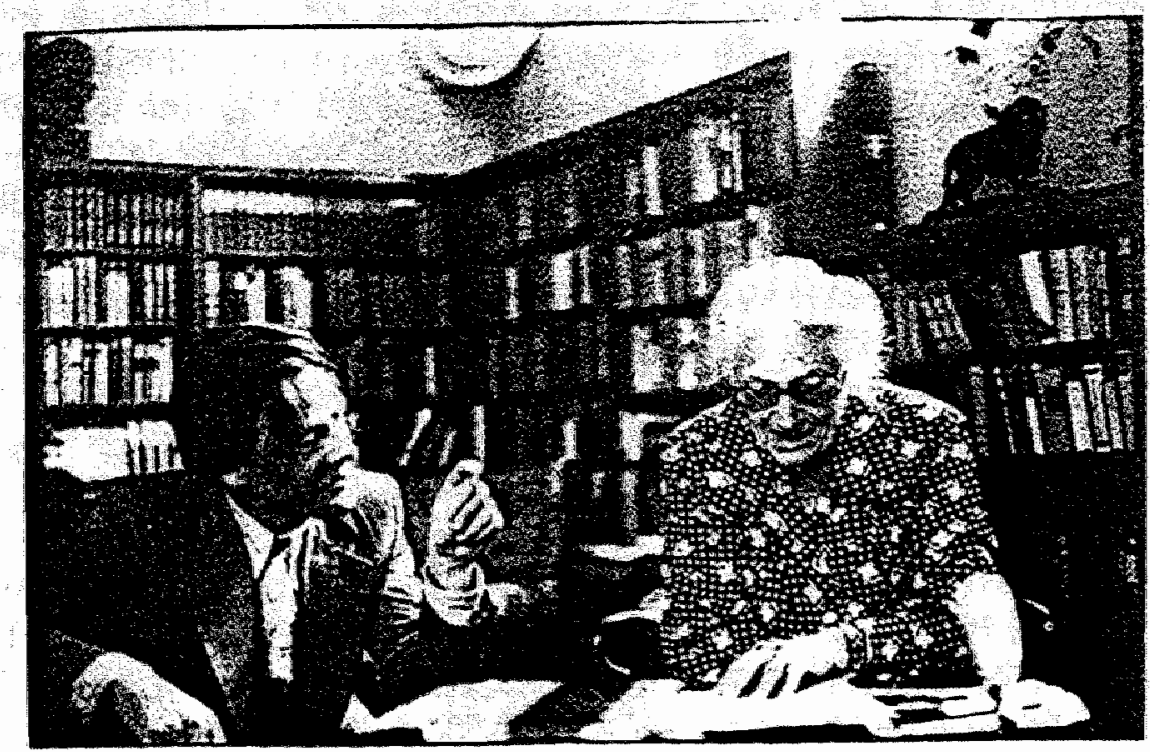


Een enkele foto makt nog niet een hele film. Maar in dit geval liggen de zaken anders. "We hebben er lang naar gezocht," bekent Syberberg in Filmbuch. "Een lachende en boosaardige aftocht na de voorafgaande nog verse bekentenis tot Hitler" "117 En een passend einde, is deze 'lachende' en 'boosaardige' foto zeker - let wel: 'boosaardig' niet ten opzichte van Winifred Wagner. Ter afsluiting van zijn korte beschouwing legt Berman een begrip uit, dat door Syberberg in Filmbuch wordt gebruikt om de esthetiek van de film te typeren: tendresse." "De langzame beweging van de camera, die het ritme van haar [Winifred Wagners, G.G.] discours volgt, verraadt een niet-polemische tederheid [a nonpolemical tenderness] ten opzichte van het onderwerp," verduidelijkt de literatuurwetenschapper. "Syberberg heeft geprobeerd haar te laten spreken, zonder een tendentieus commentaar op te leggen via de gebruikelijke documentaire methodes: er is geen voice over verteller, die met argumenten Winifreds fouten uitlegt, noch heeft Syberberg niet tot het onderwerp behorend materiaal geïntroduceerd - filmbeelden van nazibijeenkomsten en concentratiekampen - als montage om de tekst tegen te spreken." 119

Hoe verhoudt deze tendresse zich tot Bermans uitleg van de film? En hoe tot Bermans diagnose van Winifred Wagners Kaltschnäuzigkeit? 'De afwezigheid van elke vorm van zelfkritiek en de weigering om het verleden te onderzoeken, getuigen van een rigide vijandigheid jegens verandering en intolerantie ten opzichte van contradicties', speculeert de literatuurwetenschapper. En dit soort speculaties zijn natuurlijk Bermans goed recht. Kunst is meerduidig en niemand zal een criticus het recht ontzeggen een werk naar eigen goeddunken te interpreteren. Maar waarop baseert Berman zich? Op Syberbergs film? In de film ontbreekt een 'tendentieus commentaar', waaraan men dit soort inzichten zou kunnen ontlenen. Er is geen voice over, die op Winifred Wagners 'fouten' opmerkzaam maakt. Noch bevat de film 'tegensprekend materiaal'. "Het is een techniek van extreme gereserveerdheid, een houding van afstandelijk respect voor zijn onderwerp, die door Syberberg tendresse wordt genoemd,"

\footnotetext{
${ }^{117}$ Syberberg, a.w., p. 285.

118 idem, pp. 82ff. Tendresse betekent, legt Syberberg uit, "rust, zorgzaamheid en geduld om op weerklanken van bewegingen en woorden te wachten, mensen au sérieux nemen". Als regisseur niet "betweterig" willen zijn, of al te zeer op de voorgrond treden, maar alert en begripvol luisteren en meedenken, af en toe om een toelichting vragen, met zachte hand dirigeren en de cameraman aanwijzingen geven om de vrouw "opmerkzaam, onmerkbaar" te volgen. "En dan gebeurt er iets merkwaardigs, zoals misschien bij de psychoanalyse, of bij de straal die vliegtuigen veilig naar boven leidt of naar hun plaats van bestemming. Er ontstaat een wederzijds contact tussen de partners, die tevens de uiterste distantie en een helder hoofd bewaren." Want ook Syberbergs werkwijze heeft wel wat van die van een analyticus. Weliswaar ligt Winifred Wagner in de film nog net niet op de sofa, maar ze wordt wel gefilmd in een vertrouwde - en dus vertrouwenwekkende omgeving. De beslissing om de film op te nemen in de zijvleugel van de villa Wahnfried - "het huis waarin ze leeft, zit, praat en gewend is gasten te ontvangen" - blijkt weloverwogen genomen te zijn. Zelfs een ogenschijnlijk futiel detail als een stoel, heeft de warme belangstelling van de regisseur. Nagegaan dient te worden, merkt Syberberg op in Filmbuch, of een stoel al dan niet geriefelijk zit. Een oncomfortabele stoel zou makkelijk kunnen leiden tot "intense reacties". Een dergelijke stoel leent zich dan ook beter voor een pakkende slotscène dan om de film mee te beginnen. Zit de vrouw eenmaal op de juiste stoel, dan blijkt het maken van een film als Winifred Wagner slechts een kwestie van geduld. Het behoeft geen betoog, dat het initiatief bij de vrouw zelf ligt. De persoon voor de camera "formuleert" en "presenteert zichzelf". Ze kiest haar eigen woorden, haar eigen tempo en manier van spreken, haar eigen mimiek en lichaamstaal. En bij de regisseur vindt ze een luisterend oor. Hij dient zoveel mogelijk onzichtbaar te zijn; moet zich volledig kunnen 'terugtrekken' en 'transparant' worden, zonder zijn bovenbewustzijn en overwicht te verliezen. Met open geest, vrij van waardeoordelen, kunnen luisteren en meedenken - dat is waar het bij het maken van een dergelijke film op aankomt. Daarom is van cruciaal belang, aldus Syberberg, dat de regisseur vooraf "niets onderzoekt". Voorkennis staat een spontane reactie in de weg en werkt "betweterigheid" in de hand. "Alles wat de latere toeschouwer [tijdens het bekijken van de film, G.G.] te weten komt, zal ook de regisseur [tijdens de opnamen, G.G.] voor het eerst volkomen naïef reagerend, horen en in zich opnemen."

${ }^{119}$ Berman, a.w., pp. 370, 371.
} 
schrijft John Sandford. "Alleen de vaak ironische kopjes impliceren een externe kritiek op Winifred Wagners uitlatingen." 120

Als voorbeeld van een dergelijk 'ironisch kopje', waaruit 'externe kritiek' zou moeten blijken, citeert Sandford een tussentekst waarin de filmer zich expliciet richt tot de critici van zijn protestgeneratie van '68: "Aan de critici van mijn generatie. Het is geen persoonlijke verdienste, niet in barbaarse tijden te hebben geleefd en niet op een riskante plek op de proef te zijn gesteld. Het is relatief makkelijk om geen nazi te zijn in een tijd waarin geen Hitler bestaat". Deze tekst, legt Sandford uit, "is bedoeld als een waarschuwing tegen overhaaste en intolerante morele eigendunk van de jongere generatie". Maar, voegt hij hieraan toe, de tekst "roept eveneens vragen op over Winifred Wagners dubieuze attitude in een tijd waarin géén Hitler bestaat"! !21

Inventiviteit kan Syberbergs buitenlandse exegeten niet worden ontzegd. Zelfs een tussentekst die onmiskenbaar bedoeld is als een verzoek aan de jongere generatie om zich terughoudend op te stellen - ik zou bijna schrijven: zich niet te gedragen als een Dieter wordt omgebogen tot een impliciete kritiek op de tot de oudere generatie behorende Winifred Wagner. Een van de weinigen binnen de serieuze, Angelsaksische receptie, die het probleem moet hebben aangevoeld, is Susan Sontag. Het begrip rouwverwerking, schrijft Sontag in haar essay over de Hitler-film (1980), "duikt voor het eerst op aan het slot van de film over Winifred Wagner. Daar krijgen we te lezen: 'Deze film maakt deel uit van Hans Jürgen Syberbergs Trauerarbeit'. We zien daarbij een glimlachende Syberberg." 122

\subsection{Slot}

"Syberbergs film is belangrijk geweest," schrijft Gerard R. Koch in zijn hierboven reeds aangehaalde artikel in de Frankfurter Allgemeine van 20 maart 1980, waarin hij zich tevens afvraagt 'wiens geesteskind' de regisseur van dit werk zou kunnen zijn: "Hij [niet Syberberg dus, maar de film, G.G.] heeft een symptomatische figuur uit de Duitse geschiedenis aan de algemene verdringing onttrokken; hij heeft bepaalde inzichten in het wezen van het fascisme en de 'banaliteit van het kwaad' verschaft (...) en menig louterend proces in gang gezet."123 Dit strookt in grote lijnen met de manier waarop de film ook door de auteurs van de in dit hoofdstuk besproken Angelsaksische commentaren is gerecipieerd. En bekijk je het aldus, dan valt wel wat te zeggen voor het voorstel van Thomas Elsaesser om Syberbergs films op te vatten als 'populaire teksten met een eigen politiek onbewuste, dat zich per definitie aan de controle van de maker onttrekt en precies om deze reden een cultureel en historisch feit op zichzelf wordt'. Niettemin lijken een tweetal kanttekeningen me van belang.

Het is waar: elk kunstwerk dankt voor een niet onbelangrijk deel zijn culturele, historische en politieke betekenis aan de receptie, die niet noodzakelijk met de bedoelingen van de maker hoeft samen te vallen of zelfs volkomen ermee in strijd kan zijn. Doet de laatstgenoemde situatie zich voor, dan ligt het inderdaad voor de hand het meerduidige werk tegen de eenduidige opvattingen van de maker in bescherming te nemen, zoals Elsaesser in zijn essay uit ' 95 bepleit. Maar de toetssteen om de geldigheid van een interpretatie te bepalen, kan niet anders dan het werk zelf zijn. De interpretatiemogelijkheden van een

\footnotetext{
${ }^{120}$ Sandford, The New German Cinema, a.w., pp. 125, 126. Zie eveneens: Sandford, Hans Jürgen Syberberg, a.w., p. 9 .

${ }^{121}$ Sandford, The New German Cinema, a.w., p. 126.

${ }^{122}$ Sontag, S, Syberbergs Hitler. in: In het teken van Saturnus. Essays. Vert. D. Brisk. Weesp. 1984. pp. 181222. zie: 220 .

${ }^{123}$ Koch, a.w., p. 25.
} 
kunstwerk zijn niet oneindig - zeker niet indien het werk in kwestie een historische documentaire is. Het kan een interpretatie tegenspreken, waarbij het op de keper beschouwd weinig uitmaakt of deze afkomstig is van de maker dan wel van derden, of een zekere populariteit geniet. Ja, er zijn zelfs gevallen denkbaar waarin het raadzaam is een werk niet zozeer tegen zijn maker in bescherming te nemen, als wel tegen zijn receptie. Zoals festivalleider Wieland Wagner na '45 de 'populaire teksten' van zijn grootvader in bescherming heeft proberen te nemen tegen hun receptie ten tijde van het oude Bayreuth. ${ }^{124}$ Zover wil ik hier niet gaan. Al kan ik me moeilijk aan de indruk onttrekken, dat deze Angelsaksische commentaren soms op wel heel vernuftige wijze aan het werk zelf zijn voorbij geschreven.

Maar eigenlijk doet het er ook niet toe, hoe de interpretaties van Elsaesser cum suis zich verhouden tot het werk zelf. Van een scheiding tussen vorm en vent is bij hen immers geen sprake. Het zijn niet Syberbergs buitenlandse exegeten, maar juíst Duitse critici als Koch, Sombart en Günter, die een strikt onderscheid maken tussen het ook in hun ogen waardevolle werk en de maker, die ze verdenken van verwardheid en politiek-onfatsoenlijke sympathieën. Elsaesser en de zijnen daarentegen hebben zich veeleer de rol aangemeten van diens woordvoerder. Door hen wordt het werk geheel en al vanuit de intenties van de maker geïnterpreteerd. En als zodanig, dat wil zeggen als intentionalistische interpretaties, dienen deze Angelsaksische commentaren dan ook te worden beoordeeld. We zullen ons moeten afvragen of de auteurs met hun interpretatie recht doen aan wat Syberberg denkt, verafschuwt, wil, probeert, dan wel nastreeft. Vooruitlopend op het volgende hoofdstuk kunnen we over het antwoord kort zijn. Wie wil weten waar Syberberg voor staat, zal de commentaren van Elsaesser, Berman, Sandford en Santner tegen de keer in moeten lezen. Draai alle opvattingen die aan hem worden toegedicht om in het exacte tegendeel en je krijgt, zoals we zullen zien, een redelijk waarheidsgetrouw beeld van zijn bedoelingen.

Onder Duitse critici is het in dit verband bon-ton met de beschuldigende vinger te wijzen naar Susan Sontag, met wier Hitler-essay de fabuleuze roem overzee van deze filmmaker begin jaren ' 80 een aanvang heeft genomen. ${ }^{125}$ Toch treft de publiciste mijns inziens weinig blaam voor de pijnlijke vergissingen van hen die ná haar over dit oeuvre hebben geschreven. Ik wees er reeds op in de inleiding van dit hoofdstuk, dat Syberbergs bewonderaars niet over één kam mogen worden geschoren. Daarvoor vormen ze eenvoudig te zeer een gemêleerd gezelschap. Van Elsaesser, Berman, Sandford en Santner onderscheidt Sontag zich bijvoorbeeld in positieve zin door haar aanmerkelijk minder volgzame houding. ${ }^{126}$ De ambiguiteit, die ze in Syberbergs positie ten opzichte van Wagner meent te bespeuren (zie hoofdstuk 3 ), is in hoge mate typerend voor haar eigen positie ten opzichte van deze 'tweede verschijning'. Sontags Hitler-essay bevat precies dat 'curieuze brouwsel' van 'overgave en wantrouwen', 'onenigheid en hartstochtelijke ironie', dat volgens Thomas Mann inherent is aan elke 'hogere vorm" van Wagner-kritiek. ${ }^{127}$

Zo is het ook Sontag vanželfsprekend niet ontgaan, dat de filmer "pretendeert" met zijn Winifred-Wagner-documentaire 'de taak van het treuren' op zich te nemen. En ook zij vermoedt, dat Syberberg het begrip Trauerarbeit heeft ontleend aan Alexander en Margarete

\footnotetext{
124 Zie: hoofdstuk 3, paragraaf 7.

${ }^{125}$ Zie bijvoorbeeld: Fest, a.w., p. 266. Haacke, a.w., passim. Hamm, P., Syberbergs Kampf. Der Regisseur des Hitler-Films als Autor: in: Die Zeit. 32 (1981). p. 34. Jeziorkowski, $\mathbb{K}$, Das Glück der Wurzelbürste. in: Der Spiegel. 26 (1981) pp. 167-170, zie: p. 167.

126 "Überhaupt miBtraut sie [Sontag; G.G.] Syberbergs selbstdarstellungen im zusammenhang mit seinem HitlerFilm," merkt de Duitse publiciste Gabriele Förg scherp op. Förg, G., Der Schlaf der Vernunft gebiert Monstern. Eine Collage zu Hans Jürgen Syberberg. in: Unsere Wagner: Joseph Bewys, Heiner Müller, Karlheinz Stockhausen, Hans Jürgen Syberberg. Essays. Hrsg. G. Förg. Frankfurt am Main, 1984. pp. 124-163, zie: 159. ${ }^{127}$ Zie hoofdstuk 3, paragraaf 1.
} 
Mitscherlich, wier populaire hypothese over het Duitse 'onvermogen om te rouwen' hij tot "de zijne" zou hebben gemaakt. ${ }^{128}$ Maar in plaats van de verklaringen van de regisseur klakkeloos over te nemen, ${ }^{129}$ vertrouwt Sontag liever op haar eigen waarneming. De publiciste toont zich in dit essay een scherp observator. Ze merkt dingen op, die vrijwel alle critici ná haar zijn ontgaan. Bijvoorbeeld (zie hierboven) dat treuren wel eens op gespannen voet zou kunnen staan met glimlachen. Tussen het beeld van de glimlachende Syberberg aan het slot van de documentaire en de tussentekst waarin dezelfde Syberberg zijn film presenteert als een Trauerarbeit, bestaat mogelijk een frictie die in de commentaren van minder oplettende recensenten wordt weggeredeneerd: "Met zijn niet te onderdrukken aanleg tot verontwaardiging en enthousiasme werpt hij zich op 'de taak van het treuren'," probeert Sontag deze frictie te verwoorden. "Syberberg bezit niet de ambivalentie, de traagheid, de complexiteit en de gespannenheid, die bij een Saturnische aard horen. Hij is geen werkelijke melancholicus, maar een geëxalteerde figuur." ${ }^{130}$ Zoals eveneens zou blijken uit de onderwerpskeuze van de filmcyclus De Graal. Want het kan haast niet anders, denkt Sontag, of er gaat voor Syberberg een "bekoring" uit van "zelfverzekerde en egomane figuren" als Ludwig II, Karl May, Adolf Hitler, Richard Wagner en diens schoondochter Winifred Wagner-Williams - "(...) Allen leden ze aan grootheidswaan; ze logen alsof het gedrukt stond, lieten zich door de wildste dromen meeslepen en waren virtuozen van het grandioze. (...) Grootsheid is (...) datgene, waar Syberberg zich vooral op richt.",131

Sontag zegt het nog net niet met zoveel woorden. Maar vanuit deze opmerking naar de constatering, dat Syberberg de oude dame wel eens zou kunnen bewonderen, is een aanmerkelijk kleinere stap dan vanuit de commentaren van Elsaesser, Berman, Sandford en Santner. Waarmee ik niet wil beweren, dat haar interpretatie geen vragen zou oproepen. Kennelijk heeft de publiciste een bepaalde voorstelling van treuren, waaraan het werk van Syberberg niet beantwoordt. Om welke voorstelling het hier precies gaat, wordt in haar essay echter niet goed duidelijk. Nu eens verwijst ze naar Die Unfăhigkeit zu trauern, ${ }^{132}$ dan weer naar Über den Begriff der Geschichte, waarin de Duitse filosoof Walter Benjamin melancholie omschrijft als (in Sontags woorden) 'een inlevingsproces dat zijn oorsprong vindt in traagheid van harte, apathie'. "Syberberg heeft wel wat van Benjamins positieve leerzame kijk op melancholie," meent ze. ${ }^{133}$ En dat is natuurlijk goed mogelijk. Maar als we dan toch vrijelijk aan het associëren zijn, laten zich nog wel meer treurmodellen bedenken die direct of indirect iets met het werk van Syberberg te maken zouden kunnen hebben.

Wat de discussie aanzienlijk bemoeilijkt is, dat vrijwel niemand lijkt te weten wat Syberbergs eigen opvattingen over het treuren zijn. Is het inderdaad zo vanzelfsprekend, dat hij het begrip rouwverwerking aan de Mitscherlichs heeft ontleend? Ook Sontag moet toegeven, dat

\footnotetext{
${ }^{128}$ Sontag, a.w., pp. $204 \mathrm{f}$.

${ }^{129}$ idem, p. 205: "(...) Het valt te betwijfellen of de inspiratie voor de film [Hitler, G.G.] hieruit [de theorie van de Mitscherlichs, G.G.] is geput. Het is eerder aan te nemen, dat Syberberg het begrip Trauerarbeit als een psychologische en morele rechtvaardiging heeft gebruikt voor zijn vormgeving door middel van herhaling en herverwerking".

130 idem, p. 220.

131 idem, pp. $206 \mathrm{f}$.

132 "Hierin wordt vastgesteld," vat Sontag (idem, p. 204) de inhoud van deze studie samen, "dat de Duitsers lijden aan massale melancholie, voortgevloeid uit hun voortdurend loochenen wan de collectieve verantwoordelijkheid voor hun nationaal-socialistische verleden en hun starre weigering dit te betreuren". Terecht heeft Santner (a.w., p. 192) deze samenvatting gecorrigeerd: "Sontag is wrong, I think, wenn she claims that the Mitscherlichs had diagnosed the Germans as being afflicted by mass melancholia in the postwar periode". Immers: de 'werkhypothese' van de Mitscherlichs luidt juist, dat de Duitsers erin geslaagd zouden zijn een collectieve melancholische depressie te omzeilen (zie paragraaf 5). ${ }^{133}$ Sontag, a.w., p. 220 . Voor Benjamin, zie: Benjamin, W., Über den Begriff der Geschichte. in: Schriften I.2.
Frankfurt am Main, 1974 .
} 
hij nimmer naar hun studie verwijst. ${ }^{134}$ Waarom niet? Koketteert de filmer niet graag met zijn belezenheid? Wil hij zijn exegeten niet het gras voor de voeten wegmaaien? Of is hij misschien huiverig, dat zijn film vanuit de theorie van de Mitscherlichs wordt geïnterpreteerd?

${ }^{134}$ Sontag, a.w., p. 205. 


\subsection{Inleiding}

"Het merkwaardige is, dat Syberberg haar blijkbaar bewondert," merkt Renée in 't Veld op in haar boekje Uit liefde voor de Führer. Vrouwen van het Derde Rijk (1995). "Voor hem is Winifred Wagner de grande dame van Bayreuth, 'een realiste, vol noblesse, open en diplomatiek'. Meer nog, eigenlijk is ze ook nog een vroeg-geëmancipeerde, een Women Lib's figuur." Vooral deze laatste suggestie stuit bij de historica op onbegrip. Geëmancipeerd mag men deze voormalige festivalleidster misschien wel noemen, meent ze. We hebben hier per slot van rekening van doen met een zelfstandige vrouw, die als het erop aankwam zeer goed in staat bleek haar eigen wil door te zetten; vitaal en opgewassen tegen mannen, ook in de masculiene nazi-wereld. Maar een Women Lib's figuur? "Uit niets blijkt, dat dit streven [de vrouwenbevrijding, G.G.] ooit enige aandacht heeft gehad van deze bewonderaarster van Hitler en aanhangster van het zo apert vrouw-vijandige nationaal-socialisme."1

We zouden in dit verband nog een stapje verder kunnen gaan: ook in Syberbergs werk is weinig dat wijst op een eventuele affiniteit met het gedachtegoed van het feminisme. Integendeel: een vleugje feministisch bewustzijn is precies datgene wat Susan Sontag (1980) in de Hitler-film tevergeefs heeft gezocht. Afgezien hiervan en van een marxistische analyse, is in Syberbergs film met zijn bevlogen spraakzaamheid vrijwel alles te vinden, stelt de publiciste vast. ${ }^{2}$ In Die freudlose Gesellschaft (1981), een bundel notities uit de tijd van deze film, laat Syberberg zich zelfs kennen als een fervente tegenstander van het vrouwelijke emancipatiestreven, dat alleen maar zou hebben geleid tot "vermannelijking" en een verlies van het 'de vrouw' eigene - wat dit ook moge zijn. ${ }^{3}$ Maar met Syberberg weet je het maar nooit. Elders, meer specifiek in een door In 't Veld aangehaalde tekst in de bundel Filmbuch (1976), noemt hij de oude dame wel degelijk "een geëmancipeerde". En dit is nog niet alles: hij wil zijn documentaire bovendien begrepen zien als een persoonlijke bijdrage aan het (toenmalige) Jaar van de Vrouw. Heeft de filmer wellicht een kortstondig feministisch reveil doorgemaakt? Zo'n vaart blijkt het niet te lopen.

De flirt met het feminisme heeft bij een nadere beschouwing verdacht veel weg van een pesterijtje. Winifred Wagner, kunnen we in de bewuste tekst lezen, is een "sterke vrouw", die zich in de "mannenwereld van het Derde Rijk" uitstekend staande wist te houden; eigenlijk een geëmancipeerde tegen wil en dank, een "moordwijf," "de pendant van Rosa Luxemburg" - de legendarische Spartakiste, die in links-feministische kringen (we schrijven midden jaren '70) als een icoon van de vrouwenstrijd wordt vereerd. De beslissing om 1975 uit te roepen tot het Jaar van de Vrouw zal in deze kringen ongetwijfeld met instemming zijn begroet. Zelf blijkt Syberberg in een bijzin, die In 't Veld over het hoofd moeten hebben gezien, minder te spreken over een dergelijke pijnlijke "uitwas" van "het officiële racisme". Maar Syberberg is de kwaadste niet. Als het moet, is hij gaarne bereid met dit portret van een tegendraadse geëmancipeerde zijn steentje bij te dragen. ${ }^{4}$ En zo kennen we de filmer weer. Hier is inderdaad de man aan het woord, die in zijn Hitler-film er niet voor zal terugschrikken

\footnotetext{
'In 't Veld, R., Uit liefde voor de Führer. Vrouwen van het Derde Rijk. Zutphen, 1995. pp. 11 Lf.

${ }^{2}$ Sontag, S., Syberbergs Hitler. in: In het teken van Saturnus. Essays. Vert. D. Brisk. Weesp, 1984. pp. 181222 , zie: 219 .

${ }^{3}$ Syberberg, H.J., Die freudlose Gesellschaft. Notizen aus den letzten Jahr. München, Wien, 1981. pp. $27,43$.

${ }^{4}$ Syberberg, H.J., Syberbergs Filmbuch. München, 1976. pp. 250, 251. In het boekje van In 't Veld ontbreekt een annotatie. Maar ik vermoed, dat ze haar opmerking over de Women Lib's figuur op deze tekst baseert.
} 
de Führer hoogstpersoonlijk vanuit het hiernamaals een lofzang op "het nieuwe racisme van de vrouwenbeweging" te laten afsteken: "En als we niet voor het moederschap zijn, dan zijn we toch gewoon ertegen! Zolang we maar triomferen, onverbiddelijk en genadeloos.".

Dit neemt niet weg, dat Renée in 't Veld als een van de weinige buitenlandse critici de strekking van de tekst in Filmbuch goed heeft aangevoeld. Er is geen enkele twijfel over mogelijk, dat Syberberg deze oude dame bewondert. Hij wil haar niet bekritiseren, zoals nogal wat van zijn exegeten in vooral de Verenigde Staten denken, maar haar juist aan het (Duitse) publiek ten voorbeeld stellen. Winifred Wagner wordt door hem op een voetstuk geplaatst, als... ja, als wat? In elk geval niet als een boegbeeld van de vrouwenemancipatie. Maar wat het dan wel is dat deze 'oude nationaal-socialiste' (haar eigen woorden) ${ }^{6}$ in zijn ogen zo bewonderenswaardig maakt, laat zich minder eenvoudig vaststellen. In dit hoofdstuk wil ik niettemin een poging wagen. Het lijkt misschien een detail in de totale discussie rond zijn werk. Zo besteden Thomas Elsaesser, Russell Berman, John Sandford en Eric Santner aan deze documentaire hooguit enkele pagina's, als een soort opmaat tot het werk dat doorgaans wordt beschouwd als het magnum opus uit dit oeuvre: Hitler, ein Film aus Deutschland (1977). Toch ben ik ervan overtuigd, dat het ontsluieren van het raadsel van Syberbergs bewondering ons helpt een beter zicht te krijgen op zijn positie - en hiermee indirect ook op de verschillen met zijn buitenlandse achterban.

Vooral om dit laatste is het me in dit hoofdstuk te doen. De inzet moge duidelijk zijn. Aan het slot van het vorige hoofdstuk, waarin ik uitvoerig ben ingegaan op de Angelsaksische receptie van Winifred Wagner und die Geschichte des Hauses Wahnfried von 1914-1975 (1975), bleven we achter met een onbestemd gevoel. Hoewel ons dit nadrukkelijk werd beloofd, hadden we sterk de indruk dat de besproken commentaren geen recht deden aan de intenties van de maker van dit werk. Ik zal nu laten zien, dat deze indruk meer dan terecht was. Naar een verklaring voor de Babylonische spraakverwarring, die zich jarenlang heeft afgespeeld tussen deze filmer en een niet onaanzienlijk deel van zijn buitenlandse achterban, kunnen we slechts gissen. Dat critici uit het Angelsaksische taalgebied niet in staat zouden zijn Duits te lezen, zoals de Duitse kunstenaar en academiedocent Hans Haacke (1982) heeft geopperd, ${ }^{7}$ lijkt me onwaarschijnlijk. Al is het natuurlijk wel zo, dat het inhoudelijk begrijpen van Syberbergs teksten, behalve een gedegen kennis van de toenmalige (politieke) verhoudingen in de Bondsrepubliek, ook een zeker fingerspitzengefühl vereist. Want dat we hier van doen hebben met een kunstenaar, die 'graag aanstoot geeft' (Sontag), moge onderhand duidelijk zijn. Wie hierop niet bedacht is, wordt onherroepelijk op het verkeerde been gezet. Zo iemand zou inderdaad makkelijk kunnen denken dat Winifred Wagner in deze film wordt geportretteerd als een 'vroeg-geëmancipeerde'. Of, pijnlijker nog, als een afschrikwekkend voorbeeld van het door het links-geëngageerde psychiaterechtpaar Alexander en Margarete Mitscherlich geconstateerde Duitse 'onvermogen om te rouwen'.

Je zou het een klassiek geval van épater le bourgeois kunnen noemen, ware het niet dat een dergelijk begrip sterk de associatie wekt met provoceren om het provoceren. En daarvan kan bij Syberberg toch ook weer geen sprake zijn. Niet slechts gaat achter zijn

\footnotetext{
${ }^{5}$ Syberberg, H.J., Hitler, ein Film aus Deutschland. Hamburg, 1978. p. 236. Zie eveneens de monoloog van de 'buikspreekpop-Hitler', waaruit dit citaat afkomstig is, in hoofdstuk 6, paragraaf 3.

${ }^{6}$ Zie: hoofdstuk 4, paragraaf 2.

${ }^{7}$ Haacke, H., To the editor. in: Art Forum. (december 1982) pp. 3f. Anderen, zoals de Amerikaanse historicus Walter Laqueur, hebben het 'onbegrip' in vooral de Verenigde Staten toegeschreven aan het aldaar heersende post-Vietnam-traum: zelf zwaar getraumatiseerd zouden Amerikaanse critici hun eigen preoccupatie met schuld en verantwoordelijkheid projecteren op een Duitse filmmaker als Syberberg. Zie: Laqueur, W., Was ist los mit den Deutschen? Übersetzt von O. Weith. Frankfurt am Main, Berlin, 1985, 1988. p. 140.

Sontag, a.w., p. 206.

9 Zie: hoofdstuk 4 , de paragrafen 5 en 6.
} 
bewieroking van de oude dame een opmerkelijk consistente voorstelling schuil van Duitsland en Duitse geschiedenis, die hem welhaast noodzakelijk met de auteurs van de in het vorige hoofdstuk besproken commentaren in conflict moet brengen; ook in zijn keuze van opponenten laat zich wel degelijk een rode lijn aanwijzen die als sinds jeugdwerken als de verfilming van Brechts 'verboden' Urfaust (1953) of de verdediging van het theater van de absurdisten in Zum Drama Friedrich Dürrenmatts door dit oeuvre loopt. ${ }^{10}$ Zoals we zagen in de voorafgaande hoofdstukken wordt de verbindende schakel in dit oeuvre gevormd door de polemiek tegen een richting in de Duitse cultuurtheorie, waarvan Georg Lukács en de late Thomas Mann de meest bekende en invloedrijke vertegenwoordigers zijn. Typerend voor deze richting is, dat ze het cultuur- en mentaliteitshistorische substraat van de nazi-barbarij zoekt in een vermeend 'irrationele', dat wil zeggen tegen de Verlichting gerichte traditie binnen de Duitse cultuurgeschiedenis, die zou lopen via Schelling, Schopenhauer, Wagner en Nietzsche naar de 'zogenaamde avant-garde" (Lukács) van het naturalisme tot het absurdisme." Volgen we Jürgen Habermas, dan zou dit 'irrationele' anti-Verlichtingsdenken in de Bondsrepubliek van de late jaren ' 70 een heuse renaissance doomaken, die een ernstige bedreiging vormt voor het in zijn ogen ware linkse project van de Aufarbeitung van de Duitse "Verlichtingstraditie van Lessing tot Marx" waarmee Lukács en Mann in het interbellum een aanvang hebben gemaakt. En vooral in eigen land geniet Syberberg de reputatie een apologeet van deze Tendenzwende te zijn. ${ }^{12}$ Zelf mag de filmer zich graag beroepen op de grote tegenspelers van Lukács en Mann binnen het linkse cultuurdebat: Bertolt Brecht, Hans Mayer en Ernst Bloch. Het belangrijkste argument, waarmee hij zijn 'irrationele' kunstwerken verdedigt is aan de laatstgenoemde ontleend: de ware kritische filosoof of kunstenaar legt zich niet neer bij de pervertering, maar ontwikkelt strategieën om het geroofde culturele erfgoed weer aan de nazi's te ontfutselen. ${ }^{13}$

Maar laten we bij het begin beginnen. Vanwaar Syberbergs bewondering voor deze oude dame?

\subsection{Bekennen}

Om Winifred Wagners optreden in de film te beschrijven zoekt Syberberg steevast zijn toevlucht tot het Duitse werkwoord bekennen. Wat we in deze film te zien krijgen, wordt hij niet moe te benadrukken, is "een vrouw die sich bekennt".14 "Zonder koppig te zijn of boos te worden bekennt ze zich tot haar verleden en in deze houding is ze uniek." Hieruit bestond, meent Syberberg, ook "haar schandaal": een vrouw uit de Hitler-generatie bekannte sich tot Hitler. ${ }^{16}$ En hij hoopt dat van deze Bekenntnis een louterend effect zal uitgaan. Want het gaat in deze Trauerarbeit om: "die kathartische Funktion einmal zu sehen wie eine sich bekennt". ${ }^{17}$ Zoveel belang blijkt Syberberg te hechten aan dit bekennen, dat hij de Engelse versie van de documentaire zelfs een nieuwe titel heeft gegeven: The Confessions of Winifred Wagner - naar we mogen aannemen een vertaling van: Die Bekenntnisse Winifred Wagners.

\footnotetext{
${ }^{10} \mathrm{Zie}$ : de paragrafen 2.3 en 2.5 .

11 Zie: de paragrafen $2.4 \mathrm{en} 3.4$.

12 Zie: paragraaf 4.1 .

${ }^{13}$ Zie: de paragrafen 3.6 en 3.7 .

${ }_{14}$ Syberberg, Filmbuch, aww, p. 247.

${ }^{15}$ Wirbel um offene Worte Winifreds. Fin-Bekenntnisse gerieten in politisches Zwielicht. in: Richard Wagner. Ein deutsches Thema. Eine Dokumentation zur Wirkungsgeschichte Richard Wagners (1876-1976). Hrsg. H.

Zelinsky. Berlin, Wien, 1976, 1983. p. 273.

${ }_{16}$ Syberberg, H.J., Eine Zeugin und eine Schuldige. in: Der Spiegel. 11 (10 maart 1980). pp. 234,235, zie: 234.

${ }^{17}$ Syberberg, Filmbuch, a.w., p. 264.
} 
Sommige critici hebben deze ingreep betreurd. De nieuwe Engelse titel zou ten onrechte de associatie wekken met een confession of guilt - een schuldbekentenis. ${ }^{18}$ Maar dit is niet het eerste waar je aan denkt bij een vrouw die sich bekennt. Het Duitse bekennen mag niet worden verward met het Engelse confess - (schuld) bekennen, (op)biechten. Natuurlijk, ook in het Duits kun je Schuld bekennen. Dat Winifred Wagner dit in de film zou hebben gedaan, zul je Syberberg overigens niet horen beweren. Wel heeft de vrouw, naar hij meent, met haar Bekenntnis "de schuld op zich genomen"19 - een subtiel verschil, want strikt genomen is het mogelijk de schuld op je te nemen, zonder eigen schuld te bekennen of zelfs maar schuldig te zijn. Denk in dit verband aan het Lam Gods, dat Zelf zonder zonde was, maar niettemin de zonden van de wereld op Zich nam. Vergezocht? Zoals gezegd: bij Syberberg weet je het maar nooit.

Anders dan het Engelse confess, heeft het Duitse bekennen echter in veel geringere mate deze connotatie met schuld en boetedoening. Het is moeilijk er precies de vinger achter te krijgen. Maar confess suggereert een zekere gêne, misschien zelfs deemoed. ${ }^{20}$ Opbiechten of schuld bekennen is iets, dat je doorgaans met gebogen hoofd doet. Terwijl bekennen juist een zelfverzekerde en kordate houding veronderstelt. Dit is wat ik heb gedaan; het zij zo, ik doe er niet moeilijk over, maar bekenne mich offen dazu. Het Engelse en het Duitse woord betekenen bovendien niet geheel hetzelfde. Misschien laat bekennen zich nog het makkelijkste vertalen als belijden. Je kunt schuld belijden - in het Engels inderdaad confess. Maar ook, bijvoorbeeld, een geloof - waarvoor in het Engels een ander woord bestaat, namelijk profess. Het Engelse zelfstandige naamwoord confession kent deze dubbelzinnigheid weer wel. Het kan zowel slaan op een schuldbekentenis (Schuldbekenntnis, Schuldgeständnis) of een biecht (Beichte), als op een geloofsbelijdenis (Glaubensbekenntnis). ${ }^{21}$ "This film is an act of confession, a confession of faith," verduidelijkt Syberberg in een Engelse toelichting. ${ }^{22}$ Geen bekentenis in de zin van ons Nederlandse woord: het bekennen van wat men liever niet bekennen zou. Maar (hetgeen volgens van Dale een germanisme is) in de zin van: het zich bekennen tot een geloof of een overtuiging, een mening of een opvatting, een partij of een politicus, een gevoel of een vriendschap, een handeling of een misstap enzovoorts. Qua gevoelswaarde komt het Duitse bekennen ongetwijfeld nog het meest overeen met het Nederlandse opkomen voor of uitkomen voor. 'Eine Frau, die sich bekennt', is een vrouw die er rond voor uitkomt, volmondig kleur bekent, onomwonden haar gedachten en gevoelens naar voren brengt, zonder ook maar iets onder stoelen of banken te steken. En, in dit verband niet onbelangrijk,

\footnotetext{
${ }^{18}$ Berman, R.A., Hans Jürgen Syberberg. Of Fantastic and Magical Worlds. in: New German Filmmakers. From Oberhausen through the 1970s. ed. K. Phillips. New York, 1984. pp. 359-378, zie: 369. Sandford, J., The New German Cinema. London, 1980. pp. 125, 126. Zie eveneens: hoofdstuk 4, paragraaf 4.

${ }^{19}$ Syberberg, Eine Zeugin und eine Schuldige. a.w., p. 234. Zie eveneens: Syberberg, H.J., Die Kunst als Rettung aus der deutschen Misere. Ein Essay. in: Hitler, ein Film aus Deutschland. a.w., p. 34.

20 "Confess. 1. If someone confesses to doing something wrong or something that they are ashamed of, they admit that they did it. 2. If someone confesses or confesses their sins, they tell God or a priest about their sins so that they can be forgiven. 3. You use expressions like 'I confess', 'I must confess', or 'I have to confess' to apologize slightly for admitting something you are ashamed of or that you think might offend or annoy someone." Collins Cobuild English Dictionary. ed. J. Sinclair. London, 1995.

${ }^{21}$ In het Duits ligt bij de woorden bekennen en Bekenntnis de tweede betekenis meer voor de hand. Het Duitse etymologische woordenboek, Der Große Duden. Band 7. Etymologie. Herkunftswörterbuch der deutschen Sprache. Hrsg. P. Grebe. Mannheim, 1963, geeft onder het trefwoord bekennen het volgende: "Der heutige allein gültige Sinn 'gestehen, als Überzeugung aussprechen', eigtl. 'bekannt machen' geht von der mittelalterl. Rechtssprache aus und ist von den Mystikern im 14. Jh. in religiösem Sinn (...) ausgeprächt worden. (...) Bekenntnis bedeutet u.a. auch 'Geständnis, Zeugnis, Glaube'; der heutige Gebrauch ist von 'Konfession' beeinflußt, das sich zu 'Bekenntnisgruppe' entwickelt hat," 22 Filmography. in: Syberberg. A Filmmaker from Germany. ed. H. Stewart. Edinburgh, 1992. pp. 44-57, zie: p.
50 .
} 
een dergelijke vrouw schaamt zich niet voor haar Bekenntmis. Fier en zelfverzekerd, met geheven hoofd, legt ze getuigenis af van haar geloof - "openhartig, (...) standvastig en lachend, (...) welhaast trots," aldus Syberberg. ${ }^{23}$ Dit is waar ik voor sta, ik wind er geen doekjes om, maar kom er rond voor uit. En ja, "waarom eigenlijk niet?"

Vooral deze laatste, door Syberberg zelf bedachte woorden, ${ }^{24}$ tekenen de vrouw ten voeten uit: ongenaakbaar en eigenzinnig, een tikkeltje "boosaardig" (Syberberg) ${ }^{25}$ ook, want ze weet drommels goed dat ze met haar belijdenis menigeen tegen de haren zal instrijken, ${ }^{26}$ maar altijd met de waardigheid van de grande dame. "Ondanks alles," moet de Duitse filmcriticus Winifried Günther (1976) toegeven, is deze oude dame "fascinerend": "Het is haar krachtige uitstraling en soevereiniteit, ja zelfs haar soms nog altijd een "bazige" indruk makende manier van doen, die op de een of andere manier ontzag verlangen." ${ }^{27}$ En Günther blijkt niet de enige criticus te zijn, die aan het bekijken van de film gemengde gevoelens heeft over gehouden. De scherpe grens die ze trekt tussen de 'goede oom' en de massamoordenaar Hitler illustreert "op ontstellende wijze het probleem van de banaliteit van het kwaad", schrijft bijwoorbeeld de Bayreuth welgezinde muziekcriticus Dieter Rexroth (1975). Maar de "openhartigheid", waarmee ze "sich (...) bekennt (...) tot een persoonlijk mensbeeld van Hitler imponeert en dwingt respect af." In dit verband niet oninteressant is ook een terloopse opmerking van de Britse musicoloog Geoffrey Skelton, in zijn beroemde, in 1971 vier jaar voor Syberbergs film! - verschenen biografie van de oudste zoon: Wieland Wagner. The positive sceptic. Volgen we Skelton, dan was de "onboetvaardigheid" van Wieland Wagners moeder reeds ruimschoots voor haar spraakmakende coming out in de zomer van '75 een publiek geheim, waaraan vrijwel niemand op of rond de Groene Heuvel aanstoot leek te nemen. Integendeel: " $\mathrm{Zij}$ [Winifred Wagner, G.G.] genoot grote populariteit in het stadje Bayreuth - zelfs onder hen die niet sympathiseerden met haar politieke denkbeelden". Deze populariteit had ze te danken aan "her honesty in standing up for her beliefs" - de eerlijkheid, waarmee ze opkwam voor haar overtuigingen, zo men wil: sich zu ihrer Überzeugungen bekannte. Hierdoor onderscheidde ze zich in positieve zin van zoveel andere Duitsers; die "druk doende waren met veinzen, dat hun trouw aan Hitler weinig meer zou hebben behelst dan uiterlijk vertoon". ${ }^{29}$

En misschien is dit een facet van Winifred Wagners karakter, waarvoor sommige critici te weinig oog hebben gehad. De vrouw mag dan koppig zijn, in de zin dat ze het allemaal beter meent te weten dan alle historische onderzoeken en denazificatierechtbanken bij elkaar (Nicolaus Sombart); ${ }^{30}$ ondanks alles zou je haar ook soeverein, principieel, moedig en recht door zee kunnen noemen. En kennelijk hoeft men geen nazi te zijn, om zich door deze eigenschappen te laten imponeren. Ook Syberberg kan naar eigen zeggen voor Winifred

\footnotetext{
${ }^{23}$ Syberberg, Filmbuch, a.w., pp. $246,247$.

24 Zie hoofdstuk 4, paragraaf 8 .

${ }^{25}$ Syberberg, a.w, p. 285.

26 "Met de weduwe Rost van Tonningen deelde ze het vermogen en blijkbaar ook de behoefte om de buitenwereld te schofferen met haar luid verkondigde bewondering voor de pathologische moordenaars van het nazi-regime," schrijft In "t Veld. a.w., p. 112.

${ }^{27}$ Günther, W., Winifred Wagner und die Geschichte des Hauses Wahnfried von 1914-75. in: Medium. 6 (mei 1976). pp. 32,33 , zie: 32 .

${ }^{28}$ Rexroth, D, Winifred Wagner, das Haus Wahnfried - und Adolf Hitler als 'Mensch'. in: Richard Wagner. Ein deutsches Thema, a.w., p. 272.

${ }^{29}$ Skelton, G., Wieland Wagner. The positive sceptic. London, 1971. pp. 14-15: "(...) She enjoyed great popularity in the town of Bayreuth - even among those who had no sympathy with her political views - for, her honesty in standing up for her beliefs when practically all others in Germany were busy pretending that their allegiance to Hitler had been on the surface only".

${ }^{30}$ Zie: hoofdstuk 4 , paragraaf 3 .
} 
Wagners politieke denkbeelden "ïberhaupt geen waardering" opbrengen. ${ }^{31}$ Maar hij bewondert haar "moed" en "eerlijkheid". 32 Wat men ook van deze vrouw mag denken; ze is, vermoedt Syberberg, in elk geval oprecht. Of hadden we misschien liever gezien, dat ze in de film haar ware gedachten en gevoelens voor zich zou hebben gehouden en zou hebben volstaan met het geven van politiek correcte antwoorden. "Hier? Vandaag? In Heidelberg?," antwoordt Albert Speer in een NBC-interview uit 1976 op de vraag, wat hij zou doen wanneer Hitler plotseling weer in levenden lijve zou opduiken. "I would call the police!". Dit citaat wordt door Syberberg aangehaald in de bundel Filmbuch (1976) en gecontrasteerd met een opmerking van Winifred Wagner een jaar eerder in de film: "Wanneer Hitler hier vandaag door de deur naar binnen zou komen, zou ik net zo vrolijk en net zo gelukkig zijn als altijd, om hem hier te zien en weer bij ons te hebben." ${ }^{33}$ Zo spreekt een vrouw, die sich bekennt. Ze draait er niet om heen, maar speelt gewoon open kaart. Een dergelijke vrouw kun je recht in de ogen kijken. Hetgeen, lijkt Syberberg te suggereren, van Speer niet kan worden gezegd.

\subsection{Het pedagogische schema van beschuldiging en verontschuldiging}

Maar hoe zit het dan met de veelgehoorde kritiek, dat de voormalige festivalleidster gebukt zou gaan onder emotionele rigiditeit? "Waar schuld ontstaat verwachten we berouw en de behoefte om het weer goed te maken. Waar verlies werd geleden is treurnis, waar het ideaal werd geschonden, gezichtsverlies plaats vond, is schaamte de natuurlijke consequentie." Aldus Alexander en Margarete Mitscherlich in Die Unfähigkeit zu trauern (1967). ${ }^{34}$ Welnu, Winifred Wagner is, ook volgens Syberberg, 'een schuldige'. ${ }^{35}$ En ze heeft hoe dan ook (gezichts-)verlies geleden. Haar kennelijke naoorlogse populariteit in het stadje Bayreuth ten spijt, heeft de vrouw wel wat van de "fanatieke nationaal-socialiste", waarover de Duitse schrijver Botho Strauß opmerkt in Paare, Passanten (1981): "Plotseling gold ze als 'de gek'. Zij, zojuist nog de meest gezonde, het meest één met zichzelf." ${ }^{36} \mathrm{Al}$ valt dit aan de manier waarop ze zich in de film gedraagt nauwelijks af te lezen. Dertig jaar na dato presenteert ze zich nog steeds met de air van een grande dame. Alsof ze niet pijnlijk in haar eer is getroffen, zich niet schuldig heeft gemaakt, of voor haar verleden zou hoeven te gêneren. Meer nog: de vrouw is "duchtig onboetvaardig" (John Sandford) ${ }^{37}$ Het meest in het oog springend, merkt Eric Santner (1990) op, is "een welhaast grotesk onvermogen om berouw te voelen voor haar betrokkenheid bij Hitler en het nationaal-socialisme, empathie met hen die leden, of begrip voor hen die verzet leverden tegen het nazi-regime". En dient dit niet "tekenend" te worden genoemd voor " $(. .$.$) de bevroren zijde van een persoon, die het ten enen male ontbreekt aan$ een vermogen om te rouwen" ${ }^{38}$ Het is vooral op dit punt, dat Syberberg fundamenteel met de auteurs van de in het vorige hoofdstuk besproken commentaren van mening blijkt te verschillen.

\footnotetext{
${ }^{31}$ Wirbel um offene Worte Winifreds. a.w.. Zie eveneens: hoofdstuk 4, paragraaf 7.

${ }^{32}$ Syberberg, a.w, p. 246.

33 idem, p. 261.

${ }^{34}$ Mitscherlich, A., Mitscherlich, M., Die Unfähigkeit zu trawern. Grundlagen kollektiven Verhaltens. München, Zürich, 1967, 1990. p. 36.

${ }^{35}$ Syberberg, Eine Zeugin und eine Schuldige, a.w..

${ }^{36}$ Strauß, B., Paare, Passanten. München, Wien, 1981, 1984. p. 172.

${ }^{37}$ Sandford, $J$, Hans Jürgen Syberberg: Films from Germany. in: Syberberg. A Filmmaker from Germany. a.w.,

p. 9. Voor Sandfords interpretatie van de Winifred-Wagner-documentaire, zie: hoofdstuk 4, paragraaf 6 .

${ }^{38}$ Santner, E.L., Stranded Objects. Mourning. Memory, and Film in Postwar Germany. Ithaca, London, 1990. .

129. Voor Santners interpretatie van de Winifred-Wagner-documentaire, zie: hoofdstuk 4, paragraaf 6.
} 
Neem het volgende citaat uit het allereerste interview (juli 1975), dat Syberberg naar aanleiding van deze film heeft gegeven: "Zonder kwaad te worden of koppig te zijn, bekennt sie sich zu ihrer Vergangenheit en in deze houding is ze uniek. Wie heeft tegenwoordig al de moed om te zeggen: ik heb meegedaan en ben daarom niet kwaad op de geschiedenis van mijn leven? Er lopen nog zoveel verbitterde figuren rond. Dan is het toch iets bijzonders wenn jemand sich so frei zu seinem Leben bekennt". ${ }^{39}$ Hoe je het ook wendt of keert: op grond van dit citaat is slechts één conclusie mogelijk. Anders dan bijvoorbeeld Santner en Russell Berman (1984) met een beroep op de rouwtheorie van de Mitscherlichs betogen, ${ }^{40}$ huldigt Syberberg de opvatting dat de, zoals ze het zelf in de film noemt; Kaltschnäuzigkeit ${ }^{41}$ van deze oude dame niet "paradigmatisch" is voor de "collectieve psychologische gevoelshuishouding van het naoorlogse Duitsland'. Integendeel: Winifred Wagner is 'uniek'. En wat haar 'uniek' maakt is juist, dat ze niet gebukt gaat onder emotionele rigiditeit, maar 'frank en vrij opkomt voor haar leven'. Zeker: van 'berouw', 'treurnis' of 'schaamte', valt bij haar zelfs niet het geringste spoortje te bekennen. Laat staan van 'woede', waaraan Eric Santner in zijn interpretatie (zie paragraaf 4.6) zoveel belang hecht. Maar zijn dit soort gevoelens wel zo 'natuurlijk', als de Mitscherlichs in hun studie willen doen geloven?

In een interview uit 1977 , afgenomen een week na het begin van de opnamen van Hitler, ein Film aus Deutschland maakt de Nederlandse schrijver Léon de Winter de filmer attent op een tweetal incidenten. In een aflevering van de Duitse politieserie Tatort stonden op het bureau van een rijke industrieel twee Messerschmitt-modellen, zonder dat deze een duidelijke functie hadden binnen het verhaal. Kort daarop wijdde het boulevardblad BildZeitung een groot artikel aan het huidige leven van voormalige Duitse oorlogshelden. Beide incidenten blijken De Winter, die zich in dit interview nadrukkelijk profileert als "kind van joodse ouders", onaangenaam te hebben verrast. Maar voor een kind van Duitse ouders, dat naar eigen zeggen in zijn jonge jaren nog zelf met Messerschmitt-modellen heeft gespeeld (per slot van rekening is de Messerschmitt " $(. .$.$) een mooi vliegtuig, zoals ook een auto mooi$ kan zijn") liggen de zaken anders. "Het zou veel erger zijn als ze zo'n Messerschmitt niet op hun bureau hadden staan (...)," repliceert Syberberg.

"De moeilijkheid blijft, dat de meerderheid van het Duitse volk onder Fitler tevreden was. Men was toen jong, ging 's avonds dansen, men trouwde. Die tijd heeft voor velen de aantrekkingskracht van een voorbije jeugd. Men weet dat het een slechte tijd was, een slecht verleden, maar men was toen jong, met alle aantrekkelijkheden van dien. Daar komt bij, dat men zich toen enige jaren de machtigste van de wereld voelde. Er was niet alleen 1945, daaraan vooraf ging een grootse tijd voor hen. Ik zou het verbazingwekkend vinden als ze daar nu allemaal op zouden schelden. Psychologisch, voor een heel volk, zou dat slecht zijn. Ik vind het niet alleen natuurlijk, maar ook goed dat dit alles eruit komt. Als een heel volk zich nu nog zou geselen onder de schuld, dan zou er iets heel gevaarlijks groeien. Ik geloof dat men zo niet kan existeren. Er is dan wel geen Versailles, waar wat wordt gedicteerd. Maar er bestaat wel een psychologisch Versailles en dat is gevaarlijk." 42

\footnotetext{
${ }^{39}$ Wirbel um offene Worte Winifreds, a.w..

${ }^{40}$ Voor Bermans interpretatie van de Winifred-Wagner-documentaire, zie: hoofdstuk 4, paragraaf 4 .

${ }^{41}$ Zie: hoofdstuk 4, paragraaf 8.

${ }^{42}$ Winter, de, L., Het Duizendjarig Rijk als filmlokatie. in: Hollands Diep. 6 (26 maart 1977). pp. 40-43, zie: 43. Zie eveneens: Syberberg, HJ., Einleitung. in: Fotografie der 30er Jahre. Eine Anthologie. Hrsg. H.J. Syberberg. München, 1977. pp. 5-7: "Für uns Deutsche sind es die goldenen Jahren des Hitlerschen Friedens von seinen demokratischen Abstimmungssiegen bis zum Einmarsch in Paris. (...) Nostalgie oder Entsetzen befallt unsere Väter und Mütter, wenn sie das Glück hatten, zu überleben. Für die Meisten war es eine schöne Zeit, ein
} 
Helaas verzuimt Syberberg concrete voorbeelden te geven van dit, door hem geconstateerde "psychologische Versailles'. Maar voor tijdgenoten zal het volstrekt duidelijk zijn geweest, waar de filmer zich tegen richt. "Een demagoog als Franz Jozef Strauß", weten de Mitscherlichs, "is het inmiddels gelukt om de poging tot zelfanalyse van ons gedrag ten tijde van het Derde Rijk af te sehilderen als iets abnormaals - als een masochistische pervertering van boete-Duitsers". ${ }^{43} \mathrm{En}$ op zijn laatst sinds de publicatie van de Winifred-Wagnernecrologieën (maart 1980) bestaat onder Duitse critici brede consensus, dat ook Syberberg in deze - politieke - hoek dient te worden gesitueerd. ${ }^{44}$ Of deze indeling terecht is, valt nog te bezien. Zo blijkt ook een buitenstaander als de Nederlands/Britse publicist Ian Buruma (1994) aan zijn reizen door de Bondsrepubliek van de vroege jaren ' 90 het ongemakkelijke gevoel te hebben overgehouden, "dat een overmaat aan verontschuldiging kan veranderen in een vorm van zelfkastijding". " En wat te denken van de interpretatie die de Zwitserse psychoanalytica Alice Miller biedt van Syberbergs Hitler-film in Am Anfang war Erziehung (1980), een vervolg op het bekende, uit 1979 daterende Das Drama des begabten Kindes und die Suche nach dem Wahren selbst?

Alvorens op de film in te gaan bespreekt Miller een casus, die verrassende overeenkomsten vertoont met het verhaal van Susanne uit Santners Stranded Objects (zie paragraaf 4.6). Een jonge Duitse vrouw, geboren in 1936, lijdt aan depressies. En net als in het verhaal van Susanne is het ook hier de zoon, die een verlaat verwerkingsproces op gang brengt door zijn moeder met het onverwerkte verleden te confronteren. Maar er bestaat één cruciaal verschil: de ommekeer wordt niet teweeg gebracht door het in schoolverband aufarbeiten van de holocaust. In plaats van, zoals Santners Dieter en diens klasgenoten, archieven te raadplegen of contact op te nemen met joodse overlevenden, doet deze zoon iets volstrekt anders: hij begint samen met schoolvriendjes hakenkruisen te kalken en met andere rekwisieten uit de Hitler-tijd te spelen. Dit tot grote ontzetting van zijn moeder: "Zij vond die spelletjes griezelig, ze wilde er niets mee te maken hebben, ze voelde zich zelfs, als voormalig lid van een antifascistische studentengroep, gekwetst door haar kind en reageerde ongewild autoritair en vijandig." Pas na een intensieve therapie, schrijft Miller, zal de moeder gaan onderkennen dat ze, door op deze wijze te reageren, niet slechts de roep om affectieve aandacht van haar kind negeerde, maar tevens haar eigen 'ware zelf' verdrong. ${ }^{46}$ Want volgen we Miller, dan leven Duitsers uit de tweede generatie, die de oorlog als kind of puber hebben meegemaakt, emotioneel en intellectueel in twee verschillende werelden, die "zich moeilijk met elkaar in harmonie laten brengen zonder een belangrijk deel van hun zelf te verloochenen". Enerzijds hebben ze na ' 45 de gruwelijke waarheid over het nationaalsocialistische systeem vernomen en deze latere kennis intellectueel geïntegreerd; anderzijds koesteren ze intense gevoelens, die zijn verbonden met stemmen, liederen, toespraken, jubelende menigten uit de kindertijd. En in de meeste gevallen, constateert Miller, gaan dergelijke impressies gepaard met "trots, enthousiasme en blijde hoop" met precies die gevoelens, die binnen 'de psychoanalyse van het Duitse onvermogen om te rouwen' een sterke indicatie zijn voor een pathologische afweer van andere, meer 'natuurlijke' gevoelens als woede, schaamte, berouw, treurnis, of compassie met de

Aufbruch im Geschwindigkeitsrausch, voll Sauberkeit, Kraft, Macht, Ordnung, Freude und Triumph. Eine schlimme Zeit für eine Minderheit, und sie repräsentierte oft die Besten."

${ }^{43}$ Mitscherlich, Mitscherlich, a.w., p. 65.

44 Zie: hoofdstuk 4, paragraaf 7.

${ }^{45}$ Buruma, I., Het loon van de schuld. Herinneringen aan de oorlog in Duitsland en Japan. Vert. T. Davids. Amsterdam, Antwerpen, 1994. p. 14.

${ }^{46}$ Miller, A., In den beginne was er opvoeding. Vert. T. Davids. Houten, 1983. pp. $134 \mathrm{ff}$.

${ }^{47}$ idem, p. 138. 
slachtoffers. ${ }^{48}$ Overbodig hieraan toe te voegen, dat deze psychoanalytica een volstrekt ander behandelingsprogramma voorstaat dan de Mitscherlichs. Zij pleit ervoor dit soort gevoelens toe te laten en in een spelsituatie uit te leven, zoals in Syberbergs Hitler-film zou gebeuren. Syberberg, aldus Miller, heeft in deze film niets anders willen uitbeelden dan zijn subjectieve waarheid. Hij heeft zich overgegeven aan subjectieve gevoelens, fantasieën en dromen, en aldus een historisch beeld gecreëerd, waarin veel Duitsers van zijn generatie zich kunnen terugvinden:

"Ik ken geen kunstwerk waarin de ambivalenties van een groot deel van deze Duitse generatie beter tot uitdrukking komen dan Hans Jürgen Syberbergs Hitler, ein Film aus Deutschland. (...) De fascinatie van het begaafde kind voor de muziek van Wagner, voor pracht en praal van militaire marsen, voor het emotioneel geladen geschreeuw van de Führer over de radio; de fantasie van Hitler als een machtige en toch ongevaarlijk pop - dat alles kan in deze film ruimte vinden. Maar daarnaast is er ook ruimte voor ontzetting en afgrijzen, en vooral ook voor de reële pijn van de volwassene, die in films over dit onderwerp tot nu toe nauwelijks voelbaar is geweest, omdat men dergelijke gevoelens pas kan voelen wanneer men zich heeft bevrijd van het pedagogische schema van beschuldiging en verontschuldiging., ${ }^{49}$

Zowel Am Anfang war Erziehung, als Das Drama des begabten Kindes schuren dicht aan tegen de antipsychiatrie. ${ }^{50}$ Uitgangspunt is de hypothese, dat psychische problemen van de volwassene kunnen worden herleid tot de terreur van een disciplinerende opvoeding, die het kind-in-onszelf zou hebben verminkt. En in de gevestigde psychiatrie, waarin naar haar mening wat al te zeer de nadruk is komen te liggen op de controle die de patiënt als volwassene moet uitoefenen over zijn eigen gevoels- en driftleven, ontwaart Miller de erfgenaam van de opvoedende ouders uit de vroegste kindertijd. ${ }^{51}$ Maar onomstreden is de psychoanalyse van de Mitscherlichs ook binnen de gevestigde psychiatrie allerminst. Zoals onder meer blijkt uit een in 1992 verschenen studie van de Duitse psychoanalyticus Tilmann Moser (overigens een leerling van het echtpaar).

In hoge mate typerend voor de psychoanalyse van het Duitse 'onvermogen om te rouwen' is volgens Moser "de mengeling tussen psychoanalyse en verwijtende moraal". Al is dit nog te zwak uitgedrukt. De theorie van de Mitscherlichs, betoogt Moser, heeft veel weg van een "psychoanalytische boetepreek". In de omgang met hun patiënten gedragen deze psychotherapeuten zich als "aanklagers", die hun eigen woede over wat in de Hitler-tijd is gebeurd nauwelijks weten te beteugelen en in wier handen de diagnose verwordt tot "een morele knuppel tegen een collectief, waarvoor nauwelijks nog verzachtende omstandigheden gelden" - "Een niet aflatende woede op de Duitsers van de late jaren '70 doordringt de tekst [van Die Unfähigkeit zu trauern, G.G.], ook daar waar het ogenschijnlijk gaat om het begrijpen van onvermijdelijke ontwikkelingen". Van een bereidheid om zich in de patiënt in te leven is weinig te merken. Alles staat in het teken van "een aandringen om eindelijk schuld

\footnotetext{
${ }^{48}$ Zie: hoofdstuk 4 , paragraaf 5 .

${ }^{49}$ Miller, a.w., pp. $138 \mathrm{f}$.

${ }^{50}$ Zie bijvoorbeeld: Lange, $\mathrm{S}$, de, Alice Miller: Het drama van het begaafde kind. 1979. in: NRC Handelsbiad. 09-04-1999.

51 "Het complete strafsysteem van psychiatrische inrichtingen, de geraffineerde manieren waarop de patiënt wordt vernederd, hebben net als de opvoeding tot doel de geheimtaal van de zieke eindelijk tot zwijgen te brengen." Milller, a.w., pp. $129 \mathrm{f}$. Zie eveneens: Miller, A. Het drama van het begaafde kind. Een studie over het narcisme. Vert. T. Davids. Bussum, 1981. pp. 7-36. Alsmede: Lange, de, a.w., passim.
} 
te voelen, alsof een biecht, berouw, schuldgevoel het hoogste behandelingsdoel is". 52 Wat dat betreft mogen de in hoofdstuk 4 besproken commentaren gerust illustratief worden genoemd. Voortdurend heb je het ongemakkelijk gevoel, dat in deze commentaren onder het mom van een psychoanalytische Trauerarbeit het denazificatieproces nog eens dunnetjes wordt overgedaan. Soms inpliciet, zoals in de duiding van Eric Santner ${ }^{53}$ Maar niet zelden ook expliciet. "De leden van de denazificatierechtbank hadden natuurlijk volkomen gelijk, toen ze lachten," meent bijvoorbeeld Gottfried Wagner, die het naar eigen zeggen als zijn levenstaak ziet op de Groene Heuvel een Trauerarbeit naar het model van de Mitscherlichs te initiëren. "Grootmoeder was natuurlijk in werkelijkheid een buitengewoon politiek agerende vrouw." "54 Winifred Wagner wordt voor de tweede keer in haar leven in de beklaagdenbank geplaatst en schuldig bevonden. Alles wat ze ter eigen verdediging inbrengt, wordt tegen haar gebruikt opgevat als een symptoom van haar 'onvermogen te rouwen'. Wat werkelijk in de vrouw omgaat, komen we niet te weten. "Het is," aldus Moser over de Mitscherlichs, "de omkering van de psychoanalytische criminologie, die probeerde via invoeling ook in contact te komen met de misdadigers, om buiten de straf om een toegang te vinden tot het gekwelde gemoed."

Om de theorie van de Mitscherlichs op waarde te kumnen schatten, is de ontstaanscontext - Die Unfahigkeit zu trauern verschijnt in 1967 - van groot belang. In het licht van de duizenden monumenten die het land inmiddels bevolken, doet het door hen geschetste beeld van het naoorlogse Duitse historische besef op zijn zachtst gezegd nogal gedateerd aan. ${ }^{56}$ Maar begin jaren ' 60 is de publieke aandacht voor met name het joodse leed nog een betrekkelijk marginaal verschijnsel - zij het niet enkel in Duitsland, maar wereldwijd. Alexander en Margarete Mitscherlich schrijven hun studie in een tijd waarin baanbrekende ontwikkelingen plaats vinden in het denken over de Tweede Wereldoorlog. Mede als gevolg van het met veel publiciteit omgeven Eichmann-proces in Jeruzalem, waarin de omvang en gruwelijkheid van de massamoord voor het eerst zichtbaar wordt gemaakt, groeit de holocaust uit tot een universeel en zelfstandig thema, dat een alsmaar centralere plaats zal gaan innemen in het historische besef. ${ }^{57}$ Tegelijk neemt de morele sensibiliteit omtrent het nazi-verleden toe - met name onder de nieuwe generatie die, zelf in of rond de oorlog geboren, midden jaren " 60 politiek bewust wordt in de schaduw van het Eichmannproces. Deze ontwikkelingen lopen in elkaar over. Auschwitz verschuift naar het centrum van

\footnotetext{
${ }_{52}$ Moser, T., Vorsicht Berihrung. Uber Sexualisierung, Spaltung, NS-Erbe und Stasi-Angst. Frankfurt am Main, 1992. pp. $204 \mathrm{f}, 208$.

53 "Wanneer Wilhelm Furtwängler haar vraagt naar haar gevoelens over de manier waarop ze na de oorlog werd behandeld door het publiek en haar rechters, tekent haar antwoord de bevroren zijde van een persoon die het ten enenmale ontbreekt aan een vermogen orn te rouwen." Santner, a.w., p. 129. Zie eveneens: hoofdstuk 4, de paragrafen 6 en 8 .

${ }_{34}$ Wagner, G[ottfried], Wer nicht mit dem Wolf heult. Autobiographische Aufzeichmungen eines WagnerUrenkels. Köln, 1997. p. 129. Zie eveneens: hoofdstuk 4, paragraaf 7.

${ }^{55}$ Moser, a.w., pp. 207f.

56 "Soms kreeg je de indruk, vooral in Berlijn, dat het Duitse geheugen was als een grote tong die voortdurend een pijnlijke kies aftaste," aldus Buruma, a.w., p. 14. "De Duitse oorlog werd niet alleen herdacht op televisie, op de radio, in wijkcentra, scholen en musea; hij werd herhaald, herdacht en bewerkt." Een observatie die in een wel heel schril contrast staat met de diagnose van Margarete Mitscherlich in de bundel Erinnerungsarbeit: "Is het zinloos om zich voor te stellen, hoe de samenleving van de Duitsers eruit zou hebben gezien, wanneer ze zich na de oorlog wel de moeite hadden getroost hun bloederige verleden treurend te verwerken - in plaats van het te verdringen, te bewerken? Ze hebben het niet gedaan en zullen het vermoedelijk ook niet doen (...)". Mitscherlich, M., Erinnerungsarbeit. Zur Psychoanalyse der Unfähigkeit zu trauern. Frankfurt am Main, 1987. p. 161 .

${ }^{57}$ Ik volg hier in grote lijnen: Vree, $F_{\text {, }}$, van, In de schaduw van Auschwitz. Herinneringen, beelden, geschiedenis. Groningen, 1995. pp. 7-26. Zie eveneens: Berghe, van den, G., De uitbuiting van de Holocaust. Antwerpen, Baarn, z.j., pp. 107-178.
} 
het historische besef en krijgt meer en meer het karakter van een moreel ijkpunt. ${ }^{58}$ We zouden dit ook anders kunnen formuleren. Vanaf het midden van de jaren " 60 zal het collectieve historische besef meer en meer met dat van de slachtoffers van het nazi-regime gaan samenvallen. Hún lijden komt in het centrum van de publieke aandacht te staan. ${ }^{59}$ Vergangenheitsbewältigung wordt, in de woorden van Margarete Mitscherlich (1997), een uiting van zorgende solidariteit en identificatie, empathie en compassie met de slachtoffers van gruwelen uit het verleden'. ${ }^{60}$ Kortom: van Betroffenheit.

Dit woord, dat in beschouwingen vaak wordt gebruikt als een sleutel tot de manier waarop de Westduitsers sinds het midden van de jaren 60 met het nazi-verleden omgaan, komt nog het meest dicht in de buurt bij de mentaliteit die spreekt uit Die Unfähigkeit zu trauern. Het is een van die typische Duitse woorden, waarvan de connotatie in een vertaling onherroepelijk verloren gaat. Je zou kunnen zeggen: Betroffenheit (letterlijk volgens van Dale: onthutsing, ontsteltenis, bedremmeldheid, verlegenheid) is het tegendeel van Kaltschnäuzigkeit. Het is datgene wat de emotioneel verdoofde Duitsers volgens de Mitscherlichs zouden ontberen. Of beter: waarvan ze niet voldoende blijk zouden geven. Want Betroffenheit is, zo lijkt het soms, vooral schijn voor het oog, een kwestie van uiterlijk vertoon; je gevoelens laten spreken, maar ook spreken met je gevoel, in je woorden laten doorklinken dat het je niet koud laat. "Terugblikkend was het meest griezelige aan hem zijn objectiviteit," beschrijft de Susanne uit Santners casus het gebrek aan Betroffenheit van haar vader, de tot inkeer gekomen concentratiekampemployee die haar heeft meegenomen op een studiereis naar Auschwitz. "Zijn verslagen en beschrijvingen, zijn nauwkeurige samenvattingen van de gebeurtenissen. Nooit zag ik tranen. Nooit hoorde ik hem onderbreken in het midden, stoppen... niet in staat om verder te spreken. Alleen maar die monotone litanieën, alsof hij ze oplas uit een script." Wie betroffen is, voelt zich emotioneel betrokken, pijnlijk getroffen zelfs. Zo iemand leeft met de slachtoffers mee, identificeert zich affectief met hun leed. Maar Betroffenheit houdt ook een zeker schuldgevoel in, schaamte of zelfs gêne. Betroffen zijn betekent: door het tonen van moreel-juiste emoties (ontsteltenis, treurnis, schaamte, wroeging, woede) schuldbewust buigen voor de slachtoffers; met wier leed je je onthutst en gegeneerd solidair verklaart. Het woord heeft dan ook sterk de connotatie van morele zuiverheid. "Betroffen zijn is een manier om "het verleden te verwerken': men toont berouw, men biecht, wordt vergeven en gezuiverd," aldus Ian Buruma. "De vele oproepen in West-Duitsland om te 'rouwen' over het verleden, om aan rouwverwerking (Trauerarbeit) te doen, maken deel uit van dat zuiveringsritueel.",62

Indirect zijn deze 'vele oproepen' ook een indicatie van de enorme impact, die het boek van de Mitscherlichs in de Bondsrepubliek moet hebben gehad. Die Unfähigkeit zu trauern mag met recht een cultuurhistorisch monument worden genoemd. Het belang van dit werk schuilt nog niet eens zozeer in de inhoud - hoewel het psychoanalytische

\footnotetext{
${ }^{58}$ Vree, van, a.w., passim.

${ }^{59}$ ibidem. Zie eveneens: Vos, Ch., Televisie en Bezetting. Een onderzoek naar de documentaire verbeelding van de Tweede Wereldoorlog in Nederland. Hilversum, 1995. pp. $153 \mathrm{ff}$. De Nederlandse historicus Bas Blokker schrijft in dit verband zelfs over een 'holocaustisering' van het historische besef. Blokker, B., Verschoten kleuren van een verre oorlog. Het kantelend beeld van de bezettingsjaren. in: NRC Handelsblad. 16-03-2001. p. 31.

${ }^{60}$ Mitscherlich, M., e.a., How do Germans face their guilt?/Former West Germans and their Past. in: Partisan Review. 4 (1995). pp. 527-535, zie: 531.

${ }^{61}$ Santner, a.w., p 44 . Zie eveneens: hoofdstuk 4, paragraaf 6 .

${ }^{62}$ Buruma, a.w., pp. $28 \mathrm{f}$. Zie eveneens: Stephan, C., Der Betroffenheitskult. Eine politische Sittengeschichte. Berlin, 1993. passim. Alsmede: Bohrer, K.H, Provinzialismus (II). Ein Psychogramm. in: Merkur. Deutsche Zeitschrift für europäisches Denken. 3 (1991). pp. $255 f f$ Goossens, G., Vrienden, het wordt menens! De opkomst van een Duitse intellectuele voorhoede. (Groene-Essay). in: De Groene Amsterdammer. 16 (1995). pp. $28 \mathrm{f}$.
} 
verdringingsparadigma in de discussie over het Duitse oorlogsverleden tot op de dag van vandaag het gangbare lijkt. (Studies over oorlogsverwerking in de Duitse kunsten, waarin de jaren ' 50 niet worden aangeduid als de periode van 'het onvermogen om te rouwen', zijn opmerkelijk schaars.) Minstens even belangrijk is de toonzetting. Met hun Betroffenheit hebben de Mitscherlichs niet alleen de 'horror' van een generatie verwoord; ze hebben bovendien een voorbeeld gesteld van morele zuiverheid, dat tot ver in de jaren ' 90 normatief zal blijven. Terecht heeft de Nederlandse historicus Friso Wielenga (1993) erop gewezen, dat de titel van hun studie, Die Unfähigkeit zu trauern, in kringen van de protestgeneratie van ' 68 een eigen leven is gaan leiden: "Zonder aanziens des persoons werd dit begrip gebruikt als een aanklacht tegen de oudere generatie en wanneer men zich daartegen verzette was dat voor de aanklagers een bewijs temeer voor de juistheid van de beschuldiging. (...) De diagnose was gesteld en het citeren van de boektitel, aantrekkelijk door zijn simpelheid, leek voldoende om de juistheid ervan te bevestigen. (...) Daarbij presenteerde men zich graag als diegenen, die het door de Mitscherlichs geconstateerde onvermogen om te rouwen doorbraken, [aldus aanspraak makend op een] moreel betere positie". ${ }^{63}$

Bekijk je het in dit licht dan is het niet zo vreemd, dat Syberberg zich genoodzaakt heeft gezien aan de Winifred-Wagner-documentaire een tussentekst toe te voegen, waarin hij de critici van zijn protestgeneratie waarschuwt tegen "ijdele rechtschapenheid" of, in de woorden van John Sandford, tegen "overhaaste en intolerante morele eigendunk". ${ }^{64}$ We zouden ons zelfs voorzichtig kunnen afvragen, of het hier niet ook deels gaat om een poging de vrouw in bescherming te nemen tegen precies dat soort psychoanalyse, waarvan zijn buitenlandse bewonderaars veronderstellen dat Syberberg die in deze documentaire zou beoefenen.

${ }^{63}$ Wielenga, F., Schaduwen wan de Duitse geschiedenis. De omgang met het nazi-en DDR-verleden in de Bondsrepubiiek Duitsland. Amsterdam, 1993. pp. 204f, 208. De meest bekende en invloedrijke kritiek op de Mitscherlichs stamt van de filosoof en politicoloog Herman Lübbe, die in een essay uit 1983 een alternatieve visie op de Adenauer-tijd heeft ontwikkeld. Volgen we Lübbe, dan moeten we ons ervoor hoeden het naoorlogse zwijgen over het nazi-verleden al te lichtvaardig op te vatten als ontkenning of verdringing. Veeleer ging het hier om een begrijpelijke en noodzakelijke reactie op de alomtegenwoordigheid van de herinnering. Het jaar 1945 markeert een breuk in de geschiedenis, een nieuw begin en de generatie van de Adenauer-tijd stond voor de moeizame taak dit nieuwe begin vorm te geven in een tijd waarin de continuiteiten met Hitler-Duitsland nog overal pijnlijk zichtbaar waren. Omdat de meerderheid van de Duitsers zich kort daarvoor met het nationaalsocialisme had geïdentificeerd en de nieuwe staat onmogelijk tégen deze meerderheid kon worden opgebouwd zelfs met de beste wil van de wereld kon men niet miljoenen Duitsers in quarantaine plaatsen -, was zwijgen de enige oplossing om een zeker staatkundig draagvlak te creëren. De relatieve politieke stilte van de jaren ' 50 , dat wil zeggen "die gewisse Zurückhaltung in der öffentlichen Thematisierung individueller oder auch institutioneller Nazi-Vergangenheiten", voorkwam een verdere ontwrichting van de samenleving en schiep een klimaat, waarin de overgang van de ene naar de andere samenlevingsvorm mogelijk werd, zonder dat in deze jaren - althans volgens Lübbe - ook maar iets werd vergeten. Men wist donders goed wat de buurman op zijn kerfstok had en was hierover net zo moreel verontwaardigd als toekomstige generaties, maar maakte deze verontwaardiging omwille van de lieve vrede niet publiek. En de buurman besefte, dat hij zich gezien zijn verleden terughoudend diende op te stellen en zijn maatschappelijke functie moet afstaan aan een minder belast iemand. Lübbe, H., Der Nationalsozialismus im Bewustsein der deutschen Gegenwart. in: Die Aufdringlichkeit der Geschichte. Henausforderungen der Moderne yom Historismus bis zum Nationalsozialismus. Graz, Wien, 1989. pp. 334-350. Voor een - uiteraard negatieve - reactie op Lübbe van Margarete Mitscherlich, zie: Mitscherlich, a.w., pp. 16, 38, 141 .

64 "Aan de critici van mijn generatie. Het is geen persoonlijke verdienste, niet in barbaarse tijden te hebben geleefd en niet op een riskante plek op de proef te zijn gesteld. Het is relatief makkelijk om geen nazi te zijn in een tijd waarin geen Hitler bestaat." Syberberg, Filmbuch, a.w., p. 282 Sandford, a.w., p. 9. Zie eveneens: hoofdstuk 4 , paragraaf 8 . 


\subsection{De ingeslagen en geleerde weg van het argumenteren.}

Hoe het ook zij: belangrijk is vooralsnog dat Winifred Wagner in de optiek van de filmer zelf niet gebukt gaan onder emotionele rigiditeit. Noch kan wat hem betreft sprake zijn van een ongepaste emotionele reactie. Het tegendeel is waar. Gezien haar levensloop zou het juist zie het hierboven aangehaalde interview met De Winter - 'verbazingwekkend' en zelfs 'griezelig' zijn, indien de vrouw zich in de film niet in deze zin had geuit; maar 'op haar grootse tijd was gaan schelden'. Dit zou er namelijk op neerkomen, lijkt Syberberg te redeneren, dat Winifred Wagner haar ware gevoelens opkropt, ja zelfs tegen haar gevoel invoelt. In dat geval zouden we pas werkelijk kunnen spreken van een schizofrene persoonlijkheid (Nicolaus Sombart) met een 'eigenaardige splitsing' in haar gevoelsleven (Thomas Elsaesser). ${ }^{65}$ Vanuit de '(massa-)psychologie' geredeneerd zou een dergelijke situatie niet alleen 'ongezond' zijn, maar bovendien 'gevaarlijk'. Zeker wanneer het tegen-jegevoel-in-voelen ook nog eens een morele verplichting wordt. Bijvoorbeeld indien we op morele gronden van de vrouw zouden eisen, dat ze haar ware gevoelens uitroeit en het moeten voelen van woede, schaamte, berouw enzovoorts als een soort categorische imperatief aan haar opdringen. Zo creëer je de fameuze kat in het naww. En een dergelijke kat maakt, zoals bekend, rare sprongen. 'Er is dan wel geen Versailles, waar wat wordt gedicteerd. Maar er bestaat wel een psychologisch Versailles en dat is gevaarlijk.' Aldus Syberberg in het interview met De Winter.

Wat, zo zullen we ons moeten afvragen, zou Syberberg kunnen bedoelen met een dergelijke historisch beladen vergelijking? Dat de Duitsers, die net als in 1919 eenzijdig voor de door hen verloren oorlog aansprakelijk worden gesteld, opnieuw onevenredig zwaar hebben moeten boeten - misschien nog wel zwaarder, in de zin dat de herstelbetaling ditmaal bestond uit de opgave van, wat Miller noemt, hun 'ware zelf'? Of, beter nog: uit de opgave van wat de literatuurwetenschapper Karl Heinz Bohrer (zie hoofdstuk 3) probeert te omschrijven als "de ons Duitsers aangeboren grote stijl van de verbeelding, van de metafysica, van de rebellie tegen het normatieve' - de 'door de liberale en linkse intelligentsia op straffe van eer en invloed domweg verboden stij]' van het Duitse “irrationalisme'? ${ }^{66}$ Dit zou inderdaad een adequate samenvatting zijn van het pamflet Die Kunst als Rettung aus der deutschen Misere (1978). We hoeven hier niet in herhaling te vallen. Zoals we zagen in hoofdstuk 3 hanteert Syberberg in deze Hitler-script-inleiding - net als Bohrer overigens in zijn essay - een essentialistisch concept van Duitse identiteit: het Duitse 'irrationalisme', in de zin van de Duitse mythopoëtische ziel of Innerlichkeit, is 'de vervloekte navelstreng van het Duitse wezen'. En geheel in de lijn van de "irrationalisme"kritiek van Lukács en de late Thomas Mann zouden de Duitsers na ' 45 deze 'navelstreng' hebben doorgesneden door hun eigen Duitse gevoelsleven 'als fascistisch te verdoemen" en aldus 'zonder strijd aan de nazi's cadeau te doen" - "afgestaan, onderhands verkocht, verdrongen". 67

Ook de Mitscherlichs beroepen zich in Die Unfahigkeit zu trauern nadrukkelijk op Lukács - al heeft het marxisme in hun studie wel zijn ereplaats "als levend werkende kracht van een eigen Duitse cultuur" (Lukács) ${ }^{68}$ moeten afstaan aan de psychoanalyse van Sigmund Freud, "het kostbaarste instrument van mensenkennis, dat we bezitten". 69 De pedagogische

\footnotetext{
65 Zie: hoofdstuk 4 , de paragrafen 3 en 4.

${ }^{66}$ Bohrer, K.H. Deutschland - noch eine geistige Möglichkeit? Bemerkungen zu einem nationalen Tabu. in:

Frankfurter Allgemeine Zeitung. 28-04-1979. Zie eveneens: de paragrafen 3.8 en 4.1.

${ }^{67}$ Syberberg, Die Kunst als Rettung..., a.w., p. 14f. Zie eveneens: hoofdstuk 3, de paragrafen 5 en 7 .

${ }^{68}$ Lukäcs, G., Die Zerstörung der Vermunft. Neuwied am Rhein, Berlin, 1962. p. 660.

${ }^{69}$ Mitscherlich, Mitscherlich, a.w., p. 85.
} 
"oproep" van Lukács aan "het volk van Marx en Goethe" om "arbeid te verrichten', wo wordt door Alexander en Margarete Mitscherlich overgenomen en geherïnterpreteerd als een oproep tot het verrichten van Trauer-Arbeit (rouw-verwerking) in klassiek freudiaanse zin. Over het uiteindelijke doel van deze arbeid blijken de freudiaanse psychotherapeuten en de hegeliaanse marxist opmerkelijk eensgezind. Diens ontmaskering van de irrationele' traditiesporen in de Duitse cultuurgeschiedenis als een poel van ideologisch verderf, wordt door de Mitscherlichs niet ter discussie gesteld, maar volmondig onderschreven. En ook hen blijkt het te doen om een 'radicale overwinning' van deze historische pathologie:

"Zolang we er niet in slagen, ons (...) uit de stereotypen van onze geschiedenis los te maken - het Derde Rijk vertegenwoordigde slechts een laatste epoche - zullen we aan ons psychosociale immobilisme vastgeketend blijven, als aan een ziekte met verlammingsverschijnselen. 'De collectieve verantwoordelijkheid van een natie voor een fase in haar ontwikkeling,' schrijft Georg Lukács, 'is iets dermate abstracts en ongrijpbaars, dat het recalcitrant maakt. En toch kan een fase als de Hitler-tijd alleen dan in ons geheugen als afgedaan en vernietigd worden beschouwd, wanneer de intellectuele en morele mentaliteit, die haar tot vervulling bracht, beweging, richting en vorm gaf, radicaal overwonnen wordt. Pas dan wordt het voor anderen - voor andere volken - mogelijk, op de ommekeer te vertrouwen, het verleden als werkelijk voorbij verleden te beleven.", 71

Hooguit verschillen de Mitscherlichs met de filosoof van mening over de juiste weg die tot een dergelijke 'radicale overwinning' zou moeten leiden:

"Radicaal overwinnen" [de Mitscherlichs citeren opnieuw Lukács, G.G.] kan men (...) slechts op grond van een betrouwbaar in het bewustzijn verankerd weten (...), omdat dat, wat gebeurd is, alleen kon gebeuren, omdat dit bewustzijn gecorrumpeerd was. Wat als gevolg van een nu al twee decennia durende censuur van ons bewustzijn niet als pijnlijke herinnering wordt toegelaten, kan ongevraagd uit het verleden terugkeren, want het is niet 'verwerkt' verleden geworden. (...) Zonder een pijnvolle herinneringsarbeid (...) werken onbewust de oude idealen voort, die in het nationaalsocialisme de fatale wending van onze geschiedenis hebben veroorzaakt."72

Niet: "afbreken, verbreken en opbreken", zoals Lukács dacht. ${ }^{73}$ Maar: erinnern, wiederholen, durcharbeiten (de drie "kennisstappen' van de freudiaanse Trauerarbeit). ${ }^{74}$ Alleen zo is, om Lukács in Die Zerstörung der Vernunft (1954) te parafraseren, "een wending naar genezing"75 mogelijk. En er zal dan ook nog heel wat pijnvol en moeizaam rouw-werk moeten worden verzet, alvorens dit land met zichzelf in het reine komt - niet slechts in de

\footnotetext{
${ }^{70}$ Lukács, a.w., pp. 35, 660ff. Zie eveneens: hoofdstuk 2, paragraaf 4.

${ }^{71}$ Mitscherlich, Mitscherlich, a.w., p. 82. De Mitscherlichs citeren: Lukács, G., Von Nietzsche bis Hitler. Frankfurt an Main, 1966. p. 21. In Die Zerstörung der Vernunft formuleert Lukács hetzelfde in iets andere bewoordingen: "Sie [de geschiedenis van het irrationalisme, G.G] muß eben deshalb eingehend studiert werden, damit die Deutschen sie radikal überwinden und ihr Fortleben oder ihre Wiederkehr energisch verhindern können. Das Volk von Dürer und Thomas Münzer, von Goethe und Karl Marx hat so viel großes in seiner Vergangenheit, hat so große Perspektiven für seine zukunft, daß es keinen Grund hat, vor einer schonungslosen Abrechnung mit einer gefährlichen Vergangenheit und ihrem schädlichen, gefahrdrohenden Erbe zurïckzuschrecken." Lukács, Die Zerstörung der Vermunft, a.w., p. 35.

${ }^{72}$ Mitscherlich, Mitscherlich a.w., pp. $82 f$.

${ }^{73}$ Lukács, a.w., p. 262. Zie eveneens: hoofdstuk 2, paragraaf 4.

${ }^{74}$ Mitscherlich, Mitscherlich, a.w., p. 24.

${ }^{75}$ Lukăcs, a.w, p. 262. Zie eveneens: hoofdstuk 2, paragraaf 4.
} 
psychiatrie, de politiek, het gezin (feminisme), op de werkvloer, of aan de universiteiten, maar zeker ook in de kunsten, waar deze hernieuwde oproep van de Mitscherlichs in de jaren 70 breed navolging vindt. ${ }^{76}$ We zouden in dit verband bijvoorbeeld kunnen denken aan het (kunst-)historische debat over de 'fascinerende esthetiek' van het faseisme, waarvan Susan Sontag één van de gangmakers is. Tweemaal, merkt Syberberg op in Die freudlose Gesellschaft, heeft deze Amerikaanse publiciste een essay gewijd aan een cineast uit Duitsland.

"Het essay over Leni Riefenstahl was hen [de Duitse critici, G.G.] dierbaar. Het bevestigde de ingeslagen en geleerde weg van het argumenteren. Ze hoefden geen nieuwe arbeid te verrichten, niet na te denken, niets te veranderen. Er was geen moed voor nodig, om er mee in te stemmen. Maar nu, in het tweede geval [Sontags essay over de Hitler-film, G.G.]? Wat hebben ze geleerd, veranderd, opgehelderd, gewerkt aan zichzelf? Hier [in Syberbergs films, G.G.] gaat het niet om afhaken en toeslaan. Hier gaat het niet om snelle, stoere naziverbranding (...),"77

\subsection{Fascistische hunkeringen volgens Susan Sontag}

Zoals hijzelf reeds laat doorschemeren in dit citaat leent Sontags beroemde essay over die andere grande dame van het Derde Rijk, de cineaste Leni Riefenstahl, zich goed om duidelijk te maken waar deze filmer zo van gruwt. Misschien laat Fascinating Fascism (1974), zoals de titel luidt, zich nog het beste typeren als een vroege kritiek op (wat we tegenwoordig zouden noemen) het postmoderne kunstgevoel, dat door Sontag wordt beschouwd als een uitvloeisel van de popcultuur van de jaren ' 60 . Het is een kunstgevoel dat, aldus de publiciste, enerzijds wordt gekenmerkt door een ironisch formalisme, anderzijds door een begerig recyclen van stijlen uit het verleden - en dan vooral stijlen, die het zwaarste aan de kaak zijn gesteld. Zoals het jarenlang verguisde neo-classicisme van Riefenstahl, dat begin jaren ' 70 binnen het avant-gardistische filmwereldje in New York en Parijs met "veelbetekenend gegniffel" als een soort camp of pop avant la lettre wordt herontdekt. ${ }^{38}$

Riefenstahl blijkt opnieuw een graag geziene gaste op internationale filmfestivals. Feministische theoretici plaatsen haar op één lijn met Agnès Varda; films en fotoboeken van haar hand worden in gerenommeerde bladen als The Village Voice en Cahiers du Cinéma

\footnotetext{
${ }^{76}$ Zo bespeurt de filmtheoreticus Klaus Kreimeier in zijn vroege studie Kino und Filmindustrie in der BRD. onder de Nieuwe Duitse Filmmakers, waartoe Syberberg wordt gerekend, een "zelfverplichting tot Aufarbeitung". De jonge generatie is "doordrongen van de voorstelling in hun films te moeten 'afrekenen', "verwerken', 'overwinnen', wat de samenleving, waarin ze leven, kennelijk op eigen kracht niet overwinnen kan". Het is een mentaliteit, die bij Kreimeier herinneringen oproept aan de zogenaamde Nullpunkt-literatoren uit de jaren direct na de oorlog. De belangrijkste vertegenwoordiger van deze West-Duitse stroming, Heinrich Böll, werd door Lukács beschouwd als de rechtmatige erfgenaam van het anti- 'irrationalistische' humanisme van de late Thomas Mann. Kreimeier, K., Kino und Filmindustrie in der BRD. Ideologieproduktionen und Klassenwirklichkeit nach 1945. Kronberg, 1973. p. 241. Voor de visie van Lukács op Böll: Sziklai L., Georg Lukács - kritiker der unreinen Vernunft. Brüche in der frühen Politiktheorie von Georg Lukács. in: Georg Lukács. Kultur - Politik - Ontologie. Hrsg. U. Bermbach, G. Trautman. Opladen, 1987. pp. 187-199, zie: 197. ${ }^{77}$ Syberberg, Die freudlose Gesellschaft. a.w, pp. 276 f. Syberberg schrijft: "Zweimal hat Susan Sontag in ihren wohl zweidutzend Essays zu Personen der Kulturgeschichte über Deutsche geschrieben, nicht über Bloch, Marcuse, Adorno, Enzensberger, Grass, Böll, Brecht, Beuys, Stein, Habermas, Mitscherlich oder sonstige Preisträger und die GröBten des Landes, sonder über Leni Riefenstahl und Syberberg. Über zwei Filmleute also." Het titelessay van Sontags bundel In het teken van Saturnus (a.w., pp. 146-180) gaat over Walter Benjamin.

${ }^{78}$ Sontag S., Fascinerend fascisme. in: In het teken van Saturnus. a.w., pp. 130-135. Zelf schrijft Sontag over het 'moderne kunstgevoel'.
} 
bewierookt als tijdloze hommages aan de klassieke schoonheid. Dit alles betekent niet, vermoedt Sontag, dat het nazi-verleden van Riefenstahl plotseling aanvaardbaar zou zijn geworden. "Het is alleen maar zo dat het, nu we cultureel in een volgend stadium zijn terecht gekomen, niet meer meetelt. ${ }^{, 79}$ Het kunstwerk wordt louter nog op zijn esthetische merites beoordeeld. Men bewondert de films van Riefenstahl om hun schoonheid en cinematografische vernuft, heeft zich een manier van kijken aangewend die hierop neerkomt, dat men de kwalijke politieke ideologie eruit zift om alleen de esthetiek over te houden. Volgen we echter Sontag, dan berust een dergelijke kieskeurig formalistische scheiding tussen esthetiek en ideologie op een pijnlijk misverstand omtrent nazi-kunst. "(...) Over het algemeen denkt men dat nationaal-socialisme alleen maar synoniem is met wreedheid en terreur. Maar dat is niet zo. Het nationaal-socialisme - het fascisme in het algemeen - staat een ideaal voor of, liever gezegd, verscheidene idealen die onder andere vlaggen hardnekkig zijn blijven bestaan: het ideaal van het leven als een kunst; de verheerlijking van schoonheid; het fetisjisme van de heldenmoed; het opgaan in extatische gevoelens van gemeenschapszin; verwerping van het verstand; het grote gezin van de mensheid (waarover de leiders het ouderschap uitoefenen)." 80

Het nazi-regime had een intrigerende januskop. De hunkering naar sublieme schoonheid, naar zuiverheid, volmaaktheid, irrationele extase en samensmeltende totaliteit, waarvan de films en fotoboeken van Riefenstahl doortrokken zijn, was een hoofdbestanddeel van de nationaal-socialistische ideologie. Aan het dodenkamp Buchenwald, met Goethe's favoriete eik als middelpunt, grensde het wonderschone Weimar, de stad van de dichters en de denkers. Tot ver in de jaren '60, stelt de Duitse historicus Peter Reichel in zijn standaardwerk Der schöne Schein des Dritten Reiches (1991), was dit andere gezicht van het nazi-regime, dat op tijdgenoten zo'n grote fascinatie moet hebben uitgeoefend, binnen het Westduitse wetenschappelijke debat een non-onderwerp. Steevast werd het Derde Rijk afgeschilderd als een weerzinwekkend totalitair geweldregime. Nieuw edoch is het thema van de 'fascinerende' esthetiek van het fascisme geenszins. Reeds in de jaren ' 30 hebben antifascistische emigranten als Walter Benjamin, Bert Brecht en Ernst Bloch het voorwerk verricht, waar Sontag in haar essay de vruchten van plukt. ${ }^{81}$ Ook Lukács stipt het thema in Die Zerstörung der Vernunfi zijdelings aan, wanneer hij het vermogen van de nazi's om de arbeidersmassa 'te betoveren' en 'te bedriegen' toeschrijft aan een effectieve propagandastrategie, die zou berusten op een symbiose van Duitse levensfilosofie en Amerikaanse reclametechnieken. ${ }^{82}$ Maar het meest schatplichtig is Sontag aan een andere klassieker uit de emigranten-literatuur: From Caligari to Hitler (1947).

Wat Zerstörung der Vernunft is binnen de filosofie, is deze (eveneens grotendeels tijdens de ballingschap in de Hitler-jaren geschreven) studie van Siegfried Kracauer binnen de filmtheorie. Met Lukács is Kracauer van mening, dat de oplossing van het raadsel van de 'betovering' die van de nazi-beweging op brede lagen van de Duitse bevolking uitging, dient te worden gezocht in de 'irrationele' Duitse geestesgeschiedenis. Beide studies hebben sterk

\footnotetext{
79 idem, p. 115 .

so idem, pp. $132 \mathrm{f}$.

${ }^{81}$ Ik denk in dit verband aan Benjamins aura-filosofie in zijn Kunstwerk-essay (Benjamin, W., Het kunstwerk in het tijdperk van zijn technische reproduceerbaarheid. Vert. H. Hoeks. Nijmegen, 1985. pp. 7-42), aan Brechts uiteenzetting met de 'theatraliteit van het fascisme' in Der Messingkauf (Brecht, B., Gesammelte Werke 16. Schriften zum Theater 2. Frankfurt am Main, 1967. pp. 500-657) en aan Blochs analyse van de 'ongelijktijdige' aantrekkingskracht van het fascisme op de arbeidersklasse in Erbschaft dieser Zeit (Bloch, E., Erbschaft dieser Zeit. Frankfurt am Main, 1985. Zie eveneens: hoofdstuk 3, paragraaf 6).

${ }^{82}$ Lukács, a.w., p. 630 f.
} 
het karakter van history reading backwards. ${ }^{83}$ Met hun kennis van het latere als een soort microscopische bril kijken de auteurs naar het vroegere, waarin ze vervolgens tal van prefascistische tendensen ontwaren, die welhaast noodzakelijk in het fascisme moesten uitmonden: van Nietzsche en de levensfilosofie naar de (film-)kunst van het expressionisme (Das Cabinett des Dr. Caligari), en van hieruit linea recta naar de vlees geworden Caligari Hitler. Uitgangspunt van Kracauers studie is de aanname, dat filmanalyse kan fungeren als een sleutel tot het 'collectieve onbewuste' van een natie. In de nationale cinema weerspiegelen zich de wens- en angstdromen van een volk. ${ }^{84}$ En dromen hebben, zoals bekend, niet zelden een profetische betekenis. Zo verwijzen (om het tot een enkel voorbeeld te beperken, dat Sontag aan deze studie ontleent) de in berglandschapen gesitueerde avonturenfilms van Arnold Fanck, waarin Riefenstahl halverwege de jaren '20 als actrice debuteerde, binnen Kracauers diepteduiding vooruit naar de "uiteindelijke versmelting van bergcultus en Führer-cultus" in het Derde Rijk. Hun onverbloemde heroïsme, hun heimwee naar een ongerepte, nog niet 'onttoverde' werkelijkheid, hun cultivering van het intuïtieve en het mythische - dit alles zou films als Der heilige Berg (1925) of Die weisse Hölle von Piz Palü (1929) "symptomatisch" maken voor een "irrationalisme", dat door de filmtheoreticus met terugwerkende kracht wordt ontmaskerd als het psychische substraat van de nazibarbarij. ${ }^{85}$

Vanzelfsprekend bestaan tussen Benjamin, Brecht, Bloch, Lukács en Kracauer tal van inhoudelijke meningsverschillen. Zoals we in de voorafgaande hoofdstukken hebben gezien (het expressionisme-debat, de formalisme/realisme-strijd), is het vertoog van de emigranten niet minder heterogeen dan het latere door interne stammentwisten verscheurde vertoog van Nieuw Links. Maar al deze studies hebben tenminste één ding gemeenschappelijk: inzet van de theorievorming is het formuleren van een antifascistische strategie in de concrete, alledaagse strijd tegen het historische fascisme ${ }^{86}$ En wellicht verklaart dit mede waarom deze kritische fascisme-theorie na de overwinning op het historische fascisme al snel in vergetelheid zou raken - althans in de Bondsrepubliek, want in het stalinistische Oosten ging de antifascistische strijd na '45 onverdroten voort. ${ }^{87}$ In het Westduitse wetenschappelijke debat, schrijft Peter Reichel, bleven de studies van de emigranten lange tijd nagenoeg opopgemerkt. Nog in de vroege jaren "60 was het werk van Benjamin of Kracauer (van wiens Caligari pas in 1958, 11 jaar na de Amerikaanse uitgave, een ingekorte Duitse versie verscheen ${ }^{88}$ ) in de Westduitse boekhandel even moeilijk te verkrijgen als dat van Theodor Adorno of Erich Fromm - twee andere antifascistische pioniers op het terrein van het

\footnotetext{
${ }^{83}$ Zoals de historicus Chris Vos de studie van Kracauer typeert. Vos, Ch., Het verleden in bewegend beeld. Een inleiding in de analyse van audiovisueel materiaal. Houten, 1991. p. 92f.

${ }^{84}$ Kracauer, S., Von Caligari zu Hitler. Eine psychologische Geschichte des deutschen Films. Frankfurt am Main, 1984, 1995. pp. 9-18.

${ }^{85}$ Kracauer, pp. 119-121, 271-273, 287. Hoewel Sontag slechts éen keer naar Kracauer verwijst, zijn vrijwel alle argumenten die ze tegen Riefenstahl inbrengt uit deze studie afkomstig. Zo neemt ze niet slechts in vrijwel letterlijke bewoordingen Kracauers analyse van de Fanck-films over ("De bergbeklimmingen in de films van Fanck vormden een visueel onweerlegbaar metafora voor het onbeperkte streven naar het zowel schone als angstaanjagende, dat later zijn vorm zou vinden in de Führer-aanbidding."); ook het argument dat Triumph des Willens geen cinéma-vérité zou zijn maar geënsceneerde geschiedenis, is aan Kracauer [a.w., pp. 352-356] ontleend. Sontag, a.w., pp. 103-114. Voor een kritiek op deze visie van Kracauer en Sontag, zie bijvoorbeeld: Leeflang, Th., Leni Riefenstahl. Baarn, 1991. pp. 49-74. Of anders, uiteraard, de memoires van de grande dame zelf. Riefenstahl, L., A Memoir. New York, 1993. pp. 622f.

${ }^{86}$ In de woorden van Benjamin, a.w, p. 42 : "Zo is het gesteld met de esthetisering van de politiek, die het fascisme bedrijft. Het communisme antwoordt daarop met de politisering van de kunst".

${ }^{87}$ Flierl, Th., e.a., Mythos Antifaschismus. Ein Traditionskabinett wird kommentiert. Berlin, 1992.

${ }^{88}$ Ik ontleen deze informatie aan het 'nawoord van de bezorger' in: Kracauer, a.w., pp. $603 \mathrm{ff}$.
} 
onderzoek naar de relatie tussen esthetiek en politiek in het Derde Rijk. "Dat," constateert Reichel, "veranderde voorgoed met de beweging van ' 68 ". 89

Binnen het generatieconfliet van de jaren ' 60 en ' 70 , dat in de Bondsrepubliek meer nog dan elders wordt overschaduwd door de herinnering aan de oorlog, is antifascisme één van de belangrijkste drijfveren in de strijd tegen de vermolmde postnazistische democratie van de generatie van het Duitse 'onvermogen om te rouwen'. En met het weer opbloeien van de antifascistische strijd, wint ook het gedachtegoed van de antifascistische gidsen uit het verleden opnieuw aan betekenis. Het vertoog van ' 68 is in grote lijnen een herneming en actualisering van een antifascistisch vertoog, dat in de vroege jaren ' 20 in de Weimarrepubliek ontstond en na Hitlers machtsovername in de Verenigde Staten en de Sovjet Unie werd voortgezet. ${ }^{90}$ Tal van thema's uit de emigrantenliteratuur van weleer, worden vanaf het midden van de jaren '60 door een Nieuw Linkse intelligentsia aan de vergetelheid onttrokken, afgestoft en verder uitgediept. Zo ook het thema van het 'fascinerende fascisme', dat vanaf pakweg 1968 (Erwin Leisers documentaire over filmpropaganda in het Berde Rijk ${ }^{91}$ ) het onderwerp zal worden van een vloedgolf van sociaal-kritische studies, tentoonstellingen, films en kunstwerken, met de Berlijnse overzichtstentoonstelling Inszenierung der Macht $(1987)^{92}$ als onbetwist hoogtepunt. "Nieuwe perspectieven en verder voerende aanlopen," merkt Peter Reichel op, "kwamen vaak van buiten de vakwetenschap, vaak van Duits-joodse emigranten, die het land kenden, eraan leden en toch vanuit een bevrijdende distantie wisten te schrijven". ${ }^{93}$ De meest invloedrijke studies zijn: The Nationalisation of the Masses (1975) van George Mosse, Kitsch und Tod (1982) van Saul Friedländer (beiden joodse emigranten) ${ }^{94}$ en Fascinating Fascism van Susan Sontag. "Zelf door een moraliserend spreken over het verleden niet geïmponeerd en onbelast; kon Sontag met analytische blik de invloed van het nationaal-socialisme op de massa esthetisch verklaren uit een geënsceneerde verbinding van schoonheid en geweld," aldus Reichel. ${ }^{95}$

Inderdaad laat Sontag in dit essay zien, dat de erfenis van de Duitse emigranten bij haar in goede handen is. Geheel in de geest van de studies waaruit ze put, is ook Fascinating Fascism een strijdbare tekst. De ambities van de auteur beperken zich niet tot het ontmaskeren van Riefenstahl als "allerakeligste propagandiste" voor het Derde Rijk. Zij wil meer dan alleen een groep trendy cinefielen voorlichten over de ware aard van nazi-kunst, door hen bij wijze van spreken met de neus op de feiten uit Kracauers fascisme-theorie te drukken. Meer nog dan een vroege kritiek op het postmoderne kunstgevoel, is Fascinating Fascism een oproep aan de generatiegenoten van ' 68 om toch vooral waakzaam te zijn. Bij het ontbreken van een historisch perspectief, houdt ze haar vrienden van de Cahiers $d u$ Cinéma voor, maakt een ironisch formalisme "de weg vrij voor een merkwaardig onoplettende aanvaarding van propaganda voor allerlei destructieve gevoelens - gevoelens waarvan men de consequenties weigert au sérieux te nemen".

\footnotetext{
${ }^{89}$ Reichel, a.w., pp. $27 \mathrm{f}$.

${ }^{90}$ Zoals bijvoorbeeid Antonia Grunenberg, hoogleraar politicologie in Aken en Bremen, laat zien. Grunenberg, A., Antifaschismus - ein deutscher Mythos. Hamburg, 1993. pp. 145-170.

${ }_{91}^{9}$ Leiser, E., 'Deutschland erwache!' Propaganda im Film des Dritten Reiches. Hamburg, 1968, 1989.

${ }^{92}$ Inszenierung der Macht - Äshetische Faszination im Faschismus. Hrsg. Neue Gesellschaft für Bildende

Kunst. Kreuzberg, 1987.

${ }_{93}$ Reichel, a.w., p. 18.

${ }^{94}$ Mosse, G. L., Die Nationalisierung der Massen. Politische Symbolik und Massenbewegungen in Deutschland von dem Napoleonischen Krieg bis zum Dritten Reich. Übersetzt von O. Weith. Frankfurt am Main, Berlin, Wien, 1976. Friedländer, S., Kitsch und Tod. Der Widerschein des Nazismus. Übersetzt von M. Grendacher. München, Wien, 1984, 1986.

${ }^{95}$ Reichel, a.w., pp. 19.
} 


\begin{abstract}
"Deze idealen [die het fascisme voorstond, G.G.] leven bij vele mensen, en het is onoprecht en tautologisch te beweren dat je alleen door Triumph des Willens en Olympia gegrepen wordt omdat ze door een geniale cineaste gemaakt zouden zijn. Riefenstahls films maken nog steeds indruk, onder andere doordat de verlangens die men destijds koesterde nog steeds worden ervaren, doordat ze een romantisch ideaal behelzen waarmee velen zich verbonden blijven voelen en dat tot uitdrukking komt in uiteenlopende vormen van culturele onenigheid en propaganda voor nieuwe gemeenschapsvormen als de jeugd-rockcultuur, de oertherapie, de antipsychiatrie, passieve aanhang van de Derde Wereld en geloof in occulte verschijnselen. De verheerlijking van gemeenschap sluit het nastreven van absoluut leiderschap niet uit; integendeel, ze kan er zelfs onontkoombaar toe leiden. (Het hoeft dan ook niet te verbazen dat vrij veel jongeren die zich tegenwoordig in het stof werpen voor goeroes en zich de meest potsierlijke autocratische tucht laten welgevallen, anti-autoritaire en anti-elitaire figuren van de jaren zestig zijn.) De huidige denazificatie van Riefenstahl en rehabilitatie als onbedwingbare priesteres van de schoonheid - eerst als cineaste en nu als fotografe - vormen een veeg teken voor wat betreft de aanwezige vermogens om fascistische hunkeringen in ons midden op het spoor te komen." 96
\end{abstract}

'Irrationele' tradities van vele eeuwen, wist Lukács reeds, laten zich niet eenvoudig overwinnen. Ze kunnen altijd, in een ander gedaante, weer de kop opsteken. Daarom dient ook de tegenwoordige tijd nauwlettend door de microscopische bril van het nazi-verleden in de gaten te worden gehouden. Het fascisme - of beter: de eigen fascisme-theorie - fungeert in dit 'irrationalisme'-kritische denken als een soort lakmoesproef, waarin de meest uiteenlopende zaken worden ondergedompeld - "mogen ze, ogenschijnlijk, nog zo ver van het hitlerisme verwijderd zijn, nog zo weinig zulke intenties hebben" (Lukács). ${ }^{97}$ En als een olievlek breidt het zuur zich uit over verleden, heden en toekomst. Het behoeft geen betoog, dat de uitkomst van de proef sterk afhankelijk is van de persoonlijke obsessies van de laborant. Waren het bij Lukács nog met name Franse existentialisten en Amerikaanse anticommunisten die pijnlijk blauw uitsloegen, ${ }^{98}$ Sontag zoekt haar voorbeelden van het "huidige fascisme" in een andere hoek. "Ontmaskerd als symptomatisch voor de 'fascistische hunkeringen in ons midden' worden niet slechts Riefenstahls uit de jaren " 70 daterende coffee-table-book The Last of the Nuba, grote delen van de tegencultuur van de jaren ' 60 , een obscuur Brits fotowerkje over SS-attributen, de traditionalistische rêverieën van Yukio Mishima, of films van Visconti ( La caduta degli Dei), Cavani (Il portiere di Notti), Kubrick (200I) en Disney (Fantasia). Ook de neo-classicistische kunst van het stalinisme, bij Lukács nog antifascistisch par excellence, ontsnapt niet aan de 'onbevangen analytische blik' van de Amerikaanse publiciste. Want '(...) uiteraard zijn er kenmerken van fascistische kunst in overvloed terug te vinden in de officiële kunstwerken van communistische landen"."

In zijn zwaar op Fascinating Fascism leunende essay Kitsch und Tod, doet Saul Friedländer het voor de hand liggende: hij voegt de door Sontag zo bewonderde Hitler-film van Syberberg toe aan deze lijst van naoorlogse kunstwerken "met bepaalde vaste structuren

\footnotetext{
${ }^{96}$ Sontag, a.w, pp. $133 \mathrm{f}$.

97 Lukács, a.w., p. 10 .

${ }^{98}{ }_{1 \mathrm{dem}}$ pp. $663 \mathrm{ff}$.

${ }^{99}$ Sontag a.w., p. 122 .

100 idem, p. $126 \mathrm{f}$.
} 
van fascistische kunst". ${ }^{101}$ Volgen we Friedländer, dan kunnen exact dezelfde structururelementen, die door Sontag in bijvoorbeeld La caduta degli Dei of de Disney-film Fantasia als crypto-fascistisch zijn ontmaskerd, in groten getale in deze film worden aangetroffen. Meer nog. voor Friedländer blijkt Hitler, ein Film aus Deutschland met stip het meest alarmerende geval van een 'weerspiegeling van fascistische esthetiek', die hij in navoliging van Sontag in de kunsten van na 68 meent te bespeuren. ${ }^{102}$ Tijdens een eind jaren ' 80 aan een Amerikaanse universiteit gehouden symposium over 'nazi-kitsch', waaraan ook de publiciste deelneemt, schrikt hij er zelfs niet voor terug de Hitler-film op een lijn te plaatsen met Riefenstahls Triumph des Willens. "Het is erg makkelijk om af te rekenen met Mickey Mouse; afrekenen met dit soort kitsch daarentegen is bijzonder moeilijk", aldus de historicus. En geheel in de geest van Fascinating Fascism, roept hij de auteur van Syberbergs Hitler op om toch vooral waakzaam te zijn: "Ik ben geneigd te stellen, dat je je welhaast moet dwingen om ten overstaan van Syberberg of Riefenstahl of vergelijkbare representaties [van nazi-esthetiek, G.G.] een moreel oordeel te vellen:" Het komt hem te staan op een fikse reprimande van Sontag: "But surely Saul, je kunt Riefenstahl niet vergelijken met Syberberg. Syberbergs film is überhaupt geen representatie; het is een kritisch werk. Je denkt misschien dat het gecorrumpeerd is door zijn relatie met het materiaal; maar het is, om een woord te gebruiken, dat ik nooit eerder heb gebruikt: a work of deconstruction. Het is niet hypnotiserend op een eenvoudig niveau. Hoeveel mensen kunnen deze film bekijken en erdoor bewogen worden? Je moet behoorlijk sophisticated zijn en over een brede culturele bagage beschikken, om door deze film bewogen te kunnen worden. Je kunt geen onmiddellijke emotionele respons hebben."

Nu zou je uiteraard kunnen tegenwerpen, dat je ook behoorlijk sophisticated moet zijn om bewogen te kunnen worden door, pakweg, Ezra Pounds lofzangen op de 'gekruisigde' Mussolini in Canto LXXIV. En toch lijkt dit wel degelijk het criterium aan de hand waarvan Sontag het fascistische kaf van Syberbergs koren denkt te kunnen scheiden. Voor haar is de esthetiek van Syberbergs Hitler welhaast het exacte tegendeel van wat ze begrijpt onder nazikunst: niet eenvoudig, figuratief en emotioneel, maar veeleisend complex, abstract en hyperintellectualistisch. Het is een hermetische, in zichzelf gesloten beeldtaal, die het massapubliek van zich vervreemdt. Zelfs voor de kleine elite van intellectuele fijnproevers, die zich erdoor aangesproken voelt, ligt de lat dermate hoog, dat een 'onmiddellijke emotionele respons" niet mogelijk is. Als propagandavehikel in het Derde Rijk, zou Hitler, ein Film aus Deutschland ten enen male ongeschikt zijn geweest. De sociaal-politieke functie van nazi-kunst bestond immers juist eruit, dat een zo breed mogelijk publiek het hoofd op hol diende te worden gebracht. Films als Triumph des Willens of "de populaire stukken met wagneriaanse trekjes"104 van Arnold Fanck zijn gericht op inpalmen, betoveren, overdonderen, meeslepen, hypnotiseren op een eenvoudig niveau. Dergelijke films appelleren direct aan lagere instincten - de 'fascistische hunkeringen' naar schoonheid, zuiverheid, onkreukbaarheid, totaliteit... Vandaar ook dat de Riefenstahl-renaissance van begin jaren ' 70 niet beperkt blijft tot een kleine groep avant-gardistische intellectuelen. Wat Sontag in Fascinating Fascism zo mogelijk nog meer zorgen baart, is dat in het kielzog van deze trendsetters ook een "naïef",

\footnotetext{
101 idem, p. 126.

${ }^{102}$ Friedländer, a.w., passim. Zie eveneens: Friedländer, S., Introduction. in: Probing the Limits of Representation. Nazism and the 'Final Solution'. ed. S. Friedländer. Cambridge, Massachusetts, London, England, 1992. pp. $14 \mathrm{ff}$.

${ }^{103}$ Salmagundi. A quaterly of the humanities and social sciences. 85-86 (winter-spring 1990). pp. 197-313, zie: 217.

104 Sontag, a.w., p. 104.
} 
"minder ontwikkeld" publiek van meelopers de schone schijn van het Derde Rijk herontdekt. ${ }^{105}$

In 1974, niet lang voor de publicatie van Fascinating Fascism, vindt in Frankfurt am Main een berucht incident plaats, waaraan ook Sontag terloops refereert om duidelijk te maken hoe intens 'de fascistische hunkeringen in ons midden' nog steeds zijn. Voor het eerst sinds het einde van de oorlog worden kunstwerken van het Derde Rijk uit het depot gehaald en tijdens een overzichtstentoonstelling aan het publiek gepresenteerd. De bewuste tentoonstelling, Kunst im 3. Reich - Dokumente der Unterwerfung, heeft overduidelijk een antifascistisch-pedagogische opzet. Werken van onder meer Arno Breker zijn ingebed in een sociaal-kritische context van foto's uit de concentratiekampen en didactische teksten van Brecht en Benjamin. Niettemin blijkt al snel, dat het massaal toegestroomde publiek er aanzienlijk minder serieuze bedoelingen op na houdt. "Wat tot dan - ongezien - in de schilderkunst als nationalistische Blut-und-Boden-kitsch werd verguisd, in de architectuur als mensverachtend monumentalisme werd veroordeeld en in de beeldende kunst als leugenachtige expressie van een heroïsch-zuiver schoonheidsideaal zonder zintuiglijkheid gold," schrijft Peter Reichel, "dat ondervond nu onverwacht grote belangstelling, deels welgevallen, ja zelfs onverbloemde bewondering". En de tentoonstellingscatalogus wordt een heuse bestseller. ${ }^{106}$

Het enthousiasme van dit 'naïeve Duitse publiek' (Sontag) zal in de daaropvolgende jaren als een schrikbeeld boven het debat over het 'fascinerende fascisme' blijven hangen. Het infectiegevaar, dat kennelijk aan dit soort kunst inherent is, stelt (kunst-)historici, tentoonstellingmakers en kunstenaars voor een dilemma. Het is, meent de Britse historicus Simon Schama in Landscape and Memory (1995), een variant van het alledaagse, onoplosbare dilemma van de antropoloog: hoe het 'andere' representeren zonder zichzelf te verliezen in een distantieloze onderdompeling? ${ }^{107} \mathrm{Om}$ iets te kunnen begrijpen van de fascinatie die van het fascisme uitging, zal men zich enerzijds met deze kunst moeten inlaten - zoals een ziekte onmogelijk kan worden bestudeerd zonder de aanwezigheid van de zieke. Terwijl anderzijds voortdurend het risico bestaat, dat men sluimerende "fascistische hunkeringen' aanwakkert en aldus nieuwe infectiehaarden creêert. ${ }^{108}$ Zo betwijfelt Saul Friedländer in Kitsch und Tod niet zozeer, dat Syberbergs Hitler een waardevolle bijdrage is aan dit debat - als een 'weerspiegeling van fascistische esthetiek' zou de film ons kunnen helpen "het verleden zelf, en dan met name de psychologische dimensie ervan beter te begrijpen". ${ }^{109}$ Wel wantrouwt hij de maker, die tegen het infectiegevaar niet immuun zou zijn: "De aandacht verschuift stapsgewijs van een evocatie van het nazisme zelf, van de gruweldaden en de pijn (...) naar een wellustige beklemming en meeslepende beelden, die men alsmaar weer wil terugzien. Het resultaat is misschien een meesterwerk - maar een meesterwerk, waarbij je voortdurend het gevoel hebt, dat het in een verkeerde toonsoort is geschreven (...)". ${ }^{110}$

Maar welke 'toonsoort' is dan wel de juiste, in de omgang met dit soort kunst? Moeten we, verzucht Simon Schama, een cordon sanitaire optrekken van beschermende ironie? Of aan onze publicaties "certificaten van morele zuiverheid [toevoegen], waarin onder ede wordt verklaard dat we geen smerige zaakjes met de duivel doen onder het voorwendsel

\footnotetext{
${ }^{105}$ idem, $129 \mathrm{f}, 134$.

${ }^{106}$ Reichel, a.w., p. 28. Sontag, a.w., p. 129. Zie eveneens: Grasskamp, W., Diè unbewältigte Moderne. Kunst und Öfentlichkeit. München, 1989. pp. 154f, 169.

${ }^{107}$ Sichama, S., Landscape and Memory. London, 1995. p. 134.

${ }^{0} 08$ Vergl. Grasskamp, a.w., p. 153. Reichel, a.w., p. 8f.

${ }^{109}$ Friedländer, Kitsch und Tod, a.w., p. 13.

110 idem, p. 17. Zie eveneens Reichel, a.w., p. 377f, die deze kritiek van Friedländer onderschrijft.
} 
van wetenschappelijk werk"? ${ }^{11 !}$ De samenstellers van de in 1983/'84 in Berlijn en Düsseldorf gehouden tentoonstelling Skulptur und Macht hebben een andere oplossing bedacht. Het betreft hier een poging tot rehabilitatie van figuratieve kunst uit de jaren ' 30 en ' 40 , die weliswaar niet door het nazi-regime als "ontaard" werd beschouwd, maar evenmin tot de officiële staatskunst behoorde. Een confrontatie van sculpturen van bijvoorbeeld de latere DDR-beeldhouwer Fritz Cremer met het werk van 'nazi-kunstenaars' als de onvermijdelijke Arno Breker, zou het kwalitatieve verschil zichtbaar moeten maken. Er schuilt echter een addertje onder het gras: van Breker cum suis worden geen originele stukken gepresenteerd, maar uitsluitend grofkorrelige foto-reproducties. Een "morele kwestie van artistieke integriteit", aldus één van de samenstellers in het "voorwoord' van de catalogus. De beeldhouwwerken van Breker zijn nu eenmaal geen kunst, maar "knoeiwerk" - hooguit interessant om "gecorrumpeerd artistiek denken aan te tonen". En onder geen enkele voorwaarde mag de indruk worden gewekt, dat het geoorloofd zou zijn van deze "non-kunst" als kunst te genieten. "Dat daarbij eventueel de wetenschappelijke integriteit (...) niet volledig aan haar trekken zou kunnen komen, moesten we (...) op de koop toenemen."112

\subsection{De gistende werking en lenigheid van het dialectische intellect}

Het valt niet mee een beter voorbeeld te bedenken van het door Syberberg in het hierboven aangehaalde interview met De Winter geconstateerde 'psychologische Versailles'. En tot op zekere hoogte hoeft dit ook niet te verbazen: zijn visie op het naoorlogse Duitsland zal hoe dan ook gekleurd zijn door persoonlijke ervaringen binnen deze kunstwereld van de jaren '70, die hij anders dan de psychiatrie van de Mitscherlichs van binnenuit kent. Laat ik eens proberen vanuit het perspectief van de filmer te beschrijven, wat hier precies gaande is.

Het moge duidelijk zijn, dat het in dit kunstdebat slechts zijdelings gaat om kunst. Onderwerp van debat zijn veeleer bepaalde gevoelens, die niet slechts kunstwerken uit het Derde Rijk, maar bijvoorbeeld ook de films van Kubrick en Disney of de literatuur van Mishima bij een 'naïef publiek' blijken op te roepen. Men heeft ontdekt, dat de nazi's soortgelijke gevoelens koesterden. En aan dit inzicht verbindt men de conclusie, dat we hier dus van doen hebben met 'faseistische hunkeringen', die dertig jaar na het einde van de oorlog nog steeds springlevend zijn. Rond deze hunkeringen is, aldus Syberberg, een soort volkspedagogische praktijk ontstaan - een netwerk van re-education-instellingen met vertakkingen naar het buitenland, dat vrijwel alle domeinen van het maatschappelijke leven in de Bondsrepubliek omvat: de kunstwereld, de universiteiten, de media, de politiek, ja zelfs de psychiatrie. Van hieruit "dicteert (...) een handvol opiniemakende figuren (...) wat 60 miljoen (...) moeten denken, voelen en doen". ${ }^{113}$ Het opvoedkundige advies is helder: de 'fascistische hunkeringen in ons midden' dienen te worden 'opgespoord', ten einde ze middels een psychoanalytische Trauerarbeit of anderszins 'radicaal te overwinnen'. Wie het advies in twijfel trekt, geldt als politiek verdacht. Zo iemand zou vijandig staan ten opzichte van het Verlichtingsdenken. Want op deze volkspedagogiek "rust de wijding van een ideologie uit het verleden, die ze graag Verlichting noemen"114 - dat wil zeggen: de 'irrationalisme'-kritiek van Lukács en de late Thomas Mann, die indertijd tevens het

\footnotetext{
"II Schama, a.w., p. 134.

${ }^{112}$ Szymanski, R., Vorwort. in: Skulptur und Macht. Figurative Plastik im Deutschland der 30er und 40er Jahre. Hrsg. Akademie der Künste. Berlin, 1983. p. 5. Zie eveneens: Grasskamp, a.w., p. 154.

113 Syberberg, Die Kunst als Rettung..., a.w., pp. 12, 43.

${ }^{114}$ idem, p. 31.
} 
ideologische fundament heeft gevormd van de re-education-politiek in de vroege DDR. ${ }^{115}$ En vanzelfsprekend ontsnapt ook de kunstenaar niet aan de "meningenterreur" van de pedagogen. Alsmaar weer, in "geestdodende rituelen van het zinledige", wordt hem gemaand: "men moet het bewustzijn veranderen, denkimpulsen geven, iets teweeg brengen, aantonen, aufarbeiten, duidelijk maken, concreet zijn, politiek denken, leerprocessen op gang brengen, zich van dwangneurosen bevrijden, enzovoorts". ${ }^{116}$

Maar bestaat er dan überhaupt reden om aan de correctheid van het pedagogische advies te twijfelen? Natuurlijk, moet ook Syberberg toegeven: op de constatering, dat de fascisten hunkerden naar schoonheid, zuiverheid, irrationele extase enzovoorts, valt weinig af te dingen. Maar de conclusie die aan deze constatering wordt verbonden is zijns inziens zelfdestructief, gevaarlijk en logisch geredeneerd onjuist. Zelfdestructief, omdat zij een moedwillige vernietiging legitimeert van precies datgene wat op zijn laatst sinds Friedrich Schiller het eigene van de Duitse Kultur uitmaakt. ${ }^{117}$ Wat zou dit Volk van de Dichters en de Denkers zijn zonder zijn verlangen naar het schone, het zuivere of de irrationele extase? Gevaarlijk, omdat (zie paragraaf 4 ) door een heel volk te verplichten blijvend tegen het eigen gevoel in te voelen de fameuze kat in het nauw wordt gecreeerd. Want is de reactie van het 'naïeve publiek' niet een sterke indicatie, dat dit soort gevoelens wel degelijk een natuurlijke, elke Duitser bij wijze van spreken aangeboren emotionele respons zijn? Hoewel zelfs de meest rabiate didactische middelen niet worden geschuwd - denk aan de combinatie van Brekers sculpturen met foto's uit de nationaal-socialistische moordfabrieken - voelt de gewone Duitse man en vrouw volgens Syberberg geen afschuw, schaamte, verdriet of wroeging, maar enthousiasme, vreugde, geluk, ja misschien zelfs trots. En logisch geredeneerd onjuist, omdat uit de premisse: de fascisten hunkerden naar a., niet noodzakelijk volgt: hunkeren naar $a$. is in wezen fascistisch.

Wat dit laatste punt betreft kan een voorbeeld misschien verhelderend werken. Zoals we zagen in het vorige hoofdstuk omschrijft Winifred Wagner zichzelf in de film als een "waanzinnig trouw persoon". ${ }^{18}$ Volgen we Russell Berman dan kan deze 'trouw" niet los worden gezien van de ideologie van het nationaal-socialisme, waarvan het cultuur- en mentaliteitshistorische substraat zou worden gevormd door het (oud-Bayreuther) wagnerianisme: "De motieven van loyaliteit, stabiliteit en trouw, waarop ze [Winifred Wagner, G.G.] zich bewust beroept, maken deel uit van de wagneriaanse ideologische erfenis waarin het gezonde, het homogene en het zuivere de oppositie vormen van het vermengde, het gedifferentieerde en het veranderende". ${ }^{119}$ En inderdaad: dit soort zaken stonden zowel bij de oud-Bayreuther wagnerianen als bij de nationaal-socialisten in hoog aanzien. Niet zonder reden, merkt Syberberg op in een essay uit 1980, liet Heinrich Himmler op de dolken van zijn SS-ers de leuzen In Treue Fest en Unsere Ehre ist die Treue graveren. ${ }^{120}$ Maar is dit een argument tegen trouw, loyaliteit, stabiliteit, gezondheid, homogeniteit en zuiverheid? Uit de premisse: de nazi's droegen waarden als trouw een warm hart toe, volgt toch niet noodzakelijk: waarden als trouw zijn in wezen nazistisch? Uit deze premisse volgt slechts, dat óók de nazi's waarden als trouw een warm hart toedroegen.

Een kleine twee eeuwen voor Himmler, in de tijd van de Verlichting, speelde het klokkenspel van Potsdam op verzoek van Frederik de Grote de melodie Üb' 'immer Treu und

\footnotetext{
${ }^{115}$ Zie: de paragrafen 2.4 en 3.4 .

${ }^{116}$ Syberberg, a.w., p. 60 .

${ }^{117}$ Zie: hoofdstuk 3, paragraaf 5 .

118 Zie: hoofdstuk 4 , paragraaf 2.

${ }^{119}$ Berman, a.w., p. 270. Zie eveneens: hoofdstuk 4, paragraaf 4.

${ }^{120}$ Syberberg, H.J., La 'Treue". Hitlers Opfer: eine verlorene Generation. in: Die Tageszeitung. 22-09-1980. Een deel van deze tekst staat eveneens afdrukt in: Syberberg, Die freudlose Gesellschaft, a.w., pp. $239 \mathrm{ff}$.
} 
Redlichkeit Hetgeen betekent, verduidelijkt Syberberg: "zonder trouw geen redelijkheid". 121 Is nu ook deze melodie, die in de Hitler-tijd nog dagelijks op de radio te horen was, met terugwerkende kracht in wezen nazistisch geworden - uitgerekend deze melodie, zojuist nog het summum van Verlichte wijsheid? En zou de opgave van dergelijke waarden niet "een groot verlies" betekenen voor "de oude ethische en geestelijke mogelijkheden van onze traditie"? "Het woord Treue kent in het Engels en het Frans geen equivalent. Er bestaat faithful, sûr, true, loyal, fidèle. Volgens het etymologische woordenboek stamt het Middelhoogduitse 'triuve' van het Indo-germaanse 'dereu(o)' $=\operatorname{der}$ Baum, 'fest wie der Baum, kernholzartig Fest' [standvastig als de boom, ijzersterk standvastig]. Boeken zou men kunnen schrijven, hele verhandelingen over het verlies van de Treue, niet alleen in de Duitse taal sinds 1945. Waartoe behoorden woorden en daarachter liggende wereiden als: Ere, Gnade, Maze, Staete, Zwivel, Erbermde, Zucht, Vröuede, Frouwe, hoger Muot, hohe Minne, enzovoorts? Alles Hitler cadeau doen?"122

Het is vooral in dit soort passages, dat Syberberg zich telkens weer een gretig lezer toont van Ernst Bloch. Zeker: op bewondering voor de trouw van de belijdende nazi Winifred Wagner-Williams heeft deze huisfilosoof van het Nieuwe Bayreuth zich nimmer laten betrappen. Integendeel: volgen we Gottfried Wagner, dan zou Bloch mede naar aanleiding van deze documentaire een uitnodiging hebben afgewimpeld om een bijdrage te leveren aan de festiviteiten rond het honderdjarige jubileum van het festival in "76: "Bloch verklaarde daartoe als jood en antifascist niet in staat te zijn. Door Syberberg en Winifred Wagner zou de oude relatie tussen Wagners muziek en de nazi's opnieuw zijn bezegeld en de door Wieland en Wolfgang Wagner bedreven denazificatie van Bayreuth zijn gedesavoueerd." 123 Toch is de manier van redeneren onmiskenbaar door Bloch gesouffleerd. Zoals gezegd behoort Bloch tot die intellectuelen uit de emigrantengeneratie, die met hun fascismetheorieèn een onuitwisbaar stempel op het debat over de 'schone schijn' van het Derde Rijk hebben gedrukt. Als een van de eersten heeft hij reeds ten tijde van de nazi's zelf onderkend, dat de door Sontag geanalyseerde hunkeringen een hoofdbestanddeel vormen van hun ideologie. In studies als Das Prinzip Hoffnung (1954) volgt Bloch de sporen van dit soort, wat hij noemt, "ongelijktijdige' bewustzijnvormen terug tot in de middeleeuwen en laat hij zien hoe het verlangen naar het schone, het zuivere (de Graal!), de irrationele extase enzovoorts de cultuur van het Avondland doortrekt. Maar anders dan bij Sontag is de programmatische inzet van Blochs dialectiek niet de ontmaskering van dit verlangen als in wezen fascistisch. Want een dergelijke, 'irrationalisme'-kritische strategie, zou inderdaad óók volgens Bloch niet alleen logisch geredeneerd onjuist zijn, maar er bovendien op neerkomen dat grote delen van het Duits/Europees/joodse culturele erfgoed en gevoelsleven zonder strijd aan de nazi"s cadeau worden gedaan. Bloch bewandelt exact de tegenovergestelde weg. Door de verstrengeling met het nationaal-socialisme zo nauwgezet mogelijk te onderzoeken probeert hij aan te tonen dat het hier niet gaat om 'fascistische hunkeringen', maar om hunkeringen die door het fascisme zijn geannexeerd. En wat is geannexeerd, kan ook weer worden terugveroverd. Hetgeen, zoals we zagen in hoofdstuk 3, in zijn optiek de taak zou moeten zijn van elke ware kritische filosofie: het betwisten van de aanspraken van de nazi's óók op grote delen van ons gevoelsleven. ${ }^{124}$

\footnotetext{
121 ibidem.

122 ibidem. Der Große Duden. Band 7. Etymologile, a.w., p. 719: "Der heutige Form geht zurück auf mhd. triuwe, das im 14. Jh. neben gleichbed. älteres mhd. getriuwe, ahd gitriuwi (...) trat. (...) Die Wortgruppe gehört zu dem (...) idg. deru- "Eiche, Baum" (...). Das Adjektiv treu bedeutet demnach eintl. "stark, fest wie ein Baum?""

${ }^{\Downarrow 23}$ Wagner, G[ottfried], a.w., p. 156.

124 Zie: hoofdstuk 3 , paragraaf 6 .
} 
Rest de vraag, waarom de conventies van de 'irrationalisme'-kritiek in de Bondsrepubliek van de jaren "70 zo hardnekkig zijn? Wel, vermoedt Syberberg, voor een niet gering deel zal het iets te maken hebben met een combinatie van conformisme, denkluiheid en regelrechte domheid. Want van de intellectuele capaciteiten van de critici van zijn protestgeneratie van ' 68 heeft hij over het algemeen geen hoge dunk. Van "de gistende werking en lenigheid van het dialectische intellect", die zo typerend is voor de studies van een oude emigrantenfilosoof als Ernst Bloch; is in het vertoog van '68 zijns inziens weinig te merken - "Ein intellektuell armes Volk, das nicht einmal mehr die selbst verkündetete Prämisse der Dialektik befolgt". 25 Vandaar de populariteit van een essay als Sontags Fascinating Fascism. Dit essay "bevestigt de ingeslagen en geleerde weg van het argumenteren. Ze hoeven geen nieuwe arbeid te verrichten, niet na te denken, niets te veranderen". En vandaar ook, dat zijn eigen films zo moeilijk liggen. In deze films gaat het immers niet 'om afhaken en toeslaan', laat staan om 'snelle, stoere nazi-verbranding'. ${ }^{126}$ In deze films gaat het om iets volstrekt anders, namelijk: om het ontwikkelen van een strategie van herijking, die het mogelijk maakt het geroofde culturele erfgoed weer terug te veroveren. ${ }^{127}$ Op de nazi's, die grote delen van de Duitse cultuurgeschiedenis en het Duitse gevoelsleven hebben geannexeerd. Én op de ideologen van de anti-'irrationele' re-education, die het geannexeerde vervalsen als in wezen fascistisch en het aldus 'zonder strijd aan Hitler en Goebbels cadeau doen'.

Voor een niet gering deel, aldus nog steeds Syberberg, komt het echter ook door een gebrek aan courage. Want anders dan in het geval van Sontags 'irrationalisme'-kritiek in Fascinating Fascism ("Er is geen moed voor nodig, om ermee in te stemmen" ${ }^{128}$ ), vereist dit project van de dialectische herijking daarvan een niet geringe dosis. Courage om de 'meningenterreur' van de genoemde ideologen te trotseren én om zelf vuile handen te maken in de omgang met goederen en gevoelens, die door het nationaal-socialisme besmet zijn geraakt. Courage ook om het eigen gevoelsleven, de na ' 45 als fascistisch vervloekte Duitse ziel, te doorvorsen. En daarvan is, meent hij, in het vertoog van ' 68 al evenmin veel te merken. Veeleer wordt dit vertoog getekend door een "smetvrees, die stilaan dodelijk begint te worden". ${ }^{129}$ Immers: hoe anders kan de welhaast panische overreactie worden verklaard, dan als een symptoom van een diepgewortelde angst - voor de toorn van de ideologen, voor de smet van de annexatie én voor hunkeringen, die deze aufarbeitende Duitse jongeren zelf maar al te goed kennen? ${ }^{130}$ "Vervuld van angst voor de eigen aangeboren Sehnsucht" en "verteerd door een zelfdestructieve pijn" worden ze "heen en weer geworpen tussen het taboe en hun eigenlijke bestemming": 131

"Vol zelfhaat en agressie vanwege de door hen verdrongen innerlijke irrationaliteit, doden $(. .$.$) [ze] in schuldige smetvrees zelfvernietigend het aan hen meest verwante,$ hoe dichterbij ze het vermoeden. (...) Meedogenloos en gekwetst, allergisch voor de symptomen van de eigen verdringingen. (...) Het zijn de lieden, die allang niet meer weten, waarom ze samenleving zeggen in plaats van, zoals vroeger, Duitsland, volk of vaderland, en die de mond vol hebben over cultuur als Bildungspolitik. Het zijn.

\footnotetext{
${ }^{125}$ Syberberg, Die Kunst als Rettung.., a.w., pp. 16, 45 .

${ }^{126} \mathrm{Zie}$ het aan het slot van paragraaf 4 aangehaalde cital uit Die freudlose Gesellschaft.

${ }^{127}$ Zie: hoofdstuk 3 , paragraaf 7 .

${ }^{128}$ Zie wederom het aan het slot van paragraaf 4 aangehaalde citaat uit Die freudlose Gesellschaft.

${ }^{129}$ Syberberg, a.w., p. 43 .

130 "Also, ich könnte da in meinem Fall von verhinderten Kritikern einiges Privates sagen, wo ich weiß das sie eigentlich genau so denken wie ich und vielleicht sogar wollen, daß ich manche Dingen gegen ihre Kritik tue..." Interview met de auteur en Eling Delleman, zomer 1991.

${ }^{131}$ Syberberg, H.J., Der Wald steht schwarz und schweiget. Neue Notizen aus Deutschland. Zürich, 1984. p. 15.
} 
dezelfde lieden, die hun gevoelens uitroeien en niet meer kunnen lijden en het treuren hebben verleerd en daarom ook geen eigen schuld meer kennen, omdat ze de samenleving voor hun daden verantwoordelijk stellen."132

En het zijn, zouden we hieraan kunnen toevoegen, precies deze lieden, waarvan Syberberg hoopt dat ze tijdens het bekijken van de Winifred-Wagner-documentaire een 'traumatisch bewustwordingsproces' (Santner) ${ }^{133}$ zullen doormaken. Want laten we dat vooral niet vergeten: het gaat in deze filmische Trauerarbeit om 'die kathartische Funktion, einmal zu sehen, wie eine sich bekennt'.

\subsection{Een duistere eed van trouw}

Om de therapeutische inzet van de documentaire te kunnen begrijpen zullen we kort moeten terugkeren naar Alice Millers interpretatie van Hitler, ein Film aus Deutschland. Zoals we zagen in paragraaf 3 bouwt Miller haar interpretatie op rond een casus. Een kind uit de derde generatie begint plotseling hakenkruisen te kalken en met andere rekwisieten uit de Hitler-tijd te spelen. En de moeder, een voormalig lid van een antifascistische studentengroep, reageert vijandig, ja zelfs ronduit agressief. Middels een breed scala aan strafmaatregelen probeert ze "de spelletjes van haar kind te "liquideren". Maar gaandeweg zal ook zij een tweetal dingen gaan onderkennen. Ten eerste: dat verboden en taboes averechts werken - de spelletjes nemen alleen maar in omvang en frequentie toe. En ten tweede: dat haar agressiviteit voortvloeit uit een diep gewortelde angst voor eigen hunkeringen, die ze jarenlang heeft verloochend en verdrongen. Ja, ze zal gaan onderkennen, dat haar pedagogiek een wanhopige poging was niet zozeer de spelletjes van haar kind te liquideren, als haar 'ware zelf'. En zo zullen deze spelletjes uiteindelijk ook voor de moeder een louterend effect hebben. Dankzij de hakenkruisen van zoonlief overwint ze haar angst en verzoent ze zich met essentiële delen van haar eigen, door een jarenlange pedagogische 'terreur' zwaar verminkte gevoelsleven. Aldus Miller in Am Anfang war Erziehung. ${ }^{\text {I3 }}$

In Syberbergs documentaire wordt de rol van het hakenkruisen kalkende kind vervuld door een tegendraadse grootmoeder, waarop 'het pedagogische schema van beschuldiging en verontschuldiging' (Miller) overduidelijk geen enkele vat heeft gehad. Dwars tegen de naoorlogse verdringingsmechanismen in, de 'meningenterreur' van de re-educationideologen trotserend, is deze 'moedige' oude dame trouw gebleven aan haar 'ware zelf'. En aan de vooravond van haar levenseinde permitteert ze zich nog eenmaal de, zoals Syberberg het noemt in de film, "persoonlijke luxe van het hart". Lachend, met geheven hoofd, fier en zelfverzekerd, zonder zich te genêren of gebukt te gaan onder een schuldcomplex, 'standvastig als de boom, ijzersterk standvastig', komt ze op voor haar overtuigingen én gevoelens - bekennt sie sich dazu. Dat haar vriend Hitler heel wat op zijn kerfstok had? Ze weet het. En ze keurt het ook niet goed. Maar verloochenen zal ze haar vriendschap met Hitler nooit. Dat kan ze niet. Het zou indruisen tegen haar gevoel. ${ }^{135}$

Goed, ook Syberberg is zich terdege ervan bewust dat andere, moreel betere omgangsvormen met de recente geschiedenis mogelijk zijn. Ook hij is onder de indruk van de fameuze knieval van Willy Brandt op 7 december 1970 voor het getto-monument in Warschau. Wat Brandt op de belijdende nazi voor heeft, zijn in elk geval twee dingen: zijn

\footnotetext{
${ }^{132}$ Syberberg, Die Kunst als Rettung..., a.w., p. 60.

133 Zie: hoofdstuk 4, paragraaf 6.

${ }_{134}^{134}$ Miller, In den beginne was er opvoeding, a.w., pp. $134 \mathrm{ff}$.

${ }^{1.35}$ Zie: hoofdstuk 4, paragraaf 2.
} 
knieval was een schuldbekentenis én een uiting van empathie met de slachtoffers. En hiertoe is Winifred Wagner overduidelijk niet bereid. Maar wie wel uit haar generatie? "Er was tot dusver slechts één die voor de slachtoffers boog en knielde, en die was er niet bij, toen de anderen schuldig werden." ${ }^{136}$ Geen onbelangrijk detail. De voormalige emigrant Brandt was een oud-verzetsman, een vertegenwoordiger van het andere, antifascistische Duitsland. Zo iemand maakt nu eenmaal makkelijker een buiging voor de slachtoffers dan een schuldige. De psychische weerstanden, die hij moet overwinnen, zijn aanzienlijk geringer. Brandts buiging was een symbolisch gebaar, doordrenkt van christelijke retoriek. Zelf zonder schuld boog de bondskanselier plaatsvervangend en nam hij de schuld op zich - de schuld van hen, die eigenlijk hadden moeten buigen, maar hiertoe psychisch niet in staat waren. ${ }^{137}$

Winifred Wagner, stelt Syberberg, heeft slechts gedaan wat ze kon. ${ }^{138}$ En toch was ook haar gebaar niet zonder betekenis. Volgen we de filmer, dan bestaan er zelfs verrassende parallellen tussen Brandts buiging en de belijdenis van de oude dame. Zo was ook deze buiging allesbehalve een uiting van deemoed of schaamte. "Stofhappen was geenszins Brandts bedoeling," merkt Dirk-Jan van Baar scherp op in een column in de Volkskrant van 15 september $1997 .{ }^{139}$ Het ging om een 'bekentenis' in de Duitse zin van het woord. Fier en zelfverzekerd boog Brandt, in naam van de schuldigen, voor de slachtoffers. En wie neerknielt, komt innerlijk gesterkt overeind ${ }^{140}$ Door "bij wijze van spreken met geheven hoofd te knielen", schrijft de historicus Peter Brandt (inderdaad de zoon van) in een kort essay (1997), werd de gebeurtenis "een plechtigheid van nationale waardigheid - en juist niet van nationale onwaardigheid". ${ }^{141}$ "Of, zoals Syberberg het in Filmbuch formuleert: al knielende stond Brandt in "de trotse traditie van het Duitsdenkende verzet". ${ }^{142}$

In deze traditie staat Winifred Wagner niet. Echter wel in een andere, niet minder 'trotse' en deutschbewußte: die van de Wagner-cultus in Bayreuth - een van "onze trotse Europese geestelijke centra". ${ }^{143}$ Ook haar 'belijdenis' is een 'daad van waardigheid - en juist niet van onwaardigheid'. En er is meer. Het uitspreken van een schuldbekentenis ligt niet in haar psychische mogelijkheden. Maar ze heeft, meent Syberberg, wel iets anders gedaan, dat van een schuldige nauwelijks minder moed en innerlijke kracht vergt. Namelijk: zich "volstrekt openhartig en voor het eerst volstrekt eerlijk" met het schuldige verleden geassocieerd en hiermee indirect "de schuld op zich genomen" - ook de schuld van hen, die tot een dergelijke Bekenntnis niet in staat zijn. ${ }^{44}$ "Een monument van burgermoed [Zivilcourage]", noemt Syberberg deze vrouw. "Ze loopt er niet voor weg". ${ }^{145}$ Zoals zoveel anderen, die "er nu niets meer van willen weten, van een land dat zich ooit het Duitse Rijk noemde" en een "democratisch gekozen" politicus, die "vurig werd bemind door miljoenen". ${ }^{46}$ Deze vrouw is niet met stomheid geslagen als het schuldige verleden ter sprake komt. Ze hult zich niet in stilzwijgen, probeert haar trouw aan Hitler niet te bagatelliseren. Noch verloochent ze haar eigen identiteit. Zoals haar kleinzoon Gottfried

\footnotetext{
${ }^{136}$ Syberberg, Filmbuch, a.w., p. 260.

${ }^{137}$ Zie bijvoorbeeld: Pross, H., Der Kniefall zur Befreiung. Willy Brandt am 7. Dezember 1970 vor dem

Warschauer Ghetto-Denkmal. in: Memory. Zeitung zur Ausstellung Deutschlandbilder Kunst aus einem geteilten Land. Hrsg. Martin-Gropius-Bau. 7 september $1997-11$ januari 1998. p. 36.

${ }_{138}^{138}$ Syberberg, a.w., p. 293.

139 Baar, van, D.J., Een eenmalige knieval. in: de Volkskrant. 15-09-1997.

${ }^{140}$ Pross, a.w., p. 36

${ }^{141}$ Brandt, P., Der Kniefall von Warschau. in: Memory. a.w., p. 37. Hetzelfde punt wordt gemaakt door Van Baar, a.w.

${ }^{142}$ Syberberg, a.w., p. 260.

${ }^{143}$ idem, p. 247.

${ }^{144}$ Syberberg, Die Kunst als Rettung..., a.w., p. 34

${ }^{145}$ Wirbel um offene Worte Winifreds. a.w..

${ }^{146}$ Syberberg, a.w., p. 246.
} 
Wagner, die zich naar eigen zeggen in het buitenland bij voorkeur voorstelt als Geoffrey Cartwright en in interviews liever geen Duits praat. De schaamte zou te groot zijn. ${ }^{147}$

Dit soort vluchtgedrag is de oude dame ten enenmale vreemd. Zij windt er geen doekjes om, maar komt er rond voor uit. $Z$ ij is Winifred Wagner-Williams, de grande dame van het oude Bayreuth, de hartsvriendin van Adolf Hitler, Duitsnationaliste én nationaalsocialiste van het eerste uur. En in die hoedanigheid staat ze Syberberg te woord - "trouw aan haar grootse tijd". " "Volstrekt openhartig en voor het eerst volstrekt eerlijk', geeft ze antwoord op de meest pijnlijke vragen. "Eine Frau, die sich bekennt, offen, englisch-deutsch, europaischer Background, die spricht, endlich. ${ }^{* 149}$ Nee, de politisering van het festival onder haar leiding was geen bedrijfsongeval. Zij heeft haar leven lang in Hitler geloofd. Van meet af aan en met heel haar hart. En niet alleen zij. Allemaal hebben ze in haar vreugde en geluk gedeeld. Haar man Siegfried ("total deutschbewußt"150), haar schoonzuster Eva, haar zwager Houston Stewart Chamberlain, haar zonen Wieland en Wolfgang, Furtwängler, Tietjen, Preetorius... het overgrote deel van het Duitse volk. Met deze belijdenis, denkt Syberberg, heeft Winifred Wagner de eerste stap gezet. "De volgende wordt van de anderen verwacht". ${ }^{51}$ Bijvoorbeeld: van haar familieden. In plaats van de film als "geklets"152 van een "koppige Welshe"153 te verwerpen, zal festivalleider Wolfgang Wagner de belijdenis van zijn moeder moeten aanvaarden. Hij zal, stelt Syberberg, deze belijdenis tot de zijne moeten maken en met een schuldbekentenis (in de Duitse zin van het woord) moeten aanvullen. Want wie met geheven hoofd neerknielt, komt innerlijk gesterkt overeind. "Schuld is een gecompliceerde zaak, zoals de oude Grieken reeds wisten. $\mathrm{Zij}$ verlangt de allergrootste opmerkzaamheid, sluipt binnen, neemt wraak voor minachting op kinderen en kleinkinderen, en grijpt meedogenloos dag en nacht hele families en volkeren. Schuld vereist arbeid, die men op het verkeerde moment geboren misschien niet in staat is te verrichten."154 Zoals deze schuldige moeder en grootmoeder.

Maar Winifred Wagner, zo kunnen we Syberbergs visie samenvatten, heeft gedaan wat ze kon. En alleen dankzij de eerlijkheid, de moed en de emotionele spontaniteit van deze vrouw uit de eerste generatie, wordt het nu ook voor de tweede en derde generatie mogelijk een verlaat verwerkingsproces te initiëren. ${ }^{155}$ Door er rond voor uit te komen, dat de Hitlertijd voor haar en het merendeel van de Duitsers een 'grootse tijd' was, heeft ze "velen van hun leugens verlost". ${ }^{156}$. Door te laten zien, dat een dergelijke belijdenis mogelijk is, zonder zijn waardigheid te verliezen, heeft ze "de Duitsers die zich vergisten, verloren, schuldig werden, hun eer teruggeschonken - niet door de feiten, die we kennen, maar door haar karakter: een raadsel onoplosbaar". En door "trouw" te blijven "aan ooit verknoeide

\footnotetext{
1477 Voermans, E., Wagner tegen wil en dank. in: Het Parool. 27-02-1996. p. 45. Hetgeen, als we de Amerikaanse historicus Walter Laqueur, a.w., p. 177 mogen geloven, in hoge mate typerend is voor de manier waarop de Duitsers gedurende de eerste naoorlogse decennia met hum nationale identiteit omgingen: "Es war die Zeit, als Deutsche, die ins Ausland reisten, am liebsten nicht als solche erkannt werden wollten. Die Nation war in diesen Jahren beiseite gelegt, und es sah so aus, als sei Deutschland im Begriff, seine Identität in einer größeren Einheit zu verlieren - Europa."

Ts Syberberg, Filmbuch, a.w., p. 264.

149 idem, p. 246.

150 Citaat ontleend aan de documentaire.

${ }^{151}$ Syberberg, a.w.y p. 293.

${ }^{152}$ Pressekonferenz mit Wolfgang Wagner: "Politik ist im Festspielhaus weggewischt". in: Richard Wagner. Ein deutsches Thema, a.w., p. 272.

153 Wagner, W., Lebens-Akte. Autobiographie. München, 1994, 1997. p. 48

154 Syberberg, a.w., p. 293.

${ }^{155}$ En niet, zoals Santner, a.w., p. 45 denkt: "Alleen dankzij de woede en het verdriet van de derde generatie (...), werd het ook voor de eerste generatie mogelijk een verlaat verwerkingsproces te initiëren".

156 Syberberg, Die Kunst als Rettung..., a.w., p. 34.
} 
geschiedenis" en "zonder sentimenteel gedoe de verantwoording op zich te nemen voor de nederlaag" heeft ze de Duitsers "met hun geschiedenis verzoend". "Uitgerekend zij, met deze duistere eed van trouw. Dat deed en doet pijn, moet pijn doen. Zoals alle Trauerarbeit."

\subsection{Slot}

Met een Trauerarbeit in de zin van de Mitscherlichs, zoals de auteurs van de in het vorige hoofdstuk besproken Angelsaksische commentaren veronderstellen, heeft dit alles weinig van doen. En dat Syberberg inmiddels is opgehouden het begrip Trauerarbeit te gebruiken, ${ }^{158} \mathrm{zal}$ dan ook mede zijn ingegeven door een behoefte een einde te maken aan deze verwarring. "Ik vind begrippen als Trauerarbeit of, in psychoanalytische zin, melancholie, tegenwoordig niet erg zinvoll," antwoordt hij in een interview uit 1991 op de vraag, in hoeverre zijn eigen opvattingen over rouwverwerking aan de maatschappijpsychologische rouwtheorie van de Mitscherlichs schatplichtig zijn. "Ik vind, men zou veel praktischer en veel... flinker met dit soort dingen moeten omgaan. Dat wil zeggen... niet met zo weinig geheven hoofd [so wenig erhobenen Hauptes], maar met een zekere hoogte... (...) En melancholie, Trauerarbeit, is iets dat we met gebogen hoofd [mit gesenkten Haupte] doen..."159 Als Syberberg dit

${ }^{157}$ Syberberg, Eine Zeugin und eine Schuldige. a.w., pp. $234 f$.

${ }^{158}$ Zoals cok Santner opmerkt aan het slot van het hoofdstuk over Syberberg in zijn Duitsland-studie Stranded Objects. "(...) Syberberg, since Hitler, has renounced the term Trauerarbeit and instead insisted on terms he sees as being more compatible with the changing intentions of his art and cultural criticism". Voor deze werwerping van het begrip Trauerarbeit geeft Santner de volgende verklaring. Weliswaar zou het Syberberg in zijn Hitler-film te doen zijn om 'een poging de Trauerarbeit, waar de Mitscherlichs om vroegen, in een esthetische praktijk te vertalen'. Maar uiteindelijk, denkt Santner, komt de filmer niet verder dan de eerste fase van de freudiaanse Trauerarbeit: het doorbreken van de afweer, hetgeen binnen de theorie van de Mitscherlichs noodzakelijk een melancholische depressie tot gevolg heeft. "So rather than working through and helping to overcome the inability of mourning, Syberberg's film is intended to induce melancholy, that psychological state that, according to the Mitscherlichs, never emerged in the postwar period because of a ready availability of new narcisissistic fixes in the consumerist bacchanalia of the "economic miracle". Santner, a.w., pp. 147f. Zoals we echter in dit hoofdstuk hebben gezien, heeft Syberberg een volstrekt andere visie op de manier waarop de Duitsers hun nazi-verleden hebben verwerkt. Niet de pathologische afweer van melancholische gevoelens als woede, schaamte, verdriet, berouw enzovoorts is het probleern, maar juist de masochistische zelfkastijding onder de schuld'. En ook als het gaat om de vraag, hoe de Duitsers hum nazi-verleden dan wel hadden moeten verwerken, verschilt hij fundamenteel met de Mitscherlichs van mening. Is Trauerarbeit, in de zin van de Mitscherlichs, een moeizaam en pijnvol proces van afscheid nemen van de traditionele identificatie-objecten (het onderkennen en doorwerken van melancholie), opdat opnieuw ruimte ontstaat voor een empathische identificatie met de 'bevrijders' en - bovenal - de joodse slachtoffers (zie hoofdstuk 4, paragraaf 5); inzet van de syberbergiaanse Trauerarbeit is juist het weer 'vrij worden van de bedrukkende vloek van de schuld' (het onderkennen en doorwerken van het aan Duitsland opgelegde 'psychologische Versailles'), opdat opnieuw ruimte ontstaat voor een empathische identificatie met de 'trotse' Duitse cultuurtradities.

${ }^{159}$ Interview met de auteur en Eling Delleman, zomer 1991. Tijdens een in datzelfde jaar gehouden persconferentie (niet gepubliceerd) naar aanleiding van de Brusselse opvoering van Ein Traum, was sonst? (1990/"91), stelt Syberberg het volgende: "Ik heb grote moeite met dat begrip Trauerarbeit. Het wordt zo makkelijk gezegd: Trauerarbeit zus, Trauerarbeit zo. Ook zelf heb ik het vroeger vaak in de mond genomen. En wie niet? Dit Nachkriegsbegriff is zo invloedrijk geweest.. Het heeft, meer dan wat ook, een stempel gedrukt op ons en ons werk. Maar tegenwoordig zou ik het anders formuleren. Ik bedoel Trauerarbeit heeft toch ook met tragedie van doen... Die connotatie gaat in dit psychoanalytische begrip volkomen verloren. Wat is Trauerarbeit? Wanneer je tegenwoordig naar Venetiè reist en je ziet daar die explosie van het massatoerisme... $\mathrm{ja}$, dan kan ik erg treurig worden. Maar Trauerarbeit is beslist iets anders dan droefheid of nostalgie. Het is voor mij een bepaalde houding van soevereiniteit ten opzichte van die totale Umwertung aller Werte, die tegenwoordig overal in onze cultuur gaande is. Het is ook een poging iets van het verlorene weer terug te winnen, al was het maar als herinnering in onze kunstwerken. Zoiets moet me indertijd ook voor ogen hebben gestaan. Maar zoals gezegd zou ik het tegenwoordig onacceptabel winden, wanneer mijn werk werd 
interview geeft heeft hij zijn eigen coming out al achter de rug. Maar om erachter te komen wat de filmer hier zou kunnen bedoelen, hoeven we niet latere pamfletten als Das Rechte-tun (1995) erbij te halen. We kunnen volstaan met het bekijken van deze documentaire uit het midden jaren ' 70 .

En toch: anders dan de late Syberberg begrijpt die van de Winifred-Wagnerdocumentaire zijn werk niet als 'rechts'. Hij ziet zichzelf als een intellectuele kunstenaar of, zo men wil, een kunst scheppende intellectueel, die in een weliswaar dissidente, maar desalniettemin uitgesproken linkse denktraditie staat. Meer specifiek: in de denktraditie van de neo-marxistische avant-gardisten Ernst Bloch, Hans Mayer en, niet te vergeten, zijn 'artistieke pleegvader' Bertolt Brecht - de grote tegenspelers van de door Lukács en de late Thomas Mann geïnitieerde 'irrationalisme'-kritische richting in de Duitse cultuurtheorie, waarvan de psychoanalyse van de Mitscherlichs en het debat over de 'schone schijn' van het Derde Rijk gerust vertalingen in respectievelijk een psychiatrische en een (kunst-)historische praktijk mogen worden genoemd. "Alle filmmakers in Duitsland zijn min of meer politiek," vertelt Syberberg in een interview, dat hij in 1979 heeft gegeven tijdens een symposium rond zijn werk aan de universiteit van Pennsylvania.

"Ook al valt het niet meteen op, hun films zijn doordrenkt van politiek denken. We zouden anders niet kunnen bestaan, want ons publiek is politiek. Natuurlijk, oudere, conservatieve mensen, hebben met ons werk weinig op. Ons publiek is doorgaans links. In zekere zin voel ik me erg eenzaam. Naar mijn stellige overtuiging, ben ik de enige onder de linksen, die nog een oppositionele positie inneemt. Ik zie mezelf als een oppositie tegen links, omdat we tegenwoordig een links intellectueel establishment hebben en ik van mening ben dat er altijd een oppositie moet zijn, wanneer een bepaalde groep (de linksen en de intellectuelen niet uitgezonderd) aan de macht komt. Maar ik heb het niet over een oppositie vanuit rechts; ik heb het over iemand, die weerstand biedt tegen de stroperigheid van de macht." 160

$\mathrm{Nu}$ valt yoor dit zelfbeeld van Syberberg als een linkse kunstenaar misschien wel wat te zeggen. ${ }^{161}$ Per slot van rekening doet hij, zoals we in paragraaf 6 zagen, wel degelijk moeite langs de lijnen van Bloch verder te denken en diens inzichten naar het linkse cultuurdebat van de jaren '70 te transponeren. De 'enige onder de linksen, die nog een oppositionele positie' inneemt, is deze filmmaker echter beslist niet. Integendeel: de 'oppositie vanuit links' tegen het linkse intellectuele establishment en haar volkspedagogische praktijk, is juist zéér eigentijds. Er is iets aan het veranderen in de Bondsrepubliek van de late jaren " 70 - daarover bestaat brede consensus. De een, Jürgen Habermas, spreekt laatdunkend over een conservatief-reactionaire Tendenzwende ${ }^{162}$ de ander, de Amerikaanse historicus Walter Laqueur, meer welwillend over een 'herontdekt patriottisme'. ${ }^{63}$

Voorbeelden zijn legio. Linkse (of zichzelf links noemende) intellectuelen als Botho Strauß storten zich vol overgave op verboden vruchten als de literatuur van Ernst Jünger ${ }^{164}$ of hekelen, zoals Martin Walser in 1977, de "geallieerde strafexpeditie" van de Duitse deling,

geïnterpreteerd als een Trauerarbeit. Of, aithans, als een Trauerarbeit in psychoanalytische zin. Arbeit an der 160 rauer kan er misschien nog net mee door. Tegen Trauerarbeit heb ik echter grote bezwaren. "

${ }_{160}$ Erkkila, B., Hans Jürgen Syberberg; An Interview. in: Syberberg, A Filmmaker from Germany, a.w., p. 29.

Eerder versch. in: Literature/Film Quarterly. ed. Salısbury State University. Salisbury, 1982.

${ }_{161}$ Zie: hoofdstuk 7, de paragrafen 4 tot 6 ; hoofdstuk 8, paragraaf 4.

${ }^{162}$ Habermas, J., Kleine Politische Schriften. (I-IV). Frankfurt am Main, 1981. pp. 309-464. Zie eveneens:

hoofdstuk 4, paragraaf 1 .

${ }_{163}$ Laqueur, a.w., pp. $175 \mathrm{ff}$.

164 Zie: hoofdstuk 8 , paragraaf 4. 
waarbij de linkerflank van de Bondsrepubliek zich wat al te gemakzuchtig zou hebben neergelegd: "Net zo min als de DDR mogen we de BRD erkennen. De wond genaamd Duitsland moet worden opengehouden." ${ }^{165}$ Zelfs Rudy Dutschke, het onbetwiste boegbeeld van de protestgeneratie, verwijt in een interview uit datzelfde jaar links-Duitsland "een blinde vlek voor het Duitse vraagstuk". ${ }^{166}$ In de architectuur doet een nieuw traditionalisme zijn intrede als reactie op het moderne bouwen dat de Duitse steden zou hebben veranderd in betonnen bunkers zonder historische substantie. ${ }^{167}$ Componisten als Wolfgang Rihm ontworstelen zich aan het keurslijf van de seriële muziek en geven zich over aan een vrolijk eclecticisme. ${ }^{168}$ Beeldende kunstenaars herontdekken in het voetspoor van de nationale sjamaan Joseph Beuys de Duitse romantiek. ${ }^{169}$ In de schilderkunst maakt het abstracte vlak plaats voor een nieuw figuratisme ${ }^{170}$ en tieren welig de Duitse motieven ${ }^{171}$ - zoals de titel luidt van een reeks stillevens uit 1972 van Markus Lüpertz, de schilderende dandy uit Düsseldorf die zichzelf graag mag typeren als een "contrarevolutionair" (contra de revolutie van ' 68 wel te verstaan). ${ }^{172}$ Nieuwe Duitse Filmmakers als Werner Herzog en Edgar Reitz maken hun publiek "tot een virtuele natie van Heimatvertriebenen" (de Duitse filmcriticus Georg Seeßlen). ${ }^{173}$ Jarenlang, merkt Laqueur op in Germany Today (1985), was Heimat voor Duitse intellectuelen slechts een ander woord voor kitsch: "Volksliederen en lokale gebruiken waren het onderwerp van spot of golden als gevaarlijke overblijfselen uit het nazi-verleden. (...) Omdat het nationaal-socialisme Heimat had gepropagandeerd, rustte op dit begrip een taboe." Nu, in de jaren '70, raakt ook het Heimatgefühl weer erg in de mode. Het leven op het platteland, "tot voor kort welhaast per definitie fascistoïde", wordt herontdekt; ja er ontstaat zowaar een nieuwe línkse politieke stroming, die de - mentale - terugkeer van stad naar platteland als één van haar programmapunten heeft: de Grünen. "Enkele intellectuelen rationaliseren het in neo-maxistische termen," aldus Laqueur. "Heimat zou niet reactionair zijn, maar toekomstgericht." ${ }^{174}$ Zoals Ernst Bloch reeds in Das Prinzip Hoffnung betoogde. ${ }^{175}$

Ook Karl Heinz Bohrers, mede door Syberberg geïnspireerde Bemerkungen zu einem nationalen Tabu (1978), waarmee ik hoofdstuk 3 afsloot, passen in deze trend. Zoals we zagen breekt Bohrer een lans voor een rehabilitatie van Duitsland als 'geestelijke mogelijkheid' en veegt hij de vloer aan met de jarenlange betutteling door de 'irrationalisme'-kritische richting van Lukács tot Habermas: "Wir wurden doch zu lange

\footnotetext{
${ }^{165}$ Citaat ontleend aan: Boterman, F., Terug naar Berlijn. Duitsland na de val van de muur. Amsterdam, 1999. p. 172. Boterman heeft dit citaat ontleend aan: Walser, M., Wer ist ein Schriftsteller? Aufsätze und Reden.

Frankfurt am Main, 1979. p. 101. Zie eveneens: Laqueur, a.w., p. 204.

${ }^{166}$ Zie: Greß, F., Jaschke, H.G., Schönekäs, K., Neue Rechte und Rechtsextremismus in Europa.

Bundesrepublik, Frankreich, Großbrittannien. Opladen, 1990. p. 267.

${ }^{167}$ Laqueur, a.w., pp. $47 \mathrm{fff}$.

${ }_{168}$ Weid, J.N., von der, Die Musik des 20. Jahrhunderts. Von Claude Debussy bis Wolfgang Rihm. Übersetzt von A. Ginhold. Leipzig, 2001.pp. 458ff.

169 Ernste Spiele. Der Geist der Romantik in der deutschen Kunst 1790-1990. Hrsg. C. Vitali. München, 1995. pp. 60ff, $68 \mathrm{ff}$.

${ }^{170}$ Refigured Painting. The German Image 1960-88. ed. Th. Krens, M. Govan, J. Thompson. New York, München, 1989.

${ }^{171}$ Schütz, H., Transformation und Wiederkehr. Zur künstlerischen Rezeption nationalsozialistischer Ästhetik. in Kunstforum. 95 (juni, juli, 1988). pp. 64-98. Zie eveneens: Alltwegg, J., Das Ende der Revolution und der Avantgarden. in: Deutsche Kunst der späten 80er Jahre. Hrsg. K. Thomas. Köln, 1988.

${ }_{172}$ Grasskamp, W., Der lange Marsch durch die Illusionen. Über Kunst und Politik. München, 1995. pp. 79-94. Zie eveneens: Bussmann, G., Markus Lüpertz. Deutsche Motive. in: Arbeit in Geschichte / Geschichte in Arbeit. Hrsg. G. Bussmann. Hamburg, 1988. pp. 176-181.

${ }^{173}$ Seeßlen, G, Land der Väter und der Verräter. Nationale Identität und nationale Helden: Nur tote Deutsche sind gute Deutsche. in: Spiegel Special. 100 Jahre Kino. 12 (december 1994). pp. 116-124, zie: 124.

${ }_{174}^{174}$ Laqueur, a.w., pp. 176f, 204ff.

${ }^{175}$ Bloch, E., Das Prinzip Hoffnung. Dritter Band. Frankfurt am Main, 1959, 1976. p. 1628.
} 
belehrt ${ }^{, 176}$ - een parafrasering van een Nietzsche-citaat, waarin de regisseur van de WinifredWagner-documentaire zich ongetwijfeld zal kunnen vinden. Want voor Syberberg is deze Tendenzwende een teken van hoop in een overigens "barre tijd zonder Duitse identiteit". ${ }^{177}$ $\mathrm{Na}$ een decennialange zelfkastijding in een opgelegd pedagogisch schema van verontschuldiging en beschuldiging', komen de Duitsers eindelijk hun 'smetvrees' te boven en verzoenen ze zich met hun vervloekte en verdrongen 'ware zelf'. En met zijn filmische treurwerken probeert Syberberg dit traumatische bewustwordingsproces te bespoedigen. Zo ook met zijn eerstvolgende werk na de Winifred-Wagner-documentaire, het magnum opus Hitler, ein Film aus Deutschland:

"Na de voorstelling in Cannes heb ik met Ulrich Gregor en zijn vrouw gesproken, die tot dusver mijn films niet erg konden appreciëren, maar van Hitler onder de indruk waren. Voor hen, die uit mijn generatie stammen, betekende de film een soort verlossing, in de religieuze zin van het woord. Na deze film, vertelden ze me, zouden ze graag het strand oplopen en nog een keer het Horst-Wessel-Lied zingen, zoals ze het in hun kindertijd hadden gezongen (want het ging om iemand uit mijn generatie), daarna zou alles voorbij zijn, men hoefde niet langer erover te spreken. Hier was, op een bepaalde wijze, een macht gebroken... Aan het eind van de film zal de toeschouwer niet opstaan en met geheven vuist agressief de Internationale tegen Hitler zingen. Veeleer zal iemand aan zee dit lied zingen, dat hij als kind onder Hitler zong." "178

\footnotetext{
${ }^{176}$ Bohrer, a.w..

${ }^{177}$ Syberberg, Die Kunst als Rettung..., a.w., p. 48. Zie eveneens: Syberberg, H.J., Alpträume akzeptieren. in: Frankfurter Allgemeine Zeitung. 03-05-1979, waarin hij deze Tendenzwende interpreteert als een teken dat de Nachkriegszeit ten einde loopt: "Es geht in unserem Lande eine Umwälzung vor sich (...)".

${ }^{178}$ Citaat ontleend aan: Oudart, J.-P., Verführung und Terror im Kino. in: Syberbergs Hitler-Film. Texte von Susan Sontag, Jean-Pierre Faye, Jean-Pierre Oudart, Christian Zimmer, Michel Foucault, Bernard Sabel, Alberto Moravia, Vito Zaggario, Heiner Müller. Hrsg. K. Eder. München, Wien, 1980. pp. 27-50, zie: 44f.
} 


\subsection{Inleiding}

Wie niet beter weet zou makkelijk kunnen veronderstellen, dat we hier vandoen hebben met een fragment uit een nogal knullig gemaakte B-fillm. Laten we zeggen: het type film waarop de Amerikaan Edward D. Wood Jr. ooit het patent had. De grafsteen uit papier-maché, met de initialen RW als opschrift, zou in elk geval zo aan een van diens producties ontleend kunnen zijn. En hetzelfde geldt voor het geschilderde achtergronddecor, dat de villa Wahnfried bij nacht moet verbeelden. Dorre bladeren op de vloer zorgen voor een quasi-naturalistisch effect. En als finishing touch is de filmer druk in de weer geweest met een rookmachine. Maar dit is niet Plan 9 from outer Space. We hebben het over de meest bekende scène van Hitler, ein Film aus Deutschland (1977).'

De plaats van handeling behoeft inmiddels geen nadere introductie. Twee jaar na zijn Bayreuth-documentaire Winifred Wagner und die Geschichte des Hauses Wahnfried (1975) neemt Syberberg ons opnieuw mee naar 'één van de trotse geestelijke centra' van de Duitse Kultur. ${ }^{2}$ We bevinden ons in het Heilige der Heilige van de Wagner-cultus: de tuin achter de kunstenaarsvilla Wahnfried, waar de Meester samen met zijn eega Cosima begraven ligt. Het is nacht. De grafsteen is gekanteld. Uit het geopende graf stijgen slierten nevel op. Na enkele tellen worden in de nevel de contouren zichtbaar van een kleine gestalte, die zich aarzelend uit het graf opricht. Het mannetje gaat gekleed in een Romeinse toga. Zijn gezicht is opzichtig wit geschminkt en in zijn haar hangen spinnewebben. Het bekende snorretje moet duidelijk maken, wie we hier voor ons hebben. Zichtbaar onwennig, alsof hij zojuist is ontwaakt uit een diepe slaap, kijkt de schim van Hitler (een rol van de yoormalige Brecht-acteur Heinz Schubert) om zich heen. Dan volgt een blik van herkenning." Hier werd het geestelijke zwaard gesmeed waarmee we triomfeerden". En tot zijn middel staande in het graf, de toga losjes rond de schouders gedrapeerd, richt dit creature from hell zich nog én keer tot zijn volk, met een monoloog die het midden houdt tussen een lijkrede, een redevoering, een apologie en een regelrechte Publikumsbeschimpfung: "Ja, luistert u maar goed, doorstaat u het, dames en heren! Ik ben een mens, met twee ogen en oren, net als jullie. En wanneer jullie mij steken, bloed ik dan niet? Ik ook. Ook ik ben een van jullie".

Honend neemt het monster aan het eind van de scene weer van ons afscheid, de rechterarm gestrekt in de Romeinse groet, de latere groet van het Italiaanse fascisme: "Voor eeuwig, jullie broeder Hitler". Twee van top tot teen in zwarte kledij gestoken figuren naast het graf, hebben al die tijd de wederopstanding zwijgend gade geslagen. Uit de speakers schettert, het zal niet verbazen, pompeuze Wagner-muziek, meer specifiek: de ouverture van de 'grand opéra' Rienzi. Ook horen we enkele historische geluidsdocumenten, waaronder een fragment uit de nieuwjaarstoespraak van 1943 waarin Joseph Goebbels zich met een smeekbede richt tot de "Almachtige": "Houdt de Führer gezond en vol kracht en besluitvaardigheid". Daarbij zien we het lijkbleke gezicht van het mannetje in het graf van papier-maché, dat nota bene niet eens zijn eigen graf is. Brechtiaanse ironie? Vervreemdend is deze potsierlijke spookverschijning zeker - echter niet meer of minder dan de bordkartonnen UFO's in de films van Ed Wood. Pas wanneer je de scène enkele malen hebt teruggezien, wordt duidelijk hoe vernuftig dit ogenschijnlijk zo simpele beeld in elkaar zit. Wat bij een

\footnotetext{
${ }^{1}$ Voor de bewuste scène, zie: Syberberg, H.J., Hitler, ein Film aus Deutschland. Hamburg, 1978. pp. 162-164. [Hierna geannoteerd als: Hitler.]

${ }^{2}$ Zoals hij in Filmbuch de Groene Heuvel typeert. Zie: Syberberg, H.J., Syberbergs Filmbuch. München, 1976 p. 247.
} 

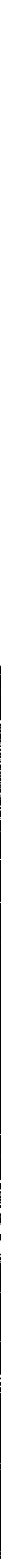
oppervlakkige beschouwing weinig meer leek te behelzen dan een knipoog naar de B-film, blijkt dan een ingenieus gecomponeerd tableau vivant te zijn, vol dubbele bodems en allegorische verwijzingen.

De wederopstanding van 'Hitler' duurt amper tien minuten. Wanneer we de scène tegen het eind van het tweede deel van de film tegenkomen, liggen reeds een kleine drie uur achter ons, waarin we van de ene verbazing in de andere zijn gevallen. De totale speelduur van Hitler, ein Film aus Deutschland bedraagt zeven uur. En toch zouden we alleen al aan dit tableau een heel hoofdstuk kunnen wijden. Zover zullen we niet gaan. Ik wil me in deze en de volgende paragraaf beperken tot enkele inleidende kanttekeningen, die de lezer wellicht een indruk kunnen geven van het werk dat we hier voor ons hebben. Deze film uitleggen aan iemand die hem niet uit eigen ervaring kent, is overigens beslist niet de eenvoudigste zaak van de wereld. Anders dan een foto of een schilderij, kan een complexe film van zeven uur niet als illustratieve reproductie aan de tekst worden toegevoegd. Er is geen duidelijke verhaallijn, geen handeling, laat staan een (dramatische) plot, waaraan ik mijn uitleg zou kunnen ophangen. Noch laten zich zo een, twee, drie voorbeelden uit de filmgeschiedenis bedenken, waarmee dit in alle opzichten uitzonderlijke werk kan worden vergeleken. Of het zouden al Syberbergs eigen multimedia-installaties uit de jaren ' 80 en '90 moeten zijn. "Een film, die kan worden betreden als een ruimte", noemt Syberberg één van deze installaties, de neoPlatoonse lieu de mémoire Cave of Memory (1997). ${ }^{3}$ En hoewel het ruimtelijk betreden van een film van celluloid vanzelfsprekend fysiek onmogelijk is, komt een dergelijke kenschets misschien nog het meest dicht in de buurt. De tijd, merkt de Franse filosoof Christian Zimmer (1978) scherp op, lijkt in deze film opgeheven. "Hij bestaat uitsluitend uit ruimte (...). Uit een afgebakende, gesloten, kunstmatige ruimte. Waarin het verleden echter in de vorm van ruïnes, van restanten, aanwezig is.",

Deze ruimte wordt gevormd door de plek, waar de film in een tijdbestek van twintig dagen, met een minimaal budget (naar verluidt een miljoen D-Mark) en een handvol acteurs is opgenomen. De gehele film speelt zich af in een donkere, hermetisch van de buitenwereld afgesloten studio-ruimte. In een van de openingsscènes heet een rondbuikige circusdirecteur (wederom vertolkt door Schubert) ons welkom in dit atelier van de kunstenaar. Zeven uur lang zijn we te gast in Syberbergs film-werkplaats en mogen we toezien hoe de regisseur zijn ambacht uitoefent. Onze rondtocht door het atelier begint in een vertrek (zie afbeelding 2), dat nog het meeste weg heeft van een opslagkamer, al denk je onwillekeurig ook aan een ruïnelandschap. Het speelvlak, een kale vloer van dorre bladeren en verbrande aarde, ligt bezaaid met attributen van velerlei herkomst. De nachtelijk-geheimzinnige belichting, de onharmonisch kaderloze compositie en de schijnbare onsamenhangendheid van de verschillende figuren en voorwerpen, lijken geïnspireerd door Dürers kopergravure Melancolia I. Sommige attributen zijn ook daadwerkelijk aan deze gravure ontleend: de ladder, de ruitvormige zwarte steen. Andere verwijzen naar het ambacht van het film-maken: elektriciteitskabels, lampen, luidsprekers, poppen in alle soorten en maten (gezien het geringe budget, dat het inhuren van figuranten onmogelijk maakt, een handig hulpmiddel voor het verbeelden van massa-scènes), een keet van asfaltpapier, waarin cinefielen ongetwijfeld een replica zullen herkennen van Edisons eerste filmstudio, de Black Mary. Maar het merendeel heeft sterk het karakter van cultuurhistorische objets trouvés, of uit hun oorspronkelijke context losgemaakte culturele tekens: rekwisieten uit (speel-)films, brokstukken van theateren operadecors, fragmenten van foto's, schilderijen en sculpturen, parafernalia uit de Hitler-

\footnotetext{
${ }^{3}$ Niet gepubliceerde voordracht van Syberberg in het kader van het lezingenprogramma 'Honderd dagen/ Honderd gasten' van Documenta X, Kassel 1997. Voor Cave of Memory, zie: hoofdstuk 8, paragraaf 3.

${ }^{4}$ Zimmer, Chr., Hitler unter uns. in: Syberbergs Hitler-Film. Texte von Susan Sontag, Jean-Pierre Faye, JeanPierre Oudart, Christian Zimmer, Michel Foucault, Bernard Sobel, Alberto Moravia, Vito Zaggario, Heiner Müller. Hrsg. K. Eder. München, Wien, 1980. pp. 51f.
} 
tijd enzovoorts. Zo ontwaren we, om maar wat te noemen, de reusachtige megafoon uit Lola Montez van Max Ophüls, de wereldbol uit Chaplins The Great Dictator, de glazen toverbol waarin sneeuw dwarrelt uit Citizen Kane, de veraste boom uit de Walküre, de baby uit de Morgen van Philipp Otto Runge, de door Franz Graf von Pocci ontworpen Kasperl uit het Münchense Marionettentheater...

Temidden van deze cultuurhistorische citaten, speelt een meisje met poppen (een rol van Syberbergs negenjarige dochtertje Amelie). Wie goed kijkt merkt, dat haar speelgoed stuk is. Het meisje houdt geen hele poppen in de hand, maar een romp, een hoofd, enkele ledematen. En gelaten probeert ze de delen weer in elkaar te passen. Het is een mooie allegorie, voor wat ons de komende uren te wachten staat. In elk geval geen historische film in de gebruikelijke zin van het woord. "We tonen niet de niet herhaalbare realiteit," laat de regisseur bij monde van de circusdirecteur weten, die bij een nadere beschouwing eveneens een beeldcitaat blijkt te zijn (uit de reeds genoemde film van Ophüls: Lola Montez). "Noch de gevoelens van de slachtoffers met hun geschiedenissen. Of de geschiedenissen van de auteurs van wetenschappelijke handboeken (...)". " Veeleer lijkt deze film te gaan over het artistieke proces van het (re-)produceren en (re-)construeren van geschiedenis. ${ }^{6}$ of beter: over het kunst-werk van het al spelende (her-)scheppen van geschiedenis uit restanten, brokstukken, dode sporen. Hiertoe behoren, naast de objets trouvés, ook geluidsdocumenten, flarden muziek en tekstfragmenten uit de meest heterogene bronnen, variërend van wetenschappelijke studies, politieke redevoeringen en kunstenaarsmanifesten tot verslagen uit roddelbladen, weerberichten en esoterische fillosofietjes. Dit alles samen vormt het materiaal, waarmee de filmmaker en zijn acteurs 'aan het werk' zullen gaan en waaruit ze, door de delen alsmaar weer te herschikken, steeds nieuwe geschiedenisbeelden zullen bouwen. De opzichtig theatrale mise-en-scène, die al deze beelden met elkaar gemeenschappelijk hebben, benadrukt het gemaakt-zijn. Alles wat cinema tot een realistisch medium maakt, is in deze film welbewust opgegeven. Voortdurend ben je je ervan bewust, dat je kijkt naar een art-work in progress, zo men wil: een kunst-werk in de steigers. En mocht je het voor een moment vergeten, dan word je er wel aan herinnerd door de acteurs, die herhaaldelijk uit hun rol stappen om tekst en uitleg te geven, of om ons deelgenoot te maken van de problemen waarmee ze worstelen. In het laatste deel gaat Syberberg zelfs zover, dat hij zijn alter ego in deze film, de Oostenrijkse multimedia-kunstenaar annex rockstar André Heller, een dikke drie kwartier laat voorlezen uit de geschreven conceptversie. "Men zou dit alles kunnen spelen in acht tot tien scènes," mijmert Heller vanachter een schrijftafel, met het script in de hand. "Men zou het misschien kunnen. Niet dan? Het is allemaal erg moeilijk."7

Kunst, die haar gemaakt-zijn laat zien, stelt Theodor Adorno in Asthetische Theorie $(1970)$, toont tevens haar geworden-zijn en heft hierdoor de schone schijn op een eigen wereld te vormen; de blik achter de schermen verstoort de illusie en maakt het publiek tot toeschouwers op distantie. ${ }^{8}$ Maar het eigenaardige is, dat dit inzicht op deze overduidelijk gefabriceerde film niet van toepassing lijkt. Integendeel: Hitler, ein Film aus Deutschland is, daarover bestaat onder voor- en tegenstanders brede consensus, een welhaast hypnotiserend werk, dat de toeschouwer juist dwingt zijn distantie op te geven en participant te worden. Vanaf het eerste moment wordt je binnengezogen in een wonderlijk kunst-universum, waaruit

\footnotetext{
${ }^{5}$ Hitler, a.w., p. 81.

${ }^{6}$ Vergl. Kaes, A., Holocaust and the End of History. Postmodern Historiography in Cinema. in: Probing the Limits of Representation. Nazism and Final Solution. ed. S. Friedländer. Cambridge, Mass., London, 1992. pp. 206-222.

${ }^{7}$ Hitler, p. 241.

Adorno, Th. W., Asthetische Theorie. Frankfurt am Main, 1970, 1972. pp. 45ff. Zie eveneens: Steunebrink, G., Ik zal niet beschaamd staan in eeuwigheid". Adorno en de betekenis van de Tweede Wereldoorlog voor de kunst. in: Een halve eeww geleden. De verwerking van de Tweede Wereldoorlog in de literatutr. red. H. Ester, W. de Moor. Kampen, 1994. pp. 68-79.
} 
je je slechts 'met veel moeite weer kunt losmaken' (Susan Sontag). Of, om Brechts kritiek op de wagneriaanse esthetica te parafraseren: alles in deze film lijkt te zijn gericht op een 'versmelting' van het publiek met het gebeuren op het witte doek. ${ }^{10}$ Want het is niet zomaar een kunstwerk, dat hier in de steigers staat. De bouwtekening wordt, naar het zich laat aanzien, verschaft door Wagners Ring des Nibelungen. De uitzonderlijk lange speelduur, de tetralogie-vorm, de symbolistische beeldtaal, het onvoorstelbare eclecticisme van stijlen en uitdrukkingsvormen - het zijn stuk voor stuk Wagner-citaten.

Zoals de naar een alomvattende synthese strevende muziekdrama's van Wagner tal van heterogene theatrale vormen - grand opéra, oratorium, opera buffa, baroktheater - in zich absorberen, zo heeft ook dit "protoplasma van een Gesamtkunstwerk" (de theatermaker Heiner Müller) ${ }^{11}$ veel weg van een greep in de grabbelton van de kunstgeschiedenis. De stijl is afwisselend die van de tragedie, de Wagner-opera, het cabaret, de dodendans, de sciencefiction-film, het brechtiaanse leertheater, de parodie, het theatrum mundi, een horrorkabinet, het circus, de filosofische dialoog... De geschiedenis wordt geënsceneerd in een revue van tableaus, sketches en ruimtelijke installaties; een grote show met schokkende cabaretteksten, wijsgerige reflecties en curieuze allegorieën. Hitler herrijst uit Wagners graf. Himmler laat zich nog eenmaal masseren. Het verkoolde stoffelijke overschot van Goebbels copuleert met een levensgrote sekspop van rubber. We zitten op de eretribune tijdens de opening van het eerste naoorlogse Adolf-Hitler-pretpark, laten ons door een blinde ziener in een rolstoel onderwijzen over de onder nazi-wetenschappers populaire Welteislehre en aanschouwen vol afgrijzen hoe een bloeddorstige SS-er, terwijl hij in razernij babypoppen verscheurt, de beroemde woorden declameert van de kindermoordenaar $M$ uit de gelijknamige film van Fritz Lang. "Aangezien we geen Hitler hebben, die we in een kooi kunnen tentoonstellen, om hem te bespuwen, te schoppen, of zijn handen te kussen (...), stel ik voor: iedereen speelt zichzelf," oppert de circusdirecteur. "Speelt hier voor alle anderen zijn Hitler. Zoals hij hem ook tegenwoordig nog graag speelt, thuis, in het stille kamertje voor de spiegel. Of op de motorfiets tijdens een tocht door de wind, met een hakenkruis of Moeder Maria als amulet onder de leren jas, op de borst, dicht bij het hart."12 En dus spelen de acteurs om beurten hun eigen voorstelling van Hitler - Hitler als huisschilder, als psychopaat, als Narcissus, als Eeuwige Jood, als Nero, als Napoleon, als Chaplin in zijn rol van Hitler, als Frankenstein, als een ontbloot achterwerk met daarbij de tekst: "De grootste scheet van de eeuw"...

Tussen al deze tafereeltjes bestaat ogenschijnlijk geen enkel narratief verband. Wat de chaos niettemin tot een hechte eenheid maakt, is de ruimte waarbinnen het geheel is gesitueerd: Syberbergs cinefiele geschiedenisfabriek. En, niet te vergeten, het materiaal: de gedeconstrueerde object-, beeld-, tekst- en geluidcitaten, die als leidmotieven door de ruimte heen zijn gemonteerd en in steeds wisselende samenstellingen telkens weer opduiken. In feite komt deze Film aus Deutschland neer op een zeven uur durende object/beeld/tekst/geluidcollage, die op haar beurt weer is samengesteld uit een reeks kleinere soortgelijke collages. Je kunt een dergelijk audiovisueel mozaiek op twee manieren beleven. Horizontaal, dat wil zeggen: als een wandeling door de ruimte, van scène tot scène, met de chronologie van de montage als een soort plattegrond. Maar ook verticaal, als een opeenstapeling van betekenislagen, die elk scène afzonderlijk tot een cluster van connotaties maken. Ik ben me ervan bewust, dat dit nogal abstract klinkt. Maar misschien kan een concreet voorbeeld een en ander verhelderen. Laten we daarom met het concrete voorbeeld van het hierboven

\footnotetext{
${ }^{9}$ Sontag, S., Syberbergs Hitler. in: In het teken van Saturnus. Essays. Vert. D. Brisk. Weesp, 1984. pp. 181-222, zie: $219 f$.

${ }^{10}$ Brecht, B., Gesammelte Werke 17. Schriften zum Theater 3. Frankfurt am Main, 1967, 1990. pp. 1010f. Zie eveneens: hoofdstuk 3, de paragrafen 1 en 3 .

${ }^{11}$ Müller, H., Die Einsamkeit des Films. in: Syberbergs Hitler-film, a.w., p. 82.

${ }^{12}$ Hitler, a.w., p. 88.
} 
beschreven tableau van 'Hitlers' wederopstanding uit het graf van Wagner onze rondtocht door het atelier beginnen. Want dat is, waartoe ik de lezer in dit hoofdstuk zou willen uitnodigen. We zullen een tocht maken door de geschiedenisfabriek; een beetje rondsnuffelen op de werkvloer, wat indrukken opdoen en het kunst-werk zelf vragen laten opwerpen.

\subsection{Voor eeuwig, onze broeder ${ }^{13}$}

De Amerikaanse literatuurwetenschapper Russell Berman (1984) heeft erop gewezen, dat elk beeld van Hitler, ein Film aus Deutschland is opgebouwd uit vijf lagen. ${ }^{14}$ Dit geldt ook voor het beeld van 'Hitlers' wederopstanding. De eerste laag wordt gevormd door een (op de studiowand geprojecteerde) achtergrond: het geschilderde decor: de villa Wahnfried bij nacht. De tweede door de voorgrond, die in dit geval diverse elementen bevat: een acteur die een zekere uiterlijke gelijkenis vertoont met de historische Hitler, de Romeinse toga, de grafsteen met de initialen RW, verdorde bladeren, de twee in het zwart gehulde figuren. De derde door de muziek: Wagners Rienzi-ouverture. De vierde door geluiden op de soundtrack: fragmenten uit enkele historische geluidsdocumenten: een radio-opname van de nationaal-socialistische dodenherdenking van 1942, de oudejaarstoespraak van Goebbels van een jaar later, een opname van het Duitsland-lied (de strofe die na " 45 werd geschrapt: "Deutschland, Deutschland, über alles"), gejuich van de massa ("Heil Hitler! Sieg Heil! Sieg Heil! Sieg Heill! Sieg Heill'). En de vijfde, tenslotte, door de gesproken tekst: 'Hitlers' monoloog.

We gaan bewust zozeer in detail, want niets in dit tableau is zonder betekenis. Neem de monoloog, die geheel en al blijkt te bestaan uit een aaneenrijging van citaten. Zo is de hierboven reeds aangehaalde openingszin, 'Hier werd het geestelijke zwaard gesmeed, waarmee we triomfeerden', een parafrasering van een historische uitspraak van Hitler in een brief aan Siegfried Wagner, waarin hij zijn schatplichtigheid betuigt aan de oud-Bayeuther ideologie: "Eerst door de Meester en dan door [Houston Stewart] Chamberlain [werd] het geestelijke zwaard gesmeed, waarmee we tegenwoordig vechten". ${ }^{15}$ En verwijzen de slotwoorden, 'Voor eeuwig, jullie broeder Hitler', naar Bruder Hitler - een opstel uit 1938 van Thomas Mann, waarin Hitler wordt geparodieerd als een "ietwat onaangename en beschamende" kunstbroeder. ${ }^{16}$ Ook de regel waarmee deze spook-Hitler het publiek uit de tent probeert te lokken, 'Wanneer jullie mij steken, bloed ik dan niet?', is een citaat. Een dubbel citaat nog wel. De opmerking zou zowel ontleend kunnen zijn aan The Merchant of Venice, alsook aan To Be or not to Be van Ernst Lubitsch, waarin een als Hitler vermomde acteur ten overstaan van de 'echte' Hitler deze woorden van Shylock aanhaalt.

De ironie moge duidelijk zijn. Wie oh wie is dit mannetje, dat hier vanuit Wagners graf tot ons spreekt? Een duivels gebroed van het wagnerianisme? De geestverschijning van een overleden collega-kunstenaar? De Duitse reïncarnatie van Shylock, Mefistofeles, die ons vanuit de hel maant het contract dat we met hem hebben afgesloten alsnog na te komen? (Het Faust-motief loopt als een rode draad door de film. ${ }^{17}$ ) Of toch veeleer, hetgeen de vorige opties niet hoeft uit te sluiten, een acteur in de rol van een acteur, die op zijn beurt weer de rol vertolkt van een bekende historische figuur die, aldus Brecht in de Messingkauf, ook zelf

\footnotetext{
${ }_{14}^{13}$ Alle citaten in deze paragraaf zijn, tenzij anders aangegeven, ontleend aan: idem, pp. 162-164.

${ }^{14}$ Berman, R., Hans Jürgen Syberberg. Of Fantastic and Magical Worlds. in: New German Filmmakers. From Oberhausen throught the 1970s. ed. K. Phillips. New York, 1984. pp. 359-378, zie: 372ff,

${ }_{16}^{15}$ Citaat ontleend aan: Köhler, J., Wagners Hitler. Der Prophet und sein Vollstrecker. München, 1997. p. 177.

${ }^{16}$ Mann, Th., Bruder Hitler. in: An die gesittete Welt. Politische Schriften und Reden im Exil. Frankfurt am Main, 1986. pp. 253-259.

${ }^{17}$ Volgen we de Franse filosoof Jean-Pierre Faye, dan heeft Syberberg met deze film zelfs het 'derde deel' van de Faust geschreven. Faye, J-P., Faust, Teil III. in: Syberbergs Hitler-film. a.w., pp. 33-35.
} 
graag de bühne mocht beklimmen "om een acteur na te doen". ${ }^{18}$ De opzichtig theatrale miseen-scène doet het laatste vermoeden. Voor de theatermaker Brecht was Hitler bovenal de grote showman: een derderangs entertainer, onder wiens regie Duitsland veranderde in een reusachtige Wagner-opera ("de Bayreuther Republiek"19) met de massa in een figurantenrol. En een grote showman is ook deze zwaar geschminkte Hitler-figuur, met zijn ronduit belachelijke Romeinse pakje dat verdacht veel weg heeft van een theaterkostuum. Zelfgenoegzaam neemt de kunstbroeder aan het slot van zijn optreden het gejuich van de massa in ontvangst. "Heil Hitler! Sieg Heill Sieg Heill Sieg Heill".

Onwillekeurig dringt de associatie zich op met Brechts Hitler-parodie Der unaufhaltsame Aufstieg des Arturo Ui, waarin de titelheld acteerlessen neemt. $\mathrm{Na}$ de spoedcursus met succes te hebben doorlopen, declameert Arturo Ui/Richard III/Hitler als een volleerd acteur enkele strofes uit The Life and Death of Julius Caesar - de lijkrede van Antonius. ${ }^{20}$ Heeft de 'gangsterkoning' hier de toga maar weer eens aangetrokken om nog één keer als Antonius te kunnen schitteren - dit maal met een lijkrede op zichzelf, de Julius Caesar van de twintigste eeuw? "Ik weet, ik zal tot grootste mens aller tijden worden uitverkoren of ondergaan, door allen vervloekt en verdoemd tot in alle eeuwigheid," schmiert het kereltje in Wagners graf. Hoe het ook zij; het Verzamelde Werk van Brecht moet voor deze 'Hitler' in de uitbeelding van zijn rol sowieso een dankbare bron van inspiratie zijn geweest. "(...) Hij is zelf kunstenaar, zijn propagandaminister zegt tegen hem: de grootste," maakt Brecht zich vrolijk in een vermakelijk opstel uit 1939. "Zonder (...) muziek (...) kan hij niet leven. (...) De architectuur is hem van alle kunsten het meest dierbaar."21 En inderdaad: "(...) Ben ik niet de laatste van het ras van de grote scheppers, die in een monumentale verdringing van het seksuele en het privé-leven hun werken genadeloos tegen zichzelf tot stand brengen, zoals Leonardo en Michelangelo?," vraagt ook onze kunstbroeder zich af. "En wat zou ik, (...) de kunstenaar (...), zijn geweest zonder mijn muziek en de architectuur, zonder mijn Rienzi, waarmee het allemaal begon (...)?"

Een kleine hint aan de toeschouwer om de muziek in de duiding van dit tableau vooral niet over het hoofd te zien? Het inzicht, dat 'het met zijn Rienzi allemaal zou zijn begonnen', dankt 'Hitler' niet aan Brecht. Het gaat wederom om een parafrasering van een historisch Hitler-citaat. In 1939, tijdens één van zijn talrijke pelgrimages naar de Groene Heuvel, zou de kunstbroeder, in gedachten verzonken naast het graf van de Meester, ten overstaan van festivalleidster Winifred Wagner-Williams de legendarische woorden hebben gesproken: "In jener Stunde begann es". De ontboezeming verwijst naar een ingrijpende gebeurtenis uit Hitlers jeugd, waarover zijn oude schoolkameraad August Kubizek uitvoerig bericht in Adolf Hitler, mein Jugendfreund (1953). Het verhaal gaat als volgt. Als zeventienjarige scholier zou Hitler, na in het operahuis van Linz samen met zijn kameraad een uitvoering van de Rienzi te hebben bijgewoond, door het dolle heen zijn geraakt. Het leek alsof een vreemde macht van hem bezit had genomen. Tot diep in de nacht oreerde hij "in grandioze, meeslepende beelden" over "een opdracht", die hij "ooit van het volk ontvangen zou, om het uit de slavernij te bevrijden en tot vrijheid te verheffen". Gelijk de titelheld van Wagners grand opéra, Cola di Rienzi - de 'volkstribuun' van proletarische afkomst, die in het Rome van de $14^{\mathrm{e}}$ eeuw op min of meer democratische wijze aan de macht kwam met een tweeledig programma: de

\footnotetext{
${ }^{18}$ Brecht, B., Gesammelte Werke 16. Schriften zum Theater 2. Frankfurt am Main, 1967, 1990. p. 561.

${ }^{19}$ Brecht, B., Gesammelte Werke 18. Schriften zum Literatur und Kunst 1. Frankfurt am Main, 1967, 1990. pp. $254 \mathrm{ff}$.

${ }^{20}$ Brecht, B., Gesammelte Werke 4. Stücke 4. Frankfurt am Main, 1967, 1990. pp. 1768ff.

${ }^{21}$ Brecht, Gesammelte Werke 18, a.w., p. 254.
} 
vergane glorie van het oude Rome in ere herstellen én het volk bevrijden van het juk van een in verval geraakte aristocratie. "Rienzi Heil"?", juicht de massa in Wagners opera. ${ }^{22}$

De gebeurtenis, warvan de historische juistheid overigens wordt betwist, speelt een belangrijke rol in de Führer-cultus. Tijdens deze Rienzi-uitvoering in het operahuis van Linz, zou bij Hitler voor het eerst de gedachte zijn opgekomen "ook zo'n volkstribuun of politicus te worden" (citaat van de historische Hitler). En zo werd hij op het officiële Führer-portret van het Derde Rijk dan ook afgebeeld: in het historische kostuum van Wagners "laatste tribuun" - de Duitse Cola di Rienzi uit Wagners muziek herboren. Niet zonder reden begonnen de Rijkspartijdagen te Neurenberg, tijdens welke de massa deze gereïncarneerde volkstribuun mocht bejubelen, steevast met het spelen van de Rienzi-ouverture. ${ }^{23}$ Maar er is meer. Volgen we Kubizek, dan vereenzelvigde de jonge Hitler zich niet enkel met de held van Wagners opera. Ook de totaalkunstenaar zelf zou voor de zeventienjarige scholier hebben gefungeerd als een soort Über-Vater of Ik-Ideaal in psychoanalytische zin. "Vanaf het eerste moment, waarop Richard Wagner in zijn leven kwam, liet diens genie hem niet meer los," aldus Kubizek. "Met ongelooflijke taaiheid en wilskracht verdiepte hij zich in diens leven en werk. Ik had nog nooit zoiets meegemaakt. Hij identificeerde zich geheel en al met Richard Wagners persoonlijkheid [eignete sich die Persönlichkeits Richard Wagners an, ja erwarb ihn so vollkommen für sich, als könnte dieser Teil seines eigenen Wesens werden]. Met bevend hart las hij alles, wat hij over de Meester te pakken kon krijgen, goed en slecht, lovend en afwijzend. Met name had hij belangstelling voor biografische literatuur, aantekeningen, brieven, dagboeken, zijn autobiografische schets. Steeds dieper drong hij in diens leven. Adolf Hitler kende geen groter verlangen dan eenmaal naar Bayreuth te gaan, het nationale bedevaartsoord van de Duitsers, de villa Wahnfried te zien, een wijle aan het graf van de meester te staan en... de uitvoering van diens werken mee te beleven." 24

Hier, in dit tableau, laat Syberberg deze "hartstochtelijke jeugddroom" (Kubizek) in vervulling gaan en stelt hij 'Hitler' niet slechts in staat de uitvoering van een Wagner-opera mee te beleven, maar ook nog eens zelf de hoofdrol te vertolken. Op "de plek, die voor ons altijd het meest heilig was" (wederom Kubizek) ${ }^{25}$ herrijst de kunstenaar-politicus uit het graf van zijn alter ego en speelt hij wild gesticulerend, terwijl de ouverture van Wagners grand opéra door de bioscoopzaal schalt, nog eenmal zijn lievelingsrol van de wedergeboren Romeinse volkstribuun. Dat deze spookachtige Rienzi-uitvoering in het holst van de nacht plaats vindt, zal geen toeval zijn. Middernacht is het uur van de demonen, de wilde zone van het etmaal. Ook het menselijke bestaan kent zijn nachtzijde: het duistere, ontoegankelijke oerlandschap van de driften en de begeerten. "Wij allen dromen van reizen door het heelal in ons innerlijk," luidt de openingstekst van deze film. "Nach innen geht der geheimnisvolle Weg. Ins Innere der Nacht." 26 (Een parafrasering van een deel van een beroemde regel van Novalis: ${ }^{27}$ ) Nosferatu, de prins van de nacht, wist als geen ander hoe hij onze verboden hunkeringen kon bespelen. "Ik was en ben het eindpunt van jullie meest geheime wensen, legenden en werkelijkheid van jullie dromen, daar moeten we nu doorheen," sneert de

\footnotetext{
${ }^{22}$ Kubizek, A, Über Hitler und Wagner. in: Richard Wagner. Ein deutsches Thema. Eine Dokumentation zur Wirkungsgeschichte Richard Wagmers. 1876-1976. Hrsg. H. Zelinsky. Berlin, Wien, 1983. p. 231. Köhler, a.w., pp. 31-49. Zie eveneens de aan het script toegevoegde 'Namen- und Begriffserläuterungen' in: Hitler, a.w., pp. 308-309, onder het trefwoord 'Rienzi'. Alsmede: Vaget, H.R., Syberbergs Our Hitler. Wagnerianism and Alienation. in: The Massachusetts Review. (23) 1982. pp. 593-612, waarin de Rienzi-allegorie in dit tablean verder wordt uitgediept.

${ }^{23}$ Zie: Köhler, a.w., pp. $31 \mathrm{ff}$, waaraan ook dit Hitler-citaat is ontleend.

${ }^{24}$ Kubizek, a.w.

25 Beide citaten ontleend aan ibidem.

${ }^{26}$ Hitler, a.w., p. 64.

27 "Nach innen geht der geheimnisvolle weg. In uns oder nirgends ist die Ewigheit mit ihren Welten." Citaat ontleend aan: Kluckhohn, $\mathrm{P}$, Das Ideengut der deutschen Romantik. Tübingen, 1966. p. 43.
} 
charismatische demon in het graf. En laten we in dit verband ook niet vergeten, dat Nacht über Bayreuth de titel is van een boek uit de jaren ' 40 , waarin Winifred Wagners dochter Friedelind stelling neemt tegen de politieke Umnachtung van haar familie... ${ }^{28}$

De connotaties zijn dermate talrijk, dat je er een beetje moedeloos van wordt. Zo is het 'nacht'-motief vanzelfsprekend eveneens een allegorie voor de vergankelijkheid. En hetzelfde geldt voor de verdorde bladeren, die de filmer rond het graf heeft uitgestrooid (sinds Hitler een steeds terugkerend rekwisiet in Syberbergs werk). Evengoed zou je dit tableau dan ook kunnen duiden als een memento mori. Niet alleen wordt de setting gevormd door een dodenakker. Alle elementen, waaruit het beeld is opgebouwd, zijn bovendien doods, zonder leven. Er heerst in deze film, merkt Susan Sontag (1980) op "een doodsheid als op de maan". We bevinden ons "in het land der doden, een filmwalhalla". ${ }^{29}$ Terwijl de Hitler-schim spreekt, klinkt op de achtergrond voortdurend een monotone stem, die tergend langzaam een voor een de namen oproept van de overledenen (het geluidsdocument van de nationaal-socialistische dodenherdenking). En, of het inmiddels allemaal al niet genoeg is: ook de compositie van dit memento mori is weer een citaat. Want wie mocht denken, dat het beeld van de wederopstanding uif het graf is gebaseerd op een eigen ontwerp van de regisseur, komt bedrogen uit. We hebben hier van doen met redelijk getrouwe driedimensionale kopie van een houtgravure van Gustave Doré (zie afbeelding 3), een illustratie bij de Goddelijke Komedie. Dante is met zijn gids Vergillius afgedaald in dat gedeelde van de hel, waar de heidenen verblijven - de ketters, de eeuwig verdoemden. Het graf van een van hen, Farinata, is geopend. Honend richt hij het woord tot de voorbijgangers: "Zodra ik bij deze tombe stond kkeek hij me wat laatdunkend aan en vroeg: 'Wie waren uw vaderen?"' (Hel 10: 40-42).

Het zal nauwelijks nog als een verrassing komen, dat dit beeld-citaat dubbelzinnig is. Binnen de betekenende context van de film, kan de retorische vraag van Farinata op tenminste drie manieren worden uitgelegd. Als: "Wie waren uw voorvaderen?" (de nationaalsocialistische ouders en grootouders als de voorzaten van de postnazistische Duitsers). Als: "Wie waren uw geestelijke vaderen?" (vrijwel alles wat Syberberg aan het naoorlogse Duitsland tegenstaat, van de pornografie tot de massademocratie, wordt in de film toegeschreven aan de verderfelijke invloed van 'Hitler" ${ }^{30}$ - "het slechte geweten van onze democratische systemen", zoals de schim in het graf zichzelf typeert). Maar ook als: "Wie was én is uw Über-Vater?" Want wanneer de tekenen niet bedriegen, moet deze 'Hitler' eveneens een gretig lezer zijn van de geschriften van Alexander en Margarete Mitscherlich. ${ }^{31}$ Meer nog: naar het zich laat aanzien is het belangrijkste argument waarmee de demon zijn 'historische rol' probeert te rechtvaardigen, door de psychoanalyse van het Duitse 'onvermogen om te rouwen' gesouffleerd. "Onder 'Hitler'," schrijft Susan Sontag, "verstaat Syberberg niet alleen het historische monster zelf, dat voor de dood van tientallen miljoenen mensen verantwoordelijk is. Hij roept een soort Hitler-substantie op, die Hitler zelf heeft overleefd - een spookverschijning in de hedendaagse cultuur, een oerbegrip van het kwaad dat het heden doordrenkt en het verleden herschept." ${ }^{, 32}$ Maar is deze spookverschijning, "door allen vervloekt en verdoemd tot in alle eeuwigheid', niet 'ook een mens, met twee oren en ogen net als wij', waarop we de eigen angsten, schuldgevoelens en frustraties projecteren?

Binnen de psychoanalyse van het Duitse 'onvermogen om te rouwen' is de naoorlogse Hitler-demonisering een omkering van de oude projectie- derealisatie- en identificatiestrategieën. De positieve idealisering van de totem 'Hitler' is omgeslagen in haar

\footnotetext{
${ }^{28}$ Wagner, F, Cooper, P., Eeuwig laaiend vuur. De geschiedenis van Richard Wagners kleindochter. Vert. A.M. Bottenham. Amsterdam, 1947.

29 Sontag, a.w., p. 187 .

30 Vergl idem, pp. $201 \mathrm{f}$.

${ }^{31}$ Voor de rouw-theorie van Alexander en Margarete Mitscherlich, zie: hoofdstuk 4, paragraaf 5.

${ }^{32}$ Sontag, a.w., pp. $201 \mathrm{f}$.
} 

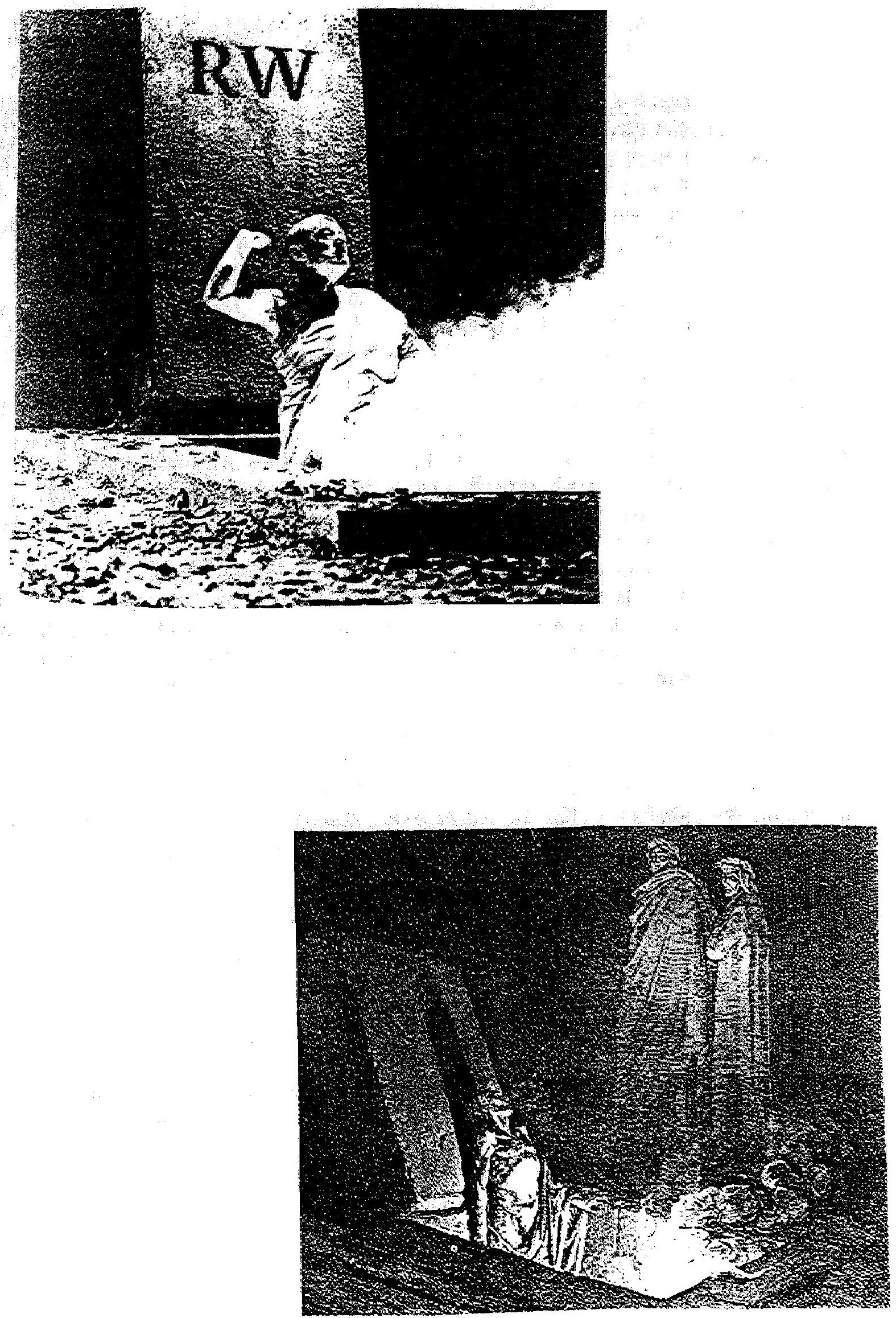
tegendeel. De Fïhrer van weleer is een negatief ik-Ideaal geworden - een collectieve ÜberVater of, zoals hij door de Mitscherlichs ook wel wordt genoemd, Big Brother, ${ }^{33}$ waartegen men zich en masse afzet. Van deze Grote Spook-Broer kunnen de Duitsers zich slechts bevrijden, middels een moeizaam en pijnvol proces van erimnern, wiederholen, durcharbeiten. Of ze hierin echter ooit zullen slagen, is nog maar de vraag. De Grote SpookBroer in dit tableau, heeft zo zijn bedenkingen: "Ik was en ben het einde van jullie meest geheime wensen, legenden en werkelijkheid van jullie dromen. Daar moeten we nu doorheen. Uiteindelijk. Eindtijd? Nachtmerries? Nog lang niet, wanneer ik de Godin van de geschiedenis om mijn voorzienigheid vraag, die ik ken als geen van jullie. (...) Voor eeuwig, jullie broeder Hitler."

Maar Onze Broer is de kwaadste niet. Als het moet is hij gaarne bereid het publiek een handje te helpen bij het op gang brengen van de traumatische herinnering. En geheel in overeenstemming met de rouw-theorie van de Mitscherlichs onthult Hitler/Farinata/Shylock, dat hij in een inmiddels verdrongen verleden heeft gefungeerd als het object van een narcistische identificatie door het Duitse collectief:

"Er was toch niemand anders, die de door mij gewenste rol wilde en kon overnemen. Dus hebben ze mij geroepen. Eerst de bourgeoisie. Dan de militairen, die zich in hun vuile handen wreven van plezier. En ook ter verdediging van hun eer. Dacht $u$, dat ik het niet door had? Vervolgens de industriëlen. Om het bolsjewisme te verdrijven, van wiens Lenin ik veel leerde en wiens Stalin in het geniep mag worden vereerd. Dan de kleinburgers. En de arbeiders, van wie ik veel wensen kon vervullen. En de jeugd, die ik weer een doel gaf in het leven. En de studenten, die me nodig hadden. En de intellectuelen, die zich dankzij mij bevrijd voelden van de joodse maffia van hun vrienden en vijanden. Inderdaad. En het buitenland, dat blij was eindelijk weer rust te kennen in Europa, kracht en waardigheid. En men zou er ook eens bij moeten stil staan, hoeveel mensen ik iets gaf, dat de moeite waard is om ertegen te zijn. Vergelijk daarmee eens het leven van zovelen, lusteloos en leeg. Ik gaf hen; wat ze in me wilden zien. Wilden horen, wilden doen. Waarvoor ze zelf niet de moed hadden. Ik deed en beval het voor hen. Want het gaat toch om hen allen, niet om mij. Duitsland, jazeker, ik heb het werkelijk lief, uiteraard op mijn manier. Zoals ik altijd zei. Of niet soms? $\mathrm{Zij}$ haten mij uit verwantschap."

Zoals de mens, de politicus, de kunstenaar, de showman zich narcistisch vereenzelvigde met 'zijn' Wagner en de titelheld uit diens grand opéra, zo ontleenden én ontlenen de Duitsers hun collectieve identiteit aan een narcistische identificatie in positieve of negatieve zin met "hun' volkstribuun, kunstbroeder, Grote Broer, Über-Vater, wensdroom, Farinata, Shylock, nachtmerrie. (Our Hitler luidt de Amerikaanse titel van deze film.) Citaten uit de meest heterogene bronnen worden opnieuw samengevoegd tot één opmerkelijk coherent geheel, dat niettemin volstrekt meerduidig is. Zou het inderdaad de these van de Mitscherlichs zj.jn, dat Hitler heeft gefungeerd als het libidineuze object van een collectieve verliefdheid, waardoor deze 'Hitler' zich laat souffleren? Of moeten we het toch veeleer zoeken in een volstrekt andere hoek? Bijvoorbeeld in de hoek van een Conservatieve Revolutionair als Ernst Jünger, die in het oorlogsdagboek Strahlungen filosofeert over de "erotische rangorde van de wereld", waarbinnen "droomvangers" zouden opereren. Daaronder verstaan we, verduidelijkt Jünger, "een soort mensen, die de dromen van anderen opvangen en in hun leven verwerkelijken". ${ }^{4}$

\footnotetext{
${ }^{33}$ Mitscherlich, A., Mitscherlich; M., Die Unfähigkeit zu trauern. Grundlagen kollektiven Verhaltens. München, 1967,1990 . p. 62 .

${ }^{34}$ Jünger, E., Strahlungen I. Gärten und Straßen, Das erste Pariser Tagebuch, Kaukasisische Aufzeichnungen. Frankfurt am Main, 1979, 1988. pp. 334. Zie eveneens: Jünger, E., Strahlungen II. Das zweite Pariser Tagebuch,
} 
Of in de hoek van Jüngers geestverwant Hermann Rauschning, die reeds in zijn in 1940 verschenen Gespräche mit Hitler waarschuwt voor een mogelijke wederopstanding van het Kwaad na de nederlaag: "Zijn [Hitlers, G.G.] overweldigende, legendevormende kracht, zal des te sterker zijn, naarmate de nederlaag groter wordt, die anderen te verantwoorden zullen hebben. De mythe Hitler zal door de jaren heen voortduren en krachten wekken, die ooit de nederlaag in de grootste triomf zullen veranderen". "Hitler' als een weerspiegeling van 'onze meest geheime wensen, legenden en werkelijkheid van onze dromen' - 'voor eeuwig onze Grote Broer'. En Bayreuth als de plek, 'waar het geestelijke zwaard werd gesmeed', waarmee deze Droomvanger 'triomfeerde', Of hij wel eens in Bayreuth was geweest, wilde Hitler graag van Rauschning weten. "Hij, Hitler, was door het toeval of het lot al vroeg met Wagner in aanraking gekomen. In een welhaast hysterische opwinding had hij ondervonden, dat alles, wat hij over deze grote geest las, met zijn diepste, onbewuste, sluimerende opvattingen overeenstemde". 36

Vergezocht? Geenszins. Als we Syberberg zelf mogen geloven, zijn Rauschnings Hitler-gesprekken een bron waaraan hij menig citaat in deze film heeft ontleend. ${ }^{37}$ Maar eigenlijk doet het er ook niet toe, of de regisseur het er allemaal wel zo bewust heeft ingelegd. Het tableau vraagt welhaast om een over-interpretatie - zo men wil: een projectie van onze fantasie. Of in elk geval doet het een sterk beroep op ons associatievermogen. De toeschouwer wordt uitgedaagd zelf betekenissen toe te kennen aan een beeld, waarvan de interpretatiemogelijkheden door de zwaarte van de culturele ballast schier oneindig lijken. Het is aan ons, de herkomst van de overvloed aan citaten te traceren en verbanden te leggen tussen de diverse componenten. Zo mogen we zelf uitmaken wat de eventuele link is tussen de opzichtig theatrale mise-en-scène en 'Hitlers' suggestie, dat hij weinig meer zou zijn dan een projectie van onze eigen angsten en begeerten. Projectie, derealisatie en identificatie, in de zin van de Mitscherlichs, zijn mechanismen in de (collectieve) psyche. Maar, zo nodigt dit tableau ons uit te denken: is theater, in zijn aristotelische, wagneriaanse variant (het theater van de 'versmelting") niet evenzeer een kwestie van projectie, derealisatie en identificatie? En wat te denken van de kunstvorm, die in deze Film aus Deutschland wordt beoefend: de droomfabriek cinema? Gesteld dat 'Hitler' inderdaad, zoals Brecht de historische Hitler gekscherend heeft geportretteerd, een derderangs acteur was in een Wagner-opera van nationale proporties. Of, zoals de Duitse publicist Gert Kalow betoogt in een studie uit 1967, waaruit Syberberg ongetwijfeld eveneens het nodige heeft geput: "(...) een regisseur, die de massa dirigeerde als een koor" - "Wij waren de acteurs en figuranten in dit Gesamtkunstwerk, deze grootste Wagner-opera aller tijden". ${ }^{38}$ Waarom dan geen megalomane cineast, onder wiens regie Duitsland werd omgetoverd tot "een filmisch Gesamtkunstwerk van staat en

\footnotetext{
Kirchhorster Blätter, Die Hïtte im Weinberg. Frankfurt am Main, 1979, 1988. p. 611, waarin Jünger het concept op Hitler toepast: "Als ich ihn hörte, hatte ich den Eindruck eines blassen, begeisterten Menschen, der nicht so sehr neue Gedanken brachte als neue Kräfte entfesselte. Es schien weniger, daß er des Wortes mächtig, als daß das Wort seiner mächtig war. So stellt man sich ein Medium vor, das fast verzehrt wird von den Kräften, die ihm zuströmen. Der Mond mußte in seinem Horoskop eine Rolle spielen; Mussolini war demgegenüber ein solarischer Typ, viel klarer und durchsichtiger, berechenbarer auch. In Hitler haben sich gerade die Klugen getäuscht. Er hatte das bleiche, unausgesprochene Gesicht des Lunarischen. Er zog Kräfte aus dem Unbestimmten, sammelte und reflektierte sie wie ein Hohlspiegel; er war ein Traumfänger."

${ }^{35}$ Rauschning, H., Gespräche mit Hitler. New York, 1940. pp. 264f. Overigens wordt de authenticiteit van deze Hitler-gesprekken betwist. Zie bijvoorbeeld: Schreiber, G., Hitler Interpretationen 1923-1983. Ergebnisse, Methoden und Probleme der Forschung. Darmstadt, 1984. pp. 144ff. Lorenz, Ch., De constructie van het verleden. Een inleiding in de theorie van de geschiedenis. Amsterdam, Meppel, 1987, 1994. pp. 65f.

${ }^{36}$ Rauschning, a.w., p. $215 \mathrm{f}$.

${ }^{37}$ Zie bijvoorbeeld: Syberberg, H.J., Der Walt steht schwarz und schweiget. Neue Notizen aus Deutschland. Zürich, 1984. p. 90.

${ }^{38}$ Kalow, G., Hitler - das Gesamtdeutsche Trauma. Zur Kritik des politischen Bewustseins. München, 1967. p. 36.
} 
politiek en volk', ${ }^{39}$ met de volkstribuun/kunstbroeder/grote showman/ÜberVater/droomvanger als het stralende middelpunt? "Wie de film heeft, heeft de toekomst, heeft de wereld," laat Syberberg eén van zijn acteurs elders in de film opmerken. "En er is slechts één toekomst: de toekomst van de film. Daarvan was hij zich bewust, die ze (...) de grootste veldheer aller tijden (...) noemden. Maar van wie ik weet, dat hij werkelijk de grootste was: de grootste filmmaker aller tijden"

Je zou in dit tableau inderdaad een memento mori kunnen zien, maar ook een visualisatie van de rouw-theorie van de Mitscherlichs, of van Walter Benjamins "leerzame positieve kijk op melancholie" (zoals Susan Sontag vermoedt, die de allegorische betekenis van de verdorde bladeren op de vloer in deze zin interpreteert ${ }^{41}$ ). Het is zowel een grandguignol, alsook een brechtiaans leerstuk, een sociaal-psychologisch Hitler- en Duitslandportret, een cynische kanttekening bij de wederopbouw in Bayreuth, een pastiche op de Führer-cultus en Hitler-demonisering, of een Mahnmal dat de herinnering aan het duistere verleden levend houdt. Maar het is ook, en misschien zelfs bovenal, een complexe allegorie voor de historische schuld én louterende potenties van de kunsten in het algemeen en de totaalkunst cinema in het bijzonder. Zoals blijkt uit de twee in het zwart gehulde figuren naast het graf. Wie zijn deze geheimzinnige gestalten, die hier de rollen van Dante en zijn gids mogen vertolken?

Welnu, aan wie Syberberg de rol heeft toebedacht van Vergillius, of (zoals hij in mijn Duitse vertaling van de Goddelijke Komedie wordt genoemd) de Meister, valt niet moeilijk te raden. Het is de Meister hoogstpersoonlijk, meer specifiek: een levensgrote pop gekleed in de mantel van Richard Wagner, die ons in dit tableau door de onderwereld gidst en zwijgend toeziet hoe een monstrueuze verschijning herrijst uit zijn eigen graf. De allegorische identiteit van de gestalte aan zijn zijde, laat zich minder eenvoudig vaststellen. Al zijn we dit personage in de film wel al vaker tegengekomen. Als "de zwijgende somnambule", observeert Susan Sontag, waart het negenjarige dochtertje van de regisseur, Amelie Syberberg (zie afbeelding 4), "door het dampende landschap van de hel". 42 Afgezien van het gezicht, is haar lijfje geheel bedekt door een zwarte cape - "de zwarte schoudermantel van oude vrouwen", aldus het script. ${ }^{43}$ En op haar hoofd draagt ze, als een soort rouwsluier, slingers celluloid. "Alice in Wonderland, de geest van de film" (Sontag)? ${ }^{44}$ "De Engel van de geschiedenis, vluchtend voor een verleden, dat zich lijkt op te hopen als een reusachtige berg van puin" (de Duits/Amerikaanse literatuurwetenschapper Anton Kaes)? Zoals Walter Benjamin opmerkt over de Angelus Novus van Paul Klee: "Zijn gezicht is naar het verleden gekeerd. Waar wij een opeenvolging van gebeurtenissen zien, ziet hij een enkele catastrofe die steeds ruines op elkaar stapelt en hem voor de voeten smijt"? ${ }^{45}$

Misschien helpt het te weten, dat het hier weer eens een citaat betreft - een beeldcitaat binnen het grotere beeldcitaat uit de Goddelijke Komedie. De 'zwijgende somnambule' is gebaseerd op een Franse propagandaprent uit de Eerste Wereldoorlog (zie de afbeeldingen 5 en 6), die op haar beurt weer een imitatie moet zijn van een bid- of heiligenprentje: een meisje, de onschuld zelve nog, bidt op haar knieën voor een 'zegevierende vrede' - de kleine madonna van het Franse patriottisme. Een dergelijk citaat uit de profane devotie, staat in de films van De Graal (de grote cyclus waarvan Hitler deel uitmaakt) niet op zichzelf. Het centrale beeld van Ludwig-Requiem für einen jungfräulichen König (1972), dat ook in deze

\footnotetext{
${ }^{39}$ Hitler, a.w., pp. $261 f$.

40 idem, pp. $145 \mathrm{f}$.

${ }^{41}$ Sontag, a.w., pp. 187, $220 f$.

42 idem, p. $193 \mathrm{f}$.

${ }^{43}$ Hitler, a.w., p. 71 .

${ }^{44}$ Sontag, a.w. p. 193.

${ }^{45}$ Kaes, A., From Hitler to Heimat. The Return of History as Film. Cambridge, Mass., London, 1989. p. 47.
} 


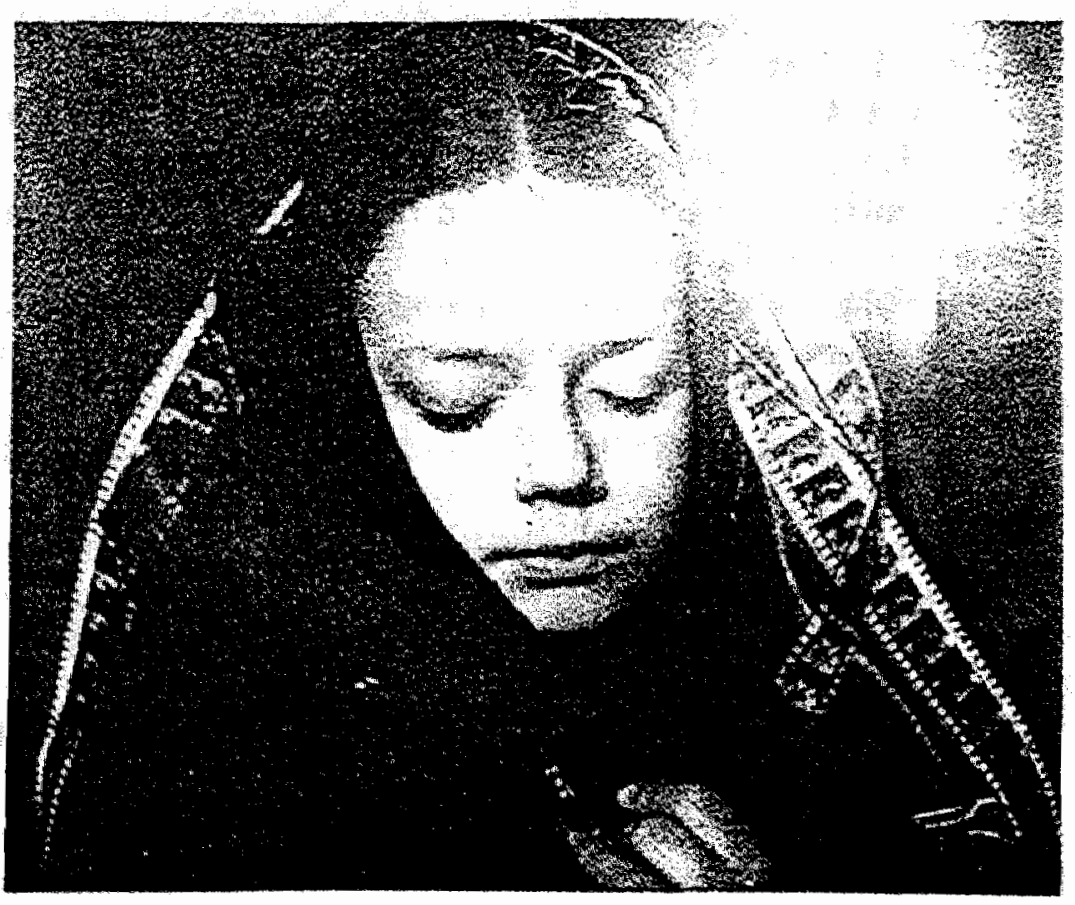




\section{6}
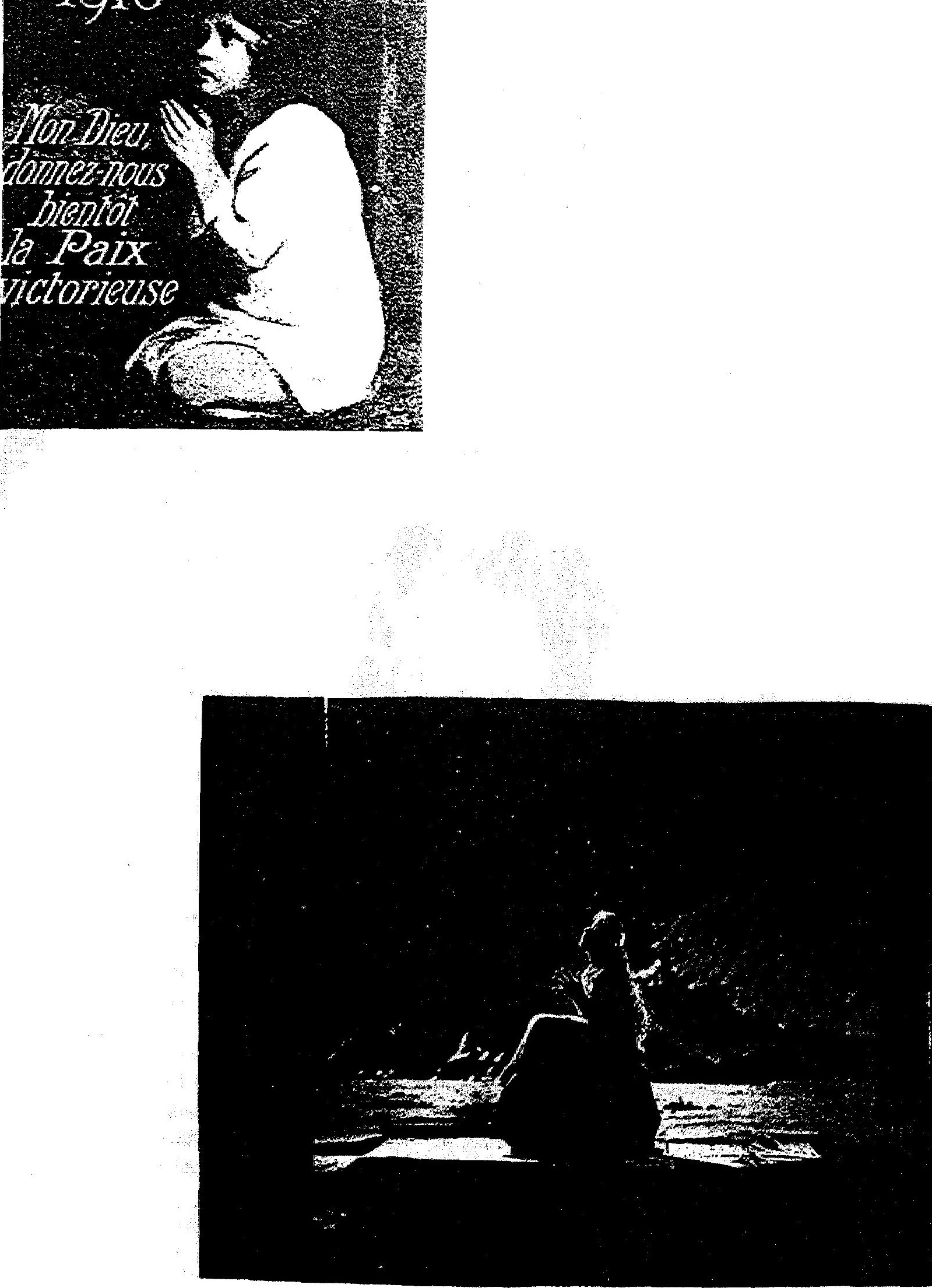

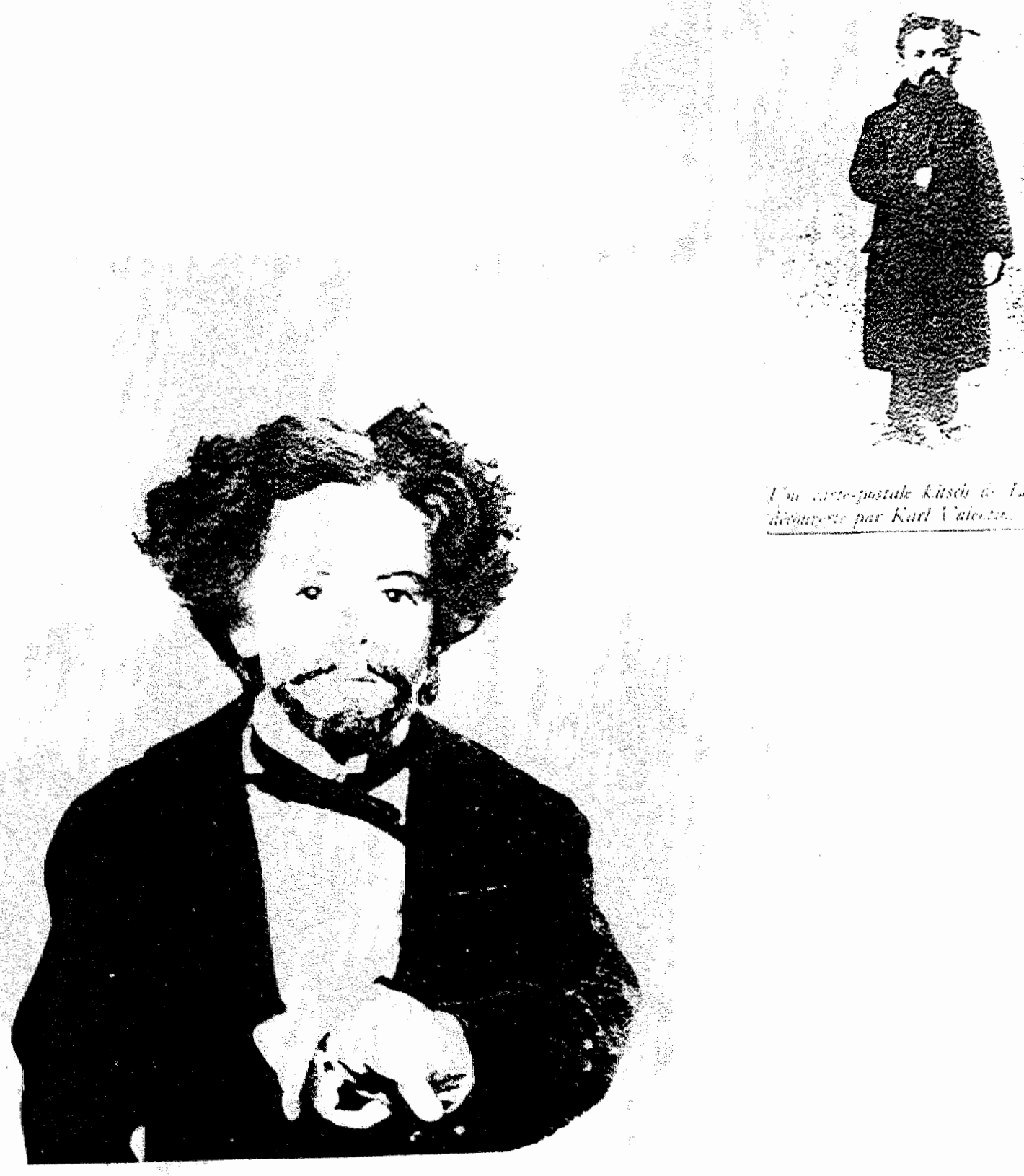

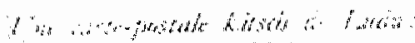

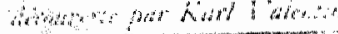


film enkele malen opduikt, was geënt op een kitscherige ansichtkaart (zie de afbeeldingen 7 en 8), zoals die bij duizenden worden verkocht in de bedevaartsoorden van de in Zuid-Beieren als een ware heilige vereerde zwanenkoning Ludwig II. We zien de 'maagdelijke koning' als kind, maar mèt baard. Uit een van zijn ooghoeken biggelt een traan.

Een verdrietig jongetje, met de baard van een volwassen man. Een met stomheid geslagen meisje, in de kledij van een oude vrouw in rouw. Tegelijk kind èn volwassene, maagdelijk èn bedorven, onschuldig èn schuldig... Een allegorie voor de verloren onschuld? Of wellicht voor het tragische van de Duitse cultuurtradities, die sinds de verkrachting door de nazi's hun onschuld hebben verloren en tegelijk nooit zonder schuld waren? Zoals het ooit zo 'trotse geestelijke centrum' in Bayreuth, dat door een zelfgeschapen monster werd geruïneerd? Of de Duitse cinema? In een van de beginscènes van de film legt de 'schuldige maagd' een knuffelbeest met Hitler-snorretje in een reusachtige wieg. Rondom de wieg staan figuren opgesteld uit de expressionistische Weimar-cinema, waaronder ook de fameuze Dr. Caligari - de diabolische hypnotiseur, die dankzij de klassieke studie van Siegfried Kracauer is uitgegroeid tot het symbool bij uitstek van prefascistische tendensen in de Duitse cultuuren mentaliteitsgeschiedenis From Caligari to Hitler (1947), zoals de titel van Kracauers studie luidt, is zowel een dieptepsychologie, alsook een aanklacht tegen een cinema, die de tijd voor de nazi's rijp zou hebben gemaakt, door met figuren als deze Caligari, Nosferatu of de kindermoordenaar $\mathrm{M}$ in te spelen op sluimerende angsten onder de Duitse bevolking. Volgen we Kracauer, dan was het Derde Rijk niets anders dan 'de verwerkelijking van wat in de Duitse cinema van meet af aan in potentie aanwezig was' - 'Zelfbenoemde Caligari's gaven talrijke gehypnotiseerde Cecare's bevelen om te moorden. Razende Mabuse's begingen krankzinnige misdaden, zonder er ooit voor te worden gestraft en geesteszieke Iwan's bedachten ongehoorde martelingen" 46 "Het kind, als steeds terugkerende samenbindende figuur," merkt Syberberg op in een toelichting, "is zowel schuld, want het brengt de pop Hitler in het spel en legt het in de wieg van het Caligari-beeld, alsook de hoogste rechtsprekende instantie van de naïviteit, voor wiens geestesoog alles plaats vindt, als een horrorvisioen in het innerlijk. Het is beide tegelijk.",47

Van 'Hitlers' geboorte uit de wieg van Caligari naar zijn wedergeboorte uit het graf van Wagner, is slechts een kleine stap. Om deze stap voor de kijker nog wat makkelijker te maken, laat Syberberg de wederopstandingsscène voorafgaan door een tableau, waarin zijn alter ego André Heller, wandelend door de tuin van de villa Wahnfried temidden van dezelfde figuren uit de expressionistische cinema passages declameert uit het geboortemanifest van het Italiaanse Futurisme. En gaandeweg begint het te dagen. Het is niet, zoals we aanvankelijk dachten, de stijl van de Amerikaanse B-film uit de jaren '50, die hier wordt nagebootst. De theatrale mise-en-scène verwijst, zoals Anton Kaes terecht heeft geopperd, naar de theatrale beeldtaal van de vroege expressionistische Duitse film. ${ }^{48}$ 'Hitler' mag dan zijn uitgedost als de titelheld van Wagners grand opéra; hij spreekt de (beeld-)taal van Dr. Caligari - de grootste 'Droomvanger' (Jünger) uit de Duitse filmgeschiedenis. Zwijgend aanschouwt zijn eigen, rouwende moeder, hoe uit het knuffelbeest, dat ze in het eerste deel van de film nog zo zorgzaam in een wieg heeft gelegd, een waar monster is gegroeid: 'Ja, ik was en ben het einde van jullie meest geheime wensen, legenden en werkelijkheid van jullie cinefiele dromen'...

Laten we een voorbeeld nemen aan Susan Sontag en deze zwarte moeder, met haar rouwsluier van celluloid, een naam geven. Laten we haar niet Alice in Wonderland noemen, maar de Zwarte Maria - naar de eerste filmstudio van Edison, waarmee de filmgeschiedenis rond het begin van de vorige eeuw een aanvang nam: de Black Mary, "het heilige apparaat,

\footnotetext{
${ }^{46}$ Kracauer, S., Von Caligari zu Hitler. Eine psychologische Geschichte des deutschen Films. Frankfurt am Main, 1984, 1995. p. 287. Voor Kracauers 'diepte-duiding', zie eveneens: hoofdstuk 5, paragraaf 5.

${ }^{47}$ Syberberg, H.J., Die Kunst als Rettung aus der deutschen Misere. Ein Essay. in: Hitler, a.w., p. 24.

${ }^{48}$ Kaes, a.w., pp. $42 \mathrm{ff}$.
} 
(...) de zwarte moeder van onze fantasie". ${ }^{49}$ In tal van verschijningsvormen wordt deze geboorte-studio van de cinema door Syberberg in zijn eigen studio ten tonele gevoerd: als "een zwarte steen, uit de hemel gevallen" 50 (inderdaad: de ruitvormige zwarte steen uit Melancolia ); als een kopie op originele schaal; als een miniatuurmaquette in de glazen toverbol uit Citizen Kane, die in het animatiebeeld waarmee de film opent ook daadwerkelijk, omhuld door een traan (melancholie), uit de hemel valt - uit 'het heelal in ons innerlijk', het 'binnenste van de nacht', Nacht über Bayreuth. Want ook moeders worden geboren. En was het niet Theodor Adorno, die Bayreuth de cinema laat baren? In Wagners muziekdrama's, aldus Adorno in Versuch über Wagner (1952) "vindt de geboorte van de film plaats uit de geest van de muziek". ${ }^{51}$ Hier zien we de Meister met zijn dochtertje - niet toevallig gespeeld door het dochtertje van 'Wagners tweede verschijning'. Een oude schuldige moeder in rouw. En tegelijk een jong onschuldig meisje, vervuld van naïeve hoop.

Wie de jeugd heeft, heeft de toekomst, zegt men wel. 'En er is slechts één toekomst: de toekomst van de film'. "Uitsluitend een eigentijdse kunstfilm over deze Hitler in ons kan hoop bieden," mijmert Syberberg in het pamflet Die Kunst als Rettung aus der deutschen Misere (1978), dat als inleiding op het Hitler-script is gepubliceerd. "In het belang van onze toekomst, moeten we hem en daarmee ons overwinnen [überwinden, besiegen] (....)". "Mon Dieu, donnez-nous bientôt la Paix victorieuse," bidt de kleine madonna van het Franse patriottisme. 'Lieve Heer, geef ons weldra de zegevierende vrede'. In de laatste scène van de film, het moment van katharsis, zal ook haar Duitse zusje (zie afbeelding 6) de rouwsluier afwerpen en in gebed op de knieën zinken. De muziek van Wagner, die tot dan op de soundtrack heeft overheerst, maakt plaats voor het slotkoor van Beethovens Negende. Een einde, dat tegelijk een nieuw begin is. Het was Beethovens Negende waarmee de eerste steenlegging van het festivalhuis in Bayreuth werd ingewijd. Het Rheingold, het eerste deel van de Ring, begint met een parafrasering van het openingsakkoord van deze symfonie. ${ }^{53}$ Zoals het Ludwig-Requiem, het eerste deel van De Graal, begon met het openingsakkoord van het Rheingold. De cirkel heeft zich gesloten...

\subsection{De som van onze ervaringen}

Tot zover enkele kanttekeningen bij een kleine tien minuten uit een film van zeven uur. "Ik vond deze dampende frasen; dit hoogdravende geklets, dat zich als diepzinnigheid voordoet; dit opdringerige, maar tegelijk geheel vrijblijvende gerommel met Bildungsgütern; dit volslagen willekeurige, ook de vervalsing niet schuwende arrangement van historische feiten; deze hemeltergende discrepantie tussen een stoutmoedige pretentie en de banaliteit van de verklaring - ik vond dat alles volstrekt onverdraaglijk," moppert de Duitse historicus Reinhard Kühnl (1980). "Ik ondervond de gehele film als één massieve poging de toeschouwer middels een adembenemende opeenvolging van emotionele aanslagen in woord en beeld van zijn verstand te beroven. ${ }^{.54}$ En zo zullen zich velen hebben gevoeld.

De film mag dan zijn ontworpen als een wandeling door het atelier van de kunstenaar; als kijker waan je je veeleer in een soort virtuele achtbaan, die op volle kracht door het spookhuis van de Duitse cultuurgeschiedenis dendert. Nog maar amper ben je bekomen van

\footnotetext{
${ }^{49}$ Hitler, a.w., 271.

so ibidem.

${ }^{51}$ Adomo, Th., Versuch über Wagner. Frankfurt am Main, 1952. p. 100.

${ }_{52}^{52}$ Syberberg, Die Kunst als Rettung..., a.w., p. 9.

${ }^{53}$ Zie bijvoorbeeld: Magee, B., Aspects of Wagner. London, 1972. pp. 19ff. Tanner, M., Wagner. London, 1996, 1997. pp. 48ff,

${ }^{54}$ Kühnl, R., Einübung ins Irrationale. in: Sammlung: Jahrbuch für antifaschistische Literatur und Kunst. Band 4. Frankfurt am Main, 1981. p. 123.
} 
het schrikbeeld van 'Hitlers' wederopstanding, of de filmer neemt je al weer mee naar een volgend tableau, dat zo mogelijk nog complexer in elkaar zit: op een lied van Brecht, waarin Hitler en zijn trawanten vanuit de hel hun terugkeer aankondigen, dansen zwarte GI's met blonde Duitse meisjes rond het inmiddels weer gesloten Wagner-graf de jitterbug - "De tijd moet komen/ wij doden ontwaken/ niet in witte kledij/ zwart staan we op". ${ }^{55}$ En aanvankelijk ben je ook nog wel bereid enige moeite te doen om de allegorische betekenis van een dergelijk beeld te ontsluieren. Vol goede moed ga je in je geheugen op zoek naar een aanknopingspunt, dat je wellicht zou kunnen helpen de clou te doorzien. Het zal toch niet de bedoeling zijn, dat we hier een link leggen tussen de huidskleur van de Amerikaanse militairen en de kleur van de outfit van de nazi-spoken uit Brechts lied?, tob je nog, terwijl de achtbaan alweer enkele tableaus verder is. Maar al snel laat je alle hoop varen. Hitler, ein Film aus Deutschland is een werk dat de toeschouwer voor een eenduidige keuze stelt. Ofwel het voorbeeld van het gros van de Duitse critici volgen en geërgerd, maar bij volle verstand, de bioscoop verlaten. Ofwel het verstand op nul zetten en je volledig overgeven aan deze cinefiele hellevaart, met het risico dat je aan het eind van de rit inderdaad je verstand zult hebben verloren.

Natuurlijk, Syberberg gunt zijn publiek nog een derde optie. Hoewel de film uitsluitend op groot doek tot zijn recht komt, is eveneens een video-versie in omloop. En je zou ervoor kunnen kiezen de band in huis te halen om in alle rust, met de boekenkast binnen handbereik, beeld voor beeld te bestuderen. Maar wie hiertoe overgaat zal ontdekken, dat de misere van de interpreet dan pas goed begint. Elke poging tot detailanalyse is gedoemd vroeg of laat te verzanden in een waar moeras van intertekstuele verwijzingen. Niet slechts moet je, zoals Susan Sontag met veel gevoel voor understatement opmerkt tijdens een eind jaren ' 80 aan een Amerikaanse universiteit gehouden symposium, "behoorlijk sophisticated zijn en over een brede culturele bagage beschikken $(\ldots)^{\prime \prime} ;{ }^{56}$ je moet ook behoorlijk goed thuis zijn in het oeuvre van deze cineast. Want wie de allegorieën tot in detail zou willen doorgronden, kan niet volstaan met deze ene film. Hitler is immers nog maar een "hoofdstuk" uit een veel grotere film - de pakweg (het kan een uurtje meer of minder zijn) 23 uur durende cyclus De Graal, waarvan de delen voortdurend in elkaar grijpen. Zo verwijst het beeld van 'Hitlers' wederopstanding zowel terug naar het slotbeeld van het Ludwig-Requiem (de wederopstanding van de sprookjeskoning als 'een mythe in de herinnering van zijn volk'), alsook naar een sleutelscène van Karl May - Auf der Suche nach dem verlorenen Paradies (1974). Tijdens een bezoek aan de kermis bekijken Emma en Clara May in een Guckkasten filmpjes van Georges Méliès, de grote magiër uit de begindagen van de cinema - "een kleine hommage", aldus de Amerikaanse literatuurwetenschapper Eric Santner (1990), aan een filmkunstenaar, "wiens illusionistische landschappen weer worden geciteerd in Hitler en Parsifal" ${ }^{57}$ Eén van deze filmpjes is gesitueerd op een kerkhof; uit een tombe herrijst een spook...

En ook in deze zin hadden we het tableau kunnen duiden: als een eerbetoon aan een bepaalde vorm van cinema, dat tegelijk een statement is. In een tijd waarin de markt wordt overspoeld door de ene blockbuster na de andere, bestaan er nog steeds magiërs à la Méliès die kunnen toveren met bordkarton en papier-maché. Maar laten we het niet nog ingewikkelder maken, dan het al is. Kijken naar Hitler, ein Film aus Deutschland staat gelijk aan het consumeren van een cultuurhistorische overdosis. Deze film bevat domweg teveel van het goede. Het is volstrekt onmogelijk de inhoud ook maar bij benadering samen te vatten.

\footnotetext{
${ }^{55}$ Hitler, a.w., pp. 164, 165.

${ }^{56}$ Salmagundi. A Quarterly of the humanities and the social sciences. 85-86. (winter-spring 1990). pp. 117-313, zie: 217.

${ }^{57}$ Santner, E.L., Stranded Objects. Mourning, Memory, and Film in Postwar Germany. Ithaca, London, 1990. p. 120.
} 
Wat het eventuele thema of onderwerp zou kunnen zijn, blijft, zelfs na veelvulding bekijken, in nevelen gehuld (hetgeen, dankzij het intensieve gebruik van de rookmachine, gerust letterlijk mag worden genomen). De een, Susan Sontag, vermoedt dat het onderwerp Hitler moet zijn "hét onderwerp van de twintigste eeuw". 0 nzin, repliceert de ander, de Amsterdamse filmtheoreticus Thomas Elsaesser (1981): "Susan Sontag vergist zich deerlijk (...). Het is een misverstand te denken dat deze film over Hitler zou gaan". "Het onderwerp, meent Elsaesser, is niets anders dan de droomfabriek film zelf. Het is een film over film; een visueel essay over kijken en bekeken worden, projectie en realiteit, identificatie en vervreemding, enzovoorts. Terwijl een derde, de Franse cultuurfilosoof Philippe Lacoue-Labarthe (1981), er weer stellig van overtuigd is, dat "Syberbergs cinema slechts éen thema kent: Duitsland". ${ }^{\circ}$

Misschien mogen we voorzichtig opperen dat de film tenminste drie thema's moet kennen. Het zijn de drie zelfstandige naamwoorden uit de titel: Hitler, Film, Deutschland. Maar dit betekent nog niet, dat we hiermee de inhoud adequaat zouden hebben samengevat. 'Hitler', 'film' en 'Duitsland' zijn hooguit de hoofdmotieven, waarmee Syberberg een halo aan bijmotieven heeft verbonden. Al is 'halo' niet geheel het juiste woord, omdat het nog een zekere kern verondersteld. Je zou beter kunnen spreken over een thematische wolk, die weliswaar uit de hoofdmotieven voortvloeit, maar met het vorderen van de uren alsmaar meer uitdijt - tot een massieve mistbank, waarbinnen je geen hand voor ogen meer ziet, laat staan de bomen van dit allegorische bos. "Syberberg is een meester van de overdaad (...)," moet ook Sontag toegeven. "Zijn moeilijkheid (...) is, dat hij niets kan loslaten. (...) Zijn film tracht alles te zeggen." Waarbij je je zou kunnen afvragen, of deze breedsprakigheid een karaktertrekje is, of toch veeleer samenhangt met de wagneriaanse uitgangspunten die de filmmaker huldigt: Gesantkunst, in de zin waarin Wagner dit concept begreep, behelst immers meer dan een amalgama van stijlen en uitdrukkingsvormen. Het was Wagner ook te doen om een "synthese van het weten". De scheiding tussen verstand en gevoel, theoretische en praktische kennis, kunst en wetenschap diende te worden overwonnen in een 'totaalwerk', dat alle levenservaringen van de tijd waarin het ontstond in zich opnam en tot een collectieve ervaring transformeerde. ${ }^{62}$ En niets minder dan dat, moet ook Syberberg voor ogen hebben gestaan. "Hoe alle inzichten uit de sociologie en de psychologie en de maatschappijwetenschappen en de politiek samenvatten, als film monteren, versmelten, onder één noemer brengen?," verwoordt hij in Die Kunst als Rettung aus der deutschen Misere de uitdaging, waarvoor hij zich met deze film gesteld zag. "Onder éen noemer brengen, zonder belangrijke zaken weg te laten, heel zintuiglijk, zonder historische reconstructies, maar met alle technische middelen die deze eeuw ons ter beschikking stelt. Deze eeuw van de film, de radio en de projectie (...).",63

Nu behoeft het geen betoog, dat een dergelijke summa in een tijd, die bij uitstek wordt gekenmerkt door 'onoverzichtelijkheid' (Jürgen Habermas ${ }^{64}$ ) nooit veel meer kan zijn dan een artistieke utopie. Maar met zijn citeerwoede komt Syberberg wel een heel eind. En er wordt ook geen enkele poging gedaan om te verbloemen, dat dit Gesamtkunstwerk nog niet af is. Integendeel: nadrukkelijk presenteert de film zichzelf als een kunst-werk in uitvoering. Het gaat nog maar om een ruwe schets, die we naar believen met onze eigen kennis en

\footnotetext{
58 Sontag, a.w., p. 183.

59 Elsaesser, Th., Myth as the Phantasmagoria of History: H.J. Syberberg, Cinema and Representation. in: New German Critique. 24-25 (Fall/Winter 1981-'82). pp. 108-154, zie: $112 \mathrm{f}$.

${ }^{60}$ Lacoue-Labarthe, Ph., Syberberg: uber Deutschland nach Hitler. in: Politics/Poetics. Hrsg. Documenta X. Kassel, 1997. pp. 480-484, zie: 480. [Eerder versch. in: Libération. 03-12-1981.]

${ }^{61}$ Sontag, a.w., pp. 205, $219,221$.

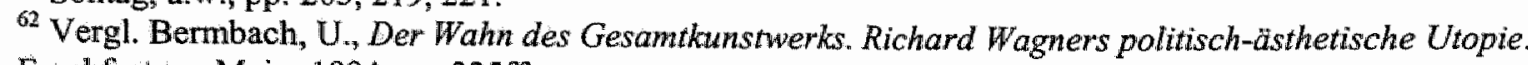

Frankfurt am Main, 1994. pp. 225ff.

${ }^{63}$ Syberberg, a. ., p. 22.

${ }^{64}$ Habermas, J., De nieuwe onoverzichtelikheid en andere opstellen. Vert. J. Boom. Kampen, 1989.
} 
levenservaringen mogen invullen - zoals ik hierboven aan de hand van een fragment heb gedaan. Welke invulling we eraan geven, is sterk afhankelijk van de persoonlijke achtergrond. Het ontwerp biedt voor ieder wat wils. De filmtheoreticus mag er een film over film in zien, de cultuurfilosoof een film over Duitse cultuurgeschiedenis, enzovoorts. Al deze associaties worden door Syberbergs ambigue montagebeelden opgeroepen en komen het werk ook ten goede.

Eigenlijk is het idee achter deze film betrekkelijk eenvoudig. Hoe meer wij erin leggen, des te rijker aan connotaties wordt het werk. Op zichzelf genomen is dit uiteraard weinig opzienbarend. De receptie genereert voor een niet onbelangrijk deel de betekenis(sen) van een kunstwerk. Maar in dit geval mogen we misschien nog een stap verder gaan. Met enige goede wil zou je staande kunnen houden, dat dit Gesamtkunstwerk in een interactie met het publiek gestalte krijgt. Als een soort spons zuigt het werk zich vol met betekenis(sen), die wij erin projecteren - zonder evenwel ooit het punt van voltooiing te bereiken. Want Syberbergs multimedia-collage is geen puzzel, waarvan de stukjes naadloos in elkaar passen. Evenals de geschiedenis zelf, heeft ook dit artwork in progress sterk het karakter van een discussie zonder eind. En naar het zich laat aanzien, heeft de maker er ook alles aan gedaan om het aantal interpretatiemogelijkheden oneindig te houden. Het wemelt in deze film van de citaten, waarvan je als toeschouwer onmogelijk de betekenis(sen) kunt doorschouwen - ook al ben je nog zo sophisticated en ken je het oeuvre van de cineast van haver tot gort. Dat bijvoorbeeld een kei en een blok hout afkomstig zijn van respectievelijk het Festspielhaus in Bayreuth en het in ' 45 afgebrande privé-schouwburgje van Ludwig II op de Lindenhof; of dat een Boeddhabeeldje en een foto van Joseph Roth in de film zijn ingebracht door steracteur André Heller, die deze attributen koestert als een soort talisman, ${ }^{65}$ kun je als toeschouwer eenvoudig niet weten. Niet de uitkomst van de puzzel is van belang, maar het puzzelen. De nadruk ligt, zoals hierboven reeds opgemerkt, op het kunst-werk - het "fantasiehandwerk" van het associëren, (re-)produceren en (hinein-)interpretieren. Zeven uur lang mogen we onze fantasie uitleven in een creatief spel met geciteerde beelden, objecten, teksten en geluiden. "En dit zijn de spelregels," onthult de circusdirecteur in de openingsscène. "Er zullen geen helden zijn, alleen wijzelf. En er zal geen story zijn, alleen die van ons en ons innerlijk.,

Volgen we de circusdirecteur, dan dient dit het werkelijke thema van deze film te worden genoemd. "Het gaat om ons," wordt de man niet moe te benadrukken. "Om ons allen"68 - de regisseur, de acteurs, de crew, het publiek. Het gaat om onze eigen herinneringen en ervaringen; om onze hunkeringen, wensdromen en angsten, die in de omgang met het materiaal vrijkomen en op het witte doek worden teruggeprojecteerd, waar ze tot een collectieve ervaring versmelten. Dat Syberberg hieraan zoveel waarde hecht heeft uiteraard alles te maken met de 'louterende werking', die hij aan de films van De Graal toekent. Zoals we zagen in het vorige hoofdstuk huldigt hij de opvatting, dat een jarenlange zelfkastijding in een opgelegd 'pedagogisch schema van beschuldiging en verontschuldiging' de Duitsers zou hebben vervreemd van hun ware mythopoëtische zelf - het elke Duitser bij wijze van spreken aangeboren 'irrationele' gevoelsleven dat, geheel in de lijn van de 'irrationalisme'-kritiek van Georg Lukács en de late Thomas Mann, in het linkse cultuurdebat van de jaren ' 70 als 'fascistische hunkeringen in ons midden' (Sontag) is getaboeiseerd. En door de Duitsers een louterend spel te laten spelen met door de nazi's geoccupeerd materiaal, wil Syberberg - aldus de inleiding van het Hitler-script - hen helpen hun 'smetvrees' te boven te komen, 'weer vrij te worden van de onderdrukkende vloek van de schuld' en zich te verzoenen met deze na '45 'verdrongen" en "verraden' "Kräften des uns eigentümlichen Wesens". "Identiteiten

\footnotetext{
${ }^{65}$ Ik ontleen deze informatie aan: Sontag, a.w., p. 213.

${ }^{66}$ Hitler, a.w. p. 88.

${ }^{67}$ idem, p. 80 .

${ }^{68}$ idem, p. 88 .
} 
terugvinden, genezen en verlossen" - dat is waar het Syberberg naar eigen zeggen in deze film om te doen is. ${ }^{69}$ Inderdaad: zoals de oud-Bayreuther wagnerianen hoopten, dat het ontaarde Duitse volk in een louterend spel met dramatisch vormgegeven mythen uit de eigen Duitse cultuurgeschiedenis de weg zou terugvinden naar zijn substantiële identiteit, die in de chaos van de moderniteit verloren dreigde te gaan. ${ }^{70}$

Althans zo zou het in theorie moeten zijn. In de praktijk krijgen 'wij", bedoeld wordt het Duitse publiek waarvoor dit op oud-Bayreuther leest geschoeide nationale Erziehungsund Einigungswerk in eerste instantie bedoeld lijkt te zijn, ${ }^{71}$ slechts een zeer beperkte ruimte om ons innerlijk te uiten. Daarvoor is het ego van hen, die ons in dit louterend spel voorgaan, de filmmaker voorop, simpelweg te groot. "De film," stelt de Duitse filmcriticus Hans Blumenberg (1978), "speelt zich af in een hermetisch systeem van persoonlijke obsessies, dat kritische vragen uitsluit." ${ }^{\text {,72 }}$ En het zijn niet onze obsessies, waarop Blumenberg hier doelt, maar die van de regisseur. Diens obsessies alleen al zijn zo enorm, dat ze de hele ruimte vullen. Of anders geformuleerd: niet wijzelf, maar Syberberg is de ware held van dit epos - de story van zijn innerlijk. Wij, de bezoekers van het atelier, hebben het nakijken. Men heeft ons hier naar toe gelokt met de belofte, dat we een spel zouden mogen spelen. Eenmaal binnen wordt echter al snel duidelijk, dat het spel een one-man-show is, met onszelf in de rol van een soort applausmachine. Discussie of tegenspraak worden niet op prijs gesteld. We zijn uitsluitend uitgenodigd om ons te verbazen over de spitsvondigheid en vingervlugheid van de magiër. "(...) Zijn filmset lijkt op een gigantische speelgoedwinkel, met Syberberg als een monsterlijk kind, scharrelend door de rekwisieten van zijn verbeelding," observeert de Nederlands/Britse publicist Ian Buruma (1990): ${ }^{73}$ En hoewel ongetwijfeld hoogbegaafd, zouden we hier aan kunnen toevoegen, heeft dit kind toch zeer zeker ook enkele minder aangename eigenschappen. Het houdt ervan om in het middelpunt van de belangstelling te staan en zijn speelkameraadjes met zijn eruditie en zwarte magie te overdonderen. En ja, zoals je wel vaker ziet bij hoogbegaafde kinderen, is ook Syberberg een beetje een pestkop. Want er wordt wat afgepest in dit filmatelier. Al zou je dit op grond van buitenlandse commentaren misschien niet snel zeggen. Om de provocatie te kunnen aanvoelen moet je Duitser zijn, liefst een generatiegenoot van de regisseur en als het even kan ook nog filmcriticus van beroep. Een "Angstmacherfilm," noemt de Duitse filmcriticus Dietrich Kuhlbrodt (1981) dit werk - een film, die bang maakt. "Syberberg omsingelt zijn vijanden met een heel arsenaal van angst-, dreig-, en vergeldingstekens, wapens en munitie. (...) En de vijanden komen naar hem toe van overal vandaan." ${ }^{74}$

Zelf komt Kuhlbrodt er nog genadig van af. Hij behoort niet tot de 'vijanden' die in dit filmatelier met naam en toenaam aan de schandpaal worden genageld. Zoals Winfried Günther of Klaus Eder - nota bene de redacteur van een bundel met bewierokende buitenlandse essays over deze film. Hun namen kunnen worden teruggevonden op een tweetal schoolborden, die Syberberg halverwege het eerste deel van de film in de studio heeft

\footnotetext{
${ }^{69}$ Syberberg, a.w., pp. 9f, 14f. Zie eveneens: hoofdstuk 3, paragraaf 5; hoofdstuk 5, passim.

${ }^{70}$ Zie bijvoorbeeld: Ulbricht, J.H., Die Geburt der deutschen aus dem Geiste der Tragödlie. in: Wege nach Weimar. Auf der Such nach der Einheit von Kunst und Politik. Hrsg. H. Wilderotter, M. Dorrmann. Weimar, 1999. pp. 127-142.

${ }^{71}$ Onder 'ons' begrijpt de circusdirecteur: “(...) de mensen die hem [Hitler, G.G.] hebben gekozen en hem alles hebben geofferd, dat wil zeggen: zichzelf en hun ideeën, zonen, vaders, vrienden en hun beeld van de wereld, steden, hele landstreken: het geweten en de ziel". Hitler, a.w., p. 88.

${ }^{72}$ Blumenberg, H., Träume in Trümmern. Hans-Jürgen Syberbergs "Hitler'. in: Kinozeit. Aufsätze und Kritiken zum modernen Film 1976-1980. Frankfurt am Main, 1980, 1986. pp. 139-142, zie: 140.

${ }_{73}$ Buruma, I., There's no place like Heimat. in: The New York Review of Books. 20 (20-12-1990). pp. 34-43, zie: 43.

${ }^{74}$ Kuhlbrodt, D., Preußische Fülmästhetik und ihre Strategien. in: Preussen. Versuch einer Bilanz. Band 5. Preussen im Film. Eine Retrospektive der Stiftung Deutsche Kinemathek. Hrsg. A. Marquardt, H. Rathsack. Hamburg, 1981. pp. 74-97, zie: 93f.
} 
opgesteld. Beide borden dragen het opschrift: "Kulturholle rondom ons". Het ene bord is gewijd aan de 'hel' in het Oosten van Duitsland. Naast een reeks citaten uit het officiële partijorgaan Neues Deutschland prijken de namen van prominente figuren uit het cultuurestablishment van de DDR, die hebben ingestemd met de Ausbürgerung van de dissidente protestzanger Wolf Biermann in het najaar van ${ }^{7} 76{ }^{75}$ Het andere bord heeft betrekking op de situatie in de Bondsrepubliek. Het bevat, benevens een bloemlezing uit hun werk, een lijst met namen van bekende Westduitse filmcritici, waaronder ook Günther en Eder. Voor deze borden heeft Syberberg enkele etalagepoppen gegroepeerd, die de opiniemakers in het naoorlogse Duitsland moeten verbeelden. Hun hoofden zijn overgoten met bloed en in hun handen houden ze reusachtige penissen. Op de soundtrack klinkt een historisch geluidsfragment: een radio-opname van de nationaal-socialistische boekverbranding. Waaraan Günther en Eder het hebben verdiend om hier met de nazi's en de bonzen van het stalinisme over een kam te worden geschoren? Wel, het antwoord op deze vraag laat zich raden. Beide critici hebben zich ooit in minder lovende bewoordingen uitgelaten over een van Syberbergs Gesamtkunstwerken... 76

Het is zeker niet de enige scène, waarin de huisheer de gelegenheid te baat neemt om eens duchtig met zijn gal om zich heen te spuwen. $I$ tiranno nazista come presento per parlare dei demoni d'oggi luidt de titel van een essay van de Italiaanse historicus Vito Zagarrio (1979) in de door Eder samengestelde bundel: "De nazi-tiran als voorwendsel om over de demonen van vandaag te spreken'. ${ }^{77}$ En inderdaad: wanneer je de film nauwlettend bekijkt valt op, dat het eigenlijk niet zozeer geschiedenis-beelden zijn, die Syberberg in zijn atelier heeft gebouwd. Veeleer gaat het om beelden, waarin langs de omweg van het verleden commentaar wordt geleverd op het heden. "Het is niet enkel de historische Hitler die me interesseert, maar ik gebruik hier een extreem kwaad om iets te kunnen zeggen over actuele zaken," bekent ook de filmmaker zelf in een interview uit $1983 .^{78}$ Soms is de link met de actualiteit losjes, bijvoorbeeld in het hierboven geanalyseerde wederopstandingstableau, waarvan je je zou kunnen afvragen of het niet ook een pastiche is op het midden jaren " 70 in alle hevigheid losgebarsten publieksdebat over het 'onverwerkte verleden' van het Wagnerfestival - er waart een spook over de Groene Heuvel, Maar niet zelden zit Syberberg zo dicht op de actualiteit, dat zijn beelden alleen al door de afstand in tijd bijna hermetisch aandoen. Behalve sophisticated en een groot kenner van het oeuvre van de cineast, moet je ook behoorlijk goed op de hoogte zijn van het reilen en zeilen in de Bondsrepubliek van de late jaren ' 70 om in het woud van allegorieën je weg te kunnen vinden. Elders in het eerste deel van de film ligt op een tafel in de studionimte het verkoolde lichaam van Goebbels. Rondom de tafel staan etalagepoppen, gehuld in met bloed besmeurde slagersjassen. Op hun rug dragen ze de initialen EL, JF, LC, AS enzovoorts. Hoeveel toeschouwers - laat staan buitenlandse toeschouwers - zouden tegenwoordig nog weten, dat deze initialen staan voor

\footnotetext{
${ }^{75}$ Voor deze affaire, die in 1977 , het jaar waarin Syberberg zijn film maakt, tot verhitte debatten leidt in de West-Duitse media en de intelligentsia in de DDR voorgoed in twee kampen zal splitsen, zie bijwoorbeeld: Ober Wolf Biermann: Texte von Heinrich Böll... Hrsg. A.M. Mytze. Berlin, 1977.

${ }^{76}$ Wat Eder over Syberbergs werk heeft geschreven, is me niet bekend. Voor de kritiek van Günther op de documentaire over Winifred Wagner, zie hoofdstuk 4, paragraaf 3.

${ }^{77}$ Zagarrio, V., Der Nazi-Tyrann als Vorwand um von den Dämonen won heute zu sprechen. in: Syberbergs Hitler-Film. a.w., pp. 77-80.

${ }^{78}$ Revue Belge du Cinéma: Hans Jürgen Syberberg. 3 (1983). p. 12. Zie eveneens: Schiller, B., Our Hitler as visual politics. in: Performing Arts Journal. 12 (1980).
} 


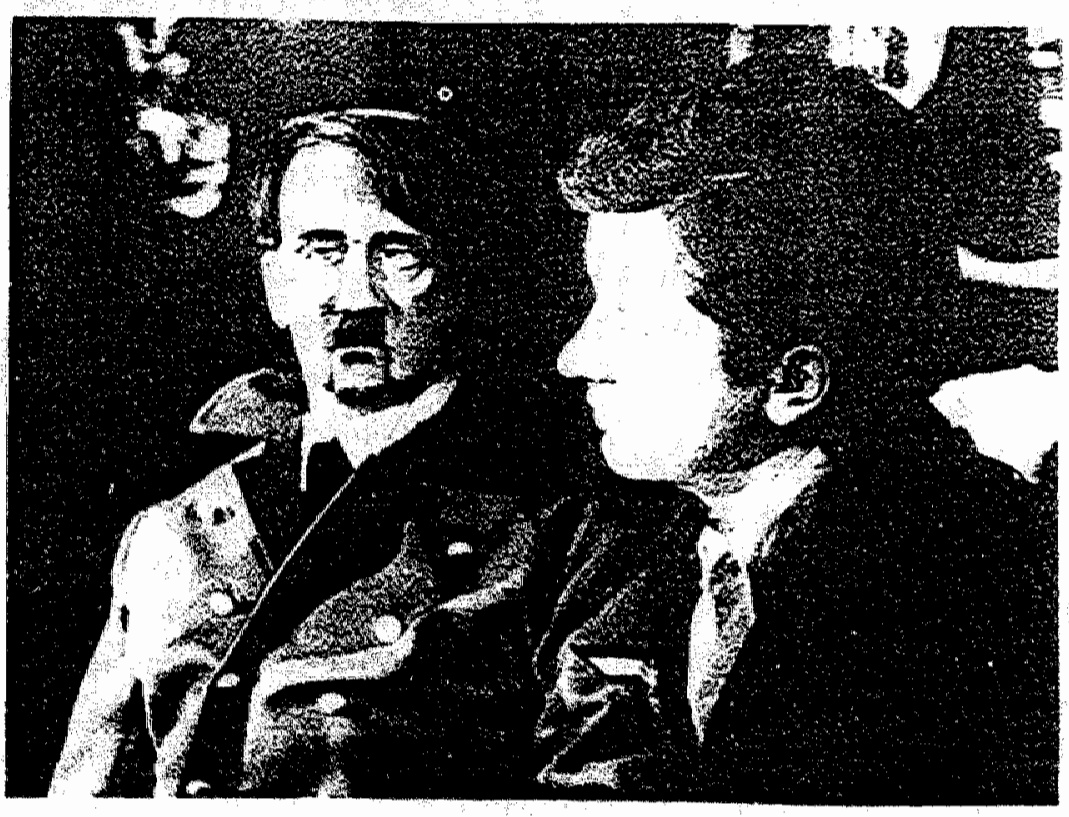


indertijd beroemde historici, publicisten en cineasten, die zich verdienstelijk hebben gemaakt op het terrein van de Vergangenheitsbewältigung? ? $^{79}$

Gedegen kennis van de toenmalige actualiteit vereist ook een scène aan het slot van het derde deel, waarin een buikspreekpop met de gelaatstrekken van Hitler (zie afbeelding 9) minutenlang de loftrompet mag steken over de naoorlogse wereldorde. Om iets van de sfeer van dit werk te kunnen proeven, lijkt een langer citaat me lonend:

"Een pluimpje van Adolf Hitler voor deze wereld na mij. Kan ik niet tevreden zijn met mijn onsterfelijkheid? Neem de landkaart van Europa. Hoe zou die eruit hebben gezien zonder mij? Niemand heeft het Avondland zo grondig veranderd als wij. We hebben de Russen tot aan de Elbe gebracht en de joden hun staat geschonken. En de Verenigde Staten een kolonie op hun manier. Vraag maar eens informatie op over Hollywood en haar afzetmarkten. Ik ken de trucjes zoals niemand van jullie. Wat men ten overstaan van de massa doet en zegt. Ik ben de leerschool van de succesvolle democraten. En ze zijn op de goede weg, onze erfenis over te nemen. Ieder op eigen wijze. (...) En ik prijs Idi Amin, de woordvoerder van Afrika en mijn bewonderaar. Door de paus ontvangen, is dat niks? Zoals de Arabier Arafat, met de revolver op zak, door de Verenigde Naties. (...) Ook mag ik de Verenigde Staten prijzen, waarin de voorstanders van de doodstraf alsmaar in aantal toenemen. Houdt moed! Pas de uitroeiing van de Amerikaanse Indianen maakte de nobele daden van de vooruitgang mogelijk. En pas het wegvagen van de Russische aristocratie en de cultuur van de bourgeoisie garandeerde de triomf van het proletariaat. Alles strijdt, spant zich in, werkt in kampen, heropvoedt, moordt, helpt de ander. (...) Ook het Oosten van Duitsland verdient mijn lof, ik zal niet kleinzerig zijn. Met het bloederige rood van hun kleinburgerlijke vlag lopen ze weer voorop in de wereld. (...) Het ware model Duitsland. Am deutschen Wesen soll die Welt genesen. (...) En het Westen van ons restland Duitsland? Ik begroet de terroristen en de anarchisten. Zo klein zijn wij ook ooit begonnen. Precies zo. (...) En alle lof ook voor de vrouwenbeweging, het nieuwe racisme, wereldwijd, maar nergens zo radicaal als bij ons. Als we niet voor het moederschap zijn, dan zijn we toch gewoon ertegen! Waar het op aankomt is, dat we triomferen, onverbiddelijk en genadeloos. Wat zeggen de Duitse kanselier en de vakbonden en allen, die de werkloosheid als ons grootste probleem beschouwen, dat tegen elke prijs moet worden opgelost? Dat ken ik. En ik kan jullie ook vertellen hoe. (...) Maar de wereld is een riool. De adelaars van Europa sterven uit, leven enkel nog in Afrika. (...) Is dat de wereld, die jullie tegenover de mijne plaatsen? Neem me niet kwalijk. Steekpenningen van Lockheed en oliebaronnen voor jullie politici. Alles goed en wel. Maar waar blijft de grote lijn, het concept van de grote architect, de consequente architectuur? Ik heb het nu niet over het raffinement van de corruptie, de gemakzuchtige compromissen van de functionarissen en de handelaren. Ik heb het over de logos van deze eeuw, heel openhartig. Over de kunst van de politiek, die jullie in angst en beven verzet. Wat we nodig hebben is de moderne kunstenaar, die het meesterwerk tot stand brengt. (...). En toch hebben we getriomfeerd, over de gehele linie en overal, alleen in een andere gedaante. Denk aan de nieuwe woorden: samenleving in plaats van vaderland en ideologie in plaats van filosofie, ambtenaar in plaats van mens, gezindheid in plaats van geweten, noodzaak in plaats van kwaliteit, concreet in plaats van juist, maakbaarheid van de samenleving en vrijetijdsindustrie in plaats van Kultur, behoeftebevrediging in plaats van geluk. Duitsland als leermeester van de wereld. Economie in Oost en West, samen met de Jappen. En als het om

\footnotetext{
${ }^{79}$ De juiste oplossing van het raadsel is: Erwin Leiser (Deutschland erwache!), Joachim Fest (Hitler - eine Karriere), Liliane Cavani (Nightporter), Albert Speer (Der Sklavenstaat).
} 
toerisme gaat, zijn we overijverig als de mieren. Ook een vorm van wereldheerschappij, zij het niet volgens mijn methoden. Een bitter inzicht. Alles strijdt met alle middelen! Alleen mijn persoon is de boeman van de wereld. Dat is het lot dat ik dragen moet. Zolang de ideeën maar verder leven in ons. Iedereen draagt schuld. Maar wie is God meer nabij dan de schuldige? En wat in een tijd zonder God? Aangezien we hemzelf hebben afgezet. (..) Lang leve de mediocriteit, de vrijheid en gelijkheid voor de internationale middenmoot. Onder minderwaardigen uitsluitend met belangstelling voor winsttoename en loonsverbetering, zichzelf te gronde richtend, onverbiddelijk, genadeloos, op hun einde toegaand en wat voor één. Zonder mij! Bravo. Ze liquideren zichzelf, alleen langzamer. Niet dan?"

Si monumentum requiris, circumspice, luiden de slotwoorden van Allan Bullocks klassieke Hitler-biografie Leven en ondergang van een tiran (1952). ${ }^{81}$ Zo gij zijn monument zoekt, kijk om $u$ heen. Het had het motto kunnen zijn van deze film. "In Duitsland," voorspelt Syberberg in een tijdens de opnamen afgenomen interview (herfst 1977), "zal de film een vreselijke woede oproepen. Een schandaal. (..) Hij is ongelooflijk complex en agressief. En de agressiviteit richt zich meer op het heden dan op Hitler, die voor mij per slot van rekening een historische verschijning is." 82

\subsection{Het heden: de Duitse herfst van 1977}

In de eindaftiteling heeft Syberberg zijn film tot op de dag nauwkeurig gedateerd: "25 februari - 20 oktober 1977. München, de dag na Mogadishu-Stammheim-Mulhaus". ${ }^{83} \mathrm{De}$ namen verwijzen naar een reeks recente gebeurtenissen, die de adem van de Westduitse natie hebben doen stokken. Op 18 oktober komt op het vliegveld van Magadishu met geweld een einde aan de kaping van een passagierstoestel van de Duitse Lufthansa door leden van de Rote Armee Fraktion. Nog dezelfde nacht beroven drie kopstukken van dezelfde linkse stadsguerrilla, Andreas Baader, Gudrun Ensslin en Jan-Carl Raspe, zich in de zwaar bewaakte gevangenis van Stammheim van hun leven. De volgende ochtend, 19 oktober, wordt in de nabijheid van het Franse Müllhausen het stoffelijk overschot gevonden van de ontvoerde werkgeversvoorzitter Hanns Martin Schleyer - in de ogen van de terroristen en hun sympathisanten de personificatie bij uitstek van de 'boosaardige nazi-vader'. Het is de bloedige ontknoping van zeven weken vol terreur, haat, verwarring, paranoia en extreme maatschappelijk polarisatie, die de geschiedenis zijn ingegaan als: de 'Duitse herfst'.

Wie in deze 'zwarte herfstweken' de Bondsrepubliek bezoekt, waant zich in een belegerde vesting. Het straatbeeld wordt gedomineerd door tot hun tanden bewapende politiemensen, prikkeldraadversperringen en rondcirkelende helikopters. Politici roepen op tot nationale saamhorigheid. Kranten en opiniebladen publiceren open brieven, waarin bekende intellectuelen de republiek verdedigen. Alom wordt aangenomen, dat de Bondsrepubliek de meest ingrijpende politieke crisis uit haar bestaan doormaakt en de nog maar dertig jaar oude liberale democratie zich wederom aan de rand van de afgrond bevindt. Onenigheid bestaat hooguit over de vraag, welke krachten als de doodgravers dienen te worden aangemerkt. Vanuit kringen rond de CDU/CSU wordt steeds luider met de beschuldigende vinger gewezen in de richting van Nieuw Linkse professoren uit de school van Frankfurt, die met hun antifascistische "kritische theorie" de studerende jeugd tot terreurdaden tegen het

\footnotetext{
${ }^{80}$ Hitler, a.w., pp. $231-236$.

${ }^{81}$ Bullock, A., Hitler. Leven en ondergang van een tiran. Vert. J. Vandenberg. Utrecht, 1952. p. 538.

${ }^{82}$ Winter, de, L., Het Duizendjarig Rijk als filmlokatie. in: Hollands Diep. 6 (26-03-1977). pp. $40-43$, zie: 43 .
Hitler, a.w., p. 285 .
} 
postnazistische Duitsland zouden hebben opgehitst. "(...) De rebellie van '68 verwerken is belangrijker dan voor de zoveelste keer Hitler overwinnen;" zal de neo-conservatieve historicus Ernst Nolte enkele jaren later schrijven. ${ }^{84}$ Anderen, waaronder de Frankfurter fillosoof Jürgen Habermas, waarschuwen in alarmerende bewoordingen voor de opkomst van een Nieuw Rechtse intelligentsia, die "de onverdraaglijk gespannen situatie" zou misbruiken om "onder de bevolking een pogromachtige stemming op te roepen". "Een ogenblik van jeugdrevolte was (...) voldoende om jaren van reactie op gang te brengen," aldus Habermas in zijn Brief zur Verteidigung der Republik (herfst 1977). ${ }^{85}$

Zoals de meidagen van ' 68 het symbool zijn geworden van het Nieuw Linkse protest, zo staat de 'Duitse herfst' van ' 77 voor de zogenaamde Tendenzwende - een conservatieve kentering in de publieke opinie, die uiteindelijk zal uitmonden in het aantreden van de regering-Kohl, de geistig-moralische Wende van ' $82 .{ }^{86}$ Het fenomeen is niet specifiek Duits. Wereldwijd maken conservatieve regeringen zich op voor een aflossing van de wacht. En het hetzelfde geldt voor het crisisgevoel, dat de Westduitse samenleving nog lang nadien in zijn greep zal houden. No future wordt in de dagen van de punk- en kraakbeweging van New York tot Amsterdam een populaire leuze. Maar nergens zijn dit soort gevoelens zo intens en wijd verbreid als in de Bondsrepubliek, waar het publieke debat tot ver in de jaren ' 80 doortrokken zal zijn van "(...) angst, een depressieve stemming, hysterie, alsof de Apocalyps, de ondergang nabij is" (de politicoloog Christian Graf von Krockow) ${ }^{87}$ "Wanneer de Duitsers nog polytheïsten waren geweest," verzucht de Amerikaanse historicus Walter Laqueur (1985), "hadden ze beslist een angstcultus; zouden ze standbeelden voor de goden van de angst hebben opgericht en offers hebben gebracht." ${ }^{288}$ Van deze, blijkbaar diep gewortelde angst laten zich tal van voorbeelden bedenken, variërend van het 'Wij zijn bang!', waarmee de antikernwapenbeweging grote delen van de bevolking op de been weet te brengen, tot de beangstigende, apocalyptische beelden van deze Angstmacherfilm (Kuhlbrodt) van Syberberg. Volgen we Eric Santner, dan vertoont het decorbeeld zelfs een treffende gelijkenis met " $(. .$. de Schädelstätte of calvarie aan het eind van de reis van de geest door de geschiedenis van het bewustzijn in Hegels fenomenologie". ${ }^{89}$

Er valt veel voor te zeggen deze film eerst en vooral op te vatten als een product van de tijd waarin hij is ontstaan. Van de ironische lichtvoetigheid, die zo typerend was voor vroegere werken als Die Grafen Pocci $(1967)^{90}$ zijn we hier ver verwijderd. De tendresse van de nog maar twee jaar eerder tot stand gekomen documentaire over Winifred Wagner ${ }^{91}$, heeft plaats gemaakt voor tristesse, fureur en détresse - treurnis, woede en angst. "De film articuleert een wijd verbreid onbehagen over de tegenwoordige wereld," constateert Kühnl. ${ }^{92}$ Maar dit is nog te zwak uitgedrukt. Er heerst in deze film-factory een paniek, die zich zoveell jaar na dato nog slechts zeer moeilijk laat navoelen. Wat dat betreft, mag het hierboven aangehaalde lange citaat uit de donderpreek, die Syberberg bij monde van de buikspreekpopHitler op het filmhuispubliek loslaat, gerust representatief worden genoemd voor de teneur van de film in zijn geheel. Het zal geen toeval zijn, dat een van de acteurs nog eens expliciet naar deze sleutelscène uit het derde deel terugverwijst, als hij aan het slot van de film de 'morele plot' voor ons samenvat:

\footnotetext{
${ }^{84}$ Citaat ontleend aan. Gillen, E., Tabula rasa und Innerlichkeit. Deutschlandbilder vor und nach 1945. in: Deutschlandbilder. Kunst aus einem geteilten Land. Hrsg. E. Gillen. Berlin, 1997, pp. 48-54, zie: 54 .

${ }^{85}$ Habermas, J., Kleine politische Schriften (I-IV). Frankfurt am Main, 1981. pp. 364-406, zie: 364, $385 f$.

${ }^{86}$ Voor het fenomeen van de Tendenzwende, zie: hoofdstuk 4, paragraaf 1, hoofdstuk 5, paragraaf 8.

${ }^{87} \mathrm{Krockow}$; Ch., Graf von, Die Deutschen in ihrem Jahrhundert 1890-1990. Hamburg, 1990, 1994. p. 607.

${ }^{88}$ Laqueur, W., Was ist los mit den Deutschen? Übersetzt von O. Weith. Frankfurt am Main, 1985, 1988. p. 12.

${ }^{89}$ Santner, a.w., p. 143.

${ }^{90}$ Zie hoofdstuk 2, paragraaf 9 .

${ }^{91}$ Zie hoofdstuk 4, paragraaf 8 .

${ }^{92}$ Kühnl. a.w., p. 125.
} 
"Na de reis door deze wereld, wie is God meer nabij dan de schuldige. Wat echter in een tijd zonder God, aangezien we hemzelf hebben afgezet? Aldus sprak de duivel in een van zijn rollen. Ten langen leste cynisch en moralistisch, of toch veeleer menselijk, over Godenschemering zonder Goden, de Apocalyps van de vooruitgang, eindtijd door de milieudood van de soort mens in het subversieve gekrioel van de insecten, of zielendood wan een ijstijd-samenleving, wereldgericht zonder juristen en daarom eindelijk rechtvaardig, oneindig verschrikkelijk. Plaats makend voor het volgende geslacht, op de volgende ster, nadat deze definitief zelfdestructief werd, dankzij de soort mens". 93

Het zijn teksten die, vanuit ons huidige perspectief; wetende dat de wereld ook na deze 'zwarte herfstweken' gewoon is blijven voortbestaan, op zijn zachtst gezegd nogal overspannen aandoen. Niettemin moet dit 'doemdenken' (een begrip dat gedurende deze periode ontstaat) voor tijdgenoten zeer herkenbaar zijn geweest. Sterker: wanneer hun afkeer van anarchisten, terroristen en feministen niet zo groot was, zouden deze filmer en zijn buikspreekpop - 'De wereld is een riool' - zich ongetwijfeld goed thuis hebben gevoeld bij de nieuwe politieke partij van de Grïnen, waarvan de oprichting eind jaren '70 niet lang meer op zich zal laten wachten. Want de datering in de eindaftiteling is om nog een andere reden interessant: voor het eerst plaatst Syberberg een werk van zijn hand nadrukkelijk binnen een politieke context:

In latere essays heeft Thomas Elsaesser zich er wel eens over beklaagd, dat de Hitlerregisseur in de jaren ' 90 "increasingly political" zou zijn geworden. 94 Maar zo er al sprake mocht zijn van een politisering, ben ik toch veeleer geneigd dit proces ergens halverwege de jaren ' 70 te laten beginnen. Syberbergs geschriften spreken in dit verband een zo mogelijk nog duidelijkere taal dan zijn films. Lag in Filmbuch (1976), een bundel artikelen uit de periode $1965 \cdot 75$, de nadruk nog geheel op het artistieke werk, dat middels een uitputtende zelfexegese tegen het onbegrip van de criticasters in bescherming diende te worden genomen; in de inleiding van het Hitler-script, Die Kunst als Rettung aus der deutschen Misere (1978), kondigt zich onmiskenbaar een nieuwe tendens aan. Van de 51 pagina's, die dit 'essay' telt, zijn 11 gewijd aan een uiteenzetting van het neo-wagneriaanse esthetische programma ${ }^{95}$ van de Hitler-film en 16 aan een afrekening met de (West-)Duitse filmcritici. De resterende 24 pagina's bestaan uit een verbitterde aanklacht tegen, wat we in hoofdstuk 5 hebben genoemd, het 'psychologische Versailles': de vernietiging van het Duitse mythopoëtische eigene in de door de bezetter verordonneerde re-education. Kort daarop, in het pamflet Die freudlose Gesellschaft (1981), het eerste deel van een trilogie 'Notizen 1976-"90', waartoe ook Der Wald steht schwarz und schweiget (1984) en het beruchte Vom Unglück und Glück der Kunst in Deutschland nach dem letzten Kriege (1990) behoren, is de omslag compleet. "Het mag gerust opmerkelijk worden genoemd," meent Zeit-redacteur Peter Hamm in een bespreking, "dat in een boek van 388 pagina's vrijwel geen enkele gedenkwaardige gedachte opduikt over zijn [Syberbergs, G.G.] eigen métier en een intellectuele discussie met zijn artistieke voorbeelden evenmin plaats vindt als met zijn collega's." 96

We zouden aan dit alles geen aandacht hoeven te besteden - ware het niet dat Hitler, ein Film aus Deutschland en Die freudlose Gesellschaft zozeer in elkaars verlengde liggen.

\footnotetext{
${ }^{93}$ Hitler, a.w., p. 270.

${ }_{94}^{94}$ Elsaesser, Th., Fassbinder's Germany. History, Identity, Subject. Amsterdam, 1996. p. 145.

${ }^{95}$ Zie hoofdstuk 3, paragraaf 5 .

${ }^{96}$ Hamm, P., Syberbergs Kampf. Der Regisseur des Hitler-Films als Autor. in: Die Zeit. 32 (31-07-1981). p. 34.
} 
Terecht spreekt Eric Santner (1992) over een cultuurkritisch postscriptum" bij de film. ${ }^{97} \mathrm{Hij}$ had ook kunnen spreken over een vijfde deel, of een voortzetting met andere - literaire middelen. Zowel qua thematiek als ook qua stijl, zou het hierboven aangehaalde lange citaat van de buikspreekpop-Hitler even goed een aforisme uit Die freudlose Gesellschaft kunnen zijn. Terwijl omgekeerd nogal wat 'wijsheden' uit dit pamflet ongetwijfeld beter tot hun recht zouden komen, indien de filmer ervoor had geopteerd ze temidden van de ruines in de studionuimte te laten voordragen door een in Wagners ochtendmantel gehulde André Heller, met zijn lichtelijk geaffecteerde Oostenrijkse accent:

\begin{abstract}
"Aan alle huis-, stad- en wereldkrakers. Aan de drop outs en opbouwwerkers van onze tegenwoordige tijd en toekomst. Wat zal komen na ' 68 , na buitenparlementaire oppositie, terrorisme, anarchie, feminisme, drugs, sekten, links/rechts-problemen, groeipolitiek, verzorgings- en wegwerpsamenleving, pornografie, cinefilie, pluralisme, Verlichting, uitbuiting van de natuur, na huisbezettingen, demonstraties tegen kernenergie, alternatieven en alle utopieën en revoluties, na het Nürnberg van onze dagelijkse vredesmisdaden aan het slot en de bevriezing van het grote lachen van onze laatste treurnis? Aan de twijfelenden, vertwijfelden, gedesillhsioneerden, de outcasts van de rationaliteit van onze dagelijkse beslommeringen en de ongelovigen in het Principe Hoop ik vond mijn mythe, de mythe van de herinnering, het substraat van de fantasie, een heilzame mogelijkheid nog, ook voor algemeen gebruik, de mogelijkheid, productief te worden, juist nu. En jullie? Lang leve de kunst. De kunst van de herinnering. Maar ook de herinnering aan de kunst."
\end{abstract}

"Mijn God, ik was werkelijk provocerend!," zou de cineast volgens Ian Buruma niet zonder zelfgenoegzaamheid hebben uitgeroepen na afloop van een vertoning van zijn Hitler-film in 1990. ${ }^{99}$ En dat is inderdaad, waar je Syberberg voortdurend van verdenkt. Aldoor heb je het ongemakkelijk gevoel, dat het hem wel eens vooral erom te doen zou kunnen zijn het 'weldenkende' deel van de Westduitse natie schrik aan te jagen. Zo ook tijdens het lezen van Die freudlose Gesellschaft. Het enige verschil met de Hitler-film is, dat Syberberg er dit maal níet voor heeft geopteerd zijn 'wijsheden' in de mond te leggen van een buikspreekpop of één van zijn acteurs. Hier, in dit pamflet, verschuilt hij zich níet achter een fictief personage, maar spreekt hij op persoonlijke titel. Hetgeen mede zou kunnen verklaren waarom de publicatie van Die freudlose Gesellschaft in 1981 het tot dan grootste schandaal uit zijn carrière veroorzaakt. Persoonlijk ken ik slechts één positieve Duitse recensie van dit pamflet. Maar die stond dan ook in Criticón - het huisblad van de Nieuw Rechtse historicus Armin Mohler, de voormalige privé-secretaris van Ernst Jünger, die zich tot doel heeft gesteld in de Bondsrepubliek een nieuwe Conservatieve Revolutie te ontketenen naar het model van de oude uit de Weimar-tijd: ${ }^{100}$

"Dat iemand, die de zege van het establishment van de linkse cultuurhoeders moet ontberen, niet capituleert en zich aanpast, maar terugslaat door de mechanismen van

\footnotetext{
${ }^{97}$ Santner, E., The trouble with Hitler: Postwar German Aesthetics and the legacy of Fascism. in: New German Critique. 57 (Summer 1992). pp. 5-24, zie: 8f.

${ }_{98}^{98}$ Flaptekst van Die freudlose Gesellschaft.

${ }^{99}$ Buruma, a.w., p. 34.

${ }^{100}$ Voor Mohler, die in ons land hoofdzakelijk bekendheid geniet als auteur van het uit 1949 daterende proefschrift Die konservative Revolution in Deutschland 1918-1932. Ein Handbuch. Darmstadt, 1972, 1994, zie bijvoorbeeld: Greß, F., Jaschke, H-G., Schönekäs, K., Neue Rechte und Rechtsextremismus in Europa. Bundesrepublik, Frankreich, Grossbrittannien. Opladen, 1990. pp. 258ff; 277ff, 280ff. Alsmede: Herzinger, R., Revolutionärer Umbruch in die Stammesgemeinschaft? Die Ideologie(n) der Neuen Rechten und ihre Zeitschriften. in: Deutschland Archiv. 12 (1993). pp. 1389-1403, zie: 1391 ff. Zie eveneens: paragraaf 7.7.
} 
het doodslaan respectievelijk doodzwijgen aan de kaak te stellen - dat maakt dit boek zo waardevol. Gepresenteerd wordt een aanklacht tegen het mediabedrijf van de 'linkse intellectuelen', zoals die in deze scherpte en met een dergelijke overvloed aan voorbeelden recentelijk niemand heeft geformuleerd! Syberberg bejegent het vermeend links-liberale cultuurbedrijf zonder ideologische oogkleppen. (..) Het is dan ook geen toeval, dat het een Amerikaanse intellectuele was, die vanuit den vreemde in haar essaybundel Syberbergs Hitler met kennis van zaken heeft weten te appreciëren. Ook haar in deze bundel gepubliceerde opstel Fascinerend Fascisme over Leni Riefenstahl zou zo genuanceerd door geen van de West-Duitse salon-linksen geschreven kunnen zijn. Want zij kennen slechts hun eigen dogma's, echter niet de Geist der Leidenschaft - zoals de titel van Susan Sontags essay over Elias Canetti luidt.".101

\subsection{Partizanenexistentie}

"In een soort retorische jujitsu," schrijft de Amerikaanse publicist Jacob Heilbrunn (1996), "schilderen ze zichzelf af als revolutionairen, strijdend tegen een 'totalitaire' samenleving, die meedogenloos wordt bestuurd door een verbitterde generatie van "68". ${ }^{102}$ Heilbrunn doelt hier op de figuren, die de duistere schemerzone bevolken van rechts-extremistische undergroundbladen als Deutsche National-Zeitung, Mut, Nation Europa, Junge Freiheit of het genoemde Criticón. Het is een bont allegaartje, dat we in deze subcultuur tegenkomen: rancuneuze nazi's, gesjeesde studenten, gedesillusioneerde linksen, wapenfreaks en milieuactivisten, cultuurconservatieven, holocaust-ontkenners, christelijke fundamentalisten en postmodern angehauchte intellectuele avonturiers. Maar al deze activisten van Oud en Nieuw Rechts hebben tenminste eén ding met elkaar gemeenschappelijk: ze delen Syberbergs afkeer van alles, wat ook maar enigszins geassocieerd kan worden met het Nieuw Linkse cultuurestablishment van Jürgen Habermas en de zijnen. ${ }^{103}$ En dat de filmer vroeg of laat vanuit deze hoek bijval zou krijgen, kon dan ook nilet uitblijven.

Zeker, in het Westduitsland van de Tendenzwende behoren dit soort geluiden allang niet meer tot het monopolie van Oud en Nieuw Rechts. Zelfs een uitgesproken linkse figuur als de Beierse Hell's Angel ${ }^{104}$ Rainer Werner Fassbinder, Syberbergs postuum ook in eigen land zo gewaardeerde collega uit de Nieuwe Duitse Cinema, liet er bij leven en welzijn geen misverstand over bestaan, dat hij de Bondsrepubliek uit de grond van zijn hart haatte, omdat het leven aldaar alsmaar onvrijer zou worden. Dan voelde Fassbinder zich in Parijs of New York, waar hij eveneens huizen bezat en (net als Syberberg) zijn grootste triomfen had gevierd, toch meer op zijn gemak. Herhaaldelijk speelde hij zelfs met de mogelijkheid de Bondsrepubliek voorgoed te verlaten. Bijvoorbeeld nadat de 'weldenkende' goegemeente hem weer eens had beschuldigd van antisemitisme. ${ }^{105}$ "Vroeger, toen ik nog films maakte, waarin de vertegenwoordigers van minderheden goed waren en de anderen boosaardig, kon de [Westduitse, G.G.] samenleving mijn films buitengewoon appreciëren," verzuchtte hij in een in 1977 (het jaar van Syberbergs Hitler) afgenomen interview. "Maar toen ik op het veel

\footnotetext{
${ }^{101}$ Platzdasch, G., Mechanismen der Gleichschalung. in: Criticón. 71 (Mai/Juni, 1982). pp. 129f.

${ }_{102}^{102}$ Heilbrum, J., Germany's New Right. in: Foreign Affairs. november/december, 1996. pp. 80-98, zie: 81.

${ }^{103}$ Voor Syberbergs visie op dit cultuurestablishment, zie: hoofdstuk 5, paragraaf 6.

${ }_{104}$ Zoals Faßbinder wordt getypeerd in: Phillips, K., Introduction. in: New German Filmmakers, a.w., pp. ix-xxv, zie: $\mathrm{x}$.

${ }^{105}$ Laqueur, a.w. pp. $14 \mathrm{ff}$.
} 
juistere idee kwam, de minderheden zo te tonen, als ze door de samenleving zijn geworden met hun hele wangedrag, konden mijn films plotseling niet langer door de beugel."106

Fassbinder vreesde, dat dit soort verdachtmakingen wel eens het begin kon zijn van een nieuwe dictatuur, die alle mensen gelijkschakelde. Ooit zou het nog eens zover komen, dat iedereen in Duitsland op elkaar leek; zich hetzelfde kleedde en hetzelfde dacht. ${ }^{107}$ Of, zoals Syberberg het formuleert in Die freudlose Gesellschaft:

"Het meest kwalijke aan de geestelijke situatie van het kritische leven in Duitsland na Hitler is deze gelijkvormigheid, deze eensgezindheid in de oppositie tegen Hitler. Dat brengt de discussie uit het noodzakelijk ritme (...), verlamt de oppositie tegen het officiële leven, dat zich uitsluitend nog oriënteert op deze Hitler-oppositie van de meest primitieve soort, die niet mag worden aangetast, niet ter discussie mag worden gesteld, want dat zou wel eens verkeerd begrepen kunnen worden, met name door de brede massa, ook al weten zij en wij inmiddels beter. (...) De grote kentekenen van dit systeem maken deze macht liberaal, in de zin dat zij geen censuur, geen boekverbrandingen, geen concentratiekampen nodig heeft. De tegenstander wordt eenvoudig niet serieus genomen, uitgezonden, gedrukt of bediscussieerd. Alle redacties, commissies; alsmede film- en cultuurkamers, worden door dezelfde figuren uit dit establishment bemand. (...) Een ieder die waarschuwde, werd als nazi verdacht en onschadelijk gemaakt. In geen ander land kunnen zij die waarschuwen zo snel worden uitgeschakeld. (...) Zolang we dit stompzinnige antifascisme niet bekritiseren, leven we diep in de erfenis van de Hitler-tijd." 108

En, zijn paranoia ten spijt, heeft de filmer hier wel degelijk een punt, merkt Ian Buruma op: "Het is (...) waar, dat antifascisme is 'gereïficeerd" - om een uitdrukking te gebruiken, die werd uitgevonden door de grote joodse linkse denker hoogstpersoonlijk, Karl Marx. Het was [in de beide Duitslanden van voor 1990, G.G.] niet iets waarover je van mening kon verschillen. Antifascisme was de staatsreligie en het historische alibi van het ancien régime in de Oostelijke helft van Duitsland. En het gaf de linkse intellectuelen in de Bondsrepubliek een soort morele knuppel waarmee elke uitdaging van rechts kon worden afgeslagen." 109 Maar dit betekent niet, dat er geen rakvlakken zouden bestaan tussen de Syberberg van Die freudlose Gesellschaft en het vertoog van Oud en Nieuw Rechts, waarin hij uiteindelijk verzeild zal raken. Die zijn er namelijk wel degelijk. En dan denk ik niet alleen aan inhoudelijk thema's als het "psychologische Versailles', 110 maar zeker ook aan de sfeer die spreekt uit zijn boeken en kunstwerken. Volgen we zijn Duitse criticasters, dan hoef je een boek als Die freudlose Gesellschaft immers niet van kaft tot kaft door te nemen om te weten te komen vanuit welke hoek in dit filmatelier de wind waait. Het volstaat om het boek op een willekeurige pagina

\footnotetext{
106. 'Ich habe mich mit meinen Filmfiguren verändert,' Eün Gespräch mit Hella Schlumberger über Arbeit und Liebe, die Ausbeutbarkeit der Gefühle und die Sehnsuch nach einer Utopie, 1977. in: Politics/Poetics. a.w., p. 480 .

${ }^{107}$ Laqueur, a.w., pp. $14 \mathrm{ff}$.

${ }^{108}$ Syberberg, a.w., pp. $79,97,173,133,223$.

109 Buruma, a.w., p. 37 .

${ }^{110}$ De kritiek op de naoorlogse re-education, denazificatie en Vergangenheitsbewältigung; op de geest van '68, het "constitutionele patriottisme" en de "kritische" theorie uit Frankfurt - "de school van onze kritiek en haar misverstanden", aldus Syberberg, Der Wald, a.W., pp. 181f - is, het zal niet verbazen, het hoofdthema van de Duitse Neue Rechte. Zie in dit verband bijwoorbeeld: Mohler, A. Die deutschen in der Mühle. Zum Stand der Vergangenheitsbewältigung nach 'Holocaust' und der Anti-Diwald-Kampagne. in: Criticón. 52 (maart/april 1979). pp. 55-59. Mohler, A., Vergangenheitsbewältigung. Von der Läuterung zur Mamipulation. StuttgartDegerloch, 1968. Diwald, H., Mut zur Geschichte. Bergisch Gladbach, 1983.
} 
open te slaan en de blik over de bladspiegel te laten dwalen, langs al die typisch syberbergiaanse kronkelzinnen.

Het is een eigenaardig soort namaak oud-Duits, dat de filmer zich in de loop der jaren heeft eigen gemaakt; een curieus brouwsel van archaïsmen en neologismen, op smaak gebracht door een gepeperd sausje soldateske metaforiek, die je niet zo een, twee, drie uit de pen van een zichzelf links noemende kunstenaar zou verwachten. Neem het volgende citaat: "Kunst als Gegenwelt, als einzige Opposition einer Demokratie, als Relikt aus aristokratischen Zeiten, diesmal als elitärer Stoßtrupp gegen Verfassungstendenzen, Partisanendasein, von der Opposition zür Übernahme der Regentsehaft, geistig, moralisch, um zu überleben heute und für später. Opposition gegen sich selbst, gegen die Bequemlichkeit der politischen Gewohnheit." "Nog afgezien van de inhoud, is dit niet het soort Duits dat doorgaans aan Westduitse universiteiten - laat staan aan die van Frankfurt - of in de salonfähige media van de Bondsrepubliek wordt gebezigd. Het is meer het quasimetafysische taaltje, dat hoort bij deze Nieuw en Oud Rechtse subcultuur, die op zijn laatst sinds het aantreden van de protestgeneratie van ' 68 ondergronds is gegaan - zo men wil: innerlijk is geëmigreerd. De associatie dringt zich op met de politieke partizanen-leer, die één van de meest vooraanstaande naoorlogse innerlijke emigranten, de staatsrechtsgeleerde Carl Schmitt, aan de vooravond van de studentenonlusten heeft ontwikkeld. ${ }^{12} \mathrm{Of}$, meer nog, met Ernst Jüngers esthetiek van het innerlijke verzet, waaraan Schmitt in zijn Theorie des Partisanen (1963) schatplichtig is. ${ }^{13}$ De tot partizaan geworden innerlijke emigrant van Jünger kent diverse gedaanten. Bijvoorbeeld die van de 'Woudloper' [Waldgänger] uit het in 1951 verschenen pamflet Der Waldgang, in de Spiegel ooit getypeerd als: "een handboek van de stadsguerrilla (...), waarin zinnen te vinden zijn, die (...) sinds de Duitse herfst nauwelijks meer geschreven konden worden zonder dat de auteur daarvoor voor de rechter kwam". 114

Zoals elke innerlijke emigrant, leidt ook de Woudloper een dubbelleven. Naar buiten toe gedraagt hij zich als een loyale burger; een dichter/soldaat in ruste, die de woelingen van de samenleving de rug heeft toegekeerd en zijn laatste levensdagen slijt ergens op het platteland, in een kluizenaarshut aan de rand van het Woud, alwaar hij zich graag mag laten fêteren door de machtigen der aarde. (Tot de talrijke beroemdheden, die in de loop der jaren de veldweg naar Wilfingen wisten te vinden, behoren onder meer Mitterand en Kohl.) Maar de schijn bedriegt. Zijn désinvolture is een zorgvuldig gecultiveerd ethos van verzet. Innerlijk leeft de op het oog zo brave dichtervorst op voet van oorlog met de politiek-sociale realiteit van de moderne tijd. De natuurlijke opponenten van de Woudloper zijn de door de "storm van de geschiedenis" (Benjamin) verblinde functionarissen van het vooruitgangsgeloof, die met hun waandenkbeelden deze monstrueuze anomalie legitimeren. En zijn gehele innerlijke wezen is erop gericht de moderne Moloch tot ontploffing te brengen, door zand te strooien in de machinery of destruction. In het holst van de nacht trekt hij erop uit om in het geniep zijn

\footnotetext{
11 "Kunst als tegenwereld, als enige oppositie binnen een democratie, als relict uit aristocratische tijden, dit maal als elitaire aanvalscolonne tegen tendensen van de grondwet; partizanenexistentie, van de oppositie tot de overname van het regentschap, geestelijk, moreel, om te kunnen overleven mu en later. Oppositie tegen zichzelf, tegen de gemakzuchtigheid van de politieke gewoonten." Syberberg, Die freudlose Gesellschaft, a.w., p. 22.

112 Voor een bespreking van Schmitt, C., Theorie des Partisanen - Zwischenbemerkungen zum Begriff des Politischen. Berlin, 1963, zie: Sombart, N., Die deutschen Männer und ihre Feinde. Carl Schmitt-ein deutsches Schicksal zwischen Männerbund und Matriarchatsmythos. München, Wien, 1991. pp. 363-368.

${ }^{113}$ Voor de invloed van Jünger op Schmitts partizanen-leer, zie bijvoorbeeld: Meyer, M., Ernst Jünger. München, Wien, 1990, 1993. p. 662. Tommissen, P., Ernst Jünger en Carl Schmitt. Een balans. in: Yang. 2-3 (april-september 1992) pp. 226-235, zie: 229 .

Augstein, R, Karasek, H., Wieser, H., 'Broederschap drinken met de dood". Interview met Ernst Jünger
(fragment). in: Yang, a.w., pp. 239-251, zie: 248. [Eerder verschenen in: Der Spiegel. 33 (1982).]
} 
subversieve handwerk te beoefenen. 115 "De Woudloper (..) kent zijn dwangkampen, de schuilplaatsen van de onderdrukten, de minderheden die wachten tot hun uur gekomen is," aldus Jünger. "Hij voert de kleine oorlog langs de spoorwegen en aanvoerwegen, vormt een bedreiging voor de bruggen, kabels en depots. (..) De Woudloper beschikt niet over de grote strijdmiddelen. Maar hij weet hoe wapens, die miljoenen kosten, door één moedige daad vernietigd kunnen worden. Hij kent hun tactische zwakheden, hun kwetsbaarheid, hun ontvlambaarheid."116

We mogen deze manmoedige soldatenpraat niet al te letterlijk nemen. Evenals Syberbergs 'partizaan' is ook de Woudloper van Jünger in hoofdzaak een metafoor voor de positie van de kunstenaar ten opzichte van de moderne Leviathan. Het Woud, dat deze eenzame strijder tot zijn uitvalsbasis heeft gemaakt en waar hij telkens weer naar terugkeert om nieuwe levenskrachten op te doen, is niets anders dan de 'tegenwereld' of ware Welt van de kunst, de filosofie en de theologie. ${ }^{117} \mathrm{En}$ in tegenstelling tot de plebejers van de linkse stadsguerrilla, bezondigt de verfijnde estheet van de Woud- of Kultur-guerrilla zich ook niet aan het werpen met molotovcocktails, laat staan dat het bij hem opkomt om een passagierstoestel van de Duitse Lufthansa te kidnappen. Zijn verzet is vele malen subversiever. In een wereld, die geheel en al in het teken staat van nihilisme en mediocriteit, houdt hij met zijn 'elitaire' kunst-werk de herinnering levend aan 'aristocratische tijden", waarin de leugen nog niet regeerde. Het kunst-werk van de anamnese vormt de enige, echte totale oppositie binnen een aufgeklärte mediacratie, die in naam van de 'aristocratie van de waarheid"118 of de "kosmische harmonie"119 van het zijnde tot op haar fundamenten wordt bestreden. In deze zin dient ook de titel te worden begrepen van het tweede deel van Syberbergs Notizen, waarin expliciet aan de Woudloper-esthetica van Jünger wordt gerefereerd. ${ }^{120}$ Der Wald steht schwarz und schweiget, een strofe uit een gedicht van Matthias Claudius, verwijst niet enkel naar de deplorabele staat van het door de uitlaatgassen van de moderniteit geteisterde Duitse woud (niet toevallig samen met de adelaar, waarvan de buikspreekpop-Hitler het 'uitsterven in Europa' betreurt, hèt Duitse symbool bij uitstek). Het is ook een allegorie voor het sterven van de Kultur. ${ }^{121}$

\subsection{Het motief van de post-histoire}

In hetzelfde jaar als de Hitler-film verschijnt van de hand van Ernst Jünger de fantasieroman Eumeswil (1977). Het boek biedt zowel een verdere verfijning van de Woudloper-esthetica, ${ }^{122}$ als ook een intrigerende metafysische parabel over de post-histoire. Plaats van handeling is Eumeswil - een fictieve, in de verre toekomst gesitueerde stad, aan "een windstille lagune

\footnotetext{
${ }^{115}$ Ik volg hier in grote lijnen: Meyer, a.w., pp. 405-429. Ipema, J., Ernst Jünger in Nederland. Enkele kanttekeningen. in: Yang, aw, pp. 184-201, zie: 189ff. Schwilk, H., Der Traum des Anarchen. in: Magie der Heiterkeit. Emst Jünger zum Hundertsten. Hrsg. H. Schwilk, G. Fidal. Stuttgart, 1995. pp. $269-277$.

${ }^{116}$ Citaat ontleend aan: Augstein, Karasek, Wieser, a.w., p. 248.

117 Meyer, a.w, pp. $424 \mathrm{f}$.

${ }^{118}$ Syberberg, Die freudlose Gesellschaft, a.w., p. 30.

119 Ipema, a.w., p. 189.

${ }^{120}$ Syberberg, Der Wald, a.w., pp. 97f, 372, 376.

121 idem, p. 373 .

122 Jünger maakt een subtiel verschil tussen de soldaat, de 'Arbeiter', de anarchist, de 'Anarch", de woudloper en de partizaan. Zo onderscheidt de woudloper zich onder meer van de partizaan, doordat de laatstgenoemde altijd in een collectief optreedt. Jünger, $\mathrm{E}_{\text {., }}$ Sämtliche Werke. Dritte Abteilung. Erzählende Schriften III. Band 17.

Eumeswil. Stuttgart, 1980. p. 137. Het onderscheid is echter zo subtiel, dat ik hierboven ervan ben uitgaan dat de woudloper een partizaan mag worden genoend. Ik volg hier de literatuur. Zo spreekt Jüngers intellectuele biograaf, de publicist Martin Meyer, naar aanleiding van de woudloper-esthetica over een "partizanentheorie". Meyer, a.w., p. 428.
} 
waar enorme hoeveelheden strandgoed van verdronken schepen is aangespoeld". ${ }^{23}$ Als een pelgrim, die na een lange reis moe het hoofd in de schoot heeft gelegd, is de geschiedenis aan haar einde gekomen. De Goden hebben de mensheid reeds lang geleden de rug toegekeerd; het Huis van de traditie is "uitgestorven" - "versteend tot een sarcofaag van de geest, een mausoleum van een uitgebrande wereld". 124

Natuurlijk, ook in de post-histoire worden bij tijd en wijle nog wel eens conflicten uitgevochten. Er lopen zelfs nog lieden rond met een uitgesproken opinie. Zo trekken enkele professoren om hun studenten te imponeren fel van leer tegen de staat, waarbij ze vervolgens in een moeite door aankloppen om salaris, pensioen en kinderbijslag te innen. ${ }^{125}$ Maar de "grote ideeën", waarvoor "miljoenen hun leven hebben gelaten", zijn "opgebruikt". Afgezien van het eigen genot of het geroezemoes van de waan van de dag, wordt niets meer serieus genomen. Uitsluitend wanneer de inhoud van het loonzakje in het geding is, of tijdens karnaval, wil het volk nog wel eens de straat optrekken om te demonstreren. ${ }^{126}$ Maatschappelijke verschillen zijn uitgewist. 'De elite is vernietigd, de demos tot massa geëgaliseerd. "127. 'Besneden of onbesneden, wit, geel, neger, arm of rijk' - in de toekomstwereld van Eumeswil is het allemaal om het even. "Over het algemeen kan men hier doen, wat men wil," verzucht de ik-figuur/verteller Manuel Venator, historicus van beroep. ${ }^{128}$

Als "een technicus in dienst van een sloopbedrijf", voelt de historicus Venator zichzelf in dit Kultur-hiernamaals, waarin de geschiedenis is verworden tot "een kadaver". ${ }^{29}$ Zijn dagen brengt hij door achter de Luminar - een soort computer of digitaal databestand, waarin de dode geschiedenis ligt opgeslagen. Het is een wonderlijke apparaat, door hemzelf getypeerd als "een tijdmachine die tegelijk de tijd opheft". ${ }^{130}$ Niet slechts kan de gebruiker met één enkele druk op de knop diverse historische werelden voor zijin geestesoog laten verschijnen; hij kan bovendien, door de machine met bepaalde premissen te voeden, zich verschillende hypothetische versies van de geschiedenis laten voorspelen. Door Manuel Venator (wiens naam zoveel betekent als: de jager of onderzoeker, die God aan zijn zijde heeft) wordt de Luminar hoofdzakelijk gebruikt als een instrument om antwoord te krijgen op een brandende vraag, die hem gedurende het gehele boek bezighoudt - tot hij in de epiloog voorgoed in het Woud verdwijnt: waar ging het mis? Moeten de kiemen van de catastrofe, zoals één van Venators leermeesters vermoedt, worden gezocht in de periode direct na de wereldoorlogen - een door en door nihilistische tijd, waarin aan alles werd getwijfeld, behalve aan wetenschap en techniek, en de taal begon te verloederen ("Geschiedenisverlies en taalverlies zijn twee zijden van dezelfde medaille.")? ${ }^{131}$ Of dient het verval veeleer te worden toeschreven aan een weeffout in de schepping en was de ondergang van meet aan als een soort fatum of erfschuld in de Kultur van het Avondland ingebakken? ${ }^{132}$ "Wat precies gaande was, wisten zelfs de tijdgenoten niet," tobt de historicus. "Hier, in Eumeswil, heeft het perspectief zich in zoverre versimpeld, dat de droomachtige elementen hebben toegenomen en de realiteit afzwakken. Als historicus kan ik hen [de utopieën van de geschiedenis, G.G.] niet serieus nemen, wel als duider van dromen. Ik kijk door hen naar de geschiedenis met haar kathedralen en paleizen terug, als naar een verzonken Atlantis. Ik hoor de klank van de klokken uit de diepte; dat is een pijnvol genot. (...) Een van de symbolen voor ruimten zonder

\footnotetext{
123 Jünger, a.w., p. 19

124 idem, pp. $60,71,144 f$.

125 idem, pp. $108,124$.

126 idem, p. $60,71,74 f$.

127 idem, pp. 95, 199.

128 idem, p. 75 .

${ }^{129}$ idem, pp. 52, 97f, 169.

${ }^{130}$ idem, p. 353 .

131 idem, pp. $84,375$.

13.2 idem, pp. 10 ff.
} 
geschiedenis is de vuilstortplaats. De ruimte wordt door het afval bedreigd. Het puin wordt niet meer verwerkt, zoals in de Kulturen; het overwoekert de beschavingen. Wanneer een schip keldert, spoelen de wrakstukken aan op het strand."133

'Stranded Objects' noemt Eric Santner de cultururhistorische citaten, die in de studioruimte van Hitler over het speelvlak liggen uitgestrooid ${ }^{134}$ - 'gestrande objecten', wrakstukken, bergen van puin, losgeslagen door de 'storm van de geschiedenis' (Benjamin) en aangespoeld op het strand van een geschiedenisloze ruimte: de vuilstortplaats van de Syberberg-Factory. En inderdaad heeft Syberberg overduidelijk eveneens met dit motief van de post-histoire gespeeld. " (...) Hoe moet men, hoe moet ik, hoe moeten wij, wie ben ik, wie zijn wij, wie speelt ons en wie spelen wij, waarom, wat blijft, nog een keer alles samen, restanten van een verloren Kultur en een verloren leven, ons Europa voor de ineenstorting," mijmeren de acteurs in één van de openingsscènes. "Afscheid van het Avondland. Sub-specie aeternitatis en alles op film, onze nieuwe kans. De geschiedenis van de dood van het oude Licht, waarvan wij leefden en onze Kultur, een ver gezang." ${ }^{35}$ De tekst verwijst naar een bekende studie van Hans Sedlmayr, waarop ik in hoofdstuk 2 reeds uitvoerig ben ingegaan: het in 1963 verschenen Tod des Lichtes. ${ }^{136}$ Zoals we zagen in dat hoofdstuk slaat de titel op het oorspronkelijke, ongeschapen en scheppende Goddelijke Licht, dat de Kultur van het Avondland in haar vroegere, premoderne fasen doorstroomde - tot de krachten van de Duisternis - lees: Verlichting - haar van dit transcendente centrum (Mitte) beroofden en de moderne chaos van de -ismen een aanvang nam.

Ook de opmerking van de eircusdirecteur, dat wijzelf het onderwerp van de film vormen, zou even goed vanuit deze filosofie van de post-histoire kunnen worden uitgelegd. Want volgen we de circusdirecteur, dat gaat het in dit werk niet enkel om 'ons', binnen het linkse cultuurdebat als 'fascistische hunkeringen in ons midden' getaboeïseerde Duitse gevoelsleven; het zou tevens gaan om de "Hitler in ons". ${ }^{137}$ Terecht heeft Anton Kaes ${ }^{138}$ erop gewezen, dat deze uitdrukking is ontleend aan een in de Adenauer-tijd populair boekje van de Zwitserse schrijver, kunsttheoreticus en fysionomist Max Picard, die evenals Jünger en SedImayr in de traditie van de Conservatieve Revolutie staat. In het bewuste boekje Hitler in uns selbst (1946) wordt Hitler, of meer specifiek diens gelaat, geduid als een spiegelbeeld van de chaos van de moderniteit, die op zijn beurt weer niets anders zou zijn dan een symptoom van de chaos in het innerlijk van de volkomen van God losgeraakte modeme mens:

"Zo ziet het gezicht van het totale niets er uit. Het lijkt een door een onhandige krabbelaar getekende nul en op de lege plekken, waar bij een mens de ogen en de mond zijn, heeft de krabbelaar een paar inktvlekken laten vallen. (...) In het gezicht van Hitler heeft het totale niets zijn uitdrukking gevonden (...). Maar het is geen beeld, want van het niets kan geen beeld bestaan. Het is het uiterlijk van het niets, het is de buitenkant van een lege bol. (...) Zoiets heeft nog nooit bestaan. Want in de wereld der volheid, in de wereld van de samenhang en de duur, gaat het niets ten onder. (...) Alleen in een wereld, waar iedere samenhang totaal [ontbreekt], is het mogelijk dat dit totale niets niet als het niets [wordt] herkend. Het is afgebeeld als het

\footnotetext{
133 idem, pp. $231 f, 371$,

${ }^{134}$ Santner, Stranded Objects, a.w., p. 142.

${ }^{135}$ Hitler,a.w., p. 70.

${ }^{136}$ Sedlmayr, H., Tod des Lichtes. Ubergegangene Perspektiven zur modemen Kunst. Salzburg, 1963. Zie: hoofdstuk 2, paragraaf 6 .

${ }^{137}$ Hitler, a.w., p. 88. Zie eveneens: Syberberg, Die Kunst als Rettung..., a.w., p. 9: "Ja, nur hier, in einem Film der Kunst unserer Zeit, über gerade dieser Hitler in uns, wird Hoffnung kommen dürfen".

${ }^{138}$ Kaes, a.w., p. 50: "Hitler in Syberberg's film appears as 'nothing', as Picard once called him in his 1949 book Hitler in uns selbst (Hitler in Ourselves), and at the same time as 'everything': 'Hitler" means nothing other than an empty vessel into which the most diverse legends, anecdotes, and representations can be poured".
} 
niets, glashelder afgebeeld als het niets, doch men ziet het niet: in de wereld van de totale discontinuitteit kan men namelijk niet zien." 139

Zoals de filmopera Parsifal (1982), het laatste deel van Syberbergs Graal-cyclus, is gesitueerd op, rond en in het dodenmasker van Richard Wagner, ${ }^{140}$ zo lijkt deze Hitler-film aus Deutschland zich af te spelen in dit 'totale niets' van het gelaat van de Führer. Want wat is het toneelbeeld anders dan een artistieke expressie van deze post-historische "wereld van de totale discontinuitteit', waarvan Hitlers gezicht als we Picard mogen geloven het spiegelbeeld zou zijn? "De geschiedenis," schrijft Kaes, "verschijnt in deze film als een bazaar. (...) Syberbergs film heeft veel weg van een lunapark, waarin (...) de verschillen tussen hoge en lage cultuur er niet langer toe doen en alle stijlen promiscue door elkaar wervelen." 141 En net als de windstille lagune van Eumeswil is ook dit filmische lunapark een cultuurhistorisch eindstation - "eine Projektion ins schwarze Loch der Zukunft" "Godenschemering zonder Goden, de Apocalyps van de vooruitgang, eindtijd door de milieudood van de soort mens in het subversieve gekrioel van de insecten, of zielendood van een ijstijd-samenleving.' Wie hier vertoeft, zal - om het met een Dante-citaat te zeggen - 'alle hoop moeten laten varen'. Of misschien toch niet helemaal?

Al laat hun komst nog duizend jaar op zich wachten, voorspelt de (dan inmiddels) hoogbejaarde Ernst Jünger in een essay uit 1993: de Goden moeten én zullen op aarde wederkeren - "(...) Want zonder Goden geen Kultur". 143 Zelfs Sedlmayr, die nog vele malen sceptischer staat ten opzichte van de moderniteit, houdt aan het slot van Verlust der Mitte (1948) rekening met de mogelijkheid, dat de Christus-Mens ooit zijn plaats op de vacant geraakte troon in der Mitte opnieuw zal innemen. ${ }^{144}$ Zoals ook de regisseur van Hitler, ein Film aus Deutschland nog lang niet van zins lijkt de handdoek in de ring van de 'Kulturhölle rondom ons' te gooien. Want Kaes vergist zich deerlijk, als hij schrijft dat 'de fragmenten fragmenten blijven"; "Ze liggen versplinterd rond op Syberbergs toneel, dood en zonder context". "Dit filmische ruinnelandschap mag dan veel weg hebben van de vuilstortplaats in Eumeswil - het stort is rechtstreeks verbonden met de geschiedenisfabriek. En anders dan in Jüngers apocalyptische visioen stapelt het puin zich hier dan ook niet op, maar wordt het, zoals in vroegere Kulturen (zie hierboven) gebruikelijk was, (her-)verwerkt - tot levende geschiedenis gerecycled, ja, wie weet, zelfs tot nieuwe Kultur.

Midden op de vuilstortplaats, "in der Mitte," schrijft Syberberg met een knipoog naar Sedlmayrs Verlust der Mitte, ${ }^{146}$ dat wil zeggen: op de vacant geraakte troon van de ChristusMens, staat de "zwarte zon van het Licht". Het is de Black Mary, de geboortestudio van de cinema, een soort Luminar uit celluloid - zij het dat dit "heilige apparaat" aanzienlijk meer mogelijkheden biedt dan de "tijd opheffende tijdmachine' van de historicus Venator. Deze "zwarte kamer," de "zwarte moeder van onze fantasie", stelt ons niet slechts in staat "oude geschiedenissen" opnieuw te beleven - "geschiedenissen van heimwee, hunkering en

\footnotetext{
${ }_{140}^{139}$ Picard, M. Hitler in whs selbst. Erlenbach-Zürich, 1946, pp. $68 \mathrm{ff}$.

140 Zie: hoofdstuk 3 , paragraaf 1 .

141 Kaes, a.w., p. 47.
}

142 Hitler, a.w., p. 285. "Syberbergs flitler kent geen beweging voorwaarts," observeert Kaes, a.w., pp. 48f. "In plaats daarvan roept hij elegische herinneringen op aan een glorie uit het verleden en een gevoel van de Apocalyps. Waar ontwikkeling of verandering niet langer mogelijk zijn, verdwijnt de toekomst."

${ }_{143}$ Jünger, E., Gestaltwandel. Eine Prognose auf das 21. Jahrhundert. in: Die Zeit. 29 (16 Juli 1993). p. 36.

144 Sedlmayr, Verlust der Minte a.w., pp. 246 ff, Zie eveneens; hoofdstuk 2, paragraaf 6. Net als Sedlmayr zoekt ook Picard de uitweg uit de moderne crisis in een ethisch-religieus reveil . Zie bijvoorbeeld: Picard, M., Die Flucht vor Gott. Warm ist der Mensch allein? Erlenbach, 1935, 1958. pp. 148ff. Picard, M., Die Alomisierung
in der modernen Kunst. Hamburg, 1954 .

$145 \mathrm{Kaes}$, a.w., p. 48.

146 Syberberg, H.J., Gesamtkunstwerk. in: Der Hang zum Gesamtkunstwerk. Europäische Utopien seit 1800.
Hrsg. S. Haen. Aurau, 1983. pp. 433f. 
waanzin in ons innerlijk, nadat van buiten geleidelijk alles verbouwd is". Het is bovendien een soort energiecentrale, een autonoom Licht-opwekkend en Licht-gevend centrum, de generator van de geschiedenisfabriek, waaruit een nieuw, bezielend Licht over de ruïnes straalt - "een kunstmatig Licht, ditmaal, uit het zwarte omhulsel van onze film-fantasie voor het innerlijke oog". ${ }^{47}$ Solang die Erinnering taugt, luidt de titel van een veelgeciteerd aforisme uit Die freudlose Gesellschaft. De tekst gaat als volgt:

"Vroeger trokken we de wereld in, reisden, studeerden, filosofeerden, leerden van de natuur en de mensen en van de avonturen in de wouden en dalen. We lazen en discussieerden, bakkeleiden over theater en filosofeerden en maakten ons dingen eigen, waaruit vervolgens nieuwe daden ontstonden. $\mathrm{Nu}$ is de wereld opgedeeld, vergeven aan de geschiedenis en de tradities van onze Kultur, die de bron vormen van onze werken. Gigantische depots van de oude Kulturen vol citaten, waaruit zich nieuwe Kulturen vormen. Alles, wat we laten zien, laten horen, is al eens gebruikt, aangeraakt en alleen uit de herschikking van de systemen en de fragmenten kan, wanneer het lukt, het nieuwe ontstaan. Uit het oude is ons nieuwe gebouwd. Het is ons lot, onze kans en onze nieuwe Lust, die ihre Ewigkeit will, zoals voorheen. De mythologieën van de dolende Odysseus van vandaag zijn uit citaten van de wetenschap van onze geschiedenis gebouwd en de angst, die de Penelope van vandaag te horen krijgt, dreigt chaotisch aan de horizonnen van de landschappen in ons, als een voorgevoel van het einde van alle geschiedenis. Waarop vervolgens Prospero nog eenmaal zijn toverstaf neerlegt, na de eindeloze gang van Beatrice en alle doden van de Fausts en Tristans en Wotans. Alsmaar weer, zolang de herinnering deugt."148

\subsection{Counterhistory}

Nogal wat exegeten, waaronder ook Kaes, ${ }^{149}$ hebben in dit nietzschiaanse aforisme ("Weh spricht: Vergeh!/ doch alle Lust will Ewigkeit -,- will tiefe, tiefe Ewigkeit!" 150 ) een bekentenis tot het postmodernisme menen te lezen. En je zou denken, dat in een dergelijke indeling weinig kwaad schuilt. De betekenis van het begrip postmodernisme is, sinds het in de vroege jaren '70 werd geïntroduceerd, zozeer opgerekt, dat onderhand zelfs V. 1. Lenin zou kunnen doorgaan voor een postmodernist. ${ }^{151}$ Ook het werk van Ernst Jünger wordt door sommigen geïnterpreteerd als postmodern. ${ }^{152}$ Toch heeft Syberberg zich altijd met klem van het

${ }^{147}$ Hitler, a.w., pp. 70, 271,

${ }^{148}$ Syberberg, Die freudlose Gesellschaft, a.w., p. 83 .

${ }^{149}$ Kaes, a.w., p. 47: "Syberbergs stilistische strategie van profilering, naast elkaar plaatsing, contradictie en intertekstualiteit verraadt zijn affiniteit met de poettica van het postmodernisme (...)". Zie eveneens: Kaes, Holocaust and the End of History, a.w., passim. Ook Santner, a.w., passim begrijpt het werk van Syberberg als 'postmodern'.

${ }_{150}^{150}$ Nietzsche, F., Also sprach Zarathustra. Vierter und letzter Teil. Das Trunkene Lied. 11/12.

151 "Het woord postmodernisme is (..) gaan lijken op een geldstuk dat door vele vingers is gegaan. De beeldenaar is afgesleten en het gewicht komt niet meer overeen met de ijkwaarde. Niet de nominale waarde is van belang maar de ruilwaarde. Het muntstuk wordt slechts geaccepteerd dankzij de volharding van de conventie. Het kan als betaalmiddel functioneren, enkel door het feit dat het circuleert." Dijk, H., van, Het postmoderne en architectuur: we wéten zoveel. in: Het postmoderne aan kinderen verklaard. red.

Bonnefantenmuseum Maastricht, Museum van Hedendaagse Kunst Antwerpen. Maastricht, Antwerpen, 1988. pp. $22-37$, zie: 22 .

${ }^{152}$ Bijvoorbeeld door Peter Koslowski in zijn in 1991 verschenen studie Der Mythos der Moderne. Die dichterische Philosophie Ernst Jüngers. Zie: Graef, O., van, Een apotheose van het postmoderne. in: Yang, a.w., pp. 236-238. 
predikaat postmodernisme menen te moeten distantiëren. "Ik voel me niet erg prettig bij een dergelijke indeling", bekent hij in een interview uit 1987. "Ik zou me, wanneer het al moet, veeleer in de hoek van een anti-modernisme situeren (...)" ${ }^{153}$ En voor wie deze filmer door de jaren heen nauwlettend heeft gevolgd, zal dit niet als een verrassing komen. Een kleine tien jaar eerder, in de Hitler-script-inleiding Die Kunst als Rettung aus der deutschen Misere, heeft hij zich immers reeds nadrukkelijk in deze hoek gesitueerd. Dat wil zeggen: in de hoek van de romantische Gegenaufklärung, ${ }^{154}$ waardoor ook het decorbeeld van Hitler mede zou zijn geïnspireerd. "De romantici hadden de gewoonte grote ruïnebeelden te schilderen (bijvoorbeeld Eldena van Caspar David Friedrich)," verduidelijkt Syberberg in Der Wald steht schwarz und schweiget. "Wat ze daarmee beoogden was niet zozeer contemplatie of culture morte; het was de zinnenprikkelende kracht van het associëren. Men ketent de meest uiteenlopende lagen en lijnen van gedachten en gevoelens aaneen, dood plus geschiedenis plus de eigen toestand, kunst en leven."155

Interessanter echter dan de vraag, of we hier al dan niet van doen hebben met een postmodern kunstwerk, lijkt me het volgende te zijn: de collage-esthetiek van deze film biedt ruimte voor enkele staaltjes 'retorische jujitsu' (Heilbrunn), die zelfs in de politieke underground van Oud en Nieuw Rechts ongehoord zijn. In de handen van de vrijelijk associërende en combinerende filmmagiër wordt de geschiedenis als een bal van was, die hij naar believen kan kneden tot een zéér explosief geheel. Zo kan hij, door zwarte GI's als een reïncarnatie van de nazi-spoken samen met blonde Duitse meisjes te laten dansen rond Wagners graf, de naoorlogse ontheiliging én onteigening van de Duitse cultuurtradities aan de kaak stellen. Of, door Westduitse filmeritici af te beelden als geestverwanten van de nationaal-socialistische boekverbranders en de stalinistisehe Biermann-vervolgers in de DDR, zijn gram halen op de criticasters in eigen land. Hij kan, door een buikspreekpop-Hitler de loftrompet te laten steken op de anarchisten, terroristen en feministen, de antifascistische protestgeneratie van ' 68 ridiculiseren. Of, door illustere historici, publicisten en cineasten die zich verdienstelijk hebben gemaakt op het terrein van de Vergangenheitsbewältigung in met bloed besmeurde slagerjassen te laten poseren rond het verkoolde stoffelijke overschot van Goebbels; nog eenmaal zijn gal spuien over het 'psychologische Versailles' - de vernederende, zelfkastijdende "business met de schuldvraag", 156 die het ooit zo trotse volk van Wagner en Nietzsche onwaardig zou zijn.

Er bestaat een treffendere aanduiding dan postmodernisme voor het genre van geschiedschrijving, dat Syberberg in deze film beoefent; een aanduiding, die nauw aansluit bij één van de etiketten ('Kunst als Gegenwelt'), die hij zelf gebruikt: counterhistory. De bedenker van deze naam is de historicus Amos Funkenstein, die in Berkeley een leerstoel voor joodse geschiedenis bekleedt. Counterhistory, schrijft Funkenstein in een in 1992 gepubliceerd essay, is een 'polemische' geschiedschrijving. Haar doel is "de vervorming van het zelfbeeld van de opponent door de deconstructie van diens herinnering". En haar methode bestaat "uit het systematisch binnenste buiten keren van de door de opponent meest vertrouwde bronnen - die Geschichte gegen den Strich kämmen". Volgen we Funkenstein,

\footnotetext{
${ }^{153}$ Rötzer, F., Mit kleinsten Mitteln sehr Anspruchsvolles offerieren. Gespräche über Ästhetik (III). in: Frankfurter Rundschau. 02-10-1987. p. 2.

${ }_{154}$ Zie: hoofdstuk 3, paragraaf 5. Terecht spreekt Karl Heinz Bohrer naar aanleiding van de Hitler-film over 'een scandaleuze enscenering van de gegenaufklärerische romantiek": "Het is de programmatische verwerping van de 'rede" en de irrationele cultus van de krankzinnige outsider". Bohrer, K.H., Die drie Kulturen. in: Stichworte zur "geistigen Situation der Zeit". Band 2: Politik und Kultur. Hrsg. J. Habermas. Frankfurt am Main, 1980. pp. 636669, zie: 657.

${ }^{155}$ Syberberg, Der Wald, a.w., p. 199. Inderdaad, ook het romantische ruïnebeeld was natuurlijk reeds "een zinnebeeld voor een bevroren wereld", zoals Kaes, Holocaust and the End of History, a.w., p. 219 het decorbeeld van Hitler interpreteert. Denk in dit verband alleen al aan Friedrichs Zee van ijs uit 1824.

${ }^{156}$ Hitler, a.w., pp. $120 \mathrm{f}$.
} 
dan kent het genre een lange traditie, die terugreikt tot in de antieke tijd en de vroege middeleeuwen (de ketterse geschiedschrijving). Het meest bekende voorbeeld in onze dagen is het historische revisionisme van figuren als de Franse holocaust-ontkenner Robert Faurrison. ${ }^{157}$ Waarbij Syberberg, zoals we in het hierna volgende hoofdstuk nog meer in detail zullen zien, reeds ten tijde van de Hitler-film gevaarlijk dicht in de buurt komt.

Maar revisionistisch waren Syberbergs films altijd al - en wel in de zin waarin bijvoorbeeld ook de studies van Ernst Bloch revisionistisch zijn. Dat wil zeggen: ze probeerden een revisie te bieden van de sinds Georg Lukács en de late Thomas Mann in vooral linkse kringen gemeengoed geworden gewoonte om de Duitse cultuurgeschiedenis op te delen in goede en foute, gezonde en decadente of zieke, progressieve en reactionaire, linkse en rechtse, humanistische en fascistische traditiesporen. ${ }^{158}$ Want daaraan bestaat van oudsher behoefte, verzucht Hans Mayer in zijn in 1996 verschenen Brecht-monografie over de cultuurtheorie van Lukács: "Een duidelijke oplossing. Zuivere verhoudingen. Stalin - we weten het - hield van zuivere verhoudingen."159 Aan deze 'zuivere verhoudingen' heeft Syberberg zich nooit veel gelegen laten liggen. Zo ook niet in Hitler, ein Film aus Deutschland. "De agressiviteit is groot," constateert Karl Heinz Bohrer (1980). "Niet omdat de auteur-regisseur mythen ensceneert, maar omdat de taboes en conventies van het naoorlogse Duitsland worden opengebroken:" 160 Waarbij ook Bohrer, zoals we zagen in hoofdstuk 3, denkt aan de 'conventies' van de 'irrationalisme'-kritiek, die grote delen van de Duitse cultuurgeschiedenis zijns inziens tot een "nationaal taboe" maken, dat ook "kunstrichtingen en cultuurconcepten [treft], waaronder buitenlandse, die zich zelfs niet met de meest kwade wil als reactionair, regressief of fascistisch laten omschrijven". ${ }^{161}$

${ }^{157}$ Funkenstein, A., History, Counterhistory, and Narrative. in: Probing the Limits of Representation, a.w., pp. 66-81. In een interview uit 1991 antwoordt Syberberg op de vraag, in hoeverre zijn Hitler-film mag worden beschouwd als een vorm van geschiedschrijving, het volgende: "Moeilijk..., want men zou eerst moeten overdenken: wat is geschiedenis en geschiedschrijving, en wat is documentatie en interpretatie? Ik bedoel, aan de ene kant hebben we de feiten, de realiteiten, die we geschiedenis noemen. Deze realiteiten worden overgeleverd, door de generaties heen, en sinds de nieuwe tijd ook schriftelijk. Oorspronkelijk door orale, mythische representaties, verhalen, herinneringen, vervolgens ook in geschreven vormen. En, tegenwoordig, datgene wat men wetenschap noemt. Met wisselende belangen van de epochen, de ideologieën en de filosofieën. En het zal natuurlijk altijd zeer verschillend zijn. Maar we weten, dat de legenden niet zelden sterker zijn dan de realiteiten. Inmiddels kennen we ook de representatie van de realiteit door de media. Dat wil zeggen: kranten, radio, televisie... een zeer sterk en machtig apparaat op het terrein van het bewustzijn. En we weten, dat ook veel onderhuids, onder de media existeert. Dat wil zeggen: er bestaat, wat men noemt, een zwijgende meerderheid. Men gelooft niet alles; wat wordt gezegd, wat geschreven staat in de kranten. En dat is naturulijk een interessant fenomeen. Niet enkel in het Oosten bestaat zoiets, maar ook in het Westen. Niet enkel in het Oosten was datgene wat men officieel schreef en zei anders, dan hoe het werkelijk was. Ook in het Westen, bestaat zoiets; Ook de kunst neemt tegenwoordig een deel van de geschiedschrijving, van de herinnering voor haar rekening. En zij zal altijd schatplichtig zijn aan de esthetiek van de tijd. Natuurlijk zal men... zullen alle machtigen, wie het ook mogen zijn, proberen de geschiedenis, de herinnering in hun zin te schrijven. Mijn werk is controversieel, omdat ik bepaalde dingen doe en andere niet. En wie weigert mee te doen, is verdacht en wordt bestreden. Goed, Hitler, zoveel is duidelijk, heeft een bepaalde vorm van kunst niet toegestaan. Hij heeft deze kunst verboden en verbrand. Maar dat doen de anderen natuurlijk ook. Niet enkel uit modegevoeligheid, maar ook bewust, in de zin dat men bepaalde dingen niet toestaat en verhindert. Men geeft geen geld. Of men verspreidt negatieve propagandameningen, met als gevolg dat niemand er naar toe gaat. Er vindt een voortdurend proces van uitsluiting plaats, niet enkel kwalitatief of modieus, maar ook heel direct met een eigenaardig soort consensus. $\mathrm{Ja}$, en ergens in dit geheel heeft natuurlijk ook de filmische geschiedschrijving haar plaats. De mijne in het bijzonder. Omdat ik bepaalde dingen doe en andere niet. En dat is natuurlijk een strijd." Interview met de auteur en Eling Delleman, zomer 1991.

${ }_{158} \mathrm{Zie}$ : hoofdstuk 2, de paragrafen 4, 5,8,10; hoofdstuk 3, de paragrafen 4,6,7 en 8; hoofdstuk 5, paragraaf 6 .

${ }^{159}$ Mayer, H., Brecht. Frankfurt am Main, 1996. p. 242.

${ }^{160}$ Bohrer, a.w., p. 657.

${ }^{161}$ Bohrer, K.H., Deutschland - noch eine geistige Möglichkeit? Bemerkungen zu einem nationalen Tabu. in: Frankfurter Allgemeine Zeitung. 28-04-1979. Zie eveneens: de paragrafen 3.8 en 4.1. 
Met deze, zoals Syberberg het zelf noemt, 'ingeslagen en geleerde weg van het argumenteren," ${ }^{162}$ staat Hitler, ein Film aus Deutschland inderdaad overduidelijk op gespannen voet. Enerzijds biedt de film welhaast een staalkaart van het in de Bondsrepubliek van de jaren " 70 "dlomweg verbodene" (Bohrer) ${ }^{163}$ - van de romantiek en het neoromantische, post-nietzschiaanse denken van de Conservatieve Revolutie tot de 'zogenaamde avant-garde' (Lukács) van het expressionisme. Anderzijds maakt de film, alleen al door zijn bestaan, dit verbod voortdurend tot probleem. Of meer specifiek: daagt hij ons, alleen door zijn bestaan, voortdurend uit erover na te denken wat we precies bedoelen wanneer we dit materiaal, waaruit hij is opgebouwd, bestempelen als fout, decadent, ziek, reactionair, rechts of fascistisch. Op de keper beschouwd bevat dit werk twee soorten materiaal. Naast primair materiaal, dat met het nationaal-socialisme is verstrengeld geraakt, ook een overvloed aan secundair materiaal, waarin over deze verstrengeling wordt gereflecteerd. Bijvoorbeeld, om het tot het tableau van 'Hitlers' wederopstanding uit het graf van Wagner te beperken: al dan niet expliciete verwijzingen naar de fascisme-theorieën van Brecht, Mann, Adorno, Kracauer, Friedelind Wagner, Rauschning, Jünger, Kalow, Alexander en Margarete Mitscherlich, Benjamin, enzovoort, enzovoort. Ja, het is, zoals reeds gezegd in een eerder hoofdstuk, beslist niet te ver gezocht in dit tableau naast tal van andere zaken óók een visualisatie te zien van Manns fameuze woorden aan Emil Preetorius over de geestverwantschap tussen Wagner en Hitler. ${ }^{164}$ Het probleem is alleen welke conclusie uit dit soort inzichten dient te worden getrokken. "Alles Hitler en Goebbels cadeau doen?"165

Syberbergs antwoord op deze retorische, door Ernst Bloch gesouffleerde vraag, die hij in zijn pamfletten telkens weer aan ons voorlegt, moge na de voorafgaande hoofdstukken bekend worden verondersteld. De ware kritische filosoof of kunstenaar, zo heeft hij uit Blochs studies geleerd, legt zich niet neer bij de pervertering, maar ontwikkelt strategieën van herijking om het geroofde culturele erfgoed weer op de nazi's terug te veroveren. ${ }^{166}$ In concreto komen deze strategieẻn erop neer, dat een aantal voor de hand liggende zaken nog eens kritisch worden overdacht. Om te beginnen dient de aard van het (primaire) materiaal zo nauwkeurig mogelijk te worden bepaald, waarbij vanzelfsprekend ook de fascisme-theorieën van Kracauer, Mann of de Mitscherlichs een handig hulpmiddel kunnen zijn. Was het fascisme de min of meer noodzakelijke actualisering van een reeds in het materiaal aanwezige potentie? Of bevat het tevens elementen, die niet in wezen fascistisch zijn, maar door de fascisten werden misbruikt? En zo ja, bevinden zich daaronder eventueel ook elementen die voor het postfascistische Duitsland van waarde hadden kunnen zijn. Hebben deze elementen door de fascistische occupatie voorgoed hun betekenis verloren? Of is het wellicht mogelijk het geoccupeerde voor het postfascistische Duitsland opnieuw betekenisvol te maken, door het op de een of andere manier te denazificeren en te revitaliseren?

Ongetwijfeld laat deze filmfabriek zich nog het beste vergelijken met een laboratorium. Het is het laboratorium van een kunstenaar, die proefondervindelijk onderzoekt of zich onder het geoccupeerde materiaal dat hij uit de meest uiteenlopende bronnen heeft verzameld wellicht toch nog elementen bevinden, die na ' 45 ten onrechte als in wezen fascistisch zijn getaboeïseerd. En de methode die hij hiertoe hanteert is het 'fantasiehandwerk" van het 'herschikken van de delen', de 'zinnenprikkelende kracht van het associëren'. De negentiende-eeuwse esthetiek van het wagneriaanse Gesamtkunstwerk wordt door een combinatie met Brechts leer van het epische theater weer op het niveau van de avant-garde

\footnotetext{
162 Zie: hoofdstuk 5, paragraaf 4.

${ }^{163}$ Bohrer, a.w..

164 Zie: hoofdstuk 3, de paragrafen 1 en 7.

165 Syberberg, a.w., p. 15.

${ }^{166} \mathrm{Zie}$ : hoofdstuk 3, de paragrafen 6 en 7 ; hoofdstuk 5 , paragraaf 6 .
} 
gebracht. ${ }^{167}$ Het romantische rü̈nebeeld ontvangt nieuwe impulsen van het wagneriaanse leidmotief, de surrealistische collage, de installatie, het symbolistische theater en de allegorische beeldtaal van het theater van de absurdisten. ${ }^{168}$ De oud-Bayreuther ideologie krijgt een nieuwe actualiteitswaarde door een toepassing op de naoorlogse 'volkspedagogische praktijk' van de 'irrationalisme'-kritiek. ${ }^{169}$ En in de Woudloper-esthetica van Jünger ontwaart de kunstenaar waardevolle aanknopingspunten voor het formuleren van een esthetiek van het verzet tegen dit 'psychologische Versailles'. Het (neo-)romantische motief van de post-histoire wordt vertaald tot een expressie van het apocalyptische levensgevoel, waaraan de Bondsrepubliek ten tijde van de 'zwarte herfst' ten prooi lijkt te zijn gevallen. In het nieuwe Licht van de cinema vindt de wedergeboorte plaats van het oude Licht, waarvan Sedlmayr het verlies betreurde. Het aloude devies Am deutschen Wesen soll die Welt genesen blijkt bij een nadere beschouwing een sterk element te bevatten van het 'principe hoop' in de zin van Bloch....170

En onderwijl wordt in het laboratorium heel wat afgetobd over de hamvraag hoe het geperverteerde materiaal zich verhoudt tot de politieke praktijken van Hitler en Goebbels. Dit laatste, de verstrengeling van het materiaal met de nazi-barbarij, zou ik zelf het thema of onderwerp van deze film willen noemen. "Ik ben de maker van films, teksten, de waarnemer van werk en reageer kritisch," aldus Syberberg in Die freudlose Gesellschaft.

"Zij zullen mij voor zich moeten zien te winnen. En niet wij hen, als een stel meelopers. Zij zullen ons moeten overtuigen. Want wij zijn het, die voorop lopen: een avant-garde van het beschouwende denken. Wij bepalen wat progressief is. Hier is het ijkpunt: kunst als speerpunt van het beschouwende, praktische denken over ontwikkelingen in de geschiedenis, de seismograaf van het leven van alledag. En is iets niet helemaal volgens hun boekje? Dan zullen zij moeten nadenken, zoals wij elke dag opnieuw doen. Het is ons beroep en ik kan u verzekeren: het gaat niet van een leien dakje. Wij zijn de voortschrijdende onrust en verontrusting: een productieve onrust, die een nooit bereikbare rust zoekt, het paradijs van de utopieën, van de zintuiglijke ideeën voor een zo groot mogelijke gemeenschap, samenleving of solidariteit voor allen, in zoverre dit mogelijk is. En we richten ons tot hen, die hebben opgehouden nieuwsgierig te zijn en sterven in een gemakzuchtige onverschilligheid en agressieve vijandigheid." 171

\subsection{Slot}

Er is iets aan het veranderen in de Bondsrepubliek van de late jaren ' 70 , schreef ik in het slot van het vorige hoofdstuk. Dat is ook de visie van de kunsthistoricus en tentoonstellingsmaker Georg Bussmann, die onder meer naam heeft gemaakt met de legendarische 'antifascistische' overzichtstentoonstelling Kunst im 3. Reich - Dokumente der Unterwerfung (1974) waarop ik in paragraaf 5.5 uitvoerig ben ingegaan. Niet slechts lijkt zich in kringen van linkse, of zichzelf links noemende intellectuelen als Bohrer, Martin Walser of Botho Strauß iets te voltrekken, dat nog het meeste weg heeft van een Duits reveil en vervagen de 'zuivere verhoudingen' (Mayer) tussen links en rechts tot een 'nieuwe onoverzichtelijkheid'

\footnotetext{
167 Zie: hoofdstuk 3 , paragraaf 3.

${ }^{168}$ Voor de invloed van het symbolisme en het surrealisme op deze film, zie: Sontag, a.w., passim. Voor de invloed van het absurdistische theater (het symbool!), zie: hoofdstuk 2, paragraaf 8 .

${ }^{169} \mathrm{Zie}$ : hoofdstuk 3, paragraaf 5; hoofdstuk 5, paragraaf 4.

${ }^{170} \mathrm{Zie}$ hoofdstuk 3, paragraaf 8.

${ }^{17 \|}$ Syberberg, Die freudlose Gesellschaft, a.w., pp. $234 \mathrm{f}$.
} 
(Habermas). ${ }^{172}$ Ook in de omgang van de Westduitse kunsten met het thema fascisme kan, aldus Bussmann in een in 1988 verschenen essay, een "nieuw geluid" worden beluisterd. ${ }^{173}$ Afgaande op Bussmanns analyse schuilt het nieuwe van dit 'nieuwe geluid' in een drietal dingen. Ten eerste: "verzet tegen een specifieke kunstopvatting van de jaren $70,(.$.$) kunst$ als sociaaltherapie, het erweiterte Kunstbegriff enzovoort". ${ }^{174}$ Ten tweede: "Naast vormen van een kritisch gedistantieerde afrekening treden benaderingen, dat wil zeggen pogingen, mythen en esthetieken, die door het fascisme zijn misbruikt, terug te winnen. Door een ander gebruik uit te proberen wordt getracht deze vormen en inhouden van hun potentieel fascistische connotatie te zuiveren." En ten derde: "Naast de houding van het antifascisme treedt nu het streven 'niet-fascist' (...) te zijn". 175

Terecht noemt Bussmann Hitler, ein Film aus Deutschland een van de vroegste en wellicht daarom ook meest controversiële voorbeelden van dit door hem bespeurde "nieuwe geluid. ${ }^{176}$ Sterker: bijna zou je tegen beter weten in gaan vermoeden, dat de Hitler-regisseur model moet hebben gestaan voor deze profielschets van het nieuwe type Westduitse kunstenaar van de late jaren '70. Tegen beter weten in, want Bussmann heeft een lange reeks modellen tot zijn beschikking: Anselm Kiefer, Markus Lüpertz, Georg Baselitz, Albert Oehlen, Helmut Federle, Günther Förg, Gerhard Merz enzovoort - stuk voor stuk kunstenaars, die in het linkse cultuurdebat van die dagen ervan worden verdacht apologeten van de Tendenzwende te zijn. ${ }^{177}$ Bussmann, daarentegen, blijkt aanmerkelijk milder in zijn oordeel. "Tijdens een discussie aan de Münchense academie heeft men ook mij onlangs ervan beschuldigd, dat ik een kunstmakelaar van de Wende zou zijn," vertelt hij in een in " 88 afgenomen interview.

"Dat mag men gerust vinden. Maar dan zou ik op mijn beurt wel graag willen weten, of er nog een andere manier bestaat om met jongeren, Spätgeborenen, over de Duitse geschiedenis te spreken. Blijkbaar werden in het faseisme-debat, zoals dat tot dusver is gevoerd, bepaalde zaken als afgedaan beschouwd, die niet als afgedaan konden worden beschouwd, omdat ze niet afgedaan waren - en dat hoeft niet noodzakelijk negatief te zijn. Het discussiëren en nadenken gaat verder. Dat behoort nu eenmaal tot ons beroep en wellicht ook wel een beetje tot ons [Duitsers, G.G.]. (...) Kunst im. 3. Reich - Dokumente der Unterwerfung was een riskante tentoonstelling, maar we wisten wie onze opponenten waren. Dat wil zeggen: de tentoonstelling had (...) een overduidelijke antifascistische signatuur. We namen indertijd een eenduidige positie in. (...) Maar dit elan van de jaren '70 (..) - dat kan ik tegenwoordig niet langer opbrengen. (...) Op de keper beschouwd zijn er twee mogelijkheden om de discussie [met de genoemde kunstenaars, G.G.] te voeren: hun werk zonder pardon verbieden of toelaten, zoals ik doe. Voor mij is deze kunst juist en noodzakelijk." 178

\footnotetext{
${ }^{172}$ Zie: hoofdstuk 4, paragraaf 1 ; hoofdstuk 5 , paragraaf 8 .

${ }^{173}$ Bussmann, G., Arbeit in Geschichte / Geschichte in Arbeit. in: Arbeit in Geschichte / Geschichte in Arbeit. Hrsg. G. Bussmann. Berlin 1988. pp. 11-16, zie: 14.

${ }^{174}$ Schütz, H., 'Ich kann beim besten Willen kein Hakenkreuz entdecken'. Georg Bussmann im Gespräch mit Heinz Schütz. in: Kunstforum. 95 (juni, juli 1988). pp. 99-103, zie: 100.

${ }_{175}$ Bussmann, a.w., p. 14.

${ }^{176}$ Schütz, a.w., passim. Bussmann, G., 'Ich kann beim besten Willen kein Hakenkreuz erkennen'. in:

Faszination und Gewalt. Zur politischen Ästhetik des Nationalsozialismus. Hrsg. B. Ogan, W.W. Weiß.

Nürnberg, 1992. pp. 291-294.

${ }^{177}$ Schütz, a.w., passim. Arbeit in Geschichte / Geschichte in Arbeit, a.w., passim. Zie eveneens: Schütz, H., Transformation und Wiederkehr. Zur künstlerischen Rezeption nationalsozialistischer Symbole und Ästhetik. in: Kunstforum, a.w., pp. 64-98. Alsmede: hoofdstuk 4, paragraaf 1 .

${ }^{178}$ Schütz, Ich kann beim besten Willen..., a.w., pp: 99f, 103.
} 
Dat de eerste twee, door Bussmann in zijn profielschets opgesomde eigenschappen van dit nieuwe type kunstenaar op de Hitler-regisseur van toepassing zijn, behoeft, naar ik meen, geen nadere toelichting meer. ${ }^{179} \mathrm{Ik}$ beperk me gemakshalve tot het derde punt: de weigering een eenduidige positie pro of contra in te nemen. Volgen we Syberberg, dan raken we hier namelijk aan de kern van het verschil tussen hemzelf en een oude emigrantenfilosoof als Ernst Bloch, die zich in zijn studies nadrukkelijk profileert als antifascist. Of tussen hemzelf en een avant-garde-kunstenaar uit de vorige generatie als de zwaar aan Bloch schatplichtige "linkse wagneriaan' Wieland Wagner. ${ }^{180}$ Voor beiden geldt dat ze, elk op hun manier, persoonlijk betroffen en betrokken waren: Bloch als jood en neo-marxist, Wieland Wagner als een soort pleegkind van de Führer hoogstpersoonlijk. ${ }^{181}$ Aan het baanbrekende gehalte van hun werk doet dit naturlijk niets af. "Zijn [Wieland Wagners, G.G.] esthetische stap is belangrijk geweest (...)," stelt Syberberg in Der Wald steht schwarz und schweiget. Echter, voegt hij hieraan toe: "Van meet af aan was duidelijk dat Wieland, gezien (...) zijn nauwe persoonlijke band met Hitler, deze noodzakelijke daad [dat wil zeggen: de herijking van Wagners werk, G.G.] niet tot een goed einde kon brengen". ${ }^{182}$ Daarvoor is, meent Syberberg, een zekere emotionele afstand nodig, die bij deze vorige generatie om begrijpelijke redenen ontbrak, maar waarover hijzelf, dankzij de hem vergunde 'genade van de late geboorte', wél denkt te beschikken: "Voor mij is Hitler niet iemand, die ik moet verdringen of beschouw als mijn directe vijand. Eerder is hij voor mij een historische figuur. Ook voor zijn aanhangers geldt dat. Ze zijn sympathiek of niet, zoals andere mensen." "183

Deze (grotere) emotionele afstand tot het nazi-verleden, aldus nog steeds Syberberg, maakt het mogelijk de uitkomsten van de herijking, die de vorige generatie heeft proberen te bieden, nog eens kritisch tegen het licht te houden - met een onbevangen blik, niet vertroebeld door de zware last van de schuldvraag, door ideologische vooringenomenheid of de traumatische ervaringen van vlucht en ballingschap. Maar hoever kun je gaan met een denazificatie van door het nationaal-socialisme geoccupeerd materiaal? "Erst wenn ein SSMann gut sein darf in Deutschland (und wir dürfen hinzufügen: kllug) und ein Jude menschlich schlecht sind wir wieder frei," luidt Syberbergs antwoord op deze vraag - let wel: níet in het beruchte, uit 1990 daterende pamflet Vom Unglück und Glück der Kunst in Deutschland nach dem letzten Kriege waarvan (zoals we zagen in hoofdstuk 1) het vermeend antisemitische gehalte ók door bewonderaars fel wordt bekritiseerd, maar in het 'cultuurtheoretische postscriptum' (Santner) bij deze Hitler-film uit het midden van de jaren

\footnotetext{
${ }^{179}$ Voor Syberbergs visie op het, volgens Bussmann in hoge mate voor de jaren '70 typerende concept van kunst als sociaaltherapie, zie: hoofdstuk 5 , paragraaf 6 .

${ }^{180}$ Zie: hoofdstuk 3, paragraaf 7.

181 "Wieland in fact in very young years is reported to have thrown his arms round Hitler and cried: "You schould be our daddy, and daddy should be our uncle." Skelton, G., Wieland Wagner. The positive sceptic. London, 1971.pp. 21, 81. Zie eveneens: Syberberg, Filmbuch, a.w., p. 272. Syberberg, Die freudlose Gesellschaft, a.w, pp. 266f: "Het trefwoord na ' 45 was 'uitmesten'. Het was afkomstig van Wieland Wagner, die zich van het trauma van zijn grootvader Richard wilde bevrijden, doordat hij in het door bommen verwoeste huis alle oude meubels en overgebleven dingen uit de negentiende eeuw stuk sloeg, de horror van zijn kindertijd en herinneringen (...). En doordat hij de graven van de honden in de tuin en dat van de destijds geliefde papagaai [van grootmoeder Cosima, G.G.] hoogstpersoonlijk, met eigen hand en bijl, wegvaagde." Alsmede: hoofdstuk 4, paragraaf 2.

${ }_{182}$ Syberberg, Der Wald, a.w., pp. $317 \mathrm{f}$.

${ }^{183}$ Winter, de, a.w., p. 43. En zo, zouden we hieraan kunnen toevoegen, wordt Winifred Wagner dan ook, zoals we in de voorafgaande hoofdstukken hebben gezien, in de documentaire Winifred Wagner und die Geschichte des Hauses Wahnfried geportretteerd: niet als een afschrikwekkend voorbeeld van het door de Mitscherlichs geconstateerde onvermogen om te rouwen, maar als een vrouw van vlees en bloed, met aangename en minder aangename eigenschappen. Zie in dit verband eveneens: Syberberg, a.w., pp. 317f: "Aber letzlich konnte Richard Wagner nur (...) erlöst werden (...) von einem, der dem. Hitler hinter sich hatte und aus der Nach-HitlerGeneration kam (...)". Dat wil zeggen: Syberberg zelf.

${ }^{184}$ Syberberg, Die freudlose Gesellschaft, a.w., p. 26.
} 
'70 Die freudlose Gesellschaft. ${ }^{184}$ Want een "ongehoord nieuwtje", merkt de Duitse publicist Lothar Baier fijntjes op in een essay uit 1991, is het antisemitisme van de late Syberberg allerminst. ${ }^{185}$ We zullen ons nog een keer op de werkvloer van de geschiedenisfabriek moeten wagen.

${ }^{185}$ Baier, L., Eine ungeheuerliche Neuigkeit? Nachfrage zur Debatte um den Pamphlettisten Syberberg. in: Neue Rundschau. 1 (1991). pp. $117-130$. 


\title{
Hoofdstuk 7 Tweeërlei zonsondergangen
}

\subsection{Inleiding}

Een kleine zes uur zijn verstreken, als de geschiedenisfabriek plotseling tot stilstand komt. Het licht in de werkplaats dooft uit; het witte doek verandert in een zwart vlak. Uit de duisternis klinkt de panische stem van een Duits sprekende vrouw:

\begin{abstract}
"Vandaag prijzen we ons gelukkig, dat we alles achter ons hebben. We weten niet hoe we ooit de bevrijders, onze bevrijders, moeten danken. We weten slechts dat, wanneer we hier naar buiten komen, we al datgene wat we hier beleefd hebben naar de wereld toe moeten uitschreeuwen, want anders kunnen we niet leven. Mensen, die dit nu horen, zullen misschien denken, dat we niet helemaal bij ons verstand zijn. Maar wanneer je begint te vertellen is het allemaal zo wreed. Het zijn zulke verschrikkelijke dingen, die je beleefd hebt, dat je geen woorden vindt om ze te beschrijven. Iemand, die er niet bij geweest is, zal dat absoluut niet begrijpen. Hoe vreselijk alsmaar weer deze rode gloeiende vlam in onze herinnering staat. Wanneer we vandaag de dag de zon zien ondergaan, denken we aan de stookplaats in Auschwitz, die duizenden mensen heeft weggerukt. En je moest toezien, je was zo vertwijfeld, je balde de vuisten en kon niets eraan doen, omdat je onderdrukt werd en gefolterd, omdat je de vreselijke pech had als jood geboren te worden. Geen andere misdaad heb je begaan dan domweg als jood op de wereld te komen. En als jood is men daar de oven ingegaan."
\end{abstract}

Deze stem, maak ik op uit het script, is ontleend aan een radioreportage van de BBC uit april 1945 over de bevrijding van het concentratiekamp Auschwitz. ${ }^{1}$ Maar dat hoef je niet te weten om erdoor bewogen te worden. Ook zonder op de hoogte te zijn van de herkomst van het document, voelen we de tragiek feilloos aan. Het is alsof alle toekomstige getuigenissen van holocaust-overlevenden reeds in deze vroege noodkreet vanuit het centrum van de hel samensmelten. We zijn ermee vertrouwd uit de literatuur, van Jacques Presser en Theodor Adorno, tot Bruno Bettelheim, Primo Levi en Elie Wiesel. De paradox dat historische ervaringen zo extreem kunnen zijn, dat hun directe verwoording als verraad aan de herinnering wordt gevoeld. Tegelijkertijd echter voelen de overlevenden het als hun plicht jegens de doden de verschrikkingen van het verleden voor het nageslacht te bewaren. Het is hun tragiek, dat ze een verhaal moeten vertellen, dat in feite niet communiceerbaar is - voor wie er niet bij was, 'absoluut onbegrijpelijk' blijft. "'De woorden zelf dreigen in staking te gaan (...)," verzucht de ik-figuur in Pressers novelle De nacht der Girondijnen (1957). Zoals

\footnotetext{
${ }^{1}$ Syberberg, H.J., Hitler, ein Film aus Deutschland. Hamburg, 1978, p. 254. [Hierna geannoteerd als: Hitler.]

${ }^{2}$ Zie bijvoorbeeld: Bettelheim, B., Surviving and other essays. London, 1979. Probing the Limits of Representation. Nazism and the 'Final Solution'. ed. S. Friedländer. Cambridge, Mass., London, 1992. Felman, S., Laub, D., Testimony. Crisis of witnessing in literature, psychoanalysis, and history. New York, London, 1992. Avisar, I., Screening the Holocaust. Cinema's Images of the Unimaginable. Bloomington, Indianapolis, 1988. Alsmede: Goossens, G., Pott, H., Syberbergs oorlog. Cinema en geschiedschrijving. in: Hermeneutiek en cultuur. Interpretatie in de kunst- en cultuurwetenschappen. red. F. Ankersmit e.a. Amsterdam, 1995. pp. 157179.

${ }^{3}$ Presser, J., De nacht der Girondijnen. z.p., 1957. p. 10. Zie eveneens: Presser, J., Ondergang. De vervolging en verdelging van het Nederlandse jodendom 1940-1945. Eersie deel. 's-Gravenhage, 1965. p. 3f: "De lezer zal
} 
ook de ongebreidelde fantasie van de regisseur van Hitler, ein Film aus Deutschland het nu plotseling lijkt te laten afweten. Want het is, binnen de betekenende context van de film, niet zomaar een licht, dat hier uitdooft. Wat we in deze scène meemaken, is niets minder dan een totale verduistering van "het nieuwe Licht uit de Zwarte Zon van onze filmfantasie'. "Al probeert hij te zwijgen (...), hij kan het spreken niet laten - zo enorm vurig en gretig is hij," observeert Susan Sontag (1980). Maar ten overstaan van Auschwitz, lijkt zelfs deze praatzieke filmmagiër met stomheid geslagen. Alles wat kennelijk nog bij hem opkomt, is een zwart vlak en een doodsbange stem, die spreekt over zonsondergangen en over de onmogelijkheid om over Auschwitz te spreken.

In zijn in 1989 verschenen studie From Hitler to Heimat verbaast. Anton Kaes zich erover, dat de film "geen beelden vindt" voor "de angst en de terreur die het nazisme zijn slachtoffers heeft doen ondergaan". "Maar ook dit zwarte vlak is vanzelfsprekend een, zij het niet-mimetisch beeld - misschien zelfs een beeld, dat meer recht doet aan de ervaringen van de slachtoffers, "de nonsens, non-sens, zinloosheid" (Presser) ${ }^{7}$ van wat ze vertellen moeten, dan welke mimetische verbeelding ook. Is afbeelden, verbeelden, verwoorden, vertellen immers niet ook altijd verklaren, en dus het ondenkbare rationaliseren, het zinloze zin geven, de waanzin normaliseren? Volgen we de Franse filosoof Christian Zimmer (1978), dan raken we hier aan de kern van dit kunstwerk van de anamnese. Het theater, betoogt Zimmer, wordt door deze theatrale film van zijn mimetische functies beroof. De film vertelt geen geschiedenis, noch biedt hij een realistische weergave van de historische werkelijkheid. Hij bestaat uitsluitend uit een abstracte ruimte, die niet zozeer een verbeelding is van de geschiedenis, als wel van de onmogelijkheid om de geschiedenis te verbeelden. Ja, deze donkere, hermetisch van de buitenwereld afgesloten filmruimte vol dode sporen, vermoedt Zimmer, is niets anders dan een vertaling in een esthetische praktijk van de machteloze 'schreeuw' van de overlevenden." "De gedeporteerde in Syberbergs film heeft gelijk: dat is niet langer een probleem van de historici. Men moet schreeuwen om verder te kunnen leven. Of men geloofd wordt of niet, doet er niet langer toe. Het alternatief is onbelangrijk geworden. (...) De enige waarheid, de enige legitimiteit, de enige trouw, is de schreeuw." 9

Er heerst in deze film-factory, schreef ik in het voorafgaande hoofdstuk, een paniek, die zich zoveel jaar na dato nog slechts zeer moeilijk laat navoelen ${ }^{10}$ - alsof, zouden we hier met Zimmer aan kunnen toevoegen, iemand zeven uur lang zijn angsten en frustraties tegen ons 'uitschreeuwt'. Al zullen we wel, alvorens met deze interpretatie in te stemmen, eerst zorgvuldig moeten nagaan wie hier schreeuwt en - bovenal - waarom. Terecht merkt de Franse filosoof Jean-Pierre Faye (1978) op, dat de hierboven aangehaalde woorden van de Auschwitz-overlevende helemaal aan het eind van de film als een soort echo terugkeren echter niet, of niet slechts als een echo bij, zoals Faye meent te beluisteren, de beroemde, in de eindaftiteling opgenomen strofe over een door het denken aan Duitsland verstoorde

\footnotetext{
van tijd tot tijd, evenals de schrijver zelf somtijds tijdens zijn werk, nauwelijks weerstand kunnen bieden aan de gedachte: dit kan niet gebeurd zijn. Een vernietiging van zo verpletterende zinloosheid kan niet hebben plaats gevonden; men is eenvoudig niet toegankelijk voor een beeld van zo monsterachtige absurditeit. En toch moet deze schrijver zich die weg banen. Hoe?"

${ }^{4}$ Hitler, a.w., pp. 70, 271. Zie eveneens: hoofdstuk 6, paragraaf 6 .

${ }^{5}$ Sontag, S., Syberbergs Hitler. in: In het teken van Saturnus. Essays. Vert. D. Brisk. Weesp, 1984. pp. 181-222, zie: 219 .

"Kaes, A., From Hitler to Heimat. The return of History as Film. Cambridge, Mass, London, 1989. p. 65.

${ }^{7}$ Presser, De nacht, a.w., p. 10.

${ }^{8}$ Zimmer, Chr., Hitler unter uns. in: Syberbergs Hitler-Film. Texte von Susan Sontag, Jean-Pierre Faye, JeanPierre Oudart, Christian Zimmer, Michel Foucault, Bernard Sobel, Alberto Moravia, Vito Zagarrio, Heiner Müller. Hrsg. K. Eder. München, Wien, 1980. pp. 51-68, zie: $51 \mathrm{ff}$.

idem, p. 51.

${ }^{10}$ Zie: hoofdstuk 6 , paragraaf 4.
} 
nachtrust van Heinrich Heine, "de 'Duitse jood' en vriend van Marx"." "Nu zal men misschien zeggen, dat we niet goed bij ons hoofd zijn (...)," citeert een in Wagners mantel gehulde acteur in één van de slotscénes de Auschwitz-over]evende ("Mensen, die dit nu horen, zullen misschien denken, dat we niet helemaal bij ons verstand zijn'), terwijl hij de pose aanneemt van de Melancholie uit Durers kopergravure. ${ }^{12} \mathrm{En}$ dit is inderdaad, wat verscheidene Duitse critici hebben gezegd. De schrik van het voorafgaande tableau zit dan namelijk nog goed in de benen.

Op een tafel in de studioruimte (zie afbeelding 1) heeft een inmiddels oude bekende plaats genomen: de buikspreekpop-Hitler, die in het derde deel de loftrompet heeft mogen steken over de naoorlogse wereldorde. ${ }^{13}$ Een acteur, Syberbergs alter ego André Heller, ${ }^{14}$ betreedt het podium. Hij gaat in de regisseurstoel zitten en knoopt een gesprek aan met de pop. $\mathrm{Na}$ alle lovende woorden van de buikspreekpop-Hitler over de "vooruitgang in de wereld", lijkt Heller nu de tijd gekomen om het eens te hebben over het "verloren leven". Want evenals de Auschwitz-overlevende blijkt ook het alter ego van de regisseur te worden gekweld door een 'rode gloeiende vlam' in zijn herinnering. Ook hij kan namelijk 'geen zonsondergang' meer zien zonder aan Auschwitz te denken. En het is ook zijn tragiek, dat hij een verhaal moet vertellen, dat in feite niet communiceerbaar is - voor wie er niet bij was, 'absoluut onbegrijpelijk" blijft. "Hoe moet ik dat jou duidelijk maken? En mezelf? En alle kinderen en kleinkinderen, die dit alles niet gekend hebben? Dit vroegere leven, dat ze tegenwoordig allemaal al vergeten zijn, vergiftigd door de nieuwe erfenis van jouw tijd." mompelt hij met droevige stem tegen de pop, terwijl het Keizerkwartet van Haydn, de muziek van het Duitsland-Lied, uit de speakers klinkt.

"Jij hebt ons de zonsondergangen afgepakt, zonsondergangen van Caspar David Friedrich. Het is jouw schuld, dat we geen korenveld meer kunnen zien, zonder aan jou te denken. (...) In Israël leeft geen Karl Kraus, geen Musil, geen Kafka, geen Schnitzler, geen Altenberg, geen Friedell, geen Polgar. Zij hebben daar slechts behoefte aan Moshe Dajan. Ik begrijp dat zeer goed. Jij hebt de Eeuwige Jood gedood. Berlijn en Wenen heb je vernietigd. (...) Je hebt de Russen tot aan de Elbe gebracht. (...) Huizen heb je op je geweten; huizen zonder ziel, met uitgebrande ogen, zonder tranen, steden die niet huilen kunnen. (...) Het is jouw schuld, dat we de trots van onze herbergen hebben verloren, door gemakzuchtige fastfood-restaurants verdreven, uit angst van de mensen, dat ze nog zouden kunnen houden van hun beroep en van iets anders dan geld, het onvervangbare vervangbare, het enige dat jij hen hebt gelaten, omdat je verder alles hebt geoccupeerd en door jouw greep vergiftigd. Alles. De eer, de trouw, het landleven, de arbeidsijver, de film, de waardigheid, vaderland, vaderland, trots, geloof. Jij bent de executeur van het Avondland, democratisch gekozen, met de triomf van het geld, het materialisme over ons. De pest van onze eeuw. (...) Het woord magie en mythe en dienen en heersen, Führer, autoriteit, is kapot, weg, verbannen tot in alle eeuwigheid. En wij zijn uitgewist. Hier groeit niets meer. Een heel volk heeft opgehouden te bestaan, in de diaspora van de geest en de elite. De nieuwen werden ontworpen, ontwikkeld, de nieuwe mens is een feit. De pest van het materialisme heeft getriomfeerd in Oost en West. Proficiat." 15

\footnotetext{
${ }^{11}$ Faye, J.P., Faust, Teil III. in: Syberbergs Hitler-Film. a.w., pp. 33-35, zie: 35. Faye refereert aan: Hitler, a.w., p. 284.

${ }^{12}$ Hitler, a.w., p. 270.

${ }^{13}$ Zie hoofdstuk 6, paragraaf 3.

"Zelf spreekt Syberberg over "mijn contrasterende spiegel". Syberberg, H.J., Die freudlose Gesellschaft.

Notizen aus dem letzten Jahr. München, Wien, 1981. p. 383.

${ }^{15}$ Hitler, a.w., pp. $268 \mathrm{f}$.
} 
Eigenaardig genoeg heeft bij mijn weten nooit iemand de link gelegd tussen de woorden van de Auschwitz-overlevende en deze sleutelscène. Wellicht komt het omdat Syberbergs visie op 'de joden' pas ná 1990 een kernthema wordt in de serieuze, wetenschappelijke receptie van zijn werk. Zoals we zagen in hoofdstuk 1, ontstaat in dat jaar grote opschudding over het pamflet Vom Unglück und Glück der Kunst in Deutschland nach dem letzten Kriege (1990), waarmee Syberberg óók in de ogen van zijn (overwegend) buitenlandse achterban de grens van het betamelijke zou hebben overschreven. De grote werken van de jaren '70, de Winifred-Wagner-documentaire (1975) en het magnum opus Hitler, ein Film aus Deutschland (1977) worden als voorheen om hun diepe inzichten in de Duitse cultuurgeschiedenis bewonderd. Maar de maker van deze werken zou de oude niet meer zijn. Hij zou halverwege de jaren ' 80 het spoor bijster zijn geraakt, ja zich zelfs hebben ontpopt tot een onvervalste antisemiet. ${ }^{16}$ In de hierna volgende pagina's zal de denkweg worden geschetst, die de Hitler-regisseur in de jaren ná Hitler heeft afgelegd. Toch vrees ik, dat we deze weg zullen moeten laten beginnen in het magnum opus zelf. En wel met de scandaleuze deconstructie van de 'schreeuw' van een overlevende uit Auschwitz.

\subsection{Hitler, een film van een jood uit Duitsland}

Het is, voor het begrijpen van dit tableau, zeker geen onbelangrijk detail: de acteur, die hier in navolging van de Auschwitz-overlevende zijn horror 'uitschreeuwt', de Oostenrijkse multimedia-kunstenaar André Heller, is van vaderszijde joods. Wie nauwkeurig naar zijn woorden luistert zal ontdekken, dat de monoloog op zijn minst voor een deel op hem is toegeschreven. Zoals ook de muziekkeuze duidelijk maakt: Haydn schreef zijn Keizerkwartet opus 74 no. 3 ('Gott erhalte Franz') oorspronkelijk als hymne voor de Habsburgse monarchie. Met enige goede wil zou je in het tableau ('Jij hebt de Eeuwige Jood gedood') zelfs een klaagzang kunnen zien op het verdwijnen van de joodse intelligentsia 'uit ons midden' - een onrecht, dat Syberberg na aan het hart ligt.

Die freudlose Gesellschaft, het als een "cultuurkritisch postscriptum" (Eric Santner) ${ }^{17}$ bij deze film verschenen pamflet uit 1981, opent en sluit met de constatering, dat 'sinds Hitler niemand in Duitsland meer kan zeggen: de joden dragen schuld'. "Dat onderscheidt ons radicaal van alle andere landen in de westerse wereld en van onze vaderen van Richard Wagner tot Karl Kraus. Sinds vijfendertig jaar bestaan de joden bij ons niet meer." niet 'de joden', zoals Syberberg ze graag ziet. Want als de filmmaker in zijn scripts of pamfletten in gunstige zin schrijft over 'de joden', blijkt hij steeds een bepaald type voor ogen te hebben: geassimileerd, deutschbewußt, vervuld van verdriet over de teloorgang van de 'trotse' Duitse cultuurtradities. "Stel je voor, ik was een droevige jood uit Duitsland, huilend, omdat ik niet mocht meedoen, niet werd uitgenodigd, hoewel we altijd de trouwste

\footnotetext{
${ }^{16}$ Zie bijvoorbeeld: Santner, E.L., The trouble with Hitler: Postwar German Aesthetics and the Legacy of Fascism. in: New German Critique. 57 (Summer 1992). pp. 5-24. Elsaesser, Th., Fassbinder's Germany. History, Identity, Subject. Amsterdam, 1996. pp. 209f. Lacoue-Labarthe, Ph., Syberberg: über Deutschland nach Hitler. in: Politics/Poetics. Hrsg. Documenta X. Kassel, 1997. pp. 480-484, zie: 484. Buruma, I., There's No Place Like Heimat. in: The New York Review of Books. 20 (1990). pp. 34-43. Zimmer, D.E., Die Farbe Braun. Ignorant oder Wahnsinniger - zur Debatte Hans Jürgen Syberberg in der Ost-Berliner Akademie. in: Die Zeit. 19-11-1990. Baier, L., Eine ungeheuerliche Neuigkeit? Nachfragen zur Debatte um den Pamphletisten Syberberg. in: Neue Rundschau. 1 (1991). pp. 117-130. Alsmede: hoofdstuk 1, paragraaf 2.

${ }^{17}$ Santner, E.L., Stranded Objects. Mourning, Memory, and Film in Postwar Germany. Ithaca, London, 1990, pp. 8f. Voor het pamflet Die freudlose Gesellschaft, zie eveneens: hoofdstuk 6, de paragrafen 4 en 5.

${ }^{18}$ Syberberg, a.w., p. 8. Zie eveneens: pp. 378, 383f.
} 
nationalisten waren, onverbiddelijk en gewiekst en vol liefde voor de Heimat. (...)," houdt een van de acteurs elders in de film de buikspreekpop-Hitler voor. "Elke joodse emigrant uit Duitsland is in zijn innerlijk altijd eerst en vooral Duitser. Hoe dom van jou, dat niet te onderkennen, (...) daarmee niet te spelen." ${ }^{\prime 19}$ En in plaats daarvan de 'Eeuwige Jood' te vermoorden.

Het is jouw schuld, zo zouden we Hellers woorden kunnen interpreteren, dat de joden in Israël of waar ook ter wereld geen Duits schilderij meer kunnen bekijken, geen Duitse muziek meer kunnen beluisteren of Duitse poëzie lezen, zonder te denken aan 'de oven in Auschwitz, die duizenden van mensen weggerukt heeft'. Vanuit het perspectief van jouw joodse slachtoffers heeft de Kultur definitief haar onschuld verloren. Voor hen is de Groene Heuvel in Bayreuth, dit 'trotse Duitse cultuurcentrum' (Syberberg) ${ }^{20}$, enkel nog "de ruimte waarin de relaties leesbaar worden tussen de metafysische sabbat, waar Wagner naar verlangde en de politieke formuleringen van dergelijke verlangens in het nazisme" (Santner) ${ }^{21}$ De tijden dat joodse tranen over Duitsland nog bitter vloeiden, zijn voorgoed voorbij. Denkend aan Duitsland in de nacht, voelen ze enkel nog woede... 'Ik begrijp dat zeer goed,' verzucht Heller, terwijl hij (figuurlijk gesproken) de tranen uit zijn ogen wist.

Hier, in dit tableau, ontmoeten we de uitzondering op de regel: een 'Duits/Oostenrijkse jood', die 'het verdriet van Duitsland' nog wel deelt - de wederopstanding of tweede verschijning van de 'Eeuwige Duits/Oostenrijkse Joden' Kraus, Musil, Kafka, Schnitzler, Altenberg, Friedell, Polgar. En tegelijk is Heller meer dan dat, namelijk het alter ego van de regisseur. Het zal dan ook geen toeval zijn, dat de 'zonsondergangen van Caspar David Friedrich' in deze joods/Duits/Oostenrijkse klaagzang zo'n prominente plaats innemen. De verwijzing kan op een tweetal wijzen worden uitgelegd. $\mathrm{Om}$ te beginnen is Friedrich één van de belangrijkste exponenten van een geestesstroming, die sinds Georg Lukács en de late Thomas Mann binnen het linkse cultuurdebat steevast wordt bestempeld als fout, decadent, ziek, reactionair, rechts en in wezen fascistisch: het 'irrationalisme'. ${ }^{22}$ Zoals we zagen in de voorafgaande hoofdstukken, is het Syberberg van meet af aan te doen geweest om een herijking van deze 'irrationele' traditiesporen. ${ }^{23}$ Waarbij hij zich in pamfletten uit de jaren '70 en de vroege jaren ' 80 telkens weer beroept op Ernst Bloch, die samen met Bertolt Brecht en Hans Mayer behoort tot de grote tegenspelers binnen het linkse cultuurdebat van de door Lukács en de late Mann geinitieerde 'irrationalisme'kritische richting. ${ }^{24}$ Ook het zonsondergangen-tableau is wederom onmiskenbaar door Bloch geïnspireerd. Net als in diens studies verschijnt 'Hitler' hier als de grote rover die, zo luidt Hellers aanklacht, grote delen van de Duitse cultuurgeschiedenis van 'ons' heeft 'afgepakt' door hen te 'occuperen' en met 'zijn greep te vergiftigen'. Tot zijn buit behoren esthetische vormen als de 'zonsondergangen' en 'korenvelden' van de Duitse romantiek, woorden als 'magie', 'dienen', 'heersen', 'Führer', 'autoriteit', of normen en waarden als 'eer', 'trouw', 'landleven', 'arbeidsijver', 'vaderland', 'trots' en 'geloof'. En net als in de studies van Bloch, wordt de pervertering betreurd als een verlies - niet slechts voor het Duitse, maar ook voor het joodse culturele erfgoed, waarvan de genoemde esthetische vormen, woorden, en normen en waarden volgens deze joodse emigrant eveneens een essentieel bestanddeel vormden. ${ }^{25}$ "Wat," vraagt Syberberg zich af in de inleiding van het Hitler-script (1978), "zou Einstein

\footnotetext{
${ }^{19}$ Hitler, a.w., p. 232.

${ }^{20}$ Syberberg, H.J., Syberbergs Filmbuch. München, 1976. p. 247

${ }^{21}$ Santner, a.w., p. 128. Zie eveneens: hoofdstuk 4, paragraaf 6 .

${ }^{22}$ Zie: de paragrafen $2.4,3.4,4.1,5.4,5.5$.

${ }^{23}$ Zie: de paragrafen $2.5,2.10,3.7,3.8,5.6,6.7,6.8$.

${ }^{24} \mathrm{Zie}$ : de paragrafen $3.6,3.7,5.6$.

${ }^{25}$ Zie: paragraaf 3.6 .
} 
zijn zonder zijn muziek, de Duitse romantiek en de klassieken?"26 Louter, zoals Heller oppert, Moshe Dajan?

Behalve een exponent van het 'irrationalisme', is Caspar David Friedrich echter ook de grote landschapschilder van het oude Pommeren - Syberbergs verwoeste Heimatland. ${ }^{27}$ 'Een heel volk heeft opgehouden te bestaan,' klaagt Heller. Ongetwijfeld heeft de opmerking betrekking op het Duitse volk in zijn geheel, de deutschbewußße Duits/Oostenrijkse joden meegerekend. Door geheel in de lijn van de irrationalisme-kritiek van Lukács en de late Mann grote delen van de eigen cultuurgeschiedenis en het eigen gevoelsleven te taboeïseren en te verdringen als in wezen fascistisch zouden de Duitsers zichzelf "geestelijk" hebben "onterfd en onteigend" - "We leven in een land zonder [geestelijke, G.G.] Heimat". ${ }^{28}$ Maar wellicht heeft Syberberg, toen hij deze klaagzang voor zijn joodse alter ego Heller schreef, ook gedacht aan het 'uitgewiste' volk van de Pommeren. De geschiedenis mag bekend worden verondersteld. Naar schatting 14 miljoen Duitsers werden in de jaren direct na de oorlog met geweld verdreven uit de zogenaamde Ostgebiete. Tussen de 2 en 2.8 miljoen vonden de dood, hetzij door de ontberingen waarmee ze tijdens hun vlucht en deportatie werden geconfronteerd, hetzij door de terreur van het Rode Leger, dat zich moordend en verkrachtend een weg naar Berlijn baande. ${ }^{29}$ Sindsdien, stelt de historicus Alfred Heuß, één van de nestors van de naoorlogse Duitse conservatieve geschiedschrijving, in een studie uit 1984, "(...) bestaan geen Schlesier, Pommern, Ostpreußen, Sudetendeutsche enzovoorts meer. Hun talen, respectievelijk 'dialecten' (...) worden niet meer gesproken en moeten in historisch geworden woordenboeken (voor zover die er zijn) worden opgezocht.". En de nabestaanden van deze "phylocide" of "stammenmoord" $(\mathrm{Heu} /)^{30}$ leven, zoals de buikspreekpop-Hitler het noemt, over "ons restland Duitsland"3! verstrooid - "in de diaspora van de geest en de elite'. Een Duitse diaspora dit maal.

Tot deze Heimatvertriebenen behoort de Hitler-regisseur zelf, wiens wieg een kleine honderdvijftig kilometer ten westen van de Oder stond, strikt genomen niet. Maar als het gaat om het verlies van Heimat in overdrachtelijke zin, kan ook de zoon van de onteigende hereboer van het Voor-Pommerse dorpje Nossendorf een hartig woordje meepraten. Zijn persoonlijke 'diaspora' begint in het laatste oorlogsjaar, met het verlies van de rechten van de vader, het verwoesten van het geboortehuis en het openbreken van de aristocratische plattelandscultuur van het oude Pommeren, het symbolisehe Huis van de kinderjaren. ${ }^{32}$ Wanneer hij acht jaar later (vrijwillig) de Russische bezettingszone verlaat, heeft het Land van de Vader, het Pommeren van de Junker en de hereboeren, 'opgehouden te bestaan'. Het is, in luttele jaren tijd, van de aardbodem weggevaagd. "Deze 32 jaar na de laatste grote Europese oorlog," luidt één van de openingsteksten van de film:

"Pruisen gerüneerd, een grote Europese provincie uitgewist, alles met zich meesleurend, een belangrijk centrum weg, het centrum Berlijn, een heel land zonder

\footnotetext{
${ }^{26}$ Syberberg, H.J., Die Kunst als Rettung aus der deutschen Misere. Ein Essay. in: Hitler, a.w., p. 15.

27 "Geburt (...) im einfachen Vorpommern auf dem Land, dem Lande Casper David Friedrichs und Otto Runges und auch Bismarcks (...)." Syberberg, Filmbuch, a.w., p. 110.

${ }^{28}$ Syberberg, Die Kunst als Rettung, a.w., pp. 14 f. Zie eveneens: hoofdstuk. 3, paragraaf 5.

${ }^{29}$ Ik ontleen deze cijfers aan: Kogelfranz, S, Der lange Weg des Leidens. Die Vertreibung aus dem Osten. in: Spiegel Spezial. Die deutschen nach der Stunde Null. 1945-1948. 4 (1995). pp. 60-66. Lehmann, A., Im fremden ungewoll Zuhause. Flüchtlinge und Vertriebene in Westdeutschland 1945-1990. München, 1991. Schoenberg, H.W., Germans from the east. A study of their migration, resettlement, and subsequent group history since 1945. Den Haag, 1970.

${ }^{30}$ Heuß, A., Versagen und Verhängnis. Vom Ruin deutscher Geschichte und ihres Verständnisses. Berlin, 1984.

p. 208.

${ }^{31}$ Hitler, p. 236.

${ }^{32}$ Zie: hoofdstuk 2, paragraaf 2.
} 
identiteit. En vandaar opnieuw bedreigend. Zes miljoen uit hun Heimat verdreven [cursief van G.G.], met één enkel handgebaar op de speeltafel van de geschiedenis, waarover ze nooit meer mochten spreken, zonder zichzelf te verliezen. De grote zelf geprovoceerde volksverhuizing na de grootste massamoord van de eeuw op vijanden en vrienden. Zo staan we hier nu, 32 jaar later, met grote investeringen, oneindig zwaar betaald. Hoe verdacht zijn zij, die vragen, waarom wij dat hier doen, dit spreken, spelen, tonen, bloeden. Het einde van een erfenis. Vragen, waarom een film over dat alles? Was denn sonst?"33

En ook in deze zin zou je het tableau kunnen interpreteren: als een klaagzang op een verloren Kulturnation waarin "eer, trouw, landleven, arbeidsijver, waardigheid, vaderland, trots, geloof, magie, mytbe, dienen, heersen, Fithrer en autoriteit' er nog wel toe deden en het leven nog niet verziekt werd door de Zivilisation met haar verheerlijking van rationalisme en materialisme: de 'pest van onze eeuw', aldus Heller. In het verdriet van de 'Eeuwige Jood' Heller weerspiegelt zich het verdriet van een nabestaande uit het afgebrande Pommernland. Zoals de hymne van de Habsburgse monarchie tevens het Duitse volkslied is, zo versmelten in dit tableau de heimwee van een Oostenrijkse jood en een Pommerse Heimat-loze naar hun respectievelijke vaderlanden - 'vaderland, vaderland", 'Wenen, Berlijn', 'zes miljoen uit hun Heimat verdreven'. (Het getal 'zes miljoen' slaat vermoedelijk op de volgens officiële cijfers 6.817.000 Duitsers die tussen 1945 en 1950 werden verdreven uit Oost-Pruisen. ${ }^{34}$ ) 'Hoe moet ik dat jou duidelijk maken? En mezelf? En alle kinderen en kleinkinderen, die dit alles niet gekend hebben.' Dit vroegere leven in de Weense jodenbuurt én op het Pommerse platteland... Hoe duidelijk maken, wat het wil zeggen je waardigheid, eergevoel, trots of geloof te hebben verloren aan iemand voor wie de betekenis van dit soort begrippen volstrekt vreend is geworden? Hoe getuigen van een 'stammenmoord' (Heuß), wanneer het begrip 'stam' enkel nog associaties oproept met de Blut-und-Boden-barbarij van de nationaalsocialisten?

Het is, al met al, weer eens een buitengewoon complex spel met mystificaties, dat hier wordt opgevoerd. De zoon van een joodse vader verwoordt in een klaagzang, waarin een duidelijke echo doorklinkt van de getuigenis van een overlevende van Auschwitz, het verdriet van de zoon van een Pommerse hereboer, die op zijn beurt weer in de huid kruipt van een jodenhater uit Bayreuth over wie - bestaat er een mooier voorbeeld van ironie? - het hardnekkige gerucht de ronde doet, dat hij van vaderszijde joods zou zijn geweest - een joodse bastaard, vervuld van zelfhaat. ${ }^{35}$ Immers, aldus Wagners tweede verschijning in Der Wald steht schwarz und schweiget (1984), zo lagen de zaken nu eenmaal in de tijd vóór Auschwitz: "Wie niet tegen de joden was, was nooit jood". ${ }^{36}$ Per slot van rekening waren de joden altijd de 'meest trouwe' Duitsnationalisten - 'onverbiddelijk, gewiekst en vol liefde voor de Heimat'. En de tweede verschijning zelf? Maken al deze mystificerende genealogieën niet ook hem tot een joodse bastaard? Syberberg mag er graag over fantaseren. Neem de volgende passage uit Die freudlose Gesellschaft:

"Hoe zou het zijn, wanneer ik op zijn minst de bastaard was van een joodse moeder, of zelfs van een echte proletarische loonarbeider uit Pommeren? (...) Dan had deze film wellicht Hitler, een film van een jood uit Duitsland geheten. (...) Ik zie de

\footnotetext{
${ }^{33}$ Hitler, a.w., p. 97.

${ }^{34}$ Cijfer ontleend aan: Schoenberg, a.w., p. 33.

${ }^{35}$ Zie bijvoorbeeld: Gutman, R.W., Richard Wagner. The Man, His Mind and His Music. Harmondsworth, 1968, 1971. pp. 24-36.

${ }^{36}$ Syberberg, H.J., Der Wald steht schwarz und schwetget. Neue Notizen aus Deutschland. Zürich, 1984 . p. 124.
} 
gezichten [van de Duitse critici, G.G.] al voor me, vervuld van schuld over wat ze hebben aangericht. (...) En mezelf, een joodse loonarbeiderszoon (...), in de hel van mijn universum recht sprekend over de post-Hitler-generatie."37

Zoals zijn joodse alter ego André Heller in dit tableau recht spreekt over de postnazistische "Kulturhölle rondom ons". ${ }^{38}$ Want anders dan je op het eerste oog misschien zou denken, is het niet de historische Hitler die hier in de beklaagdenbank staat.

In dit filmatelier, dat zijn naam draagt, is de historische Hitler de grote afwezige. "(...) We hebben geen Hitler, die we in een kooi kunnen tentoonstellen om hem te bespuwen, te schoppen of zijn handen te kussen (...)," laat de circusdirecteur reeds in eén van de openingsscènes weten. ${ }^{39}$ Hier, in deze donkere, hermetisch van de buitenwereld afgesloten studioruimte, zijn we 'onder elkaar' - alleen gelaten temidden van de ruïnes. Alles wat rest van de historische Hitler is een buikspreekpop met zijn gelaatstrekken, waarop we onze frustraties mogen botvieren. Maar wat zou deze pop zijn zonder ons? Wij zijn het, die de marionet laten spreken en bewegen - zo men wil: die hem vullen met betekenissen. En dit tableau dient dan ook, aldus het script, te worden opgevat als een innerlijke monoloog of als een zelfgesprek ${ }^{40}$ - een meditatie over de eigen schuld. Voor een niet onbelangrijk deel betreft het hier een erfschuld uit het recente verleden. Door de 'Grote Broeder' 41 democratisch in het zadel te helpen en zijn misdadige politiek ten uitvoer te brengen, hebben de ouders en de grootouders van de tegenwoordige Duitsers zelf het latere onheil over zich afgeroepen - 'zelf geprovoceerd'. Zijzelf hebben de Russen tot aan de Elbe gebracht, de verwoesting van hun steden uitgelokt en de symbolische orde van het oude Duitsland gedrenkt in bloed. Ze hebben het, kortom, geheel aan zichzelf te wijten, dat ze geen zonsondergang van Caspar David Friedrich meer kunnen zien zonder aan Auschwitz te denken. En toch is dit slechts een deel van het verhaal. Laten we immers niet vergeten, dat Heller zijn anklacht richt tegen dezelfde pop, die we in het derde deel hebben leren kennen als een vurig pleitbezorger van 'de vooruitgang in de wereld' - "Een pluimpje van Adolf Hitler voor deze wereld na mij. Kan ik niet tevreden zijn met mijn onsterfelijkheid?"42

'Hitler', merkt Susan Sontag scherp op, verschijnt in deze film als een hyperbool voor al datgene wat de filmmaker aan de wereld van ná de historische Hitler verafschuwt "Van Hitler naar de pornografie, van Hitler naar de zielloze consumptiemaatschappij van de Duitse Bondsrepubliek, van Hitler naar de grove dwangmethoden van de DDR" ${ }^{43} \mathrm{Om}$ daarover vooral geen misverstand te laten bestaan, laat Syberberg het tableau voorafgaan door een macaber apocalyptisch visioen. "Stel," mijmert Heller, terwijl we recht in het gezicht kijken van een levensgrote sekspop,

"we stonden voor Hitler als voor Christus tijdens het Laatste Oordeel met zijn vraag: wat hebben jullie van de wereld gemaakt en van jullie leven, na mij, zonder mij? Het Laatste Oordeel met de duivel als opperste rechter, de vrolijke Apocalyps, eindelijk, de meest zwarte van alle missen. Zijn grote lofzang op de vooruitgang in de wereld, het ware overwinningsfeest aan het einde van de wereld. De geschiedenis van de dood van het oude Licht, van de heilige Graal tot aan de ondergang van het Avondland. Wat zei Thomas Mann ook al weer in de jaren '30? 'God help ons verduisterde en

\footnotetext{
${ }^{37}$ Syberberg, Die freudlose Gesellschaft, a.w., p. 153.

${ }^{38}$ Hitler, a.w., pp. $116 \mathrm{ff}$.

39 idem, p. 88 .

40 idem, p. 231 .

${ }^{41}$ Zie hoofdstuk 6, paragraaf 2.

${ }^{42}$ Hitler, a.w., p. 232. Zie eveneens: hoofdstuk 6, paragraaf 3.

${ }^{43}$ Sontag, a.w., p. 201.
} 
misbruikte land en leer het vrede te sluiten met zichzelf en zijn wereld'. Wat zou hij zeggen, vandaag de dag? Of onze kinderen, morgen? Als ze zien, wat wij van onze vrijheid gemaakt hebben en van ons: dwergmensen zonder ziel in de dode plasticschoot van een leeg poppengezicht, als spiegel van onze steden en taal. En ze schiepen zich goden naar hun evenbeeld. De finale van onze tegenwoordige existentie, een nieuwe family of men, in het onmenselijke, afgematte gezicht van onze verspeelde vrijheid. Vrijheid zonder menselijk gelaat. Hitler, hier is jouw triomf.,"44

De schuld verschuift van het nazistische verleden naar het postnazistische heden. De doden staan op uit hun geruineerde graven om de nazaten ter yerantwoording te roepen: "In tien jaar tijd vernietigden de uitlaatgassen van auto's evenveel Kultur als vroeger in vier eeuwen. En dat in de naoorlogse jaren meer in onze steden werd verwoest door wederopbouw dan door de bommen van de laatste oorlog, is een bekende grap uit onze realiteit. End-Sieg, EndLösung." 45 En dit maal zijn er geen 'Eeuwige Joden', waarop we onze schuld kunnen afwentelen. Zelfs de grote zondebok 'Hitler', de Shylock van de twintigste eeuw, ${ }^{46}$ heeft ons reeds lang geleden verlaten. De schuld voor deze Kultur-holocaust ná de historische Hitler, de definitieve End-Lösung van het Duitse vraagstuk in de post-histoire van de Kultur, komt geheel en al voor rekening van ons. Wijzelf zullen ons voor onze naoorlogse zonden moeten verantwoorden, wanneer het Uur gekomen is. Hier, in het zonsondergangen-tableau aan het slot van het vierde en laatste deel van de film, lijkt Syberberg alvast een voorschot te nemen op deze 'vrolijke Apocalyps, de meest zwarte van alle missen' - zij het dat niet Lucifer heeft plaats genomen op de rechterstoel.

Deze mystificerende fantasie van hemzelf in de rol van een 'rechtsprekend joods slachtoffer', waarvan het zonsondergangen-tableau een verbeelding lijkt te zijn, wordt door Syberberg in begeleidende pamfletten tot in het groteske doorgespeeld. Daarvan laten zich zoveel voorbeelden geven, dat er bijna geen beginnen aan lijkt. Om het tot een aantal tamelijk lukrake citaten uit Die freudlose Gesellschaft te beperken:
"Ja, ik ben een ontaarde. Een ontaarde van deze democratische vrijheid en haar chauvinistische mediaestablishment. Zonder emigratie van mijn films naar het buitenland waren ze allang dood. (...) Het gaat enkel nog om de geschiedschrijving, om de vermelding van [mijn] bestaan in het buitenland. Ze laten je zelfs niet eervol emigreren. En Auschwitz bestaat ook zonder gas en omheiningen en verbrandingen. (...) Keiner kann sagen sie haben es nicht gewußt. (..) Elk land, elke tijd en dus ook elke generatie, kent haar eigen joden, zeker in Duitsland. (...) André Hellers vader was jood en in deze zoon weerspiegelden zich mijn diepste gedachten over Duitsland. Dus toch? Duitsland zonder joden? Nee. Eén, een halve, en dan nog uit Wenen, werd gevonden. Is het dus toch de schuld van de joden? Nu deze Hitler, hun Hitler als film? Plotseling wordt het allemaal begrijpelijk. Ze hebben gelijk. Het is hun probleem. Eigenlijk allemaal een probleem van de joden in het buitenland [het overgrote deel van Syberbergs buitenlandse bewonderaars is joods, G.G.]. (...) Wanneer ik joods was, zou alles duidelijk zijn en verklaarbaar. In dat geval echter: wee hen!.,"47

\footnotetext{
${ }^{44}$ Hitler, a.w., pp. $267 f$.

${ }^{45}$ idem, p. 248.

${ }^{46}$ Zie hoofdstuk 6, paragraaf 2

${ }^{47}$ Syberberg, a.w., pp. 46, 172, 196, 220, 323, 355, $383 f$.
} 


\subsection{Een Kehre?}

Gezien hun kritiek op de Syberberg van de jaren '90 ontkomen we er niet aan de vraag te stellen: hoe is deze mystificerende fantasie indertijd door bewonderaars beoordeeld? Het antwoord kan kort zijn: een enkele uitzondering daargelaten is dit gekoketteer met joods slachtofferschap in de serieuze wetenschappelijke receptie tot 1990 een non-issue. De uitzondering wordt gevormd door Eric Santner. In zijn relatief laat verschenen Duitslandstudie Stranded Objects (1990) stelt deze Amerikaanse literatururwetenschapper vast, dat Syberberg in pamfletten als Die freudlose Gesellschaft en Der Wald steht schwarz und schweiget gebruik maakt van "formuleringen die verwant zijn aan het discours dat in de loop der jaren is ontstaan over het onderwerp van de Holocaust om zijn eigen behandeling in Duitsland te beschrijven." 48 Maar Santner is dan nog opmerkelijk mild in zijn oordeel.

Goed, geheel zonder risico is het spel dat hier wordt gespeeld allerminst, aldus Santner in Stranded Objects, ongetwijfeld met het midden jaren ' 80 door Jürgen Habermas aangezwengelde debat over Andreas Hillgrubers Zweierlei Untergang (1986) in het achterhoofd:

"(...) Dit soort verschuivingen van het ene niveau van discours naar het andere, (...) bijvoorbeeld de discussie over de uniciteit van de Holocaust (...), die de vorm kunnen aannemen van dubbele plots, kunnen denkpatronen reproduceren, die voldoende zijn om de last van de schuld en het treuren domweg te verdringen en maken het mogelijk de eigen positie te herschrijven als die van het ware slachtoffer, zonder dat een dergelijke beweging noodzakelijk duidt op solidariteit of empathie met andere, meer te erkennen slachtoffers. De eigen wanhoop en verliezen worden de centrale catastrofe, die empathie voor alle anderen uitwist." 49

En ook hij moet toegeven, dat sommige statements van de filmer op het eerste oog misschien. een wat eigenaardige indruk maken. Dat geldt bijvoorbeeld voor het volgende statement uit Die freudlose Gesellschaft, waarop Santner zijdelings de aandacht vestigt: "Amerika heeft einiges wiedergutzumachen na deze Holocaust [de uit "78 daterende TV-serie, G.G.] uit Hollywood in de Duitse media".50 "Een dergelijke opmerking suggereert," meent hij, "dat voor de maker van Hitler, ein Film aus Deutschland het werkelijke geweld van de recente geschiedenis niet zozeer heeft plaatsgevonden in de Holocaust, als wel veeleer in de Holocausts, en aldus dat zielen die gevoelig zijn voor Hollywoods goedkope spelletjes met geschiedenis en ervaring de werkelijke slachtoffers zijn van de twintigste eeuw". Echter, voegt hij hieraan toe:

“Het punt achter een dergelijke schandelijke en diep beledigende retoriek (...), is heel wat minder schandelijk. Op een vaak briljante en meeslepende wijze, dwingt Syberberg zijn toeschouwers en lezers onder ogen te zien, dat de psychologische mechanismen die hebben geleid tot de constructie van plaatsen als Auschwitz vergelijkbaar zijn met de mechanismen, die voortdurend worden aangewend in, wat sinds Adorno en Horkheimer wordt genoemd, de cultuurindustrie. (...) Syberberg

\footnotetext{
48. Santner, a.w, p. 185 .

49 ibidem. Voor het debat rond Hillgruber, zie bijwoorbeeld: Anderson, P., On Emplotment: Two Kinds of Ruin. in: Probing the Limits of Representation. a.w., pp. 54-65. Santner kiest in deze controverse onvoorwaardelijk partij voor Habermas. Zie: Santner, a: w., pp. $49 \mathrm{f}$. Voor de argumenten van Habermas, zie behalve Anderson, a.w., passim, ook: Habermas, J., Eine Art Schadensabwicklung. Frankfurt am Main, 1987.

${ }^{50}$ Syberberg, a.w., p. 263.
} 
[probeert] te opereren op diverse niveaus van moreel engagement en conceptualisatie. (...) Zijn meditaties over en filmische uitvoeringen van Trauerarbeit brengen steevast de bijzondere naoorlogse Duitse taak van het treuren (en de weigering om dit te doen) in verband met andere postmoderne fenomenen en reflecties."

Heel wat minder mild is Santners oordeel in het amper twee jaar later verschenen essay The Trouble with Hitler: Postwar German Aesthetics and the Legacy of Fascism (1992). Weliswaar houdt hij ook in dit essay onomwonden vast aan zijn eerdere 'postmoderne' uitleg van de films en pamfletten uit de jaren ' 70 en de vroege jaren '80. Maar Syberbergs uitlatingen over 'de joden' in het, uit hetzelfde jaar als Stranded Objects daterende Vom Unglück und Glück der Kunst in Deutschland nach dem letzten Kriege, noemt hij ronduit "obsceen". Meer nog: de auteur van dit mieuwe pamflet blijkt "incapable of conceiving of fantasy except in deeply anti-Semitic terms" - "Hij reproduceert enkele van de meest extreme gebaren en posities van [de] ideologische constructies [uit de nazi-tijd]". ${ }^{52}$ Santner begint zijn uiteenzetting van het gedachtegoed van de Syberberg van de jaren ' 90 met een allegorisch beeld, dat ook door de filmer zelf in diverse late teksten wordt gebruikt om zijn eigen kunstpolitieke positie te verduidelijken. ${ }^{53}$ Het betreft de 'verboden' rouw van Antigone - de mythische heldin, die de Wet van Thebe overtrad door het dode lichaam van haar in de strijd tegen de stad gesneuvelde broer te begraven.

Tot op zekere hoogte, meent Santner, waren ook de grote films uit de jaren ' 70 reeds antigonistisch - met dit verschil dat de filmmaker indertijd nog wél aan de zijde stond van de Wet. De regisseur van Hitler en The Confessions of Winifred Wagner was zich nog ten volle bewust van "de ethische dimensie van het rouwen, waarop de Mitscherlichs wezen". ${ }^{54}$ Vermoedelijk doelt de literatuurwetenschapper hier op wat Alexander en Margarete Mitscherlich in Die Unfähigkeit zu trauern (1967) de "ethische plicht" noemen - de morele verplichting van de Duitsers om te treuren over de "slachtoffers van onze ideologische doeleinden". "Zoals we in hoofdstuk 4 zagen, begrijpt Santner de Hitler-film en de WinifredWagner-documentaire als 'vertalingen in een esthetische praktijk van de Trauerarbeit waar de Mitscherlichs om vroegen' - en hiermee indirect ook van de 'irrationalisme'-kritiek van Lukács en de late Thomas Mann, waarvan de rouwtheorie van de Mitscherlichs op haar beurt weer een vertaling in een psychiatrische praktijk was. ${ }^{56}$ En het is, aldus Santner, uitgerekend dit 'ethische rouwmodel', waarop Syberberg in de jaren '90 zijn giftige pijlen richt: "Zoals ik het zie, berust dit discours [in Vom Unglück und Glück der Kunst in Deutschland nach dem letzten Kriege, G.G.] op een vervanging van een ethisch model van het rouwen - dat nu wordt opgevat als repressief oedipaal en joods - door een esthetisch model, dat Syberberg lijkt te associëren met Antigone. Syberberg verwerpt, met andere woorden, de ethische dimensie van het rouwen (...). Antigone wordt nu, voor Syberberg, het vehikel voor een radicale buiten-morele en esthetische conceptie van rouw-werk - een rouwen, dat uitsluitend is onderworpen aan de wetten van het kunst-werk". ${ }^{57}$

\footnotetext{
${ }^{51}$ Santner, a.w., p. $103 \mathrm{f}$.

${ }^{52}$ Santner, The Trowble with Hitler, a.w., pp $21 \mathrm{ff}$.

${ }^{53}$ Bijvoorbeeld in: Syberberg, H.J., Kom Unglück und Glück der Kunst in Deutschland nach dem letzten Kriege.

München, 1990. pp. 161ff. Syberberg, H.J., Clever, E., Ein Traum, was sonst? Berlijn, 1990. p. 5.

${ }^{54}$ Santner, a.w. pp. 12, 22.

${ }^{55}$ Mitscherlich, A., Mitscherlich, M., Die Unfähigheit zu trauern. Grundlagen kollektiven Verhaltens. München, Zürich, 1990, 1967. p. 35.

${ }^{56}$ Santner, a.w., p. 12 . Zie in dit verband Santners interpretatie van de Winifred-Wagner-documentaire, in:

paragraaf 4.6. Voor de invloed van Lukács op de Mitscherlichs: paragraaf 5.4.

57 idem, p. 18 .
} 
Achter deze verwerping van elke vorm van moraal, vervolgt Santner, gaat een volstrekt nieuwe visie schuil op het Duitse vraagstuk:

"In de Hitler-film werd de bezoedeling van de Duitse cultuurtraditie en, bovenal, de erfenis van de Duitse romantiek (...) opgevat als een uitvloeisel van de manier waarop het nationaal-socialisme zich deze erfenis had toegeëigend en gebruikt als een cruciale ondersteuning voor de fantastische constructie van Volksgemeinschaft. In deze nieuwste revisie van de kwestie (...) wordt de ontheiliging die de polis bedreigt niet herleid tot een of andere concrete historische schuld die een smet werpt op de culturele traditie, maar veeleer tot verboden die van buiten zijn opgelegd, tot de Wet van de overwinnaars en hun beleid van morele, politieke en culturele re-education. (...) Syberbergs cruciale punt, echter, is nog radicaler (...): [ook] het zogenaamde onvermogen om te rouwen werd, in deze lezing, aan de Duitsers opgelegd (...). De kern van Syberbergs opmerkelijke en zeer verontrustende herformulering van de these van de Mitscherlichs lijkt het volgende te zijn: konden de Duitsers zich maar bevrijden van de joodse invloed (via de Frankfurter Schule) op de naoorlogse Duitse kunst, dan zouden ze kunnen beginnen met de echte verwerking van de catastrofe veroorzaakt door hun grootse inspanningen om de joodse invloed op de Duitse kunst en cultuur te elimineren." $" 58$

Thomas Elsaesser (1996), die zich in de jaren '90 eveneens van (de late) Syberberg heeft afgekeerd, schrijft in dit verband over een macabere What-if-fantasie. Wat zou er van de Duitse cultuur zijn geworden, wanneer de "bevrijders" het na de oorlog niet in de geruïneerde Kulturnation voor het zeggen hadden gehad? "Zonder de Amerikanen en hun massacultuur, waarvan de dominantie door hem [de Syberberg van Vom Unglück und Glück der Kunst in Deutschland nach dem letzten Kriege, G.G.] wordt beschouwd als een direct gevolg van Hitlers verlies van Hollywood, had een ware Duitse kunst vrij van buitenlandse invloeden zichzelf wellicht weer kunnen opbouwen." En hoe zou het zijn geweest, wanneer de jonge generatie in de jaren " 60 niet "zo vurig het melancholische pessimisme van Duitslands vooroorlogse joodse intellectuelen" had omarmd? "Door Walter Benjamin en TW Adorno tot het goede geweten te maken $(. .$.$) en van hen het negatieve perspectief op de Duitse$ romantiek, nationalisme en populaire cultuur over te nemen, heeft de generatie van de jaren '60, volgens [de late, G.G.] Syberberg, de gelegenheid voorbij laten gaan om het Duitse probleem te verwerken en zichzelf vervreemd van wat het wil zeggen een Duitser te zijn, op een niet minder fatale wijze dan de massa's die Hollywood, Disneyland en de Amerikaanse populaire muziek omarmden." 59

Het behoeft, meent Elsaesser, geen betoog, dat dit soort bespiegelingen "buitengewoon weerzinwekkend" zijn. Rond Syberbergs 'nieuwe' denkbeelden over het Duitse vraagstuk hangt onmiskenbaar de geur van "een gevaarlijk, want grotendeels onbewust antisemitisme". Niet enkel maakt de auteur van Vom Unglück und Glück der Kunst in Deutschland nach dem letzten Kriege de Duits-joodse cultuurfilosofie to "zondebok"; hij plaatst bovendien de ware toedracht van de gebeurtenissen volkomen op de kop: uitgerekend "de lucide diagnosen van de kritische theorie van de Frankfurter Schule uit de jaren "30 en '40", waarvan de Hitler-film zijn krachtigste stimulans zou hebben ontvangen, "worden bejegend alsof het ging om een jaren ' 60 'misleiding" van de Duitse jeugd". 60 Maar dat deze filmer/pamflettist niet zuiver op de graat is, denkt het overgrote deel van de Duitse critici al

\footnotetext{
58 idem, p. 17.

${ }^{59}$ Elsaesser, a.w., pp. $209 \mathrm{f}$.

${ }^{60}$ idem, pp. $154 f, 210$.
} 
veel langer te weten. En dat is dan ook tegelijk het manco van Elsaessers en Santners commentaren op de late Syberberg; in vrijwell dezelfde bewoordingen hadden ze zich kunnen uitlaten over de Syberberg van de jaren ' 70 en de vroege jaren ' 80 .

Hiermee zij niet gezegd, dat de regisseur sinds de Hitler-film geestelijk een pas op de plaats zou hebben gemaakt. Zo zout als in Vom Unglück und Glüick der Kunst in Deutschland nach dem letzten Kriege hebben we het inderdaad nog niet gegeten. "Wer mit den Juden ging wie mit den Linken machte Karriere," wordt in Der Wald steht schwarz und schweiget (1984) nog meer neutraal geformuleerd als: "Wer Karriere machen will, muß mitspielen".62 Maar welk spel het precies is, dat zo iemand zou moeten meespelen en wie de regels van dit spel bepalen, is dan al volstrekt duidelijk:

"Na ' 45 vestigde zich in Duitsland een nieuwe autoriteit: de morele van de slachtoffers van Auschwitz. (...) We hebben het graag over de bevrijding van de proletariërs, de joden, de vrouw en de seksualiteit. Wanneer men zorgvuldiger kijkt, worden slechts nieuwe mechanismen van onderdrukking geschapen. De bevrijde slaaf zoekt zich nieuwe slaven om te onderdrukken, overeenkomstig de nieuwe tijd. (...) Het ergste echter zijn zij, die dat goedkeuren, uit financiële of carrièreoverwegingen $(\ldots)$.

Reeds in Die freudlose Gesellschaft (1981) noemt Syberberg de 'partizanenstrijd' tegen de "nieuwe kaste van de aalgladde, zichzelf gemakzuchtig antifascist noemende linksen van de publieke opinie" zijn "grote thema": 64

"Links establishment, nogmaals. Het is een ziekte, het intellectuele kankergezwel, de pest van onze eeuw, en ik voel me er zelf niet geheel vrij van. Wie ooit bij Brecht en Stalin in de schoolbanken heeft gezeten, kamt er niet meer van los. Het meest erg en onverbiddelijk zijn de excuus-linksen in die feuilletons van de rechtse media, die men zich veroorloofd onder het mom van pluralisme en vrijheid. En vergis je niet: wanneer ergens iemand van rechts, zoals zij het noemen, dat wil zeggen iemand anders wordt gedoogd, dan gaat het steevast om figuren, die door de hel van Auschwitz onaantastbaar zijn geworden - een immuniteit, die bedriegt. Wanneer ik hier spreek over nestbevuiling, bedoel ik het nest van de intellectualiteit, en die is links, hetgeen gelijk staat aan macht. Alles wat wij rechts noemen is industrie en een ander verhaal. De linkse intellectuelen heulen met de macht. En wanneer dat geen verzet zou oproepen, waren we dood. (...) Nu lezen we plotseling [in Der Spiegel, G.G.] over twijfels met betrekking tot het heilige boek van de vervolgden van Auschwitz. Moeten lezen, dat delen van het manuscript van Anne Frank later, pas na 1951 namelijk, na de uitvinding van de balpen, werden geschreven in hetzelfde handschrift als het geheel, hetgeen doet vermoeden dat het geheel hoogstwaarschijnlijk niet van de hand is van een kind. (...) Criminologische bewijzen liggen op tafel; smoesjes zoals gebruikelijk. Wie van hen, die voor Ossietzky vochten en voor Dreyfus, heeft de moed om op dezelfde wijze in opstand te komen tegen de misdaden van onze dagen?"

\footnotetext{
${ }^{61}$ Syberberg, a.w., p. 14.

${ }^{62}$ Syberberg, Der Wald, a.w., p. 17.

63 idem, pp. 114, 127.

${ }^{64}$ Syberberg, Die freudlose Gesellschaft, a.w., pp. 302, 351.

${ }^{65}$ idem, pp. $231,301$.
} 
De kritiek op de naoorlogse re-education, de "jarenlange heropvoeding in de richting van sociaal-kritische, maatschappij-wetenschappelijke monoculturen", ${ }^{66}$ treedt voor het eerst op de voorgrond in een reeks pamfletten uit 1978, waaronder de Hitler-script-inleiding Die Kunst als Rettung aus der deutschen Misere:

\begin{abstract}
"Een generatie lang hebben de kinderen in Duitsland statistieken van Auschwitz van buiten geleerd. (...) Maar uit statistieken leert men geen rouw, en hoe wil men schuld afdragen, want ook dat kent zijn riten, net als het bouwen van huizen, het moorden en het triomferen. Wie heeft hen de mythe en de ethos om te treuren geleerd, de nieuwe, die voor onze tijd, met de oude wijsheden van onze tradities? Nee, men heeft hen bedrogen en ze hebben zichzelf belogen." 67
\end{abstract}

Een jaar eerder, in een op de set van de Hitler-film afgenomen interview, rept de regisseur al over een "psychologisch Versailles". ${ }^{68}$ En we zouden nog verder terug kunnen gaan in de tijd: in de zomer van' 75 , twee jaar voor de Hitler-film en vijftien jaar voor Vom Unglück und Glück der Kunst in Deutschland nach dem letzten Kriege, plaatst hij een belijdende nazi op een voetstuk als een "monument van burgermoed" 5 hebben gezien, vanuit het 'ethische rouwmodel' van de Mitscherlichs nauwelijks valt te begrijpen. Sterker nog: wat Syberberg aan de oude dame zo bewondert, bleek in dit hoofdstuk precies datgene te zijn, wat haar binnen dit 'ethische rouwmodel' tot een pathologisch én amoreel geval maakt: haar soevereine 'trouw' aan het 'eigene'. Uiteindelijk ontkwamen we er zelfs niet aan te concluderen, dat het juíst de psychoanalyse van het Duitse 'onvermogen om te rouwen' en aanverwante re-education-ideologieën moesten zijn, waartegen hij de vrouw in bescherming probeert te nemen, wanneer hij zich bijvoorbeeld in een aan de Winifred-Wagner-documentaire toegevoegde "waarschuwing tegen ijdele rechtschapenheid" richt tot de critici van zijn aufarbeitende protestgeneratie van " 68.70

Voor Syberberg, die als kind heeft moeten meemaken hoe onder het mom van socialistische heropvoeding naar het model van Lukács ${ }^{71}$ een helle cultuur van de aardbodem werd weggevaagd, zijn dit soort 'links-modernistische' fantasieën over de maakbaarheid van mens en samenleving een regelrechte grawel. ${ }^{72}$ De Duitse mythopoëtische ziel is geen historische, sociale of psychologische constructie, waaraan men naar believen kan sleutelen. 'Een heel volk heeft opgehouden te existeren, in de diaspora van de geest en de elite. De nieuwen werden ontworpen, ontwikkeld, de nieuwe mens is een feit. De pest van het materialisme heeft getriomfeerd in Oost en West. Proficiat!,' bijt Heller de buikspreekpopHitler toe in het zonsondergangen-tableau. En hoe we ons deze 'nieuwe mens' moeten voorstellen, heeft Hellers alter ego in heldere bewoordingen duidelijk gemaakt in Die Kunst

\footnotetext{
${ }^{66}$ Syberberg, H.J., Es herrscht ein ungutes Klima in diesem Land, brutal und tötend. Warum sein Hitler-Film nicht bei uns läuft, in: Die Zeit. 3 (13-01-1978), p. 31.

${ }_{67}$ Syberberg, Die Kunst als Rettung..., a.w., p. 14. Zie eveneens. hoofdstuk 5, de paragrafen 3 en 6.

68 Winter, de, L., Het Duizendjarige Rijk als filmlokatie, in: Hollands Diep. 6 (26 maart 1977). pp. 40-43, zie: 43. Zie eveneens: hoofdstuk 5 , passim.

${ }^{69}$ Wirbel um offene Worte Winifreds. Film-Bekenntnisse gerieten in politisches Zwielicht. in: Richard Wagner. Ein deutsches Thema. Eine Dokumentation zur Wirkungsgeschichte Richard Wagners (1876-1976). Hrsg. H.

Zelinsky. Berlin, Wien, 1976, 1983, p. 273.

${ }^{70}$ Syberberg, Filmbuch, a.w., p. 282. Hoofdstuk 5, passim.

${ }^{71}$ Zie: hoofdstuk 2 , paragraaf 4 .

72 . Als Hitler een utopist was, zoals Syberberg hem noemt, dan wordt Syberberg daardoor onherroepelijk een 'post-utopist' - een utopist die erkent dat de utopistische gevoelens onherstelbaar bezoedeld zijn. Syberberg gelooft niet in de 'nieuwe mens' - het eeuwige strijddoel van links en van rechts. Al voelt hij zich nog zo aangetrokken tot het credo van het romantische genie, in werkelijkheid gelooft hij alleen in Goethe en een degelijke gymnasiumopleiding." Sontag, a.w., p. 217.
} 
als Rettung aus der deutschen Misere. De 'nieuwe mens' is een Duitser die 'allang niet meer weet, waarom hij samenleving zegt in plaats van Duitsland, volk en vaderland'; die 'zijn gevoelens heeft uitgedoofd', 'niet meer kan lijden en het treuren heeft verleerd' ${ }^{73}$ Kortom: een Duitser die 'zichzelf heeft vervreemd van wat het wil zeggen een Duitser te zijn' (Elsaesser).

\subsection{Post-Hitler: Het Pruisen-Requiem}

Nogmaals: hiermee zij niet gezegd, dat Syberberg in de jaren ná de Hitler-film geestelijk een pas op de plaats zou hebben gemaakt. Behalve het wat krassere taalgebruik kan wel degelijk nog een andere en, naar ik meen, meer fundamentele verandering worden aangewezen. Het betreft de positie van waaruit Syberberg spreekt. Terecht rekenen Santner en Elsaesser zijn films en pamfletten uit de jaren ' 70 en de vroege jaren ' 80 tot een, laten we zeggen linksliberaal vertoog over Duitsland en Duitse geschiedenis, waarvan het substraat wordt gevormd door de antifascistische emigrantencultuur van het interbellum. Dat vooral in eigen land al vroeg stemmen zijn opgegaan hem als een warhoofdige Ewiggestriger uit dit vertoog weg te schrijven, doet mijns inziens aan de geldigheid van deze indeling weinig af. Dergelijke retoriek behoort nu eenmaal tot de eigenaardigheden van het linkse cultuurdebat, dat van meet af aan in het teken heeft gestaan van de uitsluiting van een als decadent of fascistisch betekende en gecategoriseerde Ander. ${ }^{74}$ Wie werden in de loop der jaren al niet verbannen naar dat fameuze Grand Hotel Afgrond - de Onderwereld van het 'zuivere' linkse denken, die door Lukács zo bloemrijk is beschreven in Die Zerstörung der Vernunft (1954)? ${ }^{75}$ Ernst Bloch, John Dos Passos, James Joyce, Bertolt Brecht, Pablo Picasso, Dmitri Sjostakovitj, Wassily Kadinsky, Vladimir Majakovski, Theodor Adorno, Samuel Beckett, Wolf Biermann, Luchino Visconti, Pier Paola Pasolini, Alfred Schnittke, Botho Strauß, Karl Heinz Bohrer, Hans Mayer, Rainer Werner Fassbinder, Martin Walser, Markus Lüpertz, Anselm Kiefer, Michel Foucault, Jacques Derrida... De lijst met namen van illustere kunstenaars en intellectuelen, die gedurende korte of lange tijd binnen het linkse cultuurdebat ervan werden verdacht hun intrek te hebben genomen in dit "fraaie en van alle comfort voorziene hotel aan de rand van de afgrond, van het niets, van de zinloosheid' (Lukács) laat zich moeiteloos aanvullen.

Ten opzichte van deze, wat de Duitse politieke filosoof Walter Kowalsky (1994) noemt, "Oud Linkse uitsluitingsmachinerie", 76 heeft het werk van Syberberg zich steeds verhouden als antithese tot these. Reeds zijn allervroegste films, die hij als scholier van amper achttien ten tijde van de formalisme/realisme-strijd aan het Brecht-theater in OostBerlijn heeft gemaakt, waren een reactie op de uitsluitingspraktijk van het stalinisme. ${ }^{77}$ En sindsdien is de polemiek tegen de sinds Lukács en de late Thomas Mann in Oud en Nieuw Linkse kringen tot conventie geworden neiging om de Duitse cultuurgeschiedenis op te delen in goede en foute, gezonde en decadente, progressieve en reactionaire, linkse en rechtse, humanistische en fascistische traditiespoien steeds als een rode draad door dit oeuvre blijven lopen. Maar - en dat is voor het begrijpen van het verschil met zijn latere positie van groot

\footnotetext{
${ }^{73}$ Syberberg, Die Kunst als Rettung..., a.w., p. 60. Zie eveneens: hoofdstuk 5, paragraaf 6.

74 Zie: de paragrafen $2.4,3.4,4.1,5.5,6.7$.

${ }^{75}$ Lukács, G. Die Zerstönung der Vernumft. Neuwied an Rhein, Berlin-Spandau, 1962. p. 219. Zie eveneens:

Lukács, G., Voorwoord. in: Theorie van de roman. Een poging tot een geschiedfilosofische beschouwing van de grote epische vormen. Vert. W. D. Tieges. Amsterdam, 1979, 1980. p. 20.

${ }^{76}$ Kowalsky, W., Comeback oder Abgesang der Rechtsintellektuellen. in: Die neue Gesellschaft /Frankfurter Hefie. 9 (september 1994). pp. 830-834, zie: 831 .

${ }^{77} \mathrm{Zie}$ : de paragrafen 2.3 tot en met 2.5 .
} 
belang - nog in een interview uit ' 81 presenteert Syberberg zijn werk niet als een "oppositie vanuit rechts". ${ }^{78}$ Dat wil zeggen: als een oppositie vanuit een positie buiten het links-liberale vertoog. De Syberberg van de Winifred-Wagner-documentaire en de Hitler-film presenteert zijn werk nog nadrukkelijk als een stellingname binnen het linkse cultuurdebat, ten gunste van een dissidente stroming waarvan de neo-marxistische avant-gardisten Bertolt Brecht, Ernst Bloch en Hans Mayer de belangrijkste vertegenwoordigers zijn. En hoewel ook deze Syberberg reeds gevaarlijk dicht in de buurt komt van dat andere, op dat moment nog ondergrondse vertoog van Oud en Nieuw Rechts, wijst niets erop dat hij dan al met dit vertoog sympathiseert of überhaupt van het bestaan ervan op de hoogte is.

Zoals we zagen in hoofdstuk 6 wordt het doen en laten van deze filmer/pamflettist vanuit de subcultuur van Oud en Nieuw Rechts al vroeg met stijgende belangstelling gade geslagen. Reeds in de zomer van ' 82 publiceert het Nieuw Rechtse blad Criticón een uitermate lovende recensie van het pamflet Die freudlose Gesellschaft. ${ }^{79}$ Delen van het pamflet waren eerder verschenen in columnvorm - echter niet in Criticón of een aanverwant rechts-extremistisch periodiek, maar in de uitgesproken links georiënteerde Berlijnse Tageszeitung. ${ }^{80} \mathrm{En}$, hoe vreemd dit op grond van het voorafgaande ook mag lijken: concrete voorbeelden van een directe beïnloeding door Nieuw Rechts heb ik in Die freudlose Gesellschaft niet kunnen ontdekken. Voor zover wel eens iets van het revisionistische geroezemoes in de rechts-extremistische underground tot dit cultuurkritische postscriptum bij de Hitler-film doordringt, gebeurt dit steeds via de reguliere kanalen van de 'fatsoenlijke' media. Zo is de in de vorige paragraaf aangehaalde passage, waarin de authenticiteit van de dagboeken van Anne Frank in twijfel wordt getrokken, gebaseerd op een artikel in Der Spiegel. Maar de grote issues, die in de jaren 70 de rechterflank van de Bondsrepubliek in beroering brengen, bijvoorbeeld de "haatcampagne" (Armin Mohler) tegen de historicus, Criticón-redacteur en (latere) partij-ideoloog van de Republikaner Hellmut Diwalld, ${ }^{81}$ lijken aan de Hitler-regisseur geheel en al te zijn voorbij gegaan. Anders dan de linkse controversen over de Tendenzwende, de 'schone schijn' van het Derde Rijk, het Duitse 'onvermogen om te rouwen', of de Biermann-Ausbürgerung, waarin hij wél expliciet stelling neemt, vallen dit soort rechtse controversen domweg buiten zijn referentiekader. Laat staan dat hij zich dan al met figuren als Diwald verwant zou voelen. Deze Syberberg van de Winifred-Wagnerdocumentaire en de Hitler-film spiegelt zich nog aan zijn 'artistieke pleegvader' Bertolt Brecht, wiens cultuurstrijd tegen 'kunstrechter' Lukács en diens epigonen hij in zijin eigen beleving voortzet. Zelfs de invloed van de 'intellectuele pleegvader' Hans Sedlmayr, die hij welldra als zijn grote voorbeeld zal gaan aanwijzen, is eind jaren " 70 nog te verwaarlozen

\footnotetext{
${ }^{78}$ Erkkila, B., Hans Jürgen Syberberg; an Interview. in: Syberberg. A Filmmaker from Germany. ed. H. Stewart. Edinburgh, 1992. pp. 27-34, zie: 29. Zie eveneens: hoofdstuk 5, paragraaf 8 .

${ }^{79} \mathrm{Zie}$ : haofdstuk 6 , paragraaf 4 .

${ }^{80}$ Syberberg, H.J., Syberberg's Notizen. Sommer auf dem Berg. in: Tageszeitung. 05-09-1980. Syberberg, H.J., Syberbergs Notizen: La 'Treue'. Hitlers Opfer eine verlorenen Generation. in: Tageszeitung. 22-09-1.980.

Overigens geldt dit ook voor alle andere teksten van zijn hand uit de jaren ' 70 en de vroege jaren ' 80 . Neem de Winifred-Wagner-necrologieën, die in de Bondsrepubliek zoveel stof hebben doen opwaaien. (Zie: hoofdstuk 4, paragraaf 7). Ze zijn gewoon verschenen in respectievelijk Die Zeit en Der Spiegel.

${ }^{81}$ Mohler, A., Die deutschen in der Mühle. Zum Stand der Vergangenheitsbewältigung nach 'Holocaust" und der Anti-Diwald-Kampagne. in: Criticón. 52 (maart/april 1979). pp. 55-59. Voor Diwald en de controverse rond zijn werk, zie eveneens: Diwald, H, Mut zur Geschichte. Bergisch Gladbach, 1983, 1984. Laqueur, W., Was ist los mit den Deutschen? Vert. O. Weith. Frankfurt am Main, Berlin, 1985. p. 194f. Brinks, J.H., De rechterflank van Duitsland. Amsterdam, 1994. pp. 79, 104ff, 115. Greß, F., Jaschke, H.-G., Schönekäs, K., Neue Rechte und rechtsextremismus in Europa. Opladen, 1990. pp. 261, 269, 272, 280f, 299, 305ff, 313, 317, 324, $329 \mathrm{ff}$.

82 Voor Syberberg stellingname in de controverse rond de Biermann-Ausbürgerung, zie behalve hoofdstuk 6 , paragraaf 3, eveneens: Syberberg, Die freudlose Gesellschaft, a.w., pp. 155, 381: "Bald sind wir aus dem Osten Deutschlands unter uns im Westen Deutschlands, wenn es um Leiden und seine Ehrlichkeit geht".
} 
gering. "Later, toen ik van de universiteit weg ging, heb ik die dingen [de kunsttheorie van Sedlmayr, G.G.] vergeten en ook bewust willen vergeten," vertelt Syberberg in een interview uit '91. "Ik heb me ervan willen bevrijden, omdat ik me erdoor belemmerd voelde. (...) En ik ben van mening, dat Sedlmayr de Hitler-film niet erg zou hebben gewaardeerd. Sterker: indertijd, toen ik de Hitler-film maakte, zou Sedlmayr dat beslist níet goed hebben gevonden. Maar tegenwoordig...? Veel van wat ik destijds heb gemaakt, vind ik ook zelf niet echt goed. Das heißt: man hat sich selbst verändert." ${ }^{33}$

We mogen ons door de verwijzingen in de Hitler-film naar Sedlmayrs theorie van de 'verloren Mitte' dan ook niet op het verkeerde been laten zetten. ${ }^{84}$ Weliswaar behoort deze theorie tot het 'geoccupeerde' materiaal, waaruit de film is opgebouwd. Zoals we echter zagen in de voorafgaande hoofdstukken ontleent Syberberg de motieven om zich met dit materiaal bezig te houden dan nog niet aan Sedlmayr, maar aan Brecht, Mayer en - bovenal Bloch: de ware kritische filosoof of kunstenaar legt zich niet neer bij de pervertering, maar ontwikkelt strategieën om het geroofde culturele erfgoed weer aan de nazi's te ontfutselen. ${ }^{85}$ Daarbij komt dat Sedlmayr van wagnerianisme en hieruit voortgevloeide stromingen als symbolisme en surrealisme op zijn zachtst gezegd geen warm voorstander was. Bekijk je het aldus, dan hebben de Sedlmayr-citaten binnen de context van het onverbloemd neowagneriaanse Gesamtkunstwerk Hitler, ein Film aus Deutschland, dat door Sontag terecht met symbolisme en surrealisme in verband wordt gebracht, sterk het karakter van esthetische en kunstfilosofische Fremdkörper. ${ }^{86}$ Zoals Syberberg zelf in de loop van de jaren '80 zal gaan onderkennen. In Vom Unglück und Glück der Kunst in Deutschland nach dem letzten Kriege verwerpt hij met een beroep op Sedlmayrs kunsttheorie de vaak als 'postmodern' aangeduide collagestijl, die vanaf Die Grafen Pocci (1967) zijn handelsmerk was. ${ }^{87}$ Het is de

\footnotetext{
${ }^{83}$ Interview met de auteur en Eling Delleman, zomer 1991:

XX: "Wir sehen in ihrer Arbeit einen Versuch, die Einsichten Hans Sedlmayrs weiter zu führen. Stimmen sie dem zu?"'

Syberberg: "Ja, sicher".

XX:" "Inwiefern sind Sie von ihm beeinflußt?"

Syberberg: "Er war einer meiner Lehrer und ich habe bei ihm viele Prüfungen gemacht, sehr viele... Er war so viel mehr Persönlichkeit als andere Lehrer... Ach, es gab da sehr viele andere, aber die waren nicht so stark. Ja, er hat mich sehr stark beëinflußt... Also, ich habe dann später gelernt, daß er vom Lande kommt, auf dem Lande aufgewachsen ist, und das bin ich auch. Daher ist mir heute einiges erklärbar. Wenn man auf dem Lande aufgewachsen ist, denkt man anders als in Städten. Man sieht das Leben und die Dinge eben anders." XX: "Mehr organisch, mehr das Ganze?"

Syberberg: "Ja, richtig, ja, ja. (...) Also, ich habe dann später, als ich von der Universität weg ging, diese Dinge vergessen und vergessen wollen. Ich habe mich davon befreien wollen, weil es mich gehindert hat. (...) Und ich bin der Meinung das Sedlmayr den Hitler-Film nicht sehr geschätzt hätte. Also, sicher hätte zur Zeit, als ich den Hitler-Film gemacht habe, Sedlmayr das nicht gut gefunden. Aber heute...? Ich finde ja manches auch nicht gut was ich damals gemacht habe. Das heiBt: man hat sich selbst verändert."

XX: "Früher haben Sie also die Gedanken Sedlmayrs von sich abgesetzt, und jetzt können Sie wieder damit arbeiten?"

Syberberg: "Sagen wir mal, sie sind mir bewust geworden. Eine lange Zeit habe ich überhaupt nicht mehr daran gedacht. Völlig verloren und uninteressant gefunden. Sie waren mir nicht mehr gegenwärtig. Dann habe ich mich wieder daran erinnert, und jetzt - ich hab jetzt auch wieder das Buch [Verlust der Mitte, G.G.] gelesen versuche ich mich zu erinnern. Also es gibt natürlich gewisse Grundwahrheiten die mir immer present blieben, aber heute ist manches, sagen wir mal, etwas vertrauter wieder."

Zie eveneens: hoofdstuk 2, paragraaf 10 .

${ }^{84}$ Zie: hoofdstuk 6 , paragraaf 6 .

${ }^{85}$ Bijvoorbeeld: hoofdstuk 6 , paragraaf 7 .

${ }^{86} \mathrm{Zie}$ : hoofdstuk 2, paragraaf 7 .

${ }^{87}$ Syberberg, Kunst in Deutschland, a.w., pp. $103 \mathrm{ff}$.
} 
climax van een "großer gedanklicher Klärung," 88 waarvan de tekenen voor het eerst duidelijk zichtbaar worden in de uit ' 84 daterende theatervoorstelling Die Nacht.

Ruim een decennium is verstreken, sinds Syberberg 'met hulp van Hans Mayer' zijn aandacht heeft verlegd van het theater van de absurdisten naar Wagner en de late romantiek: ${ }^{89}$ Sindsdien zijn, de filmopera Parsifal (1982) meegerekend, zes werken ontstaan met een totale speelduur van 23 uur, die alle direct of indirect Wagner tot onderwerp hebben. Hiermee lijkt dit onderwerp nagenoeg uitgemolken. Midden jaren' 80 is Syberberg overduidelijk toe aan een nieuwe uitdaging. ${ }^{90}$ En Die Nacht laat zich dan ook nog het beste kenschetsen als een overgangswerk. Het stuk, dat in de zomer van ' 84 in Parijs in prémiere gaat, bestaat uit een zes uur durende monoloog door Edith Clever - de voormalige Schaubiuhne-actrice, met wie hij sinds Parsifal samenwerkt. Op het eerste gezicht zijn het vooral de parallellen met de Hitler-film die frapperen. Zo is het decorbeeld grotendeels hetzelfde gebleven: een ruïnelandschap van verbrande aarde en verdorde bladeren. Had dit landschap in de Hitlerfilm echter nog veel weg van een depot of vuilstortplaats, bezaaid met materiaal; nu, in Die Nacht, is het speelvlak opmerkelijk sober ingericht. Midden op het toneel ligt een berenvel. In de hoek staat een replica van Rudolf Schadows Goethe-buste. En dan is er natuurlijk nog de actrice zelf, gehuld in een oude mantel. Staand, zittend, liggend en dansend speelt ze teksten die, het zal niet verbazen, wederom voor het overgrote deel afkomstig zijn uit het Grand Hotel Afgrond. Of, zoals een Duitse critica fijntjes opmerkt: "Was Lukács in das Fegefeuer der Vernunft verbannt hatte, schwebt geläutert (?) zu Gott empor, dessen Stelle allerdings die Kunst eingenommen hat". ${ }^{91}$ Daaronder, nog steeds, veel Wagner. Een kleine twee uur vertolkt Clever, als een soort tweede verschijning, met verve de rol van deze Meister uit Bayreuth en klinken uit haar mond diens woorden aan mecenas Ludwig II, kunstbroeder en eeuwige rival Giacomo Meyerbeer (voor Wagner de personificatie bij uitstek van de "Eeuwige Jood"' ) en de Parijze cocotte Judith Gautier, Wagners geheime liefde. ${ }^{93}$ Maar het is, aldus Syberberg in een toelichting, "een afscheid". 94 De man, tot wiens onhebbelijkheden volgens Thomas Mann onder meer behoorde dat hij zich maar wat graag 'alleen hoorde spreken ${ }^{95}$, moet dit maal een bonte kakofonie van stemmen naast zich dulden. De resterende vier uur gaan op aan het reciteren, of beter: uitbeelden van teksten van Plato, Augustinus, Goethe, Kleist, Novalis, Heine, de gebroeders Grimm, Hölderlin, Heidegger, Pound, Cioran, Beckett, Céline, het indianenopperhoofd Seattle en, last but not least, Syberberg zelf: autobiografische herinneringen aan de zonsondergangen van zijn kindertijd op het Pommerse platteland aan de vooravond van de totale zonsverduistering, zo men wil: het invallen van de totale Nacht.

\footnotetext{
${ }^{88}$ Zoals Syberberg in Zimmer, [D.E.], a.w., p. 79, de ontwikkeling typeert, die hij in de jaren ná Hitler heeft doorgemaakt.

${ }^{89}$ Zie: hoofdstuk 3 , paragraaf 1 .

90 "Inzwischen ist meine Beschäftigung mit Wagner zu einem Ende gekommen, weil er als Figur so dominierend wurde, daß er mich fast erdrückt hat," aldus Syberberg in een interview uit 1988. Müller, A., Im Gespräch mit... Hamburg, 1989. pp. 183-203, zie: p. 191.

${ }_{91}$ Mohal, A,, Paris applaudiert dem deutschen Ruinentheater. in: Silddeutsche Zeitung. 02-10-1984. p. 33.

${ }_{92}$ Amerongen, M, van, De buikspreker van God. Amsterdam, 1983. pp. $81 \mathrm{ff}$.

${ }_{93}$ Schuh, W, Die freundschaft Richard Wagners mit Judith Gautier. in: Die Briefe Richard Wagners an Judith Gautier. Zürich, Leipzig, z.j., pp. 15-97.

${ }_{94}$ Syberberg, H.J., Filmography. in: Syberberg. A Filmmaker from Germany, a.w., pp. 44-57, zie: 55: "It [Die Nacht, G.G.] was a farewell from Richard Wagner, who, for ten years, from Ludwig up until Parsifal had been important to these films".

${ }_{95}$ Mann, Th., Wagner und unsere Zeit. Aufsätze, Betrachtungen, Briefe. Hrsg. K. Mann. Frankfurt am Main, 1963, 1983. p. 168.
} 
Die Nacht is de opmaat tot een vierdelige cyclus, 96 waarin niet langer Wagner de centrale figuur is, maar Heinrich von Kleist ${ }^{97}$ - het enfant terrible van het oude Pommeren, de poeet van de vervreemding en de ontheemding. En zoals Die freudlose Gesellschaft een cultuurkritisch postscriptum was bij de Hitler-film, zo is Vom Unglück und Glück der Kunst in Deutschland nach dem letzten Kriege een cultuurkritisch postscriptum bij vooral het laatste deel van dit Requiem voor het einde van Pruisen (1984-91), zoals de overkoepelende titel luidt: Ein Traum, was sonst? (1990/91) is losjes gebaseerd op een autobiografische vertelling van Marion Gräfin Dönhoff, de grande dame van de naoorlogse Westduitse journalistiek. In Namen die keiner mehr nennt. Ostpreußen - Menschen und Geschichte (1962) beschrijft Dönhoff, hoe ze als jong meisje tijdens haar vlucht uit Oostpruisen - zoals een telg uit een oud aristocratisch geslacht betaamd: per paard - de schoondochter van Bismarck ontmoette: een krasse oude dame, die in haar jeugd nog had gejaagd en sigaren gerookt. In het gezelschap van een eveneens hoogbejaarde dienaar, was ze achtergebleven op het landgoed van de familie in het Oostpommerse Varzin. De overige bewoners hadden zich aangesloten bij de vluchtelingenstroom, die al wekenlang aan het landgoed voorbij trok. Maar zijzelf en haar dienaar waren hiertoe met geen stok te bewegen. $\mathrm{Zij}$ hadden ervoor gekozen in Varzin te blijven en tot het allerlaatste moment van de Heimat te genieten. En dat deden ze, schrijft Dönhoff, met veel grandeur. Aan tafel werden wijnen geserveerd van jaargangen waarover men normaal gesproken slechts eerbiedig kan dromen. En tijdens de ook anderszins rijkelijk bedeelde dis haalde de oude gravin, met de van haar bekende humor en scherpzinnigheid, herinneringen op aan vroeger tijden. Dat ze de komst van de Russen niet zou overleven daarvan was ze zich ten volle bewust. Ze wilde het ook niet overleven. In de tuin achter het huis had ze door haar oude dienaar alvast een graf laten delven. Weldra zou er immers niemand meer zijn, die bereid was om dit te doen. "Toen ik tenslotte afscheid nam (...) stond ze in gedachten verzonken voor de huisdeur. Ze wuifde nog eenmaal met een zeer klein zakdoekje. Ik geloof, dat ze zowaar glimlachte (...)."98

In Ein Traum, was sonst? speelt Clever deze oude gravin. De handeling - voor zover van een handeling kan worden gesproken - is opnieuw gesitueerd in een sober ingerichte 'herinneringsruimte' van verbrande aarde en verdorde bladeren. In de hoek van het toneel zijn de contouren van een graf zichtbaar. Verder wordt Clever in haar spel slechts ondersteund door een handvol rekwisieten: een glas water; een Pruisische officiersmantel; een stoel in Biedermeier-stijl; een steen uit de ruïne van het Berlijnse Stadtschloß, het eeuwenoude barokpaleis van de Hohenzollern, waarvan de restanten begin jaren ' 50 op bevel van Walter Ulbricht werden opgeblazen; een stapel boeken over de landgoederen van het oude Pommeren, waarvan "niemand de namen meer noemt" - "700 Jahre Geschichte (...) ausgelöscht" (Dönhoff). ${ }^{99}$ In de openingsscène zit ze zwijgend op de stoel, met het glas in de hand. In gedachten verzonken luistert ze naar geluiden, die ze om zich heen waarneemt. Als in een nachtmerrieachtig visioen hoort ze het geroezemoes van de toekomstige Kulturhölle: door Syberberg ter plekke uit de ether opgevangen rock- en rapmuziek, een schlager, het oeverloze gebabbel van een talkshow. Ze hoort de geluiden van de invallende Nacht: overvliegende bommenwerpers, inslaande bommen, een Duits sprekende stem met een sterk

\footnotetext{
${ }^{96}$ Die Nacht (1984/85), Phenthesilea (1987/'88), Die Marquise von O... (1989), Ein Traum, was sonst? (1990/91). Daarnaast heeft het in de tweede helft van de jaren ' 80 onafscheidelijke duo Syberberg/Clever nog een tweetal andere stage-readings gemaakt van teksten van respectievelijk James Joyce en Arthur Schnitzler: Edith Clever liest Joyce - Der Monolog der Molly Bloom aus dem letzten Kapitel der Ulysses (1986) en Fräulein Else (1986).

${ }_{97}^{9}$ Müller, a.w, p. 191.

${ }^{98}$ Dönhoff, M, Namen die keiner mehr nennt. Ostpreußen - Menschen und Geschichte. München, 1962, 1964. pp. $29 \mathrm{ff}$

idem, pp. 18, 28.
} 
Amerikaans accent, die triomfantelijk over de val en vernietiging van Aken bericht - "De stad Aken bestaat niet meer." En ze hoort de geluiden van het vroegere leven op het Pommerse platteland - háár leven, waaraan spoedig een abrupt einde zal komen: stromend water, vogels, paardenhoeven, Beethovens Pastorale, stilte... Dan - inmiddels zijn een dikke drie kwartier verstreken - staat ze op, om nog eenmaal haar stem te verheffen: "Dich stürzt ein Gott in das Verderben zum Ausgleich für das Glück aus der Vergangenheit".

Wat volgt is een verbluffend staaltje eenmans-, of beter: eenvrouwstheater. Een kleine drie uur speelt Clever fragmenten van teksten van Euripides (Trojaanse Vrouwen), Kleist (Prinz Friedrich von Homburg) en Goethe (Faust $I$ en $I$ ), waaruit ze alle rollen voor haar rekening neemt. Voor onze ogen verandert de oude gravin in Hekabe, treurend om de verwoesting van haar geboorteland. Als de jonge prins van Homburg trekt ze ten strijde tegen de vijanden van Brandenburg en snuift ze in het aangezicht van de naderende dood nog eenmaal verlekkerd de betoverende geur op van violieren en anjelieren. Ze sluit als Faust een pact met de duivel, laat zich als Gretchen het hof maken door Faust, orn vervolgens weer schijnbaar moeiteloos in een adem door de gedaanten aan te nemen van Philemon en Baucis: "Laßt uns zur Kapelle treten/ Letzten Sonnenblick zu schauen/ Laßt uns läuten, knieen, beten/ und dem alten Gott vertraun". ${ }^{100}$ De titel is ontleend aan het slot van het stuk van Kleist, waarin de keurvorst een verzoenend gebaar maakt naar de in ongenade gevallen held. ${ }^{101}$ "De zin "Een droom, wat anders?," verduidelijkt Syberberg, "staat als opschrift boven het leven van de prins geschreven, dat hem weer geschonken wordt in alle eer: een Pruisische traditie, waaraan door ons niet wordt getornd". ${ }^{102}$ Maar het moge duidelijk zijn, dat het niet alleen de prins is, die in deze dodenmis voor Pruisen een tweede leven wordt gegund - al was het maar een tweede leven als mythe in de herinnering van de kunst ${ }^{103}$ :

"Er was in de hemel dus niets dan lijden voor mij/ en geen stad werd daar meer dan Troje gehaat,/ vergeefs brachten wij offers./ Maar als een God onze stad niet ondersteboven gekeerd had,/ waren we roemloos verdwenen en zouden de mensen/ van later ons niet in muziek en gedichten bezingen./ Gaat $u \mathrm{nu}$, begraaf de dode jongen/ in zijn trieste graf./ Hij heeft de eer ontvangen/ die bij een uitvaart past:"104

Aan het eind van de voorstelling is Clever weer de oude Gräfin Bismarck. Wachtend op de komst van de Russische Agamemnon en zijn dood en verderf zaaiende Rode Troepen, heeft ze zichzelf en haar omgewoelde patria de eer bewezen, die bij een uitvaart past. Nog eenmaal heeft ze met veel grandeur het vroegere leven op het Pormmerse platteland bezongen in

\footnotetext{
${ }^{100}$ Goethe, Faust II, fuinfter Akt.

${ }^{101}$ Kleist, Prinz Friedrich von Homburg, fünfter Akt, elfter Auftritt.

${ }^{102}$ Syberberg, H.J., Over Ein Traum, was sonst? (niet gepubliceerd programmaboekje) p. 5. Niet zonder reden eindigt Clever haar spel met de woorden van het chorus mysticus aan het slot van Faust II, die de ter hemel opneming van de door God genade verleende Faust begeleiden. Zie eveneens: Syberberg, Clever, a.w., p. 12. Alsmede: Apel, F., Mißglückte Identifikation. Der preußisische Traum und das preußisische Trauma bei Heinrich von Kleist. in: Preussen. Versuch einer Bilanz. Band 4. Preußen. Dein Spree-Athen. Beiträge zu Literatur, Theater und Musik in Berlin. Hrsg. H. Kühn. Hamburg, 1981. pp. 64-85.

${ }^{103}$ Syberberg, Clever, a.w., p. 15: "Sie [Clever, G.G.] wird zur pastoralen Figur verlorener Provinzen, der Königtümer unserer Herzen, Künste, Gefühle und Reiche ganz anderer Art als dieser Welt mit wenig Aufwand, aber zuverlässiger Natur aus dem Erinnern der Kunst, wie sie uns heute zugänglich ist." Zie eveneens:

Syberberg, Der Wald, a.w., pp. 189f, 205. Syberberg, Kunst in Deutschland, a.w., pp. 157, 172, 190f. Voor een meer gedetailleerde bespreking dan in dit boek, waarin de nadruk ligt op de films van de Graal, mogelijk is, zie: Goossens, G., Een heilige misdaad. in: Feit \& Fictie. Tijdschrift voor de geschiedenis van de representatie. 4 (lente 1996). pp. 65-79. Goossens, G, Het reactionaire kunstwerk. Syberbergs Kehre. in: Krisis. Tijdschrift vaor filosofie. 61 (december 1995). pp. 41-50.

${ }_{104}$ Trojaanse vrowwen, Euripides. Vierde akte. Vert. G. Koolschijn. Amsterdam, 1996. p. 119.
} 
liederen en gedichten, en aldus weten te voorkomen dat het roemloos uit de collectieve herinnering verdwijnt. Nu gaat ze gelaten naast het graf zitten - gelijk Antigone naast het graf van haar gehate broer. Haar "heilige misdaad' is volbracht. ${ }^{105} \mathrm{Ze}$ legt het hoofd in de schoot en verzinkt in een eeuwig stilzwijgen.

\subsection{Große gedankliche Klärung}

Van de historicus Peter Burke stamt de uitspraak, dat overwinnaars niet slechts geschiedenis schrijven, maar ook geschiedenis vergeten. "Zij kunnen zich permitteren te vergeten," meent Burke, "terwijl de verliezers wat gebeurd is niet kunnen accepteren en ertoe veroordeeld zijn de gebeurtenissen steeds opnieuw te overdenken en te doorleven, zich steeds opnieuw af te vragen hoe anders het had kunnen zijn." ${ }^{\prime 106}$ En het is verleidelijk ook Syberbergs, nu al een kwart eeuw voortdurende gewroet in het Duitse verleden langs deze weg te verklaren. "Nog steeds zie ik het door de vele plunderingen overhoop gehaalde huis voor me, bestolen door een ieder die voorbij kwam" bekent hij in Aus der Zeit der letzten Unschuld (1993). "De leeggeroofde ladenkasten, vernielde schilderijen aan de muren... Het fotoalbum van de vader echter bevond zich in een geheime opbergplaats onder de trap. Hier had hij verstopt, wat voor hem het meest waardevol was. En daartoe behoorden ook deze foto's van het vroegere leven."107 Foto"s, die door de vader jaren later op zijn vlucht uit de DDR werden meegesmokkeld naar het Westen en die nu door de zoon worden gekoesterd als een memento. ${ }^{108}$ Zoals sommige andere vluchtelingen en verdrevenen uit het Oosten tot op de dag van vandaag objecten koesteren gevuld met aarde uit hun vroegere tuin of uit het graf van een dierbare ver weg in het verloren land. ${ }^{109}$ Souvenirs uit een wereld, waarnaar geen terugkeer meer mogelijk is - "niet omdat geen kindertijd opnieuw kan worden betreden, maar omdat nu lets anders ginds is" (Syberberg). ${ }^{110}$ Het enige wat de zoon van de onteigende hereboer van Nossendorf/Vorpommern nog met zijn roots verbindt, zijn deze fotoherinneringen die "de vroegste kindertijd (...) tot een mythe maken," "11 waarvan enkele ook in de filmversie van Ein Traum, was sonst? als achtergrondprojectie te zien zijn: het huis, de landerijen, de moeder zichtbaar onwennig poserend met enkele arbeidersvrouwen, de vader wandelend met zijn zoontje langs de stranden van de Oostzee....

Want dat hoort nu eenmaal bij dit kunstenaarschap: leven en werk vormen een onlosmakelijke eenheid. Dat was al zo in de tijd, waarin Syberberg zich nog bezig hield met Richard Wagner. ${ }^{112}$ En dat is nu niet veel anders. Levensgeschiedenissen van vluchtelingen en verdrevenen uit de Pruisische stamlanden aan gene zijde van de Oder worden in Ein Traum, was sonst? kunstig verweven met de eigen biografie. En het dagelijkse leven buíten het theater wordt niet minder kunstig aan de nieuwe thematiek aangepast. Midden jaren ' 80

\footnotetext{
${ }^{105}$ Antigone; Sofokles, vers 75: "Een heilige misdaad wil ik. / Ik moet de doden meer behagen dan de levenden/ want dood zijn duurt eeuwig". Vert. J. Boonen. Leuven, Amersfoort, 1975, 1993.

${ }^{106}$ Burke, $\mathrm{P}_{\text {., }}$ History as social memory. in: Memory; Culture and the Mind. ed. Th. Butler. New York, 1986. p. 106: "Another explanation might be given in terms of cultural roots. When you have them you can afford to take them for granted but when you lose them you search for them. The Irish and the Poles have been uprooted, their countries partitioned; it is no wonder they seem obsessed by their past."

${ }^{107}$ Syberberg, H.J., Aus der Zeit der letzten Unschuld. in: Drucksache 4. Berliner Ensemble 1953 - Syberberg

filmt bei Brecht. Hrsg. Berliner Ensemble. Berlijn, 1993. pp. 97-116, zie: 102.

108 ibidem.

${ }^{109}$ Lehmann, a.w., pp. $138 \mathrm{ff}$.

${ }^{110}$ Syberberg, Kunst in Deutschland, a.w., p. 95.

"II Syberberg, H.J., Au dossier d'une généalogie. in: Cahiers du Cinéma. Numéro hors-serie: Syberberg. ed. S. Daney. (februari 1980). p. 88. Zie eveneens: hoofdstuk 2, paragraaf 2.

${ }^{112}$ Zie: hoofdstuk 3 , paragraaf 2 .
} 
stapt Syberberg uit zijn jarenlange rol van een "tweede verschijning" van Richard Wagner en wordt hij een monument van vlees en bloed voor het verloren Pruisen. "Syberbergs voordracht was opmerkelijk," observeert Ian Buruma in 1991. "Een zijdeachtig zachte stem, waarin onmiskenbaar de echo doorklonk van de roemrijke geschiedenis van de Pruisische koningen - dat wil zeggen: van een Kultur, overgeleverd van generatie op generatie, via de onafgebroken bloedlijnen van het Duitse volk, dat na 45 zo wreed werd opgesplitst als straf voor de Holocaust". "13 Het is, laat daar geen misverstand over bestaan, wederom een mystificatie. Anders dan Buruma veronderstelt, ${ }^{114}$ is deze filmmaker weliswaar een vluchteling, maar géén Heimatvertriebene in de strikte zin van het woord. Noch kan hij, zoals de gravinnen Bismarck en Dönhoff, bogen op een adellijke stamboom die zeven eeuwen Pruisische geschiedenis omvat. Maar dit maal gaat het wel om een mystificatie, die iets zéér wezenlijks articuleert, dat van meet af aan als een motief op de achtergrond in zijn oeuvre aanwezig is geweest: een absurdistisch gevoel van totale ontheemding. Er bestaat geen werk van zijn hand, waarin men dit gevoel niet kan aantreffen - het gevoel een vreemdeling te zijn in eigen land én tijd, afgesneden van een traditie, van een manier van leven, denken en kunst scheppen, waarin hij zich als kind thuis heeft gevoeld: het verloren Huis van de Vader. En wanneer je er langer over nadenkt is het eigenlijk vreemd, dat het afgebrande Pommernland pas zo laat Syberbergs thema is geworden. Net als Sedlmayrs theorie van de "verloren Mitte" komen we het voor het eerst tegen in de Hitler-film. Meer specifiek in het hierboven geanalyseerde tableau, waarin Heller het verlies van de 'zonsondergangen' van de kindertijd betreurt.

Heller in het zonsondergangen-tableau en Clever in dit Requiem voor het einde van Pruisen - beiden zijn afsplitsingen van één en hetzelfde personage: Hans Jürgen Syberberg in een respectievelijk joodse en vrouwelijke travestie van de aanklager, waarvan Ernst Jünger reeds op 11 juni 1945 voorspelde, dat deze ooit uit de gelederen van de vluchtelingen en verdrevenen zou opstaan. "15 Maar een aanklager is iemand die niet enkel schade heeft geleden, maar bovendien beschikt over de middelen om dit te kunnen aantonen. "Verliest men deze middelen," stelt de Franse filosoof Jean-Francois Lyotard in zijn hoofdwerk Le Différend (1987), "dan wordt men slachtoffer. Het is eigen aan een slachtoffer, dat het niet in staat is te kunnen aantonen slecht te zijn behandeld." 116 En geldt dit niet ook een beetje voor de Pruisische Antigone die hier, in het zonsondergangen-tableau en het Requiem, haar horror uitschreeuwt? Hoe kunnen Syberberg/Clever/Heller ons dat duidelijk maken? En zichzelf? Dit vroegere geluk in die andere wereld, die nu zo wordt gehaat. En de horror van de Nacht, die erop volgde. Hoe duidelijk maken, wat het wil zeggen je vaderland, Heimat, grond, eergevoel, waardigheid, trots, geloof enzovoort te hebben verloren; te zijn verdreven uit je huis, levenswormen en taal; te hebben moeten meemaken hoe de plattegronden van je identiteit werden omgewoeld, de heilige plaatsen van de Kultur werden verwoest en onder het mom van een socialistische re-education een totale Umwertung aller Werte plaats vond ${ }^{117}$ hoe dit alles duidelijk maken, in een tijd waarin de oude esthetische vormen, woorden en

\footnotetext{
${ }^{113}$ Buruma, a.w., 34.

114 idem, p. 43: "Syberberg lost his Heimat twice, he was expelled from Pommerania at the end of the war and left the GDR in 1953. And he has been pinning for the Volk ever since, for the banners of the native soil, the sacred poetry of the German bards, the ruined castles of the ancient kings, and so on".

${ }^{115}$ Jünger, E., Strahlungen II. Das zweite Pariser Tagebuch, Kirchhorster Blätter, Die Hütte im Weinberg. München, 1979, 1988 p. 474: "Tegen de avond meldde de radio, dat de verdrijving uit het Sudetenland in volle gang is. Daaronder bevinden zich ongetwijfeld miljoenen onschuldigen, waaruit op een dag een aanklager zal opstaan".

${ }^{116}$ Lyotard, J.F., The Differend. Phrases in Dispute. Translation by G. Van den Abbeele. Manchester, 1988. pp. 5,8 .

${ }^{117}$ Syberberg, Kunst in Deutschland, a.w., p. 80 .
} 
normen en waarden volstrekt betekenisloos lijken te zijn geworden en we geen Pommerse zonsondergang meer kunnen aanschouwen zonder aan Auschwitz te denken?

Wel, diep uit je bibliotheek teksten op, die lang vóór de zondeval in dit oude idioom zijn geschreven. Bijvoorbeeld teksten van de Pommerse poète maudite Heinrich van Kleist: Prinz Friedrich von Homburg of (het materiaal van respectievelijk het tweede en derde deel van het Requiem) het Trauerspiel Phenthesilea en de novelle Die Marquise von $O$.. Kunst met een zeer grote $K$, die behoort tot het culturele erfgoed van een volk, dat na ' 45 van de aardbodem werd weggevaagd; die bij wijze van spreken uit de Pommerse klei is opgetrokken en waarin het vroegere leven met een nadien nimmer meer geëvenaarde stilistische vaardigheid in geuren en kleuren wordt geëvoceerd. En laat deze teksten spelen door een grootse tragédienne als Edith Clever. Let wel: niet in dat uitentreuren nageaapte Wilsonstijltje van het post-"68-theater - Kleist met een Stahlhelm op zijn kop, rondjes rijdend in een aftandse Amerikaanse legertruck. Dit "multiculturele, multihistorische, multipsychologische, multimorele (...) gezwam" van de zogenaamde postmoderniteit heeft naar Syberbergs mening in de Duitse kunsten al genoeg schade aangericht. ${ }^{118} \mathrm{Nee}$, geef in plaats daarvan je actrice opdracht deze teksten te spelen in een 'authentieke' stijl, die recht doet aan de Geist waaraan ze zijn ontsproten. Zeker, een onbereikbaar ideaal. Maar, denkt Syberberg, uitsluitend langs deze, authentieke weg zou het misschien kunnen lukken de ziel, die in deze teksten huist, weer kortstondig tot leven te wekken en verloren onschuld en connotaties terug te winnen. "Waar het om gaat is, dat we in onze tijd zo een sterk bewustzijn hebben van verlies," legt Clever uit in een in "91 afgenomen interview.

"Oude teksten gaan verloren. Ik merk het zelf, wanneer ik op het toneel sta: dat ik al bijna niet meer in staat ben deze teksten te spelen. Er bestaat een enorme kloof tussen ons en deze teksten. Maar misschien, heel misschien, kunnen we er nog een flard van vatten. Ach, het is allemaal zo kwetsbaar. Voortdurend heb je de neiging te vertwijfelen en denk je: eigenlijk, ja eigenlijk is het allemaal al weg. Dan probeer je het nog maar een keer... Und es fällt uns, weiß Gott, schwer es noch einmal zu beschwören:" 119

De 'Duitse geest begrijpen, eren en redden" - daarom was het Syberberg ook in de films van De Graal al te doen. ${ }^{120}$ Tot zover ligt het Requiem onmiskenbaar in het verlengde van deze eerdere mammoetcyclus - ja, mag dit nieuwe werk gerust worden beschouwd als een verdere uitdieping van het zonsondergangen-tableau in het magnum opus Hitler. Het enige verschil is, dat hij zich weer eens op een andere etage van het Grand Hotel Afgrond is gaan richten. Zoals hij begin jaren ' 70 zijn aandacht heeft verlegd van Dürenmatt naar Wagner, zo verlegt hij nu zijn aandacht van Wagner naar Kleist - of, zoals Syberberg het zelf formuleert: van het surreële naar het klassieke anti-modemisme. ${ }^{121}$ Je zou ook kunnen stellen: van Beieren naar het land van de Vader. Maar het Requiem is niet enkel een afscheid van Wagner. Het is ook, zoals ik in de vorige paragraf reeds liet doorschemeren, een afscheid van een artistieke en (kunst-)filosofische traditie, waarvan dit oeuvre tot midden jaren '80 zijn belangrijkste stimulans heeft ontvangen: de binnen het linkse cultuurdebat dissidente denktraditie van Bertolt Brecht, Hans Mayer en Ernst Bloch. Weliswaar kon ook zijn vroegere positie ten

\footnotetext{
${ }^{118}$ idem, p. 48.

${ }^{119}$ Persconferentie Syberberg/Clever naar aanleiding van de Brusselse opvoering van Ein Traum, was sonst?, zomer 1991.

${ }^{120}$ Syberberg, H.J., Winifred Wagner - Symbol unserer Vergangenheit. in: Die Zeit. 12 (1980). p. 41. Zie eveneens: hoofdstuk 3, paragraaf 7 .

${ }^{121}$ Rötzer, F, Mit kleinsten Mitteln sehr Anspruchvolles offerieren. Gespräche über Ästhetik (III). in:

Frankfurter Rundschau. 02-01-1987. p. 2.
} 
opzichte van deze traditie bezwaarlijk worden omschreven als epigonistisch - het geloof der kameraden heeft Syberberg nooit gedeeld. Als het ging om Dürrenmatt en Beckett, om Wagner, Nietzsche en de late romantiek, kon hij echter wel een heel eind met deze neomarxistische avant-gardisten optrekken. Dat ligt bij dit nieuwe thema volstrekt anders.

De grosse gedankliche Klärung begint betrekkelijk onschuldig. In de periode direct na de Hitler-film rijpt bij Syberberg langzaam maar zeker het inzicht, dat hij is aangekomen op een punt, waar hij met de esthetische en filosofische modellen, die Brecht, Mayer en Bloch hem aanreiken, niet langer uit de voeten kan. Het heeft alles te maken met het dilemma waarmee Heller in het zonsondergangen-tableau worstelt. Hoe kan het geluk van de kinderjaren en de horror van de Nacht anders worden verwoord, dan in de geperverteerde en betekenisloos geworden taal en esthetische vormen waarover de kunstenaars van het oude Pommeren nog beschikten? Heinrich von Kleist of Caspar David Friedrich kenden nog de betekenis van woorden als vaderland, Heimat, grond, eergevoel, waardigheid, trots en geloof. Zij wisten nog wat het wil zeggen te zijn verdreven uit je huis, levensvormen en taal. Maar Brecht? In Herr Puntila und sein Knecht Matti, haalt Syberberg in Aus der Zeit der letzten Unschuld herinneringen op aan zijn bezoek als achttienjarige scholier aan het Berliner Ensemble, "hoonde Brecht het bestaan van de vader als 'prehistorisch dier, estatum possessor, in het Duits hereboer genoemd, (...) vraatzuchtig en volkomen nutteloos, (...) een boosaardige landplaag'. Hetgeen ik [destijds] incasseerde, lachend, beter wetend op grond van eigen ervaringen, die belangrijk voor me waren". ${ }^{122}$ Dat wil zeggen: op grond van ervaringen, opgedaan tijdens de kindertijd op het Pommerse platteland, die een kosmopoliet als Brecht volslagen vreemd lijken te zijn. Veeleer spreekt uit dit, uit 1940 daterende 'volksstuk' een geestesgesteldheid, die het mentale substraat heeft gevormd van de verschrikkingen, die niet veel later in het land van de hereboeren en de Junker hebben plaats gevonden.

En Bloch? De filosoof van de linkse utopische hoop mocht zich er graag van bedienen: van 'besmette' termen als volk, natie, vaderland, Heimat, bodem, Führer, het Derde Rijk, de Graal. Dit alles behoorde tot het geoccupeerde Duits/joods/Europese culturele erfgoed, dat weer aan de nazi's diende te worden ontfutseld. Meer nog: Heimat is een sleutelbegrip in Blochs filosofie - Heimat, dat magische oord van de sagen, de legenden en de mythen, "das allen in die Kindheid scheint und worin noch niemand war". ${ }^{23}$ Behalve dan de verdrevenen en vluchtelingen uit het Oosten. Zij hebben er vertoefd, in deze Heimat en er met volle teugen van genoten - tot ze er voorgoed door Blochs kameraden uit werden verdreven. "Heimat als kindertijd, waarin we nooit waren? Dat werd gezegd door iemand, die de DDR van de SED heeft uitverkoren als toevluchtsoord." Aldus Syberberg in Vom Unglück und Glück der Kunst in Deutschland nach dem letzten Kriege. ${ }^{124}$ De breuk met Bloch heeft zich dan al geruime tijd eerder voltrokken. In een kort opstel uit 1985 verwerpt Syberberg dit idealistische Heimat-concept, dat hijzelf in de jaren ' 70 nog volmondig heeft onderschreven, ${ }^{125}$ ten gunste van het Bodenständige van Martin Heidegger. ${ }^{126}$ "De magische plaatsen werden bepaald door de voorouders en kunnen uitsluitend daar worden aangetroffen," meent hij nu ${ }^{127}$ - "Die Patria ist da, wo die Gräber der Väter sind". ${ }^{128}$

\footnotetext{
${ }^{122}$ Syberberg, Aus der Zeit der letzten Unschuld, a.w., p. 111.

${ }^{123}$ Bloch, E., Das Prinzip Hoffnung. Dritter Band. Frankfurt am Main, 1959, 1976. p. 1628.

${ }^{124}$ Syberberg, Kunst in Deutschland, a.w., p. 163.

${ }^{125}$ Zie: hoofdstuk 3, paragraaf 7.

${ }^{126}$ Syberberg, H.J., The Abode of the Gods. in: Sight and Sound. International Film Quarterly. 54 (1995). p.

1.25. Voor Heideggers visie op 'Heimat', zie: Haar, M., Le chant de la terre. Heidegger et les assises de

l'histoire de l'être. Paris, 1985. pp. 122-134, 296-295.

${ }_{127}^{127}$ In een interview uit 1987 met Santner! Zie: Santner, Stranded Objects, a.w., p. 131.

${ }^{128}$ Syberberg, Kunst in Deutschland, a.w., pp. $100 \mathrm{f}$.
} 
Martin Heidegger, Hans Sedlmayr, Ludwig Klages, Carl Schmitt, de gebroeders Ernst en Friedrich Georg Jünger - filosofen van het landleven en poëten van het Woud: de Wachters van de 'zachte wet' van de natuur. Voor hen is Heimat geen vage utopie of wensdroom over een kindertijd waarin we nooit waren, maar iets zéer concreets. Het is, inderdaad, de plek waar zich de graven van onze voorouders bevinden: een magisch cultuurlandschap vol collectieve herinneringen aan de rand van het Woud, bewoond en bewerkt van generatie op generatie. Het is een stuk aarde dat, dankzij een eeuwenlange cultivering door het voorgeslacht, het substraat en de fundering is gaan vormen van het Huis van onze overlevering, waarin we zijn geboren en getogen; de in de natuur gewortelde en met haar vergroeide navelstreng van onze individuele en collectieve identiteit, die ons verbindt met de eeuwigheid en waardoor onze kunstwerken, taal en levensvormen worden gevoed. Kortom: de organische, historische en metafysische 'bodem' van ons Zijn. ${ }^{129}$ Overbodig hieraan toe te voegen, dat in deze kringen de verdrijving uit het Oosten van meet af aan onderwerp is geweest van artistieke en filosofische reflectie. We hoeven in dit verband slechts te denken aan Ernst Jüngers ten tijde van de verschrikkingen zelf geschreven dagboek Die Hütte im Weinberg. Jahre der Okkupation: ${ }^{130}$ Of aan Gelassenheit (1959), waarin Heidegger het thema aangrijpt als uitgangspunt voor een filosofische verhandeling over de menselijke conditie in het technische tijdperk. ${ }^{131}$

Dit betekent niet, dat het lot van de Heimatvertriebenen buiten dit partizanen-vertoog een volslagen non-issue zou zijn. Overlevenden als Marion Gräfin Dönhoff hebben al vroeg de aandacht op deze schaduwzijde van de $8^{\text {ste }}$ mei 1945 proberen te vestigen, waarbij ze beslist geen blad voor de mond namen. Niettemin hebben dit soort geluiden binnen het linkse cultuurdebat nauwelijks enige respons gevonden - hetgeen, gelet op het feit dat (begin jaren '90) één op de vijf Duitsers stamt uit een familie van vluchtelingen en verdrevenen, ${ }^{132}$ gerust opmerkelijk mag worden genoemd. "In progressieve kringen verontschuldigt men zich dikwijls en denkt men veel na," constateert Ian Buruma in The Wages of Guilt (1993).

"Maar rouwen om de Duitse doden - de militairen en de burgers die door de geallieerde bombardementen zijn gedood, of door wraakzuchtige Poolse, Tsjechische of Slowaakse buren, die hen uit hun woonplaatsen hebben verdreven - zulk rouwen [is] een pijnlijke kwestie en [wordt] grotendeels overgelaten aan rechtse nationalisten en nostalgische overlevenden vol weemoedig verlangen naar hun verloren Heimat. $\mathrm{Er}$ zijn veel gedenktekens op dorpspleinen en begraafplaatsen in de westelijke helft van Duitsland voor de gesneuvelden van de Eerste Wereldoorlog. Er zijn heel weinig herinneringen aan degenen die in de Tweede Wereldoorlog zijn gestorven, behalve in ranzige bierkelders waar buitenlanders verre van welkom zijn."

\footnotetext{
${ }^{129}$ Haar, a.w., passim. Zie eveneens: Jünger, F.G., Die Perfektion der Technik. Frankfurt am Main, 1953, 1980.

130 Jünger, [E.], a.w., 403-662.

${ }^{1131}$ Heidegger, M., Gelassenheit. Tübingen, 1959. pp. 9-26.

${ }^{132}$ Lehmann, a.w., p. 7: "Etwa 12 Millionen Menschen sind am Ende des Zweiten Weltkriegs aus

Ostdeutschland und den deutschen Siedlungsgebieten Osteuropas geflohen oder vertrieben worden. Etwa jeder füfte, vielleicht jeder vierte, der heute in Deutschland lebt, stammt aus den Gebieten des Ostens oder kommt aus einer Familie von Vertriebenen und Flüchtlinge. Diese erzwungene Massenwanderung der Jahre 1945 und 1946 ist in der europäischen Geschichte ohne Beispiel. Doch schon zehn Jahre danach fand das Thema, wie andere Massenschicksale der Nachkriegszeit, etwa das der Kriegsgefangenen, in der politischen, wissenschaftlichen und publizistischen Öffentlichkeit nur noch wenig Interesse."

${ }^{133}$ Buruma. I., Het loon van de schuld. Herinneringen aan de oorlog in Duitsland en Japan. Vert. T. Davids. Amsterdam, Antwerpen, 1994. pp. $307 \mathrm{f}$.
} 
Of, zoals gezegd; in de kluizenaarshutten van dichters en denkers als Heidegger of de gebroeders Jünger. $\mathrm{Al}$ is dit onderscheid, vanuit het linkse vertoog bekeken, slechts zéér betrekkelijk.

De 'ranzige bierkelders' van rechts-populisten als Schönhuber en Frey, waarop Buruma in dit citaat doelt en deze schuilkerken van de verfijnde estheten van het Woud - in de ogen van de 'weldenkende' gemeente zijn het slechts verschillende verdiepingen van het Grand Hotel Afgrond, waarnaar al datgene is verbannen, dat de naam filosofie, kunst of literatuur niet waardig zou zijn. En wat in deze ogen well hiervoor doorgaat heeft het thema van de verdrijving uit het Oosten, zoals Günther Grass in 2002 (!) moet toegeven, domweg tot taboe verklaard. Met zijn in dat jaar verschenen roman Im Krebsgang wil Grass, die door velen nog steeds wordt gezien als het morele geweten van links West-Duitsland, deze fout alsnog corrigeren. Niet alleen om een lacune op de vullen, maar ook met een politiek doel: het onverteerde leed van de Vertriebenen zou het neonazisme voeden en moet alleen al daarom bespreekbaar zijn. "Nooit had men over zoveel leed mogen zwijgen, alleen omdat de eigen schuld oppermachtig was en de openlijk betoonde wroeging in al die jaren voorrang had," aldus Grass. Nooit had men het leed van de Vertriebenen aan rechts mogen overlaten: "Dit verzuim is bodemloos". ${ }^{134}$ Syberberg zegt het, zoals we zagen in paragraaf 2 , een kwart eeuw eerder in zijn Hitler-film in iets andere bewoordingen: "Miljoenen uit hun Heimat verdreven, met één enkel handgebaar op de speeltafel van de geschiedenis, waarover ze nooit meer mochten spreken, zonder zichzelf te verliezen. Hoe verdacht zijn zij, die vragen, waarom wij dat hier doen, dit spreken, spelen, tonen, bloeden.'

Reeds in de jaren ' 70 heeft de regisseur van Hitler en de Winifred-Wagnerdocumentaire het haarscherp geanalyseerd: de volkspedagogische praktijk rond het eigen Duitse gevoelsleven, waarbinnen een strikt onderscheid wordt gemaakt tussen humanistische en fascistische hunkeringen, goede en foute pijn, morele en amorele rouw. ${ }^{135}$ Maar wat hij toen nog nauwelijks durfde uit te spreken, vertrouwt hij nu, in de jaren ' 80 , zonder enige gêne aan het papier van zijn pamfletten toe: het centrum van deze re-education-praktijk wordt gevormd door een "onzalige links-joodse alliantie tegen de schuldigen", ${ }^{136}$ die de herinnering heeft geannexeerd, het recht op verdriet heeft gemonopoliseerd - ja, de rouw om het eigene tot een antigonistische, de Wet overschrijdende bezigheid heeft gemaakt. "Statussymbool vandaag de dag," noteert Ernst Jünger op 7 december 1982 in zijn dagboek. "Wie mag zijn helden, wie mag zijn vermoorde doden tonen? (...) Wie mag überhaupt zijn pijn uiten? Hier houdt de gelijkheid op."137

In 1981, het jaar van het verschijning van het Hitler-film-postscriptum Die freudlose Gesellschaft, houdt Syberberg tijdens een in Brussel georganiseerd symposium rond zijn werk een hartstochtelijk pleidooi voor een heropening van het Westduitse modernisme-debat van de vroege jaren ' $50 .{ }^{138}$ Het is de eerste keer dat hij expliciet buíten de kaders van het linkse cultuurdebat treedt, waarbinnen hij zich tot dan steeds heeft bewogen. Want anders dan het expressionisme-debat, de formalisme/realisme-strijd en de controversen rond de 'schone schijn' van het Derde Rijk, het Duitse 'onvermogen om te rouwen', de BiermannAusbürgerung en de Tendenzwende, betrof het hier nu eens voor de verandering géén exclusief links of links-liberaal onderonsje. Hier stonden niet gelijkgestemden tegenover

\footnotetext{
${ }^{134}$ Kerres, M., Oude meester Grass zorgt weer voor een rel. in: NRC Handelsblad. 9/10 februari 2002. p. 10: "De Duitse literatuur, ikzelf inbegrepen, heeft dat deel van de Duitse geschiedenis te lang links laten liggen". Zie eveneens: Scheffer, P., Echo's van de ondergang. in: NRC Handelsblad. 22 februari 2002. p. 25.

${ }^{135} \mathrm{Zie}$. hoofdstuk 5 , paragraaf 6.

${ }_{136}^{136}$ Syberberg, a.w., p. 14.

137 Jünger, E., Siebzig verweht III. Stuttgart, 1993. p. 212.

${ }^{138}$ Zie: hoofdstuk 2, paragraaf 7 .
} 
elkaar, zoals de voormalige jeugdvrienden Ernst Bloch en Georg Lukács, die decennialang ruzie hebben gemaakt over de vraag welke dialectische conclusies dienden te worden getrokken uit premissen, waarvan ze beiden de geldigheid van ganser harte onderschreven. Hier vond, in de gedaanten van Hans Sedlmayr en Theodor Wiesengrund Adorno, een frontale botsing plaats tussen twee volslagen heterogene culturen. ${ }^{139}$ In beide culturen had men niet lang daarvoor de Zon zien ondergaan - zij het vanuit volstrekt verschillende subjectposities. 140

Aan de ene kant stonden de vertegenwoordigers van het oude, 'schuldige' Duitsland, die de $8^{\text {ste }}$ mei 1945 hadden beleefd als het begin van een inktzwarte Nacht. Zij beschouwden het als hun antigonistische plicht de Duitse doden te begraven en het verwoeste Huis van de overlevering opnieuw op te bouwen. En in de uitoefening van deze plicht voelden ze zich belemmerd door, in de woorden van Carl Schmitt (1949), een handvol "dankzij de Russen opgeklommen beroepsrevolutionairen en joodse emigranten" die "ons als maatstaf van normaal Duits gedrag [werden] opgedrongen". ${ }^{141}$ Het andere front werd gevormd door de vertegenwoordigers van het nieuwe, 'onschuldige' Duitsland, die de $8^{\text {ste }}$ mei 1945 hadden beleefd als een bevrijding. $\mathrm{Zij}$ beschouwden het als hun antigonistische plicht de gruweldaden van het oude Duitsland te herdenken als een 'civilisatiebreuk' die elke voortzetting van de culturele tradities van dít Duitsland onmogelijk maakte. En in de uitoefening van deze plicht voelden ze zich belemmerd door een handvol Ewiggestrige die, in de woorden van Theodor Adorno (1951), de 'potsierlijke gedachte' koesterden dat na de joodse Zonsondergang "het leven normaal verder zou kunnen gaan of zelfs de Kultur heropgebouwd zou kunnen worden." 142 Omdat de holocaust van het joodse volk zich had afgespeeld in het hart van de westerse beschaving, verwachtte Adorno van kunstenaars en intellectuelen een reflectie op het eigen falen. In de afwijzing van de verzoening, de compromisloze negatie van de verhoudingen, die Auschwitz hadden mogelijk gemaakt, zag hij de nieuwe opgave van de naoorlogse Duitse kunsten: "Er bestaat geen schoonheid en geen troost meer, behalve in de blik die dwaalt over de horror, erin stand houdt en in het onverzachte bewustzijn van de negatie aan de mogelijkheid aan het betere vasthoudt."

Net als Brecht, Bloch en Mayer behoort ook Adorno binnen het linkse cultuurdebat tot de opponenten van de "cultuurconservatief" Lukács. ${ }^{144}$ Wat dat betreft mag het fameuze, uit ' 47 daterende opus 7 van de componist Adorno, vier liederen op gedichten van Stefan George, gerust een statement worden genoemd. Toch had Brecht hem niet hoog zitten: deze 'moraalesthetische rechter' uit de sociaal-kritische school van Frankfurt. Sterker: Adorno of Lukács - voor Brecht was het allemaal om het even. "Wiesengrund-Adorno was hier," schreef hij op 18 januari 1942 in zijn Arbeitsjournal. "Hij is rond en dik geworden en brengt een opstel over RICHARD WAGNER ten gehore, niet oninteressant, maar uitsluitend wroetend naar verdringingen, complexen, blokkades in het bewustzijn van de oude mythesmid, met dezelfde routine als Lukács (..), die (...) slechts een oude psychoanalyse

\footnotetext{
139 ibidem.

${ }^{140}$ Voor het debat over de betekenis van de $8^{\text {ste }}$ mei 1945, zie bijwoorbeeld: Reich, P., Politik mit der Erinnerung. Gedächtnisorte im Streit um die nationalsozialistische Vergangenheit. München, Wien, 1995. pp. $275 \mathrm{ff}$.

${ }^{141}$ Citaat ontleend aan: Grunenberg, A., Antifaschismus - ein deutscher Mythos. Hamburg, 1993, p. 109.

Grunenberg citeert: Schmitt, C., Glossarium. Aufzeichnungen der Jahre 1947-1951. Berlin, 1991. p. 256.

${ }_{142}$ Adorno, Th. W., Minima Moralia. Reflexionen aus dem beschädigten Leben. Frankfurt am Main, 1951, 1989 p. 56.

143 idem, p. 21.

144 Adorno, Th. W., Asthetische Theorie. Frankfurt am Main, 1970, 1972. p. 213.
} 
[verdringt]. ${ }^{.145}$ En mogelijk verklaart dit, waarom Syberberg er geen been in ziet zichzelf in zijn drie jaar na Die freudlose Gesellschaft verschenen Woudlopers-hymne Der Wald steht schwarz und schweiget (1984) nog wél binnen de traditie van de linkse avant-garde te situeren. Hoewel Adorno dan al in zijn denken een soortgelijke diabolische rol vervult als Nietzsche in de filosofie van Lukács of Habermas. ${ }^{146}$ Of beter: Adorno's epigonen. Want de negatieve dialectiek van Adorno was "aus Trauer geboren", als "Kritik zur Warnung". En doorn in het oog van de filmer is dan ook niet zozeer Adorno zelf, als wel de canonisatie en reïficatie van zijn pessimistische late filosofie in de Betroffenheitskult van "68. "Hoe het ook [door Adorno, G.G.] bedoeld werd: het effect was een poëzie- en gevoelsverbod. (...) In de handen van het vulgaire beheer werkte het als een vloek." 147 Daarvan kan, als we Syberberg mogen geloven, eenieder, die wel eens een museum voor moderne kunst bezoekt, zich met eigen ogen overtuigen. Er bestaat, inderdaad, 'geen schoonheid en geen troost meer', in deze kunstbunkers uit beton. Uitsluitend nog 'negatie'. ${ }^{148}$

Zes jaar later, in Vom Unglück und Glück der Kunst in Deutschland nach dem letzten Kriege, vindt de grosse gedankliche Klärung haar voltooiing. 35 jaar lang heeft Syberberg gewerkt binnen een vertoog, waarvan de antifascistische emigranten de founding fathers

${ }^{145}$ Citaat ontleend aan: Mittenzwei, W, Das Leben des Bertolt Brecht oder der Umgang mit den Welträtseln. Zweiter Band. Berlin, Weimar, 1986, 1997. p. 120.

${ }^{146}$ Syberberg, Der Wald, a.w., pp. 108, 114, 118, 139f, 214.

${ }^{147}$ Syberberg, Kunst in Deutschland, a.w., pp. 36, 48. Het zou te ver voeren in dit boek, waarin de nadruk ligt op de films van De Graal, tot in detail op de kritiek van de late Syberberg op Adomo in te gaan. Volgen we de Amerikaanse literatuurwetenschapster Lisa Saltzman, dan zou hij in Vom Unglïck und Glïck der Kunst in Deutschland nach dem letzten Kriege als éen van de eersten de bijbelse connotatie op het spoor zijn gekomen van Adorno's legendarisch geworden (en later weer herroepen) verzuchting uit 1949: 'Na Auschwitz een gedicht schrijven is barbaars'. "(...) Het is in de formulering zelf van zijn gebod 'na Auschwitz', dat Adorno een tijd openbaart "voor Auschwitz" - een ethische tijd, die werd gevormd door de Wet van de Hebreeuwse vaderen, waarvan zijn gebod zowel een evocatie als een bevestiging is," aldus Saltzman. "Want achter Adorno's naoorlogse gebod ligt een ander, namelijk een bijbels gebod, het tweede. 'Gij zult geen gesneden beeld maken'. Dat wil zeggen: het is pas 'na Auschwitz' dat deze Hebreeuwse moraal volledig tot gelding komt; eerst in Adorno's eigen gebod, vervolgens in zijn geschriften. Er wordt vaak gewezen op Adorno"s joodse identiteit als verklaring voor het messianistische gehalte van zijn bij uitstek emancipatoire, utopische formuleringen - een messianisme dat aanvankelijk de geseculariseerde vorm van marxisme aanneemt en later verschuift naar het terrein van de esthetica. Minder aandacht in dergelijke analyses krijgt in de regel de ethische kracht achter het gebod 'Gij zult geen gesneden beelden maken' in Adomo's geschriften". Saltzman, L., Anselm Kiefer and Art after Auschwitz. Cambridge, 1999. pp. 17f. Terecht heeft de Duitse kunsthistoricus Eckhart Gillen er echter op gewezen, dat Adorno "nooit met de gedachte aan een beeld- of schrijfverbod [heeft] gekoketteerd, zoals latere interpreten, die met begrippen als Betroffenheit of Verstummen bloemrijk klaagden over de onmogelijkheid Auschwitz te beschrijven en daarbij academische kitsch produceerden (...)." Gillen, E., Tabula rasa und Innerlichkeit. Deutschlandbilder vor und nach 1945 in. Deutschlandbilder. Kunst aus einem geteilten Land. Hrsg. E. Gillen. Berlin, 1997. pp. 48-54, zie. 52. En, zoals gezegd, is het m.i. deze Betroffenheitskult ('het vulgaire beheer') waar Syberberg zich tegen richt en niet, zoals ook Gillen veronderstelt, Adorno zelf, wiens late filosofie 'uit rouw is geboren" Waar het op aankomt is, dat Adorno's negatieve dialectiek gaandeweg deze 'vulgaire' betekenis heeft gekregen - niet slechts in het modieuze, vanuit Holocaust-studies geínitieerde debat over de limits of interpretation, waarop Gillen doelt, maar ook meer in het algemeen, in het historische besef van "68. In dit vertoog is een "vulgaire" uitleg van Adomo's late filosofie inderdaad gaan fungeren als "a moral and aesthetic dictate for the postwar era" (Saltzman) of "oberstes Gesetz der Nachloriegsadsthetik" (Syberberg, a.w., p. 36)

${ }^{148}$ Syberberg, Der Wald, a.w., pp. 112, 116: "Die früheren Zeiten entschieden schon in der Wald der Themenkonstellationen zueinander, ikonographisch, philosophisch, metaphysisch, quasi religiôs, ideologisch, geistesgeschichtlich, was zumindest Gut und Böse ist und daß Teufelswelt und göttliche Ebene ausgeglichen war mit leichtem Übergewicht zum Guten, Göttlichen, Utopischen, bis eben zu dem Punkt, wo Sedlmayr einen Verlust der Mitte beobachtete, mit allmählicher Verschiebung des Interesses zugunsten des Grotesken, Manieristischen, Dunklen der Hölle, und heute eben des kleinen Schmutzigen." Zie eveneens: Syberbergs door Sedlmayr geïnspireerde bespiegelingen over het "HäBlichkeitsgebot" en "die "Ásthetik des Kleinen,

Schmutzigen, Kranken..." in Kunst in Deutschland, a.w., passim en met name:. pp. $34 \mathrm{ff}, 38 \mathrm{ff}, 46 \mathrm{ff}, 57 \mathrm{ff}, 61 \mathrm{ff}$. 
zijn. ${ }^{149}$ "Maar de ervaringen van de thuisblijvers waren een andere. Thuis gebleven zijn wil zeggen bommennachten te hebben doorstaan, eigen schuld en rouw, hoe verschillend ook, met geheven of gebogen hoofd. Nu werd alles los gelaten en bespot. Niets meer van waarde." ${ }^{150}$ En, zo is hem in de tussenliggende tijd steeds duidelijker geworden, voor het articuleren van dit soort ervaringen bestaat simpelweg geen ruimte binnen een vertoog waarin de geschiedenis wordt geschreven én vergeten vanuit een eenzijdig perspectief. Binnen dit vertoog behoren de tranen van de Pruisische Hekabe tot, wat we met een term van Lyotard zouden kunnen noemen, 'het vergetene van de gedenktekens': ${ }^{151}$

"De wreedheid van de overwinning in het Oosten was in overeenstemming met de aard van zijn [Hitlers, G.G.] systeem. Het gemene echter was, dat deze gruwelen als bevrijding moesten worden gevierd en door de intellectuelen relativerend werden geaccepteerd, omdat de machinerie van Hitlers wreedheid tegen die van Stalin werd afgewogen. Maar pijn kan niet relatief worden begrepen. (...) Mensen [werden] verdreven, uit hun huizen, levensvormen $(. .$.$) en taal. En ze werden veroordeeld te$ zwijgen. Verslagenen. (...) De heilige plaatsen van de Kultur werden verwoest en niemand mocht huilen. (...) Hekabe is uitgeklaagd." 152

En als een heremietkreeft, die zich ontdoet van zijn te nauw geworden behuizing, legt de kunstenaar zijn "na 1945 gegroeide schild" af en keert hij terug naar Huis: naar het wereldwereld van de Vader. ${ }^{153}$

Bekenntnis. Jenseits der Nacht, luidt de titel van één van de paragrafen in dit pamflet. Het is een echte 'bekentenis' in de Duitse zin van het woord: ${ }^{154}$

"Heb niet ook ik geprobeerd in de openbaarheid op te vallen, me populair te maken (...) in het incestueuse wereldje van het internationale kunstbedrijf, het wezenlijke verdoezelend om maar fatsoenlijk te lijken? Moet niet ook ik bekennen, (...) dat ik psychisch me altijd zo heb proberen voor te doen, dat ik aan de gewenste analysen beantwoordde, $(. .$.$) in het spectrum van het pluralisme paste, de consensus vervulde -$ weliswaar niet aan de zijde van de protesteerders tegen Vietnam en '68, maar toch zo, dat ik mijn eigen positie en herkomst, misschien niet proletarisch en oppositioneel, maar toch antifascistisch, zoals men dat zo zegt, uitmat? Verzweeg ik niet lang afkomstig te zijn van het platteland, uit hiërarchische structuren van de natuur en een

\footnotetext{
${ }_{149}$ Zoals Syberberg, Kunst in Deutschland, a.w, p. 14, de Duitse emigranten typeert.

${ }^{150}$ Syberberg, H.J., Eigenes und Fremdes. Über den Verlust des Tragischen. in: Die selbstbewußte Nation. 'Anschwellender Bocksgesang' und weitere Beiträge zu einer deutschen Debatte. Hrsg. $\mathrm{H}$. Schwilk, U. Schacht. Frankfurt am Main, Berlin, 1994. pp. 124-133, zie: 127f. "Nach diesem Desaster [de Duitse nederlaag 1945, G.G.] waren Hilfen von außen gefragt. Sie kamen nicht nur von Siegern mit Okkupationsinteressen und Methoden der Mächtigen, sie kamen von ehemals aus Deutschland Geflohenen und Vertriebenen, also mitten aus uns. Wir hatten Glück. (...) Brecht, Bloch oder Thomas Mann suchten in der DDR, was sie vor dem Kriege sich mitgenommen, und wer mit dem Ost-Staate ging, sich ihm widmete, dachte für das gute einzustehen, für das er geflohen war. (...) Aber diese [de emigranten, G.G.] hatte andere Erfahrungen, wie Leben und daraus Kunst neu sich bilden sollte."

${ }_{152}^{151}$ Lyotard, J.F., Heidegger en 'de joden'. Vert. C. Janssen. Kampen, 1990. p. 28.

${ }_{152}$ Syberberg, Kunst in Deutschland, a.w., pp. 65, 80.

${ }^{153}$ Syberberg, Eigenes und Fremdes, a.w., p. 130: "An Kleist erlebte ich das uns Eigene an der Geschichte jener früheren, unverdächtigten und guten neu, legte mehr und mehr die nach 1945 gewachsenen zu eigen gemachten Schalen meines Wachtstums ab, denn Kleist [dat wil zeggen: de Geist van het oude Pommeren, G.G.] war so nur verfälschend zu erfahren (...)". Syberberg, Kunst in Deutschland, a.w., pp. 181 ff: "So gilt es denn A.bschied zu nehmen von den Übervätern der Emigrantengeneration (...)". Zie eveneens: Goossens, Het reactionaire kunstwerk, a.w., passim.

${ }^{154}$ Zie: hoofdstuk 5, paragraaf 2
} 
daarmee samenhangend aristocratisch gevormd normensysteem? (...) Had niet ook ik weet van de verschillen tussen de standen door geboorte... en zweeg? Verschillend de klassen en rassen en verdiensten, zoals bij planten, dieren, zo ook het lot van mensen. Ik zweeg. (...) Ik kende de vernederingen van de Verlichting en heb ertegen gevochten. En toch sprak ik altijd met hun tongen en vermeed alles, wat me schaden kon, in de ijdele hoop dat mijn verzet uiteindelijk ontdekt zou worden en geèerd, zoals het goede in een sprookje. (...) Heb niet ook ik geprobeerd me geliefd te maken bij de generatie van de emigranten, die onbeschadigd door de schuld van de vaderen geestelijk de wereld interpreteren, verleden en toekomst garanderen - een wereldwijde macht. Wie hier erkenning vindt, komt verder, over Duitsland heen, dit vervloekte land, veel verder. Want (...) de angst voor de banvloek van haar intellectuele pausen (...) is de basis van alle cultuur. Ginds [in het buitenland, G.G.] bestonden nog wel differenties, discussiemogelijkheden, mogelijkheden tot invoeling (...). Is nu dus ook deze auteur betrapt als een jarenlange medewerker van onze westerse staatsveiligheidsdiensten van de re-education-systemen? Was ook hij iemand, die bang en blind het hoofd boog en $\operatorname{loog}$ ? (...) En die uitsluitend met hulp van het buitenland en de overwinnaars (..) overleefde (..), in het geniep de voordelen van het pluralisme van de ondergang gebruikend (...)? Zo was ook ik, mijn andere aard ten spijt, niet gevrijwaard van deze kramp en heb meegedaan, op mijn manier (...)".155

\subsection{De flater van de neo-filosofie}

Zoals Heimat onder de invloed van conservatieve denkers als Heidegger, Schmitt, Klages, de gebroeders Jünger en - bovenal - Sedlmayr verandert van utopie in bodem, zo begrijpt de late Syberberg het nationale verschil niet langer als een historische, maar als een organische, dat wil zeggen in de natuur verankerde differentie: "Verschillend de klassen en rassen en verdiensten, zoals bij planten en dieren, zo ook het lot van mensen'. Het zijn vooral dit soort bespiegelingen, die Syberberg het voor elk kunstenaarschap dodelijke verwijt hebben opgeleverd, dat hij in Vom Unglück und Glück der Kunst in Deutschland nach dem letzten Kriege een knieval zou maken voor de Blut-und-Boden-barbarij van de nazi's. Want, zoals Jürgen Habermas opmerkt in een tekst uit 1977: "De ideologen en hun intellectuele helpers, die het conservatieve gedachtegoed proberen te reanimeren, bevinden zich in een netelige situatie. De nazi's hebben deze tradities zo grondig in diskrediet gebracht, dat in de Bondsrepubliek (...) een 'authentiek conservatisme' niet langer kon bestaan". 156 Wat dat betreft blijkt er nog weinig te zijn veranderd sinds de dagen van het modernisme-debat, waarin de conservatieve kunsttheorie van Sedlmayr door opponenten als Willi Baumeister over één kam werd geschoren met de ranzige cultuurkritiek van nazi-ideoloog Alfred Rosenberg. ${ }^{157} \mathrm{Nu}$, bijna veertig jaar later, doet een Duitse journalist het voor de hand liggende: hij confronteert de auteur van Vom Unglück und Glück der Kunst in Deutschland nach dem letzten Kriege met één van Rosenbergs pennenvruchten. Deze, op zijn beurt, moet toegeven, dat de overeenkomsten inderdaad frapperend zijn. Maar, voegt hij hieraan toe: dat Rosenberg ooit vrijwel identieke dingen heeft gezegd, hoeft toch nog niet noodzakelijk te

\footnotetext{
${ }^{155}$ Syberberg, Kunst in Dewtschland, a.w., pp. $103 \mathrm{ff}$.

${ }^{156}$ Habermas, J., Kleine Politische Schriften I- $I V$. Frankfurt am Main, 1981. p. 386.

${ }^{157}$ Zie: hoofdstuk 2, paragraaf 7.
} 
impliceren dat ze onjuist zouden zijn...? ${ }^{158}$ Scherper dan met deze anekdote zou ik het meningsverschil tussen Syberberg en zijn criticasters niet kunnen samenvatten. "Men verwijt hem zijn thema's, zonder te merken, dat hiermee slechts een taboe wordt gecontinueerd, dat Kiefer terecht ter discussie stelt: het taboe, waarmee dit materiaal van de Duitse overlevering is geoccupeerd door het misbruik van zijn laatste leveranciers." Aldus de in Münster docerende kunsthistoricus Walter Grasskamp in een (in het Westduitse kunsthistorische debat van de late jaren 80 ) invloedrijk essay uit 1984, dat indertijd de basis heeft gelegd voor de rehabilitatie van Anselm Kiefer in eigen land. ${ }^{159}$ En gaat dit niet ook op voor de auteur van Vom Unglück und Glück der Kunst in Deutschland nach dem letzten Kriege? Het gaat, denkt Grasskamp, in elk geval op voor de vroegere Syberberg van Hitler en Die freudlose Gesellschaft, die door hem in één adem met Kiefer wordt genoemd.

Jarenlang, verduidelijkt Grasskamp, gold het in de ogen van de naoorlogse Duitse communis opinio als evident, dat 'wat door het nationaal-socialisme was misbruikt zelf aan dit misbruik niet geheel zonder schuld kon zijn". ${ }^{160}$ Het geperverteerde zou "niet toevallig maar noodzakelijk in deze constellatie [zijn] geraakt" en werd uitsluitend nog opgevat "als expressie van de nationaal-socialistische ideologie". Wie erop teruggreep, laadde onherroepelijk de verdenking op zich een hardleerse Ewiggestriger, zo niet een sympathisant van het nazi-regime te zijn. ${ }^{161}$ Ook de zogenaamde Vergangenheitsbewältigung van de jaren 70 , aldus nog steeds Grasskamp, bracht hierin geen verandering. Weliswaar werd het geperverteerde nu het onderwerp van een ware vloedgolf van aufarbeitende wetenschappelijke studies, krantenartikelen, tentoonstellingen, films, kunstwerken enzovoort (het mede door Susan Sontag aangezwengelde debat over de 'schone schijn' van het Derde Rijk, waarvan ik in paragraaf 5.5 de contouren heb geschetst). Maar van een onbevooroordeelde inhoudelijke discussie kon geen sprake zijn:

"Wanneer de jongere generatie kunsthistorici zich met de kunst van het nationaalsocialisme bezig hield, dan niet om een taboe te slechten, maar om het als wetenschappelijk stigma te onderbouwen. (...) Het oordeel stond in de regel reeds van te voren vast: schuldig aan collaboratie. En omdat voor het gros van de vertegenwoordigers van dit onderzoek ethiek en esthetiek een ideologische eenheid vormden, strekte het politieke vonnis zich ook uit over het terrein van het esthetische. De esthetische kwaliteit van de nazi-kunst, die reeds bij voorbaat werd ontkend, was sowieso geen onderwerp van debat. Veeleer luidde de vraag, die door het onderzoek diende te worden beantwoord: welke bijdrage hebben de kunsten geleverd aan de stabilisering van het nationaal-socialistische regime." 162

Het waren, vervolgt Grasskamp, niet (kunst-)historici, filosofen of andere geleerde specialisten op het terrein van het fascisme-onderzoek, maar kunstenaars als Kiefer en Syberberg, die als eersten deze kennelijk diep geworstelde "smetvrees" [Berührungsangst] te boven kwamen en "het morele en intellectuele risico" namen het taboe zelf ter discussie te stellen door een tot dan volstrekt' nieuwe onderzoeksvraag te poneren: 'Staat het geperverteerde na het misbruik door de nazi's nog aan de kunsten ter beschikking'. 163 Of, in de woorden van Grasskamps collega Eckhart Gillen (1997):

\footnotetext{
${ }^{158}$ Buruma, There's No Place Like Heimat, a.w., p. 35.

${ }^{159}$ Grasskamp, W., Anselm Kiefer - Der Dachboden. in: Der vergeßliche Engel. Künstlerportraits für

Fortgeschrittene. München, 1986. pp. 7-22, zie: 14.

${ }^{160}$ idem, a.w., p. 13.

${ }^{161}$ Grasskamp, W., Die unbewältrigte Moderne: Kunst und Öffentlichkeit. München, 1989. pp. $148 \mathrm{f}$.

162 idem, pp. $153 \mathrm{f}$.

${ }^{163}$ idem, pp. 153 ff. Grasskamp, Anselm Kiefer, a.w., pp. $16 \mathrm{ff}$.
} 
"Pas in de jaren ' 70 begonnen kunstenaars en intellectuelen als Anselm Kiefer en Hans Jürgen Syberberg datgene, wat in de totale verdringing van alle door de nazi's misbruikte waarden en begrippen verloren was gegaan, opnieuw op te eisen [einzuklagen], om het in hun artistieke werk te verwerken en te sublimeren. De logica van de verdringing suggereerde, dat de romantische decorstukken, die de nazi's ooit politiek hadden geoccupeerd en voor hun doelen gebruikt, aan dit misbruik niet zonder schuld konden zijn. Zo kon het gebeuren dat kunstenaars die, zoals Anselm Kiefer, zich de handen vuil maakten bij het opnieuw doorzoeken van de verdrongen erfenis op de nationale zolder, als mythomanen aan de schandpaal werden genageld. $" 164$

Zoals we zagen in de slotparagraaf van het vorige hoofdstuk spreekt de gerenommeerde Duitse kunsthistoricus en tentoonstellingsmaker Georg Bussmann (1988), indertijd één van de hoofdrolspelers in het debat over de 'schone schijn' van het Derde Rijk, in dit verband over "een nieuw geluid in de artistieke omgang met het thema fascisme", dat zich in de loop van de jaren "80 langzaam maar zeker zal gaan doorzetten: "Naast vormen van een kritisch gedistantieerde afrekening treden benaderingen, dat wil zeggen pogingen, mythen en esthetieken, die door het fascisme zijn misbruikt, terug te winnen. Door een ander gebruik uit te proberen wordt getracht deze vormen en inhouden van hun potentieel fascistische connotatie te zuiveren. Naast de houding van het antifaseisme treedt nu het streven "nietfascist' (...) te zijn" ${ }^{165}$ En wanneer de tekenen niet bedriegen is het dit ook, wat een Franse filosoof als Philippe Lacoue-Labarthe zo aan het werk van Syberberg moet hebben aangesproken. Syberberg, meent Lacoue-Labarthe in een in 1981 verschenen recensie van Die freudlose Gesellschaft, "heeft het denken iets te denken [gegeven], wat alle analysen van het nazisme tot dusver nog niet eens bij wijze van een eerste aanzet ter sprake hebben gebracht namelijk dat het specifieke van het nazisme niets anders was dan de waarheid van de romantiek, vooropgesteld dat men met deze term de belangrijkste richting in de Duitse cultuur (en dus ook politiek) sinds het midden van de achttiende eeuw mag aanduiden". Op het eerste gezicht wekt deze lofuiting enige bevreemding. Alsof er geen Thomas Mann, geen Lukács en geen Kracauer zijn geweest. Maar Lacoue-Labarthe voegt er nog iets aan toe: "Dit betekent niet, dat Herder of Schlegel, Fichte of Nietzsche het nazisme reeds in potentie zouden 'bevatten'. Deze flater [bourde] komt voor rekening van de neo-filosofie." 166

Het doorprikken van dit 'neo-filosofische' - of beter: 'irrationalisme'-kritische misverstand schept ruimte voor een artistieke én filosofische herijking van al datgene, wat na ' 45 misschien wat al te achteloos als fout, ziek, decadent, rechts, reactionair of in wezen fascistisch overboord is geworpen. Waaronder vanzelfsprekend ook het post-nietzschiaanse denken van de Conservatieve Revolutie uit de Weimar-tijd, dat Lacoue-Labarthe in onder meer zijn zwaar op de Hitler-film leunende Heidegger-studie La fiction du politique (1987) aan een grondige revisie onderwerpt. En het kan haast niet anders, of hij moet in Syberberg een geestverwant hebben ontwaard, die als kunstenaar werkt aan een soortgelijk project. Zo wordt de filmopera Parsifal, het laatste deel van De Graal, door Lacoue-Labarthe - terecht geïnterpreteerd als: "een vertwijfelde poging Wagner weer aan het nationaal-estheticisme [nazisme, G.G.] te ontfutselen, middels een subtiele en tegelijk gewelddadige strategie van

\footnotetext{
${ }^{164}$ Gillen, a.w., p. 50.

${ }^{165}$ Bussmann, G., Arbeit in Geschichte / Geschichte in Arbeit. in: Arbeit in Geschichte / Geschichte in Arbeit. Hrsg. G. Bussmann, Berlin 1988. pp. 11-16, zie: 14. Zie eveneens: hoofdstuk 6, paragraaf 8.

${ }^{166}$ Lacoue-Labarthe, a.w., pp. $481,483$.
} 
herijking". ${ }^{167}$ Ook de bewondering van Christian Zimmer, Jean-Pierre Faye, Michel Foucault of Gilles Deleuze voor de regisseur van Hitler en Parsifal laat zich misschien langs deze weg verklaren. ${ }^{168}$ 'Jong-conservatieven', noemt Habermas deze Franse post-nietzschianen. Waarmee hij bedoelt te zeggen, dat ze het in zijn ogen ware linkse project van de herijking van de Verlichtingstraditie van Lessing tot Marx de rug zouden hebben toegekeerd, om voorgoed te verdwalen in het Woud wan Nietzsche, Heidegger en Ernst Jünger. Sterker: als we Habermas mogen geloven, bestaat er een onmiskenbare verwantschap tussen deze postnietzschiaanse Franse filosofie en het "jong-conservatieve" denken van een Nieuw Rechtse activist als Armin Mohler. Foucault, Deleuze, Jacques Derrida (de leermeester van LacoueLabarthe) - zij zijn, meent Habermas, de 'intellectuele handlangers' van dit soort Nieuw Rechtse 'ideologen', die in de jaren ' 70 'het conservatieve gedachtegoed proberen te reanimeren'. En het zou met name te danken zijn aan de verderfelijke invloed van deze Franse recycling van de Conservatieve Revolutie, dat de scheidslijnen tussen links en rechts in de Bondsrepubliek van de Tendenzwende zijn vervaagd tot een 'nieuwe onoverzichtelijkheid', die bij de Frankfurter filosoof pijnlijke associaties oproept met de oude van het interbellum. ${ }^{169}$

En inderdaad: volslagen nieuw is dit, door Bussmann geconstateerde 'nieuwe geluid' allerminst. Zelf heeft Syberberg zich op dit punt de ogen laten openen door Ernst Bloch, die reeds in het expressionisme-debat van de jaren ' 30 de vloer aanveegde met de dwalingen van het 'vulgaire marxisme'? ${ }^{170}$ Maar het is vooral buiten het linkse cultuurdebat, waar het vermeend 'nieuwe geluid' al sinds jaar en dag in alle toonaarden kan worden beluisterd. Wat te denken bijvoorbeeld van Armin Mohlers ook in het reguliere academische debat invloedrijke proefschrift Die Konservative Revolution in Deutschland (1949), waaraan het post-nietzschiaanse denken uit de Weimar-tijd zijn benaming dankt. De historicus mag zich er graag op laten voorstaan met dit werk uit de tweede helft van de jaren '40 een essentiële bijdrage te hebben geleverd aan de rehabilitatie als "cultuurhistorische sleutelfiguur" van "de indertijd gedemoniseerde en politiek verketterde Nietzsche". ${ }^{171}$ Dat de Conservatieve Revolutie - een begrip, dat bij hem grotendeels synoniem is met wat we in dit boek verstonden onder "irrationalisme, , $^{172}$ - op tal van manieren met het nationaal-socialisme is verstrengeld geraakt, wordt ook door Mohler niet ontkend. Wel heeft hij zich, aldus het voorwoord van een in 1971 verschenen herdruk van zijn (overigens onder auspiciën van Karl Jaspers tot stand gekomen) proefschrift tot doel gesteld "de conservatieve intelligentsia tegen destijds (en ook tegenwoordig nog) gangbare generalisaties en simplificaties in bescherming

${ }^{167}$ Lacoue-Labarthe, Ph., Heidegger, Art and Politics. The Fiction of the Political. Vert. C. Turner. Cambridge, Mass., Oxford, 1990. p. 63.

${ }^{168}$ Zimmer, [Chr.], a.w., passim. Faye, a.w., passim. Sobel, B., Les quatre cavaliers de l'Apocalypse et les vermisseaux quotidiens. Entretien avec Michel Foucault. in: Cahiers du Cinéma, a.w., pp. 95f. Deleuze, G., Das Zeit-Bild. Kino 2. Vert. K. Englert. Frankfurt am Main, 1991, 1997. pp. 341-345, 427-430. "Das trümmerübersäte Feld, das den Raum des Geschehens darstelt und zu dem die Kamera immer wieder zurückkehrt, erinnert an jenes andere Feld, auf das sich der große chinesisische Film Der Osten ist rot vor zehn Jahren begab - aber nun mit der Kritik dazu," aldus Faye, a.w., p. 33 over de Hitler-film. "Also genau mit dem, was die Ideologie ausgesprart hatte. In den schwarzen Zeiten des Faschismus und des 'Nazifaschismus', wie ihn die Italiener nennen. Und ebenso in den rosigen Zeiten des alten und neuen Shdanowismus..." Het 'sjadanovisme' is een ander woord voor de op de kunsttheorie van Lukács geënte cultuurpolitiek van het stalinisme. Voor Andrej Alexandrovitsj Sjadanov en (zijn rol binnen) deze cultuurpolitiek, zie: hoofdstuk 2, de paragrafen 3 en 4 .

${ }^{169}$ Habermas, a.w., pp. 439f, 444-464.

${ }^{170}$ Zie: hoofdstuk 3, de paragrafen 6 en 7.

171 Mohler, A., Die Konservative Revolution in Deutschland 1918-1932. Ein Handbuch. Darmstadt, 1994. p. XXV.

${ }^{172}$ Tot de "Conservatieve Revolutie", een geestesstroming die hij in de Goethe-tijd laat beginnen, rekent Mohler ook figuren als Wagner, Nietzsche en Dostojevski. idem, pp. 9ff. 
[te nemen]". ${ }^{173}$ Meer specifiek: tegen het vooral in linkse kringen hardnekkige misverstand, dat het nationaal-socialisme de min of meer noodzakelijk 'politieke realisatie' zou zijn geweest van wat bij Wagner en Nietzsche, Jünger en Heidegger reeds in potentie aanwezig was. In zijn optiek dient het "irrationele" of Conservatief Revolutionaire gedachtegoed te worden begrepen als "een autonoom geheel, dat niet noodzakelijkerwijs in het nationaalsocialisme uitmondt". En door de verschillen en overeenkomsten zo nauwkeurig mogelijk in kaart te brengen, probeert hij deze denktraditie weer aan de bruinhemden te ontfutselen, zo men wil: aan te tonen dat óók in het postnazistische Duitsland een 'authentiek conservatisme' (Habermas) wel degelijk tot de mogelijkheden behoort. ${ }^{174}$

\subsection{Slot}

In de zomer van '93 verschijnt in Frankrijk een, door toonaangevende intellectuelen als Pierre Bourdieu, Umberto Eco, Jacques Derrida en Paul Virilio ondertekende Oproep tot waakzaamheid. Tegen de subversieve actie van rechts in Europa, waarin wordt gewaarschuwd het zogenaamde 'postmoderne' Franse differentiedenken niet te verwarren met het etnocentrische differentiedenken van Nieuw Rechts. ${ }^{175}$ Zeker geen overbodige luxe, want de scheidslijnen zijn op zijn zachtst gezegd nogal diffuus. Niet slechts omdat het in beide gevallen gaat om een product van Franse makelij, ${ }^{176}$ maar zeker ook omdat zowel de 'postmodernisten' als de activisten van Nieuw Rechts putten uit éen en dezelfde bron. Goed, de ene Nietzsche is de andere niet. En net als Santner en Elseasser heeft ook Lacoue-Labarthe zich met klem gedistantieerd van de 'Pruisen-liefde', het 'platte neo-romanticisme' en 'domweg onvergeeflijke antisemitisme' van de late Syberberg. ${ }^{177}$ Maar Habermas is beslist niet de enige die het bange vermoeden koestert, dat Parijs in de loop van de jaren ' 70 is verworden tot een broeinest van neo-conservatieve sentimenten. Ook de zelf door deze Frankfurter filosoof als 'jong-conservatief' naar het Grand Hotel Afgrond verbannen Karl Heinz. Boher zinspeelt in een essay uit 1980 op parallellen tussen Syberbergs "agressieve antimodernisme' en 'de conservatieve wending van een groep linkse intellectuelen in Parijs". ${ }^{178}$ Helaas geeft Bohrer hiervan geen concrete voorbeelden. Op grond van Lacoue-Labarthe's Hitler-interpretatie in La fiction du politique en de reeds aangehaalde recensie van Die freudlose Gesellschaft ("één van de beste boeken die ooit over het naoorlogse Duitsland zijn geschreven") ${ }^{179}$, kan ik me echter goed voorstellen waar de literatuurwetenschapper op doelt.

Laat ik me gemakshalve beperken tot de duiding, die Lacoue-Labarthe geeft van het zonsondergangen-tableau. Wat we in dit tableau zien, legt de filosoof uit, is een acteur, die Hitler verantwoordelijk stelt voor "de definitieve non-existentie van Duitsland". ${ }^{180}$ Hetgeen tevens het thema is van de film in zijn geheel, ja van Syberbergs gehele oeuvre. Want de

\footnotetext{
173 idem, p. XXV.

${ }^{174}$ idem, pp. XXVIIff., 3-18.

${ }^{175}$ Herzinger, R., Revolutionärer Aufbruch in die Stammesgemeinschaft? Die Ideologie(n) der Neuen Rechten und ihre Zeitschriften. in: Deutschland Archiv. 12 (1993) pp. 1389-1403, zie: p. 1389.

${ }_{176}$ De bakermat van Nieuw Rechts in Europa is de Groupement de récherchex et d'études pour la civilisation ewropéenne (GRECE) - een, eind jaren' 60 als antwoord op Nieuw Links opgerichte 'denkschool' rond de historicus Alain de Benoist, die nauwe banden onderhoudt met die andere denkschool aan gene zijde van de Rijn rond Mohler. Zie bijvoorbeeld: GreB, Jaschke, Schönekäs, a.w., pp. 45-55.

177 Lacoue-Labarthe, Syberberg. Uber Deutschland nach Hitler, a.w., p. 484.

${ }^{178}$ Bohrer, K.H., Die drei Kulturen. in: Stichworte zur 'geistigen Situation der Zeit". Band 2: Politik und Kultur. Hrsg. J. Habermas. Frankfurt am Main, 1980. pp. 636-669, zie: 657. Voor de kritiek van Habermas op Bohrer, zie: hoofdstuk 4 , paragraaf 1 .

${ }^{179}$ Lacoue-Labarthe, a.w., p. 483.

${ }^{180}$ Lacoue-Labarthe, Heidegger, Art and Politics, a.w, p. 71.
} 
cinema van Syberberg, betoogt Lacoue-Labarthe, kent slechts één thema: Duitsland. Of meer specifiek: Duitsland als "geestelijke mogelijkheid". En wie de vraag stelt naar Duitsland als geestelijke mogelijkheid stelt indirect ook de vraag naar de geestelijke mogelijkheden van de Duitse kunst. Immers: wat was dit land van de dichters en de denkers door de eeuwen heen anders, dan de geestelijke mogelijkheden van zijn kunst? Martin Heidegger kon in het interbellum het Duitse vraagstuk nog geheel en al met de vraag naar de geestelijke mogelijkheden van de Duitse kunst laten samenvallen, zónder op de lachspieren van zijn toehoorders te werken. Anno 1981, het jaar van Die freudlose Gesellschaft, komt het stellen van dit soort vragen echter neer op een confrontatie. Met de 'Duitse non-existentie', dat wil zeggen: de veramerikanisering - deze "woestenij, het totale nihilisme, zelfs in de revolte". En dus ook met hen, die de woestenij verdedigen: het "kleinburgerlijke" links-liberale cultuurestablishment van de Bondsrepubliek. Dit en niets anders, meent Lacoue-Labarthe, is de inzet van Syberbergs einefiele treurkunst: treuren over het verlies van Duitsland als geestelijke mogelijkheid én over het verlies van de geestelijke mogelijkheden van de Duitse kunst. Het is een kunst met lange wortels in de Duitse cultuurgeschiedenis, die terugreiken tot het romantische ruïnebeeld, tot Dürer en het Trauerspiel van de barok. En uit deze Duitse traditie stammen ook de belangrijkste waarden, die door Syberberg in zijn films en pamfletten worden uitgedragen: betrouwbaarheid, loyaliteit, Treue. ${ }^{181}$

Een uitleg, waarin Syberberg zich ongetwijfeld zal kunnen vinden. Ik zou in dit verband nog een stap verder willen gaan: afgezien misschien van Karl Heinz Bohrer ${ }^{182}$ is geen secundaire auteur ooit zo dicht in de buurt gekomen bij waar het Syberberg inderdaad om te doen is: de 'Duitse geest begrijpen, eren en redden'. Maar zouden deze overpeinzingen over de 'definitieve non-existentie' van Duitsland erg uit de toon vallen in een Nieuw Rechts periodiek als Criticón? En er is nog iets anders, dat het beslist niet de eenvoudigste zaak van de wereld maakt om aan te geven waarin nu eigenlijk precies het verschil schuilt tussen een linkse post-nietzschiaan als Lacoue-Labarthe en een rechtse als Armin Mohler: de Franse 'postmodernisten' worden in de rechtse politieke underground gretig bestudeerd. Natuurlijk, gelijk de conservatieve revolutie van weleer is ook Nieuw Rechts geen coherente denkrichting, maar een lappendeken van splintergroeperingen. Van het 'postmoderne' Franse differentiedenken is het gros van deze groeperingen mijlenver verwijderd. Tussen een sophisticated onderzoek als La fiction du politique en de ranzige pagina's van de Deutsche National-Zeitung bestaat meer dan een wereld van verschil. En toch: neem de Münchense Matthes \& Seitz-Verlag, die vaak met Nieuw Rechts in verband wordt gebracht. ${ }^{183}$ "Ongeacht

${ }^{181}$ Lacoue-Labarthe, Syberberg. Uber Deutschland nach Hitler, a.w., pp. 480-484, Ook Lacoue-Labarthe gebruikt het Duitse woord: Voor Syberbergs visie op 'Treue', zie: hoofdstuk 5, paragraaf 6.

${ }_{82}$ Bohrer, K.H., Deutschland - noch eine geistige Möglichkeit? Bemerkungen zu einem nationalen Tabu. in: Frankfurter Allgemeine Zeitung. 28-04-1979: "Wanneer we niet terugkeren naar onze aangeboren grote stijl van de verbeelding, van de metafysica, van het domweg verbodene - zo zal hij [Syberberg, G.G.] het hebben bedoeld - zullen we voortaan geestelijk en seelisch gekoloniseerd blijven." Zie eveneens: paragraaf 3.8 .

${ }_{183}$ Zie bijvoorbeeld: Herzinger, a.w., p. 1398. Baier, a.w., p. 120ff. "Ohne dies näher zu begründen," schrijft de in de Verenigde Staten docerende Duitse germaniste Sigrid Berka, "rechnet Herzinger Botho Strauß zusammen mit Hans-Jürgen Syberberg und Gerd Bergfleth [Duits filosoof en Bataille-vertaler, G.G.] zu denjenigen

Intellektuellen, die zu Fürsprechern rechtskonservativen Ideen geworden seien (und Deckungsgeleichheiten mit dem Gedankengut der Konservativen Revolution aufweisen). (...) Unter die amorphen Splitter neurechter bzw. nationallinker Denkorgane rechnet er nicht nur Publikationen wie Criticón (...), sondern (...) auch (...) das vom Matthes \& Seitz Verlag herausgegebene Jahrbuch Der Pfahl. (...) Dern schnellen Abtasten der politischen Korrektheit müßte freilich in bezug auf das von Strauß gelegentlich belieferte entlegene Jahrbuch aus dem Niemandsland zwischen Kunst und Wissenschaft (so der Untertitel) eine gründlichere Untersuchung erst noch folgen; eine Untersuchung, die Beispielsweise, die Haltungen und Gesten unter die Lupe nimmt, deren Schulung das Jahrbuch für sich in Anspruch nimmt." Berka, S., Botho Strauß und die Debatte um den 'Bocksgesang'. in: Weimarer Beiträge. Zeitschrift für Literaturwissenschaft, Asthetik und Kulturwissenschaften. 2 (1994). Hrsg. S. Berka. pp. 165-178, zie: $170 \mathrm{f}$. 
de ideologische 'uitsluitingen' in de opinievormende openbaarheid wordt in het uitgeversfonds geen monocultuur onderhouden," aldus Axel Matthes (1990) in zijn huisblad Der Pfahl. Jahrbuch aus dem Niemandsland zwischen Kunst und Wissenschaft. "Krampachtige stichtingen van zingeving wijs ik van de hand. Vele malen liever is mij iemand, die zegt: Ik wil niet iemand van jullie zijn! - en die het niet enkel roept, maar ook nog doet!"184

Volgen we de Duitse Nieuw-Rechts-vorser Richard Herzinger, dan beweegt de Matthes \& Seitz-Verlag zich "in de duistere schemerzone tussen esthetische taboedoorbraak en irrationele Gegenaufklärung". 185 Maar in deze schemerzone beweegt zich natuurlijk ook een niet onaanzienlijk deel van de 'postmoderne' Franse filosofie. En het behoeft dan ook niet te verbazen, dat de uitgeverij met name in dit soort literatuur is gespecialiseerd: George Bataille, Michel Foucault en Jean Baudrillard. Toegegeven: de Verlag kent nog een tweede specialisatie. Je komt er ook studies tegen over Ernst Jüngers fünf Kriege. ${ }^{186}$ Want in dit fonds wordt nu eenmaal 'geen monocultuur onderhouden'. Van de zelfgenoegzaamheid, waarmee de vertegenwoordigers van, wat Lacoue-Labarthe noemt, de 'neo-fillosofie', nog de wereld dachten te kunnen opdelen in goed en fout, gezond en ziek of decadent, progressief en reactionair, links en rechts, humanistisch en fascistisch is in de Matthes \& Seitz-Verlag weinig te merken. 'Krampachtige stichtingen van zingeving,' worden ferm van de hand gewezen. "(...) Er bestaat geen soeverein, funderend subject (...)," doceert een van de bestseller-auteurs van het fonds, de post-nietzschiaan Michel Foucault. ${ }^{187}$ De dialectische Vernunft, het lakmoes in de proef van de 'irrationalisme'-critici, heeft opgehouden een objectief criterium te zijn aan de hand waarvan je het koren van het kaf zou kunnen scheiden. Wat rest is een absolute vrijheid van het denken, die zich weinig lijkt aan te trekken van die "onzalige drie-eenheid denkverbod-taboeïsering-stigmatisering" waardoor, aldus de hierboven reeds aangehaalde politieke filosoof Walter Kowalsky (geen Nieuw Rechtse activist) het publieke debat in de Bondsrepubliek al sinds jaar en dag wordt verlamd: "(...) De Oud Linkse uitsluitingsmachinerie, die elke verandering van positie rubriceert als verraad, vergroot het kamp van de verraders van dag tot dag: Hans Magnus Enzensberger, Martin Walser, Botho Strauß en velen anderen geven zich als seismografen van een nieuwe epoche rekenschap van de uitdagingen van de tijd en worden daarom meteen uit de Heilige Linkse Familie verbannen." 188

Hier, in de Matthes und Seitz-Verlag vinden ze een asiel: deze verschoppelingen uit de Heilige Linkse Familie. En het is hier ook, in dit fonds van de idiosyncratische Axel Matthes, dat twee van de meest opzienbarende pamfletten uit de jaren ' 90 het licht hebben gezien: Vom Unglück und Glück der Kunst in Deutschland nach dem letzten Kriege van de Duitse filmmaker Hans Jürgen Syberberg én Anschwellender Bocksgesang (1993) van Botho Strauß, ooit het troetelkind bij uitstek van de protestgeneratie van ' 68 :

\footnotetext{
${ }^{184}$ Matthes, A., Notiz. in: Der Pfahl. Jahrbuch aus dem Niemandsland zwischen Kunst und Wissenschaft IV. Hrsg. A. Matthes. München, 1990.

${ }^{185}$ Herzinger, a.w., p. 1398.

${ }^{186}$ Langendorf, J.-J., Ernst Jüngers fünf Kriege. in: Der Pfahl, a.w., pp. 39-63. Daarnaast bevat het aangehaalde nummer van dit jaarboek: een verhaal van Osip Mandelstam; enkele brieven van Jürgen von der Wense aan Dieter Heim; een reeks gedichten van genoemde Dieter Heim; een interview met Jorge Luis Borges; een essay van de filosoof Bernd Mattheus over Jünger; een bespreking van Habermas' Der Philosophische Diskurs der Moderne door de filosoof László F. Földényi met de veelzeggende titel Aufklärung - um jeden Preis; drie teksten van George Bataille; een essay van de filosoof en Bataille-exegeet Gerd Bergfleth over Sade; een interview met en essay van de estheticus Oswald Wiener.

${ }^{187}$ Foucault, M., Fontana, A., An Aesthetic of Existence. in: Michel Foucault. Politics, Philosophy, Culture: Interviews and other Writings 1977-1984, red. L.D. Kitzman. Vert. A. Shiridan e.a.. New York, 1988. p. 50. ${ }^{188}$ Kowalsky, a:w., 831 .
} 
"Ze hebben Heidegger verboden en Ernst Jünger vervloekt - nu moeten ze dulden, dat de grote stap van deze auteurs, dichters-filosofen, hun brave opstand als een verdroogde distel vertrapt. (...) Der Rechte - in der Richte; ein Außenseiter."189

${ }^{189}$ Strauß, B., Anschwellender Bocksgesang. in: Die selbstbewuBte Nation. a.w., pp. 19-56, zie: 25, 28. 


\subsection{Inleiding}

Of zijn landgenoten waren vergeten, dat een verenigd Duitsland ooit Auschwitz had voortgebracht?, vroeg Günther Grass zich af kort na de val van de Berlijnse Muur. En vertoonde de op handen zijnde eenwording niet alle trekjes van een kapitalistische annexatiepolitiek? ${ }^{\sharp} \mathrm{Ja}$, viel Jürgen Habermas de schrijver bij, wat was het project van de eenwording anders dan een macaber voorbeeld van "DM-nationalisme"? En al die Westduitsers, die het gevoel hadden eindelijk weer een 'normale' natie te zijn geworden gaven zij zich niet over aan een "tweede levensleugen"? " Zo slaagde de linkerflank van de Bondsrepubliek er toch nog in de Wende van 1989-1990 in haar wereldbeeld in te passen: als verdringingsstrategie én klassenstrijd, dit maal van West tegen Oost." "Iets nieuws, iets dat zich niet uit tot dan toe geldende ervaringen liet afleiden, werd plotseling zichtbaar en veranderde het 'Systemganze', in dit geval: de wereld.' Aldus Botho Strauss in een essay uit 1990. En de voorheen spraakmakende gemeente stond erbij en keek ernaar - betroffen de oude topoi recyclend: "Mach's nicht noch mal Deutschland!". Maar als 1989 iets duidelijk heeft gemaakt, betoogde Strauss, dan is het wel dat de geschiedenis naar believen sprongen maakt, zonder zich ook maar iets aan te trekken van geboden en verboden, wensdromen en boetepreken, overtuigingen en doctrines, programma's en prognoses, conventies en dialectische conclusies. "De laatste wraak van het ten val gebrachte totalitaire regime bestond dan ook uit de totale ontmaskering, de negatieve openbaring van een dolende wereldse Soteriologie: alles verkeerd van meet af aan!"6

Om een afgewogen oordeel te kunnen vormen over Syberberg, ontkomen we er niet aan tot slot ook kort stil te staan bij deze finale van het linkse cultuurdebat. Want niets minder dan dat, lijkt zich in de jaren na de val van de Muur in de Bondsrepubliek te voltrekken: het slotstuk van een links debat over Duitsland en Duitse geschiedenis, dat ooit een aanvang nam met de retorische vraag van Georg Lukács welke artistieke en filosofische stromingen in dienst stonden van de dialectische vooruitgang. Zoals we zagen in de voorafgaande hoofdstukken heeft ook Syberberg zich steeds bínnen de kaders van dit debat bewogen. Vanaf zijn allervroegste filmexperimenten aan het Brecht-theater in Oost-Berlijn (1953) speelde zijn kunstenaarschap zich steeds af tegen de achtergrond van de linkse disputen over het expressionisme, het formalisme, het Duitse 'onvermogen om te rouwen', de 'schone schijn' van het Derde Rijk, de Biermann-Ausbürgerung en de Tendenzwende van de late jaren '70. Pas in de loop van de jaren ' 80 begint hij geleidelijk aan zijn aandachtsveld te verleggen. Het is een periode van grosser gedanklicher Klärung, die haar climax vindt in het beruchte

\footnotetext{
${ }^{\prime}$ Krockow, Ch., Graf von, Die Deutschen in ihrem Jahrhundert 1890-1990. Hamburg, 1990, 1994. pp. 668ff.

${ }^{2}$ Habermas, J., Die zweite Lebenslüge der Bundesrepublik: Wir sind wieder "normal' geworden. in: Die Zeit. 51 (11-12-1992). Zie eveneens: Boterman, F., Terug naar Berlijn. Duitsland na de val van de Muur. Amsterdam, 1999. pp. $171 \mathrm{f}$.

${ }^{3}$ Vergl. Stephan, C., Der Betroffenheitskult. Eine politische Sittengeschichte. Hamburg, 1993, 1994. p. 180.

${ }^{4}$ Strauss, B., Der Aufstand gegen die sekundäre Welt. Bemerkungen zu einer Ästhetik der Anwesenheit. in: Die Zeit. 26 (22-06-1990).

${ }^{5}$ Hofman, G, Mach's nicht noch mal, Deutschland! in: Die Zeit. 44 (29-10-1993). Voor de reactie van links West-Duitsland op de val van de Muur, zie ook bijvoorbeeld Boterman, a.w., pp. 158-174. Alsmede: Meier, C., Am Ende der alten Bundesrepublik in: Merkur. Deutsche Zeitschrift für europäisches Denken. 7 (juli 1994). pp. 561-572: "Alte Formeln werden gebetsmühlenhaft wiederholt, alte Schreckbilder aus irgendwelchen intellektuellen Gruselkabinetten lassen die Gedanken erstarren."

${ }^{6}$ Strauss, a.w..
} 
pamflet Von Unglück und Glück der Kunst in Deutschland nach dem letzten Kriege, waarin de voormalige Brecht-leerling voorgoed afscheid neemt van het links-liberale vertoog. De publicatie van dit pamflet in het Wende-jaar 1990 veroorzaakt het grootste schandaal uit zijn toch al niet rimpelloos verlopen carrière. Maar de mentaliteitsomslag in de Bondsrepubliek van ná de Wende plaatst het toenmalige rumoer misschien toch in een iets ander licht. En alvorens de balans op te maken van deze kunstenaarsloopbaan (de paragrafen 4 en 5), lijkt het me dan ook van belang eerst een korte impressie te geven van dit veranderde intellectuele klimaat (paragraaf 2) en een antwoord te formuleren op de vraag, welke rol voor een filmer/pamflettist als Syberberg in de Berliner Republik wellicht nog is weggelegd (paragraaf 3).

\subsection{De Wende van 1989-1990}

Vrijwel onmiddellijk heeft 1989-1990 de betekenis gekregen van een caesuur, die Umdenken noodzakelijk maakt. In brede kring leeft het gevoel, dat men met de oude topoi niet meer verder komt. Met de eenwording is tevens een einde gekomen aan de Bondsrepubliek, in de vorm waarin zij sinds 1949 heeft bestaan. Uit de beide Duitslanden van weleer is een nieuwe, volwaardige en soevereine natie voortgekomen, die worstelt met nieuwe interne problemen en een nieuwe plaats inneemt in een ook overigens volstrekt veranderde wereld. Wie hield in de jaren ' 80 nog rekening met oorlogen in Europa? Dit betekent dat veel, wat tot 1989 als vanzelfsprekend gold, opnieuw dient te worden overdacht. Bijvoorbeeld het 'constitutionele patriottisme' - een ooit door de politicoloog Dolf Stemberger geïntroduceerd concept van collectieve identiteit, dat jarenlang vooral in linkse kringen werd beschouwd als een groot goed waaraan onder geen enkele voorwaarde mocht worden getornd. Het gold als een alternatief voor nationaal patriottisme, dat door de nazi-barbarij voorgoed zou zijn geperverteerd. Aan het deutsche Nationalgefiuhl kon 'een Duitser, die tot nuchter denken in staat was, nog slechts met gekromde tenen terugdenken, wetend waartoe het had geleid en voor wie het de weg had gebaand' (Margarete Mitscherlich). ${ }^{7}$ Dit soort gevoelens behoorden tot de 'irrationele' hunkeringen, die middels een psychoanalytische Trauerarbeit of anderszins 'radicaal' dienden te worden 'overwonnen', opdat ruimte zou ontstaan voor nieuwe, empathische identificaties met de liberale constitutie. Constitutioneel patriottisme benadrukte de historische discontinuïteit, de breuk met het verleden. Tussen heden en verleden bestond een kloof. De naam van deze kloof was Auschwitz. En elke poging de historische continuiteit te herstellen werd als een ontoelaatbare normalisering veroordeeld. Maar hoe je het ook wendt of keert: de eenwording van Duitsland was alleen mogelijk op grond van continuilteiten en gemeenschappelijkheden met de eerste Duitse Nationalstaat en werd uitsluitend historisch gelegitimeerd. ${ }^{8}$

Het is in dit licht, dat de toenmalige kritiek van Habermas en Grass dient te worden begrepen. En zij waren indertijd beslist niet de enigen, die de eenwording op morele gronden afwezen. Zo meende ook Joschka Fischer, het boegbeeld van de Grünen, in 1990 nog dat het "gelet op Auschwitz" nóóit tot een Wiedervereinigung zou mogen komen. ${ }^{9}$ Luttele jaren later

\footnotetext{
${ }^{7}$ Mitscherlich, M., Erinnerungsarbeit. Zur Psychoanalyse der Unfahigkeit zu trauern. Frankfurt am Main, 1987. pp. 20 f. Zie eveneens: hoofdstuk 4, paragraaf 5.

${ }^{8}$ Meier, a.w., passim. Boterman, a.w., pp. $169 \mathrm{ff}$. Goossens, G., 'Vrienden, het wordt menens!'. De opkomst van een Duitse intellectuele voorhoede. Groene-essay. in: De Groene Amsterdammer. 16 (1995). pp. 28f. Dassen, P., Nijhuis, T., Inleiding. Geschiedenis, identiteit en taboe. De tegenwoordigheid van het verleden in de Bondsrepubliek. in: Gegijzeld door het verleden. Controverses in Duitsland van de Historikerstreit tot het Sloterdijk-debat. red. P. Dassen, T. Nijhuis. Amsterdam; 2001. pp. 9-22.

Zie: Stephan, a.w., p. 82 .
} 
verdedigt Fischer als minister van Buitenlandse Zaken van de Berliner Republik de uitzending van Duitse troepen naar de Balkan. Het mag tekenend worden genoemd voor de mentaliteitsomslag die in korte tijd heeft plaats gevonden. Met name de protestgeneratie van '68, constateert de Nederlandse historicus Frits Boterman (1999), heeft in minder dan een decennium een draai van 180 graden gemaakt. Over de gehele linie, aldus Boterman, is sprake van een proces van ontnuchtering en ontideologisering. De "verlammende Betroffenheitskultur, zoals die vóór 1989 diep in de Bondsrepubliek was ingebrand", heeft plaats gemaakt voor pragmatisme en realisme. En hen, die nog wél deze taal van de Betroffenheit spreken, wordt in toenemende mate verweten de aansluiting bij de nieuwe tijd te hebben gemist door dogmatisch te zijn blijven vasthouden aan achterhaalde denkpatronen. ${ }^{10}$ Waartoe vanzelfsprekend óók het neo-marxisme in al zijn varianten behoort. Want zonder twijfel is dit de meest fundamentele verandering. Veertig jaar lang gold het neomarxistische denken van de antifascistische emigrantengeneratie voor de intellectuele voorhoede in Oost én West als een vast oriëntatiepunt. Georg Lukács, Ernst Bloch, Theodor Adorno, Walter Benjamin, Bert Brecht, Siegfried Kracauer, Hans Mayer enzovoort waren intellectuele, politieke en morele Leitfiguren, die in het interbellum de lijnen hadden uitgezet waarlangs het linkse cultuurdebat zich tot in de jaren ' 80 bewoog. Welnu, dit kompas, waarop velen blind meenden te kunnen varen, is door de gebeurtenissen van de herfst van ' 89 danig in de war geschopt. Met de ineenstorting van het Oostblok is ook een wereldbeeld in rook opgegaan. Het linkse idealisme, het dialectische denken, het zogenaamde 'kritische bewustzijn', de 'mythe van het antifascisme" (Antonia Grunenberg) ${ }^{11}$ zijn volledig in diskrediet geraakt. De gidsen van weleer zijn van hun voetstuk gevallen. De droom van de maakbare samenleving op grond van een ideologische blauwdruk bleek een "papieren droom" (Boterman) te zijn. "Niet in werkcolleges, maar rondom Sarajevo wordt tegenwoordig bepaald wat humanisme, solidariteit en soevereiniteit in de toekomst zullen inhouden," verzucht de publicist Andreas Kilb in Die Zeit van 2 april 1993. En massaal ontdekt links-liberaal Duitsland, dat er al die jaren nog intellectueel leven heeft bestaan buiten het eigen vertoog: "Het leesverbod, dat zich vroeger uitstrekte over alles wat niet het klassenstandpunt innam, keert zich om in een leesbevel". ".

Hoezeer het intellectuele klimaat welhaast übernacht is veranderd, blijkt ook uit de verhitte controverse die zich midden jaren ' 90 afspeelt rond een oorspronkelijk voor het elitaire underground-blad Der Pfahl geschreven essay van Botho Strauss, waarvan februari 1993 een ingekorte versie verschijnt in Der Spiegel: Anschwellender Bocksgesang. ${ }^{14}$ Net als Syberbergs Vom Unglück und Glück der Kunst in Deutschland nach dem letzten Kriege laat dit stuk van Strauss zich nog het beste typeren als een 'bekentenis' (in de Duitse zin van het woord) van een kunstenaar uit de generatie van '68 tot de 'rechtse' denktraditie van de Conservatieve Revolutie. En net als drie jaar eerder Syberberg wordt ook Strauss aanvankelijk buitengewoon fel bejegend. Wanneer Ignatz Bubis, de gezaghebbende voorzitter van de Zentralrat der Juden in Deutschland, zinspeelt op een verband tussen

\footnotetext{
${ }^{10}$ Boterman, a.w., pp. 145ff, 158ff, $217 \mathrm{ff}$. Voor het fenomeen 'Betroffenheit", zie: hoofdstuk 5, paragraaf 3.

"Grunenberg, A., Antifaschismus - ein deutscher Mythos. Essay. Hamburg, 1993.

${ }^{12}$ Boterman, a.w, pp. 160ff, 171f.

${ }^{13}$ Kilb, A., Anschwellender Geistesfinsternis in: Die Zeit. 14 (02-04-1993).

${ }^{14}$ Voor Der Pfahl, zie; hoofdstuk 7, paragraaf 8 . Voor de Bocksgesang-debatte: Goossens, a.w, passim.

Boterman, a w, 164ff. Harbers, H., Het Botho Strauss-debat. in: Gegijzeld door het verleder, a.w., pp. 101-116. Rosellini, J.J., A Revival of Conservative Literature? The "Spiegel-Symposium 1993" and Beyond. in: Beyond 1989. Re-reading German Literature since 1945. ed. K. Bullivant. Oxford, 1997. pp. 109-128. Alsmede de themanummers: Weimarer Beiträge: Zeitschrift für Literaturwissenschaft, Asthetik und Kulturwissenschaften. Das Werk von Botho Strauss und die 'Bocksgesang'-Debatte. Hrsg. S. Berka. 2 (1994). De Revisor.

Letterkundig tijdschrift voor Nederland en Vlaanderen. Bokkengezang. 3 (1995). red. A. Mertens.
} 
Strauss' 'intellectuele rechts-radicalisme" en de golf van aanslagen op asielzoekerscentra en synagogen waardoor Duitsland kort na de eenwording wordt opgeschrikt, verwoordt hij de teneur van vele commentaren. ${ }^{15}$ De dag dat dit essay verscheen, moet men op de kalender met een rood kruis markeren, meent SPD-ideoloog Peter Glotz: "Vrienden, het wordt menens!" ${ }^{16}$ En Glotz' collega van de CDU, de partij-ideoloog en parlementariër Friedbert Pflüger, ziet zelfs Duitsland 'op drift' raken. ${ }^{17} \mathrm{Al}$ snel gaat het in de Bocksgesang-Debatte echter niet langer om Strauss, maar om dit soort reacties. "Vanwaar deze woede?," vraagt Antje Vollmer van de Grünen. ${ }^{18}$ In de Frankfurter Allgemeine ontstaat een spin-off van het oorspronkelijke debat met de titel What's right, what's left? ${ }^{19}$ Inzet van dit vervolgdebat, dat door andere bladen wordt overgenomen, is de vraag of het binnen de nieuwe werkelijkheid die na 1989 is ontstaan, nog wel zin heeft te spreken over links en rechts. En zo ja, staat links dan niet tegenwoordig voor behoudend en rechts voor progressief? Waarin onderscheidt links zich van rechts? En rechts van rechtsextremisme? Moet binnen onze Verlichte democratieën niet ruimte zijn voor het soort op Conservatief Revolutionaire leest geschoeide antiVerlichtingsdenken, zoals dat door Strauss wordt uitgedragen?

Habermas wist het begin jaren '80 nog zeker: Der Geist steht links. De lijn SchellingNietzsche-Jünger was zozeer met de nazi-barbarij verstrengeld geraakt, dat in het postnazistische Duitsland een 'authentiek conservatisme' niet langer tot de mogelijkheden behoorde. In plaats daarvan diende het Duitse geestesleven in het teken te staan van de Aufarbeitung van de 'Verlichtingstraditie van Lessing tot Marx ${ }^{20}{ }^{20}$ Inmiddels begint met de opening van de archieven in het voormalige Oostblok echter gestaag duidelijk te worden, welke barbarij óók in naam van deze andere denktraditie is bedreven. En wanneer zelfs iemand als Botho Strauss te kennen geeft Jünger te verkiezen bóven Adorno - wordt het dan niet hoog tijd ook op dit zo heikele punt eens grondig $u m$ zu denken? Per slot van rekening was Strauss niet zonder reden de cultfiguur van tenminste twee generaties Westduitse academici. ${ }^{21}$ Zijn jarenlange reputatie als de filosoof onder de poëten van ' 68 had hij mede te danken aan de subtiele wijze waarop hij zich in vroegere werken als Paare, Passanten (1981) rekenschap gaf van schuld en verantwoordelijkheid.

Uiteindelijk ziet ook Bubis zich genoodzaakt zijn kritiek te nuanceren door een onderscheid te maken tussen drie typen neo-conservatieven: "intellectuele brandstichters" als de politici Franz Schönhuber en Gerhard Frey; "intellectuele wegbereiders" als de historici Ernst Nolte en Rainer Zitelmann, of de redacteuren van Nieuw Rechtse bladen als Criticón en Junge Freiheit; "intellectuele spijtoptanten" als Strauss of Hans Magnus Enzensberger, die zich afzetten tegen de hegemonie van ' $68 .^{22}$ Het is een verfijning, waarin de meeste

\footnotetext{
15 'Die gewaltige Schuld'. in: Der Spiegel. 16 (1994). pp. 168-170.

${ }^{16}$ Glotz, P., Freunde, es wird ernst! in: Wochenpost. (25-02-1993).

${ }^{17}$ Pflüger, F., Deutschland driftet. Die Konservative Revolution entdeckt ihre Kinder. Düsseldorf, Wien, New

York, Moskau, 1994. pp. 12, 35ff, 45ff.

${ }^{18}$ Vollmer, A., Woher kommt diese Wut? in: Der Spiegel. 46 (1993). pp. 254-258.

${ }^{19}$ Voor het What's right, what's left?-debat, zie: Goossens, a.w., passim. Seitz, N., Die 'What's right?'-Debatte. Das zaghafte Herantasten an eine zivile Rechte. in: Aus Politik und Zeitgeschichte. Beilage zur Wochenzeitung Das Parlament. 10 (1995). pp. 23-27. Heilbrunn, J., Germany's New Right. in: Foreign Affairs. (november/december 1996). pp. 80-98. Alsmede de themanummers: Die neue Gesellschaft/ Frankfurter Hefte. Neue konservative Intelligenz. 9 (1994). Zeitschrift für Literatur, Wissenschaft und Linguistik. Eine Zeitschrift der Unversität Gesamthochschule Siegen. Die politische 'Rechte'. Literatur, Theater, Film. 24 (1994).

${ }^{20}$ Habermas, J., Kleine Politische Schriften (I-IV). Frankfurt am Main, 1981. pp. 386, 412. Zie eveneens: de paragrafen $4.1,6.4,7.7$.

${ }^{21}$ Zoals Strauss wordt getypeerd in: Radisch, I., Der alte Mann. in: Die Zeit. 33 (12-08-1994): "Er [Strauss, G.G.] war der Philosoph der alten Bundesrepublik, ihr schlechtes Gewissen, (...) der Lebensmrodelle beschrieben hat, die für viele galten."

${ }_{22}$ 'Die gewaltige Schuld'; a.w., p. 170.
} 
deelnemers aan het debat zich kunnen vinden. Maar de affaire krijgt nog een verrassend staartje met Strauss" toestemming voor een herdruk van de integrale versie van zijn Bocksgesang-essay als inleiding van een bundel, waarin de door Bubis aangebrachte scheidslijnen op zijn zachtst gezegd nogal diffuus zijn: Die selbstbewusste Nation (1994), een initiatief van een groep jonge, ultra-conservatieve publicisten rond 'intellectuele wegbereider' Zitelmann. ${ }^{23}$ Dat de mentaliteitsomslag in de periode volgend op de Wende van 1989-1990 in deze kringen met instemming wordt begroet, behoeft amper betoog. Gedurende de gehele jaren ' 90 worden vanuit de politieke underground van Oud en Nieuw Rechts acties ondernomen, die tot doel hebben het 'ware' conservatieve denken ter rechterzijde van de CDU/CSU opnieuw salonfähig te maken. Ze reiken van spraakmakende petities als Berliner Appell-Gegen den Wiederkehr des Sozialismus (september 1993) ${ }^{24}$ en 8. Mai 1945 - Gegen das Vergessen (april 1995) ${ }^{25}$ tot het liber amiconum Magie der Heiterkeit. Ernst Jünger zum Hundertsten (1995), waarin Nieuw Rechtse activisten als Criticón-redacteur Karlheinz Weißmann zijn samengebracht met gerenommeerde intellectuelen als Strauss, Peter Sloterdijk, Rüdiger Safranski en Heiner Müller (indertijd de intendant van het Brecht-theater in Oost-Berlijn) om de jarige Woudloper lof toe te zwaaien: "De epoche van de Duitse Nachkriegsliteratur zal pas voorbij zijn, wanneer algemeen erkend wordt, dat ze veertig jaar lang in de schaduw stond van Jüngers werk" (Strauss) ${ }^{26}$

Ook Die selbstbewusste Nation maakt deel uit van deze campagne. Reeds bij het verschijnen van de ingekorte versie van Anschwellender Bocksgesang in Der Spiegel heeft spiritus rector Armin Mohler hoogstpersoonlijk de schrijver in het rechtse kamp verwelkomd - als de tot dusver "meest spectaculaire overloper," die "in de hem eigen taal de aflossing van het verstarde links-liberalisme eist en das Lebensrecht einer deutschen Rechte verdedigt". ${ }^{27}$ $\mathrm{Nu}$ mag een keur aan scribenten, met het Bokkengezang van Strauss als een soort uithangbord, zijn licht laten schijnen over de vraag wat in het nieuwe Duitsland de bijdrage zou kunnen zijn van het Conservatief Revolutionaire gedachtegoed aan de kunsten, de politiek, de geschiedschrijving, de filosofie, de rechtsgeleerdheid, de theologie, de pedagogiek enzovoort. De bundel bevat bijdragen van zo uiteenlopende auteurs als Zitelmann, Nolte, Weißmann en Roland Bubik van Junge Freiheit; de filosofen Safranski en Gerd Bergfleth; de invloedrijke kunstcriticus van de Frankfurter Allgemeine Eduard Beaucamp; de voormalige Grünen-parlementariër Alfred Mechtersheimer, een prominent vredesactivist; Willi Brandts weduwe Brigitte Seebacher en de voormalige pornoproducent Klaus Rainer Röhl, de weduwnaar van RAF-kopstuk Ulrike Meinhof; de protestantse theoloog Uwe Wolf, de joodse, in Tel Aviv geboren historicus Michael Wolffsohn, de jurist Rudolf Wassermann en, last but not least, de filmmaker Hans Jürgen Syberberg, die dan al geruime tijd in deze underground asiel heeft gevonden. ${ }^{28}$

In de ogen van sommigen, die hem gedurende eerdere fasen van de BocksgesangDebatte nog in bescherming namen, heeft Strauss door zijn naam te verbinden aan dit pamflet een grens overschreden. In de hortus conclusus van de eigen werkkamer langs de door Ernst Jünger gebaande wegen filosoferen over de mogelijkheid van een Wederkeer van de Goden

\footnotetext{
${ }^{23}$ Doerry, M., 'Lehrmeister des Hasses. ' Botho Strauss als Wortführer eines 'konservativen Manifests'. in: Der Spiegel. 42 (1994). pp. 239-242.

${ }^{24}$ Zie: Ross, W., Die selbstbewusste Nation. in: Die politische Meinung. Monatschrift zu Fragen der Zeit. (december 1994). pp. 34-36.

${ }^{25}$ 8. Mai 1945 - Gegen das Vergessen. in: Frankfurter Allgemeine Zeitung. (07-04-1995). p. 3.

${ }^{26}$ Strauss, B., Refrain einer tieferen Aufklärung. in: Magie der Heiterkeit. Ernst Jünger zum Hundertsten. Hrsg. H. Schwilk, G. Figal. Stuttgart, 1995. pp. 323-324.

${ }^{27}$ Citaat ontleend aan: Pflüger, a.w., p. 43.

${ }^{28}$ Die selbstbewusste Nation. 'Anschwellender Bocksgesang' und weitere Beiträge zu einer deutschen Debatte. Hrsg. H. Schwilk, U. Schacht. Frankfurt am Main, Berlin, 1994.
} 
en de louterende werking van een Catastrofe, zou nog tot daar aan toe zijn. Maar met deze herdruk als inleiding van een bundel die overduidelijk een Nieuw Rechtse signatuur draagt, zou zijn unpolitische Betrachtung het karakter hebben gekregen van een gevaarlijk partijpolitiek manifest. Zelf lijkt Strauss zich echter van geen kwaad bewust. Op het indringende verzoek van de redactie van Theater Heute, het toonaangevende blad waaraan hij ooit als criticus verbonden was, om zich publiekelijk van het 'bruine pact' te distantiëren, reageert hij in een eind oktober 1994 geschreven brief als volgt:

"U zult misschien gedurende de laatste jaren aan mijn boeken en opstellen hebben gemerkt, dat datgene, wat men reactionair denken noemt, voor mij vruchtbaar was (...). Wellicht wordt het ingegeven door de vreugde van het ontdekken, of door een wat al te ijverige inhaalbehoefte als gevolg van hardnekkige taboes. Wellicht houdt het ook domweg verband met een bepaalde biografische fase, die men vroeger volwassenheid noemde, maar tegenwoordig helaas dient te worden verloochend. Ik maak er aanspraak op de ontwikkeling van een vrij mens te mogen doormaken en wanneer dit ertoe leidt, dat ik me in rechts vaarwater begeef, dan maak ik er aanspraak op dat ook rechts intellectueel recht wordt gedaan en niet slechts wordt gedoogd, zoals voorheen met een welhaast ijzeren wetmatigheid alles wat links was. (...) In een politieke of politiek-strategische zin is mijn totale werk volstrekt onbruikbaar; 'wat ontbreekt is het positieve, daarover zijn de Evangelische Culturkring en alle volksvertegenwoordigers het al sinds jaar en dag roerend met elkaar eens. Rest het verwijt, dat ik met mijn reactionaire opstel veel geesten uit hun schuilplaats heb gelokt, die nu een onheilspellende factie gaan vormen. De motieven voor de verontwaardiging van de 'fatsoenlijke' mensen zijn hier niet geheel zuiver. Er bestaat in Duitsland inmiddels een nieuwe rechts intelligentsia, maar zij mag niet bestaan en dit des te minder omdat zij voortdurend de vergissingen en verwoestingen van links bij naam noemt, wat voorheen niemand deed. (...) Alle passages, die $u$ ons [de auteurs van Die selbstbewusste Nation, G.G.] ten laste legt, zou men ons met dezelfde gebaren, dezelfde afkeer, in 1965 of 1976 precies zo ten laste hebben gelegd. Maar na alles wat gebeurd is? We zijn geen statische, links-liberale samenleving. Velerlei revisies zullen op het terrein van de literatuur nog noodzakelijk zijn en ongetwijfeld plaats vinden (al is het uit geestelijke nieuwsgierigheid). ${ }^{* 29}$

Reden voor de redactie van Theater Heute om in het december-1994-nummer betroffen afscheid te nemen "van een mens, met wie velen, die probeerden te ervaren, wat leven, literatuur en theater in de Bondsrepubliek sinds 1970 was, vol nieuwsgierigheid, vol sympathie zijn opgetrokken". ${ }^{30}$ Maar de tijd dat dit soort gebaren nog op brede instemming konden rekenen, is voorgoed voorbij. Zoals in het daarop volgende nummer nog eens wordt onderstreept door een stroom ingezonden brieven, waarin "afscheid" wordt genomen van een "ooit gewaardeerd blad", dat zichzelf met zijn "pretotalitaire praktijken", "aan lager wal geraakt links mainstream-gebabbel" en "hysterische Betroffenheit" voorgoed buitenspel zou hebben geplaatst: "Omdat Botho Strauss zich vrijheden permitteert, waarin de Frankfurter Schule niet heeft voorzien, wilt $\mathrm{u}$ hem voortaan in de ban doen? - Das ist ja ein Ding!"31

\footnotetext{
${ }^{29}$ Strauss, B., Wille, F., Bekenntnisse eines Unpolitischen? Ein Briefwechsel mit Botho Strauss. in: Theater Heute. 12 (1994) pp. 1-4.

${ }^{30}$ Becker, P., von, Abschied von Botho Strauss... in: Theater Heute. a.w., pp. 4-5.

${ }^{31}$ Leser schreiben. in: Theater Heute. 1 (1995). pp. 61-63.
} 
Er zullen nog vele reprises volgen, waarvan de controverses Walser-Bubis en SloterdijkHabermas de grootste bekendheid genieten. ${ }^{32}$ Maar voor elk van deze disputen geldt, wat Frits Boterman opmerkt over de Bocksgesang-Debatte: ze hebben sterk het karakter van een "afrekening" met de Betroffenheitskultur en het links-utopische, 'kritische bewustzijn' van het establishment ten tijde van de oude Bondsrepubliek. ${ }^{33}$ Of, zoals de Nederlandse historici Patrick Dassen en Ton Nijhuis het formuleren in de bundel Gegijzeld door het verleden. Controverses in Duitsland van de Historikerstreit tot het Sloterdijk-debat. (2001): wat in dit rumoer van de jaren '90 zichtbaar wordt is "het verdwijnen van de dominantie van het sociaal-kritische paradigma". ${ }^{34} \mathrm{Al}$ is daarvan bij het verschijnen van Vom Unglück und Glück der Kunst in Deutschland nach dem letzten Kriege in het Wende-jaar 1990 nog weinig te merken. Alle links-liberale periodieken, die er in de Bondsrepubliek toe doen, wijden een of meerdere beschouwingen aan Syberbergs pamflet. En ze zijn unaniem in hun oordeel: deze filmer/pamflettist is een gevaarlijke Ewiggestriger, die met zijn als neo-conservatieve cultuurfilosofie vermomde pennenvrucht een schotschrift van Mein Kampf-achtige dimensies heeft geschreven En toch: de schijn bedriegt. "De eendrachtige, antinazistische waakzaamheid, zoals die zich in het geval van Syberberg manifesteert, is geen goed teken: ze getuigt niet van de vitaliteit, maar van de vermoeidheidsverschijnselen van de in de Bondsrepubliek dikwijls bezworen liberale consensus," concludeert de publicist Lothar Baier (1991) al een jaar later in een terugblik. ${ }^{35}$

Baier behoort niet tot Syberbergs bewonderaars. Hij is van mening, dat de filmer reeds in het Hitler-postscriptum Die freudlose Gesellschaft (1981) blijk heeft gegeven van ranzig antisemitisme. En dat dit soort neigingen dienen te worden benoemd en met kracht tegengesproken, behoeft ook wat hem betreft geen betoog. ${ }^{36}$ Maar wat hier gebeurde, was zijns inziens buiten alle proportie: een gefrustreerde filmmaker, die in eigen land al sinds jaar en dag amper respons heeft gevonden, werd met vereende krachten opgeblazen tot een heuse 'totalitaire bedreiging' voor de postnazistische Republiek. De felheid en, bovenal, eenstemmigheid van de reacties, die Syberbergs pamflet in de links-liberale media heeft opgeroepen, kunnen niet los worden gezien van het moment van publicatie, betoogt Baier. Met de implosie van de DDR is ook een stuk Bondsrepubliek voorgoed afgeschaft. Utopieën, marxisme, kritische theorie, dromen over alternatieven, het links/rechts-onderscheid - kortom al datgene wat decennialang een stempel heeft gedrukt op het wereldbeeld van het establishment in het Westen is samen met het 'reëel bestaande socialisme' in het Oosten op

\footnotetext{
${ }^{32}$ Zie bijvoorbeeld de essays Geweten en vergeten. Het Walser-Bubis-debat en Het hoeden van de moraal van de Bondsepubliek. Het Sloterdijk-debat van de hand van respectievelijk Paul Scheffer en Patrick Dassen in de bundel Gegijzeld door het verleden, a.w., pp. 179-198, 221-242: "Het Sloterdijk-debat staat niet op zichzelf. Wat erin tot uitdrukking komt is de manier waarop in het nieuwe, verenigde Duitsland langzaam afscheid genomen wordt van vaste oriëntatiepunten, maar ook van taboes van de oude Bondsrepubliek - en dat dat met veel pijn en moeite gepaard gaat. Wat dat betreft is ook de ontwikkeling van Sloterdijk zelf interessant. Op 10 december 1989, dus precies een maand na de val van de Muur, (...) sprak hij nog in positieve termen over Duitslands 'edele vijandschap ten opzichte van zichzelf (...). In later werk is deze opvatting verdwenen. Zoals hij bijvoorbeeld in een brief aan Habermas schreef, is hij nu van mening dat Duitsland het stadium van een "níet normale democratie' voorbij is en niet meer door fascistenjagers bewaakt hoeft te worden." (Dassen, a.w., p. 239.)

${ }^{33}$ Boterman, a.w, pp. $223 \mathrm{ff}$.

${ }^{34}$ Dassen, Nijhuis, a.w., pp. 14ff.

${ }^{35}$ Baier, L., Eine ungeheuerliche Netiigkeit? Nachfragen zur Debatte um den Pamphlettisten Syberberg. in: Neue Rundschau. 1 (1990) pp. 117-130, zie: 127.

${ }^{36}$ idem, pp. 118 ff, 130 .
} 
de vuilstortplaats van de geschiedenis beland. "In deze situatie kwam Syberbergs provocatie als geroepen," aldus Baier. "De antinazistische consensus heeft zich (...) nog eenmaal willen tonen en daarvoor een geëigende aanleiding gezocht. (..) Om zichzelf te bewijzen dat hij nog bestond, moest iets buiten het zelf worden gevonden waaraan de sterkte van zijn cohesie kon worden getest. (...) Al veel langer ontmaskerd als niet zuiver op de graat, was hij [Syberberg, G.G.] een dankbaar object (...). Wanneer Hellmuth Karasek in de Spiegel Syberberg beheerst het predikaat 'nazi' in het gezicht slingert, herstelt hij tevens een stuk continuitteit met de epoche waarin hijzelf (...) zijn loyaliteit aan de "marxistische principes" betuigde." 38

Een sterk argument voor de juistheid van Baiers observatie vormt de opmerkelijke wending, die de dan al ruim twee decennia voortslepende 'affaire Syberberg' in de daarop volgende jaren zal nemen. Hoe lang is het nog maar geleden, dat deze filmer geen stap kon zetten zonder te worden begeleid door een echo van alarmerend geroezemoes in de media? Een nieuw werk, het zoveelste pamflet, een redevoering, een necrologie - elke troepenbeweging van L'Etat Syberberg (de Franse filmcriticus Serge Daney) ${ }^{39}$ werd nauwlettend in kaart gebracht. $\mathrm{Nu}$, in de jaren ' 90 , gaat het rumoer uit als een nachtkaars. Dezelfde links-liberale periodieken, die bij het verschijnen van Vom Unglück und Glück der Kunst in Deutschland nach dem letzten Kriege nog de Republiek in gevaar zien, zullen nadien met geen woord meer over de auteur reppen. Sterker: de gehele binnen- en buitenlandse Syberberg-receptie na het uitwoeden van deze controverse, valt op één, hooguit twee handen te tellen. Voor dit, vrijwel totale verstommen van het "secundaire vertoog" kunnen meerdere verklaringen worden bedacht, die elkaar niet hoeven uit te sluiten. Zelf ziet Syberberg zich als het slachtoffer van een antifascistisch cordon sanitaire. ${ }^{40}$ Maar meer plausibel lijkt me te zijn, dat met het eroderen van het sociaal-kritische paradigma het werk. van Syberberg langzaam maar zeker zijn aanstootgevende karakter verliest. In een tijd waarin zelfs Günther Grass manmoedig de 'linkse taboeisering' van het leed van de Heimatvertriebenen aan de kaak stelt, ${ }^{41}$ weet het enfant terrible van de oude Bondsrepubliek nauwelijks nog pennen in beweging te brengen en maken zowel idolate bewondering, als irritatie, woede, of zelfs angst geleidelijk aan plaats voor desinteresse.

We zouden dit ook anders kunnen formuleren. Kennelijk lukt het Syberberg in dit nieuwe Duitsland van na de Wende 1989-1990 niet langer de publieke aandacht op zich te vestigen. Terwijl hierin toch, wat men ook over hem moge denken, onmiskenbaar één van zijn grootste kwaliteiten school: feilloos wist hij bij de links-liberale intelligentsia in én buiten de Bondsrepubliek steeds weer een gevoelige snaar te raken. $\mathrm{Nu}$, in de jaren ' 90 , zijn vrijwel alle taboes, die hij heeft proberen te slechten, op zijn minst bespreekbaar geworden van de re-education ${ }^{42}$ en de Betroffenheitskult van ' 68 tot het Duitse 'irrationalisme', het

\footnotetext{
${ }^{37}$ idem, p. 128: "Utopien, Marxismus, kritische Theorie, Träume von Alternativen, Unterscheidung zwischen links und rechts, das alles wurde unter Hinweis auf den Scherbenhaufen im Osten hinaus- und gleich mit dazugekehrt. Die Liquidation [van Syberberg, G.G.] wäre jedoch in Selbstliquidation übergegangen, wenn sie mit allem Schluß gemacht hätte, was die eigene 'Veltwahrnehmung für Jahrzehnte mitgeprägt hat, deshalb wurde der Antifaschismus gerettet und auf Hochglanz poliert."

${ }^{38}$ idem, pp. $127 \mathrm{ff}$.

${ }^{39}$ Daney, S., L'État Syberberg. in: La Rampe. Paris, 1983. pp. 107-113.

${ }^{40}$ Bijvoorbeeld: Syberberg, H.J., Wie man neuen Haß züchtet. in: Frankfurter Allgemeine Zeitung. 06-09-1990.

${ }^{41}$ Zie: hoofdstuk 7, paragraaf 7.

${ }^{42}$ Spoor, A.S., Nieuw Duits rechts als conservatief eerherstel. Bekering Botho Strauss staat niet op zich. in: NRC Handelsblad. 26-01-1995. p. 8: "Met hun heropvoedingspolitiek voor het Duitse volk hadden de geallieerden dan ook niet de ambitie aan te sluiten bij wat wel 'het andere Duitsland" heette, maar dat door Thomas Mann in zijn rede 'Deutschland und die Deutschen' veel beter is omschreven als 'das fehlgegangene gute Deutschland'. Zij stulpten eerder (...) hun eigen politieke denkbeelden over het Duitse puin en maakten korte metten met al te Duitse geluiden uit welke hoek dan ook. (...) Het hele Duitse volk moest worden
} 
Duitse Nationalgefühl of het Duitse slachtofferschap waarvoor geen aandacht mocht worden gevraagd "omdat het meteen opgevat zou kunnen worden als een poging tot relativering van de holocaust" (Dassen en Nijhuis). ${ }^{43}$ En het kost Syberberg overduidelijk moeite in deze nieuwe fase van de oude "nieuwe onoverzichtelijkheid" (Habermas) ${ }^{44}$ zijn weg te vinden. "Der Zeitgeist weht wieder Rechts (...)," waarschuwt de hierboven reeds aangehaalde CDUideoloog Friedbert Pflüger in 1994..$^{45}$ Maar eigenaardig genoeg heeft deze Alt-Konservativer, zoals hij nu doorgaans wordt getypeerd, ${ }^{46}$ met de geest van de jaren ' 90 amper voeling. Dat Vom Unglück und Glück der Kunst in Deutschland nach dem letzten Kriege "een sleuteltekst in een nieuwe post-1989 Conservatieve Revolutie" zou zijn, zoals de Amerikaanse literatuurwetenschapper Stephen Brockmann (1996) heeft geopperd, ${ }^{47}$ is schromelijk overdreven. Het boek mag dan in de rechts-extremistische underground in rap tempo een cultstatus hebben verworven, vergelijkbaar met Strauss' Bocksgesang; ook in deze underground beweegt Syberberg zich in de marge. Het zijn anderen, bijvoorbeeld de denktanks rond Zitelmann en Mohler, of de zichzelf als de nieuwe protestgeneratie van ' 89 manifesterende publicisten van de Junge Freiheit, die in de jaren ' 90 de rechtse agenda bepalen. In de What's right, what's left-Debatte?, die toch een kolfje naar zijn hand zou moeten zijn, is Syberberg hooguit trendvolger. Pas in 1995, dat wil zeggen twee jaar ná Strauss, zal hij het predikaat rechts als een geuzennaam omarmen, waarbij hij inhoudelijk niet veel verder komt dan nog eens te herhalen wat we in Anschwellender Bocksgesang reeds konden lezen: namelijk dat links, etymologisch gezien, staat voor het 'verkeerde' en rechts voor het 'juiste' - Do the right thing. ${ }^{48}$ En weliswaar is hij één van de auteurs van Die selbstbewusste Nation; de publiciteit rond dit pamflet gaat niet uit naar Syberberg, maar naar meer 'spectaculaire overlopers' als Strauss en Brigitte Seebacher-Brandt, of figuren als Zitelmann, Nolte en Weissmann waarvan terecht wordt aangenomen dat ze een oneindig prominentere rol in de beweging van Nieuw Rechts vervullen dan deze idiosyncratische filmmaker.

Pijnlijker is, dat Syberberg ook artistiek sterk de indruk wekt te zijn vastgelopen. Goed, er zijn nog wel enkele intrigerende aanzetten. Gedurende de eerste helft van de jaren ' 90 houdt hij zich intensief bezig met Oskar Werner, hetgeen resulteert in de wonderschone installatie Cave of Memory (Documenta X, Hebbel Theater, 1997). "Een film over de moeite die het de mens kost kunst tot stand te brengen" - zo kenschetste Syberberg ooit het werk, waarmee hij in 1965 debuteerde: de documentaire Fünfter Akt, siebente Szene over Fritz Kortner, de grand old man van het expressionistische theater. ${ }^{49}$ Het had tevens het motto kunnen zijn van deze 'grot van de herinnering', waarmee hij na een afwezigheid van zes jaar zijn come-back heeft proberen te maken in een kunstwereld, die hem bij het verschijnen van

\footnotetext{
heropgevoed. Dat was na 1945 de geallieerde benadering, waardoor niet alleen de daders van de nazi-misdaden op een paar uitzonderingen na konden onderduiken in de massa en ongestraft konden blijven, maar waardoor ook de intellectuele discussie tussen Duitsers niet op gang $\mathrm{kwam}$ (...) Buiten de consensus vallende opvattingen werden óf onmiddellijk als neo-bruin afgedaan óf als ultralinks en, na het uitbreken van de Koude oorlog, als staatsgevaarlijk aan de kaak gesteld. Het verbaast niet dat zich nu - vijftig jaar na het einde van de Tweede Wereldoorlog en rond vijf jaar na het einde van de Koude Oorlog en de Duitse deling - in Duitsland een intellectuele vleugell aandient die zich rechts will noemen en wil aanknopen bij een denktraditie die vaak al te makkelijk met de racistische totalitaire nazi-ideologie op de rommelhoop der geschiedenis is geworpen."

${ }^{43}$ Dassen, Nijhuis, a.w., p. 14.

${ }^{44}$ Habermas, J., De nieuwe onoverzichtelijkheid en andere opstellen. Vert. J. Boom e.a.. Amsterdam, 1989.

${ }^{45}$ Pflüger, a.w., p. 12.

${ }^{46}$ Bijvoorbeeld: Spoor, a.w., p. 8. Ross, a.w., p. 34.

${ }^{47}$ Brockmann, S., Syberberg's Germany. in: The German Quarterly. 69.1 (winter 1996). pp. 48-62, zie: 54.

${ }^{48}$ Strauss, B., Anschwellender Bocksgesang. in: Die selbstbewusste Nation, a.w., pp. 24f. Syberberg, H.J., Das Rechte - tun. München, 1995. p. 4.

${ }^{49}$ Syberberg, H.J., Syberbergs Filmbuch. München, 1976. p. 71. Zie eveneens: paragraaf 2.9.
} 
Vom Unglück und Glück der Kunst in Deutschland nach dem letzten Kriege als nonkunstenaar de deur wees. ${ }^{50}$ Cave of Memory - de titel verwijst uiteraard naar de grotmetafoor in de Politeia - bestaat uit een lange, donkere zaal, waarin links en rechts langs de wanden 10 videoschermen en 21 videomonitoren staan opgesteld. Het vertoonde beeldmateriaal, bij elkaar goed voor 31 uur, biedt een eigenzinnige bloemlezing van de Duits-Europese kunstgeschiedenis van Bach tot Beckett. Foto's van schilderijen, beeldhouwwerken en in de oorlog zoek geraakte kunstschatten, filosofische teksten, krantenartikelen, concertopnamen, registraties van theatervoorstellingen, fragmenten uit speelfilms, door de regisseur zelf gemaakte videobeelden van het Pommerse platteland en de verwoeste Berlijnse Wilhelmstrasse enzovoort, zijn associatief verweven tot een kakofonie van tekst, beeld en geluid. Het centrum of, zo men wil, die Mitte, wordt gevormd door een enscenering van Prinz Friedrich von Homburg - hetzelfde stuk, dat ook al centraal stond in zijn vorige werk: Ein Traum, was sonst?, de finale van de vierdelige Kleist-cyclus Requiem voor het einde van Pruisen (1984-91). ${ }^{51}$ Op twee schermen en acht monitoren kunnen we de verrichtingen gade slaan van een oude, verlopen acteur, die wanhopig probeert gestalte te geven aan de rol van de prins. Het kostuum, waarin hij gekleed gaat, is veel te nauw voor zijn vadsige lijf. Zijn haren plakken verwilderd op het bezwete gezicht, dat een pijnlijke grimas vertoont. De handen trillen. Zelfs lopen kost hem zichtbaar moeite. De bodem wankelt onder zijn voeten. Pas na geruime tijd de beelden te hebben bekeken begint het langzaam te dagen wie we hier voor ons hebben: Oskar Werner, in lang vervlogen dagen de met afstand grootste Shakespeare-vertolker van het Europese continent.

Het is typisch zo'n acteur, waarvan iedereen het gezicht kent, maar de bijbehorende naam allang is vergeten. Werner was de melancholieke, voortdurend op de rand van de hysterie balancerende blonde halfgod met de engelachtige gelaatstrekken in Truffauts Jules et Jim (1961) en Fahrenheit 541 (1966). Voor zijn rol als scheepsarts in Stanley Kramers Ship of Fools (1964) kreeg hij ooit een Oscar. Zijn Hamlet van 1953 geldt tot op de dag van vandaag als een mijlpaal. En zijn sterfscène aan het slot van Pabst' Der letzte Akt (1955), eveneens te zien in deze installatie, behoorde naar verluidt tot de grote cinemaervaringen van Orson Welles. Niemand kon zo mooi sterven als Oskar Werner! Maar in 1970, op het toppunt van zijn roem, hield de 'Europese Laurence Olivier', zoals zijn bijnaam luidde, het plotseling voor gezien en trok hij zich als een soort kluizenaar terug op een berg in Lichtenstein. Boze tongen beweren, dat een alcoholverslaving hem het spelen onmogelijk maakte. Ja, hij zou zelfs ten prooi zijn gevallen aan waanzin. ${ }^{52}$. Zelf zag Werner het echter volstrekt anders. "Sinds Camus kan men alleen nog maar revolteren of resigneren," meende hij in één van de schaarse interviews, die hij gedurende deze periode nog gaf.

"Ik kies voor de revolte, kom in opstand. Ja, ik ben ouderwets... een man met een oude ziel. Ooit ging ik naar het theater om de grote meesterwerken te spelen. Hamlet, Torquato Tasso, Don Carlos, of Kabale und Liebe, wanneer u dat nog iets zegt. Ik ben geboren in dezelfde maand als Luther en een echte protestant. Ik protesteer tegen de tegenwoordige tijdgeest. (...) Wie, zoals ik, zijn leven lang is opgekomen voor de adel van de geest en de kwaliteit van het gevoel, kan deze tegenwoordige ontheiliging van de grote meesterwerken domweg niet meemaken. Dat zou de meest goedkope vorm

\footnotetext{
${ }^{50}$ Zie: paragraaf 1.1

${ }^{51}$ Zie: paragraaf 7.4 .

${ }^{52}$ Dachs, R., Oskar Werner. Ein Nachklang. Wien, 1988. passim. Mazura, M., Oskar Werner. Maske, Mythos, Mensch. Biographie. Wien, 1986. passim. Petley, J., Oskar Werner. in: International Dictionary of Film and Filmmakers - 3 Actors and Actresses. ed. N. Thomas. London, 1992. pp. $1031 \mathrm{f}$. Oskar Werner.

Österreichischer Schauspieler und Regisseur. in: Munziger-Archiv/Int.Biograph.Archiv.
} 
van collaboratie zijn. (...) Ik ben toch geen hoer. De mensen kunnen tegenwoordig niet meer met de taal omgaan. Daarom heb ik meer dan driehonderd aanbiedingen voor filmrollen afgezegd. (...) Fassbinder ervaar ik als een braakniddel. Dan schaam ik me, dat in mijn paspoort nog steeds het beroep acteur vermeld staat. (...) Zadek, dat is toch te onnozel voor woorden. En met Handke kan men me het huis uit jagen. Masturberende pubers interesseren me niet. (...) Ik heb mijn leven lang gezocht naar voorbeelden. En daaraan heb ik ook tegenwoordig behoefte. Maar ik vind ze louter nog in oude boeken.. of in mijn herinneringen." 53

Wat iedereen voor onmogelijk hield gebeurde begin jaren ' 80 : even plotseling als hij was verdwenen, keerde Werner kortstondig terug naar het theater, de grote passie van zijn leven. Nog eenmaal probeerde hij de wereld te tonen wat kunst vermag, als de prins van Homburg in een eigen enscenering waarvan in deze Cave of Memory de souvenirs liggen opgeslagen. Als een hommage aan een ooit als groots en meeslepend ervaren kunstenaarschap die, het zal niet verbazen, tegelijk een mystificatie van het eigen kunstenaarschap is: het is het alter ego van de late Syberberg, dat we in deze beelden in de gedaante van de in ongenade gevallen prins over het toneel zien strompelen, troost puttend uit zijn herinneringen. Want veel fiducie moet de filmer er niet meer in hebben gehad. Werners laatste optreden (hij overleed luttele maanden later op 62jarige leeftijd) is de annalen ingegaan als een jammerlijk fiasco. Nog voor de pauze verliet ruim de helft van het publiek onder luid boegeroep de zaal. En zij die achterbleven hielden vol gêne de adem in. "Wat zich ginds uitgeput op het toneel bewoog, was slechts zijn schaduw, zijn masker," memoreert een van zijn biografen (1986). ${ }^{54}$ Hetgeen de acteur er niet van weerhield de voorstelling tot het einde toe uit te spelen - met geheven hoofd, trouw aan zijn idealen. Zoveel moeite kost het de mens kunst tot stand te brengen...

"Die Verzweiflung weicht der Lächerlichkeit," aldus nog eenmaal Werners biograaf over dit optreden. ${ }^{55}$ En zo, vrees ik hieraan te moeten toevoegen, staat het ook met het luttele aantal werken dat Syberberg sinds Cave of Memory nog heeft gemaakt. Wat is pijnlijker dan te moeten toezien, hoe een als groots en meeslepend ervaren kunstenaarschap vervaagt tot een schaduw van wat het ooit was? Doorbraken, zoals de ontdekking van het theater van het absurdisme (begin jaren "60), Wagner en de late romantiek (begin jaren "70) of het Pruisen van Heinrich von Kleist (halverwege de jaren '80), die in het verleden telkens weer stof opleverden waar deze filmmagiër een decennium mee vooruit kon, vinden niet meer plaats. "Het is voor mij beslist geen thema voor het leven," bezweert hij in 1991 naar aanleiding van het Pruisen-Requiem. "Men heeft me dikwijls vereenzelvigd met Wagner, me afgeschilderd als een soort reïncarnatie. Volkomen ten onrechte. Wagner heb ik natuurlijk allang achter me gelaten. En zo kan ik ook dit weer achter me laten. Tot iets nieuws komen." uit zijn handen komt, is vooral veel van hetzelfde: klaagzangen op het verloren Pruisen. Met als voorlopig dieptepunt de internetsite Das Nossendorf-Projekt (2001-). ${ }^{57}$ Op papier lijkt het misschien nog wel aardig. Als een soort hereboer in cyberspace treedt de filmer in de voetsporen van zijn vader, de burgemeester van het Pommerse dorpje Nossendorf, dat virtueel wordt gereconstrueerd in de toestand waarin het zich omstreeks zijn geboortejaar 1935 moet hebben bevonden. Meet je het echter af aan de tegenwoordige stand van de internet- en installatiekunst, dan is het van een erbarmelijk dilettantisme. En ook als we zijn

\footnotetext{
${ }^{53}$ Citaat ontleend aan: Dachs, a.w., pp. 153, 185, 198, 202.

${ }_{54}^{54}$ Mazura, a.w., p. 26. Zie eveneens; Dachs, a.w., pp. $185 \mathrm{ff}$

55 Mazura, a.w., p. 26.

${ }^{56}$ Persconferentie Syberberg/Clever naar aanleiding van de Brusselse opvoering van Ein Traum, was sonst?, zomer 1990

${ }^{57}$ www.Syberberg.de
} 
eigen artistieke en intellectuele ontwikkeling als maatstaf nemen, kan een dergelijk werk bezwaarlijk vernieuwend worden genoemd. Op zijn laatst sinds Cave of Memory, maar wellicht al vroeger, lijkt Syberberg te zijn terechtgekomen in een vicieuze cirkel van oude motieven, waaruit hij zich niet langer op eigen kracht kan bevrijden. En het zou, naar ik meen, wat al te makkelijk zijn dit onvermogen louter toe schrijven aan zijn leeftijd. (In 1997, het jaar van Cave of Memory, is hij exact even oud als Werner in diens laatste rol).

Het heeft er meer van weg, dat het eroderen van het sociaal-kritische paradigma óók de kunstenaar Syberberg parten speelt. Ik zou in dit verband nog een stap verder willen gaan. De intellectuele én artistieke impasse, die hij sinds de Wende van 1989-1990 lijkt door te maken, bevestigt wat ik in de voorafgaande hoofdstukken heb proberen aan te tonen. Namelijk dat deze vermeende Alt-Konservativer dient te worden beschouwd als een geesteskind van het links-liberale vertoog, dat hij eind jaren ' 80 heeft verlaten om het van buiten te attaqueren. Zeker, net als Botho Strauss heeft ook hij de herfstweken van 1989 beleefd als een "bevrijdende Einschnitt". ${ }^{58}$ Het trotse en zelfverzekerde Wir sind das Volk, waarmee anonieme Duitsers in Leipzig of Dresden de machtige bonzen van het stalinisme op de knieën dwongen en een wereldrijk ten val brachten; het herstel van Duitsland als een soevereine natie met de historische Mitte Berlijn als hoofdstad; het zienderogen afbladderen van het morele en intellectuele gezag van de volkspedagogen in Oost en West - voor een patriot als Syberberg is het allemaal de verwezenlijking van een droom: Ein Traum, was sonst? Maar dit laat onverlet, dat hij zich decennialang binnen het linkse cultuurdebat heeft bewogen als de spreekwoordelijke vis in het water. Nu dit debat een zachte dood sterft, spartelt de vis op het droge en snakt hij naar adem.

\subsection{Een kunstenaarsloopbaan}

Het herlezen van de Minima Moralia van Adorno bezorgde hem naar eigen zeggen een gevoel van Heimat. ${ }^{59}$ En Das Prinzip Hoffnung van Bloch noemde hij ooit zijn bijbel. ${ }^{60}$ Wat, vraagt de literatuurwetenschapper en Nieuw-Rechts-vorser Richard Herzinger zich af in een in ' 96 verschenen essay over Botho Strauss, maakt zo iemand tot een conservatieve metafysicus die de 'stereoscopische blik' van Ernst Jünger imiteert? ${ }^{61}$ Dit was tevens de vraag, die het vertrekpunt vormde van deze detailstudie van een andere, maar beslist niet minder opmerkelijke kunstenaarsloopbaan. Goed, bij een oppervlakkige beschouwing lijken Strauss en Syberberg weinig meer met elkaar te delen dan een actrice - Edith Clever, het 'eenvrouwstheater' van het Pruisen-Requiem, stond in de jaren '70 samen met de schrijver onder contract bij de Berlijnse Schaubühne en geniet nog steeds grote faam als de Lotte uit Peter Steins legendarische enscenering van Gross und Klein (1978). ${ }^{62}$ Strauss zegt het niet

\footnotetext{
${ }^{58}$ Syberberg, H.J., Befreiender Einschnitt. in: Neues Deutschland. Innenansichten einer wiederverenigten Nation. Hrsg. J. Kogel, W. Schütte, H. Zimmermann. Frankfurt am Main, 1993. pp. 120-124. Zie eveneens: Syberberg, H.J., Vom Unglück und Glück der Kunst in Deutschland nach dem letzten Kriege. München, 1990. $135 \mathrm{ff}$. Strauss spreekt in dit verband over een "postive Erschütterung". Strauss, Wille, a.w, p. 4.

${ }^{59}$ Strauss, B., Paare, Passanten. München, Wien, 1981, 1984. p. 115.

${ }^{60}$ Hage, V., Schreiben ist eine Séance. Begegnungen mit Botho Strauss. in: Strauss lesen. Hrsg. M. Radix. München, Wien, 1987. pp. 188-216.

${ }^{61}$ Herzinger, R, Die Heimkehr der romantischen Moderne. Über 'Ithaka' und die kulturphilosophischen Transformationen von Botho Strauss. in: Theater Heute. 8 (1996). pp. 7-12, zie: 10.

${ }_{62}$ Persconferentie Syberberg/Clever naar aanleiding van de Brusselse opvoering van Ein Traum, was sonst? zomer 1990:

Syberberg: "Botho Strauss... Ik ken hem niet persoonlijk. Zij [Clever, G.G.] kent hem. Maar wanneer ik hem lees, heb ik wel sterk het gevoel dat hij uit dezelfde bron komt als ik. Ook al komt hij tot volstrekt andere
} 
met zoveel woorden. Maar als hij het in Paare, Passanten (1981) laatdunkend heeft over "expressionistische bombast" en "een obscene revue van emblemen", denkt hij zonder twijfel óók aan Syberbergs Hitler ${ }^{63}$ En toch hebben deze tegenwoordige Rechtsintellektuellen, alle evidente verschillen tussen hun vroegere werk ten spijt, tenminste een ding met elkaar gemeenschappelijk: beiden zijn géén Alt-Konservativen. Al is het natuurlijk wel zo, dat zowel Strauss als Syberberg al vroeg thema's hebben aangesneden, die indertijd door een dominante stroming binnen het linkse cultuurdebat als conservatief of rechts werden geduid en achteraf gezien inderdaad een overstap naar het vertoog van de Conservatieve Revolutie op zijn minst vergemakkelijkten.

Laat ik daarvan een voorbeeld geven. In Anschwellender Bocksgesang (1993) typeert Strauss 'der Rechte' als iemand die binnen onze aufgeklärte mediacratie, "das Regime der telekratischen Öffentlichtkeit", het bestaan leidt van een outsider. Gelijk Oskar Werner over zichzelf opmerkt in het hierboven aangehaalde citaat, is ook deze rechtse outsider een 'echte protestant'. Hij levert verzet tegen 'de totaalheerschappij van de tegenwoordige tijd, die elk individueel besef van een niet-gerationaliseerd verleden, van een historisch geworden zijn, van een mythische tijd van ons wil roven en vernietigen" ${ }^{64}$ Maar "de reactionair", kunnen we reeds lezen in Strauss' essay uit 1990, waarmee ik dit hoofdstuk begon, is "niet de grote tegenhouder of onverbeterlijke achteruitgangsprofeet, die de politieke verraders van hem hebben gemaakt - hij loopt daarentegen voorop, wanneer het erom gaat iets dat vergeten is opnieuw in herinnering te roepen". ${ }^{5}$ Zijn vorm van verzet, aldus Strauss in een drie jaar eerder verschenen essay (1987), waarin hij de dichter Rudolf Borchardt naar voren schuift als het prototype van de reactionaire kunstenaar, is de "scheppende restauratie". Door "de grote literatuurtradities van het Avondland, die werden miskend of vervalst", te "herontdekken en scheppend verder te voeren," verzet de reactionaire kunstenaar zich tegen de "mythe van de Jetztlebigkeit". ${ }^{66}$ We zijn er, verduidelijkt Strauss in dit essay, allen van overtuigd geraakt, dat rationalisme goed voor ons zou zijn; verkiezen unaniem het eigen welbevinden, de aanpassing aan de tegenwoordige tijd, boven de schone leer van de herinnering en hebben de ideologiekritiek tot onze manier van strijden gemaakt. Hetgeen in onze omgang met kunst tot uiting komt in een volstrekt onvermogen "distantie te verdragen": het oude wordt modern

\footnotetext{
resultaten. Hij wordt verguisd, zeer sterk verguisd, door exact dezelfde mensen die ook mij verguizen. En wel precies om deze bronnen."

Clever: "Er zijn zeker raakvlakken. Ook hij betreurt dat men in onze tijd bepaalde díngen domweg niet meer kan doen. Dat men bijvoorbeeld niet meer kan schrijven, zoals vroeger... laten we zeggen Kleist. Dat lukt domweg niet meer. Het verschil is, dat Strauss zich altijd zeer sterk heeft bezig gehouden met de symptomen. Met wat hij waarneemt, of beluistert... op TV, op straat. Hij registreert het verval... en het maakt hem erg verdrietig." Syberberg: "Terwijl wij ons nog eenmaal als een soort koorddansers in de hoogte te begeven. Ook al weten we, dat we de tijdgeest tegen ons hebben."

Zie eveneens: Strauss, B., Die Fehler des Kopisten. München, Wien, 1997. p. 98.: "Es gibt eine neue, klar markierte Trennlinie, die zwischen dem (abfällig so genannten) "Metaphysischen" und allen übrigen bunten Kunstfreuden unserer Tage verläuft. Hier genügt der Geruch, man braucht gar nicht erst hinzusehen; die Verdammung folgt auf dem Fuß, gleichgültig übrigens, ob es sich um einen Film von Kieslowski, eine Auffih rung mit Edith Clever [cursief van G.G.] oder eine Oper von Stockhausen handelt. 'Das mystische Wabern', 'der hohe Ton' (...), sie markieren gegenwärtig die einzige Grenze, die noch feste Parteiung schafft und antagonistische Qualität besitzt. In dem Moment, da eine Sprache bereit ist für das Unvermittelbare, für AnSpruch und An-Klang; wird sie unverzüglich auf den erbitterten Widerstand der Kommunikationsangestellten stoßen."

${ }^{63}$ Strauss, Paare, Passanten, a.w., pp. 171, 180.

${ }^{64}$ Strauss, Anschwellender Bocksgesang, a.w., pp. 24f, 31.

${ }^{65}$ Strauss, Der Aufstand gegen die sekundäre Welt, a.w..

${ }^{66}$ Strauss, B., Distanz ertragen. in: Borchardt, R., Das Gespräch über Formen und Platons Lysis Deutsch. Stuttgart, 1987. pp. 101-118, zie: 102, 118.
} 
gemaakt, het onbegrijpelijke begrijpelijk." "De slechte gewoonte $(\ldots)$," betoogt hij begin jaren ' 80 in Paare, Passanten, "om het kunstwerk uitsluitend te onderzoeken op zijn kritische gebruikswaarde en zijn kwaliteit af te meten aan hetzij een subjectieve 'Betroffenheit', hetzij een oppervlakkig sociaal-criticisme, ondergraaft in zekere zin de op vrijheid gerichte symbolische orde van de kunst. Waar echter maatschappelijk nut en de overdracht van meningen voorop staan en het plezier in het spel met esthetische tekens en beperkingen, het hartstochtelijke verlangen naar het schone, dreigen te bederven, wordt de productieve herinnering, die kunst een ieder kan schenken, niet verder ontwikkeld, maar dusdanig verkort, dan men haar gerust tegen het passieve archief van de TV-mens mag inruilen." we weer terug zijn bij Strauss' latere bespiegelingen in Anschwellender Bocksgesang over de "bloederige geweldheerschappij" 69 van een totalitaire, aufgeklärte mediacratie zonder historisch besef, waarmee de rechtse outsider op voet van oorlog leeft - zij het, dat hij zich in deze passage in Paare, Passanten nog niet beroept op de partizanen-leer van Jünger. ${ }^{70} \mathrm{De}$ inspiratiebron is dan nog Adorno's kritiek op Lukács:

"Een 'pre-esthetisch parti pri ten gunste inhoud en boodschap', dat Adorno ooit de literatuurtheorie van Lukács verweet, domineert nu eenmaal de onopgesmukte belangstelling van de massa voor een kunstwerk. Toch schrik je, wanneer het ook bij een jong, nieuwsgierig publiek als het overheersende criterium opduikt, zodra men vragen stelt aan een boek of een film. Is het dan echt noodzakelijk alles nog een keer te zeggen? De grote esthetische leermeesters van onze generatie vinden tegenwoordig zo goed als geen navolging meer. (...) De publieke opinie wordt aangevoerd door een welhaast zieke, egocentrische naïviteit, die behoorlijk versleten begrippen hanteert en van geen enkele intellectuele autoriteit meer afhankelijk is."

Net zo min als de Syberberg van het uit hetzelfde jaar daterende Hitler-postscriptum Die freudlose Gesellschaft, zou ik deze Strauss van Paare, Passanten reeds willen situeren in de hoek van de Conservatieve Revolutie. Veeleer ben ik geneigd te stellen, dat Syberberg en Strauss in die dagen twee ogenschijnlijk volstrekt verschillende verschijningsvormen vertegenwoordigen van één en dezelfde dissidente stroming bínnen het linkse cultuurdebat. Tot deze stroming behoort in elk geval een niet onaanzienlijk deel van het fonds van Axel Matthes, de uitgever van zowel Anschwellender Bocksgesang als Vom Unglück und Glück der Kunst in Deutschland nach dem letzten Kriege. Bijvoorbeeld de post-nietzschiaanse filosofie van Michel Foucault en Jean Baudrillard, waaraan Strauss eveneens in Paare, Passanten in hoge mate schatplichtig is. ${ }^{72}$ Ook iemand als Karl Heinz Bohrer, die zich in de loop van de jaren ' 80 steeds nadrukkelijker zal gaan manifesteren als "de auctor intellectualis van het neoromantische en 'unpolitische' denken" (Boterman), zou ik ertoe willen rekenen. ${ }^{73}$ Maar de oorsprong dient toch echt te worden gezocht bij de founding fathers van het linksliberale vertoog: de antifascistische emigranten. Meer specifiek: bij dat deel van de emigranten, dat in het expressionisme-debat van het interbellum en de formalisme/realisme-

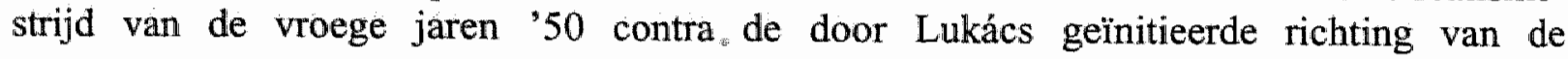

\footnotetext{
${ }^{67}$ idem, pp. 105, $112 \mathrm{ff}$.

${ }^{68}$ Strauss, Paare, Passanten, a.w., pp. $109 \mathrm{f}$.

${ }^{69}$ Strauss, Anschwellender Bocksgesang, a.w., p. 31.

${ }^{70}$ Voor deze leer zie: hoofdstuk 6, paragraaf 5.

${ }^{71}$ Strauss, Paare, Passanten, a.w., p. 109.

${ }^{72}$ idem, pp. 163-202. Voor de post-nietzschiaanse Franse filosofie en het fonds van Axel Matthes, zie: hoofdstuk 7, de paragrafen 7 en 8 .

${ }^{73}$ Boterman, a.w., p. 164 . Voor Bohrer, zie: de paragrafen 3.8 en 4.1 .
} 
'irrationalisme'-kritiek het bestaansrecht van een linkse avant-garde verdedigde: de 'grote esthetische leermeesters' Adorno, Bloch, Brecht, Mayer.

Wat Adorno en Bloch waren voor Strauss, waren Bloch, Brecht en Mayer voor Syberberg: intellectuele en artistieke Leitfiguren, door wie hij zich de ogen heeft laat openen voor 'de vergissingen en verwoestingen van een dolende wereldse Soteriologie' (Strauss). Dat Adorno deze voorbeeldfunctie voor hem nooit heeft gehad, kent een voor de hand liggende reden. Anders dan Strauss is hij niet getogen in de Bondsrepubliek, maar afkomstig uit het stalinistische Oosten. Zijn roots liggen in de dissidentencultuur van de DDR in haar begindagen, waarin Bloch, Brecht en Mayer een sleutelrol vervulden. Syberberg is, bij wijze van spreken, als kunstenaar in het toenmalige linkse rumoer hineingeboren. Zijn eerste serieuze werk ontstaat midden in het gewoel van de formalisme/realisme-strijd: de registratie van Brechts 'verboden' enscenering van de Urfaust (1953). ${ }^{74}$ En ik ben ervan overtuigd dat de sleutel tot een juist begrip van dit oeuvre in deze vingeroefening van een amper achttien jaar oude scholier dient te worden gezocht. Maken we de balans op van deze kunstenaarsloopbaan, dan moet Syberberg een tweetal dingen worden nagegeven: zijn werk was altijd zéér eigentijds en zit opmerkelijk consistent in elkaar. Zoals Cave of Memory een verdere uitdieping is van de enscenering van Prinz Friedrich von Homburg in het laatste deel van het Pruisen-Requiem, dat op zijn beurt weer een verdere uitdieping was van het zonsondergangen-tableau in het laatste deel van $\mathrm{Hitler}^{75}$ zo lijkt elke stap uit de vorige voort te vloeien. Zelf heeft (de late) Syberberg zijn oeuvre wel eens vergeleken met een boom, waaruit steeds nieuwe takken groeien. ${ }^{76}$ Aanvaarden we deze metafoor, dan wordt de stam van de boom gevormd door het 'irrationalisme' in de zin van Lukács en de kiem, waaruit het geheel is voortgesproten, door dit jeugdwerk waarmee zijn loopbaan een aanvang nam.

Ook Brecht toonde zich in zijn tegendraadse enscenering van Goethe's drama een 'echte protestant'. Door, om het in de woorden van Strauss te zeggen, 'de grote literatuurtradities van het Avondland, die werden miskend of vervalst, te herontdekken en scheppend verder te voeren,' leverde hij verzet tegen een kunstpolitiek, die zijns inziens berustte op een schadelijke dwaalleer: de cultuurtheorie van Lukács. "Hij [Brecht, G.G.] maakte aanspraak op de gehéle schatkamer van de wereldliteratuur (...)," aldus zijn biograaf Werner Mittenzwei (1969). "Bij Anzengruber hoopte hij evenzeer vingerwijzingen voor zijn scheppende arbeid te vinden als bij Homerus; Döblin en Joyce waren voor hem net zo inspirerend als de agitpropkunst van het proletarische gezelschap (...). Van de bijbel tot de Russische revolutiedrama's reikt de variëteit aan invloeden." 77 Maar voor een dergelijke omgang met het culturele erfgoed was binnen de kunstpolitiek van het stalinisme geen ruimte. De kunstenaar diende zich strikt te houden aan het door Lukács geschetste beeld van een klassenstrijd tussen 'rationele' en 'irrationele' krachten, waarvan de sporen in de cultuurgeschiedenis duidelijk zichtbaar zouden zijn. Aan de ene kant had je de lijn LessingMarx-Thomas Mann, waarvan werd aangenomen dat zij de dialectische vooruitgang

\footnotetext{
${ }^{74}$ Zie: hoofdstuk 2, paragraaf 3.

${ }^{75}$ Zie: hoofdstuk 7 , de paragrafen 4 en 5 .

${ }^{76}$ Interview met de auteur en Eling Delleman, zomer 1991. Zie eveneens: Syberberg, H.J., Der Wald steht schwarz und schweiget. Neue Notizen aus Deutschland. Zürich, 1984. p. 299: "Drie Perioden bisher. (...) Und wie das ineinander übergeht."

${ }^{77}$ Mittenzwei, W., Erprobung einer neuen Methode. Zur ästhetischen Position Bertolt Brechts. in: Positionen. Beiträge zur marxistischen Literaturtheorie in der DDR. Hrsg. W. Mittenzwei. Leipzig, 1969. pp. 59-100, zie: $77 \mathrm{ff}:$ "In den dreiBiger Jahren kames zwischen Bertolt Brecht und Georg Lukács zu einer heftigen Kontroverse über das Verhältnis zur Tradition. Brecht, der gewohnt war, in gleicher Weise auf die alte chinesisische und lateinische Dichtung, auf die Moderne, auf außerliterarische Traditionen wie auf Elemente der Volkskunst zurückzugreifen, konnte sich mit der Auffassung des ungarischen Philosophen und Literaturwissenschaftlers nicht befreunden."
} 
vertegenwoordigde; aan de andere kant de "irrationele' lijn Schelling-Nietzsche-Joyce, die men met terugwerkende kracht als het substraat van de nazi-barbarij meende te hebben ontmaskerd. Aangezien de burgerlijke cultuur in haar laat-kapitalistische, 'imperialistische' fase in een spiraal van verval zou zijn terecht gekomen, waren eigentijdse esthetische vormen van het naturalisme tot en met het absurdisme uit den boze. Het ware kritisch-realistische kunstwerk bestond uit een imitatio van de grote meesterwerken uit de epoche, waarin de bourgeoisie nog de progressieve klasse was: het klassieke Weimar. ${ }^{78}$ In de optiek van Brecht echter was een dergelijke voorstelling van zaken niet alleen rückwärtsgewandt, wereldvreemd, dialectisch onjuist en kunstvijandig, in de zin dat zij een ontoelaatbare beperking inhield van de artistieke vrijheid. Het geschiedbeeld van Lukács kwam bovendien neer op een ideollogische vervalsing - zowel van het classicisme, dat werd ondergedompeld in een wierooklucht die haaks stond op de geest van deze werken, als van grote delen van het vermeend 'irrationele', dat ten onrechte als decadent, reactionair of in wezen fascistisch werd verguisd. ${ }^{79}$

In een passage van Die freudlose Gesellschaft (1981), waarin hij zelf de balans opmaakt van zijn loopbaan tot dan toe, noemt Syberberg als één van zijn belangrijkste verdiensten: "de terugwinning van het irrationalisme, teruggehaald uit het verdomhoekje van zijn geestelijke verbanning, $(.$.$) in bescherming genomen tegen de dolenden van onze dagen$ en de tot conventie geworden verwoestingen door het zogenaamde positivistische rationalisme van onze media." ${ }^{" 80}$ Het is een kerngedachte, die in alle werken waaruit dit oeuvre is opgebouwd kan worden aangewezen. Of je nu deze vroege Brecht-films (1953) neemt of de documentaires over het expressionistische theater van Kortner (1965-'66); de uitzinnige odes aan de graven Pocci (1967), de maanzieke koning Ludwig (1972) of de volksschrijver Karl May (1974); de belijdenissen van Hitler-vriendin Winifred WagnerWilliams (1975), het neo-wagneriaanse Gesamtkunstwerk Hitler, ein film aus Deutschland (1977), de klaagzangen van de Pruisische Hekabe (1984-'91) of het gedenkteken voor het 'miskende en verguisde' kunstenaarschap van Oskar Werner $(1997)^{81}$ - steeds geldt: het gaat om een stellingname contra de 'irrationalisme'-kritiek in zowel haar dialectischmaterialistische (Lukács) als burgerlijke (Thomas Mann) ${ }^{82}$ variant en alle (kunst-)historische, filosofische of psychoanalytische derivaten. Elk van deze werken is een poging datgene, wat binnen deze 'ingeslagen en geleerde weg van het argumenteren ${ }^{83}$ als fout, ziek, decadent, reactionair, rechts en in wezen fascistisch wordt betekend, gecategoriseerd en uitgesloten, te herontdekken, van zijn smet te zuiveren en aldus terug te winnen. En de methode, die Syberberg hiertoe hanteert, is het 'scheppend verder voeren'. Dat wil zeggen: hij situeert zich als kunstenaar én pamflettist bínnen de 'geschiedenis van het irrationalisme' en probeert vanuit zijn 'materiaal' verder te werken. Artistieke en intellectuele vernieuwingen vinden plaats door telkens een andere tak van het 'irrationalisme' onder handen te nemen en uitputtend te onderzoeken, hetgeen projecten oplevert van lange adem. Op grond van de 'materiaalkeuze' kunnen grosso modo een drietal, elkaar deels overlappende fasen worden onderscheiden:

\footnotetext{
78 Zie: hoofdstuk 2, paragraaf 4; hoofdstuk 3, paragraaf 4 .

${ }^{79}$ Zie: hoofdstuk 2, paragraaf 4.

${ }^{80}$ Syberberg, H.J., Die freudlose Gesellschaft. Notizen aus dem letzten Jahr. München, Wien, 1981. p. 352.

81 "Het prototype van een miskende en verguisde kunstenaar," aldus Syberberg tijdens een voordracht in het lezingenprogramma 'Honderd dagen, honderd gasten' van Documenta $X$, Kassel 1997.

${ }^{82}$ Zie: hoofdstuk 3, paragraaf 4.

${ }^{83}$ Zie: hoofdstuk 5 , paragraaf 4.
} 
Aanvankelijk blijft Syberberg dicht in de buurt bij Brecht. Hij ziet voor zichzelf in de filmgeschiedenis een soortgelijke rol weggelegd als zijn 'artistieke pleegvader' heeft gespeeld in de geschiedenis van het theater. De cinema moet naar brechtiaans model worden omgevormd van een "pleziertheater" tot moreel drama, dat zich op het artistieke en intellectuele niveau bevindt van de theatrale avant-garde. Vroege speelfilms als Die Grafen Pocci hebben nog het meeste weg van een 'vertaling in cinema' van het moderne theater van de post-Brecht-tijd: het absurdisme van Dürrenmatt, Beckett, Ionesco, Camus, dat tevens het onderwerp vormt van zijn proefschrift Zum Drama Friedrich Dirrenmatts (1963). Aan deze post-brechtiaanse avant-garde ontleent Syberberg niet alleen tal van theatrale innovaties, maar ook het existentialistische wereldbeeld. 'Irrationalisme' betekent gedurende deze beginfase: de verwerping van de uit de Verlichting daterende en binnen de 'irrationalisme'kritiek tot dogma verheven voorstelling van een an sich redelijke, zich heilzaam ontwikkelende en maakbare werkelijkheid. ${ }^{84}$

Op een tweetal manieren neemt Syberberg het absurdisme tegen de kritiek van decadentie in bescherming. Ten eerste: door erop te wijzen, dat het 'absurde bewustzijn' correspondeert met het levensgevoel van de moderne mens. Deze vroege films articuleren een crisisbesef, dat in de ogenschijnlijk zo optimistische wederopbouwjaren wijdverbreid is niet slechts in kringen van conservatieven als Hans Sedlmayr, bij wie hij in de jaren '50 kunstgeschiedenis heeft gestudeerd, maar ook in die van Westerse neo-marxisten als Adomo of DDR-dissidenten als Bloch en Mayer. Alom wordt aangenomen dat de 'redelijke vooruitgang" (Entzauberung, instrumentelle Vernunft) in het tijdperk van de techniek desastreuze vormen heeft aangenomen. De moderne mens is op zichzelf aangewezen in een als absurd beleefde wereld. En ten tweede: door te demonstreren dat het absurdistische theater een meer eigentijdse vorm is van moreel drama in de geest van Brecht. Het biedt geen affirmatie van de zingevingscrisis, maar nodigt de mens uit tot het spelen van een moreel spel 'op basis van het tegenwoordige levensgevoel'. Inzet van het spel is het reactiveren van een 'principe hoop' in het innerlijk, dat opnieuw houvast biedt. Zelf denkt Syberberg dit 'principe hoop" te hebben gevonden in een humanistische levensfilosofie, zoals die onder meer wordt uitgedragen door de Biedermeier-dichter Adalbert Stifter: een ethos van zorgzaamheid, matigheid en berusting als antwoord op 'een vooruitgang, die alles vernietigt en tegen gunste van een kwantitatief principe de mens alsmaar meer geestelijk afstompt, alsmaar meer egaliseert' (Mayer). ${ }^{85}$

II. De wagneriaanse fase, vanaf de vroege jaren '70 (het Ludwig-Requiem) tot midden jaren '80 (Die Nacht)

Hiertoe geïnspireerd door Hans Mayer, de huisfilosoof van zowel het Brecht-theater in OostBerlijn als het Wagner-theater in Bayreuth met wie hij in die dagen nauw samenwerkt, verlegt Syberberg begin jaren '70 zijn aandacht van het postfascistische 'irrationalisme' naar het prefascistische. Meer specifiek: van het absurdisme naar Wagner en de late romantiek. ${ }^{86}$ Maar de belangrijkste inspiratiebron is gedurende deze fase onmiskenbaar een andere huisfilosoof van het Nieuwe Bayreuth: Ernst Bloch, wiens studies de blauwdruk vormen van

\footnotetext{
${ }^{84} \mathrm{Zie}$ de paragrafen $2.5,2.8,2.9,2.10$.

${ }^{85}$ ibidem.

${ }^{86}$ Zie: hoofdstuk 3, paragraaf 1.
} 
de mammoet-cyclus De Graal (1972-'82). De programmatische inzet van zijn 'irrationele' kunstwerken zal hij nu gaan formuleren in bewoordingen, die rechtstreeks aan Bloch ontleend zijn. De ware kritische fillosoof of kunstenaar legt zich niet neer bij de pervertering, maar ontwikkelt strategieèn van herijking die het mogelijk maken het geperverteerde weer te ontfutselen aan zijn ideologische vervalsers. Waartoe behalve de nazi's ook de ideologen van de 'irrationalisme'-kritiek behoren, die grote delen van het Duits/joods/Europese culturele erfgoed met terugwerkende kracht vervalsen als in wezen fascistisch en aldus de mens beroven van elk besef van een 'niet-gerationaliseerd, mythisch verleden' (Strauss), kortom: van Heimat - dat magische oord, dat "we allen in de kindertijd situeren, maar waarin niemand van ons ooit was' (Bloch). Films en pamfletten uit deze periode hebben sterk het karakter van laboratoria, volgestouwd met 'besmet' materiaal. Ook in de selectie van dit materiaal is Syberberg aantoonbaar aan Bloch schatplichtig. In navolging van de filosoof van de linkse utopische hoop houdt hij zich bezig met zaken als: de kunst van de romantiek (Runge, Friedrich, Wagner) en hieruit voortgevloeide stromingen als het symbolisme (Karl May) en het expressionisme (de Weimar-cinema); het sprookje, de legende, de mythe, de sage, de wensdroom; begrippen als volk, natie, vaderland, Heimat, bodem, Führer, de Graal, het Derde Rijk; de 'ongelijktijdige' hunkeringen naar het schone, het zuivere, het heilige, de irrationele extase enzovoort. ${ }^{87}$

Meer nog dan Brecht geldt Ernst Bloch, die in '57 in de DDR een Lehr- und Veröffentlichkeitsverbot krijgt opgelegd, binnen het linkse cultuurdebat als politiek verdacht. Zijn filosofie zou in wezen onmarxistisch zijn - een eigenaardig brouwsel van expressionistisch maniërisme en oud-testamentair pathos, overgoten met een flinterdun sausje neo-marxistische rethoretiek. ${ }^{88}$ In Syberbergs cinematografische vertaling is zelfs dit sausje geheel en al afwezig. De hem dankzij de 'genade van de late geboorte' vergunde grotere emotionele afstand tot het nazi-verleden, zou het mogelijk maken de uitkomst van de herijking, die avant-gardisten uit vorige generatie als Bloch, Brecht, Mayer en Wieland Wagner hebben proberen te bieden, nog eens kritisch tegen het licht te houden - met een onbevangen blik, niet vertroebeld door de zware last van de schuldvraag, door ideologische vooringenomenheid of de traumatische ervaringen van vlucht en ballingschap. Gesteld dat het zinvol is te streven naar een denazificatie van zwaar geperverteerde begrippen als volk, natie, Heimat, bodem, Führer, de Graal of het Derde Rijk, zoals Bloch in zijn studies betoogt waarom dan wel 'Duitsland als geestelijke mogelijkheid' (Karl Heinz Bohrer, Philippe Lacoue-Labarthe) zonder strijd aan de nazi's cadeau doen? ${ }^{89}$ Het 'principe hoop' in het innerlijk, waar hij gedurende zijn beginfase naar op zoek was, krijgt nu een Duits karakter. Het is de deutsche Innerlichkeit, in de zin van de vroege Thomas Mann of de oud-Bayreuther wagnerianen: deutsche Kultur als het 'tegenprincipe' van het onduitse Verlichtingsdenken. Am deutschen Wesen soll die Welt genesen. De absurdist van weleer is een bevlogen Duitsnationalist geworden. En als zodanig mengt hij zich in het publieke debat van die dagen. Pamfletten als Filmbuch (1976) of de Hitler-script-inleiding Die Kunst als Rettung aus der deutschen Misere (1978) bestaan in hoofdzaak uit een geactualiseerde versie ('aangepast voor onze tijd') van een, naar hij meent, gedenazificeerde oud-Bayreuther ideologie. De strijd van de oud-Bayreuther wagnerianen tegen de verderfelijke invloeden van de 'Franse geest' neemt in deze geactualiseerde versie de vorm aan van een 'partizanenstrijd' tegen de verderfelijke invloeden van de geest van '68. De door de protestgeneratie geïnitieerde Vergangenheitsbewältigung wordt fel bekritiseerd als het product en een radicalisering van

\footnotetext{
${ }^{87}$ Zie: de paragrafen $3.6,3.7,3.8,5.6,6.7$

${ }^{88}$ Zudeick, P., Der. Hintern des Teufels. Ernst Bloch-Leben und Werk. Bühl-Moos, 1985. pp. 186ff. Zie eveneens: hoofdstuk 3, paragraaf 7 .

${ }^{89}$ Zie: de paragrafien $3.8,5.6,6.8,7.8$.
} 
een door de bezetter afgedwongen links-liberale re-education, die het Duitse volk van zijn 'irrationele', mythopoëtische wezen zou hebben vervreemd (het 'psychologische Versailles'). ${ }^{90}$

En zoals het 'absurde bewustzijn" van het vroegere werk correspondeerde met het levensgevoel van de wederopbouwjaren, zo lijkt dit deutschbewusste anti-Verlichtingsdenken van De Graal een uitvergroting van het levensgevoel van delen van de - linkse - intellectuele voorhoede ná de Duitse herfst van '77. Aan de ene kant beleeft de Betroffenheitskult haar hoogtepunt en is de 'irrationalisme'-kritiek óok in het Westen uitgegroeid tot de dominante stroming binnen het linkse cultuurdebat. Want ik denk, dat we de Strauss van Paare, Passanten (zie hierboven) op dit punt gerust gelijk mogen geven. Hun ogenschijnijke populariteit bij de Westduitse protestgeneratie van " 68 ten spijt, vinden de 'grote esthetische leermeesters' Adorno, Bloch, Brecht, Mayer zeker voor zover het de omgang met het geperverteerde culturele erfgoed betreft amper navolging. Terwijl de invloed van hun opponenten Lukács en Mann al dan niet in een verwaterde vorm over vrijwel de gehele linie voelbaar is. De echo van de 'irrationalisme'-kritiek klinkt door in de psychoanalyse van het Duitse 'onvermogen om te rouwen'; in Habermas' verdediging van het 'project van de moderniteit'; vanzelfsprekend ook in de 'volkspedagogische praktijk' rond nazi-kunst, het debat over de 'schone schijn' van het Derde Rijk en de 'fascistische hunkeringen in ons midden' (Sontag). ${ }^{91}$ Aan de andere kant begint het sociaal-kritische paradigma zijn eerste vermoeidheidsverschijnselen te vertonen en vervagen de 'zuivere verhoudingen' (Mayer) tussen links en rechts tot een 'nieuwe onoverzichtelijkheid' (Habermas). De symptomen van, wat in die dagen wordt aangeduid als de Tendenzwende reiken van een 'nieuw patriottisme' onder de linkse intelligentsia en de ondermijning van het 'rationele subject' van de Verlichting in de post-nietzschiaanse Franse filosofie tot de steeds luider wordende kritiek dat het 'afbreken, verbreken, opbreken' (Lukács), zo men wil 'erinnem, wiederholen, durcharbeiten' (de Mitscherlichs) te ver zou zijn doorgeschoten. "Dat meteen Heinrich Himmler wordt geroepen, wanneer iemand 'Meister Eckhart' zegt - dát is de voortzetting van de barbarij met antifascistische middelen," aldus Strauss in een interview uit $1987 .{ }^{93}$ Zes jaar eerder, in Paare, Passanten, heeft de schrijver reeds afscheid genomen van 'de dialectiek" "(...) es muß sein: ohne sie!" - en zijn toevlucht gezocht tot een geheel eigen gedachtebrouwsel uit Adorno en Foucault. ${ }^{94}$

\footnotetext{
${ }^{90}$ Zie: de paragrafen $3.2,3.5,3.7,3.8,5.3,5.4,5.6,5.7,6.4,6.5$.

${ }^{91}$ Zie: de paragrafen $4.1,5.3,5.4,5.5,5.6,6.4,7.7$. Strauss, Die Fehler des Kopisten, a.w., p. 106:

"Ausstellungen, die den großen Gewaltregimen des Jahrhunderts gewidmet sind, führen Kunstwerke nur als

Kunstbeispiele an und behaupten eine schreckliche Übermacht des Geschïhtlichen über das stille Gesicht einer

Bronzefigur. Auf diese Weise wird der Streifzug durch die Gewalt-Epoche doppelt deprimierend, weil

Kunstwerke nur als ein Zeugnis under anderen, etwa Zeitungsartikeln und Werbeplakaten auftachen. In

Wahrheit gilt genau das Umgekehrte (...): wie flüchtig und kurzlebig erscheinen heute die erbitterten

Konfessionen politischer Führungen, verglichen mit den tiefen, über die Zeiten tragenden Beglaubigungen in den Büchern von Kafka, Rilke, Heidegger, um nur dreil Deutsche zu nennen."

${ }^{92}$ Zie: de paragrafen $4.1,5.8,6.4,6.8,7.7$.

${ }^{93}$ Hage, a.w., pp. $214 \mathrm{f}$.

${ }^{94}$ Strauss, Paare, Passanten, a.w., pp. $115 \mathrm{f}, 183 \mathrm{f}$.
} 


\section{III. De Conservatief Revolutionaire of Pruisische fase, vanaf midden jaren '80 (Die} Nacht) tot?

"Welke schatten liggen verborgen onder de breekbare korsten van deze volkspedagogen?," vraagt Syberberg zich af in Die freudlose Gesellschaft. En zijn we überhaupt nog wel in staat deze kostbaarheden op eigen kracht te delven $?^{95}$ Er zou, verzucht Strauss in zijn uit hetzelfde jaar daterende Paare, Passanten, iemand moeten komen, die een volstrekt andere taal spreekt; een eenzame schatzoeker, afkomstig uit een wereld ver weg van alle ons bekende kunstcontinenten, die zich op rooftocht begeeft in onze theaters. "En de schat, die hij opgraaft, bezit een dusdanige eigen substantie, dat ze trots, spiegelend en fonkelend, naast de door ons aanvaarde werkelijkheid mag bestaan." ${ }^{\text {"6 }}$ Voor de late Syberberg is deze schat het werk van Heinrich von Kleist, de grote dichter van het oude Pommeren. Het motief van het abgebrannte Pommernland, de verdwenen wereld van de Vader, komen we voor het eerst tegen in Hitler, ein Film aus Deutschland, het vijfde deel van De Graal.$^{97}$ Maar van de geest van het Pruisen-Requiem zijn we in dit magnum opus nog ver verwijderd.

Hoewel hij dan al wel geruime tijd in de Westduitse publieke opinie als zodanig te boek staat, beschouwt de Syberberg van de vroege jaren ' 80 zichzelf nóg niet als een Conservatieve Revolutionair. ${ }^{98}$ Deze Syberberg presenteert zijn werk nog nadrukkelijk als een stellingname bínnen het linkse cultuurdebat. Films als Die Grafen Pocci, Winifred Wagner of Hitler zijn het antwoord van een kunstenaar op een probleem, dat in het interbellum door Lukács op de linkse agenda werd geplaatst en tot het einde toe het centrale twistpunt is gebleven: hoe verhoudt de barbarij van het Derde Rijk zich tot de Duitse cultuurgeschiedenis in het algemeen en de lijn Schelling-Nietzsche en post-nietzschiaanse stromingen als het oud-Bayreuther wagnerianisme; de Conservatieve Revolutie en het existentialisme in het bijzonder. En ze borduren voort op antwoorden, die gedurende vroegere fasen van het linkse cultuurdebat zijn gegeven door Lukács' grote opponenten Brecht, Bloch en Mayer, wier positie zich misschien nog het beste laat samenvatten met een citaat van Jacques de Kadt, die ooit zei het fascisme te haten "niet omdat het alleen maar iets slechts is, maar omdat het de pervertering van zoveel goeds is". ${ }^{99}$ Pas in de loop van de jaren ' 80 , als hij zich meer intensief zal gaan verdiepen in het werk van Kleist (en het lot van de Heimatvertriebenen), rijpt bij Syberberg gaandeweg het inzicht, dat hij langs de door deze kosmopolitische emigranten gebaande denkwegen niet meer verder komt. Zolang het ging om het absurdisme, om Wagner en de late romantiek, om het symbolisme en het expressionisme, kon hij een heel eind met hen optrekken en waren hun sociaal-kritische theorieën een bron van inspiratie. $\mathrm{Nu}$ begint dit "na ' 45 gegroeide schild" alsmaar meer aan te voelen als een ballast, ja als een keurslijf waaruit hij zich moet bevrijden, "denn Kleist war so nur verfälschend zu erfahren". 100

\footnotetext{
95 Syberberg, Die freudlose Gesellschaft, a.w., p. 25.

${ }^{96}$ Strauss, a.w., p. 185.

${ }^{97}$ Zie: de paragrafen 7.2, 7.5. hoofdstuk 7 , de paragrafen 2 en 5.

${ }^{98}$ Zie: hoofdstuk 5 , paragraaf 8 .

${ }^{99}$ Citaat ontleend aan: Pels, D., 'Kan een fascist een echte intellectueel zijn?' in: de Volkskrant. 09-11-1993. Wie wil zou in Het fascisme en de nieuwe vrijheid (1939) van de oud-communist De Kadt een variant kunnen zien op Blochs Erbschaft dieser Zeit. Voor een bespreking van De Kadts houding ten opzichte van het fascisme, zie, naast het annoteerde stuk van Pels, ook het mooie opstel Jacques de Kadt (1897-1988) en de wetenschap der politiek van Josine Meyer, in: Meyer, J.W.L., Oude vrienden en een veranderde wereld. Een keuze uit eigen werk. Amsterdam, 1990. pp. 58-80: "De mythen van het fascisme verliezen hun kracht als men hun leuzen nader onderzoekt, erkent wat er waardevol in is en dat overneemt, ontdaan van de vervalsende toevoegsels". ${ }^{100}$ Syberberg, H.J., Eigenes und Fremdes. Über den Verlust des Tragischen. in: Die selbstbewusste Nation, a.w., p. 130. Zie eveneens: de paragrafen $7.4,7.5,7.6$.
} 
Vanaf het midden van de jaren 80 zal Syberberg langzaam maar zeker het linksliberale vertoog de rug gaan toekeren en zich bekennen tot het 'organische' denken van de post-nietzschiaanse Conservatieve Revolutie, dat zijns inziens meer recht doet aan de 'Pommerse geest' van een tekst als Prinz Friedrich von Homburg. Het referentiekader van deze late Syberberg is niet langer het linkse cultuurdebat, waarin de tegenstelling 'irrationalisme'-kritiek - avant-garde centraal staat, maar het Westduitse modernisme-debat van de vroege jaren '50, waarin in de gedaanten van Adorno en Sedlmayr twee volstrekt heterogene vertogen op elkaar botsten: het modernistische, kosmopolitische, 'onschuldige' vertoog van de emigranten en het anti-modernistische, bodenständige, 'schuldige' vertoog van de thuisblijvers. ${ }^{101}$ Maar wanneer Die Zeit hem in 1999 vraagt in het kader van een serie over de millenniumwissel een opstel te schrijven over het boek uit de twintigste eeuw dat voor hem het meest invloedrijk was, verzwijgt de tegenwoordige Rechtsintellektueller zijn roots niet. Zijn Jahrhundertbuch is niet Sedlmayrs Verlust der Mitte, noch Heideggers Gelassenheit of Der Waldgang van Ernst Jünger, maar Buckower Elegien: een dichtbundel van Bert Brecht uit 1953, het jaar waarin hij onder het goedkeurende oog van deze 'artistieke pleegvader' zijn eerste schreden op het pad van kunstenaar heeft gezet. ${ }^{102}$ "Natuurlijk zou Brecht aan nogal wat dingen van mijn hand beslist niet al te veel plezier hebben beleefd," verduidelijkt hij in een interview uit 1991. "Maar een goede leerling moet zijn leraar óók kunnen overwinnen en indien nodig zelfs weerleggen. Ja, een goede leerling kan zijn leermeester geen grotere dienst bewijzen, dan door hem te bevestigen én tegen hem in te werken." 103

Omstreeks dezelfde tijd, midden jaren '80, heeft ook Strauss steeds sterker het gevoel, dat hij oploopt tegen de grenzen van een paradigma. ${ }^{104}$ Twee engelen hielden de wacht bij de poorten van onze democratie, meent hij in zijn hierboven reeds aangehaalde essay uit 1987 over het werk van de dichter Rudolf Borchardt, een "schat" die hoognodig dient te worden opgegraven en overgeleverd. Naast de engel met het kritische zwaard, de hoeder van de Verlichting en het vooruitgangsdenken, stond ook die van het 'wetende, scheppende bewaren'. Dat wil zeggen: naast Benjamin en Adorno stonden ook Borchardt en Jünger. Gelezen worden ze echter allang niet meer, deze twintigste-eeuwse vertegenwoordigers van de Gegenaufklärung in de kunsten. Laat staan begrepen. Hooguit vormen ze nog een makkelijke prooi voor die "weerzinwekkende zoemende meute (...) van de vliegen van de geest", waardoor ook Nietzsche reeds werd belaagd: het secundaire vertoog van de "geleerde filistijnen', die in onze dagen de gedaante hebben aangenomen van de 'links-kritische wetenschapper'. Maar zelfs al zouden dit soort lieden mit dem Finger unter der Zeile lezen; dan nog zou het werk van Borchardt voor hen even duister blijven als een vreemde taal, die ze nooit hebben leren spreken. Je zou het, redeneert Strauss, kunnen vergelijken met de blinde vlekken en blokkades van de grote kennissystemen in de geschiedenis van de wetenschappen, waarvan onder meer Michel Foucault de werking heeft geanalyseerd. Kunstenaars verdelen we doorgaans in drie typen: de sociaal-geëngageerde romanschrijver, de betroffen anarcho-radicaal en de hermetisch-fragmentarische poëet. Voor dat andere type kunstenaar, dat Borchardt of Jünger belichamen, hebben we domweg de verkeerde dispositie. "Om het afgekapte singuliere nauwkeurig te kunnen bepalen, missen we de zintuigen en de methode. (...) Er moet altijd meteen een schemawissel, een verandering van Leitbilder aan te

\footnotetext{
${ }^{10 i}$ Zie: de paragrafen $2.7,7.6$.

${ }^{102}$ Syberberg, H.J., Mein Jahrhundertbuch: Buckower Elegien von Bertolt Brecht. in: Die Zeit. (29) 1999.

${ }^{103}$ Interview met de auteur en Eling Delleman, zomer 1991.

${ }^{104}$ Herzinger, a.W., p. 10: "Der Einfluß Adomos auf Strauss erscheint in dessen Beschreibungen [in Paare, Passanten, G.G.] freilich eher als Bedrückung und Einschüchterung denn als künstlerische Inspiration. Und so kann man in Straussens literarischer Praxis vielleicht auch den Versuch erkennen, sich von dem lähmenden Einfluß des Manichäismus der Frankfurter Schule zu befreien."
} 
pas komen, opdat we ook in detail beter kunnen zien en in staat worden gesteld een verboden of miskende dichter te herontdekken."105

Drie jaar later, bij de val van de Muur, ziet de schrijver zijn wens in vervulling gaan.

\subsection{Differentie verdragen}

Waren de jaren '70 een periode waarin "het intellectuele klimaat [werd] beheerst door een brouwsel van oude en nieuwe conservatieve stromingen," het begin van "vele jaren van reactie"? Zoals Jürgen Habermas betoogt in de bundel Kleine Politische Schriften (1981). ${ }^{106}$ Mijn indruk is een andere. De jaren '70 waren de periode waarin conservatieve auteurs als Ernst Jünger en Hans Sedlmayr, die in de wederopbouwjaren nog de bestsellerlijsten aanvoerden, ${ }^{107}$ voor lange tijd uit de gratie raakten en het 'kritische denken' van de emigrantengeneratie een renaissance doormaakte. De grote controverses van die dagen, de debatten over het Duitse 'onvermogen om te rouwen', de 'schone schijn' van het Derde Rijk en de Tendenzwende, waren in grote lijnen een herneming van een overwegend neomarxistisch vertoog, dat ten tijde van de nazi's in de ballingschapoorden van Hollywood tot Moskou ontstond. ${ }^{108}$ En veel van wat Habermas in zijn Kleine Politische Schriften of latere teksten als Der philosophische Diskurs der Moderne (1985) laat doorgaan voor rechts, blijkt bij een nadere beschouwing te behoren tot een dissidente linkse stroming, die door een andere dominante stroming binnen dit vertoog, die van de 'irrationalisme'-kritiek, van meet af aan als rechts is verguisd. Want net als de spiritus rector van de 'irrationalisme'-kritiek Georg Lukács, hanteert ook Habermas een ruime definitie van het rechtse of Nieuw Rechtse denken. Zoals Nieuw Links het modernistische project is van de herijking van "de Verlichtingstraditie van Lessing tot Marx," die "opnieuw tot een medium van intellectuele productiviteit en een aanknopingspunt van het politieke identiteitsgevoel" wordt gemaakt, zo is Nieuw Rechts het anti-modernistische project van de herijking van de (post-)nietzschiaanse Gegenaufklärung, die "vom Makel seiner Verfilzung mit dem bürokratischen Terror [wordt] reingewaschen". 109 Op grond van deze definitie rekent Habermas tot "de conservatieve ideologen en hun intellectuele helpers" niet slechts een activist als Armin Mohler, maar ook Syberberg, Anselm Kiefer en Pier Paolo Pasolini, Karl Heinz Bohrer, of Franse post-nietzschianen als Michel Foucault en Jacques Derrida, ${ }^{110}$ Zoals Lukács er indertijd niet voor terugschrok, behalve een activist als Jünger ook Bloch, Brecht, ja vrijwel de gehele intellectuele en artistieke avantgarde sinds het midden van de negentiende eeuw af te schilderen als apologeten van de Tendenzwende van het interbellum.

\footnotetext{
${ }^{105}$ Strauss, Distanz ertragen, a.w., pp. $116 f$. De opmerking over de 'vliegen van de geest' is ontleend aan: Strauss, Refrain einer tieferen Aufklärung, a.w., p. 324. Zie in dit verband eveneens: Strauss, Der Aufstand gegen die sekundäre Welt, a.w.. De opmerking over Foucault is ontleend aan: Strauss, Paare, Passanten, a.w., pp. $181 \mathrm{ff:} \mathrm{"Die} \mathrm{unfruchtbare} \mathrm{dialektische} \mathrm{Versöhlichkeit} \mathrm{des} \mathrm{Sowohl-Als-Auch} \mathrm{(...)} \mathrm{-} \mathrm{das} \mathrm{ist} \mathrm{inzwischen} \mathrm{jener}$ Schleim und Leim auch im Denken unserer aufyeklärten Bildungsstätten, der nichts Neues mehr erkennen und entstehen läßt (...). Die objektiven Hemmungen und Blindheiten der Erkenntnissysteme, wie sie Bachelard und Foucault in der Geschichte der Naturwissenschaften untersucht haben, kommen einem in den Sinn (...). (...) Wir sollten darauf gefaßt sein, daß es in Zukunft sehr viel schneller als in den vergangenen dreißig Jahren zu abrupten Ereignissen kommt, in denen die abgedrängten Strömen sich sammeln und hervorbrechen könnten, und daß die Sicherungen des modernen Rationalismus 'bei überforderter Kapazität' sehr plötzlich, ohne lange Anflaufzeit durchbrennen könnten."

${ }^{106}$ Habermas, Kleine Politische Schriften, a.w., pp. $385 \mathrm{f}$.

${ }^{107}$ Schütz, S., Anselm Kiefer - Geschichte als Material. Arbeiten 1969-1983. Köln, 1990. pp. 87ff.

${ }^{108}$ Zie: hoofdstuk 4, paragraaf 1 ; hoofdstuk 5 , de paragrafen 4 en 5.

${ }^{109}$ Habermas, a.w., p. 386.

110 idem, pp. 311-464. Zie eveneens: hoofdstuk 4, paragraaf 1.
} 
Terecht kent Habermas aan de post-nietzschiaanse Franse filosofie een sleutelrol toe bij het tot stand komen van de 'nieuwe onoverzichtelijkheid'. (De 'oude' was die, waaraan Lukács paal en perk probeerde te stellen). Met name voor de groep rond het dikwijls met Nieuw Rechts in verband gebrachte underground-blad Der Pfahl, waarmee ook de Botho Strauss van Anschwellender Bocksgesang sympathiseert, kan de betekenis van deze Franse Aufarbeitung van het post-nietzschiaanse denken moeilijk worden overschat. ${ }^{111}$ Hierin schuilt tevens een belangrijk verschil tussen Strauss en Syberberg. De invloed van Foucault, Gilles Deleuze, Jean-Pierre Faye of Philippe Lacoue-Labarthe, die hij tot zijn bewonderaars mag rekenen, is te verwaarlozen gering. Al voelt ook hij zich begin jaren ' 80 nog meer verwant met deze intellectuelen "uit dat Frankrijk, dat tegenwoordig vaak zoveel fijngevoeliger en vrijer is als het erom gaat de Duitse geest te begrijpen, te eren en te redden," 112 dan met willekeurig welke conservatieve of rechtse stroming in eigen land. Pas halverwege de jaren ' 80 , als hij zich geleidelijk aan begint los te maken uit het links-liberale vertoog, worden de eerste tekenen van een verwijdering zichtbaar. Bijvoorbeeld in een passage van het pamflet Der Wald steht schwarz und schweiget (1984), waarin hij uitvoerig stil staat bij een ontmoeting met de filosoof Gérard Grand, één van de leermeesters van Lacoue-Labarthe:

"Ik beluister hoe hij verbanden legt tussen Nietzsche en Heidegger, dwarsverbanden die me tot dan zijn ontgaan. (...) En als ik hem vertel over mijn rationele relatie tot ruïnes (...), knikt hij instemmend en mompelt: "Het is het verzet, uw symbool van het verzet'. Maar als ik in de loop van de discussie kom te spreken over mijn voornemen om Parsifal (...) op te voeren in Venetië naar aanleiding van de honderdste sterfdag [van Richard Wagner, G.G.], of in Rome op de plekken van de christenvervolging, of in Montségur, wordt hij nerveus en heeft het over drive-in bioscopen, waarin men vrij in- en uit kan lopen, hetgeen democratisch zou zijn. Dan komt plotseling de 68-er te voorschijn. (...) Er liebt Nietzsche und Heidegger und findet schöne Worte zu Syberberg. Aber es ist leichter, einen Toten zu ehren, er kann nicht stören."113

En deze verwijdering is wederzijds. Mede als gevolg van de opkomst van de Nouvelle Droite, lijkt men er aan gene zijde van de Rijn in de loop van de jaren ' 80 meer alert op te zijn geworden, dat het post-nietzschiaanse denken diverse varianten kent. Zoals we zagen in het slot van het vorige hoofdstuk verschijnt in de zomer van '93 een mede door een andere leermeester van Lacoue-Labarthe, Derrida, ondertekende Oproep tot Waakzaamheid. Tegen de subversieve actie van rechts in Europa. Binnen dit intellectuele klimaat ligt een adhesiebetuiging voor de zich openlijk als rechts afficherende Syberberg van de jaren ' 90 minder voor de hand. Zoals de kritiek van Lacoue-Labarthe op deze Syberberg onderstreept. $^{114}$

Begin jaren ' 80 kan van kritiek echter nog geen sprake zijn. In die dagen wordt Syberberg in Frankrijk nog door onder meer Lacoue-Labarthe geprezen als een belangwekkend dichter-denker, die met het Hitler-postscriptum Die freudlose Gesellschaft 'een van de beste boeken überhaupt over het naoorlogse Duitsland' zou hebben geschreven. En in tegenstelling tot de auteurs van de in hoofdstuk 4 besproken Angelsaksische commentaren, kan deze filosoof moeilijk van een inschattingsfout worden beticht. Hij is zich ten volle ervan bewust, waar het de Hitler-regisseur om te doen is: treuren over het verlies van Duitsland als geestelijke mogelijkheid en over het verlies van de geestelijke

\footnotetext{
${ }^{111} \mathrm{Zie}$ : hoofdstuk 7 , paragraaf 8.

112 Syberberg, H.J., Winifred Wagner - Symbol unserer Vergangenheit. in: Die Zeit. 12 (1980). p. 41.

${ }^{113}$ Syberberg, Der Wald, a.w., pp. $358 \mathrm{f}$.

114 Zie: hoofdstuk 7 , paragraaf 8.
} 
mogelijkheden van de Duitse kunst. Middels een subtiele en tegelijk gewelddadige strategie van herijking wordt de 'Duitse geest' in bescherming genomen tegen zowel het misbruik door de nazi's als de 'neo-filosofische flater' dat Herder of Schlegel, Fichte of Nietzsehe het nazisme reeds in potentie zouden bevatten. ${ }^{115}$ In het Westduitse linkse cultuurdebat van de jaren ' 70 is dit een afwijkend geluid - dermate afwijkend zelfs, dat de kunsthistoricus Georg Bussmann (1988) spreekt over een 'nieuw geluid'. "16 Maar het is wel een geluid, dat zich weldra steeds sterker zal gaan doorzetten - niet slechts in de filosofie, maar ook in de kunsten, waarin in de loop van de jaren ' 80 een soort copernicaanse wending plaats vindt in de omgang met het 'besmette' culturele erfgoed. En met Bussmann, Walter Grasskamp en Eckhart Gillen ben ik van mening, dat de cultuurhistorische betekenis van Syberbergs werk hierin dient te worden gezocht: als één van de eersten heeft hij een aanvang gemaakt met het 'opnieuw opeisen van al datgene, wat in de totale verdringing van alle door de nazi's misbruikte waarden en begrippen was verloren gegaan' (Gillen). ${ }^{117}$

Toch is het onbehagen van Habermas niet geheel uit de lucht gegrepen. De basisassumptie van de 'irrationalisme'-kritiek, dat 'wat door het nazisme werd misbruikt zelf aan dit misbruik niet geheel zonder schuld kon zijn' (Grasskamp), "18 mag dan een 'neofilosofische flater' (Lacoue-Labarthe) zijn; Syberbergs ontwikkeling roept wel de vraag op, hoever je kunt gaan met het terugveroveren van 'geoccupeerd' materiaal. Het antwoord op deze vraag is uiteraard sterk afhankelijk van de persoonlijke levensbeschouwing. Voor een linkse post-nietzschiaan als Lacoue-Labarthe, die de Diamat achter zich heeft gelaten, ligt de grens al een stuk verder als voor een post-nietzschiaanse neo-marxist als Bloch, die (althans in zijn eigen beleving) nog wel een dialectisch-materialistische revisie nastreeft. En de late Syberberg rekt deze grens nog wat verder op. We weten waar de denkweg, die ooit begon in het Brecht-theater in Oost-Berlijn, is geëindigd. Namelijk bij de meest radicale variant van de Gegenaufklärung: een door Ernst Jünger, Martin Heidegger, Carl Schmitt en - bovenal Hans Sedlmayr geïnspireerde filosofie van de Bodenständigkeit, die door vriend en vijand wordt verguisd als antisemitisch en fascistoïde. Maar heeft niet ook hij het recht 'de ontwikkeling van een vrij mens door te maken', zoals Botho Strauss dat voor zichzelf opeist in zijn briefwissel met de redactie van Theater Heute? Hoe dan ook dwingt het 'verdwijnen van de dominantie van het sociaal-kritische paradigma' (Dassen en Nijhuis) tot een zekere terughoudendheid. Op dit punt kan ik wel een eind meegaan met Strauss' suggestie in een repliek aan Bubis (1994), dat de links-liberale intelligentsia opnieuw zal moeten leren "differentie te verdragen"." Let wel: dit betekent niet, dat neo-conservatieven als Strauss of Syberberg met zachte handschoenen zouden moeten worden aangepakt. Het is het volste recht van een ieder op te komen voor de eigen levensbeschouwing, door wat hem of haar niet aanstaat aan die van een ander te benoemen en met kracht tegen te spreken. 'Differentie verdragen' betekent slechts aanvaarden, dat een meningsverschil soms zo fundamenteel kan zijn dat consensus ten enen male onmogelijk is en de ander in zijn waarde laten door hem intellectueel recht te doen. En daarvan was vooral in de Duitse Syberberg-receptie in het verleden weinig te merken. "Indien woorden konden doden, was Syberberg, althans op papier, een dode man," concludeert Lothar Baier in zijn balansopname van het rumoer rond Vom Unglück und Glück der Kunst in Deutschland nach dem letzten Kriege. ${ }^{120}$ In dat geval zou Syberberg echter op papier reeds rond 1980 een dode man zijn geweest. Van meet af aan

\footnotetext{
${ }^{115}$ Zie: hoofdstuk 7 , de paragrafen 7 en 8.

${ }^{116}$ Zie: hoofdstuk 6, paragraaf 8.

${ }_{117}$ Zie: hoofdstuk 6, paragraaf 8; hoofdstuk 7, paragraaf 7

118 idem.

119 Strauss, B., Der eigentliche Skandal. in: Der Spiegel. 16 (1994). pp. $168 \mathrm{f}$.

${ }^{120}$ Baier, a.w., pp. 118.
} 
hebben zijn criticasters 'het meest scherpe wapen' (Baier) te voorschijn gehaald, dat in onze post-nazistische democratieën tot hun beschikking staat: het nazisme-verwijt.

Die tijd ligt nu achter ons. Het linkse cultuurdebat is een zachte dood gestorven. De conventies van de 'irrationalisme'-kritiek zijn op de vuilstortplaats van de geschiedenis beland. En daarmee ook die "onzalige drie-eenheid denkverbod, taboeïsering, stigmatisering" (Walter Kowalsky), die het intellectuele klimaat in Oost en West decennia lang op verstikkende wijze heeft gedomineerd. ${ }^{121}$ Op zijn laatst sinds de What's right, what's left? Debatte lijkt de linkerflank van de Bondsrepubliek zich te hebben verzoend met de gedachte, dat een nieuwe, zichzelf rechts noemende intelligentsia is opgestaan die 'zich vrijheden permitteert waarin de Frankfurter Schule niet heeft voorzien'. Maar de ironie wil, dat uitgerekend deze liberalisering voor Syberbergs kunstenaarschap funest blijkt te zijn. Het is beslist geen toeval, dat hij zijn meest indrukwekkende werk, Hitler, ein Film aus Deutschland, heeft gemaakt in een tijd waarin de polarisatie op haar hoogtepunt was en de Betroffenheitskult bloeide als nadien nooit meer. Juist binnen dit repressieve intellectuele klimaat kon zijn kunstenaarschap gedijen. "feinde / sind ortsschilder, auf die ist verlass", dicht een andere leerling van Brecht, Wolf Biermann. ${ }^{122}$ En ten tijde van de oude Bondsrepubliek wist Syberberg nog feilloos wie zijn vijanden waren. Hij kende hun zwakheden, sprak hun taal, speelde met een achteraf vaak verbluffende behendigheid het spel van de kat en de muis. Bekijk je tegenwoordig een film als Hitler, dan is het volstrekt duidelijk waardoor de maker indertijd werd bewogen. Het is dezelfde "pure walging voor de heersende hysterie van het media- en cultuurestablishment" (Clemens-Peter Haase), die ook een tekst als Anschwellender Bocksgesang doortrekt, ${ }^{123}$ waaruit hij decennialang de energie heeft geput die hij nodig had om zich intellectueel en artistiek te kunnen vernieuwen. Sinds de Wende van 1989-1990 zijn 'de plaatsnaamborden' echter verschoven. Dit betekent dat ook Syberberg zal moeten umdenken, wil hij niet eindigen als een soort Ridder van de Droevige Figuur die een kwijnend bestaan leidt in een niche van het World-Wide Web. Dat hij hiertoe kennelijk niet langer in staat is mag gerust veelzeggend worden genoemd voor de mate, waarin zijn eigen wereldbeeld is vergroeid met een cultuurdebat, dat we in deze studie gedurende diverse fasen hebben gevolgd, van zijn ontstaan in het interbellum tot aan zijn zwanenzang in de jaren ' 90 .

\footnotetext{
${ }^{121}$ Kowalsky, W., Comeback oder Abgesang der Rechtsintellektuellen? in: Die neue Gesellschaft / Frankfurter Hefte. a.w., pp. 830-834.

${ }_{122}$ Biermann, W, Vom Lesen in den Innerein. in: Affenfels und Barrikade. Gedichte / Lieder / Balladen. Köln, 1996.

${ }^{123}$ Haase, C.P., Die rehabilitierung des Konservatismus. in: Die Neue Gesellschaft / Frankfurter Hefte, a.w., pp. 794-800, zie: p. 799.
} 


\section{Bronnen}

\section{A. Primair}

\section{De werken}

\section{De vroege films}

- Fünfter Akt, siebente Szene. Fritz Kortner probt Kabale und Liebe (1965)

Bayerischer Rundfunk. Documentaire. $110 \mathrm{~min}$. Zwart-wit. $16 \mathrm{~mm}$. Scenario: H.J. Syberberg. Camera: Konrad Wickler, Kurt Lorenz. Met: Fritz Kortner, Helmut Lohner, Christiane Hörbiger.

- Romy , Anatomie eines Geschichts (1965)

Rob-Houwer-Filmproduktion. Documentaire. $90 \mathrm{~min}$. Zwart-wit. $16 \mathrm{~mm}$. Scenario: H.J. Syberberg. Camera: Kurt Lorenz. Met: Romy Schneider.

- Fritz Kortner spricht Monologe für eine Schallplatte (1966)

Syberberg Filmproduktion / Preiser Records. Documentaire. 90 min. Zwart-wit. 35 mm. Scenario: H.J. Syberberg. Camera: Kurt Lorenz, Mac Lloyd, G. Hamory. Met: Fritz Kortner.

- Wilhelm von Kobell (1966)

Syberberg Filmproduktion. Documentaire. 15 min. Kleur. $35 \mathrm{~mm}$.

- Die Grafen Pocci (1967)

Syberberg Filmproduktion. Documentaire. $90 \mathrm{~min}$. Kleur. $35 \mathrm{~mm}$. Scenario: H.J. Syberberg. Camera: Kurt Lorenz, M. Lippi. Met: Konrad Pocci.

- Scarabea-Wieviel Erde braucht der Mensch? (1968)

TMS Film GmbH. Speelfilm. $130 \mathrm{~min}$. Kleur. $35 \mathrm{~mm}$. Scenario: H.J. Syberberg, naar een novelle van Tolstoj. Camera: Petrus Schloemp. Met: Walter Buschof, Nicoletta Macchiavelli, Franz Graf Treuberg e.a..

- Sex-Business made in Pasing (1969)

TMS Film GmbH. Documentaire. $100 \mathrm{~min}$. Zwart-wit. $16 \mathrm{~mm}$. Scenario: H.J. Syberberg. Camera: Christian Blackwood. Met: Alois Brummer.

- San Domingo (1970)

TMS Film GmbH. Speelfilm. 138 min. Zwart-wit. 16/35 mm. Scenario: H.J. Syberberg, naar een novelle van Kleist. Camera: Christian Blackwood. Muziek: Amon Düül. Met: Alice Ottawa, Michael König, leden van de Rode Cellen Germanistiek van de Universiteit München e.a..

- Nach meinem letzten Umzug.../ Syberberg filmt bei Brecht (1970)

TMS Film GmbH. Documentaire, bewerking van $8-\mathrm{mm}$ materiaal uit $1953.72 \mathrm{~min}$. Zwart-wit en kleur. $35 \mathrm{~mm}$. Scenario: H.J. Syberberg i.s.m. Hans Mayer (commentaar). Camera: H.J. Syberberg. Met: Curt Bois, Helene Weigel, Heinz Schubert e.a..

\section{De Graal}

- Ludwig - Requiem für einen jungfräulichen König (1972)

TMS Film GmbH / Zweites Deutsches Fernsehen. Speelfilm in twee delen. 134 min. Kleur. 16/35 mm. Scenario: H.J. Syberberg. Camera: Dietrich Lohmann. Met: Harry Baer, Peter Kern, Ingrid Caven e.a.. 
- Theodor Hierneis oder: Wie man ehem. Hofkoch wird (1972)

TMS Filmproduktion GmbH. Gedramatiseerde documentaire. 90 min. Kleur. $16 \mathrm{~mm}$.

Scenario: H.J. Syberberg, naar de memoires van Theodor Hierneis. Camera: Hermann Reichmann. Met: Walter Sedlmayr.

- Karl May - Auf der Suche nach dem verlorenen Paradies (1974)

TMS Film GmbH. Speelfilm. $187 \mathrm{~min}$. Kleur. $35 \mathrm{~mm}$. Scenario: H.J. Syberberg. Camera:

Dietrich Lohmann. Met: Helmut Käutner, Kristina Söderbaum, Käthe Gold e.a..

- Winifred Wagner und die Geschichte des Hauses Wahnfried von 1914-1975 (1975)

TMS Film GmbH i.s.m. Bayerischer Rundfunk. Documentaire. 302 min. Zwart-wit. 16 mm. Camera: Dietrich Lohmann. Met: Winifred Wagner-Williams.

- Hitler, ein Film aus Deutschland (1977)

TMS Film GmbH / WDR / INA / BBC. Speelfilm in vier delen. 440 min. Kleur. $35 \mathrm{~mm}$. Scenario: H.J. Syberberg. Camera: Dietrich Lohmann. Met: André Heller, Heinz Schubert, Amelie Syberberg e.a..

- Parsifal (1982)

TMS Film GmbH / Bayerischer Rundfunk / Gaumant. Filmopera. 255 min. Kleur. 35 mm. Scenario: H.J. Syberberg, naar Wagners muziekdrama. Camera: Igor Luther. Muziekuitvoering: Orchestre Philharmonique de Monte Carlo o.l.v. Armin Jordan / Choeur Philharmonique de Prague o:l.v. Josef Veselka. Solisten: Yvonne Minton, Wolfgang Schöne, Robert Lloyd e.a.. Met: Edith Clever, Armin Jordan, Robert Lloyd e.a..

- Parsifal (1982)

Documenta 7. Installatie.

\section{Requiem voor het einde van Pruisen.}

- Die Nacht (1984)

TMS Film Gmbh. Stage-reading in twee delen. $360 \mathrm{~min}$. Kleur. $35 \mathrm{~mm}$. Teksten van Seattle/Smith, Möricke, Nietzsche, Heine, Céline, Shakespeare, Kleist, Goethe, Wagner, Hölderlin, Plato, Beckett, Schiller, Aeschylus, Heidegger, Pythagoras, Sophocles, M. Claudius, Bachmann, Marianne v. Willemer, Syberberg. Camera: Xaver Schwarzenberger. Met: Edith Clever.

- Edith Clever liest Joyce - Der Monolog der Molly Bloom aus dem letzten Kapitel der Ulysses (1986)

Syberberg Filmproduktion / Österreichischer Rundfunk (ORF). Stage-reading. $180 \mathrm{~min}$. Kleur. Video. Tekst: James Joyce. Camera: H.J. Syberberg. Met: Edith Clever.

- Fräulein Else (1986)

Syberberg Filmproduktion. Stage-reading. 116 min. Kleur. Video. Tekst: Arthur Schnitzler. Camera: H.J. Syberberg. Met: Edith Clever.

- Penthesilea (1987/88)

TMS Film GmbH. Stage-reading. 240 min. Kleur. Video. Tekst: Heinrich von Kleist. Camera: H.J. Syberberg. Met: Edith Clever.

- Die Marquise von O... (1989)

TMS Film GmbH. Stage-reading. 224 min. Kleur. Video. Tekst: Heinrich von Kleist. Camera: H.J. Syberberg. Met: Edith Clever.

- Ein Traum, was sonst? (1990/91)

Syberberg Filmproduktion. Stage-reading. $150 \mathrm{~min}$. Kleur. Video. Teksten van Euripides, Goethe, Kleist. Camera: H.J. Syberberg. Met: Edith Clever. 


\section{Het late werk.}

- Cave of Memory (1997)

Syberberg Filmproduktion/Documenta X/Hebbel Theater Berlin. Installatie.

- Das Nossendorf-Projekt (2001-)

Internetsite.

\section{De geschriften}

- Syberberg, H.J., Zum Drama Friedrich Dürrenmatts. Zwei Modellinterpretationen zur Wesensdeutung des modernen Dramas. München, 1963.

- Syberberg, H.J. (Hrsg.), Theodor Hiernies. Ein Mundkoch erinnert sich an Ludwig II. z.p., 1972.

- Syberberg, H.J., Winifred, Wahnfried und wir. in: Zeitmagazin. 18 (1976). pp. 18-53.

- Syberberg, H.J., Syberbergs Filmbuch. München, 1976.

- Syberberg, H.J. (Hrsg.), Fotografie der 30er Jahre. Eine Anthologie. München, 1977.

- Syberberg, H.J., Es herrscht ein ungutes Klima in diesem Land, brutal und tötend. 'Hitler' - noch nicht für Deutschland. Warum sein 'Hitler'-Film nicht bei uns läuft. in: Die Zeit. 3 (1978).

- Syberberg, H.J., Die Kunst als Rettung aus der deutschen Misere. Ein Essay. in: Hitler, ein Film aus Deutschland. Hamburg, 1978.

- Syberberg, H.J., Alpträume akzeptieren. in: Frankfurter Allgemeine Zeitung. 03-03-1979.

- Syberberg, H.J., Un album de famille de cinéma / Utopies et projets / Le métier du cinéaste / Du pays mort d'une société sans joie / Au dossier d'une généalogie. in: Cahiers du Cinéma. Numéro hors-serie: Syberberg. ed. S. Daney. Paris, 1980.

- Syberberg, H.J., Eine Zeugin und eine Schuldige. in. Der Spiegel. 11 (1980). pp. 234-235.

- Syberberg, H.J., Winifred Wagner - Symbol unserer Vergangenheit. in: Die Zeit. 12 (1980).

- Syberberg, H.J., Notizen. Sommer auf dem Berg. in: Die Tageszeitung. 05-09-1980.

- Syberberg, H.J., Notizen. La 'Treue'. Hitlers Opfer: eine verlorene Generation. in: Die Tageszeitung. 22-09-1980.

- Syberberg, H.J., Die freudlose Gesellschaft. Notizen aus dem letzten Jahr. München, Wien, 1981.

- Syberberg, H.J., Parsifal. Ein Filmessay. München, 1982.

- Syberberg, H.J., To the editor. in: Art Forum. (december 1982).

- Syberberg, H.J., Gesamtkunstwerk. in: Der Hang zum Gesamtkunstwerk. Europäische Utopien seit 1800. Hrsg. S. Haen. Aurau, 1983. pp. 433-434.

- Syberberg, H.J., Der Wald steht schwarz und schweiget. Neue Notizen aus Deutschland. Zürich, 1984.

- Syberberg, H.J., The Abode of the Gods. in: Sight and Sound. International Film Quarterly. (spring 1985). p. 125.

- Syberberg, H.J., Seeing The Light. Adolphe Appia. in: The New Republic. 03-10-1988. pp. 32-36.

- Syberberg, H.J., Entgegnung. Zum Interview von André Müller. in: Die Zeit. 14-10-1988.

- Syberberg, H.J., Clever, E., Penthesilea. Berlin, 1988.

- Syberberg, H.J., Vom Unglück und Glück der Kunst in Deutschland nach dem letzten Kriege. München, 1990. 
- Syberberg, H.J., Wie man neuen Haß züchtet. Eine Stellungnahme zu den Angriffen in dieser Zeitung. in: Frankfurter Allgemeine Zeitung. 06-09-1990.

- Syberberg, H.J., Clever, E., Ein Traum, was sonst? Berlin, 1990.

- Syberberg, H.J., Over Ein Traum, was sonst? [niet gepubliceerd programmaboekje opvoering Ein Traum, was sonst? in het Brusselse Kaaitheater], 1991.

- Syberberg, H.J., Briefe über Raum. in: Theaterschrift 2. October 1992.

- Syberberg, H.J., Befreiender Einschnitt. in: Neues Deutschland. Innenansichten einer wiederverenigten Nation. Hrsg. J.D. Kögel, W. Schütte, H. Zimmermann. Frankfurt am Main, 1993.pp. 120-124.

- Syberberg, H.J., Aus der Zeit der letzten Unschuld. in: Drucksage 4. Berliner Ensemble 1953 - Syberberg filmt bei Brecht. Hrsg. Berliner Ensemble. Berlin, 1993. pp. 97-116.

- Syberberg, H.J., Eigenes und Fremdes. Über den Verlust des Tragischen. in: Die selbstbewustte Nation. 'Anschwellender Bocksgesang' und weitere Beiträge zu einer deutschen Debatte. Hrsg. H. Schwilk, U. Schacht. Frankfurt am Main, Berlin, 1994. pp. 124-133.

- Syberberg, H.J., Das Rechte - tun. München, 1995.

- Syberberg, H.J., Tönende Maske. Hans Jürgen Syberberg über seinen Parsifal-Film. in: Opernwelt. Die internationale Opernzeitschrift. 4 (1998). p. 23.

- Syberberg, H.J., Mein Jahrhundertbuch: 'Buckower Elegien' von Bertolt Brecht. in: Die Zeit. 29 (15-07-1999).

\section{Interviews en voordrachten}

- anoniem, Wirbel um offene Worte Winifreds. in: Richard Wagner, ein deutsches Thema. Eine Dokumentation zur Wirkungsgeschichte Richard Wagners 1867-1976. Hrsg. H. Zelinsky. Berlin, 1983. p. 273.

- Bilder, E., Hans Jürgen Syberberg. Amsterdam, 1983.

- Ely, N., Film aus Fortsetzung des Lebens mit anderen Mitteln... Gespräch mit Hans Jürgen Syberberg anläßlich seines Parsifal-Films. in: Neue Zeitschrift für Musik. (augustus 1982). pp. 4-7.

- Erkkila, B., Hans Jürgen Syberberg; An Interview. in: Syberberg. A Filmmaker from Germany. ed. H. Stewart. Edinburgh, 1992. pp. 27-34.

- Jansen, K., Het dodenmasker van Wagner. Hans Jürgen Syberberg over Wagner. in: NRC Handelsblad. 4-11-1983.

- Knopp, G, (Hrsg.), Hitler heute. Gespräche über ein deutsches Trauma. Aschaffenburg, 1979.

- Müller, A., Im Gespräch mit ... Hamburg, 1989. pp. 183-203.

- Pym, J., Syberberg and the Tempter of Democracy. in: Sight and Sound. International Film Quarterly. 46 (1977). pp. 227-230.

- Rayns, T., Forms of Adress. Tony Rayns interviews three German Film-Makers: Fassbinder, Wenders, Syberberg. in: Sight and Sound. International Film Quarterly. 44 (1975) 3-7.

- Revue Belge du Cinéma: Hans Jürgen Syberberg. 3 (1983).

- Roeseler, A., Dem Teufel seine Chance geben. Ein Gespräch mit Hans Jürgen Syberberg über 'Hitler, ein Film aus Deutschland'. in: Süddeutsche Zeitung. 09-12-1977.

- Rötzer, F., 'Mit kleinsten Mitteln sehr Anspruchvolles offerieren.' Gespräche über Ästhetik (III). in: Frankfurter Rundschau. 03-10-1987. 
- Roll, E., Sie hat den Glauben, ich das Bild. Edith Clever und Hans Jürgen Syberberg über ihre Arbeit an der "Penthesilea". in: Süddeutsche Zeitung. 25-06-1988.

- Schmidt, E., Der Prozeß, der Hitler im Leben erspart bleib. Bei den Dreharbeiten zu Syberbergs neuem Monsterspektakel. in: Deutsche Zeitung. 13-05-1977.

- Schiller, B,, Our Hitler as visual politics in: Performing Arts Journal. 12 (1980).

- Snell, M., Germany's heart: the modern taboe. in. New Perspectivies Quarterly. 10 (1993). pp. 20-25.

- Schwilk, H., Wir stehen fest im Sturm. in: Rheinischer Merkur / Christ und Welt. 29 (2007-1990). p. 23.

- Wiegand, W., Die deutsche Mythologie. Ein Gespräch über Hans Jürgen Syberbergs 'Parsifal'-Film. in: Frankfurter Allgemeine Zeitung. 03-04-1982.

- Winter, de, L., Het Duizendjarige Rijk als filmlokatie, in: Hollands Diep. 6 (1977). pp. 40-43.

- Zaagsma, F., Ludwig-Requiem für einen jungfräulichen König/Theodor Hiernies-oder wie man ehem. Hofkoch wird. in: Skoop. 5 (1973). 34-37.

- Interview met de auteur en Eling Delleman (niet gepubliceerd), 1991.

- Persconferentie Syberberg en Edith Clever naar aanleiding van de Brusselse opvoering Ein Traum, was sonst? (niet gepubliceerd), 1991.

- Voordracht Syberberg in het kader van het lezingenprogramma 'Honderd dagen, honderd gasten' van Documenta X (niet gepubliceerd), 1991.

\section{B. Secundair}

\section{Over Syberberg}

- anoniem, Syberberg, een omstreden cineast. in: De Telegraaf. 27-10-1983.

- anoniem, Syberberg: een genie waar je toevallig tegen moet kunnen. in: Utrechts Nieuwsblad. 24-11-1983.

- anoniem, Hans Jürgen Syberberg. Alweer een genie uit Duitsland. in: Nieuwsblad van het Noorden. 25-11-1983.

- anoniem, La nostalgie? I1 ne connaissent pas! Syberberg et Edith Clever au Kaaitheater. in: Le Soir. 21-06-1991.

- Bachmann, C.H., Eine Filmoper, die Kundry heisst. Hans Jürgen Syberbergs ParsifalVersion. in: Schweizerische Muzikzeitung./Revue musicale Suisse. 1982. pp. 338-341.

- Baier, L., Eine ungeheurliche Neuigkeit? Nachfragen zur Debatte um den Pamphlettisten Syberberg. in: Neue Rundschau. 1 (1991) pp. 117-130.

- Baumgart, R., Parsifal 1982 in Bayreuth, bei Syberberg und in Dorsts 'Merlin'. in: Theater Heute. 10 (1982) pp. 18-23.

- Berg, R, von, Deutschland, ein Film von Hitler. Hans Jürgen Syberberg im Echo der amerikanische Presse. in: Süddeutsche Zeitung. 28-02-1980.

- Berliner Ensemble (Hrsg.), Drucksage 4. Berliner Ensemble 1953 - Syberberg filmt bei Brecht. Berlin, 1993.

- Berman, R.A., Hans Jürgen Syberberg. Of Fantastic and Magical Worlds. in: New German Filmmakers. From Oberhausen through the 1960s. ed. K. Phillips. New York, 1984. pp. 359-404. 
- Biette, J.C., Winifred Wagner. (Hans Jürgen Syberberg) in: Cahiers du Cinéma. (octobre 1979). pp. 46-47.

- Blackbourn, D., The Big Show. in: London Review of Books. (3-17 march 1983). pp. 910.

- Blumenberg, H.C., Träume in Trümmern. Hans Jürgen Syberbergs Hitler. in: Kinozeit. Aufsătze und Kritiken zum modernen Film 1976-1980. Frankfurt am Main, 1980. pp. 139142.

- Bohrer, K.H., Deutschland - noch eine geistige Möglichkeit? Bemerkungen zu einem nationalen Tabu. in: Frankfurter Allgemeine Zeitung. 28-04-1979

- Bonitzer, P., Notes sur quelques films de Cannes qui ont marqué. Et sur d'autres qui ont moins marqué. in: Cahiers du Cinéma. (août, 1982). pp. 11-12.

- Boogaard, J., van den, Syberberg pleit voor Duitse cultuur zonder 'joods-linkse' invloed. in: NRC Handelsblad. 19-10-1990.

- Brock, B., The End of Avant-Garde? And so the End of Tradition? Notes on the Present 'Kulturkampf' in West Germany. in: Art Forum. (Summer 1981) pp. 62-67.

- Brock, B., Syberbergs Hitler-Film. Wer Schuld nicht will, verliert Geschichte. in: Die Gottsucherbande - Ästhetik gegen erzwungere Unmittelbarkeit. Schriften 1978-1986. Köln, 1986. pp. 441-443.

- Brock, B., Der Hang zum Gesamtkunstwerk. Pathosformeln und Energiesymbolen zur Einheit von Denken, Wollen und Können. in: Der Hang zum Gesamtkunstwerk. Europäische Utopien seit 1800. Hrsg. S. Haen. Aurau, 1983. pp. 22-39.

- Brockmann, S., Syberberg's Germany. in: The German Quarterly. 69.1 (winter 1996). pp. 48-62.

- Brunette, P., Ludwig: Requiem for a virgin king. in: Film Quarterly. (spring 1981) pp. 58-61.

- Buckley, T., At the movies. in: The New York Times. 23-03-1979.

- Buruma, I., There's No Place Like Heimat. in: The New York Review of Books. 20 (1990). pp. 34-38.

- Bussmann, G., 'Ich kann beim besten Willen kein Hakenkreuz erkennen'. in: Faszination und Gewalt. Zur politischen Ästhetik des Nationalsozialismus. Hrsg. B. Organ, W. Weiß. Nürnberg, 1992. pp. 291-294.

- Corrigan, T., The Exorcism of the Image: Syberberg's Hitler. in: New German Cinema: The Displaced Image. Austin, 1983.

- Daney, S., L'État Syberberg. in: La Rampe. Paris, 1983.

- Daney, S., Syberberg dans la tête de Wagner. in: Ciné-Journal. Paris, 1986. pp. 61-67.

- Daney, S. (ed.), Cahiers du Cinéma. Numéro hors-serie: Syberberg. Paris, 1980.

- Donner, W., 'Hitler' nach Deutschland! in: Die Zeit. 23-12-1977.

- Dusek, P., Alltagsfaschismus in Österreich. in: Zeitgeschichte. 1-12 (1979). pp. 110-115.

- Eder, K. (Hrsg.), Syberbergs Hitler-Film. Texte von Susan Sontag, Jean-Pierre Faye, Jean-Pierre Oudart, Christian Zimmer, Michel Foucault, Bernard Sobel, Alberto Moravia, Vito Zagarrio, Heiner Müller. München, Wien, 1980.

- Elsaesser, Th., Myth as the Phantasmagoria of History: Hans Jürgen Syberberg, Cinema and Representation. in: New German Critique. 24-25 (fall/winter 1981-1982). pp. 108154.

- Elsaesser, Th., New German Cinema. A History. London, 1989.

- Elsaesser, Th., Filming Fascism: Is History Just an Old Movie? in: Sight and Sound. International Film Quarterly. 5 (1992). pp. 18-21.

- Elsaesser, Th., Hitler, ein Film aus Deutschland. in: Sight and Sound. International Film Quarterly. 5 (1992). pp. 49-50. 
- Elsaesser, Th., Subject Positions, Speaking Positions: From 'Holocaust', 'Our Hitler' and 'Heimat' to 'Shoah' and Schindler's List. in: The Persistence of History. ed. V. Sobchack. New York, 1995. pp. 235-287.

- Fabian, I., Die Schallplattenaufnahme zum Jubliläum. Wagners Parsifal unter Armin Jordan - Die Musikaufnahme zu H.J. Syberbergs Parsifal-Film. in: Oper-Jahrbuch der Zeitschrift Opernwelt. Hundert Jahre Parsifal. Bilanz, Aspekte. Hrsg. I. Fabian. Zürich, 1982.

- Falcke, E., Die Ästhetik des Ganzen, des Wiedervereinens. in: Süddeutsche Zeitung. 0909-1990.

- Farocki, H., Buch: Hitler, ein Film aus Deutschland. in: Filmkritik. maart 1980. p. 142143.

- Ferron, L., Winifred Wagner. De laatste der grote cocottes. in: Hollands Diep. 12 (04-121976) pp. 30-32.

- Fischer, R., Hembus, J., Der Neue Deutsche Film. München, 1980, pp. 70-72, 135-137.

- Förg, G., Der Schlaf der Vernunft gebiert Monstern. Eine Collage zu Hans Jürgen Syberberg. in: Unsere Wagner: Joseph Beuys, Heiner Müller, Karlheinz Stockhausen, Hans Jürgen Syberberg. Hrsg. G. Förg. Frankfurt am Main, 1984. pp. 124-205.

- Franklin, J., The New German Cinema: From Oberhausen to Hamburg. London, 1983. pp. 163-177.

- Friedländer, S., Kitsch und Tod. Der widerschein des Nazismus. Ubersetzt von M. Grendacher. München, Wien, 1982, 1984.

- Gerhardt, D., Verzweiflungstat eines Grossbürgers. in: Sammlung: Jahrbuch für antifasischtische Literatur und Kunst. Frankfurt am Main, 1981. pp. 128-133.

- Gessner, P., The Day They Quit Making the Beetle. Francis Coppola may distribute new Hitler epic. in: Seven Days. 14-08-1979.

- Goldschmidt, G.A., Am deutschen Wesen. in: Theater Heute. 11 (1984). pp. 8-9.

- Günther, W., Winifred Wagner und die Geschichte des Hauses Wahnfried. in: Medium. (mei 1976). pp. 32-33.

- Goossens G., Een heilige misdaad in: Feit \& Fictie. Tijdschrift voor de geschiedenis van de representatie. 4 (1996). pp. 64-80

- Goossens, G., Op bezoek bij de 'zwarte weduwe'. in: Ex Tempore. Historisch Tijdschrift KU Nijmegen. 14 (1995). pp. 103-114.

- Goossens, G., Het reactionaire kunstwerk. Syberbergs 'Kehre'. in: Krisis. Tijdschrift voor filosofie. 61 (1995). pp. 41-50

- Goossens, G., Pott, H., Syberbergs oorlog. Cinema en geschiedschrijving. in: Hermeneutiek en cultuur. Interpretatie in de kunst- en cultuurwetenschappen. red. F.R. Ankersmit e.a.. Amsterdam, 1995. pp. 70-96

- Grundbacher, F, Horror vor dem Krieg und der Liebe. in: Die Welt. 25-11-1987.

- Haacke, H., To the editor. in: Art Forum. (December 1982). pp. 3-4.

- Hamm, P., Syberbergs Kampf. Der Regisseur des Hitler-Films als Autor. in: Die Zeit. 31 06-1981.

- Hanimann, J., Die Königin: wer sonst? Edith Clevers 'Penthesilea' oder Das preußische Arkadien / Hans Jürgen Syberbergs Kleist-Inszenierung in Paris. in: Frankfurter Allgemeine Zeitung. 17-11-1987.

- Heer, E., van, Een droom uit Duitsland. 'Ein Traum, was sonst?': de beroemde Duitse actrice Edith Clever komt voor het eerst naar Vlaanderen. in: Knack. 25 (1991). p. 114.

- Heijs, J., Afbraak van mythes in de nieuwe Duitse film: Amerika en Hitler. in: Wending. (mei 1981) pp. 302-305. 
- Heise, E., Offener Brief an Hans Jürgen Syberberg. in. Die Frankfurter Allgemeine. 0303-1979.

- Henrichs, B., Die kühne Sängerin. Theater in Paris: Edith Clever deklamiert und spielt Kleists 'Penthesilea'. in: Die Zeit. 48 (20-11-1987).

- Hertmans, S., Syberberg als Amfortas: een pastorale wonde. in: Etcetera. Tijdschrift over Theater. 35 (1991). pp. $42-43$.

- Hoberman, J., Hitler, A Script from Germany. in: American Film. Magazine of the Film and Television Arts. (november 1982). pp. 76-81.

- Höhne, P., Hitler, der größte Fílmemacher aller Zeiten. in: Medium. 2 (1980) pp. 38-40.

- Jameson, F., In the Destructive Element Immerse: Hans Jürgen Syberberg and Cultural Revolution. in: October 17. (summer 1981). pp. 99-118.

- Jelenski, C., 'Hitler', film cathartique d'Allemagne. in: La Quinzaine Littéraire. 16 (3009-1978). p. 21.

- Jerziorkowski, K., Das Glück der Wurzelbürste. in: Der Splegel. 35 (1981).

- Kaes, A., From Hitler to Heimat. The Return of History as Film. Cambridge, Mass., London, 1989.

- Kaes, A., Holocaust and the End of History: Postmodern Historiography in Cinema. in: Probing the Limits of Representation. Nazism and the 'Final Solution'. ed. S. Friedländer. Cambridge, Mass., London, 1992. pp. 206-222.

- Karasek, H., Frühling für Hitler. Zu einem Buch des unverbesserlichen Hans Jürgen Syberberg. in: Der Spiegel. 36 (1990). pp. 240-245.

- Kauffmann, S., Dreaming of Hitler. in: The New Republic. 02-02-1980. pp. 24-26.

- Koch, G.R., Syberbergs Bekenntnisse. in: Frankfurter Allgemeine Zeitung. 20-03-1980.

- Koshar, R., Hitler, a Film from Germany. in American Historical Review. (oktober 1991) pp. $1122-1124$

- Koshar, R, Hitler, a Film from Germany. Cinema, History, and the Structures of Feeling. in: Revisioning History. Film and the Construction of a New Past. ed. R.A. Rosenstone. Princeton, 1994. pp. 155-173.

- Kosler, H.C., Augenmensch mit Schaum vorm Mund. in: Frankfurter Allgemeine Zeitung. 11-12-1984.

- Kroon, H., Ludwig, kruispunt van ideeën. in: De Waarheid. 26-01-1980.

- Kroon, H., Oers, F., van, Dolen door Duitslands dromen. in: De Waarheid. 29-10-1983.

- Kroon, H., Rouwend naar het paradijs. Hans Jürgen Syberbergs 'Die Nacht'. in: VPRO Gids. 15-11-1986.

- Kuhlbrodt, D., Preußische Filmästhetik und ihre Strategien. in: Preussen. Versuch einer Bilanz. Band 5. Preussen im Film. Eine Retrospektive der Stiftung Deutsche Kinemathek. Hrsg. A. Marquardt, H. Rathsack. Hamburg, 1981. pp. 74-97.

- Kühnl, R. Einübung ins Irrationale. in: Sammlung. Jahrbuch für antifaschistische Literatur und Kunst. Frankfurt am Main, 1981. pp. 134-137.

- Kuyper, E., de, Boekbespreking. in: Streven. October 1977. pp. 95-96.

- Lacoue-Labarthe, Ph., Heidegger, Art and Politics. The Fiction of the Political. Translation by Ch. Turner. Cambridge, Massachusetts, Oxford, 1990. pp. 61-76.

- Lacoue-Labarthe, Ph., Syberberg: Über Deutschland nach Hitler. in: Politics / Poetics. Hrsg. Documenta X. Kassel, 1997. pp. 480-484.

- Lange, L.L., Facing Hitler, Facing Ourselves: Syberbergs Hitler, a Film from Germany. ed. The Simon Wiesenthal Center. in: www. wiesenthal.com

- Landy, M., Politics, Aesthetics, and Patriachy in The Confessions of Winifred Wagner. in: New German Critique. 18 (1979). pp. 151-166. 
- Lardeau, Y., Un conte d'hiver. (Hitler, un film d' Allemange) in: Cahiers du Cinéma. (février 1979). pp. 67-68.

- Ladeau, Y., La prehistoire du cinema. 'Parsifal' de Hans Jürgen Syberberg in: Cahiers $d u$ Cinéma. (août 1982). pp. 50-56.

- Lardeau, Y., L'Art dans tous ses états. Deux livres de Syberberg. in: Cahiers du Cinéma. (janvier, 1983).

- Lehmann, H.T., Die Raumfabrik - Mythos im Kino und Kinomythos. in: Mythos und Moderne. Hrsg. K.H. Bohrer. Frankfurt am Main, 1983. pp. 572-609

- Lettau, R., Im Schweiße von Wagners Angesicht. in: Der Spiegel. 49 (1977). pp. 217 218.

- Mattheus, B., Schmutz, Schmerz. Ein neues Deutschland, eine neue Kultur? Hans Jürgen Syberbergs entfesseltes Manifest für eine Wiedergeburt des Schönen, Wahren, Guten. in: Rheinischer Merkur / Christ und Welt. 29 (1990).

- Matussek, M., 'Ich hielt bei Peter Stein um ihre Hand an." Über Edith Clever und Hans Jürgen Syberberg. in: Der Spiegel. 15 (1988). pp. 218-224.

- Meier, G.D., Nachdenken über Winifred Wagner. in: www.Festspiele.de

- Mohal, A., Paris applaudiert dem deutschen Ruinentheater. in: Süddeutsche Zeitung. 0210-1984.

- Mueller, R., Hans Jürgen Syberberg's Hitler. An Interview - Montage. in: Discourse: Berkeley Journal for Theoretical Studies in Media and Culture. 2 (1980). pp. 60-82.

- Nenning, G., Auf deutschem Roß. Die neue Kunst ist groß, und Syberberg ist ihr Prophet. in: Die zeit. 27-07-1990.

- Nenning, H.A., Der standhafte Filmsoldat Hans Jürgen Syberberg. in: Stuttgarter Zeitung. 07-11-1981.

- Overbey, D.L., From Murnau to Munich. in: Sight and Sound. International Film Quarterly. 43 (1974).pp. 101-103.

- Overbey, D.L., Ludwig's Cook. in: Sight and Sound. International Film Quarterly. 43 (1974). pp. 213-214.

- Peter, J., Bibliografie van kritieken op het werk van Hans Jürgen Syberberg. Verschenen in het Engels, Frans, Duits en Nederlands. [niet gepubliceerd], 1986.

- Platzdasch, G., Mechanismen der Gleichschaltung. in: Criticón. 71 (mei, juni, 1982). pp. 129-130.

- Rahe, B., Notwendige Trauerarbeit. in: Sammlung: Jahrbuch für antifaschistische Literatur und Kunst. Frankfurt am Main, 1981. pp. 119-123.

- Rayns, T., Requiem for a Vergin King. in: Sight and Sound. International Film Quarterly. 43 (1974).

- Reijnders, F., Verdwijnpunt object. in: Van het postmodernisme. red. J. Boomgaard, S. Lopez. Amsterdam, 1985. pp. 113-137.

- Rexroth, D., Winifred Wagner, das Haus Wahnfried - und Adolf Hitler als 'Mensch'. in: Richard Wagner, ein deutsches Thema. Ein Dokumentation zur Wirkungsgeschichte Richard Wagners 1867-1976. Hrsg. H. Zelinsky. Berlin, 1983. p. 272.

- Rumler, F., 'Ohne Irrationalismus ist Deutschland nichts.' Über den Hitler-Filmregisseur Hans Jürgen Syberberg. in: Der Spiegel. 44 (1978). pp. 266-267.

- Sainderichin, G.P., Voyage a Munich. Hans Jürgen Syberberg tourne Parsifal. in: Cahiers du Cinéma. (januari 1982). pp. 22-29.

- Sandford, J., The New German Cinema. in: German Life and Letters. A Quarterly Review. (1978/1979). pp. 206-228.

- Sandford, J., The New German Cinema. London, 1980. 
- Sauvaget, D., Syberberg: Dramaturgie antinaturaliste et germanitude. in: Revue du Cinéma. (januari 1979). pp. 93-100.

- Santner, E.L., Stranded Objects. Mourning, Memory, and Film in Postwar Germany. Ithaca, London, 1990.

- Santner, E.L., The Trouble with Hitler: Postwar German Aesthetics and the Legacy of Fascism. in: New German Critique. 57 (zomer 1992). pp. 5-24.

- Schneider, M., Der ungeheure Blick des Kinos auf die Welt. Die Wissensmächte Musik und Film in Wagners/Syberbergs Parsifal. in: Merkur. Deutsche Zeitschrift für europäisisches Denken. 5 (1984). pp. 882-892.

- Schneider, R., Hitler 78 Revisited. En marge d'un film allemand dans le noir. in: Critique. (mei 1979). pp. 477-481.

- Schneider, R., Hans Jürgen Syberberg. La résurrection ambigue des dimensions mythiques. in: Cinéma Action. ed. R. Schneider. 1984. pp. 70-72.

- Schreiner, A., Voordracht voor het Syberberg-seminar. [niet gepubliceerd], 1 novernber 1983.

- Schreiner, A., Vollemans, K., Een neutrum in de hoogste zin van het woord, in -en uitademen: film der toekomst. in: Ontwerp en Theorie. Een seminar. Delft, 1981. pp. 193242.

- Schreiner, A., Vollemans, K., Hans Jürgen Syberberg: Parsifal. in: Skrien. 131 (1983). pp. 5-8.

- Simons, J., Zelfs vier uur film kan geen verlossing bieden. in: De Groene Amsterdammer. 09-11-1983.

- Simons, J., Hans Jürgen Syberberg: Parsifal. in: Skrien. 131 (1983). p. 4.

- Sierek, K., Die Kathedrale. Syberbergs Video-Bau, versunken in der Documenta X. (noch unveröffentlichte Fassung der frz. Originaltekstes.) in: www. uni-jena.de

- Sombart, N., Besuch bei der alten Dame. Zum Dokumentarfilm über Winifred Wagner. in: Merkur. 12 (1975). pp. 1166-1173.

- Sontag, S., Syberbergs Hitler. in: In het teken van Saturnus. Essays. Vert. D. Brisk. Weesp, 1984. pp. 181-222.

- Stewart, H. (ed.), Syberberg. A Filmmaker from Germany. Edinburgh, 1992.

- Sucher, C.B., Entsündigt und entsühnt? Neues Altes von Hans Jürgen Syberberg und Edith Clever im Berliner Hebbel-Theater. in: Süddeutsche Zeitung. 18-12-1990.

- Tindemans, K., 'Was ist des Teutschen Vaterland?' De besmette woorden van Syberberg. in: Etcetera. Tijdschrift over theater. 9 (1991). pp. 46-52.

- Vaget, H.R., Syberberg's Our Hitler. Wagnerianism and Alienation. in: The Massachusetts Review. 23 (1982). pp. 593-612.

- Verbeek, L., De vijanden van Hans Jürgen Syberberg. in: Etcetera. Tijdschrift over theater. 9 (1991). pp. 44-45.

- Verstappen, W., Winifred Wagner. De strijd om de leiding in de Wagner-dynastie. in: Skoop. (december 1976). pp. 11-14.

- Wagner, G., Wer nicht mit dem Wolf heult. Autobiographische Aufzeichnungen eines Wagner-Urenkels. Köln, 1997. pp. 126-137.

- Waller, G., Voor de kleinkinderen van Hitler. Zeven uur film van Hans Jürgen Syberberg. in: NRC Handelsblad. 02-12-1977.

- Wapnewski, P., 'Die Nacht' oder: schlafen die Theater? Syberbergs Hymnen an die Nacht. in: Theater Heute. 10 (1985). pp. 4-8.

- Weerdenburg, O., van, Op zoek naar nieuwe mythes om de Duitse dorst te lessen. Neofascistisch schotschrift van regisseur Syberberg. in: de Volkskrant. 07-09-1990. 
- Wesseltier, L., Syberberg's Hitler. German Romanticism Lives. in: The New Republic. 08-03-1980. pp. 27-30.

- Wiegand, W., Die Ausnahme under den Filmregisseuren. in: Frankfurter Allgemeine Zeitung. 02-12-1980.

- Wiegand, W., Denk ich an Deutschland... Syberbergs 'Die Nacht' in Nanterre: fünft Stunden mit Edith Clever. in: Frankfurter Allgemeine Zeitung. 24-09-1984.

- Wiegenstein, R.H., Bedeutungsschwanger. Syberbergs Weihestunde mit Kleists 'Marquise von O.' in: Frankfurter Rundschau. 03-04-1989.

- Wiegenstein, R.H., Ein teutscher Jüngling und seine Muse. Hans Jürgen Syberbergs 'Ein Traum, was sonst?' in: Frankfurter Rundschau. 21-12-1990.

- Wirsing, S., Mein lieber Schwan. Edith Clever mit Kleists 'Marquise von O...' in: Frankfurter Allgemeine Zeitung. 03-04-1989.

- Wirsing, S., Deutsche Kisten. 'Ein Traum, was sonst?': Syberbergs Berliner Nachkriegsmesse. in: Frankfurter Allgemeine Zeitung. 20-12-1990.

- Young, V., From Munch to Monkeys, Scandinavia to Spain. in: The Hudson Review. 4 (winter 1975) pp. 567-572.

- Zimmer, D.E., Die Farbe Braun. Ignorant oder Wahnsinniger - zur Debatte Hans Jürgen Syberbergs in der Ost-Berliner Akademie. in: Die Zeit. 19-10-1990.

- Hitler im Herzen oder die Schönheit der Hölle. Studiodiscussie over Hitler, ein Film aus Deutschland. Deelnemers: J.P. Stern, B. Brock, K.H. Bohrer, P. Pautrat, W. Schutz, B. Watson. Regie: D. Hens. Redactie: M. Wiebel. WDR 1980.

\section{Algemeen}

- Adorno, Th.W., Minima Moralia. Reflexionen aus dem beschädigten Leben. Frankfurt am Main, 1951, 1989.

- Adorno, Th.W., Versuch über Wagner. Frankfurt am Main, 1952, 1974.

- Adorno, Th.W., Asthetische Theorie. Frankfurt am Main, 1970, 1972.

- Adorno, Th.W., Horkheimer, M., Dialektik der Aufklärung. Philosophische Fragmente. Frankfirt am Main, 1971, 1980.

- Akademie der Künste (Hrsg.), Skulptur und Macht: Figurative Plastik im Deutschland der 30 er und 40er Jahre. Berlin, 1983.

- Amerongen, van, M., De buikspreker van God. Amsterdam, 1983.

- Apel, F., Mißglückte Identifikation. Der preußisische Traum und das preußisische Trauma bei Heinrich von Kleist. in: Preussen. Versuch einer Bilanz. Band 4. Preußen. Dein Spree-Athen. Beiträge zu Literatur, Theater und Musik in Berlin. Hrsg. H. Kühn. Hamburg, 1981. pp. 64-85.

- Avisar, I., Screening the Holocaust. Cinema's Images of the Unimaginable. Bloomington, Indianapolis, 1988.

- Baar, van, D.J., Een eenmalige knieval. in: de Volkskrant. 15-09-1997.

- Barck, S., Jarmatz, K. (Hrsg.), Kunst und Literatur im antifaschistischen Exil 1933-1945. Band I/I Exil in der UDSSR. Leipzig, 1989.

- Becker, P., von, Abschied von Botho Strauss... in: Theater Heute. 12 (1994). pp. 4-5.

- Beer, M., 'Eine böse, ganz giftige Brühe'. Gottfried Wagner über Richard Wagner, antisemitismus und Bayreuth. in: Opernwelt. 9 (1995). pp. 30-33. 
- Benjamin, W., Über den Begriff der Geschichte. in: Gesammelte Werke. I.2. Hrsg. R. Tiedemann, H. Schwepperhäuser. Frankfurt am Main, 1974. pp. 693-703

- Benjamin, W. Het kunstwerk in het tijdperk van zijn technische reproduceerbaarheid. Vert. H. Hoeks. Nijmegen, 1985.

- Berghe, G. van, De uitbuiting van de Holocaust. Antwerpen, Baarn, z.j.

- Berka, S. (Hrsg), Weimarer Beiträge. Zeitschrift für Literaturwissenschaft, Ästhetik und Kulturwissenschaften. Das Werk von Botho Strauß und die 'Bocksgesang'-Debatte. 2 (1994).

- Bermbach, U,, Trautmann, G. (Hrsg.), Georg Lukács. Kultur - Politik - Ontologie. Opladen, 1987.

- Bermbach, U,, Der Wahn des Gesamtkunstwerks. Richard Wagners politisch-ästhetische Utopie. Frankfurt am Main, 1994.

- Bernhard, M. (Hrsg.), Franz Graf von Pocci. München, z.j.

- Berns, E., IJsseling, S., Moyaert, P., Denken in Parijs. Taal en Lacan, Foucault, Althusser, Derrida. Alphen aan den Rijn, 1979.

- Bettelheim, B., Surviving and other essays. London, 1979.

- Bloch, E., Geist der Utopie. Erste Fassung. Frankfurt am Main, 1971, 1985.

- Bloch, E., Erbschaft dieser Zeit. Erweiterte Ausgabe. Frankfurt am Main, 1962, 1985.

- Bloch, E., Das Prinzip Hoffnung. 1-3. Frankfurt am Main, 1959, 1976.

- Blokker, B., Verschoten kleuren van een verre oorlog. Het kantelend beeld van de bezettingsjaren. in: NRC Handelsblad. 16-03-2001.

- Bohrer, K.H., Die Ästhetik des Schreckens. Die pessimistische Romantik und Ernst Jüngers Frühwerk. Frankfurt am Main, Berlin, Wien, 1978, 1983.

- Bohrer, K.H., Die drie Kulturen. in: Stichworte zur 'geistigen Situation der Zeit'. Band 2: Politik und Kultur. Hrsg. J. Habermas. Frankfurt am Main, 1980. pp. 636-669.

- Bohrer, K.H., Provinzialismus (II). Ein Psychogramm. in: Merkur. Deutsche Zeitschrift für europäisches Denken. 3 (1991). pp. $255 \mathrm{ff}$.

- Boterman, F., Terug naar Berlijn. Duitsland na de val van de Muur. Amsterdam, 1999.

- Brecht, B., Gesammelte Werke 1-20. Frankfurt am Main, 1967, 1990.

- Brinks, J.H., De rechterflank van Duitsland. Amsterdam, 1994.

- Bullock, A., Hitler. Leven en ondergang van een tiran. Vert. J. Vandenberg. Utrecht, 1952.

- Burke, P., History as Social Memory. in: Memory. History, Culture and the Mind. ed. Th. Butler. Oxford, New York, 1989.

- Buruma, I., Het loon van de schuld. Herinneringen aan de oorlog in Duitsland en Japan. Vert. T. Davids. Amsterdam, Antwerpen, 1994.

- Busch, A., Faust und Faschismus. Th. Manns 'Doktor Faustus' und A. Döblins 'November 1918' als exilliterarische Auseinandersetzung mit Deutschland. Frankfurt am Main, Bern, New York, Nancy, 1984.

- Bussmann, G. (Hrsg.), Arbeit in Geschichte / Geschichte in Arbeit. Hamburg, 1988.

- Dachs, R., Oskar Werner. Ein Nachklang. Wien, 1988.

- Dassen, P., Nijhuis, T. (red.), Gegijzeld door het verleden. Controverses in Duitsland van de Historikerstreit tot het Sloterdijk-debat. Amsterdam, 2001.

- Deleuze, G., Das Zeit-Bild. Kino 2. Übersetzt von K. Englert. Frankfurt am Main, 1991, 1997.

- Dieckmann, F., De onzetting van de Berg-Kobolden. Zondevallen en verlossingsbegrippen in Wagners Ring-Festspiel. Nexus. 19 (1997). pp. 86-112. 
- Dijk, van, H., Het postmoderne en architectuur: we wéten zoveel. in: Het postmoderne aan kinderen verklaard. red. Bonnefantenmuseum Maastricht, Museum van Hedendaagse Kunst Antwerpen. Maastricht, Antwerpen, 1988. pp. 22-37.

- Diwald, H., Mut zur Geschichte. Bergisch Gladbach, 1983.

- Documenta X (Hrsg.), Politics / Poetics. Kassel, 1997.

- Doerry, M., 'Lehrmeister des Hasses.' Botho Strauss als Wortführer eines 'konservativen Manifests'. in: Der Spiegel. 42 (1994). pp. 239-242.

Dönhoff, M., Gräfin von, Namen die keiner mehr nennt. Ostpreussen - Menschen und Geschichte. München, 1962, 1964.

- Dorrmann, M., Wilderotter, H. (Hrsg.), Wege nach Weimar. Auf der Suche nach der Einheit von Kunst und Politik. Weimar, 1999.

- Dürr, J. Die Expressionismusdebatte. Untersuchungen zum Werk von Georg Lukács. München, 1982.

- Elsaesser, Th., Fassbinder 's Germany. History, Identity, Subject. Amsterdam, 1996.

- Ely, N., Götz Friedrich - Tannhäuser oder der Künstler in der Gesellschaft. in: Regie heute: Musiktheater in unserer Zeit. Hrsg. N. Ely, S. Jeager. Berlin, 1984.

- Eörsi, I., 'Massaker als Sinnsuche'. Über die seltsame Allianz von Heiner Müller und Botho Strauss. in: Der Spiegel. 37 (1994). pp. 215-220.

- Felman, S., Laub, D., Testimony. Crisis of witnessing in literature, psychoanalysis and history. New York, London, 1992.

- Fest, J., Tegenlicht. Een Italiaanse reis. Vert. T. Davids. Amsterdam, 1990.

- Flierl, Th. e.a.., Mythos Antifaschismus. Ein Traditionskabinett wird kommentiert. Berlin, 1992.

- Foucault, M., Fontana, A., An Aesthetic of Existence. in: Michel Foucault. Politics, Philosophy, Culture: Interviews and other Writings 1977-1984. ed. L.D. Kitzman. Vert. A. Shiridan e.a.. New York, 1988

- Freud, S., Rouw en melancholie. in: Sigmund Freud - Nederlandse editie. Psychoanalytische theorie. (P.T.) 1. Amsterdam, 1985.67-91.

- Friedländer, S. (ed.) Probing the Limits of Representation. Nazism and the Final Solution': Cambridge, Mass., London, 1992. a.w., pp. 66-81.

- Gillen, E. (Hrsg.), Deutschlandbilder. Kunst aus einem geteilten Land. Berlin, 1997. pp. 48-54.

- Giordano, R., Die zweite Schuld oder Von der Last Deutscher zu sein. Hamburg, 1987.

- Glotz, P., Freunde, es wird ernst! in: Wochenpost. 25-02-1993.

- Goldschneider, G., De achterkleinzoon van Richard Wagner heeft iets recht te zetten. in: Vrij Nederland. 18-04-1993. p. 76.

- Goossens, G., 'Vrienden, het wordt menens!' De opkomst van een Duitse intellectuele voorhoede. Groene-essay. in: De Groene Amsterdammer. 16 (1995). pp. 28-29.

- Grasskamp, W., Der vergeßliche Engel. Künsterportraits für Fortgeschrittene. München, 1986.

- Grasskamp, W., Die unbewältigte Moderne. Kunst und Öffentlichkeit. München, 1989.

- Grasskamp, W., Der lange Marsch durch die Illusionen. Über Kunst und Politik. München, 1995.

- Greß, F., Jaschke, H.G., Schönekäs, K., Neue Rechte und Rechtsextremismus in Europa. Bundesrepublik, Frankreich, Großbritannien. Opladen, 1990.

- Grunenberg, A., Antifaschismus - ein deutscher Mythos. Ein Essay. Hamburg, 1993.

- Gutman, R.W., Richard Wagner. The Man, His Mind and His Music. London, 1968.

- Hage, V., Schreiben ist eine Séance. Begegnungen mit Botho Strauss. in: Strauss lesen. Hrsg. M. Radix. München, Wien, 1987. pp. 188-216. 
- Haar, M., Le chant de la terre. Heidegger et les assises de l'histoire de l'être. Paris, 1985.

- Haase, C.P., Die rehabilitierung des Konservatismus. in: Die neue Gesellschaft / Frankfurter Hefte. 9 (september 1994). pp. 794-800.

- Habermas, J., Kleine Politische Schriften I-IV. Frankfurt am Main, 1981.

- Habermas, J., Der philosophische Diskurs der Moderne. Zwölf Vorlesungen. Frankfurt am Main, 1985.

- Habermas, J., Eine Art Schadensabwicklung. Frankfurt am Main, 1987.

- Habermas, J., De nieuwe onoverzichtelijkheid en andere opstellen. red. M. Korthals. Vert. J. Boom e.a.. Amsterdam, 1989.

- Habermas, J., Die zweite Lebenslüge der Bundesrepublik: Wir sind wieder 'normal' geworden. in: Die Zeit. 51 (11-12-1992).

- Harberts, D.W., Meyer, H., Deutsche Dichtung. Anthologie und Literaturgeschichte. Amsterdam, 1959.

- Heidegger, M., Gelassenheit. Pfullingen, 1959.

- Heilbrunn, J., Germany's New Right. in: Foreign Affairs. november/december, 1996. pp. 80-98.

- Herzinger, R, Revolutionärer Umbruch in die Stammesgemeinschaft? Die Ideologie(n) der Neuen Rechten und ihre Zeitschriften. in: Deutschland Archiv. 12 (1993). pp. 13891403.

- Herzinger, R., Die obskuren Inseln der kultivierten Gemeinschaft. Heiner Müller, Christa Wolf, Volker Braun - deutsche Zivilisationskritiek und das neue Antiwestlertum. in: Die Zeit. 23 (04-06-1993).

- Herzinger, R., Die Heimkehr der romantischen Moderne. Über 'Ithaka' und die kulturphilosophischen Transformationen von Botho Strauss. in: Theater Heute. 8 (1996). pp: $7-12$

- Heuß, A., Versagen und Verhängnis. Vom Ruin deutscher Geschichte und ihres Verständnisses. Berlin, 1984.

- Hoffman, K. (Hrsg.), Die Wirklichkeit des Mythos. München, Zürich, 1965.

- Hoffmann, W., Zu einer Theorie der Kunstgeschichte. In: Zeitschrift für Kunstgeschichte. 41 (1951). pp. 118-123.

- Hofman, G., Mach's nicht noch mal, Deutschland! in: Die Zeit. 44 (29-10-1993).

- Huizinga, J., Verzamelde werken 5. Haarlem, 1950.

- Institut für Gesellschaftswissenschaften beim ZK der SED. Lehrstuhl für marxistischleninistische Kultur- und Kunstwissenschaften. (Hrsg.), Zur Theorie des sozialistischen Realismus. ed. Berlin, 1974.

- Jamme, Ch., Einführung in die Philosophie des Mythos. Band 2: Neuzeit und Gegenwart. Darmstadt, 1991,

- James, B., Wagner and the Romantic Disaster. New York, 1983.

- Jünger, E., Strahlungen I. Gärten und Straßen. Das erste Pariser Tagebuch. Kaukasische Aufzeichnungen. Stuttgart, 1979, 1988.

- Jünger, E., Stralungen II. Das zweiter Pariser Tagebuch. Kirchhorster Blätter. Die Hütte im Weinberg. Stuttgart, 1979, 1988.

- Jünger, E., Sämtliche Werke. Dritte Abteilung. Erzählende Schriften III. Band 17. Eumeswil. Stuttgart, 1977, 1980.

- Jünger, E., Siebzig verweht III. Stuttgart, 1993.

- Jünger, E., Gestaltwandel. Eine Prognose auf das 21. Jahrhundert. in: Die Zeit. 29 (16-071993).

- Jünger, F.G., Die Perfektion der Technik. Frankfurt am Main, 1953, 1980. 
- Kalow, G., Hitler - Das gesamtdeutsche Trauma. Zur Kritik des politischen Bewußtseins. München, 1967.

- Karbaum, M., Studien zur Geschichte der Bayreuther Festspiele. (1876-1976). Regensburg, 1976.

- Kerres, M., Oude meester Grass zorgt weer voor een rel. in: NRC Handelsblad. 9/10 februari 2002. p. 10.

- Kesting, J., 'Es ist viel Hitler in Wagner.' Neue Variationen zu alter Leid-Motive. in: Opernwelt. 5 (1997). pp. 60-61.

- Kilb, A., Anschwellender Geistesfinsternis. in: Die Zeit 14 (02-04-1993):

- Köhler, J, Wagners Hitler. Der Prophet und sein Vollstrecker. München, 1997.

- Kowalsky, W., Comeback oder Abgesang der Rechtsintellektuellen. in: Die neue Gesellschaft / Frankfurter Hefte. 9 (september 1994). pp. 830-834

- Kracauer, S., Von Caligari zu Hitler. Eine psychologische Geschichte des deutschen Films. Frankfurt am Main, 1979, 1984.

- Kreimeier, K., Kino und Filmindustrie in der BRD. Ideologieproduktion und Klassenwirklichkeit nach 1945. Kronberg, 1973.

- Krens, Th., Govan, M., Thompson, J., Refigured Painting. The German Image 19601980. New York, 1988.

- Krockow, Ch., Graf von, Die Deutschen in ihrem Jahrhundert. 1890-1990. Hamburg, 1990, 1994.

- Lange, de, S., Alice Miller: Het drama van het begaafde kind. 1979. in: NRC Handelsblad. 09-04-1999.

- Laplanche, J., Pontalis, J.B., Das Vokabular der Psychoanalyse. Übersetzt von. E. Moersch. Frankfurt am Main, 1973, 1986.

- Laqueur, W., Weimar. Die Kultur der Republik. Übersetzt von O. Weith, Frankfurt am Main, Berlin, Wien, 1976.

- Laqueur, W., Was ist los mit den Deutschen? Übersetzt von O. Weith. Frankfurt am Main, Berlin, 1985, 1988.

- Leeflang, Th., Leni Riefenstahl. Baarn, 1991.

- Lehmann, A., Im Fremden ungewollt zuhaus. Flüchtlinge und Vertriebene in Westdeutschland 1945-1990. München, 1991.

- Leiser, E., 'Deutschland enwache!' Propaganda im Film des Dritten Reiches. Hamburg, $1968,1989$.

- Lorens, Ch., De constructie van het verleden. Een inleiding in de theorie van de geschiedenis. Amsterdam, Meppel, 1987, 1994.

- Lübbe, H., Der Nationalsozialismus im Bewustsein der deutschen Gegenwart. in: Die Aufdringlichkeit der Geschichte. Herausforderungen der Moderne vom Historismus bis zum Nationalsozialismus. Graz, Wien, 1989. pp. 334-350.

- Lyotard, J.F., The Differend. Phrases in Dispute. Translation by G. van den Abbeele. Manchester, 1988.

- Lyotard, J.F., Heidegger en 'de joden'. Vert. C. Janssen. Kampen, 1990.

- Lukács, G., Theorie van de roman. Een poging tot een geschiedfilosofische beschouwing van de grote epische vormen. Vert. W.D. Tieges. Amsterdam, 1973, 1980.

- Lukács, G., Die Zerstörung der Vernunft. Neuwied am Rhein, Berlin-Spandau, 1962.

- Magee, B., Aspects of Wagner. London, 1968, 1972.

- Mann, Th., Doktor Faustus. Das Leben des deutschen Tonsetzers Adrian Leverkühn erzählt von einem Freunde. Frankfurt am Main, 1971, 1988.

- Mann, Th., Die Entstehung des Doktor Faustus. Roman eines Romans. Frankfurt am Main, 1984, 1989. 
- Mann, Th., Wagner und unsere Zeit. Aufsätze, Betrachtungen, Briefe. Hrsg. E. Mann. Frankfurt am Main, 1983, 1986.

- Mann, Th, Bruder Hitler. in: An die gesittete Welt. Politische Schriften und Reden im Exil. Frankfurt am Main, 1986. pp. 253-259.

- Markun, S., Ernst Bloch. Hamburg, 1977.

- Martin-Gropius-Bau (Hrsg), Memory. Zeitung zur Ausstellung Deutschlandbilder Kunst aus einem geteilten Land. 7 september 1997-11 januari 1998. p. 36.

- Matthes, A. (Hrsg.), Der Pfahl. Jahrbuch aus dem Niemandsland zwischen Kunst und Wissenschaft IV. München, 1990.

- Mayer, H., Richard Wagner in Bayreuth 1876-1976. Stuttgart, Zürich, 1976, 1978.

- Mayer, H., Brecht. Frankfurt am Main, 1996.

- Mayer, H., Metzger, H.-K., Riehn, R., Diskussion über Recht, Unrecht und Alternativen. in: Musik-konzepte 5. Richard Wagner. Wie antisemitisch darf ein Künstler sein? (juni 1981) pp. 54-76.

- Mazura, M., Oskar Werner. Maske, Mythos, Mensch. Biographie. Wien, 1986.

- Meier, C., Am Ende der alten Bundesrepublik. in: Merkur. Deutsche Zeitschrift für europäisches Denken. 7 (juli 1994). pp. 561-572.

- Mertens, A. (red.), De Revisor. Letterkundig tijdschrift voor Nederland en Vlaanderen. Bokkengezang. 3 (1995).

- Meyer, M., Ernst Jünger. München, Wien, 1990, 1993.

- Meyer, J.W.L., Jacques de Kadt (1897-1988) en de wetenschap der politiek. in: Oude vrienden en een veranderde wereld. Een keuze uit het eigen werk. Amsterdam, 1990. pp. 58-80.

- Miller, A., Het drama van het begaafde kind. Een studie over narcisme. Vert. T. Davids. Bussum, 1981.

- Miller, A., In den beginne was er opvoeding. Vert. T. Davids. Houten, 1983, 1994.

- Milnes, R., Standing up to the past. Gottfried Wagner talks to Rodney Milnes. in: Opera. 8 (1995). pp. 911-914.

- Mitscherlich, M., Erinnerungsarbeit. Zur Psychoanalyse der Unfähigkeit zu trauern. Frankfurt am Main, 1987.

- Mitscherlich, A., Mitscherlich, M, Die Unfähigkeit zu trauern. Grundlagen kollektiven Verhaltens. München, Zürich, 1967, 1990.

- Mitscherlich, M. e.a., How do Germans face their guilt? / Former West Germans and their Past. in: Partisan Review. 4 (1995). pp. 527-535

- Mittenzwei, W., Erprobung einer neuen Methode. Zur ästhetischen Position Bertolt Brechts. in: Positionen. Beiträge zur marxistischen Literaturtheorie in der DDR. Hrsg.. W. Mittenzwei. Leipzig, 1969.

- Mittenzwei, W., Das Leben des Bertolt Brecht oder Der Umgang mit den Welträtseln. 12. Berlin, Weimar, 1986, 1997.

- Mohler, A., Die Konservative Revolution in Deutschland. 1918-1932. Darmstadt, 1949, 1994.

- Mohler, A., Vergangenheitsbewältigung. Von der Läuterung zur Manipulation. StuttgartDegerloch, 1968.

- Mohler, A., Die deutschen in der Mühle. Zum Stand der Vergangenheitsbewältigung nach 'Holocaust' und der Anti-Diwald-Kampagne. in: Criticón. 52 (maart/april 1979). pp. 5559.

- Moser, T., Vorsicht Berührung. Über Sexualisierung, Spaltung, NS-Erbe und Stasi-Angst. Frankfurt am Main, 1992. 
- Mosse, G.L., Die Nationalisierung der Massen. Von den Befreiungskriegen bis zum Dritten Reich. Übersetzt von O. Weith. Frankfurt am Main, Berlin, Wien, 1976.

- Mosse, G.L., The Culture of Western Europe. The Nineteenth and Twentieth Centuries. London, 1988.

- Mytze, A. (Hrsg.), Über Wolf Biermann. Berlin, 1977.

- Neue Gesellschaft für Bildende Kunst (Hrsg.), Inszenierung der Macht - Ästhetische Faszination im Faschismus. Kreuzberg, 1987.

- Nolte, E. (Hrsg.), Theorien über den Faschismus. Köln, Berlin, 1970.

- Organ, B., Weiß, W.W. (Hrsg.), Faszination und Gewalt. Zur politischen Ästhetik des Nationalsozialismus. Nürnberg, 1992.

- Panofsky, W., Wieland Wagner. Bremen, 1964.

- Pels, D., 'Kan een fascist een echte intellectueel zijn?' in: de Volkskrant. (09-11-1993).

- Picard, M., Hitler in uns selbst. Zürich, 1946.

- Picard, M., Die Atomisierung in der modernen Kunst. Hamburg, 1954.

- Picard, M., Die Flucht vor Gott. Breisgau, 1958.

- Pflüger, F., Deutschland driftet. Die Konservative Revolution entdeckt ihre Kinder. Düsseldorf, Wien, New York, Moskau, 1994.

- Presser, J., De nacht der Girondijnen. z.p., 1957.

- Presser, J., Ondergang. De vervolging en verdelging van het Nederlandse jodendom 1940-1945. Eerste deel. 's-Gravenhage, 1965.

- Radisch, I., Der alte Mann. in: Die Zeit. 33 (12-08-1994).

- Rauschning, H, Gespräche mit Hitler. New York, 1940.

- Rebel, E., Kehr, W., Zwischen Welten. Adolf von Hildebrandt (1847-1921). Person, Haus und Wirkung. München, 1998.

- Reese-Schäfer, W., Lyotard zür Einführung. Hamburg, 1988, 1989.

- Reichel, P., Der schöne Schein des Dritten Reiches. Faszination und Gewalt des Faschismus. München, Wien, 1991.

- Reichel, P., Politik mit der Erinnerung. Gedächtnisorte im Streit um die nationalsozialistische Vergangenheit. München, Wien, 1995.

- Riefenstahl, L., A Memoir. New York, 1993.

- Rosenthal, M., Anselm Kiefer. Chicago, 1987.

- Ross, W., Die selbstbewusste Nation. in: Die politische Meinung. Monatschrift zu Fragen der Zeit. (december 1994). pp. 34-36.

- Rosellini, J.J., A Revival of Conservative Literature? The 'Spiegel-Symposium 1993' and Beyond. in: Beyond 1989. Re-reading German Literature since 1945. ed. K. Bullivant. Povidence, Oxford, 1997. pp. 109-128.

- Sabais, H.W. (Hrsg.), Die Herausforderung. Darmstädter Gespräche. München, 1963.

- Safranski, R, Fundering van mythen door kunst. Een toelichting aan de hand van Richard Wagner. Vert. M. Wildschut. in: Nexus. 19 (1997). pp. 23-36.

- Salmagundi. A quarterly of the humanities and social sciences. 85-86 (winter-spring 1990). pp. 197-313.

- Saltzman, L., Anselm Kiefer and Art after Auschwitz. Cambridge, 1999.

- Scampai, A., Holland, D. (Hrsg.), Richard Wagner Parsifal. Texte, Materialien, Kommentare. Hamburg, 1984.

- Schäfer, E.F., Wieland Wagner. Persönlichkeit und Leistung. Tübingen, 1970.

- Schama, S., Landscape \& Memory. London, 1995.

- Scheffer, P., Echo's van de ondergang. in: NRC Handelsblad. 22 februari 2002. p. 25.

- Schmitt, H.J. (Hrsg.), Die Expressionismusdebatte: Materialien zu einer marxistischen Realismuskonzeption. Frankfurt am Main, 1973, 1978. 
- Schneidt, C.E., Die Rezeption der Psychoanalyse in der deutschsprachigen Philosophie vor 1940. Frankfurt am Main, 1986.

- Schoenberg, H.W., Germans from the East. A study of their Migration, Resettlement, and Subsequent Group History since 1945. The Hague, 1970.

- Schram, D.H., Gelion, C. (red.), De verwerking van de Tweede Wereldoorlog in literatuur en kunst. Amsterdam, 1990.

- Schreiber, G., Hitler Interpretationen 1923-1983. Ergebnisse, Methoden und Probleme der Forschung. Darmstadt, 1984.

- Schumann, H.G. (Hrsg.), Konservatismus. Königstein, 1984.

- Schütz, H., Transformation und Wiederkehr. Zur künstlerischen Rezeption nationalsozialistischer Symbole und Ästhetik. in: Kunstforum. 95 (juni, juli, 1988). pp. 64-98.

- Schütz, H., 'Ich kann beim besten Willen kein Hakenkreuz entdecken'. Georg Bussmann im Gespräch mit Heinz Schütz. in: Kunstforum. 95 (juni, juli, 1988). pp. 99-103.

- Schütz, S., Anselm Kiefer - Geschichte als Material. Arbeiten 1969-1983. Köln, 1999.

- Schwilk, H., Schacht, U. (Hrsg.), Die selbstbewusste Nation. 'Anschwellender Bocksgesang' und weitere Beiträge zu einer deutschen Debatte. Frankfurt am Main, Berlin, 1994.

- Sehwilk, H., Figal, G. (Hrsg.), Magie der Heiterkeit. Ernst Jünger zum Hundersten. Stuttgart, 1995.

- Sedlmayr, H., Verlust der Mitte. Die bildende Kunst des 19. und 20. Jahrhunderts als Symptom und Symbol der Zeit. Frankfurt am Main, Berlin, 1983, 1988.

- Sedlmayr, H., Epoche und Werke. Gesammelte Schriften zur Kunstgeschichte I. Wien, 1959.

- Sedlmayr, H., Tod des Lichtes. Übergegangene Perspektiven zur modernen Kunst. Salzburg, 1963.

- Sedimayr, H., Das goldene Zeitalter. Eine Kindheit. München, Zürich, 1986.

- Seeßlen, G, Land der Väter und der Verräter. Nationale Identität und nationale Helden: Nur tote Deutsche sind gute Deutsche. in: Spiegel Special. 100 Jahre Kino. 12 (december 1994). pp. 116-124.

- Seitz, N., Die 'What's right?'-Debatte. Das zaghafte Herantasten an eine zivile Rechte. in: Aus Politik und Zeitgeschichte. Beilage zur Wochenzeitung Das Parlament. 10 (1995). pp. 23-27.

- Skelton, G., Wieland Wagner. The Positive Sceptic. London, 1971.

- Smet, de, Y., Ernst Jünger. z.p., 1963.

- Sombart, N., Die deutschen Männer und ihre Feinde. Carl Schmitt - ein deutsches Schicksal zwischen Männerbund und Matriachatsmythos. München, Wien, 1991.

- Sontag, S., Fascinerend fascisme. in: In het teken van Saturnus. Essays. Vert. D. Brisk. Weesp, 1984.

- Söring, J., Wagner und Brecht. Zur bestimmung des Musik-Theaters. in: Richard Wagner 1883-1983. Die Rezeption im 19. und 20. Jahrhundert. Hrsg. U. Müller e.a.. Stuttgart, 1984.

- Spiegel Spezial. Die Deutschen nach der Stunde Null 1945-1948. 4 (1995).

- Spoor, A.S., Nieuw Duits rechts als conservatief eerherstel. Bekering Botho Strauss staat niet op zich. in: NRC Handelsblad. 26-01-1995. p. 8.

- Staeck, K. (Hrsg.), Nazi-Kunst ins Museum? Göttingen, 1988.

- Stephan, C., Der Betroffenheitskult. Eine politische Sittengeschichte. Hamburg, 1994.

- Steunebrink, G., 'Ik zal niet beschaamd staan in eeuwigheid'. Adorno en de betekenis van de Tweede Wereldoorlog voor de kunst. in: Een halve eeuw geleden. De verwerking van 
de Tweede Wereldoorlog in de literatuur. red. H. Ester, W. de Moor. Kampen, 1994. pp. 68-79

- Strauss, B., Paare, Passanten. München, Wien, $1981,1984$.

- Strauss, B., Distanz ertragen. in: Borchardt, R., Das Gespräch über Formen und Platons Lysis Deutsch. Stuttgart, 1987. pp. 101-118.

- Strauss, B., Der Aufstand gegen die sekundäre Welt. Bemerkungen zu einer Ästhetik der Anwesenheit. in: Die Zeit. 26 (22-06-1990).

- Strauss, B., Der eigentliche Skandal. in: Der Spiegel. 16 (1994). pp. $168 \mathrm{f}$.

- Strauss, B., Die Fehler des Kopisten. München, Wien, 1997.

- Strauss, B., Wille, F. Bekenntnisse eines Unpolitischen? Ein Briefwechsel mit Botho Strauss. in: Theater Heute. 12 (1994) pp. 1-4.

- Stulz, P., Thomas, S. (Hrsg.), Die Deutsche Demokratische Republik auf dem Wege nach dem Sozialismus. Teil I. (1945-1949) Berlin, 1959.

Tanner, M., Wagner. London, 1996, 1997. pp. 451-514.

- Tappert, W. (Hrsg.), Hurenaquarium und andere Unhöflichkeiten. Richard Wagner im Spiegel der zeitgenössischen Kritik. München, 1986, 1983.

Thomas, K., Zweimal deutsche Kunst nach 1945. 40 Jahre Nähe und Ferne. Köln, 1985.

Thomas, K (Hrsg.) Deutsche Kunst der späten 80er Jahre. Köln, 1988.

Umbach, K. (Hrsg.), Richard Wagner. Ein deutsches Argernis. Hamburg, 1992.

Universität Gesamthochschule Siegen (Hrsg.), Zeitschrift für Literatur, Wissenschaft und Linguistik. Eine Zeitschrift der. Universität Gesamthochschule Siegen. Die politische 'Rechte'. Literatur, Theater, Film. 24 (1994).

- Veld, R., in 't, Uit liefde voor de Führer. Vrowwen van het Derde Rijk. Zutphen, 1995.

- Vitali, Ch. (Hrsg..), Ernste Spiele. Der Geist der Romantik in der deutschen Kunst 17901990. München, 1995.

Voermans, E., Wagner tegen wil en dank. in: Het Parool. 27-02-1996. p. 45.

Vollemans, K., Schreiner, A., Een golf van bloed. Over Wagner en wagnerianisme. Kunsthistorische Schriften 7. Amsterdam, 1981.

Vollmer, A., Woher kommt diese Wut? in: Der Spiegel. 46 (1993). pp. 254-258.

Vos, Ch., Het verleden in bewegend beeld. Een inleiding in de analyse van audiovisueel materiaal. Houten, 1991.

Vos, Ch., Televisie en Bezetting. Een onderzoek naar de documentaire verbeelding van de Tweede Wereldoorlog in Nederland. Hilversum, 1995.

Vree, F., van, In de schaduw van Auschwitz. Herineringen, beelden, geschiedenis. Groningen, 1995.

Waard, de, M., Muziek is lucht. in: NRC Handelsblad. 06-07-2001. p. 22.

Wagner, F., Cooper, P., Eeuwig laaiend vuur. De geschiedenis van Richard Wagners kleindochter. Vert. A.M. Bottenham. Amsterdam, 1947.

Wagner, N. (Hrsg..), Uber Wagner. Von Musikern, Dichtern und Liebhabern. Stuttgart, 1995.

Wagner, R., An Mathilde Wesendonk. Tagebuchblätter und Briefe 1853-1871. Berlin, 1906.

Wagner, R., An Judith Gautier. Zürich, Leipzig, z.j.

Wagner, R., Oper und Drama. Stuttgart, 1984, 1994.

Wagner, W., Wieland Wagner. Sein Denken. Aufsätze, Reden, Interviews, Briefe. Hrsg. Bayreuther Festspiele. Bayreuth, 1991.

Wagner, W., Lebens-Akte. Autobiographie. München, 1994, 1997.

Weid, J.N., von der, Die Musik des 20. Jahrhunderts. Von Claude Debussy bis Wolfgang Rihm. Übersetzt von A. Ginhold. Leipzig, 2001. 
- Wessling, B.W. (Hrsg.), Bayreuth im Dritten Reich. Richard Wagners politische Erbe. Eine Dokumentation. Mannheim, Basel, 1983.

- Wielenga, F, Schaduwen van de Duitse geschiedenis. De omgang met het nazi-en DDRverleden in de Bondsrepubliek Duitsland. Amsterdam, 1993.

- Winkler, W., Ist Botho Strauss ein Faschist? in: Die Tageszeitung. 13-02-1993.

- Wyss, B., Trauer der Vollendung. Zur Geburt der Kulturkritik. Köln, 1985, 1997.

- Zelinsky, H. (Hrsg.), Richard Wagner. Ein deutsches Thema. Eine Dokumentation zur Wirkungsgeschichte Richard Wagners (1876-1976). Berlin, 1976, 1983.

- Zelinsky, H., Die 'feuerkur' des Richard Wagners oder die 'neue religion' der 'Erlösung' durch 'Vernichtung'. in Musik-konzepte 5. Richard Wagner. Wie antisemitisch darf ein Künstler sein? (juni 1981) pp. 79-112.

- Zudeick, P., Der Hintern des Teufels. Ernst Bloch-Leben und Werk. Bühl-Moos, 1985. 


\section{Summary}

\section{Lost Sunsets: Hans Jürgen Syberberg and Leftist Thought about the Right in Germany}

This dissertation deals with the art-political theory in the work of the German filmmaker and pamphleteer Syberberg. It has the shape of an intellectual artist's biography. My main argument hooks up with the central issue in the current debate on Syberberg, the contours of which are outlined in the first, introductory chapter. This debate concerns questions like: How does Syberberg's involvement in the post-1989 Conservative Revolution in Germany relate to his earlier works, like the six-part film cycle The Grail (1972-82)? Has he indeed turned to the extreme right, as former admirers like Sontag, Lacoue-Labarthe, Elsaesser, and Santner believe? Or were his predominantly German critics correct after all, when they criticized the work of this filmmaker already in the late 1970 s as symptomatic of a rightist ideology? The Syberberg case, I suggest, should not be considered in isolation, but in light of a much broader and older leftist controversy about the right: the debate on irrationalism.

Chapter 2 addresses Syberberg's artistic apprenticeship: the period until the late 1960s. Specifically, it focuses on his father, a gentleman farmer from Nossendorf (Vorpommern) whose farm was expropriated; his brief stint at the Brecht theater in East Berlin; the influence of Sedlmayr, his professor of art history in Munich and the key opponent of Adorno in the West-German debate on Modernism; and the making of his early films (1965-1970). An imporant episode in this formative period involves Syberberg's juvenile work from 1953, the film that Brecht asked him to make of his stage version of the Urfaust; a version that was sharply criticized by the East-German regime. This took place during the heyday of the realism/formalism controversy in East Germany, which basically was a continuation of the debate on Expressionism of the 1930s, also known as the BrechtLukács controversy: Lukács set up the meanwhile classic bifurcation in German cultural history: the one between 'rational' or leftist heritage and 'irrational' or rightist heritage. The 'rational' Enlightenment tradition of Lessing, Marx, Thomas Mann, and Ulbricht was counterbalanced by the 'irrational' (or: rightist, decadent, reactionary, fascistic) antiEnlightenment tradition of Schelling, Wagner, Nietzsche, and Hitler. Lukács put the art of the avant-garde, from Naturalism to Absurdism, into the latter category as well. His critique of Germany as an 'irrational' culture provided the theoretical underpinnings for the re-education politics in the early GDR, which Brecht strongly opposed in his Urfaust staging. Supported by GDR dissidents Bloch and Mayer, Brecht defended the avant-garde's right to exist.

Syberberg's polemic against this 'irrationalism'-critique is a leitmotiv in his oeuvre. In all his works he is concerned with questioning the association of irrationalism with the right. Artistic and intellectual innovations result from persistently and painstakingly examining specific aspects of irrationalism - a method of scrutiny that typically results in long-winded projects. Initially Syberberg closely followed Brecht's model. He felt that cinema should be reshaped along Brechtian lines, moving from 'fun theater' to moral drama, which, both technically and intellectually, would be on a par with the avant-garde. Not surprisingly, then, Syberberg's early films basically come across as cinema translations of modern theater of the post-Brecht era: the absurdism of Dürrenmatt and Beckett. Syberberg shielded this post-Brechtian avant-garde from the irrationalism-critique in two ways. $\mathrm{He}$ indicated that the 'absurd conscious' corresponded well with the prevailing post-war sensibility: the early films articulate a sense of crisis that was widespread during the years of post-war reconstruction, not only in circles of cultural conservatives like Sedlmayr, but also 
in those of Western neo-Marxists like Adorno and GDR dissidents like Bloch and Mayer. Second, he also showed that the theater of the absurd was a more contemporary form of moral drama in the Brechtian tradition.

In the 1970s, the period of The Grail, Syberberg redirected his attention from postfascist to pre-faseist irrationalism: Wagner and late Romanticism. In Chapter 3 I explore the specific character of Syberberg's attitude toward Wagner and the role of The Grail in the debate on Wagner, from the Bloch-Lukács / Thomas Mann controversy to the uproar concerning the leftist 'Wagnerism' of New Bayreuth. Does Syberberg belong to the Wagnercritical tradition of the older Thomas Mann? Or are we rather dealing with someone who is akin to the (pre-war) Wagnerians of Old Bayreuth? And what are we to make of the aesthetic Wagner-Brecht formula, which the Syberberg sympathizers have frequently interpreted as an anti-Wagnerian strategy? It will be argued that Syberberg's moving from Brecht to Wagner, though, was not as large a step as is often assumed: the Brechtian didactic theater and the Wagnerian Gesamtkunstwerk belong to the same theatrical tradition (that of moral drama). Moreover, a combined Wagnerian and Brechtian aesthetic was hardly a novelty: already in the early 1960s Wieland Wagner introduced the epic theater method in Bayreuth. It is also true that Syberberg's work contains little or no evidence of Brechtian hostility against Wagner. This suggests a major difference between Syberberg and the older Mann, whose denouncing of the 'diabolic irrationalism' of the Wagner-Nietzsche-Hugo Wolf-Hitler line in Doktor Faustus (1947) was correctly interpreted by Lukács as the bourgeois counterpart of his own dialectic-materialist critique of irrationalism. As Wesseltier argued, The Grail 'reopens a specific tradition of metaphysics and culture, which Thomas Mann's Doktor Faustus was assumed to have ended'.

The main argument used by Syberberg to defend his following of Wagner is derived from Bloch, who already in the debate on Expressionism crossed swords with Lukács and Mann on this matter. The premise was that if the Nazis admired Wagner, this did not necessarily turn him into a 'spiritual predecessor' of National Socialism. The art of Romanticism gave rise to artistic traditions like Symbolism and Expressionism, and it tends to be associated with certain desires, like beauty and purity, and with particular notions (such as Volk, nation, homeland, Heimat, soil, Führer, the Grail, and the Third Reich) and narrative forms like fairy tale, legend, myth, saga, and fantasy. Yet if Nazism may have appropriated many of these notions, forms, and longings, this means that they are also subject to being 'expropriated' or regained. This, so Bloch argues, with Syberberg in his wake, should be the role of all genuine critical art and philosophy: developing 'strategies of reconsideration' that facilitate a de-Nazification. Bloch felt that such reconsideration should rely on a neo-Marxist perspective, but Syberberg's objective was to 'understand the German mind, as well as to honor and save it'. In so doing, and fully in line with the Old-Bayreuth Wagnerians, he defined the 'German mind' as the 'irrational', as the 'counterweight of Enlightenment thought'. Syberberg himself viewed this as a radicalizing of Bloch's dialectic. If it was useful to strive for de-Nazification of seriously perverted notions like 'soil', 'Führer', and 'Third Reich', as Bloch argued, why, then, should 'Germany as a mental possibility' (Bohrer) be left in the hands of the Nazis?

Subsequently, Chapter 4 is entirely devoted to a discussion of a series of commentaries on the fourth part of The Grail: the Bayreuth documentary The Confessions of Winifred Wagner (1975). The commentaries discussed all situate Syberberg's work in the debate that was started by A. and M. Mitscherlich in the mid-1960s on the German 'inability to mourn'. Syberberg's position in this social-psychological debate, as well as in the arthistorical debate on the aesthetic dimension of National Socialism that is closely tied to it, is further developed in Chapter 5, which also focuses on the Winifred Wagner documentary. 
With the emergence of the New Left protest generation of ' 68 , the critique of irrationalism became more prominent in the West as well. In a watered-down form its echo resounded in Habermas's defense of the 'project of modernity' and in Sontag's 1974 essay on Riefenstahi, 'Fascinating Fascism', one of the key texts in the art-historical debate. The Mitscherlichs, in their effort to elucidate the gist of their theory on mourning, explicitly relied on Lukács. They started from the assumption that after 1945 the Germans failed to deal with irrational emotions and phantasmagoria adequately, and; consequently, they repressed them: a 'radical victory" of the "irrational' is only possible through a psychoanalytic Trauerarbeit. Elsaesser, Berman, Sanford, and Santner argue that Syberberg, in his Grail cycle, sought to initiate such 'mourning work' in the sense of the Mitscherlichs. However, as will be elaborated in detail, this interpretation is founded on a painful misunderstanding. On the issue of how the Germans should have absorbed their Nazi past, Syberberg held a radically different opinion than the Mitscherlichs and most of his admirers. He felt that the postwar re-education effort, as a critique of irrationalism, implanted a nosophobia for the irrational self in the German psyche. With his Grail cycle, he wanted to help Germans to overcome this nosophobia. The Winifred Wagner documentary was meant to confront them with a 'courageous' old lady, who, freely and candidly, positively acknowledged her own German emotional sensibility. The Grail cycle's fifth part, Hitler, a Film from Germany (1977), a Gesamtkunstwerk made in the Old-Bayreuth style, aimed at letting the German audience play a cathartic game with cultural signs derived from 'the long history of irrationalism'.

The latter work, in fact, is the subject of Chapters 6 and 7 , which complement each other. Hitler, a Film from Germany is best characterized as a seven-hours-long collage of objects, texts, images, and sounds. This film provides a true sampling of nearly everything that since Lukács has been understood as a manifestation of irrationalism. Almost anything that former admirers like Elsaesser, Santner, and Lacoue-Labarthe accused Syberberg of in the 1990s can already be traced in this work from the mid-1970s: a hostile attitude versus Jews, an aggressive German nationalism, a celebration of Prussia, a flirting with the Conservative Revolution ideology (Sedlmayr, E. Jünger, Schmitt, Picard), as well as a polemic against the re-education effort in general and the way the 1968 generation came to terms with the past in particular. For the first time Syberberg openly received support from the extreme right. This said, we should not jump to conclusions, though. As the 'absurd conscious' of Syberberg's early films corresponded with the sensibility of the years of postwar reconstruction, so the German-minded anti-Enlightenment thought in the Hitler film appears a hyperbolic representation of the sensibility of the years following the 'German autumn' of 1977. In contrast to Habermas (1977), who claimed that the 'ideological climate' in 1970s West Germany was 'dominated by a mixture of old and new conservative movements', I argue that the 1970s was a period in which on a global basis the neo-Marxist. reflection of the emigrant generation went through a renaissance. Once the emigrant discourse gained more influence, however, the old differences surfaced as well. Much of what Habermas considered as the Old or New Right, on closer inspection turns out to belong to a dissident leftist tendency, which representatives of the critique of irrationalism decried as rightist from the outset. Examples include the post-Nietzschiar philosophy of the then admirers of Syberberg, including Lacoue-Labarthe, Foucault, Deleuze, and Faye, and the neo-Expressionist painting of Kiefer and Lüpertz, who in those days were always associated with Syberberg's art.

During this period Syberberg himself did not consider his work as an intervention 'coming from the right'. At that point his intellectual and artistic examples were still Brecht, Bloch, and Mayer. Only in the course of the 1980s Syberberg gradually arrived at the understanding that the intellectual roads taken by these emigrants were no longer his. The 
first signs of his conservative turn become visible in The Night, the beginning of a four-part theater cycle about burnt-down Pommernland, entitled Requiem for the End of Prussia (1982-1991). In his striving to represent the destruction of Pommern and the suffering of those who were driven out of the Heimat, Syberberg was faced with the confines of a paradigm in which the horrors of 8 May 1945 were exclusively shown from the angle of the winners, the (Jewish) victims of the old Germany, and those who "chose the socialist GDR as refuge'. Given this paradigm, the tears of the Prussian Hekabe became part of 'what is forgotten on the memorials'. In his infamous 1990 pamphlet Vom Unglück und Glück der Kunst in Deutschland nach dem lezten Kriege (On the Unhappiness and Happiness of Art in Germany after the Last War), Syberberg denounced German emigrant theory as 'leftistJewish' and committed himself to the 'native soil' and 'German-conscious' thought of the post-Nietzschian Conservative Revolution.

Finally, the concluding Chapter 8 situates Syberberg's conservative turn in the broader context of the changed mentality in post-1989 Germany in general, and the debate on 'What's right, what's left?' in particular. This debate was started in part by Botho Strauss's Anschwellender Bocksgesang (Louder Goat Singing, 1993), and attention is paid to some striking parallels in the artistic careers of Strauss and Syberberg. The collapse of socialist Eastern Europe caused the demise of the credibility of the emigrant generation's neo-Marxist thought, as is true of the eritique of irrationalism. In the meantime, many of the taboos that Syberberg challenged already in the 1970 s have become subject to debate. Yet, ironically, the disappearance of the dominance of the social-critical paradigm turned out to be disastrous for Syberberg's life as an artist. Undeniably, the filmmaker, who today openly sides with the right, has had trouble finding his way in the new Germany, both artistically and intellectually. This may be explained by the fact that over the years Syberberg's worldview and creative energy have become bound up with leftist debates to such degree that he is basically lost without them.

In an effort to understand the work of Syberberg, this dissertation explores the influential art-political debates that unfolded in Germany between the 1930s and the 1990s. Its main conclusion posits that Syberberg, who may have gone conservative, is certainly no Alt-Konservativer. 


\section{Dankwoord}

Ik dank Gera van Berlo, Pieter Caljé, Eling Delleman, Idie Goossens, Harrie Goossens, Mariëlle Goossens, Jeroen de Jong, Arnold Labrie, Eric Lemmens, Frederiek Lommen, Bernard Rulof, Jessica Slijkhuis, Cecile aan de Stegge en Thijs Viertelhauzen voor de bijdrage, die ze elk op hun eigen wijze hebben geleverd. Bovenal erkentelijk ben ik Manuel en Elias Stoffers, zonder wier altijd even scherpzinnige als opbeurende kritiek dit boek hoogstwaarschijnlijk nooit zou zijn geschreven. 


\section{Over de auteur}

Guido Goossens werd geboren op 26 februari 1966 in de vroedvrouwenschool te Heerlen, naar verluidt rond 5 uur in de ochtend. Hij groeide op in het Limburgse Stein, niet ver van de Belgische grens, studeerde tussen 1985 en 1993 geschiedenis en filosofie aan de Katholieke Universiteit Nijmegen en was nadien enkele jaren verbonden aan de Faculteit der Cultuurwetenschappen van de Universiteit Maastricht. Onlangs overleed zijn hond. 